UNIVERSIDADE DE SÃO PAULO

INSTITUTO DE GEOCIÊNCIAS

\title{
ESTILOS DE DEFORMAÇÕES GLACIOTECTÔNICAS NO SUBGRUPO ITARARÉ, NEOPALEOZÓICO DA BACIA DO PARANÁ
}

\author{
ALEXANDRE TOMIO
}

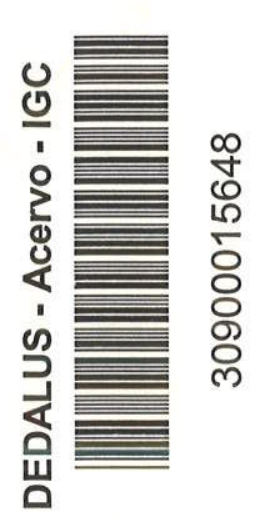

Orientador: Prof. Dr. Paulo Roberto dos Santos

TESE DE DOUTORAMENTO

COMISSÃO JULGADORA

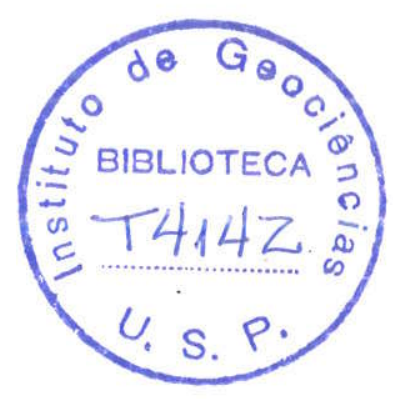

Nome

Presidente: Prof. Dr. Paulo Roberto dos Santos

Examinadores: Prof. Dr. Antonio Carlos Rocha Campos

Prof. Dr. Antonio Roberto Saad

Prof. Dr. José Alexandre de Jesus Perinotto
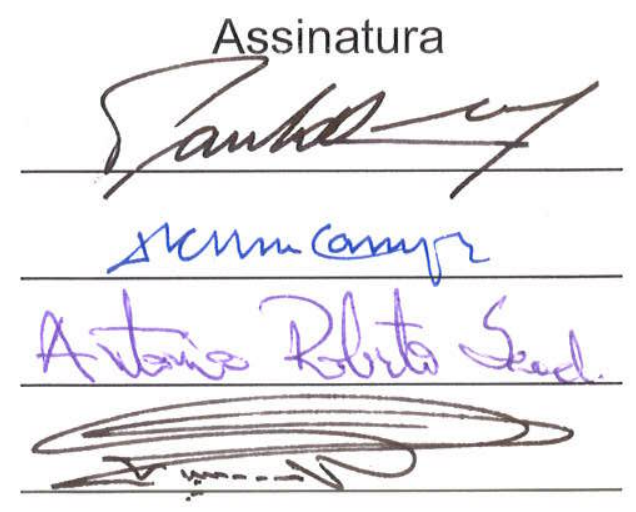

Prof. Dr. Marcel Auguste Dardenne

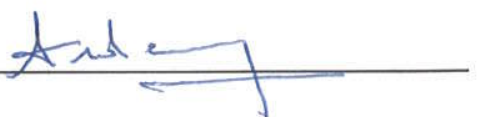

$$
\begin{aligned}
& \text { SÃO PAULO } \\
& 2004
\end{aligned}
$$




\section{Universidade de São Paulo \\ Instituto de Geociências \\ Departamento de Geologia Sedimentar e Ambiental}

\section{ESTILOS DE DEFORMAÇÕES GLACIOTECTÔNICAS NO SUBGRUPO ITARARÉ, NEOPALEOZÓICO DA BACIA DO PARANÁ}

Alexandre Tomio

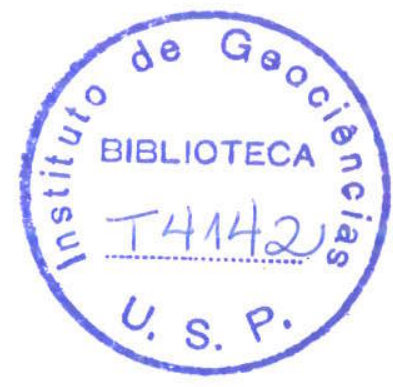

Orientador: Prof. Dr. Paulo Roberto dos Santos

\section{TESE DE DOUTORAMENTO}

Programa de Pós-Graduação em Geologia Sedimentar

São Paulo 
Aos meus pais, Lauro e Maria, e à minha esposa, Cristiane, pelo auxílio, paciência e carinho. 


\section{AGRADECIMENTOS}

A realização deste trabalho contou com a colaboração de diversas pessoas e entidades, direta ou indiretamente, visto que em 4 (quatro) anos muita coisa aconteceu, os quais desejo extemar os meus agradecimentos.

Em primeiro lugar, expresso minha gratidão ao Prof. Dr. Paulo Roberto dos Santos, pela paciência em corrigir os meus textos, pela troca de experiências, mas acima de tudo, por ser, não apenas um verdadeiro amigo, mas um segundo pai. Um pai no meio acadêmico, já que não só aconselha nas pesquisas, mas se preocupa com os seus pupilos. Obrigado por todos estes anos, desde 1994, de convivência e de ensinamento, que me possibilitaram uma formação sólida, rica, ética, moral, digna de um segundo pai. Valeu Bépo!!!

Ao Prof. Dr. Antonio Carlos Rocha-Campos, agradeço por ter me dado à oportunidade única de aprendizado, tanto acadêmico, quanto de vida, ao me integrar nas suas pesquisas e em suas façanhas. Certamente, um exemplo de pessoa aficcionada pelo que faz e de um pique que deixa qualquer guri para trás, especialmente se tiver uma nova descoberta a frente. Bom, se o Paulo seria o meu pai geológico, então o Tonny seria o meu padrinho acadêmico. Obrigado por todos os ensinamentos que esta convivência me proporcionou. Não podia esquecer da famosa frase: "Sinto o cheiro das novas descobertas que faremos hoje".

À FAPESP, pela bolsa de doutoramento (Proc. 99/11083-5) e pelo auxilio financeiro para as pesquisas na Islândia; à CAPES, pela auxílio financeiro no projeto de especialização (doutoramento sanduíche) desenvolvido na Inglaterra (Proc. BEX2287/01-3); e à University of Greenwich pelas passagens aéreas para a Islândia. Auxilios estes que foram fundamentais para a realização da pesquisa e elaboração da tese.

Aos meus pais, Lauro e Maria do Rocio, e familiares, por todo o apoio, carinho, incentivo e por terem me ensinado a ser o homem que sou hoje. Em particular, por toda a base acadêmica que recebi do meu pai, tendo continuado o seu legado, apesar de numa ciência um pouco mais complexa que a física nuclear. Mas, como todo bom filho, pretendo um dia chegar perto das 9 (nove) publicações em revistas internacionais, afinal sempre nos espelhamos nos nossos ídolos. Sem deixar de enfatizar: a minha mãe, pelo seu exemplo de vida; a minha esposa, Cristiane Berbel, pelo auxilio nos momentos difíceis e por conseguir me aturar, já que sempre estava plantado na frente do com-puta-dor; o meu irmão, Lauro César, por ser uma pessoa fabulosa e pelos auxílios de informática, principalmente, na eliminação de vírus; os meus avós, Aleixo e Maria Vanelli, e demais familiares, por estarem sempre rezando, incentivando e torcendo por mim; e os mais novos membros da minha familia os pais (Antônio Carlos Berbel e Juracides) e o irmão da Cris (Jefferson). 
To Prof. Matthew R. Bennett, thanks for all the help, scientific discutions (which are still in course by e-mail) and, specially the friendship. Without a doubt, was a very important contribution for this research and certainly will result in many other successful works. Thanks also for all the assistance during may stay in England and Iceland. It's something that I won't forget.

Aos professores do Instituto de Geociências da USP que auxiliaram no desenvolvimento desta tese, em particular, à Profa. Mary Elizabeth $\mathrm{C}$. B. de Oliveira e ao Prof. George Robert Sadowski, agradeço por terem participado de trabalhos de campo e por terem contribuído significativamente nas análises paleontológicas e estrưturais, respectivamente; ao Prof. Ricardo Hirata, pela revisão e sugestões no conteúdo hidrológico da tese, além das conversas nas vezes em que almoçamos juntos; ao Prof. Marcos Egydio da Silva, pelo auxilio nas questões ligadas à Geologia Estrutural; ao Prof. Claudio Riccomini, pela participação na Banca do Exame de Qualificação, contribuindo no incremento e melhoria da tese através de várias sugestões; ao Prof. Paulo César Fonseca Giannini e a Profa. Maria Cristina Motta de Toledo, nos assuntos relacionados aos clastos partidos e selados; ao Prof. José Roberto Canuto pela troca de informações sobre a estratigrafia do Subgrupo Itararé, além da amizade; e ao Prof. Setembrino Petri pelos conselhos e por ser um exemplo de pesquisador a ser seguido, visto a sua vontade de estar sempre a par das novas descobertas e a sua simplicidade e humildade. Agradeço também todos os demais professores do Instituto de Geociências da USP que contribuíram indiretamente neste doutoramento, pois lembro-thes que fui formado pela casa e, assim, grande parte dos meus conhecimentos sobre a geociências foram adquirido através dos professores deste instituto.

Aos amigos que contribuiram nos trabalhos de campo, Gaston Eduardo Enrich Rojas (Edir), Artur Deodato (Metanol), Marcelo Luiz Arsillo Braga, Deborah Barè e Alexandra Fernandes Oliveira. Enfatizando dois fundamentais colaboradores, Ivo Trosdtorf Junior e Rodrigo Artur Perino Salvetti, não só pela colaboração em todas as fases desta pesquisa, mas pelo companheirismo, a amizade, por terem me aturado na sala e nos campos, pelas constantes brincadeiras e por ouvirem os meus devaneios sobre os trabalhos no meio da noite, com a famosa frase: "Você está acordado? Estava pensando sobre o afloramento e acho que...".

Aos amigos antárticos, os Profs. Francisco Pinheiro Lima Filho, Fernando Mancini, José Alexandre de Jesus Perinotto (Giglio) e Luiz Eduardo Anelli; os alpinistas Sergio (Ginho), Sívio, Camilo e Rosita, e o amigo Luís Fernando Miliorini (Bizu), pelo companheirismo e aprendizado, não só relacionados aos trabalhos, mas sobre o valor real da amizade. Afinal, conviver isolados na Antártica é bem pior que num "Big Brother Global". Obrigado, também, aos demais pesquisadores antárticos e ao pessoal do NaPOc Ary Rogel. 
To the English and Icelandic friends, thanks for all the friendship. Certainly, this friendship was important, not only to learn about new cultures, but also helped me to support the distance from my family, my friends and my country. By the way, my first English breakfast was a sign of what would come, with bread, beans, two sausages, covered with mushrooms and a typical British tea (black tea with milk and without sugar). In other words, an huge hospitality!!! Special thanks are due to Martin Webb and his family, since they helped me in many situations, showing what are friends for.

Aos funcionários do Instituto de Geociências da USP, com destaque para Ivone Cardoso Gonzáles, do Laboratório de Paleontologia Sistemática, e Edson le do Centro de Pesquisas Antárticas da USP, assim como o pessoal da biblioteca, da gráfica (Claudionor, Edmir, Henrique e José Gonçalves), da laminação, da Secretaria do Departamento de Geologia Sedimentar e Ambiental (Soninha), da Seção de Apoio Acadêmico (Tadeu) e do laboratório de sedimentologia, em particular a Elaine Aparecida da Silva Sinfrônio, por toda a sua ajuda e preocupação. Não obstante, merece um agradecimento especial, às amigas Ana Paula Cabanal Pentagna e Magali Poli Fernandes Rizzo, da secretaria de pósgraduação, pelos constantes auxílios, pela amizade e pela paciência.

Aos amigos, agora vem uma infinidade de nomes, tanto da graduação, Alethéa, Anarpha, Angélica, Bizu, Buda, Cana, Campinho, Digo, Dixico, Eunuco, Fepasa, Gummi, Jânyo, Japa, Lucelene, Magri, Manah, Metralha, Mika, Ninguém, Pissão, Ricota, Sibele, Sivuca, Valisère, Veridiana, Xera, Xosquinha; como os que adquiri no decorrer do doutoramento, Afonso, Alexandra (Biza), André Ferrari, Bisteca, Braulyo, Bruce, Carlinha, Conrado, Cristiane, Cristiano, Cruz de Mello, Deise, Denise, Docinho, Emilio, Fluído, Frutinha, Gabriel, Graziela, Juliana (Sopa), Juliana Leme, Marília, Lalas, Lucas, Kollah, Penélope, Pi, Piolho, Renata (Bio), Renatão, Rodrigo, Rogério, Sabrina, Sandra, Silvia, Sueli, Tacinha, Valentino e Zeca; e os de fora da Geologia, Adriana, Andréa, Aurely, Elaine, Elliziane, Cristina, Luciana, Marcosoel, Michele, Renata, Ricardo, Rudi e Sandrinho.

Aos amigos da Colônia Menonita de Witmarsum, em particular, à familia Siebert (Carmen e Rubens) pela hospitalidade, amizade e por ter-nos advertido que trabaihar de domingo trás azar (neste dia a bateria do carro parou de funcionar). Sem dúvida é um lugar maravilhoso, não apenas pelo interesse geológico, mas pela tranquilidade e a paz que oferece.

Sei que dei uma de "Maguila", mas mesmo assim, agradeço e peço desculpas se esqueci de alguém que tenha contribuído para a minha formação nestes últimos anos. Sabe como é a Lei de Murphy, sempre haverá algum deslize. Acrescento também que mesmo aqueles que não têm nenhum título, ou mesmo escolaridade, são professores, ou mesmo doutores, pois sempre possuem algo a ensinar. Obrigado por tudo!!! 


\section{SUMÁRIO}

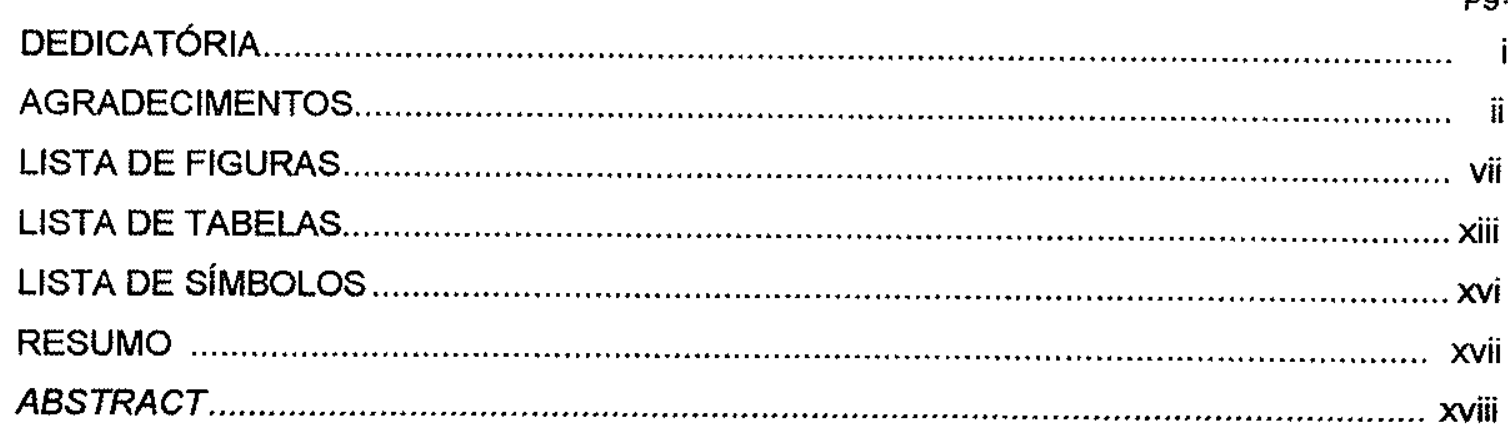

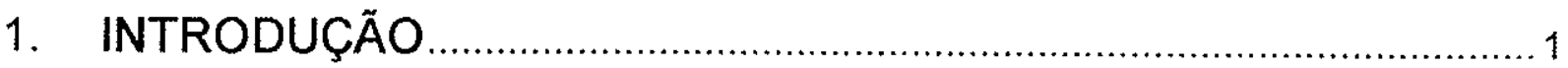

1.1. OBJETIVO

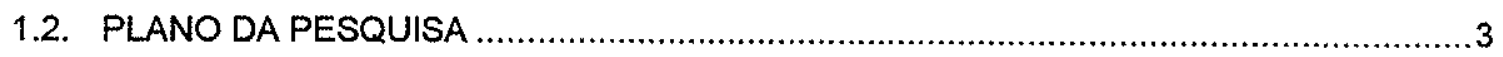

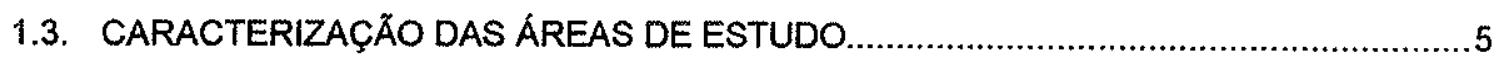

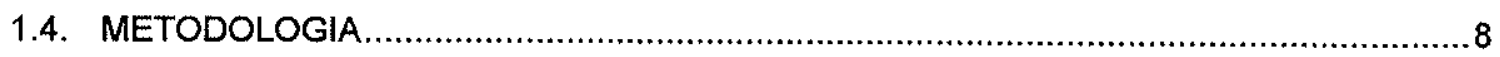

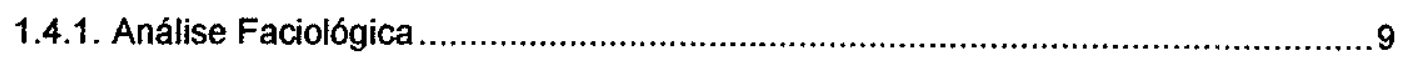

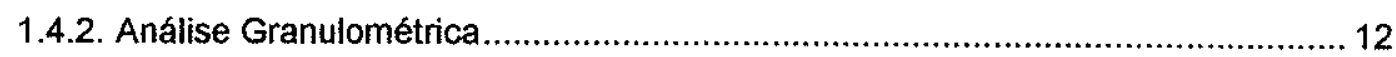

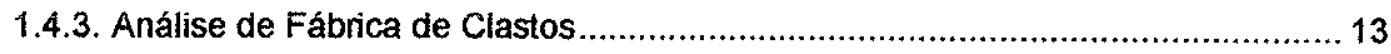

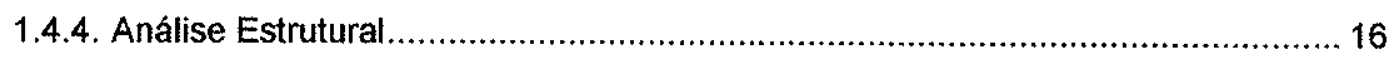

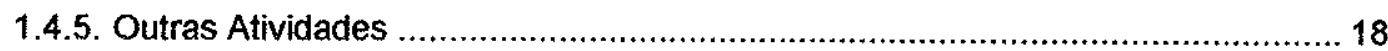

2. TRABALHOS ANTERIORES NAS ÁREAS ANALISADAS ..............20

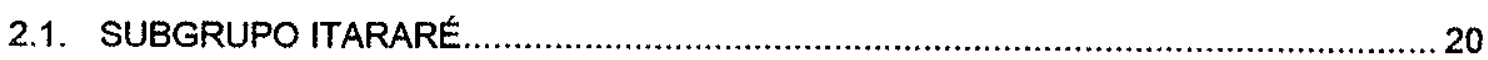

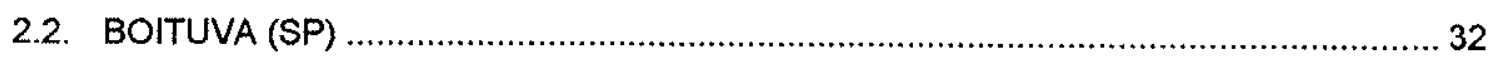

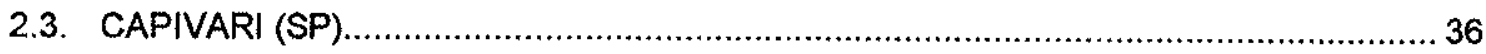

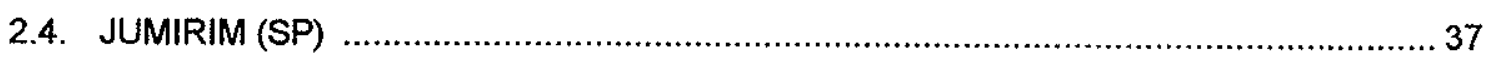

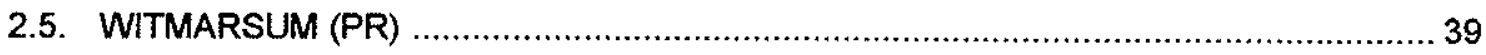

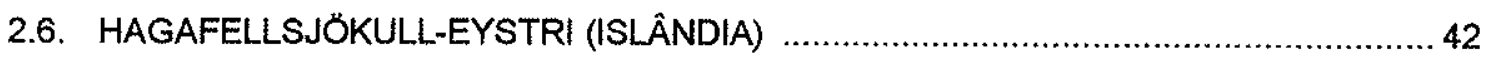

3. GLACIOTECTÔNICA

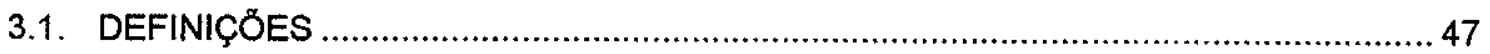

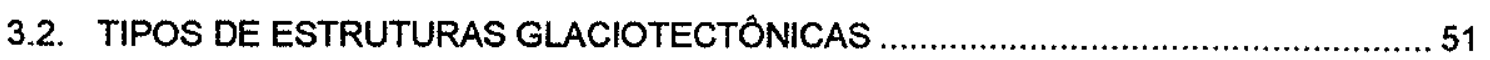


4. DEFORMAÇÕES SUBGLACIOTECTÔNICAS 57

4.1. MODELOS REOLÓGICOS DE SEDIMENTOS SUBGLACIAIS INCONSOLIDADOS ....57

4.1.1. Tipos de Acamamentos 58

4.1.2. Modelo de Amamento Viscoso (Boulton \& Hindmarsh, 1987) 60

4.1.3. Modelo de Aração (Tulaczyk et al., 2001). 68

4.1.4. Modelo da Continuidade ou do Ciclo de Deslizamento-União, Slip-Stick Cycle (Alley, 2000; Boulton et al., 2001; Bennett, 2003) 75

4.2. DESCRIÇÃO DOS AFLORAMENTOS E ESTRATIGRAFIA DE CAPIVARI .77

4.3. DESCRIÇÃO DOS AFLORAMENTOS E ESTRATIGRAFIA DE JUMIRIM. 86

4.4. CONSIDERAÇŐES SOBRE AS ESTRUTURAS SUBGLACIOTECTÓNICAS E AS IMPLICAÇŐES NA ESTRATIGRAFIA DE CAPIVARI E JUMIRIM

4.4.1. Estruturas Subglaciotectônicas

4.4.2. Hidrologia dos Sedimentos com Estruturas Subglaciotectônicas de Capivari e Jumirim

4.4.3. Implicações no Contexto Subglaciotectỏnico e Estratigráfico e Interpretações Paleogeográficas e Paleoambientais

\section{DEFORMAÇÕES PROGLACIOTECTÔNICAS}

5.1. AS ESTRUTURAS PROGLACIOTECTÔNICOS E AS MORAINAS DE EMPURRÃO..128

5.2. DESCRIÇÃO DOS AFLORAMENTOS E ESTRATIGRAFIA DE WITMARSUM (PR) ...130

5.2.1. Mapeamento Geológico e Estratigrafia

5.2.2. Tectônica Local de Witmarsum (Falha Cancela). 137

5.2.3. Estruturas Glaciotectónicas de Witmarsum

5.2.4. Considerações e Interpretações de Witmarsum. 159

5.3. ESTRUTURAS PROGLACIOTECTÔNICAS DA ISLÂNDIA. 164

6. OUTROS TIPOS DE DEFORMAÇÕES ANALISADAS 176

6.1. DESCRIÇÃO DOS AFLORAMENTOS E ESTRATIGRAFIA DE BOITUVA 176

6.2. CONSIDERAÇÕES E INTERPRETAÇÕES SOBRE O AFLORAMENTO DE BOITUVA

\section{ANEXO}

Anexo 1. Mapa Geológico da Colônia Menonita de Witmarsum 


\section{LISTA DE FIGURAS}

Figura 1.2.1

Figura 1.2.2

Figura 1.4.3.1

Figura 1.4.3.2

Figura 1.4.4.1

Figura 2.1.1

Figura 2.1.2

Figura 2.2.1

Figura 2.2.2

Figura 2.5.1

Figura 2.5.2

Figura 2.5.3

Figura 2.6.1

Figura 3.2.1

Figura 3.2.2

Figura 3.2.3

Figura 3.2.4

Figura 4.1.1

Figura 4.1.2.1

Figura 4.1.2.2

Figura 4.1.3.1

Figura 4.1.3.2

Figura 4.1.3.3

Figura 4.1.4.1

Figura 4.2.1
Mapa das áreas estudadas no Brasil e afloramentos do Subgrupo Itararé na borda leste da Bacia do Paraná. 7

Mapa de localização das áreas estudadas na Islândia. 8

Nomenciatura axial dos clastos e os principais tipos de fábricas .................. 14

Principais tipos de imbricaçães ................................................................ 14

Orientação de falhas com relação aos eixos principais de deformação........... 17

Superficie glacial múltipla, estriada e sulcada, de Palmeira (PR) ................. 21

Matacão caído em folhelhos glaciomarinho em Rio Negro (PR) ................... 21

Diagrama com dados estruturais da porção oeste do afloramento de

Boituva (SP) e esquema interpretativo das estruturas.

Diagrama com os pólos axiais observados na porção oeste do afloramento de Boituva (SP) e esquema interpretativo das estruturas. .......... 35

Painel explicativo do Sítio Geológico das Estritas de Witmarsum ................. 40

Pavimento glacial estriado e sulcado de Witmarsum ...................................... 41

Aba de Diamictito escorregado dentro de sulco a partir de crista.................. 41

Componentes geomorfológicos da região entre a geleira Hagafellsjökull-

Eystri, o lago Hagavatn e o vale Jarlheltukvisi.

Diagrama com as estruturas glaciotectônicas mais comuns arranjadas de acordo com a escala horizontal típica (logaritmica).

Diagrama esquemático dos tipos de deformações glaciotectônicas proglaciais

Diagrama esquemático dos estilos de deformação associados a geleiras ativas e estagnadas.

Distribuição teórica das geomorfologias glaciotectônicas nas margens de uma geleira continental.

Componentes do fluxo do gelo em geleiras de diferentes regimes térmicos basais.

Esquema dos resultados apresentados por um experimento sob a geleira de Breiđamerkurjökull

Quatro casos possíveis do modelo reológico viscoso das deformações subglaciais, relacionado-os às mudanças de pressão efetiva e de potencial hidráulico. 65

Representação esquemática do modelo de aração 69 Imagem de satélite que mostra as estruturas de relevo alongadas na paleo-corrente de gelo M'Clintock, Ártico do Canadá.

liustração demonstrando as deformações no substrato formadas pelas irregularidades do gelo basal .................................................................. 71

Ciclo Slip-Stick (Deslizamento-Aderência)........................................76

Mapa geológico simplificado próximo da localidade de estudo de Capivari... 78 
Figura 4.2.2

Figura 4.2.3

Figura 4.2.4

Figura 4.2.5

Figura 4.2.6

Figura 4.2.7

Figura 4.3.1

Figura 4.3.2

Figura 4.3.3

Figura 4.3.4

Figura 4.3.5

Figura 4.3.6

Figura 4.3.7

Figura 4.3.8

Figura 4.3.9

Figura 4.3.10

Figura 4.3.11

Figura 4.3.12

Figura 4.3.13

Figura 4.3.14

Figura 4.3.15

Figura 4.4.1.1

Figura 4.4.1.2
Seção esquemática de Capivari .79 Orientaçס̃es das estrias sobre os pavimentos de clastos e dos clastos dos Diamictitos e pelo método autovetores

Clasto de quartzito aroxeado, exótico, facetado e estriado, integrante do pavimento de clastos inferior de Capivari.

Pavimento de clastos sendo formado embaixo de uma geleira do Alasca .....81 Esquema listrativo do desenvolvimento de um pavimento de clastos intra-till, através do rebaixamento da interface dos horizontes $A \in B$

Diagrama de rosáceas dos Diamictitos de Capivari, baseada em dados obtidos por Rocha-Campos et al. (1976) e Salvetti (2000).

Seções, perfil e mapa do afioramento de Jumirim (SP)

Detalhe das camadas rítmicas da Associação 1.

Contato irregular inclinado entres as associações 1 e 2 , na Seção 1 de Jumirim

Intraclasto na zona de contato entre as associações 1 e 2 , na Seção 2 de Jumirim

Clasto de granito hololeucocrático, presente na base da Associação 4 de Jumirim.

Fósseis de vegetal, provavelmente um paracalamites, coletado in situ na Associação 5 de Jumirim

Diagrama esquemático e mosaico de fotos do corte leste da estrada de ferro da cidade de Jumirim.

Matacăo com marcas em crescente e estrias glaciais, presente no Pavimento de Clastos A de Jumirim

Foto do Pavimento de Clastos $B$ de Jumirim e diagrama explicativo.

Canal de arenito fraturado e falhado, acima do Diamictito 3 , na Associação 6 de Jumirim.

Perfil 1 do afloramento de Jumirim, ao longo da rodovia Marechal Rondon (SP-300)

Correlaçãa estratigráfica entre o Poço J-IG-93 e a Seção 1 de Jumirim

Fóssil de caule incorporado pelo escorregamento, possivelmente oriundo da Associação 5 de Jumirim

Clasto de ritmitos dobrados incorporados no escorregamento da Associaçăo 5 de Jumirim .

Superfície sobre sedimentos do escorregamento da Associação 5 de Jumirim, com dois conjuntos de estrias glaciais.

Seção polida de amostra do arenito, obtida próximo ao contato com o Diamictito A

Plasma bandado formando dobras de arrasto ao longo de micro-falha de acavalamento em låmina delgada de amostra de Capivari. 106 
Figura 4.4.1.3

Figura 4.4.1.4

Figura 4.4.1.5

Figura 4.4.1.6

Figura 4.4.2.1

Figura 4.4.2.2

Figura 4.4.3.1

Figura 4.4.3.2

Figura 5.2.1.1

Figura 5.2.1.2

Figura 5.2.1.3

Figura 5.2.1.4

Figura 5.2.2.1

Figura 5.2.2.2

Figura 5.2.2.3

Figura 5.2.2.4

Figura 5.2.2.5

Figura 5.2.2.6

Figura 5.2.2.7

Figura 5.2.2.8

Figura 5.2.2.9
Desenho esquemático da arquitetura das fraturas presentes na superfície aplainada formada no contato entre o arenito deformado e 0 diamictito Dm2 de Jumirim

Diagrama de rosáceas, com a indicação dos aparentes esforços principais máximo e mínimo, atuantes no arenito deformado de Jumirim....110 Condições de esforços durante a formação de fraturas em rochas intactas

Diagramas de rosáceas das fraturas presentes nos blocos $(A, B$ e $C)$ e respectivas direções de estrias glaciais presentes em cada bloco do arenito deformado da Associação 6 de Jumirim

Consolidação de sedimentos não-glaciais e glaciais.

Modelo esquemático da drenagem da água de degelo passando por um aquitarde até chegar ao aquifero subjacente.

Comparação entre a estratigrafia e dados sobre as direções das estrias e dos esforços das deformações nos arenitos em Capivari e Jumirim Ciclo Slip-Stick (Deslizamento-Aderência), adaptado de Bennett (2003). ....126 Seção geológica levantada ao longo de $6 \mathrm{~km}$ da estrada de ligação entre Witmarsum e a BR-277

Diamictito dobrado, silto-arenoso, amarelo, estratificado com bandas avermelhadas, aflorando atrás da casa da Fazenda Schoeder 135

Seção levantada no morro atrás da Pousada Siebert em Witmarsum. 136 Estratificaçäo cruzada de grande porte, seção do morro Siebert 135 "Paredão Cancela", atrás da Companhia de Laticinios Cancela 138 Estereograma com fraturas e acamamentos obtidos em campo e eixo de dobra, plano axial e eixos de esforços adquiridos indiretamente, mostrando o regime de esforços compressivos sub-horizontal nos arenitos da Formação Furnas.

Plano de falha subvertical, ondulado, sugerindo uma componente horizontal (falha transcorrente destral).

Brecha de falha produzida pelo acavalamento dos arenitos Furnas sobre os diamictitos ltararé no falhamento Cancela, ao lado do refeitório da Companhia de Laticínios Cancela.

Pavimento estriado, sobre a Formação Furnas, intensamente fraturado, formando degraus (Fazenda Schroeder).

Arenito Furnas cavalgando o diamictito Itararé.

Detalhe do diamictito Itararé que foi cavalgado por um bloco de arenito Furnas

Falha de empurrão da Fazenda Schroeder, visto de cima do bloco acavalado.

Rotação de um bloco como resultado de esforços transpressionais e transtensionais combinados, em um falhamento transcorrente sinistral 
Figura 5.2.2.10

Figura 5.2.2.11

Figura 5.2.2.12

Figura 5.2.2.13

Figura 5.2.3.1

Figura 5.2.3.2

Figura 5.2.3.3

Figura 5.2.3.4

Figura 5.2.3.5

Figura 5.2.3.6

Figura 5.2.3.7

Figura 5.2.3.8

Figura 5.2.3.9

Figura 5.2.3.10

Figura 5.2.3.11

Figura 5.2.4.1

Figura 5.2.4.2

Figura 5.2.4.3

Figura 5.2.4.4

Figura 5.2.4.5
Clastos partidos observados em campo na Fazenda Schroeder. 144 Detalhe do clasto partido que sofreu deslocamento no plano de fraturamento. 144

Círcuio de Mohr para estágios de esforços demonstrando as implicações de se aumentar igualmente um valor qualquer, representado por $\sigma$, em todos os esforços. 146

Sequência de eventos de partições e selamentos. 146 Diques clásticos localizados atrás da Companhia de Laticínios Cancela. ....149 Camada deformada de arenito médio limonitizado da Unidade 2 entre os diques clásticos .

Colinas, alongadas na direção E-W, com diamictitos deformados e falhados na base, capeados por arenitos

Diamictito Deformado $A$, da Unidade 2, presente próximo do açude da Chácara Lótus

Diagrama Schmidt-Lambert, com o contorno das concentrações dos pólos das laminações presentes e a projeção dos seus autovetores, assim como o cálculo das densidades máximas e mínimas, das dobras presentes nos diamictitos deformados

Seção Geral do Diamictito Deformado D.

Fotos do Diamictito Superior da seção do Diamictito Deformado D, orientados com o lado esquerdo para leste e o direito para oeste

Esquema ilustrativo das feições presentes no Diamictito Deformado $D$. Nota-se também a divisão das zonas analisadas

Clasto decimétrico no meio de um sistema irregular de fraturas paralelas no Diamictito Deformado D

Plano de falha inversa subhorizontal ondulado no Diamictito Deformado D

Diagrama Schmidt-Lambert, com o contorno das concentrações dos pólos das fraturas e falhas verticais presentes no afloramento do Diamictito Deformado $D$ e a projeção dos planos médios dos agrupamentos, assim como eixo de ondulação presente na falha inversa...158 Till de alojamento sobre o clássico Pavimento Estriado e Sulcado de Witmarsum 160

Moraina de empurrão localizada a frente da geleira Höfdabrekkujökull 160 Relação da inclinação do substrato e a formação de morainas de empurrão. 160

Mapa com as vergências médias das dobras recumbentes presentes nos diamictitos deformados 163

Contato entre diamictito vermelho de matriz síltica e Diamictito amarelo de matriz arenosa, ambos finamente estratificados 163 
Figura 5.3.1

Figura 5.3.2

Figura 5.3.3

Figura 5.3.4

Figura 5.3.5

Figura 5.3.6

Figura 5.3.7

Figura 5.3.8

Figura 6.1.1

Figura 6.1.2

Figura 6.1.3

Figura 6.1.4

Figura 6.1.5

Figura 6.1.6

Figura 6.1.7

Figura 6.1.8

Figura 6.1.9

Figura 6.1 .10

Figura 6.1.11

Figura 6.1.12

Figura 6.1.13
Localização e foto das morainas de empurrão relacionadas ao surge de 1998/99.

Foto e ilustração explicativa da parte superior da Seção EL3 da moraina de empurrão de 1998/99.

Foto de detalhe das estruturas rúpteis presente na porção superior da Seção EL3 da moraina de empurrão de 1998/99. 168

Sedimento congelado escavado na base de uma moraina de empurrão na região de Hagafellsjökull-Eystri.

Blocos de gelo e sedimentos congelados deformados

Mapa de localização e geomorfológico do Lobo 3 situado na margem lateral leste da geleira Hagafellsjökull-Eystri, além da orientação das crevassas de compressão.

Seções dos blocos de gelo e sedimentos congelados presentes no Lobo 3 da geleira Hagafellsjökull-Eystri..

Modelo esquemático da deformação de sub-congelamento no Lobo 3, da geleira Hagafellsjökull-Eystri, gerada durante o surge de 1998/99. 173

Seção estratigráfica do lado esquerdo do afloramento locado no $\mathrm{km} 0,5$ da rodovia Vicente Paima (SP-129).

Sequência clássica de Bouma 180

Intraclastos argilosos dispersos na matriz de arenito maciço de Boituva......182 Fóssil de bivalve dispersos na matriz de arenito maciço de Boituva. 182 Mosaico de fotos da Unidade Bd2 de Boituva, no km 0,5 da rodovia Vicente Palma (SP-129), lado esquerdo no sentido Porto Feliz a Boituva....184 Camadas horizontais plano-paralelas de ritmito $e$ arenito abaixo da superfície de descolamento, na Unidade B 185

Dobras flexurais sinclinais e anticlinais assimétricas, com espessamento nas charneiras curvilineares e flancos adelgaçados da Unidade Bd2 .185

Diagramas Schmidt-Lambert de quatro dobras da Unidade Bd2, com dados obtidos em campo e calculados estatisticamente, além da guirianda máxima que contem os pólos dos planos medidos para cada dobra, caso sejam dobras cônicas.

Dobras em caixa (box folds) da Unidade Bd2 de Boituva.

Clivagens afetando ritmitos irregulares, em dobras flexurais assimétricas, Unidade Bd2 de Boituva

Diagrama Schmidt-Lambert com curvas de contornos dos pólos axiais e medidas dos eixos das dobras, além dos autovetores deste sistema de dobras calculados através dos planos axiais (azul marinho) e eixos das dobras, que foram comparados com um plano de falha, das deformações da Unidade Bd2 de Boituva.

Camada de arenito dobrado e rompido (Unidade $\mathrm{Bd} 2$ de Boituva). 191

Falha de empurrão dúctil-rúptil na Unidade $\mathrm{Bd} 2$ de Boituva. 191 
Figura 6.1.14

Figura 6.1.15

Figura 6.2 .2
Charneira de dobra recumbente redobrada na Unidade Bd1 de Boituva......193 Os quadros tipos principais de formas tridimensionais de dobras obtidas pela superposição de dobras de cisalhamento sobre formas de dobras pré-existentes

Modelo esquemático da distribuição das deformações em deslizamento de material semiconsolidados 196

Modelo esquemático do escorregamento de um material inconsolidado, mostrando a distribuição das deformações internas 


\section{LISTA DE TABELAS}

Tabela 1.1.1

Tabela 2.1.1

Tabela 4.4.1.1

Tabela 4.4.1.2

Tabela 6.1.1

Coordenadas UTM das principais localidades estudadas.

pg.

Evolução da classificação e nomenclatura do Subgrupo Itararé

6

Comparações entre os valores apresentados pelas fraturas e as estrias glaciais

Comparação dos resultados obtidos para a determinação do esforço principal máximo aplicando-se o método de Fisher e pelas rosáceas, assim como os valores das estrias glaciais

Tabela dos autovetores de acordo com os tipos de dados estruturais 189 


\section{LISTA DE SÍMBOLOS \& ABREVIAÇÕES}

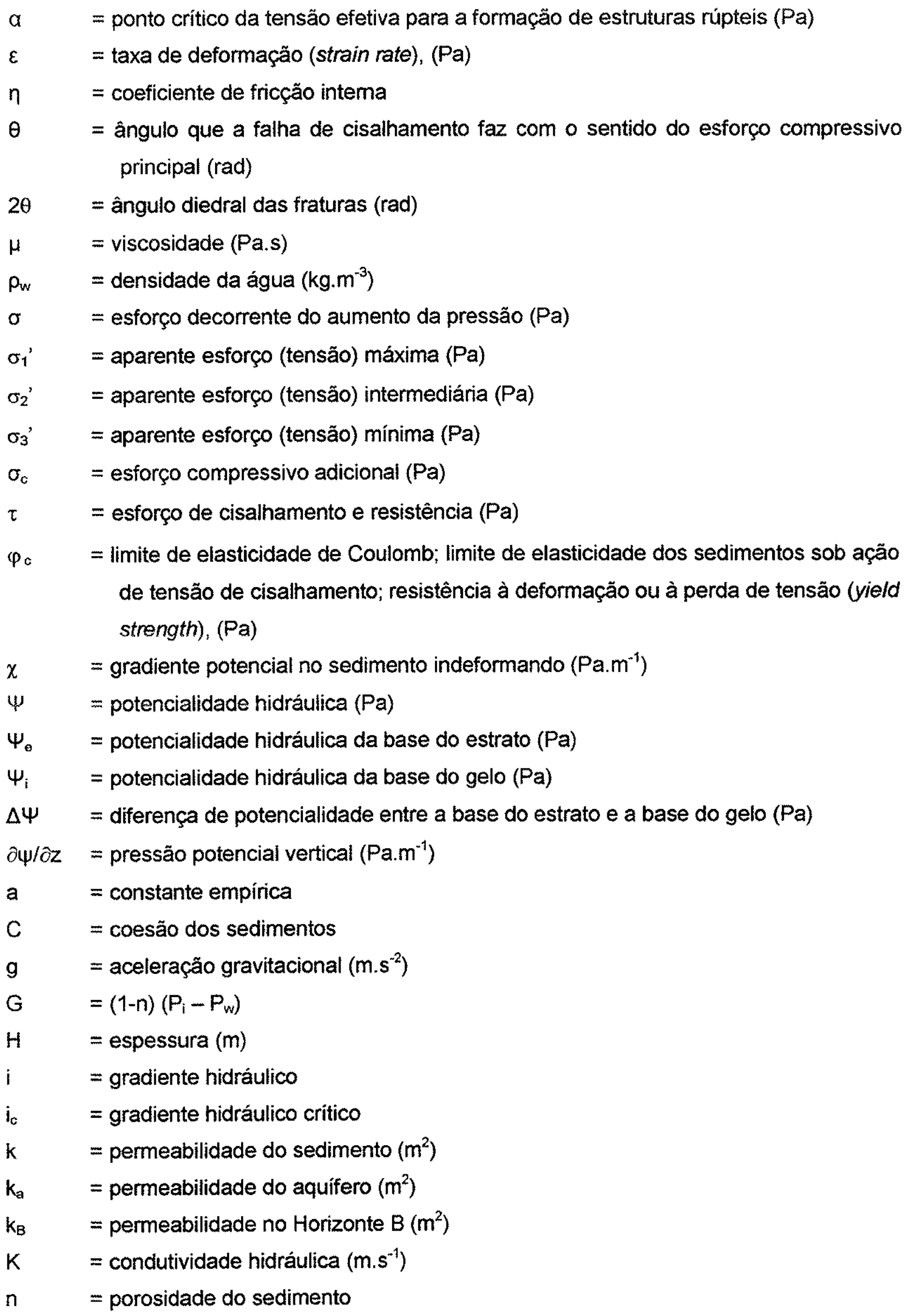




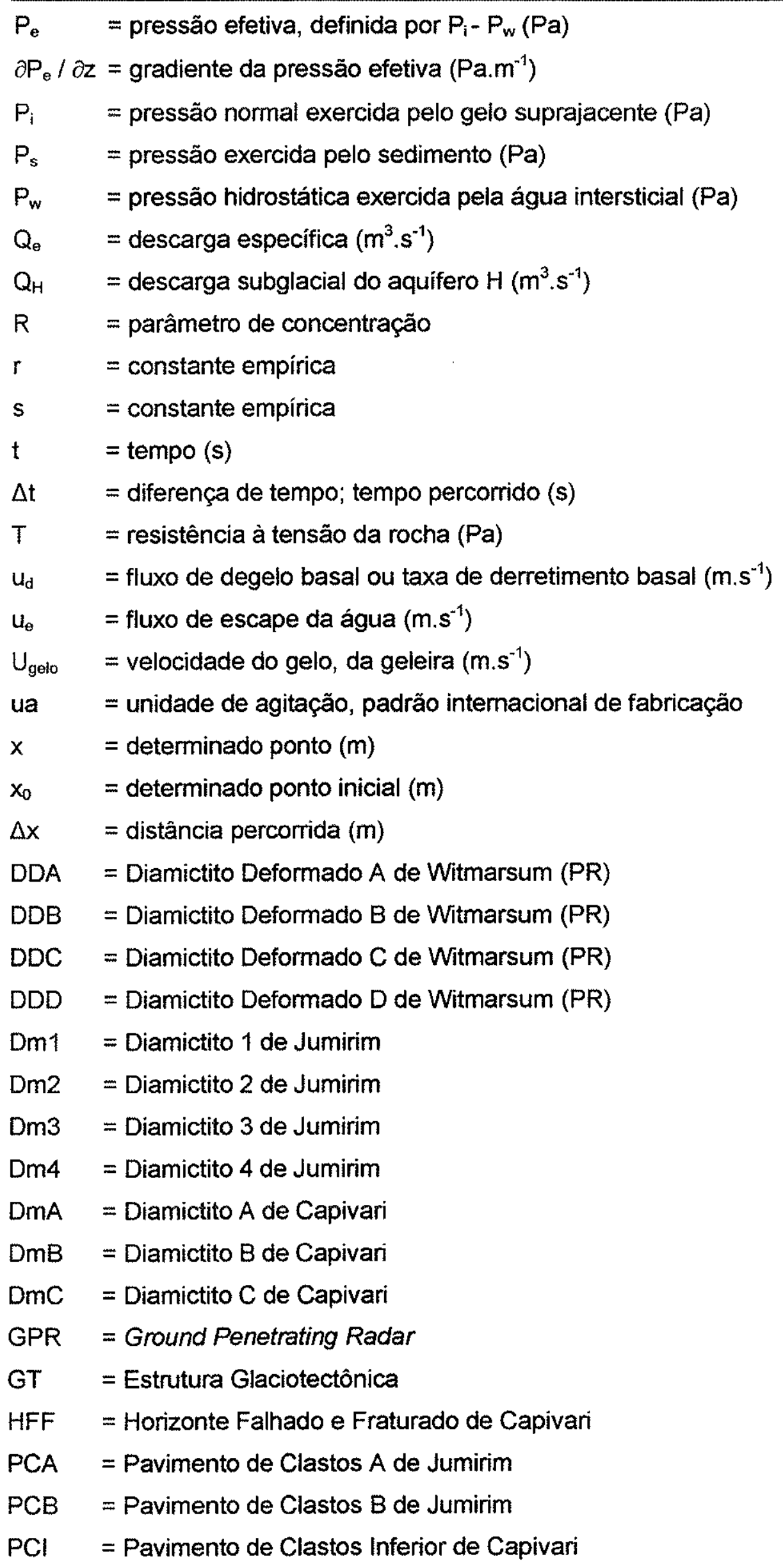


PCS = Pavimento de Clastos Superior de Capivari

Pm1890 = Moraina de empurrão associada ao surge de 1890 da Islândia

Pm1999= Moraina de empurrão associada ao surge de 1999 na Islândia

SEM = Scanning Electron Microscopy (Microscopia eletrônica de varredura)

UTM = Universal Transversal Mercator

WARR $=$ Wide Angle Reflexion and Refraction

Obs.: As unidades estão de acordo com a Système Intemational d'Unités (SI - Sistema Internacional de Unidades). 


\section{RESUMO}

Este trabalho analisa estruturas glaciotectônicas presentes em sedimentos do Subgrupo Itararé (Neopaleoźico, Bacia do Paraná), estudando os modelos de deformações glaciotectônicas e depósitos de ambiente subglacial e proglacial, nos estados de São Paulo e Paraná. Adicionalmente, como análise comparativa, estudou-se estruturas glaciotectônicas em sedimentos Recentes (Islândia) e deformações ligadas a fluxos gravitacionais de massa (Boituva). A fim de caracterizar as deformações, interpretar sua gênese e estabelecer critérios para diferenciá-las, utilizou-se análises estratigráficas, sedimentológicas e estruturais. Dentre os principais resultados, destacam-se: comprovação da existência de estruturas glaciotectônicas no Subgrupo Itararé, incluindo morainas de empurrão neopaleozóicas; classificação das estruturas glaciotectônicas relacionadas a ocorrências pré-pleistocênicas; contribuições aos modelos reológicos, sobretudo ao Ciclo de Deslizamento-Aderência; considerações genéticas às deformações em Boituva, Capivari, Jumirim e Witmarsum; novos dados sobre pavimentos de clastos de Capivari e Jumirim; análise de estruturas glaciotectônicas associadas a sedimentos congelados (Islândia); análise estrutural e da gênese das deformações em Boituva; e discussão dos métodos estruturais para distinçäo de deformaçőes glaciotectônicas e de fluxos gravitacionais de massa. 


\section{ABSTRACT}

The work analyze glaciotectonic structures present in sediments of the Itarare Subgroup (Neopaleozoic, Paraná Basin), through the study of the glaciotectonic deformation models in the subglacial and proglacial environment deposits, in the states of São Paulo and Paraná. A comparative analysis were developed involving glaciotectonic structures in Recent sediments (Iceland) and deformations related to gravitational mass flows (Boituva). To characterize the deformations, interpret its genesis and establish criteria to differentiate them, stratigraphical, sedimentological and structural analyses were used. The main results of the research are: confirmation of the existence and characterization of neopalaleozoic glaciotectonic structures generated in subglacial and proglacial environments; pre-Pleistocene glaciotectonic structures classification; contributions to the reological models of the "subglaciotectonic" structures, in particular to the Slide-Stick Cycle Model; interpretations of the genesis of the Boituva, Capivari, Jumirim and Witmarsum deformations; identification of neopaleozoic push moraines; new data about the boulder pavements of Capivari and Jumirim; description of brittle glaciotectonic structures occurrences in Iceland, which where development as consequence of the presence of frozen sediments; structural analyses of the deformations found in Boituva, with the characterization of a landslide process; analyses on the use of structural methods for discrimination between glaciotectônicas deformations and of gravitational mass flows. 


\section{INTRODUÇÃO}

\section{Deformações em rochas do Subgrupo ltararé}

Ocorrências de estruturas de cisalhamento, sob a forma de falhas e dobras, que afetam o substrato de corpos de diamictitos foram constatadas em sedimentos do Subgrupo Itararé de diversas localidades. Canuto (1985, p.125) define uma variedade (litofácies) de diamictito maciço em que um dos critérios de caracterização é a presença de uma zona de contato inferior com falhas inversas e dobras recumbentes nos sedimentos do substrato (variedade C). Esta variedade de diamictito maciço foi interpretada por Canuto (op cit.) como sendo till de alojamento, depositado na base de geleira ativa.

$\mathrm{Na}$ realidade, deformações associadas a diamictitos ou outras litologias do Subgrupo Itararé, por vezes, foram interpretadas por diversos autores, mesmo que de forma equivocada (e.g.: Washburne, 1930 e Martin, 1961), como sendo de origem subglacial. Contudo, só começaram a ser estudadas com mais ênfase há algumas décadas depois da revolução nos conceitos reológicos da interação entre a geleira e os sedimentos inconsolidados subjacentes (e.g.: Rocha-Campos et al., 2000).

Foi apenas no final da década de 70 e início da década de 80 , que se passou a aceitar que os processos de erosão/deposição resultantes do deslocamento de geleiras não são restritos a substratos rígidos (Boulton \& Jones, 1979 e outros trabalhos que se seguiram), como se acreditava anteriormente. Desde então um dos principais objetivos da Geologia Glacial tem sido interpretar as evidências sedimentológicas deixadas pelas antigas geleiras, a fim de que se possa aumentar o conhecimento a respeito da sua natureza. Os padrões de sedimentação subglacial por elas produzidos podem, da mesma forma, serem úteis para o fornecimento de evidências da atuação de processos basais em geleiras e mantos de gelo, uma vez que estes registros são geralmente de fácil acesso, quando comparados com suas contrapartes modernas.

As tentativas para se conhecer as gêneses das formas e estruturas subglaciais têm, não raro, conduzido a hipóteses conflitantes, as quais, a um tempo, não são testáveis nem refutáveis. Consequentemente, tornou-se clara a necessidade de se estruturar arcabouços teóricos adequados, ao abrigo dos quais se pudesse organizar e unificar uma ampla variedade de fatos e hipóteses, de tal forma que fosse possivel entender de que maneira as propriedades físicas do gelo da base das geleiras controlam os processos de erosão, transporte e deposição.

Embora atualmente não se tenha aicançado uma situação de consenso, a origem das estruturas glaciotectônicas tem, em grande parte, sido relacionada a condições reológicas estabelecidas pela interação entre as geleiras e seus substratos consolidados ou inconsolidados que necessitam ser melhor compreendidas. O exame dessas estruturas, à 
luz dos modemos modelos de deformaçäoformação subglacial (e.g: Hart, 1995), tem fornecido importantes dados sobre as condições reológicas e hidrológicas glaciais e suas relações com o comportamento dinâmico dos mantos de gelo. Com efeito, o fato dessas interações poderem produzir feições indicativas reconhecíveis nos sedimentos basais, potencialmente possibilita inferir a natureza e o comportamento dinâmico das geleiras que originaram esses sedimentos, além dos processos sedimentares típicos de ambientes glaciais sob a influência de geleiras temperadas. Entrementes, os modelos reológicos formulados através da caracterização de geleiras recentes e/ou pleistocênicas da Antártica, Europa e América do Norte, com substratos formados por sedimentos inconsolidados, ainda não explicam todos os resultados de recentes experimentos geotécnicos e geofísicos (Tulaczyk et al., 2001). Realmente, no que se refere aos complexos aspectos descritivos e genéticos dessa relação existem atualmente dois modelos reológicos para a interação geleira/substrato: o Modelo do Acamamento Viscoso (Boulton \& Hindmarsh, 1987) e Modelo de Sulcamento (Tulaczyk et al., 2001), além da recente proposta do Modelo do Ciclo de Deslizamento-Aderência (Slip-Stick Cycle, Alley, 2000; Boulton et al., 2001; Bennett, 2003), demonstrando a necessidade de novas pesquisas sobre este assunto.

Outrossim, ao mesmo tempo em que evoluiam e se difundiam os conceitos a respeito de deformaçöes subglaciais em substratos inconsolidados, avultavam-se também as dificuldades para bem compreender a gênese destas ocorrências e como diferenciá-las de outros processos de deformação sin-sedimentares (e.g.: fluxos gravitacionais de massa).

Uma extensão do que foi acima comentado permite considerar que a caracterização de estruturas glaciotectônicas no Subgrupo Itararé poderá contribuir substancialmente para elaboração de novos modelos reológicos a respeito da interação geleira/substrato, embora ainda se sustentem diversas controvérsias envolvendo a discriminação das estruturas glaciotectônicas das decorrentes de fluxos gravitacionais de massa (e.g.: afloramentos de Boituva, Washbume, 1930; Almeida, 1953; Martin, 1964; Rocha-Campos, 1963, 1967; Rocha-Campos et al., 1972; Gama Jr. et al., 1992; e Cerquilho, Rocha-Campos et al., 1981; Gravenor \& Rocha-Campos, 1983; Nagali \& Consoni, 1984; Fulfaro et al., 1984; RochaCampos et al., 1986; Fulfaro et al., 1991; Martini \& Rocha-Campos, 1991; Rocha-Campos et al., 2000). Neste sentido, vale a pena ainda mencionar que durante o avanço de geleiras em ambientes glaciomarinhos (como parece ser o caso do Subgrupo Itararé na maioria dos afloramentos de São Paulo, e.g.: Saad, 1977; Santos, 1979; 1987; Santos et al., 1996), além da possibilidade de ocorrerem estruturas glaciotectônicas nos seus substratos inconsolidados, a alta taxa de deposição de sedimentos nas bordas de bacias locais e a desestabilização da pilha sedimentar ali acumulada podem provocar fluxos gravitacionais de massa, turbulentos e/ou de detritos, à frente das geleiras. Desta forma, em ambientes glaciomarinhos é bem provável que possam ser formadas deformações resultantes tanto da 
ação direta (na base das geleiras) como indireta (na porção frontal) dos corpos de gelo em deslocamento.

Esta complexidade em se definir e caracterizar estruturas glaciotectônicas em sedimentos pré-pleistocênicos, associada à possibilidade de descrever sua gênese no âmbito da modelagem reológica, foram os fatores que motivaram a elaboração deste trabalho. Além disso, estes registros podem também ser úteis para a aferição dos modernos modelos reológicos e hidrológicos da interação geleiras/substratos inconsolidados ou consolidados.

\subsection{OBJETIVO}

Tendo como base os comentários acima, os seguintes objetivos principais nortearam esta pesquisa:

verificar se é possivel aplicar aos sedimentos do Subgrupo Itararé as classificações de estruturas glaciotectônicas normalmente adotadas em estudos sobre deformações em depósitos glaciogênicos do recentes, e definir critérios para classificar as estruturas glaciotectônicas pré-pleistocênicas, visto que os registros destas estruturas presentes na literatura disponivel não discutem a classificação delas quando associadas a sedimentos pré-pleistocênicos;

v verificar qual modelo reológico relacionado às estruturas glaciotectônicas formadas em ambiente subglacial melhor se aplica às deformações neopaleozóicas analisadas e, se possivel, contribuir para o aperfeiçoamento do modelo;

- avaliar como as pretéritas condições hidrológicas controlaram a natureza e a razão da deformação de sedimentos subglaciais;

$>\quad$ interpretar a origem e identificar os ambientes deposicionais específicos de estruturas de deformação registradas nos afloramentos do Subgrupo Itararé analisados; e verificar se é possivel distinguir as estruturas glaciotectônicas das decorrentes de fluxos gravitacionais de massa através de análises estruturais.

\subsection{PLANO DA PESQUISA}

Tendo em vista a problemática anteriormente exposta, considerou-se que as deformações afetando as rochas do Subgrupo Itararé (Neopaleozóico da Bacia do Paraná) poderiam ser enquadradas em duas categorias, de acordo com a sua provável origem:

a) deformações glaciotectônicas (sub- e proglaciais) de reologia rúptil e dúctil de sedimentos inconsolidados; e 
b) deformações adiastróficas, causadas por fluxos gravitacionais de sedimentos não consolidados com reologia rúptil, dúctil ou mesmo fluidal (deslizamentos, escorregamentos, fluxos diversos de massa ou fluidais).

Deformações tectônicas e neotectônicas de reologia rúptil pós-litificação não foram consideradas, pois não geram grandes dúvidas ao tentar diferenciá-las das estruturas glaciotectônicas.

Desta forma, à vista das dificuldades já apontadas em se distinguir, claramente, estruturas correspondentes a cada uma das categorias acima, tornou-se necessário realizar uma revisão de ocorrências atribuíveis, ou, historicamente, atribuídas, a cada uma delas, no sentido de se chegar a uma caracterização estrutural coerente das deformações e desenvolver critérios para a sua identificação.

Esse enfoque levou a uma ampla revisão das informações da literatura e à realização de trabalhos de campo preliminares visando a familiarização com as principais ocorrências conhecidas na Bacia do Paraná, e a busca de outros dados que complementassem o acervo inicial de dados a serem utilizados na pesquisa. Tendo em vista o grande número de afloramentos disponiveis foi necessário um procedimento seletivo e, para tanto, foram utilizados os seguintes critérios para a seleção:

a) Qualidade da exposição (extensão, grau de preservação, etc.). Este critério foi fundamental para o descarte do afloramento de Cerquilho (Rocham-Campos et al., 2000), visto que, embora seja um importante registro a ser considerado (o primeiro trabalho especificamente sobre glaciotectonismo no Subgrupo Itararé), encontra-se intensamente intemperizado e localizado atualmente no meio de um loteamento, o que dificulta o mapeamento dos seus arredores. Adicionalmente, foram também utilizadas as informações fornecidas pelos trabalhos prévios sobre esta localidade, verificando se estes se enquadram no contexto geológico da região do Médio Tietê, como delineado através de dados de subsuperfície (poços de sondagem rasos);

b) Disponibilidade de dados geológicos (estratigráficos, sedimentológicos) prévios ou em condições de serem obtidos;

c) Presença de estruturas de escala variada (milimétricas a métricas);

d) Conhecimento dos condicionamentos estratigráficos/geológicos regionais, no âmbito do Subgrupo ltararé. 


\subsection{CARACTERIZAÇÃO DAS ÁREAS DE ESTUDO}

Em conformidade com os principais objetivos da pesquisa, foram selecionadas as seguintes áreas de estudo (Figuras 1.3.1 e 1.3.2):

1) Deformações glaciotectônicas.

- Afloramentos de Capivari e Jumirim (SP); apresentam estruturas glaciotectônicas subglaciais rúpteis, além de proporcionarem a possibilidade de comparações entre as mesmas, apesar da distância considerável (aproximadamente $40 \mathrm{~km}$, calculado através das coordenadas UTM, Tabela 1.3.1). O afloramento de Capivari localiza-se em um corte de estrada entre os $\mathrm{km} 35$ e 36 da rodovia SP101, nas imediações da cidade homônima. Em Jumirim foram levantadas seções próximas do km 166,6 da Rodovia Marechal Rondon (SP-300) e nos cortes da estrada de ferro da FEPASA, entre os postes 174/10 e 174/12, que se dispõem acima e em paralelo ao intervalo estudado da rodovia.

- Afloramentos na Colônia Menonita de Witmarsum (PR); onde ocorrem prováveis estruturas glaciotectônicas proglaciais (possivelmente, morainas ${ }^{1}$ de empurrão) e diques clásticos de origem glacial. A descoberta dessas estruturas proglaciais trata-se, possivelmente, das primeiras morainas de empurrão em sedimentos pré-pleistocênicos descritas no mundo. Esta localidade encontra-se entre as rodovias BR-277 e BR-376, no município de Palmeira. Mais especificamente, as estruturas proglaciais encontram-se na Chácara Lótus e os diques clásticos ao lado da Companhia de Laticínios Cancela (ver Anexo I).

- Afioramentos de Hagafelisjökull (Islândia); em virtude da possibilidade de uma abordagem contra-atualística, através da comparação de estruturas glaciotectônicas neopaleozóicas brasileiras e análogos recentes de estruturas glaciotectônicas sub-e proglaciais, assim como as implicações do permafrost nas suas gêneses. Este trabalho compreendeu as pesquisas realizadas durante os trabalhos de campo do doutoramento sanduíche, junto à University of Greenwich (Inglaterra), na região próxima ao lago Hagavatn (Islândia) e da geleira Hagafellsjökull-Eystri, uma geleira de escape (outlet glacier) que flui para sul da calota glacial (ice cap) de Langjökull no centro da Islândia.

\footnotetext{
${ }^{1}$ Moraina (moraine), designação dada à feição topográfica derivada da acumulação de material detrítico deposicionado diretamente pela geleira, é, no nosso ponto de vista, equivocadamente traduzida como morena (e.g.: Suguio, 1998), devido ao temor de se adotar um anglicanismo. No entanto, a tradução fonética não se mostrou eficaz, face a existência da palavra com outro significado em português, por isto optou-se pelo termo em português, que se baseia no equivalente inglês.
} 
2) Deformações adiastróficas de sedimentos inconsolidados.

- Afloramento de Boituva (SP); esta localidade foi escolhida devido às controvérsias em relação a sua gênese, visto que as deformações ali ocorrentes já foram alternativamente interpretadas como estruturas glaciotectônicas e fluxos gravitacionais de massa. O afloramento situa-se no $\mathrm{km} \mathrm{0,5}$ da rodovia Vicente Palma (SP-129), que interliga a rodovia Marechal Rondon (SP-300) à cidade de Boituva. Apesar do nome, o afloramento encontra-se no município de Porto Feliz, mas como tem sido tradicionalmente referido na literatura como Boituva, esta denominação será utilizada neste trabalho.

Os afloramentos aqui referidos situam-se em municípios dos estados de São Paulo (Capivari, Jumirim e Porto Feliz) e Paraná (Palmeira, que inclui a Colônia Menonita de Witmarsum), (Figura 1.3.1) e na Islândia (Figura 1.3.2); suas coordenadas UTM (Universal Transversal Mercator) apresentam-se listadas na Tabela 1.3.1.

Tabela 1.3.1 - Coordenadas UTM das principais localidades estudadas.

\begin{tabular}{|lll|}
\hline Afloramento & Coordenadas UTM & Referência Horizontal \\
\hline Boituva (SP) & 0236650 / 7429387 & Córrego Alegre, MG \\
\hline Capivari (SP) & $0253880 / 7458710$ & Córrego Alegre, MG \\
\hline Islândia & & \\
\hline - Moraina de 1890 & $0466028 / 3122949$ & NAD27 - Greenland (Nth. American '27) \\
\hline - Morainas de 1999 & $0466505 / 3123111$ & NAD27 - Greenland (Nth. American '27) \\
\hline Jumirim (SP) & & \\
\hline - Principal & $0215249 / 7443964$ & Córrego Alegre, MG \\
\hline - Estrada de Ferro & $0215212 / 7443911$ & Córrego Alegre, MG \\
\hline - Poço do IG/SMA J-GI-93 & $0214150 / 7444950$ & Córrego Alegre, MG \\
\hline Witmarsum (PR) & & \\
\hline - Pavimento estriado de Witmarsum & $0618431 / 7187746$ & SAD-69 (Sth. American '69) \\
\hline - Paredão Cancela & $0618350 / 7187669$ & SAD-69 (Sth. American '69) \\
\hline - Diamictito Deformado A & $0617929 / 7187082$ & SAD-69 (Sth. American '69) \\
\hline - Diamictito Deformado B & 0618124 / 7187116 & SAD-69 (Sth. American '69) \\
\hline - Diamictito Deformado C & $0618195 / 7187131$ & SAD-69 (Sth. American '69) \\
\hline - Diamictito Deformado D & $0618179 / 7187127$ & SAD-69 (Sth. American '69) \\
\hline - Fazenda Gehard Schoeder & $0617148 / 7187718$ & SAD-69 (Sth. American '69) \\
\hline - Seção Siegber & 0619342 / 7186584 & SAD-69 (Sth. American '69) \\
\hline
\end{tabular}



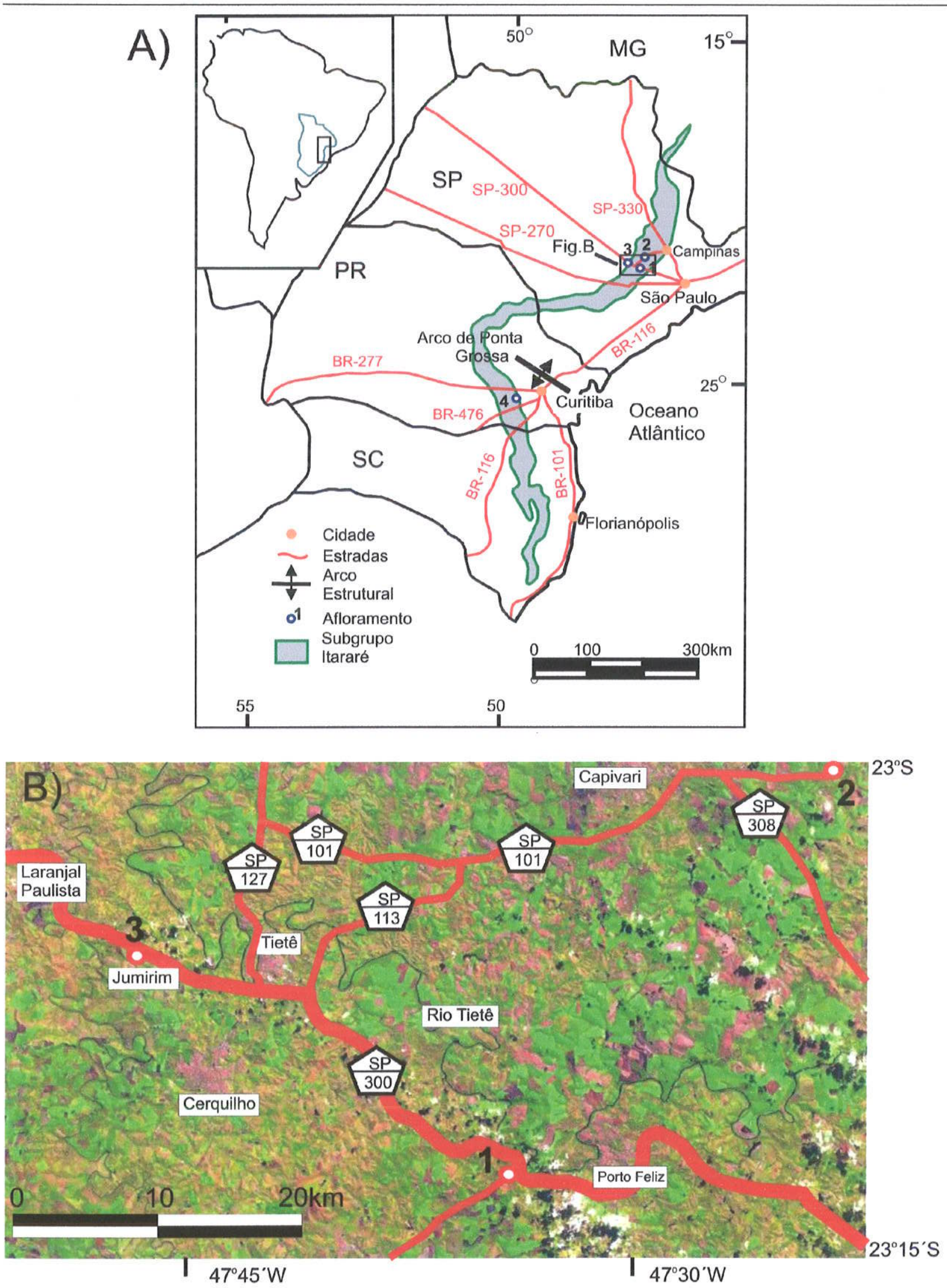

Figura 1.3.1 - Mapa das áreas estudadas no Brasil e afloramentos do Subgrupo Itararé na borda leste da Bacia do Paraná, nos Estados de São Paulo, Paraná e Santa Catarina. Afloramentos: $1=$ Boituva (SP); 2 = Capivari (SP); 3 = Jumirim (SP); e 4 = Colônia Menonita de Witmarsum (PR). A) Localização regional. B) Detalhe da localização dos afloramentos estudados no Estado de São Paulo. As imagens de satélite utilizadas na Figura 1.2.1B foram obtidas através da Embrapa Monitoramento por Satélite (2004). 


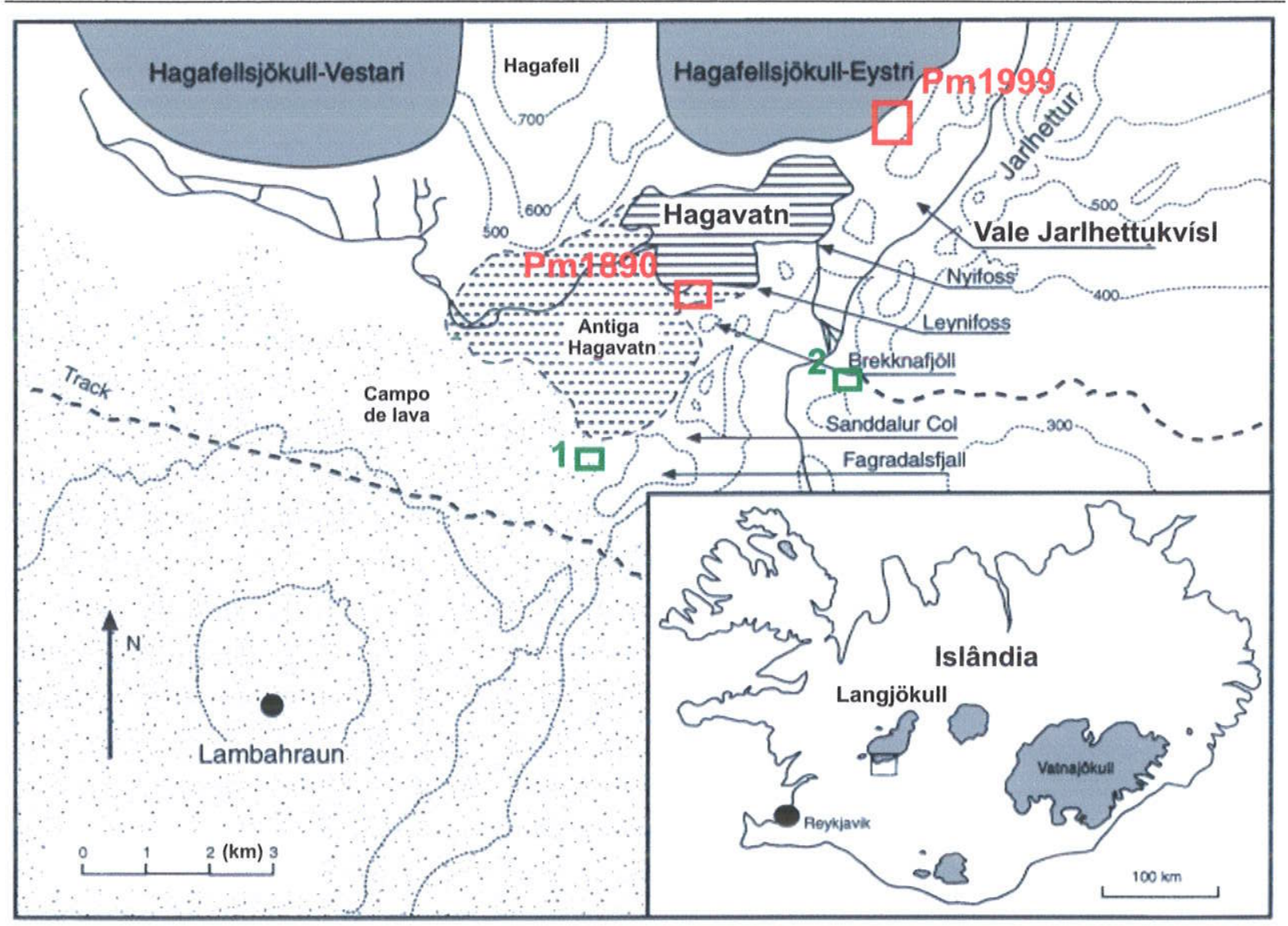

Figura 1.3.2 - Mapa de localização das áreas estudadas na Islândia. Quadrados em verde - locais de acampamento; linhas tracejadas - estradas de terra; área listrada - atual lago Hagavatn; área com pontilhado grosso - antiga abrangência do lago Hagavatn; área com pontilhado fino - campo de lava; área cinza escura - corpos de gelo; quadrado vermelho - locais de estudo das push moraines (morainas de empurrão) de 1890 e 1999, respectivamente Pm1890 e Pm1999.

\subsection{METODOLOGIA}

Nas duas últimas décadas ocorreu uma notável transformação inovadora na metodologia empregada nos estudos de geologia glacial, a qual, tradicionalmente, fundamentava-se quase que unicamente em procedimentos sedimentológicos descritivos. Este desenvolvimento científico, passando de processos unicamente descritivos para métodos qualitativos, caracterizados pela abordagem genética da análise de fácies no âmbito da relação processo/resposta, vem sendo proporcionado pela rápida evolução das técnicas e métodos utilizados (e.g.: métodos de datação, SEM, microtectônica e análises faciológicas). Neste sentido delineia-se, atualmente, uma tendência para uma abordagem metodológica integradora no contexto dos processos sedimentares glaciais e não-glaciais, rematada pelo estudo de parâmetros glaciológicos, geotécnicos e reológicos.

O presente trabalho, portanto, incorpora estas novas tendências nos estudos sedimentológicos e estratigráficos das sequências glaciogênicas neopaleozóicas brasileiras, em particular das estruturas de deformação registradas no Subgrupo Itararé. 


\subsubsection{Análise faciológica}

A conceituação de "fácies" (derivado do latim: face, aspecto, fisionomia, forma, aparência, característica ou condição), adotada neste trabalho, é condizentes com Walker (1992), segundo o qual sintetizaria o conjunto dos diferentes aspectos de uma rocha ou unidade sedimentar analisada que reflete as condições de sua origem e a distingue das demais (Bates \& Jackson,1980). Segundo Walker (op cit.), o termo fácies foi introduzido por Gressly em 1838 e, originalmente, referia-se aos aspectos litológicos e paleontológicos de uma unidade estratigráfica. Posteriormente, incorporou diversos significados e passou-se a questionar se suas atribuições referiam-se à sintese de um conjunto de caracteristica ou a uma parte restrita da unidade estratigráfica analisada. Atualmente, a definição mais usada é a apresentada por Middleton (1978), e corresponde a unidades distinguiveis através de aspectos litológicos, estruturais ou orgânicos, que podem apresentar designações informais ou breves descrições, que contribuam na interpretação do ambiente deposicional. Consequentemente, em sedimentologia, a acepção genética prevalece atualmente com atribuições restritivas, em que a fácies seria uma unidade fundamental de um sistema deposicional. Na realidade, as fácies podem ser definidas em diversas escalas e, nesse processo, seu reconhecimento e caracterização são limitados pelo tempo de estudo, pela qualidade do afloramento e a quantidade de informações disponiveis, condições estas determinantes para a quantidade de subdivisões.

As análises das relações entre as fácies permitem estudar as sequências verticais através de métodos mais sofisticados como, por exemplo, o da Análise de Cadeia de Markov, a qual, em essência, é a aplicação da Lei de Walter de Correlação de Fácies (Walker, 1992). Caso se verifique que uma sequência vertical de fácies apresenta uma variação restrita de interrelação, após a caracterização das fácies sedimentares, é possivel agrupá-las em associações faciológicas coerentes e geneticamente compativeis, denominadas associação de fácies (Hachiro, 1991). Estes dados devem, em uma primeira etapa, ser interpretados em termos de processos deposicionais e erosivos, para só então estruturar um arcabouço lógico que explique as transições verticais e horizontais das fácies. Logo, uma sequência repetitiva de fácies $A$ a $E$, por exemplo, pode ser referida como Associação de Fácies 1. Como elegantemente demonstrou Anderton (1985), esta é, normalmente, a chave para a interpretação faciológica, e é auxiliada pela presença de fácies contendo feições diagnósticas de ambientes especificos. Estas associações também são extremamente úteis ao se descrever afloramentos cujas diferenças entre as fácies ultrapassam nossa habilidade em distingui-las (Walker, 1992).

Cabe destacar, ainda, que uma ou mais características da fácies pode se modificar graduaimente, verticalmente ou lateralmente, caracterizando uma sucessão de fácies (e.g.: um arenito com granocrescência ascendente, coarsening-upward). Diferentemente das 
associações de fácies, que constituem agrupamentos de fácies com atributos intimamente relacionados.

Um modelo de fácies pode ser definido como um resumo de um determinado sistema deposicional. Segundo Walker (1992), o grande dilema na proposição de um modelo deposicional é distinguir os aspectos locais e gerais, além do que os modelos devem agir como: norma, possibilitando comparações; arcabouço e guia para futuras observações; prenunciador de uma nova situação geológica; e integrador de dados de sistemas deposicionais que o represente. Os modelos físicos, embora atraentes pela relativa simplicidade dos paradigmas idealizados para comparações, possuem reais limitações. Enquanto que o processo é definido pelo ambiente, o produto deposicional é igualmente determinado pela natureza do sedimento fornecido ao ambiente, fomecimento este caracterizado como uma variável independente. Desta forma, a grande variabilidade nas características das fácies resultantes é regra e não a exceção.

No que se refere aos sedimentos glaciogênicos, as modelagens de fácies e estrutural fazem uso dos análogos modernos que são baseados em modelos físicos e matemáticos das geleiras atuais. Desta forma, o presente estudo faz uso deste tipo de análise, pois, utilizando os dados levantados em campo e/ou obtidos através de outros métodos de estudo (e.g.: análises estruturais e de fábrica), torna-se possivel cotejar os idealizados comportamentos dinâmicos de geleiras de diferentes épocas, que serão úteis para a elaboração de um modelo consistente com os processos glaciotectônicos subglaciais paleozóicos do Subgrupo Itararé e, adicionalmente, como estes se diferenciam dos eventos atectônicos e tectônicos.

Trabalhos de campo requerem que o estabelecimento de hipóteses de trabalho seja materializado através da elaboração de modelos, os quais, após verificação e teste de campo, possam ser rejeitados ou aceitos como úteis à pesquisa. Um modelo faciológico glaciogênico aceitável constitui, em seu sentido amplo, um sumário desse ambiente deposicional especifico (ou subambiente) ou um grupo de ambientes (ou subambientes) estreitamente relacionados.

O modelo deve combinar todas as informações derivadas do campo, o que implica que os modelos glaciogênicos devem dizer respeito não somente às áreas junto a uma geleira $e$ aos processos ali ocorrentes, mas também às áreas no topo, no interior e, principaimente, de acordo com o tema do presente projeto, sob essa geleira. Contudo, como demonstra a bibliografia especializada mais modema, não existem, ainda, métodos perfeitamente acabados e adequados para o estudo de processos sedimentares ocorrentes sob e no interior das geleiras. Consequentemente, e em função de seus matizes variegados, os modelos glaciogênicos incluem, via de regra, um pouco mais de incertezas do que os 
modelos de outros ambientes sedimentares. São, não obstante, ainda extremamente úteis para auxiliar a interpretação paleoambiental.

Desta forma, no estudo das sucessões sedimentares nas áreas selecionadas buscouse a identificação de fácies sedimentares caracterizadas primariamente por seus atributos litológicos (granulométricos, composicionais e cor), estruturas sedimentares e, quando presentes, vestígios paleontológicos, e, posteriormente, dependendo das relações entre as fácies, o estabelecimento de algumas associações faciológicas. As análises faciológicas foram realizadas paralelamente aos estudos estratigráficos, sendo detalhadas de acordo com o reconhecimento dos principais eventos sedimentares, a partir do arcabouço estratigráfico.

Quando as fácies tornam-se complexas e encerram vários tipos de estruturas sedimentares, é comum, ao denominá-las, atribuir-lhes uma designação de letras ou números. Tal procedimento foi inicialmente proposto por Miall (1978) para descrever complexos pacotes de sedimentos produzidos por rios entrelaçados, e posteriormente estendido por Eyles et al. (1983) para a interpretação de diamictitos glaciais e sequências de diamictitos. Embora esta proposta de tipos de litofácies e perfis verticais tenha conduzido à adoção de esquemas descritivos de litofácies para muitas sequências de estratos resultantes de diferentes processos em ambientes muito variados, muitos dos seus aspectos e aplicabilidade são ainda controvertidos no que se refere a sedimentos glaciogênicos e, portanto, não foram adotados neste estudo.

Os levantamentos estratigráficos e faciológicos consistiram na descrição detalhada dos afloramentos e na elaboração de seções e perfis locais. As ilustrações das seções expostas enfatizaram o acompanhamento das feições sedimentares, ou seja, a identificação dos contatos, geometria extema dos depósitos, extensão lateral e geometria interna. Dependendo da qualidade dos afloramentos, estes levantamentos foram realizados a partir de coberturas fotográficas. Em muitos casos, além do desenvolvimento de painéis fotográficos com filmes coloridos ou fotos digitalizadas com alta resolução $(2048 \times 1536$ pixeis) e qualidade padrão ou fina, foram confeccionados mosaicos de fotos instantâneas (Polaroid), permitindo desenhar, no campo, sobre estas fotos, as estruturas visualizadas, que nem sempre estão nitidas no levantamento fotográfico.

Esta documentação dos aspectos geométricos externos e o reconhecimento dos padrões de associações de fácies e suas relações internas decorre da importância do controle lateral e das superfícies de descontinuidades para análises faciológicas. Segundo Miall (1985), esta metodologia tem sido reconhecida como arquitetura deposicional ressaltando o arcabouço tridimencional das fácies. 


\subsubsection{Análise Granulométrica}

Nas análises granulométricas foram utilizados dois métodos: a pipetagem tradicional e a dispersão a úmido. A comparação dos dados obtidos através destes dois procedimentos visou verificar a eficácia do Hydro 2000 , equipamento empregado no segundo método.

$O$ procedimento analítico de pipetagem seguiu o protocolo padrão utilizado pelo Laboratório de Sedimentologia do Departamento de Geologia Sedimentar e Ambiental do Instituto de Geociências da Universidade de São Paulo. Os resultados do procedimento analítico foram digitalizados em planilhas eletrônicas para cáiculo da curva acumulativa, histograma e os parâmetros estatísticos da distribuição granulométrica (diâmetro médio, desvio padrão, assimetria e curtose).

A unidade de dispersăo a úmido (Hydro 2000) é usada para caracterização granulométrica de partículas em meio líquido. Para a realização da dispersão na unidade Hydro, utiliza-se um béquer de vidro com capacidade para 600 a $1000 \mathrm{ml}$, que faz o papel de recipiente de dispersão, um agitador a hélice, uma bomba de água e duas mangueirasconduto, uma para levar o liquido até a janela da célula e outra para retorná-lo ao béquer.

A presença de bolhas de ar no líquido (água mais partículas) compromete a qualidade do ensaio, produzindo falsa obscuraçãó ${ }^{2}$. A eliminação prévia das bolhas deve ser feita através do acionamento do ultra-som, com intensidade mínima de 1000 ua (unidades de agitação, padrão internacional de fabricação). $O$ defloculante deve ser adicionado somente após encerrado o uso do ultra-som e informado na entrada de dados do software Mastersizer 2000. Em seguida, adiciona-se a amostra, em quantidade suficiente para perfazer de 50 mil a 100 mil partículas. A adição da amostra deve ser feita na forma de polpa (misturada em água destilada e deionizada), para prevenir problemas de flutuação de particulas devido à tensão superficial da água. Deve também ser executada de modo gradual, até que a obscuração atinja a faixa entre $10 \%$ e $20 \%$, com intensidade da luz entre $70 \%$ e $82 \%$.

Uma vez introduzida a amostra na concentração adequada, a medida já pode ser feita. Segundo padrões intemacionais de granulometria a laser, estabelecidos com base estatística, o número mínimo de varreduras (leituras de medida) é de 1200. Acima deste número a precisão da medida não melhora $e$, portanto, este pode ser considerado um número ideal em termos de relação custo/benefício. O Ma/vem Mastersizer tem capacidade para realizar no minimo 100 varreduras por segundo. Desse modo, o tempo de varredura ideal é de $12 \mathrm{~s}$.

\footnotetext{
${ }^{2}$ obscuração é a medida da taxa de dispersão dos raios pelas partículas sólidas, indicada pela tela de controle do software.
} 
Como o laser realiza uma leitura bidimensional dos grãos que passam pelo feixe, podem ocorrer erros de classificação em amostras ricas em argilo-minerais, que possuem forte tendência de atração eletroquímica superficial, agrupando mais de um mineral placóide. Estas partículas agrupadas (floculadas) são interpretadas pelo software como um grão único de dimensão maior do que as partículas livres. Devido a este motivo, evitou-se a utilização deste método nas amostras de argilitos, folhelhoes, ritmitos e das matrizes de diamictitos argilosos.

\subsubsection{Análise de fábrica de clastos}

A fábrica (fabric, em inglês) ou, segundo derivação do francês, petrofábrica (petrofabrique), consiste na disposição espacial dos elementos componentes de uma rocha (Suguio, 1998). Diferentemente das rochas metamórficas, que exibem uma fábrica secundária (ou de deformação), as rochas sedimentares normalmente apresentam uma fábrica primária (ou de deposição). Quando se constata a existência de uma orientação, define-se que a rocha possui uma fábrica isotrópica (Figura 1.4.3.1B e 1.4.3.1C), em contraposição com uma rocha com elementos dispostos caoticamente, cuja denominação seria uma fábrica anisotrópica (Figura 1.4.3.1D).

Em situação ideal, os mergulhos dos eixos maiores dos clastos contidos nas camadas analisadas podem ser medidos e os resultados podem ser projetados em diagramas para se determinar a existência ou não de orientação preferencial (Suguio, 2003). Para esta finalidade, utilizam-se, comumente, os diagramas de Schimidt-Lambert ou de rosáceas. Neste estudo deumse preferência ao diagrama de rosáceas para ilustrar as fábricas obtidas. Muitas vezes, a orientação preferencial é pouco nítida, necessitando que a sua determinação seja feita através de métodos estatísticos, e desta forma, no presente trabalho, o cálculo da orientação preferencial foi feito através da direção do vetor médio (mean vector direction), ferramenta estatística do shareware StereoNett (versão 2.46) ${ }^{3}$.

Segundo Collinson \& Thompson (1989), fábricas bem organizadas sugerem que os clastos estavam livres para se moverem individualmente $e$ independentemente uns dos outros e que foram seletivamente incorporados ao acamamento quando então se depuseram em posição estável. Teoricamente, a atitude final de cada particula é uma resposta a uma combinação de forças que atuaram durante e logo após a sua deposição. A gravidade tende manter a particula na sua posição deposicional original e a força de arrasto do fluxo tentará fazer com que o clasto role, principalmente no caso do eixo maior estar com orientação transversal ao sentido do fluxo do fluido.

${ }^{3}$ StereoNett (2.46, shareware) - Johannes Duyster, Institut für Geologie, Ruhr-Universität-Bochum, Alemanha, http://homepage.ruhr-uni-bochum.de/Johannes.P.Duyster/stereo/stereo1.htm. 
A) Nomenclatura axial dos clastos
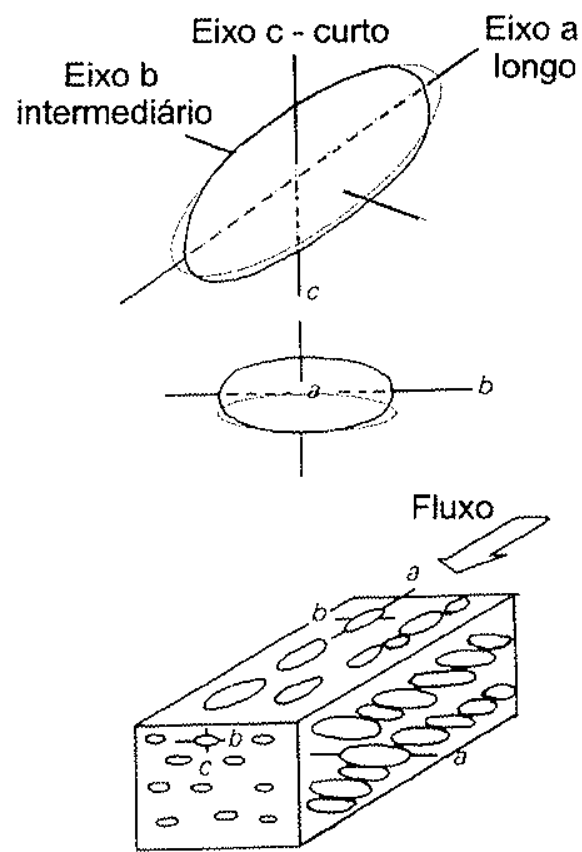

C) Fábrica isotrópica - eixos $a(p), a(i), b(t)$
B) Fábrica isotrópica - eixos $a(t), b(i), b(p)$

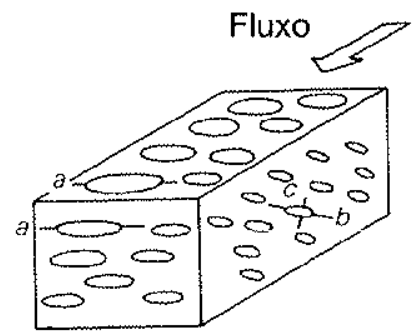

$t$ - transversal

i - imbricado

p - paralelo

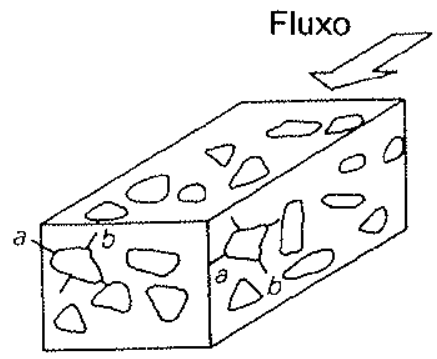

D) Fábrica anisotrópica

Figura 1.4.3.1 - Nomenclatura axial dos clastos e os principais tipos de fábricas (Collinson \& Thompson, 1989).

Situação 1

Eixo a transversal

(e.g.: Transporte fluvial)

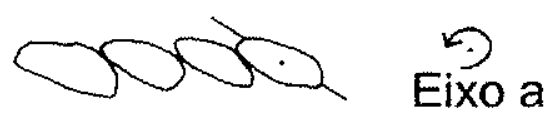

$$
\begin{aligned}
& a(t) \quad b(i) \\
& t=\text { transversal } \\
& i=\text { imbricado }
\end{aligned}
$$

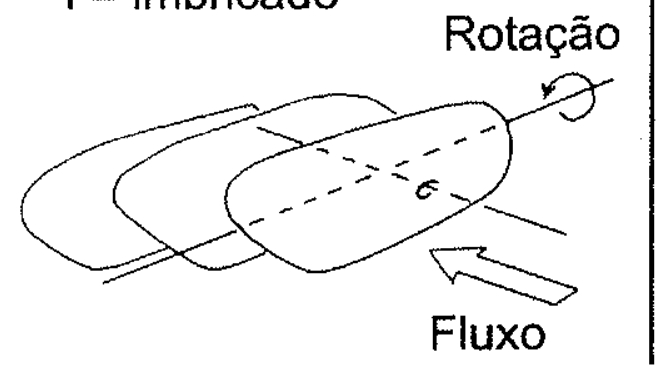

Situação 2 Eixo a paralelo (e.g.: Transporte subglacial)

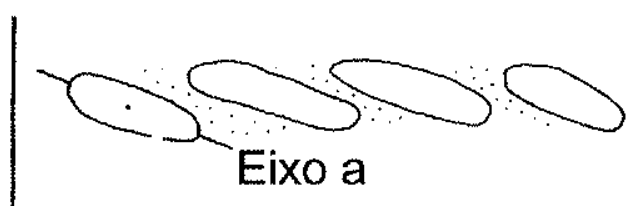

$a(p), a(i)$

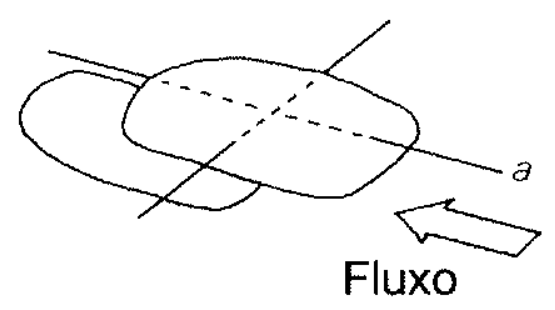

Figura 1.4.3.2 - Principais tipos de imbricações, com diagramas demonstrando a disposição espacial dos eixos da fábrica dos clastos em duas e três dimensões (adaptado de Collinson \& Thompson, 1989). 
A análise da fábrica é comumente executada quando há um enriquecimento de clastos discóides (eixos $a \approx b>c$ ) e alongados (eixos $a>b>c$ ) em uma rocha rudácea, formando inclusive imbricações de clastos. Contudo, neste caso, podem ocorrer duas situações: na primeira (Figura 1.4.3.2), o eixo a (o eixo com comprimento maior, Figura 1.4.3.1A) encontra-se na direção transversal à direção de mergulho do clastos e o eixo $\underline{\mathrm{b}}$ (o

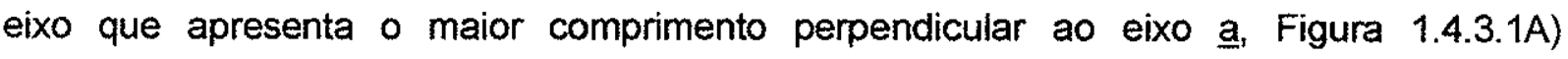
apresenta-se paralelo; no segundo caso (Figura 1.4.3.2), o eixo b é transversal e o eixo a é paralelo ao mergulho do clasto. Exemplos da primeira variante ocorrem preferenciaimente em condições fluviais, onde o sentido da corrente é oposto ao sentido do mergulho (a montante) dos eixos $\underline{b}$ dos clastos. Em contrapartida, quando o eixo a é paralelo ao mergulho do clastos, um possivel exemplo seria o transporte subglacial, sendo o sentido do mergulho do eixo a dos clastos opostos ao sentido do deslocamento da geleira e/ou do fluxo gravitacional de massa. No entanto, como comentado por Collinson \& Thompson (1989), a utilização desses tipos de dados deve ser feita com muita cautela e critério, já que os clastos, em avalanches, por exemplo, podem apresentar o eixo a mergulhando paralelamente e no mesmo sentido que o deslocamento gravitacional de massa, ou seja, com sentido oposto à imbricação desenvolvida na maior parte desse tipo de fluxo de sedimentos. Segundo Drewry (1986), apesar dos inúmeros trabalhos apresentados nos últimos 100 anos sobre fábricas em sedimentos glaciais, existe ainda muita controvérsia quanto a sua aplicabilidade para determinação do sentido de fluxos gravitacionais e de deslocamento de geleiras. Com efeito, a influência no desenvolvimento da fábrica atribuída ao formato dos clastos constitui um fator ainda não totalmente entendido $e_{1}$ como menciona, por exemplo, Drake (1974), os clastos com formato de bastão, ou em ponta, normalmente encontravam-se mais alinhados paralelamente à direção da geleira, do que os clastos com formas esféricas ou discóides.

Neste trabalho, procedeu-se uma análise das fábricas dos clastos de diamictitos de Capivarti e Jumirim. Segundo Collinson \& Thompson (1989), a fábrica de clastos em rochas paraconglomeráticas, como os diamictitos, é de difícil interpretação, apesar de serem comumente usadas para determinar a orientação imposta pelo mecanismo de transporte e diferenciar os diamictitos de origem glacial (tills), dos decorrentes de fluxos de massa, ou mesmo para discriminar diferentes tipos de tills (e.g.: till de alojamento subglacial, de till supraglacial), através da caracterização das fábricas glacigênicas (Dowdeswell et al., 1985; Dowdeswell \& Sharp, 1986). Embora muitos tills apresentem a orientação do eixo maior dos clastos paralela ao deslocamento do fluxo de gelo, os padrões raramente são bem definidos, fato que dificulta a sua interpretação.

Merece, também, ser destacado que, embora a análise da fábrica dos clastos seja um método que pode indicar a orientação de deslocamento do agente de transporte e 
deposição dos clastos, o desconhecimento do controle exercido pelo ambiente e pelos processos deposicionais, bem como os efeitos da compactação pós-deposicional, colocam em risco o uso irrestrito deste método. Consequentemente, faz-se necessário considerar que a análise da fábrica, neste trabalho, visa, apenas, identificar de forma aproximada a orientação preferencial destes clastos, sem, contudo, determinar como precisos os valores obtidos.

\subsubsection{Análise Estrutural}

Os levantamentos das estruturas consistiu no reconhecimento, descrição, classificação, esquematização e determinação dos elementos estruturais (e.g.: eixos, flancos, planos axiais, lineações, clivagens, foliações, planos de falha, de fratura e de juntas, entre outros elementos), visando sempre a obtenção de indicadores cinemáticos, quanto factiveis. Infelizmente, devido à qualidade dos afloramentos e as litologias envolvidas, nem sempre foi possivel reconhecer bons indicadores cinemáticos de algumas estruturas (e.g.: estrias em planos de falhas); contudo, em muitas situações, o sentido de deslocamento foi determinado através do reconhecimento de elementos deslocados ou de dobras de arrastro. Os dados estruturais foram medidos principalmente através da bússola modelo Gekom da Breithaupt Kassel (tipo Clar) e, em alguns casos, também foram utilizadas bússolas do tipo Brunton. Algumas vezes, após a leitura da direção das estruturas analisadas com a bússola Clar, foi utilizada a bússola Brunton para as medidas das inclinações, haja vista que o clinômetro destas bússolas faz leituras com erro de até $1^{\circ}$ (um grau), enquanto que as Gekom apresentam maior imprecisão ( $5^{\circ}$, cinco graus).

Para os tratamentos $e$ análises dos dados estruturais através de projeções em estereogramas adotou-se o diagrama de Schimidt-Lambert, hemisfério inferior, $e$ os programas TectonicsFP (versão demo) ${ }^{4}$ e StereoNett (versão 2.46), procurando sempre ter cuidado no formato com que os dados são inseridos nos programas. O objetivo deste tipo de análise é diagnosticar a disposição espacial dos elementos estruturais associados a cada deformação. Assim, através das análises em estereogramas dos elementos estruturais, é possivel incorporar as interpretações a respeito do comportamento cinemático das sequências analisadas. Em termos de estilos estruturais, as posições no espaço dos eixos principais de deformação, quando relacionados às falhas, podem estar associadas a três situações extremas, sem considerar as situações intermediárias (Figura 1.4.4.1): 1) $\sigma_{1}$ vertical, $\sigma_{2}$ e $\sigma_{3}$ no plano horizontal, caracterizando uma falha normal, em estilo distensivo; 2) $\sigma_{3}$ vertical, $\sigma_{1}$ e $\sigma_{2}$ no plano horizontal, caracterizando uma falha reserva ou acavalada (dependendo da inclinação do plano de falha), em estilo compressivo; e 3) $\sigma_{2}$ vertical, $\sigma_{1}$ e $\sigma_{3}$ no plano horizontal, caracterizando uma falha direcional, em estilo transcorrente.

\footnotetext{
${ }^{4}$ TectonicsFP (versão demo 1.6.1155-DEM) - Copyright @ 1996-2000, Franz Reiter \& Peter Acs, http://homepage.uibk.ac.at/homepage/c715/c71508/.
} 
A)
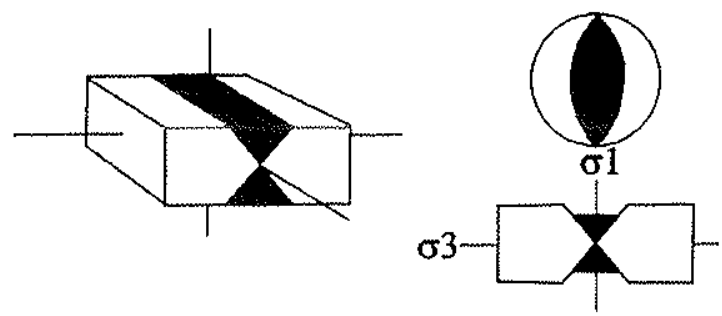

B)

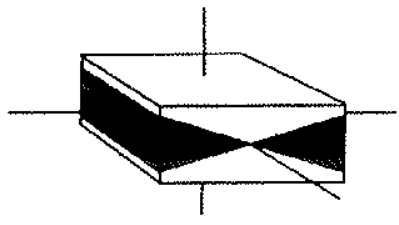

C)

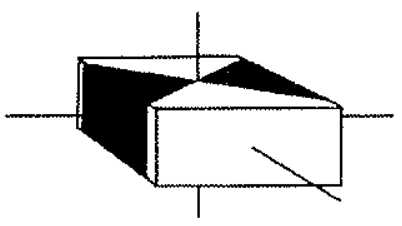

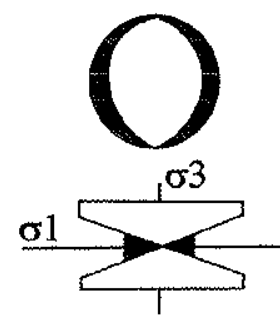

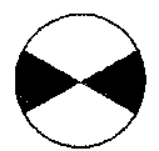

$\sigma 2$

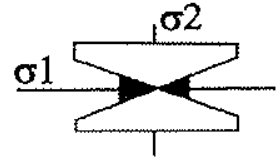

Figura 1.4.4.1 - Orientação de falhas com relação aos eixos principais de deformação. A) falhas normais; B) falhas reversas; C) falhas transcorrentes, (Park, 1989).

$\mathrm{Na}$ determinação dos esforços tectônicos ou atectônicos (giaciotectônicos) geradores dos padrões de fraturamento, por exemplo, ou seja, na identificaçäo dos campos de tensões, procurou-se identificar a correta individualização e ordenação cronológica dos conjuntos de estruturas analisadas, além da ordenação estratigráfica rigorosa dos sedimentos estudados, para melhor aplicação de modelos de interpretação.

Com relação às análises de sistemas de juntas e fraturas, visando a definição dos esforços geradores, atentou-se para seus reais significados, devido às possiveis interpretações controversas quanto à natureza (de extensão, cisalhamento ou híbridas) e ao fato de poderem estar relacionadas a múltiplas fases (Hancock \& Engelder, 1989). No caso de juntas ou fraturas de extensão, o eixo de extensão máxima $\left(\sigma_{3}\right)$ orienta-se perpendicularmente ao plano da estrutura. Já no caso de juntas ou fraturas de cisalhamento, ocorrem famílias conjugadas, estando o eixo de compressão máxima $\left(\sigma_{1}\right)$ localizado na bissetriz do ângulo agudo formado pelos planos conjugados.

Em muitos casos, também fez-se uso das ferramentas estatísticas dos programas TectonicsFP e StereoNett. Nas análises sobre as fábricas dos clastos e as fraturas glciotectônicas, por exemplo, foram usados diagramas de Rosáceas (Rose diagrams), que é um tipo de representação gráfica de frequência direcional de elementos lineares (e.g.: fábricas de clastos) e planares (e.g.: fraturas), (Suguio, 1998). Conforme já mencionado no tópico sobre as análises de fábrica, outra ferramenta estatística utilizada foi a direção do 
vetor médio (mean vector direction) do StereoNett, que, conforme o próprio nome indica, calcula a direção do vetor que representa a média dos elementos lineares analisados. Nos estudos sobre dobras cônicas foi aplicado o cálculo dos autovetores, que visa a obtenção de

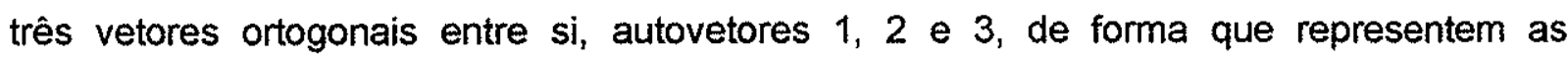
concentrações máxima, intermediária e mínima, respectivamente. No caso das dobras cônicas, os pólos dos planos obtidos nos flancos das dobras formam uma guirlanda máxima, e, assim, os autovetores 1 e 2 têm que estar contidos nesta guirlanda. Consequentemente, - autovetor 3 coincidirá com o eixo da dobra, podendo ser usado para este fim, visto que em dobras cônicas o eixo da dobra é o pólo da referida guirlanda máxima. Outra finalidade dos autovetores foi nas análises conjuntas de duas famílias de fraturas (e.g.: fraturas conjugadas), visto os valores obtidos do autovetor principal (autovetor 1) coincidirem, em muitos casos, com a direção do esforço máximo (o eixo de compressão máxima, $\sigma_{1}$ ), enquanto que o autovetor 3 representará o esforço intermediário $\left(\sigma_{2}\right)$, visto que, em fraturas conjugadas, a direção com menor concentração de vetores coincide com este esforço.

\subsubsection{Outras atividades}

As atividades de escritório compreenderam a montagem de seções e perfis estratigráficos levantados no campo, fotointerpretação detalhada e levantamentos bibliográficos. As atividades de laboratório consistiram em descrições de seções delgadas.

Visando fornecer subsidios para um bom desenvolvimento do tema e atualização dos conhecimentos, foi dada ênfase à constante consulta bibliográfica. Esta atividade contou não apenas com uma extensa revisão bibliográfica, principalmente sobre glaciotectonismo, como também, especificamente, sobre as ocorrências de estruturas tidas como glaciotectônicas registradas no Subgrupo Itararé, assim como em outras unidades geológicas brasileiras. Este levantamento contou com a contribuição de pesquisadores internacionais (e.g.: Matthew R. Bennett da University of Boumemouth, Inglaterra; Slawek M. Tulaczyk, University of Califórnia, EUA; Chirs D. Clark, University of Sheffield, Inglaterra; Frederik M. van der Wateren, Vrije Universiteit, Holanda; Sjoerd J. Kluiving, University of Alabama, EUA; \& James F.P. Cotter, University of Minnesota, EUA), e possibilitou a compilação de um bom acervo bibliográfico e de conhecimentos.

Além dos métodos já citados, também foram tentativamente empregados dois métodos geofísicos: o GPR (Ground Penetrating Radar) e o WARR (Wide Angle Reflexion and Refraction). Inicialmente estes dois aparelhos foram utilizados no afloramento de Capivari com o auxílio do Prof. Dr. Jorge Porsani (IAG-USP). Infelizmente, estes equipamentos não se mostraram eficazes na determinação da continuidade lateral das feições geométricas relacionadas aos pavimentos de clastos e às deformações, devido a grande concentração de minerais argilosos. Na Islândia, vislumbrou-se a possibilidade de 
utilizar o GPR para determinar, de maneira indireta, a forma das deformações glaciotectônicas das morainas de empurrão. Contudo, novamente, a experiência foi frustrada, pela inutilização dos aparelhos. Embora essas ocorrências tenham prejudicado os estudos geofísicos, foi possível levantar, na Islândia, um perfil geofísico de baixa qualidade, mas que, mesmo assim, demonstrou algumas feições de arrastro típicas de morainas de empurrão. 


\section{TRABALHOS ANTERIORES NAS ÁREAS ESTUDADAS}

\subsection{SUBGRUPO ITARARÉ}

O Subgrupo Itararé, unidade estratigráfica neopaleozóica da Bacia do Paraná, que expõem-se nas áreas brasileiras estudadas, compõe-se basicamente de rochas clásticas representadas por arenitos, argilitos, siltitos, ritmitos, folhelhos, diamictitos e conglomerados, alem de poucos registros de rochas carbonosas, na forma de leitos de carvão. A litologia mais comum é o arenito, cuja granulação varia de muito fina a grossa, frequentemente feldspático, em geral mal selecionado, com matriz síltico-argilosa e cores claras variando entre rosadas, amareladas e esbranquiçadas. Com relação às estruturas sedimentares, os arenitos são comumente maciços ou apresentam estratificações cruzadas tangenciais e acanaladas, além de estratificações do tipo "hummockys", estratificações gradativas e marcas onduladas. Entre as rochas clásticas pelíticas, destacam-se as estruturas maciças, as laminações plano-paralelas e cruzadas de pequeno porte, as estruturas deformadas, gradativas e de sobrecarga, além de pistas de organismos e concreções. Os diamictitos, por sua vez, apresentam estrutura normalmente maciça, embora localmente apresentem estratificações incipientes e deformações, matriz arenosa a argilosa, contendo clastos dispersos, que variam de milimétricos a métricos (além de raros decamétricos) de litologias variadas, tais como granito, gnaisse, quartzito (raros aroxeados), arenitos, filitos, entre outros, sendo que alguns facetados e/ou estriados.

Clastos facetados e/ou estriados são considerados como uma das evidências de filiação glaciogênica desta unidade litoestratigráfica, embora não seja esta a única. A caracterização da influência de eventos glaciais na deposição desta unidade se deve a ocorrência de: pavimentos ou superficies ${ }^{5}$, simples ou múltiplas (Figura 2.1.1), estriadas e/ou sulcadas, com raras marcas em crescente; pavimentos de clastos; "rochas moutonnée ${ }^{6 n} ;$ pseudomorfos de cunhas de gelo; estruturas glaciotectônicas; clastos caídos (Figura 2.1.2), depósitos de chuva de detritos provenientes de icebergs, entre outras ocorrências.

Em termos geotectônicos verifica-se que com a aglutinação final das placas tectônicas, no Carbonifero, e formação do continente Gondvana, desenvolveu-se o arcabouço tectônico da Bacia do Paraná com os limites estruturais atuais, estabelecendo-se o eixo deposicional da bacia entre os alinhamentos de São Jerônimo-Curiúva e do Rio Tietê (Saad, 1977; Fúlfaro et al., 1982). Contudo, anteriormente, já no pré-Devoniano, a área da

\footnotetext{
${ }^{5}$ Diferem-se quanto a sua formação, sendo o termo pavimento aqui utilizado quando a rocha estriada e/ou sulcada estava consolidada, enquanto que superfície para os caso em que o substrato estava inconsolidado ou "mole" (soft).

${ }^{6}$ Argumenta-se que a forma mais correta para designar a rocha moutonnée de Salto, seja como estruturas glaciais do tipo whale back, devido a presença de estrias em toda a sua extensão, como um dorso de baleia (Rocha-Campos, informaçäo verbal).
} 


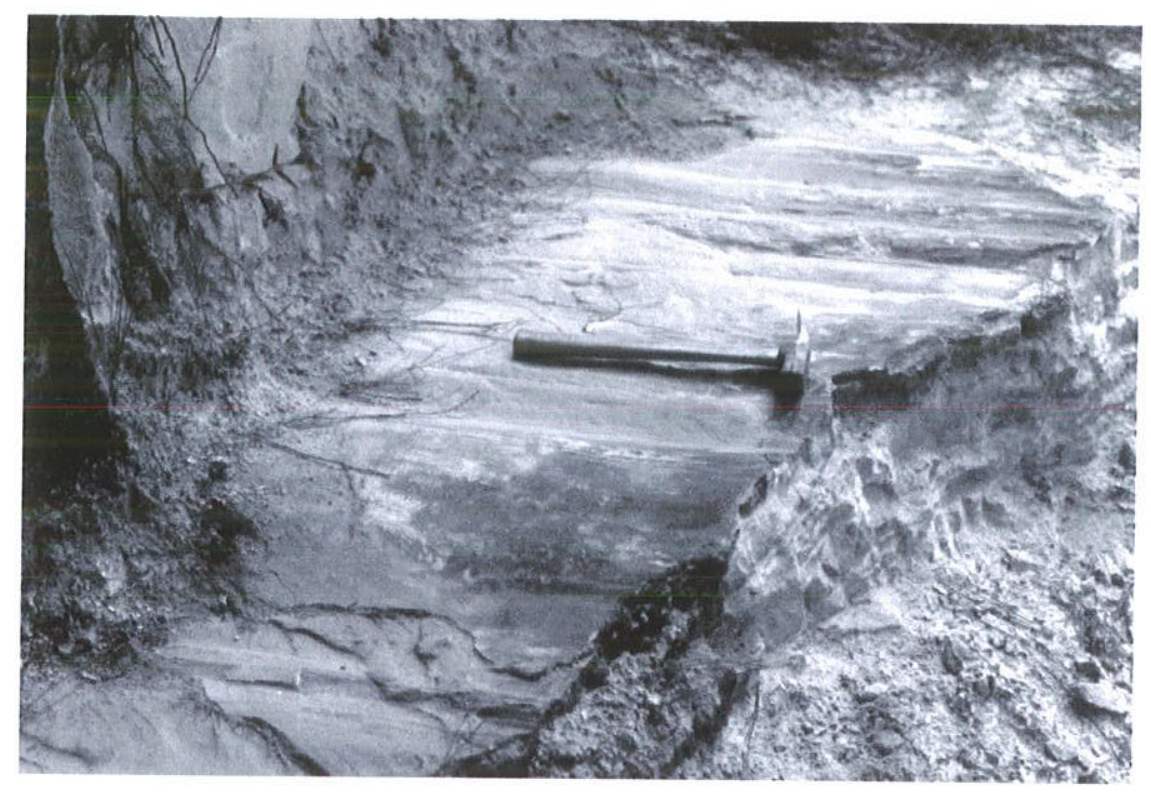

Figura 2.1.1 - Superfície glacial múltipla, estriada e sulcada, de Palmeira (PR), na BR-277. Infelizmente, este importante sítio geológico foi parcialmente destruído ao ser utilizado como área de empréstimo de areia para as obras na rodovia. Foto de Ivo Trosdtorf Junior. Escala: martelo geológico.

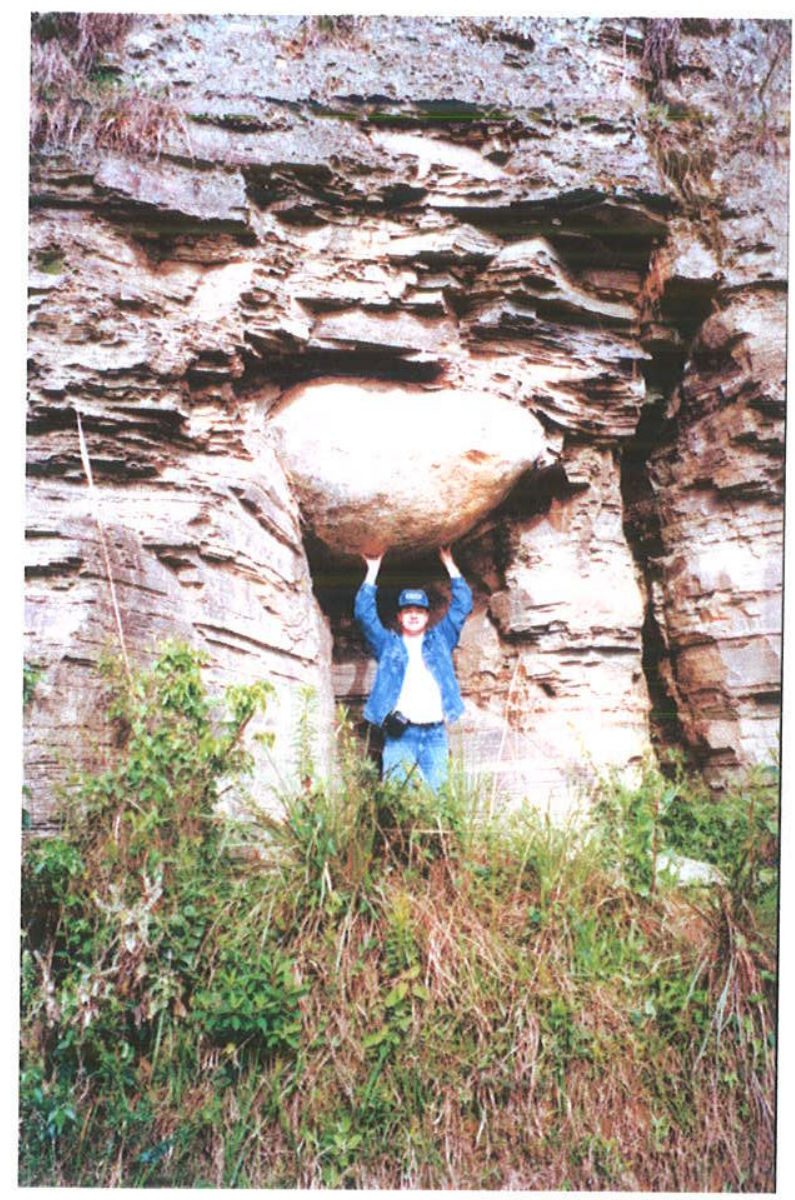

Figura 2.1.2 - Matacão caído em folhelhos glaciomarinho em Rio Negro (PR). Escala: pessoa com $1,80 \mathrm{~m}$ de altura. 
bacia apresentava-se grandemente arrasada pela erosão, apresentando-se no geral plana e desprovida de grandes depósitos conglomeráticos associados. No intervalo de tempo compreendido entre o término da sedimentação devoniana e o início da deposição do Subgrupo Itararé, o processo erosivo marginal foi retomado, provocando um arrasamento complementar do embasamento pré-cambriano e devoniano circundante sobre os quais se assentaram as geleiras que atingiram a Bacia do Paraná.

Entre as principais estruturas tectônicas que influenciaram a deposição do Subgrupo Itararé, destaca-se o Arco de Ponta Grossa, que é interpretado como tendo sido gerado principalmente no Mesozóico, associadamente ao vulcanismo básico juro-cretácico (Santos, 1987). Contudo, diversos autores apontam evidências de comportamento tectônico ativo pré-Mesozóico na região. Mapas de isoespessura total do Subgrupo Itararé (e.g.: Northfleet et al., 1969) ou de intervalos cronoestratigráficos da unidade (Santos, 1987; Santos et al., 1996), por exemplo, delineiam uma área mais elevada situada na área do atual arco. Outros dados, entretanto (Daemon \& Quadros, 1970; Zalán et al., 1991), mostram que o comportamento tectônico da área foi longevo tendo variado de positivo a negativo durante o Neopaleozóico. Esse comportamento foi, sem dúvida, um dos principais fatores que controlaram tanto a subsidência, ocasionando deposição na região do arco, como sua elevação e exposição (Trosdtorf Jr., 2002).

Após o Frasniano (Devoniano Superior), a porção sul do Arco de Ponta Grossa, assim como toda a Bacia do Paraná, sofreu movimento epirogênico ascensional que a expôs à erosão. Consequentemente, o limite superior do Grupo Paraná, tanto em superficie, quanto em subsuperfície, é de natureza erosiva (Almeida et al., 1980). Ainda, segundo Trosdtorf Jr. (2002), a inconformidade angular que separa o Grupo Paraná e o Grupo Tubaräo é tênue e indistinta em afioramento, mas bem reconhecivel em âmbito regional. $O$ hiato perdurou até o Estefaniano (Carbonífero inferior ou médio; Santos et al., 1996), e este longo periodo de exposição produziu extensa superfície, onde posteriormente se instalou o lobo glacial Paraná (Frakes \& Crowell, 1969; Santos, 1987). Na porção sul do Arco de Ponta Grossa, essa superfície extremamente plana apresenta um leve basculamento para norte (Northfleet et al., 1969), da ordem de 7' (Canuto, 2001; Canuto et al., 2001).

Uma característica marcante é a presença de lineações, correspondentes a falhas NW-SE, que cruzam o arco, que controlaram grande parte da sedimentação durante o Permo-Carbonifero, condicionarando os grandes ciclos sedimentares e estratigráficos (transgressão e regressão) presentes na área (Canuto, 2001; Canuto et al., 2001). Alinhamentos NE-SW estão relacionados a falhamentos e diques e/ou sills de diabásio da Formação Serra Geral.

De acordo com Schneider et al. (1974), a sedimentação permo-carbonífera do Subgrupo Itararé, nos estados da região sul do Brasil, deumse inicialmente através de 
depósitos continentais (Formação Campo do Tenente), que, rapidamente, passaram a marinhos (formações Mafra e Rio do Sul). A forte influência glacial se faz sentir em todos os níveis desta unidade (Santos et al., 1996), inclusive no topo da sua sequência estratigráfica, conforme constatado e comentado neste trabalho (vide Capítulo 4). Embora o nivel do mar continuasse a subir, cobrindo toda a bacia já no Eopermiano, uma importante progradação é verificada em algumas áreas do "Mar Itararé". Uma cunha de depósitos clásticos arenosos, hoje aflorante principalmente nos estados de Santa Catarina e Paraná, invadiu este mar sob a forma de pacotes deltáicos (Formação Rio Bonito). Uma vez cessado este influxo clástico, os sedimentos voltam a indicar uma transgressão marinha (Formação Palermo), tendo atingido um máximo de expressão em área durante a deposição de folhelhos betuminosos do Subgrupo Irati (Hachiro, 1996). Posteriormente, seguiu-se uma sequência regressiva formada pelas formações Teresina, Rio do Rasto e Corumbataí (Zalán et al., 1991).

A revisão extensiva da evolução do conhecimento e o atual estado da arte desses tópicos não são objetivos específicos da presente tese. Este subcapítulo almeja, contudo, por em evidência a complexidade da subdivisão desta unidade estratigráfica e as principais idéias que compõem a resenha histórica da evolução geológica da área. No setor paulista da Bacia do Paraná, os conhecimentos acerca da estratigrafia e dos processos que condicionaram a deposição dos sedimentos glaciclásticos durante o Neopaleozóico da Bacia do Paraná parecem ser ainda insuficientes para gerar a concórdia entre os pesquisadores. Inúmeros trabalhos já foram realizados na tentativa de caracterizar e compreender a distribuição e a gênese destes sedimentos, enfatizando as sucessões de eventos, os ambientes deposicionais e a evolução paleogeográfica do Subgrupo Itararé (vide relação dos principais trabalhos na Tabela 2.1.1), e, mesmo assim, ainda não foram suficientes para promover uma adequada individualização de unidades mapeáveis e a compreensão da inter-relação entre as diversas associações faciológicas presentes. Tal fato fica evidente quando se verifica, por exemplo, a subdivisão litoestratigráfica proposta por Schneider et al. (1974), que só pode ser reconhecida nos estados de Santa Catarina e sul do Paraná.

Desde os primeiros trabalhos sobre a estratigrafia do Grupo Tubarão, envolvendo tentativas de subdivisão do ltararé, todos os autores se depararam com vários problemas. Destes, a principal limitação, que afeta as tentativas de reconstituição dos ambientes de deposição do Itararé e, adicionalmente, sua divisão em unidades independentes, resulta da extrema variação lateral e vertical de fácies que o Subgrupo exibe, e a ausência de camadas-guias com extensão regional que permitam a divisão e a correlação litoestratigráfica consistente dessa espessa sequência sedimentar (Santos, 1987). Esta situação está condicionada à variabilidade dos ambientes de sedimentação que presidiram a deposição desse conjunto de rochas. 


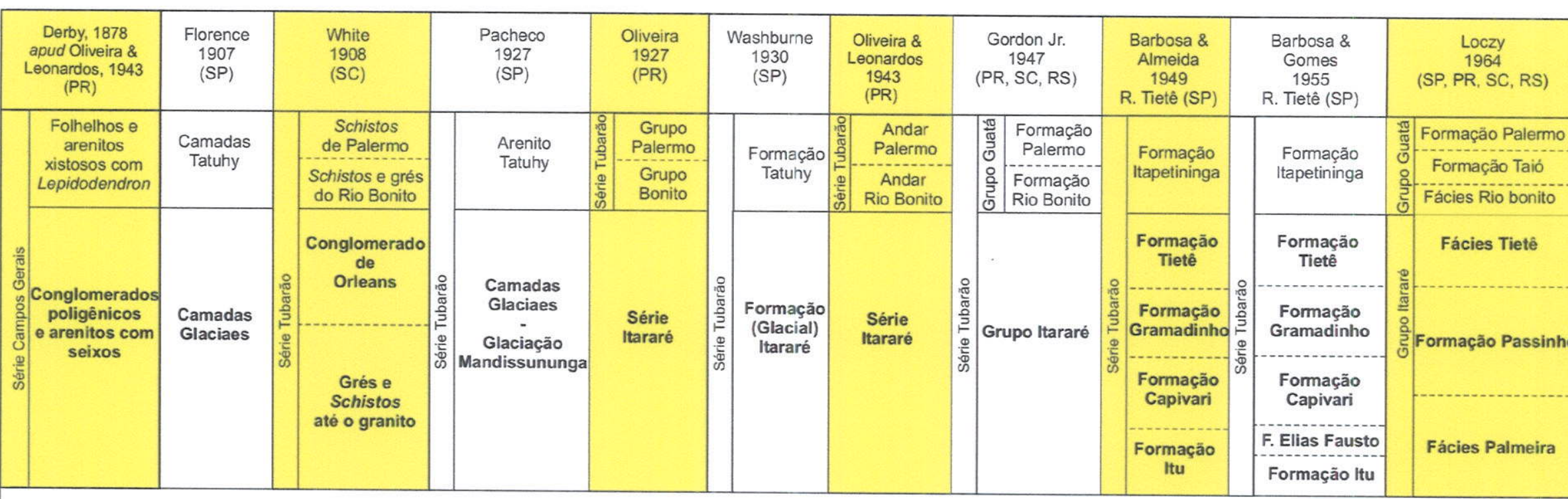

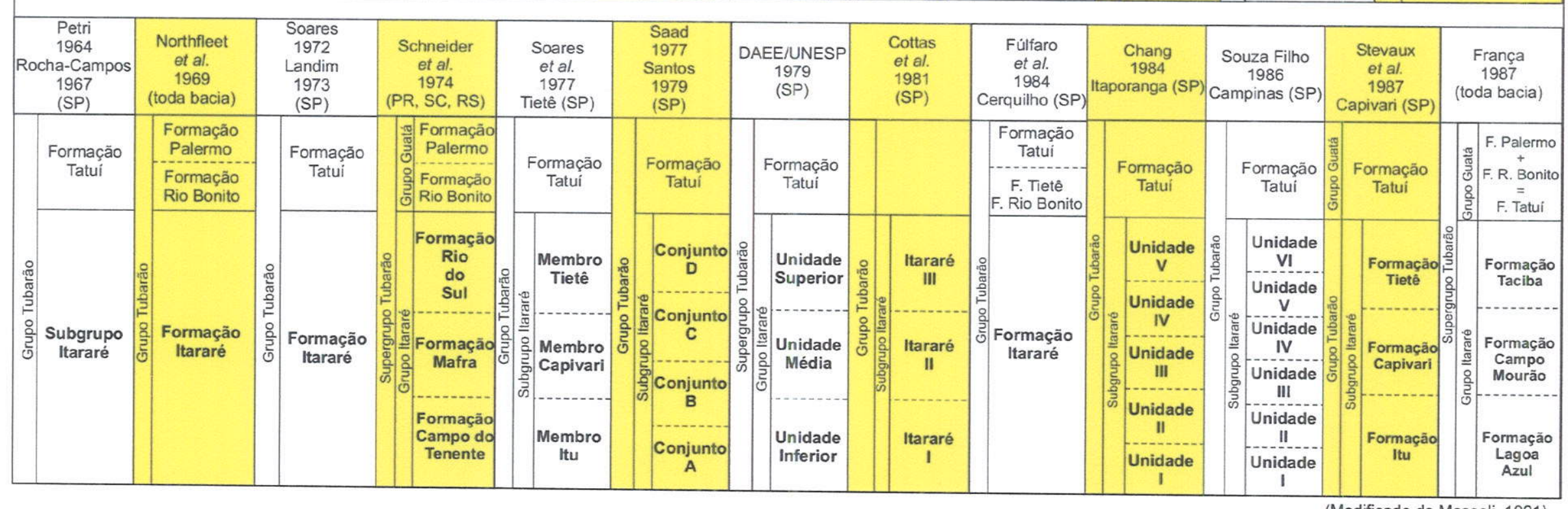


Os primeiros trabalhos a abordar informalmente o Itararé foram os de Derby (1878 apud Oliveira \& Leonardos, 1943), na então Província do Paraná, que menciona a ocorrência de depósitos de blocos poligênicos e arenitos com seixos, na base da "Série Campos Gerais", assentados sobre o devoniano fossilifero de Ponta Grossa, e de Oliveira (1889 apud Massoli, 1991), o primeiro a descrever "grés e schistos ${ }^{7}$ sem silex", de idade "carbonífera ou permiana", aflorantes nos vales dos rios Itapetininga e Paranapanema, por ele denominados "grés de Porto Feliz". No entanto, o primeiro registro de glaciação neopaleozóica na Bacia do Paraná é creditado à carta escrita pelo Sr. Orville A. Derby ao Sr. Waagen, em 1888 (Waagen, 1889), incrementando, com dados sobre a América do Sul, - trabalho anteriormente apresentado sobre as glaciação carboníferas no mundo (Waagen, 1888). Cabe, aqui, também enfatizar, os memoráveis trabalhos da Commissão Geográphica e Geológica da Província de São Paulo, da qual Derby fez parte, que reforçaram a caracterização deste ambiente glacial, como por exemplo, Florence (1907) que menciona a ocorrência de "camadas glaciaes" (grés, conglomerado e tillito), subjacentes às "camadas de Tatuhy", nas regiões de Itapetininga-Tatui e na antiga ferrovia entre Itaici e São Pedro.

White (1908), em seu clássico trabalho sobre as unidades da Bacia do Paraná, introduziu o termo cronoestratigráfico "Série do Rio Tubarão", ou simplesmente "Série Tubarão", para designar os sedimentos glaciais e as camadas de carvão, inseridos na base do "Systema de Santa Catarina", sendo, portanto, diretamente assentados sobre o embasamento e sobrepostos por depósitos pós-glaciais da "Série Passa Dois" (Tabela 2.1.1). A designação glacial, contudo, assim como para Derby (Waagen, 1889), foi atribuida somente pela presença de depósitos de "boulders" (clastos) imensos (métricos) de granito, gnaisses, quartzito e de outras rochas sotopostas, frequentemente envoltos em matriz argilosa, acinzentada e sem estratificação aparente (diamictitos maciços), denominados como "Conglomerados Orleans" e descritos nos estados do Rio Grande do Sul, Santa Catarina, Paraná e São Paulo. Até então, não haviam sido descritas estruturas tipicamente indicativas de processos operantes em ambientes glaciais (e.g.: estrias glaciais, clastos estriados e facetados), mas já se vislumbrava a possibilidade de correlação com os "conglomerados" de origem glacial Dwyka da região africana. A subdivisão, proposta por White (op cit.), da "Série" Tubarão apresentava, da base para o topo, capeando o embasamento granítico: grés amarelo e schistos, seguidos de os "conglomerados" de origem glacial (Conglomerados de Orleans). Enquanto que o pós-glacial era representado por arenitos feldspáticos associados a folhelhos cinzentos e camadas de carvão, contendo a flora de Glossopteris, denominados "Arenitos Rio Bonito" e "Folhelhos Palermo". A "Série"

\footnotetext{
${ }^{7}$ Em alguns trabalhos antigos (final do século XIX e início do século $X X$ ) era comum a adaptação de termos oriundos de outras línguas, no caso do francês e grego, sendo, respectivamente, arenito (fr. grès) e folhelho (gr. skhistos).
} 
Tubarão, então proposta em Santa Catarina, conteria $32 \mathrm{~m}$ de sedimentos glaciais e $248 \mathrm{~m}$ de sedimentos pós-glaciais.

O reconhecimento da ocorrência de sedimentação de caráter glacial só foi possivel através de Woodworth (1912), com a identificação de vários niveis de "tilitos" no Itararé (Série Glacial), nos estados de São Paulo, do Paraná e de Santa Catarina, o qual também descreveu cherts (silex) no Estado de São Paulo similares aos presentes na África do Sudoeste (protetorado da Alemanha, atual Namíbia). Na realidade, a principal contribuição de Woodworth foi ter constatado a presença de clastos estriados em testemunhos de sondagem da Comissão Geográfica e Geológica e em tilitos, com destaque para os depósitos ao longo da linha férrea entre as cidades de Itararé e Jaguariaiva, próximos ao poste 234 e acima do rio Jaguaricatú, no Estado do Paraná, que teria originado a denominação Jaguaricatú para esta glaciação.

Posteriormente, Pacheco (1927) atribuiria à glaciação permiana de Mandissununga os denominados "Tilitos de Cosmópolis", aglomerado de seixos e blocos, mais ou menos angulares, lisos ou polidos e mesmo estriados de rochas variadas, em matriz argilo-arenosa e sem estratificação, da "Série Glacial".

O termo Itararé surgiu com Oliveira (1927) após o desmembramento da Série Tubarão de White (1908) em duas sequências: "Série Itararé" (inferior), glacial, e "Série Tubarão" (superior), pós-glacial, contendo carväo e flora de Glossopteris. A "Série" Itararé incluiria sedimentos compostos por seixos e calhaus de rochas de dimensões consideráveis, dispersos em matriz argilosa, descritos por Oliveira (op cit.) na bacia hidrogräfica do rio Itararé, no Estado do Paraná. Desta forma, a origem do nome estaria associada a esta ocorrência, visto que seria imprópria a manutenção da denominação "Orleans", termo este aplicado a um dos "membros" menos característicos desta série, enquanto que, segundo Oliveira (op cit.), a denominação "Jaguaricatü", teria aplicação à fase tilítica destes depósitos.

Washbume (1930) foi o primeiro a considerar o Itararé como uma unidade litoestratigráfica formal - Formação (Glacial) Itararé - sendo constituida por sedimentos glaciais, lacustres e fluviais, de idade carbonifera e posicionada na coluna estratigráfica entre as formações Faxina (devoniana) e Tatuhy (carbonífera), base e topo, respectivamente, contudo, normalmente o contato basal encontra-se, no Estado de São Paulo, com rochas metamórficas e ígneas do cristalino. Devido à ausência de grandes corpos de conglomerados, que caracterizariam os depósitos formados na frente de geleiras aterradas, e a abundância de argila entre os tilitos, Washburne (op cit.) considerou que as geleiras teriam avançado para corpos subaquáticos. Outros importantes legados deste trabalho são suas observações sobre a ocorrência de sedimentos várvicos e sedimentos com clastos caídos e a interpretação do sentido do deslocamento da geleira, para oeste ou 
noroeste, dado este relacionado à direção do primeiro registro então atribuido a estruturas deformadas subglacialmente (glaciotectônicas) do Brasil, no municipio de Porto Feliz.

A partir da década de 40, muitos autores passaram a debater as classificações estratigráficas adotadas e o uso inadequado do termo "Tubarão", defendendo a volta à proposição inicial de White (1908), além da definição correta dos limites entre as unidades glaciais e pós-glaciais, visto que alegavam haver evidências de interdigitações entre as respectivas fácies. Isto se deu, sobretudo, após os trabalhos de Washburne (1930) e Leinz (1937), que forneceram importantes informações a respeito da glaciação neopaleozóica, tais como descrições de feições glaciais, dados sobre direção e deslocamento do gelo e a ocorrência de sedimentos com caráter várvico no Brasil. Almeida (1945), por exemplo, baseando-se em Oliveira (1927), inicialmente dividiu a unidade glacial em Série Itararé e Grupo Bonito (Série Tubarão), as quais representariam duas glaciações distintas, separadas por uma transgressão marinha relacionada a um interglacial. No entanto, o termo Rio Bonito já estava sendo adotado na região sul como equivalente das unidades pós-glaciais, e, sendo assim, Almeida (op cit) concluiu, com base nos critérios da prioridade e pelo que dispunha o então "Código Internacional de Taxionomia Estratigráfica", que o conjunto de sedimentos glaciais, flúvio-glaciais e marinhos, com carvão permo-carbonifero, deveria ser chamado de Série Tubarão, conforme White (1908). Na realidade, houve um equívoco ao se correlacionar os carvões inter-glaciais com pós-glaciais, e Almeida (op cit, p.15), inclusive, fez o seguinte comentário:

"Não sei até que ponto se pode considerar os carvões do Paraná e de outros estados do sul do Brasil como pertencentes à Série ltararé, isto é, formados antes do último episódio glacial. Faltam secções de detalhe e suficientemente amplas na maioria das áreas de ocomência de carvão do Grupo Bonito, e o conhecimento que até agora possue do nosso permo-carbonífero não permite muita generalização".

Para Gordon Jr. (1947), o Itararé conservaria o mesmo nome introduzido por Oliveira (1927), porém caracterizado pelo conceito litoestratigráfico de grupo, e incluiria todos os sedimentos glaciogênicos (gerados pela ação direta do gelo) e também os depósitos fluviais, lacustres e marinhos neles intercalados, assim como os leitos carbonosos entremeados. 0 Grupo Guatá incluiria os sedimentos com restos vegetais e camadas de carvão, sobrepostas ao Grupo Itararé, sendo subdividido em Formação Rio Bonito e Folhelho Palermo.

Em 1946 foi reportada por Marger Gutmans, no "ll Congresso Panamericano de Engenharia de Minas e Geologia", a descoberta da roche moutonnée de Salto, no trabalho intitulado "Estrias glaciais no Estado de São Paulo" (Barbosa \& Almeida, 1949), seis anos depois de ter sido encontrada a primeira superficie estriadas sobre um granodiorito, com direção N348, entre São Bento e Mafra (Barbosa, 1940). Infelizmente, consta que o trabalho de Gutmans não foi publicado, embora tenha sido uma valiosa contribuição oral. 
Barbosa \& Almeida (1949), baseados em dados obtidos em diversos afloramentos de São Paulo e na sondagem de Araquá (SP), propuseram as formações Itu (glacial inferior), Capivari (transgressão marinha), Gramadinho (glacial médio), Tietê (glacial superior) e Itapetininga (pós-glacial), como subdivisões da Série Tubarão para a área da bacia do rio Tietê (SP). Neste caso, a transgressão marinha da Formação Gramadinho seria evidenciada por fósseis marinhos encontrados próximos à cidade de Capivari, enquanto que as camadas de carvão do rio Sorocaba (Mato Seco e Cerquilho) e no rio Capivari, da Formação Tietê, ocorreriam, estratigraficamente, abaixo das camadas do "Tilito Jurú Mirim" (Jumirim), a última ocorrência glacial neopaleozóica. Posteriormente, Barbosa \& Gomes (1958) incluiriam a Formação Elias Fausto entre as formações Itu e Capivari, que anteriormente fazia parte da Formação ltu. Segundo estes autores, justificava-se essa separação porque o conjunto Elias Fausto era essencialmente glacial, representando o avanço das geleiras sobre os sedimentos flúvio-lacustrinos da Formação Itu, bem mais antiga que o Tilito Salto, da base desta formação.

Estas colunas geológicas (Barbosa \& Almeida, 1949 e Barbosa \& Gomes, 1958), entretanto, cairam em desuso devido, sobretudo, à inexistência de continuidade lateral e a ausência de limites definidos entre as unidades, o que inviabilizou seu uso em trabalhos de mapeamento. Além do mais, na década de 50 , principalmente nos estados da região sul, alguns trabalhos ainda mantiveram a denominação "Grupo Itararé", seguindo os autores que os precederam. Beuerlen (1955), por exemplo, subdividiu o Grupo Itararé em quatro unidades glaciais separadas por sedimentos considerados interglaciais. Correlacionou, ainda, apesar da grande distância, as camadas de "tilito" a outras descritas nos estados de São Paulo e Santa Catarina. Maack (1946) e Lange (1954), a partir de horizontes marinhos correlacionáveis paleontologicamente, e considerando a possível extensão regional dessas unidades, subdividiram o Itararé em diferentes formações, distinguindo sedimentos gláciomarinhos e glácio-continentais. Loczy (1964), complementando estes trabahos, subdividiu a "Série" Tubarão em: fácies glacial continental inferior (Palmeira), Formação Passinho (primeira ingressão marinha) e fácies glacial continental superior (Tietê). Segundo Loczy (op cit.), a Formação Passarinho seria um ótimo horizonte-guia, pois representava "uma deposição estratigráfica fixa". Todos esses trabalhos, no entanto, foram abandonados por não se comprovar a continuidade lateral das camadas-guia marinhas propostas por tais subdivisões.

Petri (1964) e Rocha-Campos (1967) abandonaram definitivamente o termo cronoestratigráfico "Série" Tubarão e adotaram a designação litoestratigráfica de Grupo, no mesmo sentido de Gordon Jr. (1947), (Tabela 2.1.1), classificando, ainda, o ltararé, como Subgrupo. Para Petri (1964), o Subgrupo Itararé consistiria de " 5 a 6 niveis de tilitos intercalados em conglomerados, arenitos, folhelhos, calcários, argilitos, siltitos, varvitos e 
pequenas camadas de carvão". Admitia, ainda, a possibilidade de interdigitação entre o glacial e o pós-glacial, de modo que, parte do Grupo Guatá, de Santa Catarina, corresponderia à parte do Itararé, de São Paulo. Segundo Rocha-Campos (1967), o Subgrupo Itararé incluiria sedimentos tipicamente glaciais, além dos relacionados indiretamente com a glaciação. Esta sequência inferior glacial e os sedimentos pós-glaciais - Subgrupo Guatá nos Estados do Rio Grande do Sul, Santa Catarina e Paraná - foram por ele considerados essencialmente sincrônicos. Estes sedimentos pós-giaciais, em São Paulo, são agrupados na Formação Tatú, juntamente com a Formação Taquaral, do Subgrupo Irati (Grupo Passa Dois, Permiano), sobreposta (Hachiro, 1996).

Northfleet et al. (1969) separaram, dentro do Grupo Tubarão, a Formação Itararé, sobreposta pelas formações Rio Bonito e Palermo. Como critério operacional para definir a base da Formação Rio Bonito, colocaram o contato na base do primeiro nivel de arenito acima do mais alto diamictito da sequência sedimentar do Itararé.

Andrade \& Soares (1971) diferenciaram, na zona do médio Tietê, três intervalos na "Formação" Itararé. O intervalo basal apresentaria conglomerados e arenitos conglomeráticos, sobrepostos por siltitos, ritmitos e folhelhos, com raras ocorrências de diamictitos; afioraria na região de $\mathrm{Itu}$, Salto e Campinas, com $200 \mathrm{~m}$ de espessura. $\mathrm{O}$ intervalo médio conteria arenitos médios, argilitos, ritmitos, folhelhos e siltitos aos quais se associariam o carvão de Monte Mor e esparsas lentes de diamictitos. Sua espessura máxima chegaria a $600 \mathrm{~m}$, aflorando em Porto Feliz, Tietê, Monte Mor e Capivari, onde ocorreriam ainda fósseis marinhos. O pacote superior conteria arenitos grossos, passando abruptamente para siltitos, ritmitos $e$ folhelhos, sobrepostos por arenitos finos a conglomeráticos, e diamictitos, situando-se no topo da sequência do carvão de Cerquilho; a espessura máxima de 150 foi levantada entre Tietê e Laranjal Paulista.

Soares (1972), enfocando o limite glacial/pós-glacial do Grupo Tubarão em São Paulo, considerou a Formação Tatuí correspondente, por homotaxia, ao Grupo Guatá dos estados do sul, não constituindo, contudo, a mesma unidade litoestratigráfica. Ressaltou, ainda, a existência de uma quebra no registro estratigráfico entre o pacote glacial e o pós-glacial no centro-leste de São Paulo, afirmando que "a base do Tatuí é uma superfície de descontinuidade na sedimentação, sob a forma de uma discordância erosiva". Saad (1977), entretanto, baseado, sobretudo em evidências bioestratigráficas, não reconheceu tal discordância.

Landim (1973), para os mesmos sedimentos agrupados sob a denominação de Subgrupo Itararé (Petri, 1964; Rocha-Campos, 1967), utilizou o termo Formação Itararé, embora tenha reconhecido ser possivel o desmembramento em outras formações tão logo surgissem novas informações. Advogou, ainda, o topo do mais alto diamictito como o contato entre os sedimentos glaciais e pós-giaciais da Formação Tatuí. 
Em 1974, Schneider e colaboradores publicaram uma revisão estratigráfica da Bacia do Paraná, subdividindo o proposto Supergrupo Tubarão e elevando o Itararé à categoria de Grupo, subdividindo-o nas formações Campo do Tenente, Mafra e Rio do Sul, classificação essa válida somente para os estados de Santa Catarina e Paraná (Tabela 2.1.1). Em São Paulo, o "Grupo Itararé" permaneceu indiviso, segundo esses autores, pela falta de trabalhos de detalhe que comprovassem a continuidade lateral das formações definidas no sul. Como característica principal da unidade, consideraram a ocorrência de diamictitos como refletindo a influência glacial em seus diversos ambientes deposicionais.

Saad (1977) distinguiu no Subgrupo ltararé em quatro unidades informais (Tabela 2.1.1), baseando-se na predominância de clásticos grossos e finos presentes nas unidades levantadas em seções de superfície praticamente paralelas ao mergulho das camadas. A partir da base, denominou os conjuntos de A, B, C e D, com predominância, alternada, de clásticos grossos e finos, respectivamente. Considerou, ainda, um conjunto $E$ equivalente à Formação Tatuí. Essa foi, até então, a mais abrangente proposição de subdivisão do Subgrupo Itararé, ainda que de caráter informal, pois englobou a porção centro e sul do Estado de São Paulo.

Soares et al. (1977), introduzindo o conceito de análise ambiental como suporte a trabalhos de cunho estratigráfico no Subgrupo Itararé em São Paulo, reconheceram quatro associações litológicas apenas na porção superior da unidade (Associações I, II, III e IV) (Tabela 2.1.1). O próprio autor, entretanto, afirma não ser uma classificação válida à toda a bacia, devido à limitações da área de estudo e a constante recorrência de litologias em todos os níveis do itararé. Constataram, porém, a ocorrência de associações litológicas com significado genético, não adotadas formalmente em função da pequena extensão da área investigada.

Em 1979, o convênio DAEE/UNESP permitiu a realização do mapeamento faciológico do "Supergrupo" Tubarão no Estado de São Paulo, na escala 1:50.000, tendo sido então proposta a divisão estratigráfica informal do "Grupo" Itararé nas unidades Inferior (arenitos e lamitos), Média (arenitos finos, siltitos e lamitos) e Superior (arenitos finos a grossos e lamitos), (Tabela 2.1.1). Este trabalho englobou toda a porção aflorante do Itararé em São Paulo, não tendo havido, porém, um controle de campo compativel com a escala adotada, valendo-se principalmente da fotointerpretação para delimitação das unidades propostas. Além disso, a caracterização das unidades não foi devidamente estabelecida, visto a recorrência dos litotipos descritos.

Fúlfaro et al. (1980), por entenderem que a subdivisão do "Grupo" Itararé proposta por Schneider et al. (1974) era válida tão somente na área-tipo, rebaixaram-no à categoria de formação, considerando assim o Itararé estratigraficamente indiviso. No entanto, Wu et al. (1980) e Gama Jr. et al. (1980) dividiram faciologicamente o "Grupo" Itararé em três 
unidades litoestratigráficas (Inferior, Média e Superior), conforme sugerido pelo trabalho do convênio DAEE/UNESP (1979).

Gama Jr. et al. (1982), considerando as subdivisões de Schneider et al. (1974) para o Grupo Itararé como não operacionais em toda a bacia, adotam a simplificação anteriormente introduzida por Fúlfaro et al. (1980), mantendo o Itararé na categoria de Formação para toda a bacia. Esses autores separam a Bacia do Paraná em setores (sul, centro, norte e nordeste), postulam que o contato entre as formações Rio Bonito e Itararé era concordante e diácrono (sendo mais antigo no sul e mais novo no domínio nordeste), e afirmaram que a Formação Palermo se sobrepunha concordantemente à Formação Rio Bonito nos dominios centro e sul, passando ambas lateralmente à Formação Tatuí nos domínios norte e nordeste.

Fúlfaro et al. (1984) consideraram os sedimentos glaciais sotopostos à Formação Tatuí como pertencentes à "Formação" Itararé, tida como indivisa. No entanto, redefiniram a "Formação Tietê", de Barbosa \& Almeida (1949), como sendo pós-glacial, originada pelo retrabalhamento dos sedimentos glaciais do Itararé, e situando-a estratigraficamente no Grupo Guatá, e considerada sincrônica à Formação Rio Bonito (Tabela 2.1.1).

Landim et al. (1986), estudando a bacia do baixo rio Capivari, admitiram a existência, no "Grupo" Itararé, de duas unidades genéticas distintas: sistema deltaico com incursões glaciais, na parte média; e sistema costeiro, na porção superior. O sistema deltaico incluiria as ocorrências de fósseis marinhos de Hortolândia e Capivari e o carvão de Monte Mor, sendo denominado Membro Capivari. O registro rochoso do sistema costeiro foi denominado Membro Tietê, correspondendo à Formação Tietê de Fúlfaro et al. (1984) e à Formação Rio Bonito. À porção inferior do "Grupo" Itararé, identificadas nas regiões de Campinas, Salto, Itu e Sorocaba, e composta por diamictitos recobertos por argilas laminadas, denominaram Membro Porto Feliz.

Stevaux et al. (1987) propuseram uma coluna estratigráfica para o Subgrupo Itararé, na região de Capivari, a qual compreenderia, a partir da base, as formações Itu, Capivari e Tietê (Tabela 2.1.1), com algumas modificações da descrição original de Barbosa \& Almeida (1949).

Santos (1987) subdividiu todo o Subgrupo Itararé em intervalos bioestratigráficos, com base em informações de superfície e subsuperficie, com base nos dados de palinologia utilizados por Daemon \& Quadros (1970). Estas informações possibilitaram o refinamento do quadro paleogeográfico estimado para todo o Itararé.

Em seguida, França $(1987,1994)$ e França \& Potter (1988) retomaram o termo Grupo para designar o Itararé, e o dividiram em três formações: Lagoa Azul, Campo Mourão e Taciba, a partir de dados de diagrafia geofísica de subsuperfície, sendo aflorante somente a Formação Taciba (Tabela 2.1.1). Esta divisão, no entanto, ainda gera controvérsias, pois 
ainda não se resolveu o problema do dificil reconhecimento, em campo, dessas unidades e a ausência de controle bioestratigráfico. Aliás, a denominação "Taciba" foi empregada inadequadamente por esses autores, pois Soares et al. (1979) utilizaram o termo "Taciba" para designar uma fácies da "Formação" Bauru, o que contraria o disposto pelo Código de Nomenclatura Estratigráfica.

Verifica-se, portanto, que ainda existe muita controvérsia, particularmente no setor paulista da Bacia do Paraná, sobre qual a hierarquia estratigráfica mais adequada e como se deve subdividir esta unidade com sedimentos neopaleozóicos depositados num período com forte influência glacial. Desta forma, utilizou-se, para as áreas analisadas no Estado de São Paulo, a classificação adotada por Petri (1964) e Rocha-Campos (1967), visto que a solução destes problemas não faz parte das metas deste trabalho. Consequentemente, nas localidades de Boituva, Capivari e Jumirim, além de suas adjacências, esta unidade será designada por "Subgrupo Itararé", na forma indivisa. No Estado do Paraná, mais especificamente na região de Witmarsum, adotou-se a classificação de Schneider et al. (1974), cuja sedimentação permo-carbonífera do Subgrupo Itararé é subdividida, do mais antigo para o mais recente, em formações Campo do Tenente, Mafra e Rio do Sul.

\subsection{BOITUVA (SP)}

O afioramento situado no km 0,5 da rodovia Vicente Palma (SP-129, Figura 1.3.1), que interliga a rodovia Marechal Rondon (SP-300) à Cidade de Boituva, embora localizado no município de Porto Feliz, tem sido tradicionalmente referido na literatura como Boituva, denominação esta que será utilizada neste trabalho. Esta localidade serve para ilustrar alguns aspectos da atual controvérsia a respeito da origem dos sedimentos glaciais deformados, em particular no que tange à discriminação entre depósitos glaciotectônicos (Washburne, 1930; Almeida, 1953; Martin, 1964) e os resultantes de fluxos gravitacionais de massa (Rocha-Campos, 1963, 1967; Rocha-Campos et al., 1972; Gama Jr. et al., 1992). É importante, portanto, que se tente caracterizar e, se possivel, distinguir os dois processos e seus produtos através da comparação entre os parâmetros sedimentológicos e de geologia estrutural. Com efeito, como vem sendo constatado no Pleistoceno e no Quaternário, os dois ambientes apresentam mudanças previsiveis de facies (e.g.: Thorsteinsson \& Raymond, 2000), as quais, no contexto dos fluxos gravitacionais de massa, são controlados por parâmetros sedimentares, enquanto que, no que se refere à gênese glaciotectônica, estes são tanto sedimentares como tectônicos.

Além disso, existem certas similaridades entre as estruturas resultantes desses dois processos, na medida em que ambos afetam sedimentos com variáveis conteúdos de água intersticial e baixa resistência à deformaçăo. Sequências glaciogênicas, marinhas ou terrestres, são usualmente compostas por sedimentos resultantes de processos de fluxos 
gravitacionais de sedimentos, correntes de tração, agradação e chuva de partículas/grãos (rain-out), com mudanças de facies previsiveis e relacionadas à distância da margem do gelo. Em contraste, o movimento de sedimentos no ambiente glaciotectônico subglacial é controlado pela ação direta da geleira, onde a deformação por cisalhamento é o processo dominante. Desta forma as mudanças de facies estão relacionadas à intensidade da deformação resultante, à pressão efetiva atuante sobre os sedimentos subglaciais e à natureza desses sedimentos.

Um estudo integrado como o aqui proposto, é, portanto, potencialmente útil para uma tentativa de caracterizar e distinguir esses ambientes, assim como para lançar luz sobre eventuais controvérsias que possam surgir, e algumas delas, na realidade, já tem surgido, no estudo da sequência glaciogênica encerrada no Subgrupo Itararé.

Washburne (1930, p. 24) pioneiramente referiu-se a deformações que, a seu juizo, teriam sido provocadas por deslocamentos das geleiras neopaleozóicas sobre sedimentos inconsolidados (deformações glaciotectônicas) do Subgrupo ltararé. Suas interpretações foram baseadas em observaçōes e análises de dobras que afetaram sedimentos do Subgrupo Itarare ao norte de Porto Feliz, as quais sugeriam um sentido de esforço para oeste e, deste modo, foi o primeiro a interpretar o sentido de movimento das geleiras continentais neopaleozóicas na Bacia do Paraná através de dados estruturais, embora a interpretação da gênese das estruturas estivesse equivocada, de acordo com os resultados apresentados neste trabalho. Outro problema a complicar as tentativas atuais de estudo dessas ocorrências é a dificuldade de identificar sua precisa localização no campo. Almeida (1953), por exemplo, a situava como possivelmente localizada na margem esquerda do rio Tietê, nas vizinhanças do km 135 da rodovia entre Porto Feliz e Tietê.

Estruturas semelhantes, expressas sob a forma de intensas deformações afetando camadas de "varvitos" e folhelhos, foram posteriormente reconhecidas no $\mathrm{km} \mathrm{166,4} \mathrm{da}$ Estrada de Ferro Sorocabana, próximo de Porto Feliz, e no $\mathrm{km} \mathrm{156,} \mathrm{pouco} \mathrm{além} \mathrm{de}$ Indaiatuba (Barbosa \& Almeida, 1949; Almeida, 1953). Barbosa \& Almeida (1949, p. 8) consideraram estas deformações como resultantes da diferença de competência entre as camadas laminadas e as de arenito que nelas se intercalavam, durante as deformações causadas por intrusões de corpos de diabásios (sills e/ou diques), como, por exemplo, um sill com $40 \mathrm{~m}$ de espessura que aflora nas proximidades.

No que concerne ao afloramento localizado no $\mathrm{km} \mathrm{0,5}$ da rodovia Vicente Palma (SP. 129), que interliga a rodovia Marechal Rondon (SP-300) à cidade de Boituva, aqui identificado como Boituva, Almeida (1953) o interpretou como condizente com o estudo apresentado anteriormente por Washbume em 1930. No referido trabalho, Almeida (op cit.) menciona que constatou ali a presença de camadas não deformadas sendo capeadas por $30 \mathrm{~m}$ de sedimentos dobrados e falhados, eliminando, desta forma, a relação, sugerida por 
Barbosa \& Almeida (1949), de causa e efeito entre a intrusão de rochas básicas e a deformação dos sedimentos.

A natureza das deformaçōes, sua intercalação entre camadas não dobradas $€$ a presença da cobertura de diamictito são os principais argumentos que Almeida (1953) utilizou para atribuir sua gênese às pressões exercidas pelos avanços de geleiras sobre depósitos lacustres, embora o capeamento por camadas de diamictito não tenha sido observado em nenhum afloramento da localidade. Analisando a orientação das dobras, em particular os planos axiais e as superfícies de falhas, método também utilizado por Martin (1961, 1964), Almeida (1953) inferiu que a movimentação da massa de gelo ocorreu para NW, interpretação condizente com a de Washburne (1930) e com as já então conhecidas estrias glaciais da rocha moutonnée de Salto, SP (Gutmans, 1946, apud Almeida, 1948).

Martin (1964, p. 45), contudo, foi o único que ilustrou, esquematicamente, em diagrama Schmidt-Lambert (Figuras 2.2 .1 e 2.2.2), suas interpretações a respeito das deformações do afloramento citado por Almeida (1953). Através destes diagramas Martin (op cit) conjeturou que o sentido dos esforços, que teriam originado as estruturas assimétricas redobradas, seria unidirecional e com sentido de NE para SW. Concluiu que este esforço estaria relacionado à passagem de uma massa de gelo sobre o sedimento inconsolidado. Nesta linha de raciocínio, verifica-se que tais considerações foram reforçadas pela menção anterior de Almeida (op cit.) a respeito da existência de um horizonte deformado, aparentemente capeado por arenito e diamictito com camadas imbricadas e acavaladas, cujas direções são semelhantes às das dobras em questão. No entanto, não se tem conhecimento, atualmente, a respeito de outras referências sobre este segundo afloramento e sobre a exatidão quanto a sua localização; Almeida (op cit.) menciona apenas que se encontrava a $800 \mathrm{~m}$ a oeste do afloramento aqui denominado Boituva.

Rocha-Campos (1963), por sua vez, interpretou as estruturas de Boituva como deformações produzidas por escorregamento subaquático de sedimentos sob efeito da gravidade, interpretação esta que prevalece atualmente. Além das estruturas já mencionadas por Almeida (1953), Rocha-Campos (1963) comenta que a sequência "várvica" (rítmica) de siltitos e argilitos possui dobramentos complicados, com muitas dobras reviradas, deitadas ou recumbentes, cortadas por falhamentos. $\mathrm{Na}$ parte basal do afloramento, notou ele a ocorrência de dobramentos interpretados como resultantes de recalque de sobrecarga (load cast), com camadas de arenitos horizontais na sua parte superior, sobre sedimentos "várvicos" mais plásticos.

Ainda, segundo Rocha-Campos (1963), não se verificou a associação direta, ou pelo menos próxima, de tilito, ou outro depósito glacial, com as sequências dobradas, mesmo supondo-se que os antigos sedimentos glaciais tivessem sido erodidos, devido à distância entre tais depósitos e as faixas deformadas e não deformadas. Suas observações sugerem 
que os dobramentos apresentam características de deformação plástica: espessamento nas cristas dos anticlinais e sinclinais, estruturas em constriçöes (pinch and swell) das camadas de arenito, com variações de espessura muitas vezes descontínuas, além da presença comum de estruturas do tipo de recalque por sobrecarga. Desta forma, Rocha-Campos (1963) interpretou que as deformações teriam sido causadas por simples escorregamento subaquático em lagos proglaciais, onde a movimentação dos sedimentos teria sido facilitada pelo declive primário da margem da bacia. Um pequeno aumento da inclinação do declive, particularmente causado por compactação diferencial, seria um fator com capacidade de desestabilizar a pilha sedimentar e provocar a movimentação do material, uma vez que os leitos de areia, saturados de água e intercalados em sedimentos plásticos como siltitos e argilitos, são bem instáveis nestas condições. Logo, parte das deformações ter-se-ia originado por aumento de carga resultante do maior afluxo de areias, durante um período de degelo.

\section{BOITUVA}

(Porção oeste do corte)

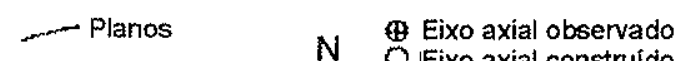
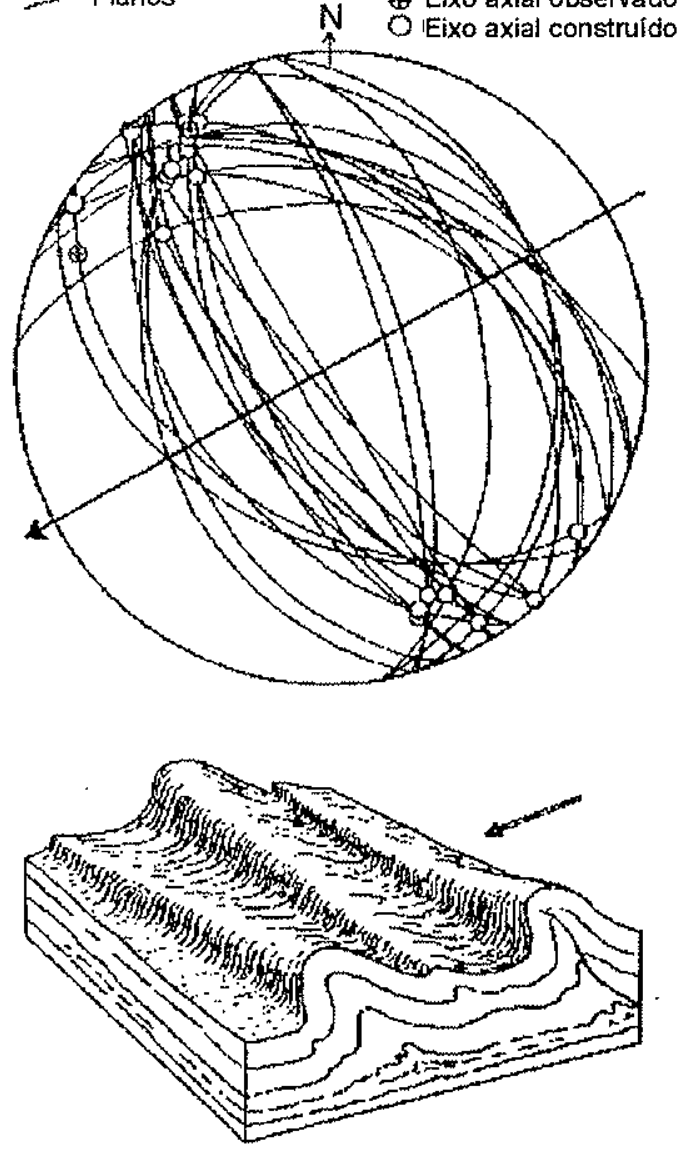

Figura 2.2.1 - Diagrama com dados estruturais da porção oeste do afloramento de Boituva (SP) e esquema interpretativo das estruturas, sem escala. (Martin, 1964, fig.11, p.45).

\section{BOITUVA}

(Porçāo leste do corte)

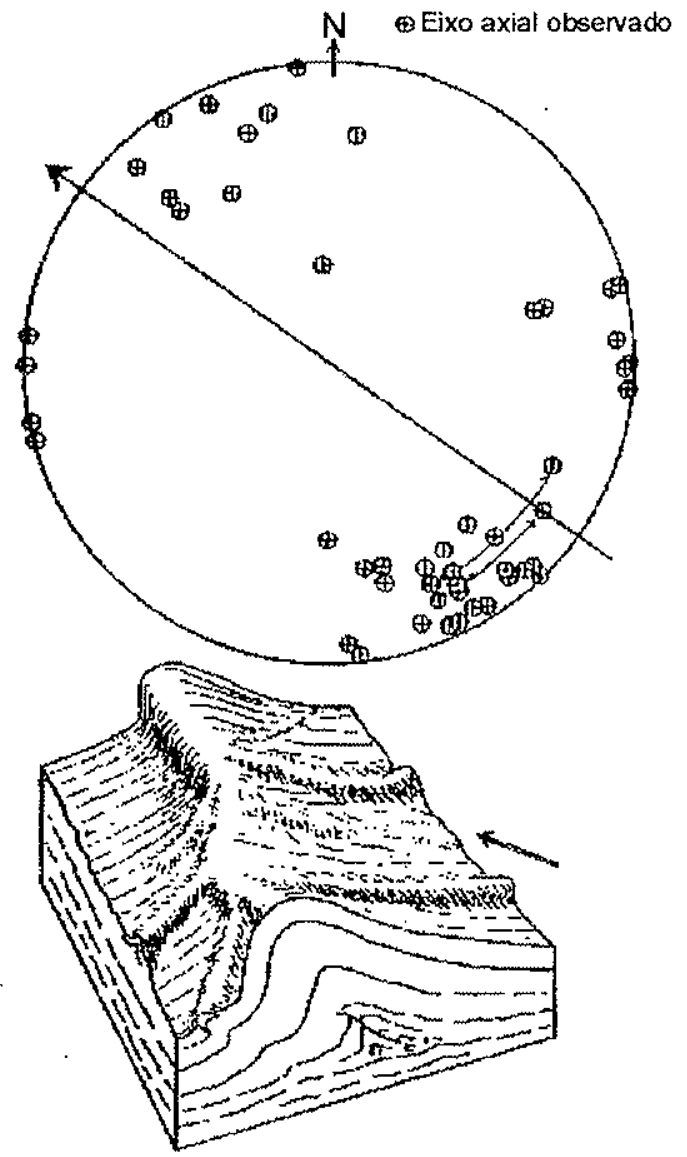

Figura 2.2.2 - Diagrama com os pólos axiais observados na porção oeste do afloramento de Boituva (SP) e esquema interpretativo das estruturas, sem escala. As duas setas presentes na porção inferior a direita do diagrama representam a rotação dos eixos (Martin, 1964, fig.12, p.46.) 
Posteriormente, Gama Jr. et al. (1992) complementaram as observações de RochaCampos (1963), sugerindo que as várias camadas de arenitos maciços intercaladas na porção basal da sequência, resultaram de um empilhamento de facies geradas por corrente de turbidez, de diferentes intensidades, derivadas de eventos discretos de transbordamento de correntes confinadas em canais subaquosos. Estes, também, consideram os escorregamentos acima da superfície de deslizamento como sendo o fim dos eventos de transbordamento.

\subsection{CAPIVARI (SP)}

O afloramento localizado em um corte de estrada entre os $\mathrm{km} 35$ e 36 da rodovia SP101, nas imediações de Capivari, é importante para o presente estudo, pois poderá permitir melhor compreender a inter-relação entre deformações glaciotectônicas e os pavimentos de clastos associados a diamictitos. Os trabalhos realizados nesta localidade contaram, inicialmente, com a colaboração do atual pós-graduando Rodrigo Artur Perino Salvetti no estabelecimento da estratigrafia, sedimentologia, fábrica dos clastos e mapeamento geológico, em decorrência do seu projeto de iniciação científica do CNPq finalizado em julho de 2000 e intitulado: "Contribuição à origem de pavimentos de clastos glaciais no Subgrupo Itararé (Neopaleozóico), em Capivari, SP" (Salvetti, 2000).

Até o presente momento, as informações disponiveis a respeito do afloramento de Capivari enfatizaram a gênese e as características dos dois pavimentos de clastos ali ocorrentes (Rocha-Campos et al., 1976, 1977, 1992, 1993; Cotter et al., 1992; Salvetti, 2000), tendo sido apenas comentada, brevemente, a possível existência de estruturas glaciotectônicas associadas à sequência local.

Inicialmente, Rocha-Campos et al. (1976) descreveram dois pavimentos de clastos ocorrentes em dois níveis estratigráficos diferentes dentro de um único diamictito, como sendo do tipo intratillito. Análises posteriores permitiram constatar que se tratava de pavimentos de clastos do tipo intertillito (Rocha-Campos et al., 1992, 1993; Cotter et al., 1992), e que os registros estratigráficos presentes representavam, pelo menos, 3 (três) fases de avanço e recuo da margem de um corpo de gelo terrestre.

Segundo o modelo da gênese dos pavimentos de Capivari proposto por RochaCampos et al. (1992) e Cotter et al. (1992), os pavimentos resultariam de múltiplos avanços de geleiras, possibilitando a deposição de till basal, e dos consequentes recuos das margens dessas geleiras, quanto ocorria erosão e concentração seletiva dos clastos, que seriam relocados por um novo avanço. 


\subsection{JUMIRIM (SP)}

A área pesquisada localiza-se no Município de Jumirim, Estado de Säo Paulo, distando aproximadamente $150 \mathrm{~km}$ de São Paulo. Há vários acessos partindo da capital paulista à área analisada, dentre os quais sugere-se a seguinte trajetória: rodovias Castelo Branco (SP-280), Antonio Pires de Almeida (SP-127) e Marechal Rondon (SP-300). Os afloramentos analisados encontram-se no lado esquerdo do km 166,6 a 167,6 da Rodovia Marechal Rondon (SP-300), no sentido de Laranjal Paulista, e nos cortes da estrada de ferro da FEPASA, situado logo acima, em ambos os lados do corte, entre os postes $174 / 10$ e $174 / 12$, que se encontram paralelos ao intervalo estudado da rodovia.

Os trabalhos mais antigos que se referem a esta região, atribuem-lhe o mesmo nome da então estação ferroviária da E. F. Sorrocabana: "Jurú Mirim" (que em tupinguarani significa pequeno salto), que, com o passar do tempo, tornou-se simplesmente "Jumirim". A citação geológica mais antiga está registrada no trabalho de Barbosa \& Almeida (1949), que já atribuiram aos diamictitos a denominação genética de "tilito", destacando-os como membro (Membro Tilito Jurú Mirim) da então "Formação Tietê".

Barbosa \& Almeida (1949) não descreveram os diamictitos, apesar de os denominarem "tilitos", mas destacam as suas possíveis correlaçöes com outros afloramentos e implicações estratigráficas. Segundo eles, o "Tilito Jurú Mirim" poderia atingir $20 \mathrm{~m}$ de espessura e seria separado, no contato superior da então "Formação Itapetininga" (equivalente a atual Formação Tatui), por arenitos finos. Estes "tilitos" seriam correlatos aos identificados na sondagem no. 4 de Anhembi, entre as profundidades 282,8 e $305 \mathrm{~m}$, capeando $10,8 \mathrm{~m}$ de arenitos brancos e folhelhos cinzas, sucessão esta também verificada pelos pesquisadores nas cercanias de Jumirim.

Barbosa \& Aimeida (1949) chamaram a atenção para a posição estratigráfica destes "tilitos", que, segundo eles, encontravam-se acima das ocorrências de carvão de Cerquilho, Mato Seco e rio Capivari, as quais, desde aquela época, apresentam incertezas a respeito de seus posicionamentos estratigráficos (e.g.: o carvão de Cerquilho). Não cabe aqui esclarecer, ou mesmo tentar esclarecer, tais dúvidas que ainda persistem, mas sim referir às primeiras citações deste último evento glacial registrado no Neopaleozóico do Estado de São Paulo. O fato é que o diamictito aflorante nas imediações da cidade de Jumirim foi, por vezes, considerado um marco estratigráfico do término da sequência glacial, aqui denominada Subgrupo Itararé.

Com relação ao afloramento aqui analisado, verifica-se que, até o presente momento, a maioria dos trabalhos anteriormente realizados na área concentraram-se na análise dos pavimentos de clastos que ocorrem intercalados na seção local (Rocha-Campos et al., 1968, 1969; RochamCampos et al., 1972). Estas concentraçöes horizontais de clastos, facetados e estriados, dentro do diamictito, interpretados como decorrentes de ação glacial, foram 
descritas pioneiramente por Rocha-Campos et al. (1968), no afloramento ao longo do leito da antiga ferrovia Sorocabana. Neste afloramento, Rocha-Campos et al. (1968) descreveram um pavimento de clastos (Pavimento B, Lucio, 1999) entalhado no topo da sequência cuja base encontra-se ao nivel da rodovia SP-300 situado imediatamente mais abaixo. A posterior descoberta de marcas em crescente e estrias glaciais sobre a face superior de um dos matacões do pavimento (Rocha-Campos et al., 1969) reforçou as evidências sobre uma origem glacial para os pavimentos de clastos, de modo análogo aos ocorrentes em sedimentos do Pleistoceno da América do Norte.

Mais recentemente Rocha-Campos et al. (1992) e Cotter et al. (1992) discutiram várias hipóteses a respeito da provável origem dos pavimentos de clastos de Jumirim, tendo como base os reexames dos afloramentos situados na estrada de ferro. Desta forma foi possivel reconhecer a ocorrência de outros niveis de diamictitos e um segundo pavimento de clastos.

Diferentemente do apresentado nos trabalhos anteriores, Pires (2001, p.57) interpretou os conglomerados da base do afloramento Sul da Rodovia Marechal Rondon (SP-300), aqui referidos como pertencentes à Associação 4, como depósitos do tipo F5 (facies de granulação grossa) da classificação de Mutti (1992 apud Della Fávera, 2000). Esta atribuição implica em uma gênese do depósito como associada a eventos ocorridos imediatamente após a transformação de um fluxo hiperconcentrado para uma corrente de turbidez de alta densidade. Os arenitos com granodecrescência ascendente sobrejacentes aos conglomerados, são considerados por Pires (op. cit.) como equivalentes à Facies F8 de Mutti (1992 apud Della Fávera, 2000), ou seja, depósitos produzidos pela concentração de sedimentos após um salto hidráulico, seguido de deposição de sedimentos em suspensão. Este quadro assim delineado implica estar diante de um contexto de lobos deposicionais, onde correntes de turbidez arenosas de alta densidade seriam depositadas a partir da suspensão e por esforços tracionais localizados em ambientes canalizados.

No entanto, esta interpretação, aparentemente, não considera a possibilidade de serem esses depósitos do tipo flúvio-deltaicos, mais especificamente do tipo planície de lavagem subaquática (subaqueous outwash) de Rust (1977). Objeções à interpretação proposta por Pires (2001), começam a se estruturar quando se integra os demais dados presentes no afloramento ao contexto estratigráfico local, principaimente no que concerne: aos sedimentos siltosos com fósseis vegetais, aos pavimentos de clastos, aos arenitos deformados, à superficie estriada e aos diamictitos, que ocorrem logo acima deste depósito e que serão detalhados mais adiante.

O nivel de conhecimento alcançado até o momento, permite manter a hipótese de que - afloramento de Jumirim pode se constituir em mais um exemplo de estruturas glaciotectônicas rúpteis registradas no Subgrupo Itararé. Este afloramento não só possibilita o seu cotejamento, em termos de processos, com o afloramento de Capivari, e permitindo, 
desta forma, compreender melhor e de modo mais claro os eventos que influenciaram a gênese dos pavimentos de clastos ocorrentes em ambas as localidades, mas também se tornou um fator importante em termos da sua estratigrafia e das novas ocorrências de fósseis de plantas descobertas através deste estudo.

\subsection{WITMARSUM (PR)}

A Colônia Menonita de Witmarsum (PR) localiza-se entre as rodovias BR-277 e BR376, no município de Palmeira. A importância geológica desta localidade, não reside somente no recém inaugurado "Sítio Geológico das Estrias Glaciais de Witmarsum" (Figuras 2.5.1 e 2.5.2), mas também em outras ocorrências de estruturas subgiacias e proglaciais que afloram na regiäo.

Todavia, com exceção do trabalho de Trosdtorf Jr. (2002), que as menciona, praticamente não há registros de trabalhos sobre estruturas glaciotectônicas na região. Os trabalhos anteriormente desenvolvidos nesta localidade e adjacências ou foram de mapeamento geológico básico, como as folhas de Quero-Quero, Porto Amazonas, Campo Limpo e Contenda (Fuck et al., 1965; Palka et al., 1965; Muratori et al., 1965; Trein et al., 1965), ou estão relacionados aos pavimentos estriados por abrasão glacial sobre arenitos da Formação Furnas (Devoniano) ou às superfícies estriadas em diamictito e arenito do próprio Subgrupo Itararé (Fuck \& Bigarela, 1967; Bigarella et al., 1967; Rocha-Campos, 1967; Canuto, 1985; Santos, 1987; Santos et al., 1996; Vesely \& Assine, 1998; RochaCampos et al., 1999; Trosdtorf Jr. et al., 2001, Trosdtorf Jr., 2002; Trosdtorf Jr. et al., no prelo). As estrias glaciais cobrem, descontinuamente, uma superfície relativamente plana de aproximadamente de $1.500 \mathrm{~km}^{2}$, abrangendo uma considerável porção do flanco sul (SW) do Arco de Ponta Grossa, que estão muito bem analisadas no trabalho de Trosdtorf Jr. (2002).

A ocorrência de estriações glaciais, em dois niveis distintos, sobre 0 arenito Fumas e diamictito do Subgrupo Itararé, foi atribuida por Bigarella et al. (1967) e Fuck \& Bigarella (1967) a duas fases glaciais distintas, denominadas "Glaciação Rio do Salto" e "Glaciação Cancela". Paleocorrentes medidas por Bigarella \& Salamuni (1967) em arenitos do Subgrupo Itararé indicam fluxo das correntes no geral de SE-NW, e, portanto, consistentes com a orientação das estrias glaciais. Igualmente concordantes são os dados de medição da fábricas dos clastos dos diamictitos (Bigarella et al., 1967). As paleocorrentes do Subgrupo Itararé diferem das do arenito Furnas, orientadas em média de NE-SW (Fuck \& Bigarella, 1967), e permitem, associadamente ao tipo das estruturas sedimentares destes, diferenciá-los dos arenitos do Subgrupo Itararé, aos quais se assemelham (Trosdtorf Jr., 2002). 
Novos dados obtidos por Vesely \& Assine (1998), Rocha-Campos et al. (1999) e Trosdtorf Jr. et al. (no prelo), ampliaram os conhecimentos a respeito das características do ambiente glacial da região. Vesely \& Assine (op. cit.), referem-se à descoberta de várias superfícies estriadas sobre o arenito Furnas e diamictito do Subgrupo Itararé, na região entre Curitiba e Ponta Grossa, enquanto que Rocha-Campos et al. (op. cit.) descrevem afloramentos nas imediações de Palmeira (PR), onde foram identificadas de quatro a cinco superfícies glacialmente estriadas sobre arenitos do Subgrupo Itararé, estratigraficamente repetidas. Trosdtorf Jr. et al. (no prelo), por sua vez, descrevem e discutem a origem de duas superfícies sulcadas e estriadas sobre diamictitos nas proximidades de São Luiz do Purunã (Figura 2.5.3).

O trabalho de Trosdtorf Jr. (2002) permitiu caracterizar o flanco sul do Arco de Ponta Grossa como uma região-chave para estudos de Geologia Glacial do Neopaleozóico da Bacia do Paraná. Numerosos aspectos, envolvendo estratigrafia e sedimentologia glacial e processos de erosão e deposição subglacial e proglacial foram analisados, oferecendo uma visão da história da glaciação neopaleozóica da Bacia do Paraná e das características do lobo glacial Paraná, com um detalhe até então não alcançado em outras partes da Bacia do Paraná. Contribui, ainda, para a história glacial no âmbito do quadro das alterações ocorridas no condicionamento tectono-estrutural do Arco de Ponta Grossa. Foi através dos trabalhos de campo em conjunto com o geólogo Ivo Trosdtorf Jr., que foram descobertas as colinas com diamictito deformado, analisadas em detalhe no Capítulo 5 da presente tese de doutorado.

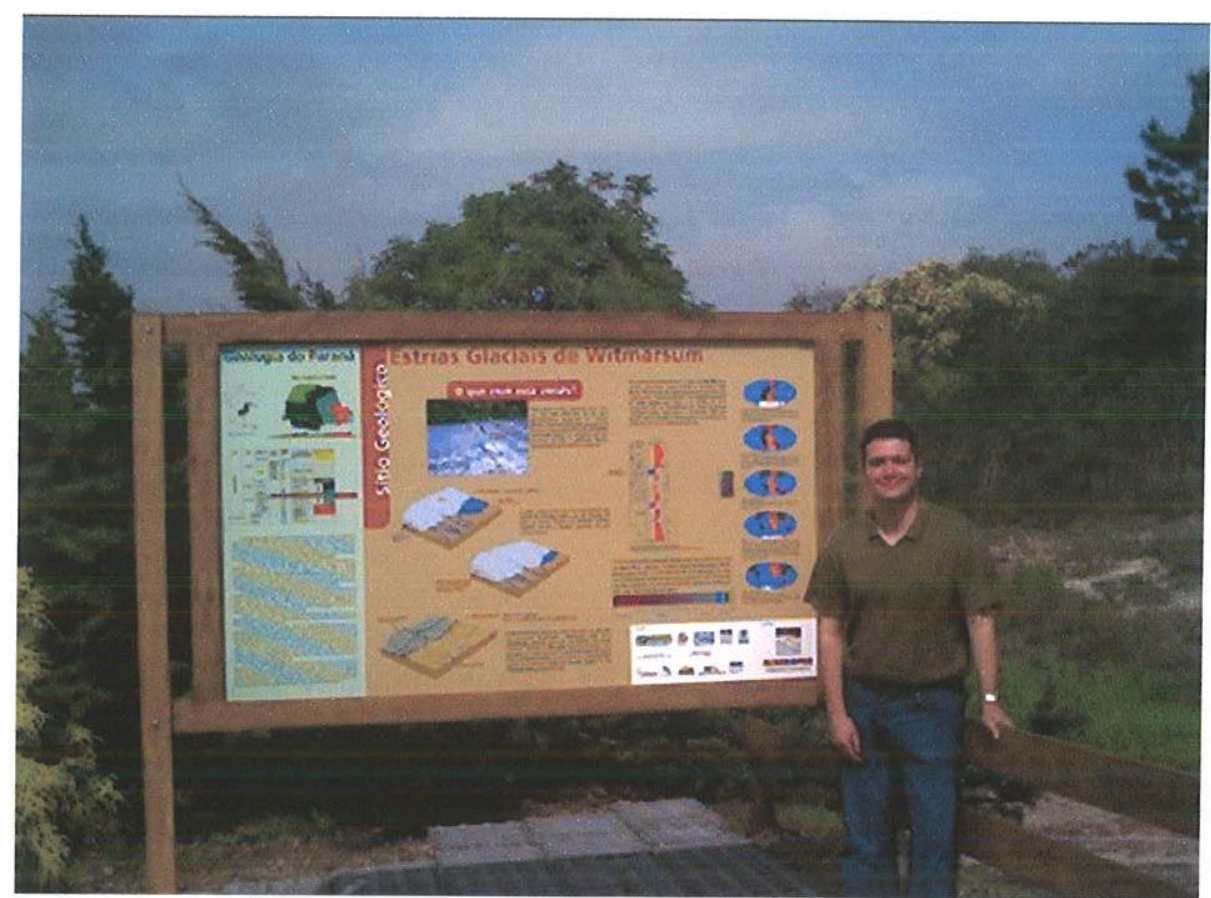

Figura 2.5.1 - Painel explicativo do Sítio Geológico das Estritas de Witmarsum, inaugurado em setembro de 2003. Foto de Rodrigo A. P. Salvetti. 


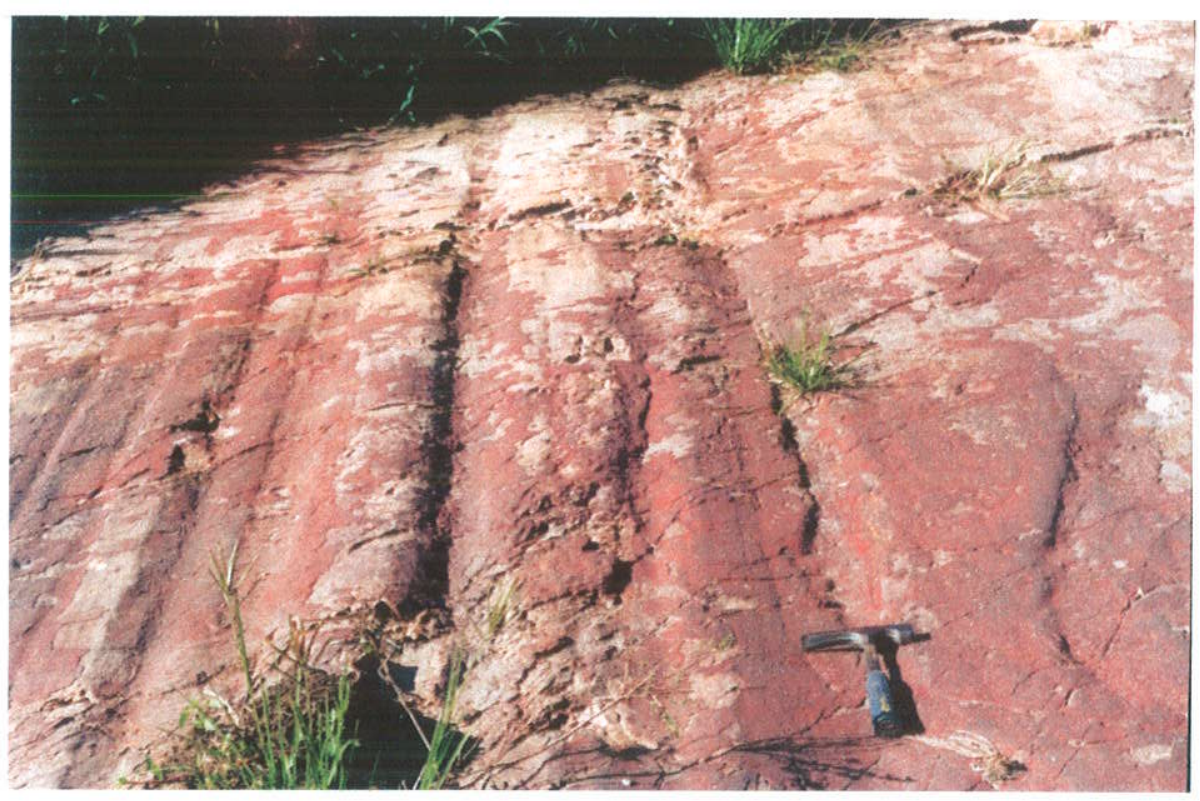

Figura 2.5.2 - Pavimento glacial estriado e sulcado de Witmarsum. Escala: martelo geológico.

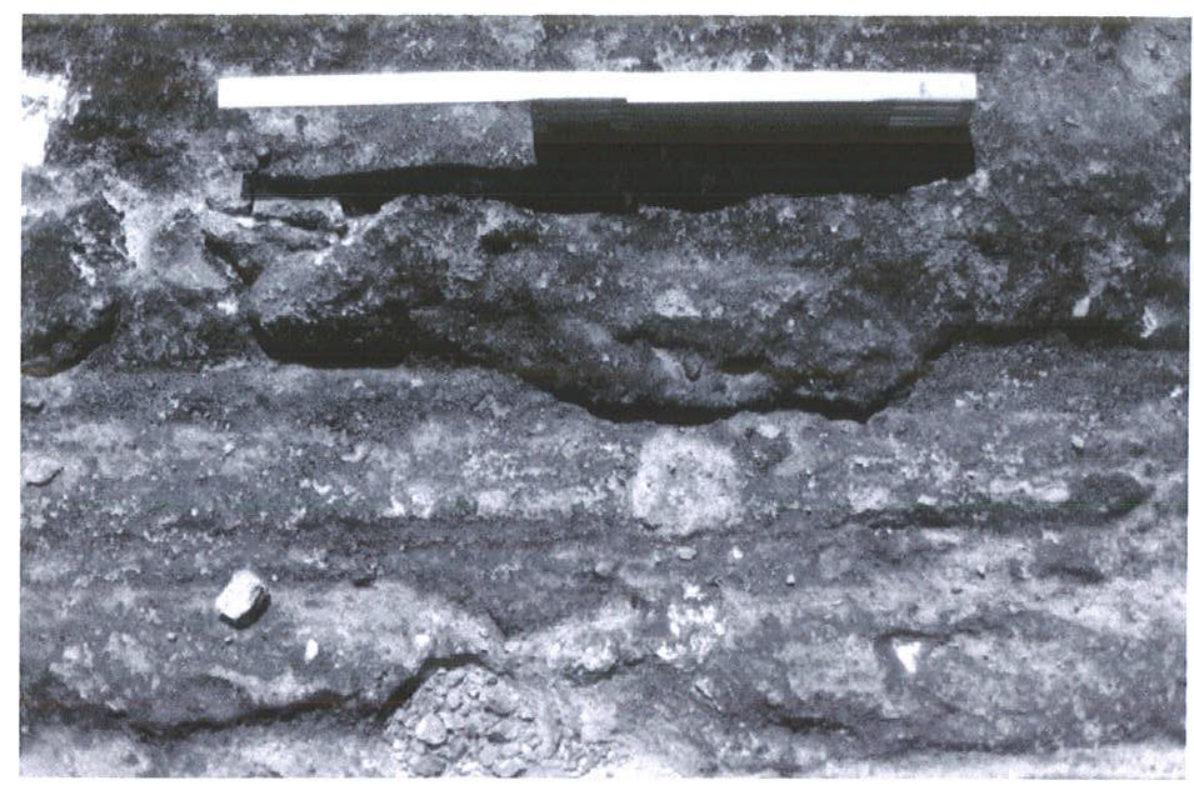

Figura 2.5.3 - Aba de diamictito escorregado dentro de sulco a partir de crista. Escala com $20 \mathrm{~cm}$ de comprimento (Trosdtorf Jr., 2002; Trosdtorf Jr. et al., no prelo). 


\subsection{HAGAFELLSJÖKULLL-EYSTRI (ISLÂNDIA)}

Este estudo realizado na Islândia fez parte do projeto da bolsa de doutoramento sanduíche, intitulado "Deformaçōes subglaciais e proglaciais do Neopaleozóico da Bacia do Paraná (Brasil) e Pleistoceno da Inglaterra e recente da Islândia: um estudo comparativo", desenvolvido na Universisty of Greenwich (Inglaterra), sob a supervisão do Prof. Dr. Matthew R. Bennett (University of Boumemouth, Inglaterra) e apoiado por financiamento da CAPES (Proc.: BEX2287/01-3), nas atividades na Inglaterra, e da FAPESP (Proc.: 99/11083-5), nos trabalhos de campo na Istândia.

Existem poucas informações disponiveis sobre a geologia desta inóspita região da Islândia. Os raros trabalhos existentes referem-se apenas às menções sobre as lavas almofadadas (pillow lavas); aos dados cartográficos e geomorfológicos; aos eventos relacionados à geleira Hagafellsjökull-Eystri; ou às ocorrências de cinzas vulcânicas utilizadas nas análises sobre a evolução do lago Hagavatn, com base nas datas conhecidas das erupções vulcânicas de Hekla, em 850-900 d.C.., 1673, 1766, e de Katla em 1721 (Bennett et al., 2000).

O único trabalho com enfoque geológico foi realizado por Bennett et al. (2000), que, na realidade, compreende os resultados obtidos a partir da primeira de uma série de expedição britânica, que contaram com a colaboração do autor desta tese durante a segunda etapa. Este primeiro estudo enfatizou as análises sôbre a sedimentação glácio-lacustrina e as flutuações Neoglaciais do lago proglacial Hagavatn, fornecendo dados importantes sobre a geomorfologia da região e os processos de transporte e sedimentação, principalmente relacionados ao lago Hagavatn. Com relação aos principais componentes geomorfológicos, Bennett et al. (op cit) destacam os seguintes: terraços formados por antigas margens de lago (shoreline); acamamentos do lago expostos atualmente, estas duas formas de relevo derivadas da variação do volume de água no lago Hagavatn; deltas em contato com gelo (ice-contact deltas); bancos de morainas (morainal-banks); e morainas (Figura 2.6.1).

Os sedimentos expostos do substrato do lago Hagavatn são compostos, basicamente, por siltes e argilas laminadas, além de areias com marcas onduladas e, frequentemente, contendo clastos de areia e argila, demonstrando terem sido depositadas por correntes de tração. Estes corpos arenosos apresentam numerosas superfícies erosivas e diminuem de espessura em direção ao centro da bacia. A presença de laminações convolutas e estruturas em chama (flame structures) indicam ter havido deposições rápidas. Esta sequência arenosa é interpretada por Bennett et al. (2000) como decorrente de fluxos turbulentos, sendo a fonte destes sedimentos os deltas na frente das geleiras (Hagafellsjökull-Vestari e -Eystri). 

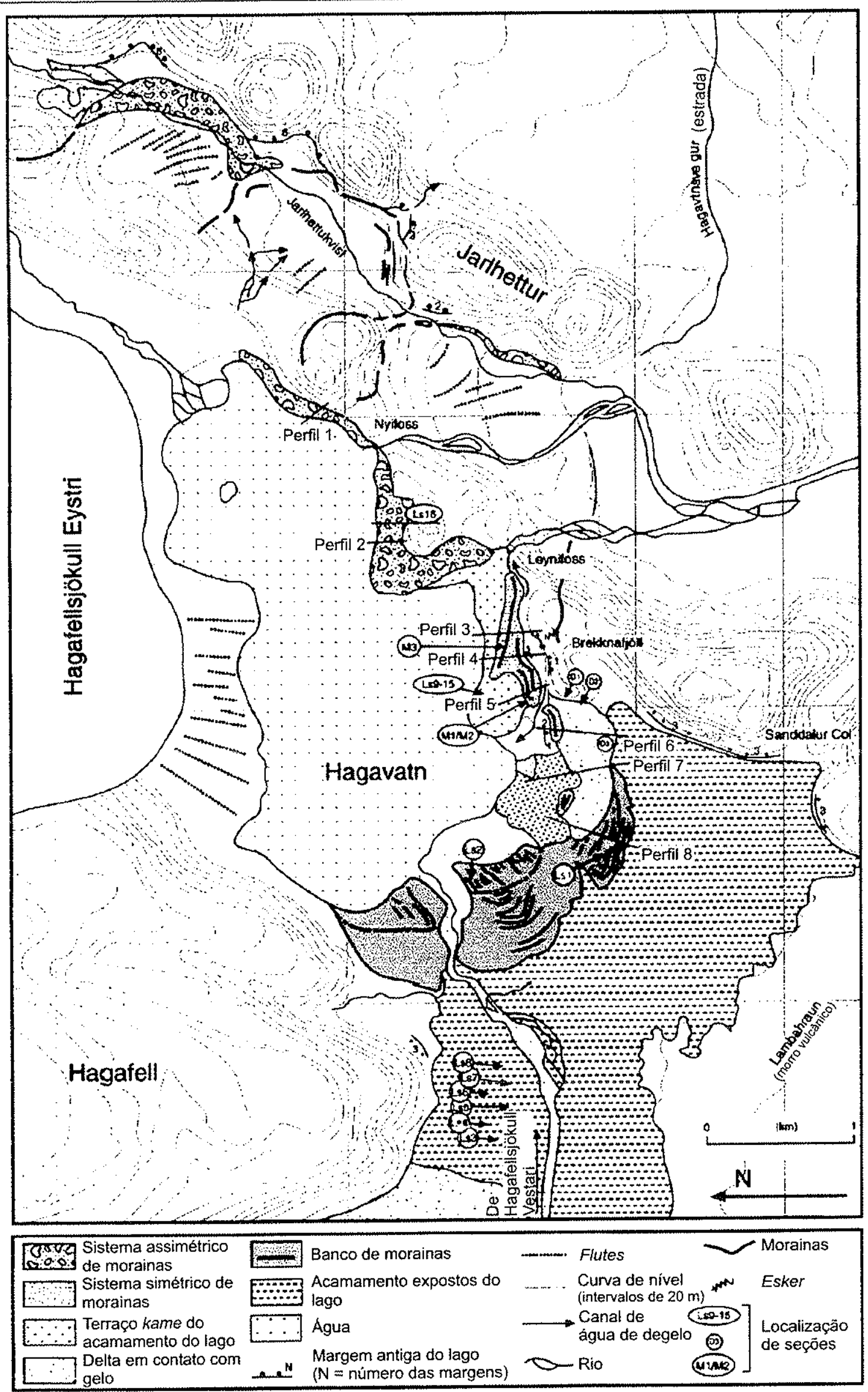

Figura 2.6.1 - Componentes geomorfológicos da região entre a geleira Hagafellsjökull-Eystri, o lago Hagavatn e o vale Jartheltukvisl (Bennett et al., 2000). 
Já os deltas em contanto com gelo (ice-contact deltas) situados nas margens da geleira, consistem em um terraço subhorizontal (1-20 de inclinação) e uma elevação equivalente ao ponto mais alto da margem do lago Hagavatn. As camadas de topo (topsets) de grânulos, capeiam camadas frontais (foresets) de areias e grânulos estratificados, apresentam inclinações que variam entre $10^{\circ}$ e $22^{\circ}$, enquanto que as camadas basais (bottomsets) são compostas por siltes e argilas maciças com clastos caídos. As porções mais distais dos deltas apresentam camadas frontais menos inclinadas (mergulho no máximo $8^{\circ}$ ), e são formadas, basicamente, por areias finas e areias finas siltosas, com estruturas sedimentares que variam entre estratificações horizontais, marcas onduladas cavalgantes, assimétricas e simétricas, estratificações cruzadas em areias grossas e estruturas em chama em siltes e areias finas. Devido à ausência de camadas frontais íngremes e a presença de marcas onduladas simétricas e direções de correntes reversas, interpretou-se que estes deltas são de águas rasas. Bennett et al. (op cit.) também sugerem que estes deltas, provavelmente, foram originados por leques de planície de lavagem subaquáticas, antes de serem expostos subaereamente (Rust, 1977). Por pertinência com o tema desta tese, vale assinalar que, em muitos locais, estes deltas foram retransportados e tectonizados formando morainas de empurrão.

Bancos de morainas (morainal-bank) é um termo usado para descrever as cristas ou acumulações de sedimentos em uma margem de gelo subaquática estável (Hambrey, 1994 apud Bennett et al, 2000). Estes bancos de morainas estão visiveis na frente progradante dos deltas e nos dois lados do rio que flui da geleira Hagafellsjökull-Vestari e são compostos por siltes e argilas, laminadas deformadas.

Três tipos de arcos de morainas ocorrem nesta região: morainas de margem de gelo (icemarginal moraines); sistemas de morainas assimétricas; e sistemas de morainas simétricas. A principal diferença entre as morainas simétricas e as assimétricas é a sua morfologia e suas dimensões, sendo as simétricas significativamente maiores. As morainas de margem de gelo compostas por pequenas cristas, de 1 a $3 \mathrm{~m}$ de altura, são comuns no limite máximo do avanço das geleiras de 1890 no vale Jarlhettukvísl e na porção leste do lago Hagavatn. Já os sistemas de morainas simétricas ocorrem em torno da margem sul e sudoeste do lago Hagavatn e podem apresentar-se isoladas ou na forma de complexos de cristas subparalelas. A maior crista simétrica apresenta $22 \mathrm{~m}$ de altura e $250 \mathrm{~m}$ de comprimento. Os sistemas de morainas assimétricas, por sua vez, constituem empilhamentos irribricados de fatias de sedimentos, de 1 a $5 \mathrm{~m}$ de espessura, cada fatia definindo um arco ou uma crista, com 10 a $150 \mathrm{~m}$ de comprimento, bem definidas, retilineas e com a face menos inclinada voltada na direção da geleira.

As morainas simétricas e as assimétricas estão detalhadas no tópico sobre as estruturas glaciotectônicas (Capítulo 5), em que são apresentados os resultados da colaboração brasileira a esta pesquisa britânica desenvolvida na Istândia. 


\section{GLACIOTECTÓNICA}

O grande valor da glaciotectônica em Geologia Glacial por muito tempo permaneceu desapercebido pelos sedimentólogos glaciais e, por isso mesmo, recebeu pouca atenção da comunidade científica, não só no Brasil, como também no resto do mundo. Segundo van der Wateren (1995a), os livros-texto de Geologia Glacial anteriores à década de noventa, como, por exemplo, Paterson (1981) e Drewry (1986), não comentam em detalhes os processos glaciotectônicos, mas apenas mencionam a possibilidade da sua ocorrência associada às geleiras e estruturas deles derivadas (ver Drewry, 1986, p. 110-112). Muitos artigos desta época não apresentam detalhes dessas estruturas ou mesmo dos processos relacionados aos eventos glaciotectônicos.

Somente nas últimas três décadas $e$, dominantemente, ao longo da última, as estruturas e os processos glaciotectônicos têm atraído um interesse maior dos cientistas. Anteriormente já se reconhecia que problemas estratigráficos em áreas glaciadas, não seriam perfeitamente resolvidos sem uma melhor compreensão das estruturas nelas contidas (e.g.: Banham, 1975, 1977; Berthelsen, 1978). Pesquisas recentes em ambientes glaciais modernos começaram a fornecer dados e evidências mais consistentes sobre os processos que ocorrem subglacialmente e próximo às margens de geleiras (e.g.: Boulton et al., 1976; Boulton, 1979; Alley et al., 1986, 1987a, 1987b; 1989), que incentivaram o desenvolvimento de estudos teóricos (e.g.: Boulton \& Jones, 1979; Moran et al., 1980; Boulton, 1987; Boulton \& Hindmarsh, 1987; Alley, 1989a, 1989b, 1991; Hart et al., 1990; Hart \& Boulton, 1991; Hart, 1995) cujos resultados vêm propiciando um sensivel avanço no entendimento das interações entre as geleiras e seus substratos, tanto no que se refere à gênese das estruturas glaciotectônicas, como também ao comportamento dinâmico das massas de gelo.

Atualmente, grande parte da bibliografia fundamental sobre a glaciotectônica foi levantada pela Comissão sobre Glaciação (Commission on Glaciation) do INQUA (Intemational Union for Quatemary Research) e encontra-se no site URL $\mathrm{http} / /$ www.geospectra.net/glatec_biblio/index.htm (Aber, 2003). São as seguintes, as seis mais importantes publicações recentes dedicadas parcial ou integralmente à glaciotectônica: "Tills and glaciotectonics" (van der Meer, 1987); "Glaciotectonics; forms and processes" (Croot, 1988); "Glaciotectonics landforms and structures" (Aber et al., 1989); "Glaciotectonics and mapping glacial deposits" (Aber, 1993); "Structural geology and sedimentology of push moraines: processes of soft sediment deformation in a glacial environment and the distribution of glaciotectonic styles" (van der Wateren, 1995a) e "Modem glacial environments - processes, dynamics and sediments" (Menzies, 1995), que apresenta 0 capítulo "Processes of glaciotectonism" (van der Wateren, 1995b). 
Até o ano de 2001, faziam parte da Comissão sobre Glaciação, do INQUA, os grupos de trabalho sobre Glaciotectônica (Work Group on Glacial Tectonics) e Processos Subglaciais (Work Group on Subglacial Processes). Atualmente, em virtude da estreita interação entre os tópicos, estes grupos de trabalho se fundiram, formando um único grupo sobre Dinâmica de Geleiras (Work Group on Glacier Dynamics). O desenvolvimento de pesquisas internacionais conjuntas tem demonstrado a preocupação da comunidade cientifica internacional com questões relacionadas à dinâmica das geleiras e à reologia dos processos de interação entre geleira e substratos litificados e inconsolidados. Outros exemplos deste interesse crescente são os simpósios internacionais, tais como o "Glacier deforming bed processes" e 0 "Glaciers and the glaciated landscape", organizados respectivamente, pelo INQUA, em 1999 e pela Intemational Glaciological Society, em 1998; a Sessão Temática sobre processo subglacial e o comportamento das calotas de gelo (Subglacial Processes and the behaviour of ice sheets), na reunião anual da Geological Society of America, em 1999, e as Edições Especiais (Special Issues) sobre "processos relacionados à deformação basal de geleiras", no Quaternary International (em 2001), "sedimentação no contato basal da geleira, processos e depósitos", no Quaternary Science Review (em 1997) e "ambientes subglaciais", Sedimentary Geology (em 1997).

Atuaimente, os grandes centros de estudos sobre a glaciotectônica encontram-se na Holanda, na Dinamarca, na Alemanha, na Polônia, na Rússia, no Reino Unido, no Canadá e nos Estados Unidos. Numerosos são os trabalhos detalhados de pesquisadores holandeses, cujo grande interesse sobre o assunto decorre do destaque topográfico das elevações do terreno de origem glacial (e.g.: os morros Dammer e Fürstenauer, no Alinhamento de Rehburg, Holanda, van der Wateren, 1995a).

Questões econômicas e ambientais também têm se traduzido em um grande alento às tentativas de compreensão dos eventos glaciotectônicos, principalmente em países da Europa e América do Norte. O aprimoramento de tais conhecimentos tem permitido melhor compreender os processos de deslocamento de poluentes em aquíferos localizados em sedimentos glaciais, além da disposição de possiveis derrames de materiais nucleares (e.g.: Wildenborg et al., 1990; van der Wateren, 1995a; Wildenborg, 2001).

Morainas e outras formas de terrenos constituidas por sedimentos glaciais são propensas a constituir bons reservatórios de água subterrânea e de materiais para construção. Não obstante, as informações indicativas do deslocamento dos corpos de gelo, tornam a glaciotectônica importante para a determinação de concentrações minerais de interesse econômico (e.g.: diamante). Nestes casos, os corpos de gelo em questão teriamse deslocado sobre regiöes fontes de tais minerais, erodido-os, transportando-os e concentrando-os em outra localidade. Possiveis evidências desta situação foram descritas no Estado de Minas Gerais (Gonzaga \& Dardenne, 1991; Karfunkel \& Chaves, 1995; Penha 
\& Angeli, 2001; Karfunkel et al., 2001; Sá Rego et al. 2001; Gonzaga, 2001; Dardene \& Campos, 2003; Rocha-Campos et al., 2003), onde, em determinados casos, houve um retrabalhamento cenozóico não glaciogênico reconcentrando os diamantes, mas que não diminui a importância da possivel ação anterior do gelo na remobilização desses minerais.

Visto que as estruturas basais de tills podem ser comparadas, em termos amplos, a milonitos e a modelos orogênicos de grande escala (van der Wateren, 1995a), o aperfeiçoamento dos modelos glaciotectônicos possibilitou também o desenvolvimento científico de modelos orogênicos de pequena escala e trabalhos de monitoramento diversos (e.g.: Boyce \& Eyles, 1981).

Outro estudo que tem se aprimorado com os progressos na área da glaciotectônica é - estudo sobre drumlins (Menzies \& Rose, 1987, 1989), que correspondem a colinas de forma oval, de 5 a $50 \mathrm{~m}$ de altura e 10 a $3.000 \mathrm{~m}$ de comprimento, e perfil assimétrico, com um lado abrupto a montante e um lado de declividade mais suave a jusante (Rocha-Campos \& Santos, 2000). A gênese dos drumlins ainda não é completamente entendida, sendo atribuída a diferentes processos, dentre os quais consta o alojamento subglacial, fusão de gelo rico em detritos e mesmo preenchimento de escavações subglaciais ou fluxo catastrófico de água subglacial (e.g.: Shaw, 1983; Dardis \& McCabe, 1987; Shaw et al., 1989). Contudo, a hipótese de origem glaciotectônica parece ser a mais aceita atualmente (e.g.: Boulton, 1987; Menzies, 1987; Boyce \& Eyles, 1991).

\subsection{DEFINIÇÕES}

Charles Lyell foi possivelmente o primeiro geólogo a discutir a gênese das deformações presentes nos estratos glaciais de Norfolk (Inglaterra) e nos Alpes italianos, assim como em outras localidades (Lyell, 1863 apud Aber et al., 1989). No entanto, como tem sido demonstrado ao longo de décadas, várias estruturas glaciotectônicas, ocorrentes em diversas partes do mundo, têm sido muitas vezes interpretadas equivocadamente como tendo sido causadas por escorregamentos (fluxos gravitacionais de massa), intrusões, vulcanismo, processos tectônicos relacionados às orogêneses, etc., o que serve para por em evidência o caráter distinto deste ramo da geologia (Pedersen, 1996).

Os primeiros conceitos glaciotectônicos foram propostos pelo geólogo inglês George Slater, um dos pioneiros a estudar morainas de empurrão (push moraines). Inicialmente, 0 termo proposto por Slater (1926 apud Aber et al., 1989) para o processo era glacial tectonics (tectônica glacial), que, posteriormente, encurtou para glaciotectonics (inglês americano) e glacitectonics (inglês britânico, pouco usado), e que em português foi traduzido para glaciotectônica. Acrescentam-se os termos: Glazitektonik em alemão, glaciotektoniek em holandês e glaciotektoniske em dinamarquês, por serem línguas de outros grandes centros de estudos sobre glaciotectônica. Slater (op cit.) não definiu a expressão "glacial tectonics", 
mas usou-a como referência às deformações perturbando sedimentos inconsolidados $e$ rochas rígidas do embasamento, assim como as deformações presentes no gelo das geleiras (Aber et al., 1989).

Contudo, até o presente momento, o significado do termo glaciotectônico ainda causa discussões e divergências, podendo ser identificadas, basicamente, duas linhas de raciocínio. A primeira considera inapropriada a utilização de uma terminologia única e especifica para a glaciotectônica e, dessa forma, utiliza apenas conceitos terminológicos de geologia estrutural (e.g.: Banham, 1977; Berthelsen, 1979; van der Wateren, 1995a, 1995b). Berthelsen (1979) comenta que as deformações formadas em rochas orogênicas consolidadas são muito similares às encontradas em rochas inconsolidadas ou fracamente consolidadas que sofreram glaciotectonismo. A principal diferença entre as estruturas seria a escala, e, desta forma, estruturas orogênicas seriam medidas em quilômetros $e$ as glaciotectônicas em metros, além do fato que as estruturas orogênicas têm um potencial de preservação maior do que as glaciotectônicas. Por outro lado, a definição proposta por van der Wateren (1995a, 1995b), considera que a glaciotectônica refere-se às deformações causadas por esforços glaciais no horizonte superior da litosfera. Esta definição exclui, portanto, os movimentos isostáticos que envolvem a crosta inteira e a reativação de grandes falhas crustais abaixo das geleiras.

De forma oposta à primeira, a segunda linha de pesquisa adota uma terminologia e uma classificação específicas para a glaciotectônica (e.g.: Brodzikowski \& van Loon, 1985, 1991; Aber et al., 1989). O termo glaciotectônico, neste caso, refere-se às deformações, em escalas variadas, criadas por eventos glaciais no substrato, que pode ou não ser litificado (Aber, 1982). O termo exclui, desta forma, outras estruturas pós-deposicionais resultantes do colapso causado pelo derretimento de gelo soterrado (Eyles, 1977; Hart \& Boulton, 1991).

A primeira linha de pesquisa enfatiza principalmente os caracteres estruturais das estruturas glaciotectônicas, contrapondo-se às escolas anglo-saxônicas, em que os atributos sedimentológicos e estratigráficos são mais enfatizados. No entanto, esta diferenciação, no nosso ponto de vista, é, em muitos casos, prejudicial à Glaciotectônica, visto que são "ferramentas" complementares. Segundo van Loon (2002), esta diferenciação é, em parte, decorrente da especialização em apenas um ramo da Geologia na formação dos geólogos e geocientistas, como de fato ocorre em muitas escolas científicas de todo mundo. Apesar de enfatizar que deve haver especialistas, van Loon destaca que a formação dos futuros cientistas precisa abranger, de forma ampla, todas as áreas das Geociências, favorecendo, desta forma, a formação de geocientistas em áreas que abrangem mais de uma área específica da Geologia, como é o caso da Tectônica Glacial (vide o próximo tópico para definição). Desta forma, neste trabalho não visamos seguir uma única linha de pesquisa, 
mas sim procuramos utilizar ambas as "ferramentas", e adaptando-as à realidade neopaleozóica brasileira.

\section{Tectônica Glacial}

A glaciotectônica não deve ser identificada com a "Tectônica Glacial", pois que estes dois termos são facilmente confundidos, principalmente na lingua inglesa, visto que apresentam, inclusive, grafia e pronuncia semelhantes, "glaciotectonics" e "glacial tectonics", respectivamente. Segundo Thorson (2000), o objetivo principal dos estudos sobre glaciotectônica é a reconstrução dos regimes das geleiras através de observações de campo, especialmente as associadas a deformações de materiais inconsolidados na base da geleira e abaixo dela, além de empurrões marginais cuja escala varia de $10^{-2}$ a $10^{3} \mathrm{~m}$, enquanto que a tectónica glacial seria o termo mais apropriado para designar deformações provocadas por geleiras tanto na base destas (glaciotectônicas), quanto de escala crustal. Em termos acadêmicos a glaciotectônica insere-se, desta forma, como uma subdisciplina da Tectônica Glacial, apesar de atualmente estar relacionada à Geologia do Quaternário (Thorson, 2000) ou à Geologia Glacial. Outros termos sugeridos, como gláciosismotectônica, glácio-sismicidade, tectônica induzida glacialmente ou simplesmente tectônica, não auxiliam na incorporação de uma importante subdivisão na Geologia, que seria útil para interligar a Glaciologia à Tectônica ou a Geologia Glacial à Geologia Estrutural. Além disso, o termo "tectônica glacial" já vem sendo utilizado frequentemente e, depois do trabalho Thorson (2000), a tendência é que se consolide.

A tectônica glacial ganhou destaque com o aprimoramento de técnicas instrumentais e computacionais, que permitem identificar variações topográficas, sísmicas e de esforços crustais, que não eram reconhecidas nas décadas passadas. Essas novas tecnologias têm permitindo diagnosticar deformações dentro e/ou abaixo de uma geleira (Thorson, 2000).

\section{Definições adotadas}

Neste trabalho adotar-se-á preferencialmente os conceitos glaciotectônicos semelhantes aos apresentados por Aber et al. (1989), Pedersen (1993, 1996) e Thorson (2000), procurando-se, contudo, uma terminologia flexivel e independente, que aproveite o que se considerou de mais adequado em ambas as linhas de pesquisa, entre os quais estão os seguintes termos:

Glaciotectônica (Glaciotectonics) - ciência que estuda a reologia e as deformações das rochas consolidadas ou inconsolidadas causadas por esforços na base de um corpo de gelo (e.g.: geieira). Na forma de adjetivo, qualifica as estruturas ou a geomorfologia resultantes da deformação causada pelo movimento da geleira. 
Glaciotectonismo (glaciotectonism) - termo geral para todos os processos glaciotectônicos.

> Tectónica Glacial (Glacial Tectonics) - ciência que estuda os movimentos e deformações provocadas por corpos de gelo (e.g.: geleiras), tanto na base destas (glaciotectônicas), quanto de escala crustal.

D Deformação glaciotectônica (glaciotectonic deformation) - deformação causada pela passagem de um corpo de gelo sobre sedimentos inconsolidadas ou rochas consolidadas preexistentes. As deformações glaciotectônicas apresentam pelo menos duas fases: os dobramentos e acavalamentos proglaciais, e os cisalhamentos e brechamentos cataclásticos subglaciais.

$>\quad$ Unidade glaciotectónica (glaciotectonic unit) - sedimentos ou rochas sedimentares deformadas durante a passagem de uma geleira. Uma unidade glaciotectônica faz parte de uma sequência glaciotectônica.

$>$ Moraina de empurrão (push moraine) - produto da deformação do gelo, sedimento e/ou rocha, que originou uma colina ou colinas transversais ou obliquas à direção do fluxo de gelo na porção frontal, na porção inferior ou na própria margem do gelo (Bennett, 2001). Estas formas construcionais englobam as morainas de blocos acavalados (thrust-block moraines), morainas acavaladas (thrust moraines), cristas compostas (composite ridges) e conjunto colina-vala (hill-hole pairs).

No presente trabalho, não se incorporou o termo "glaciotectonito" (glaciotectonite) como sendo a litologia decorrente de processos glaciotectônicos subglaciais (Pedersen, 1996), por se considerá-lo impróprio e desnecessário. Os processos glaciotectônicos não geram uma nova litologia, apenas as modificam estruturalmente, e, neste contexto, houve consenso com as observações de van der Wateren (1995a, p. 4). Cabe, contudo, adicionar que o termo "milonito", embora também seja oriundo de processos tectônicos e, portanto, não seja uma nova litologia, já está consagrado, apesar de acharmos desnecessária a designação. Todavia, o termo "glaciotectonito" ainda não é totalmente aceito e consagrado, sendo este um momento oportuno para corrigir a propagação de uma terminologia equivocada. 


\subsection{TIPOS DE ESTRUTURAS GLACIOTECTÓNICAS}

As estruturas glaciotectônicas variam em escalas desde microscópicas a regionais. Normalmente os materiais deformados são originalmente inconsolidados, restando aos consolidados uma frequência mais restrita, que inclui rochas cristalinas e sedimentos consolidados (Kupsch, 1955; Babcock et al., 1978). Uma lista completa das estruturas glaciotectônicas é praticamente impossível de ser feita devido à grande variedade dos seus tipos e escalas (Aber et al., 1989), o que torna o diagrama apresentado por Occhietti (1973 apud Aber et al., 1989) insuficiente, embora ilustre de forma clara esta grande diversidade de estruturas (Figura 3.2.1).

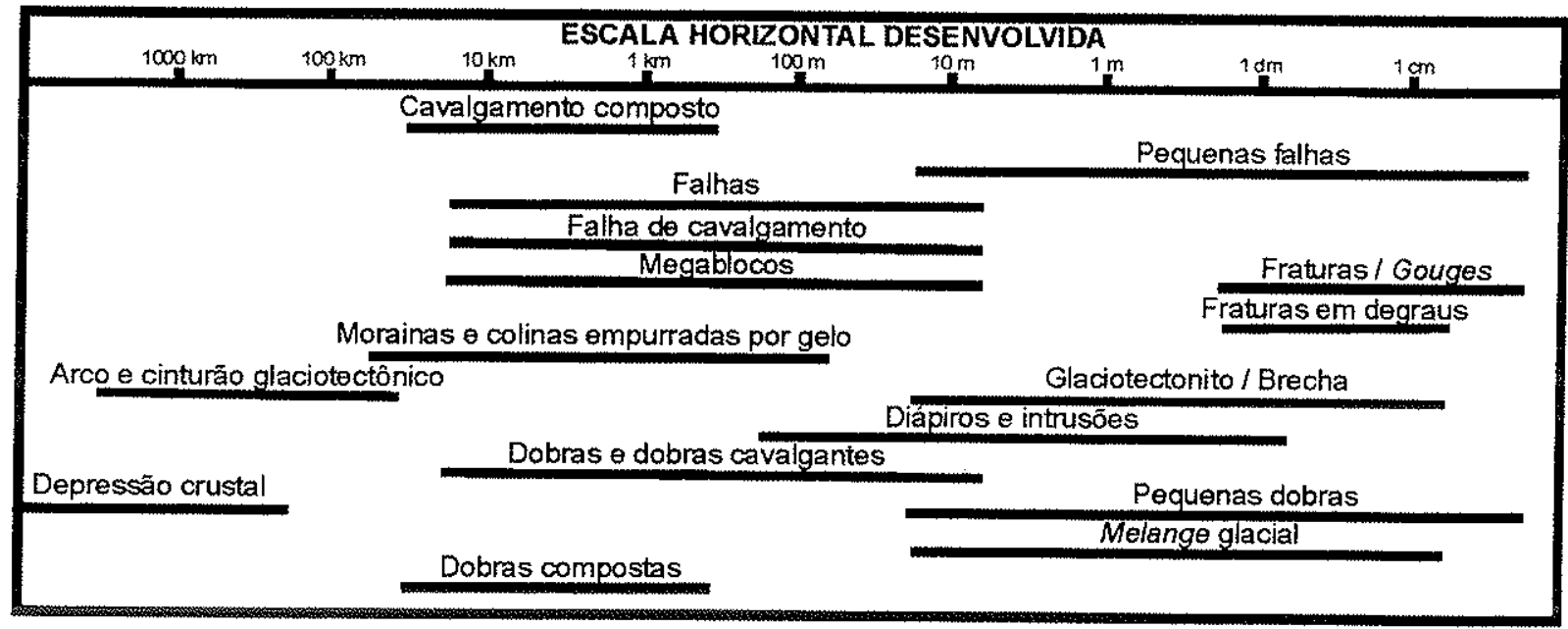

Figura 3.2.1 - Diagrama com as estruturas glaciotectônicas mais comuns arranjadas de acordo com a escala horizontal típica (logarítmica). Estruturas dúcteis na porção basal e rúpteis na porção superior (Aber et al. 1989).

Em 1975, Banham sugeriu dois estilos de deformações glaciotectônicas: endiamict (endiamict $^{8}$ ) e exodiamict (exodiamict). O primeiro representaria as estruturas glaciotectônicas pequenas, como dobras cisalhadas e achatadas, foliações, planos axiais e lineações de clastos. O termo exodiamict refere-se a tilitos ou tills com estruturas glaciotectônicas maiores, como dobras e acavalamentos formados após a deposição do diamícton (Banham, 1975). Esta classificação limita a giaciotectônica a sedimentos rudáceos, estejam eles consolidados (diamictitos) ou não (diamictons), e, no entanto, existem vários casos de outros tipos de sedimentos e rochas (areias, argilas, siltes, arenitos, etc.) que sofreram deformações glaciotectônicas (e.g.: as morainas de empurrão de Hagafellsjökull-Eystri, Bennett et al., 2003; 2004). Assim, não é recomendável a utilização desta classificação, em virtude da sua limitação em relação aos tipos litológicos envolvidos.

Posteriormente, a INQUA propôs uma classificação para as estruturas glaciotectônicas envolvendo formas de terreno, utilizando termos genéticos e não-genéticos (Goldthwait,

${ }^{8}$ Alguns pesquisadores utilizam o termo "diamict", quando querem se referir a ambos os tipos de sedimentos: diamícton e diamictitos (e.g.: Eyles et al., 1983). 
1989), sendo, contudo, de dificil utilização face a pletora de termos e o fato de utilizar descrições genéticas específicas de forma vaga e aplicá-las a diferentes fenômenos (Bennett, 2001). Outro exemplo da utilização de formas de terreno para classificar estruturas glaciotectônicas é o propostado por Aber (1988), que classifica as estruturas formadas em ambiente proglacial em cinco tipos: conjunto colina-vala (hill-hole pair); grandes cristas compostas (large composite-ridges); pequenas cristas compostas (small composite-ridges); colina cupular (cupola-hill); e acamamento plano de megablocos (flat-lying megablock). No entanto, como a forma original das estruturas pré-pleistocênicas nem sempre se manteve preservada devido aos processos erosivos, o presente trabalho não considerará, a priori, estas classificações.

No mesmo ano em que a INQUA divulgou a sua classificação para as estruturas glaciotectônicas, Aber et al. (1989) propôs que, em termos gerais, estas estruturas poderiam ser dividas em duas categorias, de acordo com o tipo de deformação: dúcteis e rúpteis. As deformações dúcteis ocorrem associadas a pequenos movimentos internos ou percolação de material em estado plástico ou fluído. Durante a deformação dúctil, a massa de rocha praticamente não apresenta resistência interna, de tal forma que uma pequena diferença de pressões pode resultar em mudanças substanciais no tamanho e/ou forma do corpo. As estruturas dúcteis são mais comuns em sedimentos inconsolidados ou estratos com granulometria bem finas (e.g.: argila, silte, folhelho e giz), formando intrusões, diápiros e vários tipos de dobras, devido à alta pressão confinada.

As estruturas rúpteis resultam em corpos falhados e fraturados e estão relacionadas ao movimento ou ajuste em planos de fraturas. As estruturas rúpteis estão mais presentes em estratos consolidados ou de granulometria mais grossa (e.g.: areia, cascalho, arenito), nos quais a pressão confinante é menor, permitindo a formação de juntas, falhas, brechas, fissuras e outros tipos de fraturas.

As estruturas rúpteis e dúcteis podem estar intimamente associadas na mesma sequência de deformação dos estratos, em virtude das diferentes resistências oferecidas por cada rocha ou sedimento, causadas, principalmente, pela litologia e espessura das camadas. Cada camada responde a um esforço de uma forma diferente, embora uma mesma camada possa desenvolver estruturas distintas devido à variação da pressão, dos fluidos contidos ou da temperatura durante a deformação.

Hart \& Boulton (1991), por outro lado, apresentaram uma classificação baseada no ambiente em que foram geradas as deformações glaciotectônicas, sugerindo, desta forma, dois tipos de deformações glaciotectônicas: a proglacial e a subglacial.

Segundo Hart \& Boulton (1991), a deformação glaciotectônica proglacial é geraimente caracterizada por grandes dobras e acavalamentos compressionais. $\mathrm{Na}$ realidade, estas estruturas abrangem estilos de deformação compressivos contínuos, que variam de dobras 
(deformação dúctil) a empilhamentos (deformação rúptil), ambos afetando sedimentos ou rochas locais ou transportados por longas distâncias; o resultado final, não obstante, depende da reologia e da competência do substrato e do comportamento do manto de gelo. Para ilustrar alguns resultados de processos de deformação proglacial, Hart \& Boulton (op cit.) também recorreram às formas topográficas para classificá-las:

a) morainas antiformais de pequena escala, exemplificadas pelas morainas na frente da geleira Holmstrømbreen, em Svalbard (Spitsbergen), Noruega (Boulton et al., 1989 apud Hart \& Boulton, 1991), (Figura 3.2.2A); e

b) grandes complexos de morainas terminais, formados por corpos alóctones, normalmente empilhados por acavalamentos, podendo inclusive apresentar duplexes e nappes. Exemplos destas estruturas são as morainas Dammeberge e Lamstedt, no norte da Alemanha (van der Wateren, 1987; Gijssel, 1987), Rhenen, na Holanda (van der Wateren, 1995a), o Alinhamento Estacionário Principal Weichselian (Weichselian Main Stationary Line), na Dinamarca (Pedersen et al., 1988), Moraina Bride, na liha de Man, Reino Unido (Thomas, 1984) e afloramentos em Alberta, Saskatchewan (ambos no Canadá) e Dakota do Norte (EUA), descritos por Moran et al. (1980), (Figura 3.2.2B).
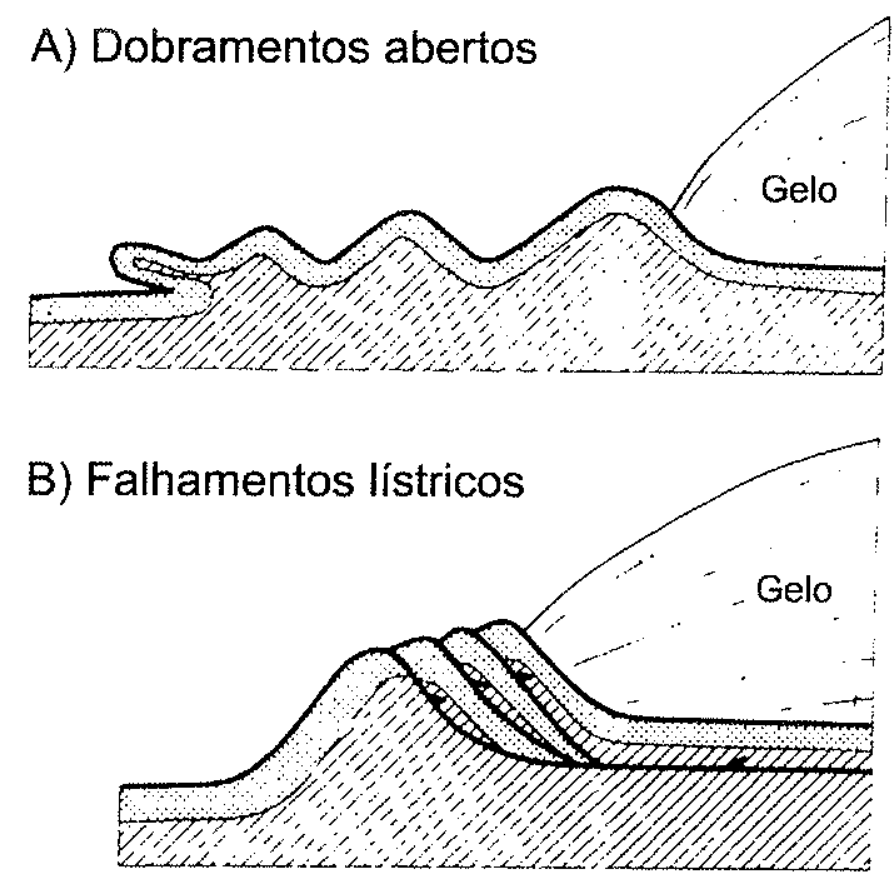

Figura 3.2.2 - Diagrama esquemático dos tipos de deformações glaciotectônicas proglaciais. A) Morainas antiformais de pequena escala; B) Grandes complexos de morainas terminais, com acavalamentos lístricos. (Hart \& Boulton, 1991).

Ainda segundo Hart \& Boulton (1991), as deformações glaciotectônicas subglaciais, por sua vez, são de difícil observação, mas foram estudadas por vários pesquisadores, como, por exemplo, MacClintock \& Dreimanis (1964), Aber (1979), Rappol \& Stoltenburg 
(1985) e Åmark (1986), que descreveram sedimentos com dobras e laminações. Cabe ressaltar os trabalhos desenvolvidos em Breiđamerkurjökull ${ }^{9}$, sudeste da Islândia, por Boulton, Hindmarsh e outros pesquisadores, que desencadearam uma série de novos estudos sobre os padrões, as propriedades reológicas, e os processos das deformações subglaciais e a sua relação com a pressão d'água e os esforços cisalhantes (e.g.: Boulton, 1979, 1982; Boulton \& Jones, 1979; Boulton \& Hindmarsh, 1987, Clarke, 1987, Hart et al., 1990). Baseando-se nos Diamictitos Laminados (previamente denominados Depósito Contorcido, Contorted Drift, por Reid, 1882 apud Hart \& Boulton, op cit.) de West Runton, em Norfolk, Reino Unido (Hart, 1987 apud Hart \& Boulton, op cit.), Hart \& Boulton (op cit) propuseram que o ambiente subglacial, com camadas deformadas, pode estar relacionado a um tipo de zona de cisalhamento, (Figura 3.2.3), visto que:

a) trata-se que uma zona amplamente deformada, planar e longa, entre limites relativamente rigidos com gelo acima e rocha ou sedimento indeformado abaixo; e

b) apresenta-se com um estilo de deformação caracteristico de zonas de cisalhamento, com dobras fechadas atenuadas e cisalhadas, dobras intrafoliais apertadas a isoclinais, texturas cataclásticas, "augens" (shear pods) e evidências de boudinage.
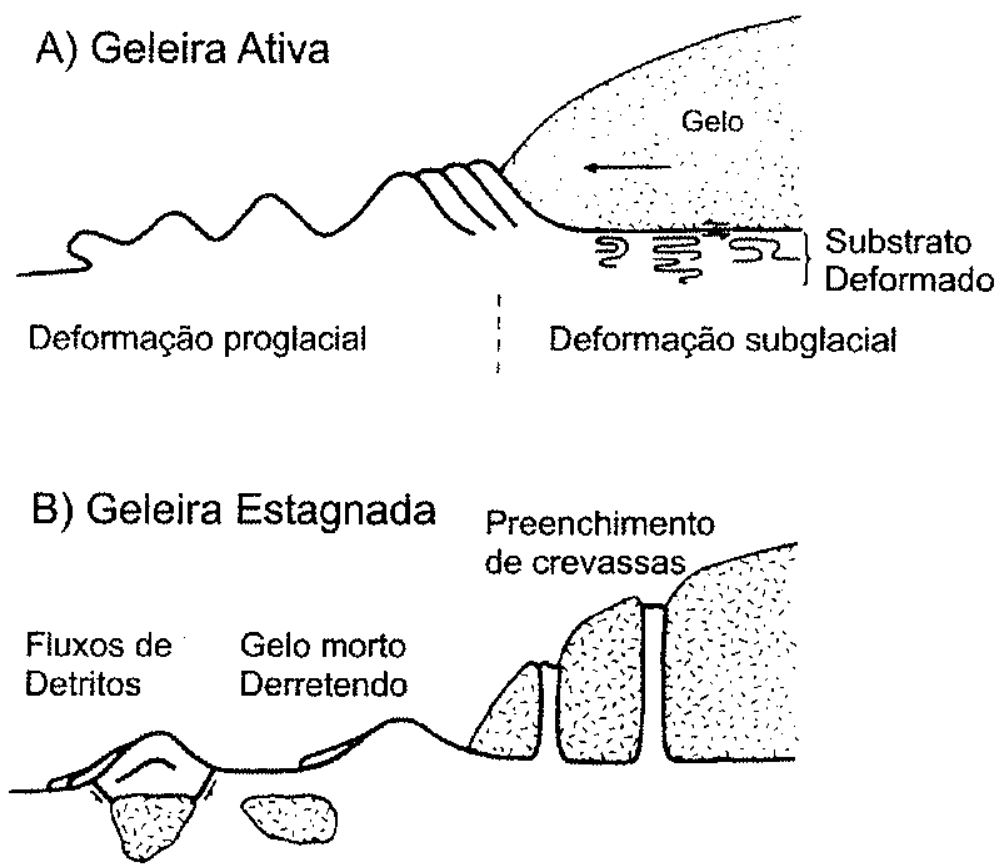

Figura 3.2.3 - Diagrama esquemático dos estilos de deformação associados a: A) geleiras ativas; e B) geleiras estagnadas (Hart \& Boulton, 1991).

\footnotetext{
${ }^{9}$ Breiđamerkurjökull é como se escreve em islandês. A fonética do "đ" do alfabeto islandês é semelhante ao "d" do alfabeto tatino. Desta forma, poderia ser transcrito simplesmente como Breidamerkurjökull. Contudo, para facilitar localização em textos em outras línguas, resoiveu-se manter a escrita original.
} 
Hart \& Boulton (1991) também salientam que, além das deformações glaciotectônicas proglaciais ou subglaciais referidas anteriormente (Figura 3.2.3A), ocorrem outros tipos de deformações. Estas são resultantes de instabilidades gravitacionais associadas a geleiras estagnadas, e podem ocorrer em ambientes proglaciais e subglaciais (Figura 3.2.3B). As deformaçöes relacionadas a instabilidades gravitacionais nas margens da geleira estão, comumente, associadas a derretimento de gelo, como as estruturas de colapso em planícies de lavagem (outwash plains) e os fluxos de detritos de tills supraglaciais (Boulton, 1970; Lawson, 1979). Entretanto, em ambientes subglaciais de geleiras estagnadas, podem também se desenvolver estruturas de preenchimento de crevasses (Hart \& Boulton, 1991).

As concepções concernentes à caracterização dos processos glaciotectônicos podem, entretanto, serem expressas em termos de regimes de fluxos compressivos e distensivos de gelo (Paterson, 1981). Nas porções internas de uma geleira ocorrem esforços distensivos, enquanto que nas margens estes são compressivos. Como tais esforços estão relacionados ao fluxo de gelo, eles acarretam uma distribuição similar nos sedimentos subglaciais e proglaciais, fato que permite a seguinte divisão em termos de regimes glaciotectônicos (van der Wateren, 1995a):

a) zonas de cisalhamento subglacial, agindo como um cinturão transportador de sedimentos; e

b) cinturões de margens compressivas, recebendo sedimentos transportados subglacialmente, assim como os transportados supraglacialmente e englacialmente, incluindo depósitos flúvio-glaciais.

O primeiro regime é caracterizado por mantos de tills deformados subglacialmente (Boulton \& Jones, 1979; Boulton, 1987; Rappol, 1987; van der Wateren, 1987), além de outros tipos de tills, que foram afetados pelo cisalhamento com diferentes intensidades. Terrenos alinhados (streamlined terrains), vales-túneis (tunnel valleys), drumlins e megaflutes são indicativos de cisalhamento subglacial (Boulton, 1987; Boulton \& Hindmarsh, 1987). Já o regime de cinturões de margens compressivas é caracterizado por tills empurrados e empilhados e por morainas de empurrão (push moraines). Comumente apresentam leques flúvio-glaciais de lavagem (outwash) na porção externa das colinas e bacias glaciais na porção interna, de onde provem a massa empurrada (Figura 3.2.4).

Em decorrência do que foi apresentado e analisado neste trabalho sobre estruturas glaciotectônicas pré-pleistocênicas, decidiu-se que estas estruturas podem ser classificadas de acordo com abordagens descritivas e genéticas, caso seja possivel definir o ambiente em que foram geradas, ou seja, uma classificação baseada em Aber et al. (1989), e Hart \& Boulton (1991). Contudo, para simplificar a designação genética sugerimos a adoção de duas novas terminologias: subglaciotectônica (subglaciotectonic) e proglaciotectónica 
(proglaciotectonic), para estruturas glaciotectônicas geradas em ambiente subglacial e proglacial, respectivamente. Em suma, o prefixo designaria o ambiente glacial em que as estruturas glaciotectônicas foram geradas, podendo se adequar o prefixo a outros ambientes glaciais (e.g.: paraglaciotectônica, supraglaciotectônica; embora estas sejam menos frequentes ou pouco preservadas no registro geológico). Quando não for possivel definir a gênese das deformações, principalmente em sedimentos pré-pleistocênicos, sugere-se a utilização do termo mais genérico, glaciotectônica. Eventualmente, também podem ocorrer estruturas poligenéticas, como, por exemplo, uma moraina de empurrão que foi acavalada posteriormente pela geleira, passando a apresentar também estruturas subglaciotectônicas. Nestes casos, o termo mais apropriado para se referir ao conjunto de estruturas geradas por processos subglaciotectônicos e proglaciotectônicos, seria o de poliglaciotectônica (polyglaciotectonic). Além destas designaçöes acrescenta-se os atributos descritivos, rúptil ou dúctil (e.g.: estruturas subglaciotectônicas rúpteis), que podem ser substituidos por termos mais específicos (e.g.: fraturas conjugadas subglaciotectônicas). Observa-se que não se trata da criação de uma nomenclatura nova, mas sim a readequação de termos já existentes.

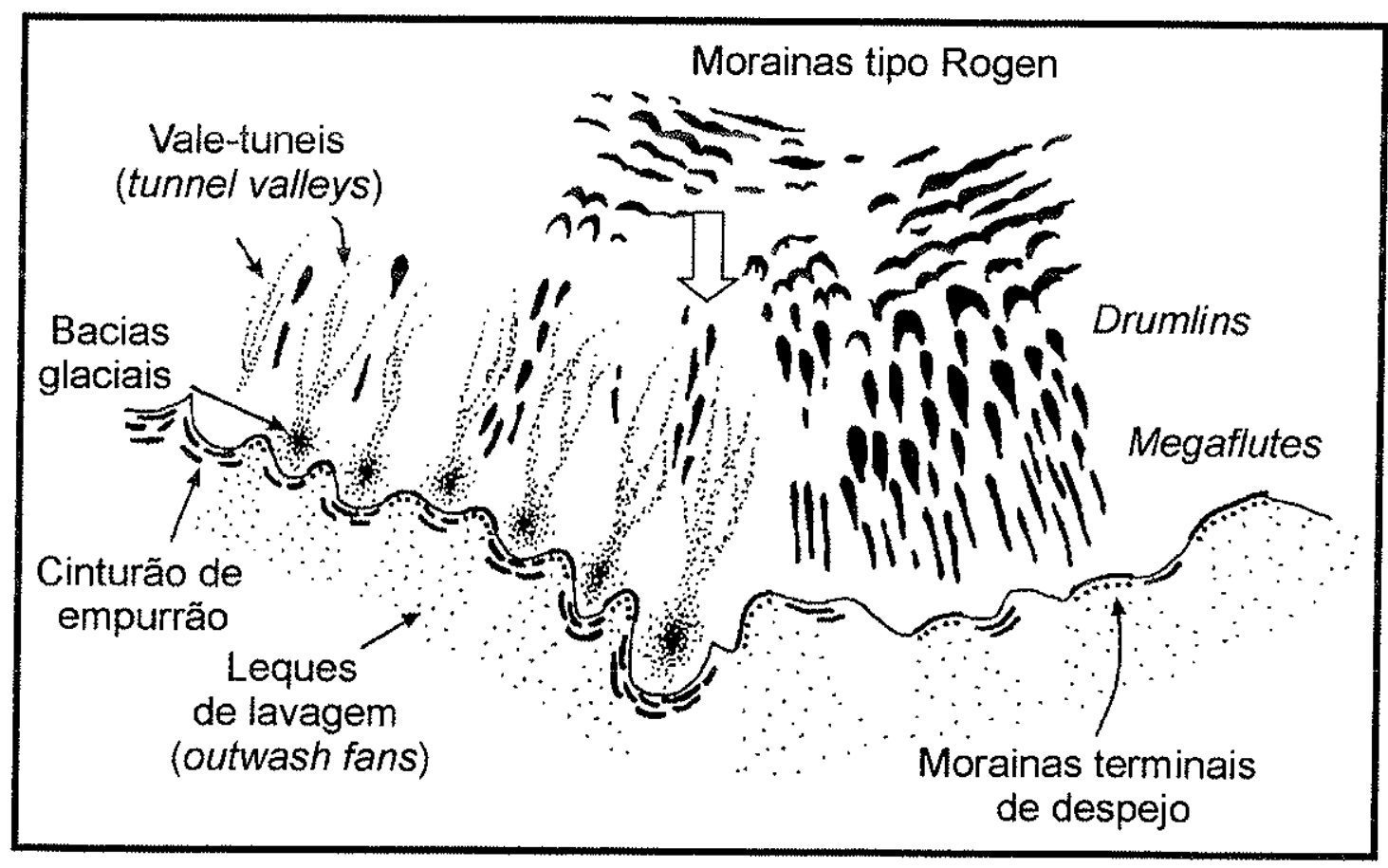

Figura 3.2.4 - Distribuição teórica das geomorfologias glaciotectônicas nas margens de uma geleira continental (van der Wateren, 1995a). Seta indica ofluxo geral do corpo de gelo. 


\section{DEFORMAÇÕES SUBGLACIOTECTÔNICA}

\subsection{MODELOS REOLÓGICOS INCONSOLIDADOS \\ DE SEDIMENTOS SUBGLACIAIS}

A natureza e o comportamento dinâmico das geleiras podem ser inferidos através do estudo dos seus sedimentos basais e, deste modo, forneceriam importantes subsídios às investigações sobre as estruturas glaciotectônicas. Até o final da década de 70 , e provavelmente como resultado da popularização do modelo de geleira alpina, ou de vale, considerava-se que as geleiras deslocavam-se principalmente sobre substratos rígidos consolidados e que a reologia do gelo e os processos de deslizamento sobre esse tipo de superfície eram os fatores determinantes da resposta dinâmica das geleiras às mudanças no seu balanço superficial de massa. Da mesma forma aceitava-se, implicitamente, que os processos de erosão/deposição, resultantes do deslocamento das geleiras sobre embasamento rochoso, poderiam ser aplicados universalmente. De acordo com esses processos os detritos seriam incorporados no gelo através do congelamento, transportados englacialmente

A - Geleira de base quente repousando sobre embasamento

Assoalho da geleira
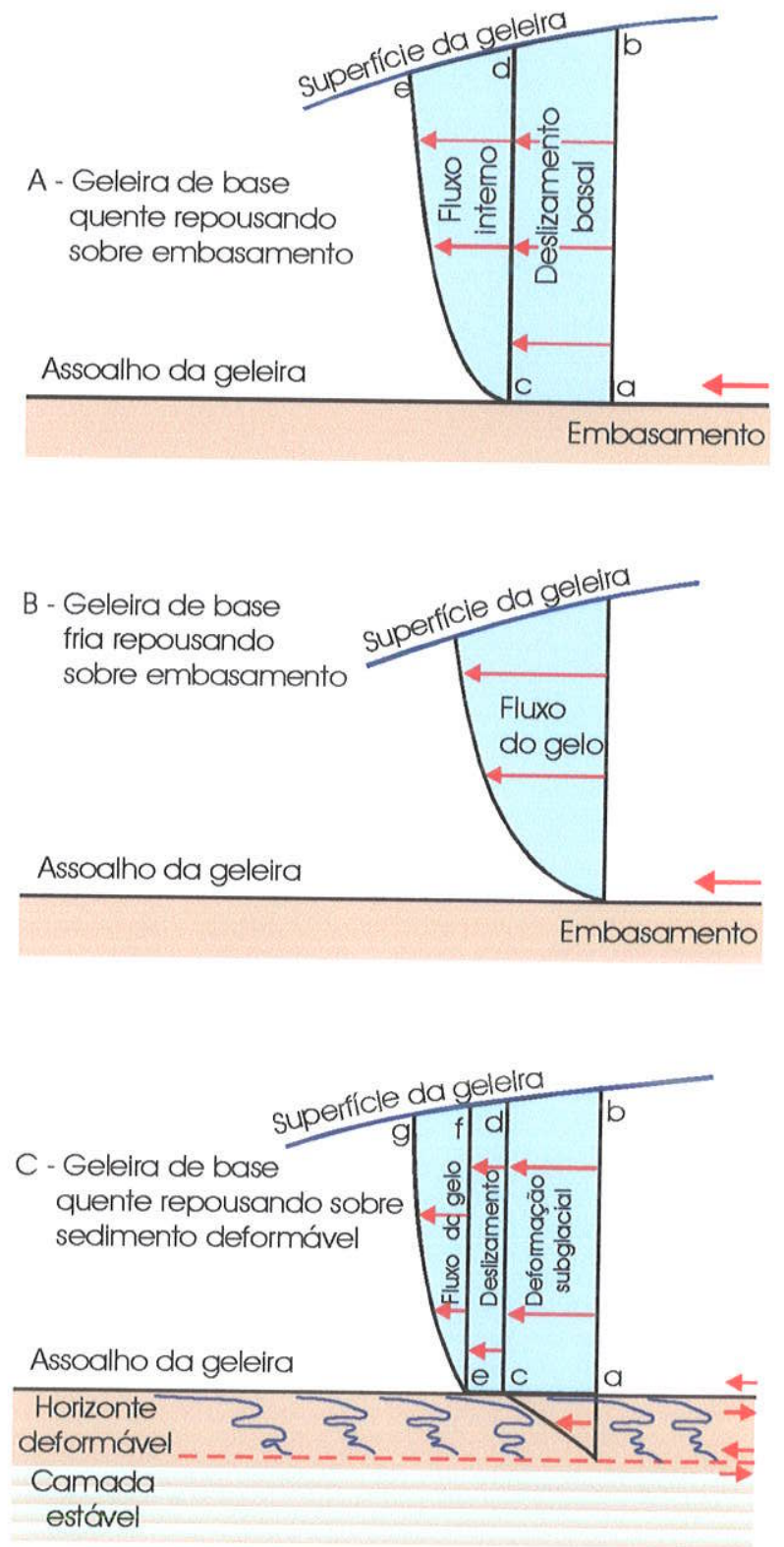
e depositados subglacialmente por alojamento, ou supraglacialmente por ablação (Figura 4.1.1).

Nessa época os processos de erosão/deposição subglaciais que se desenvolvem sobre camadas de sedimentos

Figura 4.1.1 - Componentes do fluxo do gelo em geleiras de diferentes regimes térmicos basais. A: o deslocamento é composto pela soma do deslizamento basal e da deformação interna do gelo; B: só ocorre deformação interna; e C: o deslocamento resulta da deformação subglacial, do deslizamento e da deformação interna (Boulton, 1993; RochaCampos \& Santos, 2000). não litificados não haviam sido ainda estudados, embora muitas geleiras modernas hoje repousem, pelo menos em parte, sobre substratos não litificados, assim como ocorreram também em vastas áreas das coberturas 
de gelo do Pleistoceno na Europa e América do Norte. Evidentemente, o entendimento dos processos de erosão e deposição associados a tais camadas é de extrema relevância; não somente por razões geológicas como também pela influência que a forte interação entre as geleiras e esse tipo de substrato pode exercer sobre a sua dinâmica.

Uma análise retrospectiva da evolução desses conceitos deixa claro o porquê as teorias a respeito das chamadas soft-beds (camadas moles) na deformação subglacial se desenvolveram mais tardiamente do que as teorias e observações a respeito do deslocamento sobre substrato rígido. Segundo Banham (1988), uma das razões para a escassez de dados sobre estruturas glaciotectônicas é a sua similaridade com estruturas tectônicas que não foram induzidas por eventos glaciais. Além disso, verifica-se que durante séculos, ou mesmo milênios, as geleiras de vale vêem escavando continuamente áreas de cristalino sobre as quais se assentam. Estas são, ainda hoje, muito mais acessiveis do que as áreas de sedimentação glacial pleistocênica. Evidências de deformação são atualmente encontradas associadas a espessas sequências de tills subglaciais em regiões sedimentares e a partir de dados sísmicos e de poços perfurados em correntes de gelo (ice streams) da Antártica (Kamb, 1991).

Em 1979, Boulton e Jones sugeriram, de forma pioneira, que a reologia dos sedimentos subglaciais deformáveis poderia constituir 0 fator determinante do comportamento dinâmico das coberturas de gelo (Figura 4.1.1C). Posteriormente, Alley et al. (1987a, 1987b) demonstraram, através da geofísica, a ocorrência efetiva desse processo sob a calota de gelo do oeste da Antártica ou manto de gelo da Antártica Ocidental, onde a dinâmica de pelo menos uma das maiores correntes de gelo (/ce Stream B) seria controlada pela deformação de sedimentos subglaciais com alto conteúdo de água. A presença de tais sedimentos foi posteriormente confirmada por Engelhardt et al. (1990), através da perfuração de poços.

\subsubsection{Tipos de Acamamentos}

Menzies (1989) sugeriu três tipos de acamamentos subglaciais em geleiras temperadas: acamamentos $H, Q$ e $M$. Como o Acamamento $Q$ refere-se a condições intermediárias entre o $\mathrm{H}$ e M (Quase-H e Quase-M), será dada ênfase apenas a estes dois substratos subglaciais. Cabe, contudo, destacar que a ocorrência do Acamamento $Q$ está relacionada à grande variabilidade das condições subglaciais, podendo ser gerado por mudanças na reologia dos detritos subglaciais (Boulton, 1987; Boulton \& Hindmarsh, 1987; Clarke, 1987) e no comportamento termo-mecânico do gelo basal (Boulton \& Spring, 1986), além de apresentar frequência, duração e distribuição espacial bem variadas. 
O Acamamento $\mathrm{H}$, tipicamente denominado de "hard" (duro) ou "rigid" (rigido), pode ser ocasionado por cinco condições hidráulicas subglaciais distintas (Menzies, 1989):

a) Acamamento rochoso com baixa permeabilidade (Kamb \& La Chabelle, 1964; Vivian \& Bocquet, 1973);

b) Sedimentos congelados (Freeze \& Cherry, 1979);

c) Sedimentos com baixa condutividade hidráulica ${ }^{10}\left(\mathrm{~K}<10^{-6} \mathrm{~m} \cdot \mathrm{s}^{-1}\right)$, impedindo a infiltração da água de degelo presente na interface gelo/substrato (Shoemarker, 1986);

d) Sedimentos que apesar de apresentarem alta condutividade hidráulica $\left(K>10^{-6}\right.$ $\mathrm{m} . \mathrm{s}^{-1}$ ), possuem também um aquitarde no contato superior, formando uma camada com condutividade hidráulica baixa na interface gelo/substrato. Este aquitarde teria espessura suficiente para impedir a percolação da água (Shoemarker, 1986), como, por exemplo, em sedimentos capeados por argilas;

e) Sedimentos com alta condutividade hidráulica $\left(K>10^{-6} \mathrm{~m} \cdot \mathrm{s}^{-1}\right)$ formando um aquífero com condutividade hidráulica semelhante ou superior, permitindo, dessa forma, uma alta taxa de percolação intersticial na camada superior. Neste caso, a água de degelo não produziria descargas superiores ao fluxo de água intersticial na camada superior, mantendo esta camada inativa hidraulicamente (Menzies, 1987).

Quando em contato com esses tipos de substratos, normalmente a movimentação dos corpos de gelo se dá por deslizamento. Ainda segundo Menzies (1989), nas camadas em que existe a possibilidade de mudanças na permeabilidade, o sedimento pode variar entre consolidado e dilatado, entre duro (Acamamento $H$ ) e mole (Acamamento M). Nos Acamamentos $\mathrm{H}$ com alta condutividade hidráulica (" $\mathrm{H}_{d}$ " $\mathrm{e}$ " $\mathrm{H}_{\theta}$ ") e movimento intergranular praticamente nulo, assume-se que a água de degelo atravessa os sedimentos da camada superior conforme a equação de Darcy, para fluxos saturados:

$$
Q_{0}=i . k
$$

onde, $Q_{\theta}=$ descarga especifica $\left(\mathrm{m} . \mathrm{s}^{-1}\right)$;

$i$ = gradiente hidráulico, ou seja, o excesso da pressão hidráulica; $e$

$\mathrm{k}=$ condutividade hidráulica $\left(\mathrm{m} \cdot \mathrm{s}^{-1}\right)$.

Utilizando valores tipicos para o fluxo intersticial em camadas subglaciais altamente permeáveis, Shoemaker (1986) deduziu que a fluidez é tão baixa que a efetividade de fluxo dos fluídos seria de milhares de anos (considerando que os demais parâmetros se mantenham constantes), com exceção do Acamamento $H_{\theta}$; e que o aumento rápido da

\footnotetext{
${ }^{10}$ Condutividade hidráulica $(K), K=k . \rho_{w} . g / \mu$, onde $k=$ permeabilidade do meio; $\rho_{w}=$ densidade da água; $\mathrm{g}=$ aceleração gravitacional; $\mathrm{e} \mu=$ viscosidade do líquido.
} 
pressão de água pode gerar um gradiente hidráulico crítico $\left(i_{c} \approx 1,2\right)$, que acarretaria um esforço efetivo (effective stress) nulo ou negativo. Neste segundo caso, a água intersticial seria deslocada para as camadas superiores causando fluidificação pontualmente ou, em casos mais abrangentes, ocorreria uma rápida desunião do contato gelo/substrato e o consequente deslizamento do gelo.

Consequentemente, nos Acamamentos $\mathrm{H}$, com exceção do último tipo ("H,"), a camada superior serve para isolar as camadas inferiores da água de degelo da interface gelo/substrato, de tal forma que possibilita a formação de instabilidades na interface e de canais subglaciais (Walder, 1986; Weertman, 1986; Boulton \& Dobbie, 1993). Em compensação, os Acamamentos $H_{e}$ também podem ser formar em sedimentos inconsolidados subglaciais através de mudanças localizadas da permeabilidade das camadas de sedimentos.

O Acamamento M, também é conhecido como "mobile" (móvel), "soff" (macio) e deformado. Segundo Menzies (1989), normalmente este acamamento é composto por sedimentos saturados por água, de consistência viscosa, nos quais a descarga de água de degelo não é importante, mas sim os deslocamentos da água intersticial (e.g..: Boulton \& Dent, 1974; Boulton \& Jones, 1979; Alley et al., 1986). A simples infiltração subglacial da água de degelo nos poros vazios é basicamente impossivel devido a restrições de permeabilidade e gradiente hidráulico nos sedimentos subglaciais. No entanto, se as camadas de sedimentos subglaciais forem deformadas, via deformação intergranular, através de fluxos de detritos saturados, seria possivel ocorrer descargas de água de degelo subglacial (Alley et al., 1986).

Com relação às condições reológicas dos Acamamentos $M$, atualmente consideram-se dois modelos reológicos para deformações de sedimentos inconsolidados subglacialmente: o Modelo de Acamamento Viscoso (Viscous-Bed Model, Boulton \& Hindmarsh, 1987) e o Modelo de Aração (Ploughing Model, Tulaczyk et al., 2001), que variam espacialmente como resposta às variações dos esforços cisalhantes e pressão efetiva, assim como pelas variações nas propriedades dos materiais envolvidos e o regime hidrológico dos diferentes tipos de substratos.

\subsubsection{Modelo de Acamamento Viscoso (Boulton \& Hindmarsh, 1987)}

O modelo reológico de tills deformados subglacialmente mais aceito atualmente foi desenvolvido por Boulton e Hindmarsh, em 1987, para explicar as correntes rápidas de gelo na margem da geleira Breiđamerkurjökull (sudeste da Islândia). Para tanto, eles utilizaram informações obtidas na análise dos sedimentos glaciais depositados nos $4 \mathrm{~km}$ de recuo da frente da geleira, além de estudos anteriores (e.g.: Boulton, 1974; 1979), e em vários experimentos na região frontal e em túneis escavados abaixo da geleira, nos anos de 1977 , 
$1977 / 78,1980$ e 1983. Entre os trabalhos realizados nos túneis para caracterização reológica, estão a instalação equipamentos para medição dos esforços, das pressões e dos gradientes hidráulicos, tais como marcadores de deformação (strain markers) e piezômetros, além da coleta de amostras da água e dos sedimentos subglaciais. Consequentemente foi possivel obter dados sobre a granulometria e a porosidade do till, além de estimativas da pressão de água intersticial $\left(\mathrm{P}_{\mathrm{w}}\right)$, das velocidades de deformação (strain rate) e dos esforços de cisalhamento (shear stress) do sedimento subglacial deformado, no caso, um till.

Com base nestes dados, este modelo postula que o till subglacial deve ser tratado como um fluido viscoso que deforma pervasivamente por toda a sua espessura. Outra característica é a possibilidade de retro-alimentação (canibalismo), através da erosão do substrato sedimentar. Este modelo assume que o esforço de cisalhamento gravitacional, causador do deslocamento da corrente de gelo, é completamente balanceado pelo esforço de cisalhamento basal, que surge durante a deformação viscosa do till (Alley et al., 1987a).

Anteriormente, as pesquisas a respeito da deformação dos sedimentos subglaciais (e.g., Smalley \& Unwin, 1968; Boulton, 1982) caracterizavam as condições necessárias para o início do processo de deformação através da Lei de Coulomb:

$$
\varphi_{c}=P_{e} \eta+C
$$

onde, $\varphi_{c} \quad=$ Limite de elasticidade dos sedimentos sob ação de tensão de cisalhamento, também denominado como resistência à deformação ou à perda de tensão (yield strength);

$P_{\mathrm{e}} \quad=$ Pressão efetiva, definida pela relação $P_{i}-P_{w} ;$

$P_{\mathrm{i}} \quad=$ Pressão normal exercida pelo gelo suprajacente;

$\mathrm{P}_{\mathrm{w}} \quad=$ Pressão hidrostática exercida pela água intersticial;

$\eta \quad$ = Coeficiente de friç̧åo interna; $e$

C $=$ Coesão dos sedimentos.

Verificou-se, contudo, a existência de duas dificuldades principais que se opõem à utilização direta deste modelo. Em primeiro lugar, a equação supõe que os sedimentos em condições naturais são substâncias perfeitamente plásticas, que não apresentam deformações até que seja alcançado o seu limite de elasticidade. Além disto, os sedimentos são capazes de apresentar uma razão de deformação infinitamente alta para aquele limite de elasticidade, desde que não haja incremento adicional de tensão.

O segundo obstáculo refere-se ao fato que o modelo não incorpora nenhuma razão média de deformação, a qual deve ser considerada vital para o entendimento do comportamento solidário de duas substâncias de reologias diferentes: o gelo da geleira e o sedimento a ela subjacente. 
Os experimentos de campo realizados sob a geleira Breiđamerkurjökull (Boulton \& Hindmarsh, 1987), mostraram, claramente, que a razão de deformação dos sedimentos subglaciais depende de duas variáveis importantes: o esforço de cisalhamento $(\tau)$ e a pressão efetiva $\left(P_{\Theta}\right)$.

Inicialmente, os experimentos permitiram a derivação de uma lei (expressa pela fórmula abaixo, e também conhecida com Modelo Não-Linear de Fluído de Bingham) em que se supôs que o till comportava-se como um fluído de Bingham, que não exibia deformação até que o limite de elasticidade de Coulomb fosse alcançado (vide equação 2), apresentando um comportamento viscoso após aquele ponto.

$$
\varepsilon=a \cdot P_{e}^{-r}\left(\tau-\varphi_{c}\right)^{-s}
$$

onde, $\quad \varepsilon=$ velocidade de deformação (strain rate);

$\varphi_{c}=$ limite de elasticidade de Coulomb no qual $\varphi_{c}=P e \eta+C$ (vide equação1); e

$\mathrm{a}, \mathrm{r}$ e $\mathrm{s}=$ constantes empíricas $(\mathrm{a}=7,62 ; \mathrm{r}=-1,25 ; \mathrm{s}=0,625$, em Breiđamerkurjokull) $\mathrm{e}$ independem da litologia.

Esta lei é apropriada para um fluido de Bingham, no qual nenhuma deformação ocorre até que o valor de Mohr-Coulomb do limite de elasticidade $\left(\varphi_{c}\right)$ seja alcançado, enquanto que, para valores elevados de esforço, o comportamento é viscoso não linear.

No entanto, os experimentos de Boulton \& Hindmarsh (1987) mostraram, claramente, uma deformação elástica-plástica significativa a níveis de esforço abaixo do limite de elasticidade $\left(\varphi_{c}\right)$ que poderia, dentro de um longo periodo de tempo, produzir deformações significativas claramente visiveis na estrutura de deformação do sedimento. A Figura 4.1.2.1 mostra que o Horizonte $A$ apresenta deformação viscosa não linear, enquanto que o Horizonte $B$ subjacente demonstra sinais de deformação elástica-plástica incipiente na porção superior e nenhum sinal de deformação na porção inferior.

As variações locais na litologia subglacial exercem grande influência nos padrões de deformação. Com efeito, na equação (2) os valores de $\eta$ (friç̧ão interna), $C$ (coesão dos sedimentos) e $\mathrm{P}_{\mathrm{e}}$ (pressão efetiva) são funções diretas da litologia e do estado de consolidação e, claramente, têm grande influência na razão de deformação para um dado valor do esforço. Visto que a pressão efetiva $\left(P_{e}\right)$, expressa pela relação $P_{e}=P_{i}-P_{w}$ depende da pressão exercida pela sobrecarga do gelo $\left(P_{i}\right)$, que por sua vez depende da pressão exercida pelo sedimento $\left(P_{s}\right)$ e pela água intersticial, verifica-se que:

$$
P_{i}=(1-n) P_{s}+n P_{w}
$$

onde, $n=$ porosidade do sedimento 


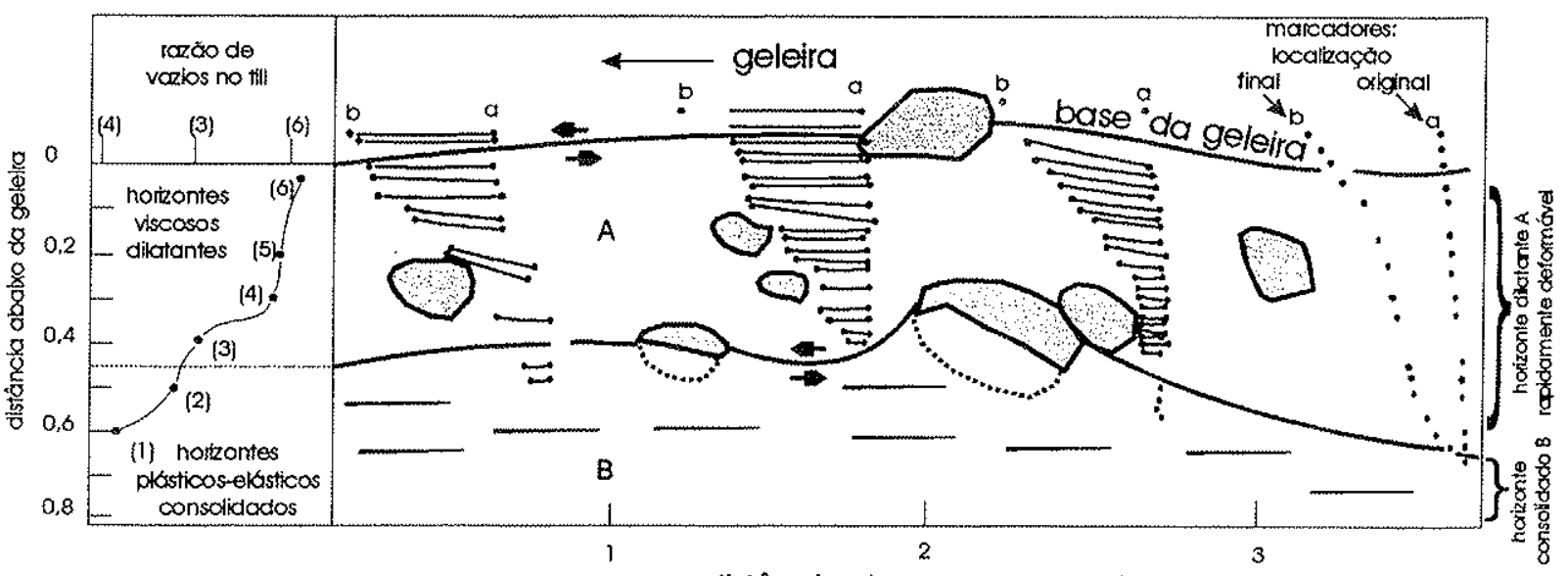

distância dos marcos - metros

Figura 4.1.2.1 - Esquema dos resultados apresentados por um experimento sob a geleira de Breiđamerkurjökull mostrando o desenvolvimento de juntas no Horizonte $B$, o deslocamento dos marcadores de a para b durante as 136 horas do experimento, assim como a localização dos grandes clastos. À esquerda estão mostrados os valores médios das razões de vazios no till subglacial. O Horizonte A é dilatante e exibe uma resposta viscosa não linear ao esforço. O Horizonte B é relativamente bem consolidado e assume-se ter uma deformação elástica-plástica (Boulton \& Hindmarsh, 1987).

Desta forma, a pressão efetiva reflete a interação que se desenvolve entre a litologia local e o padrão e a razão de produção de água no estado líquido sob a geleira. Por conseguinte, a tensão dependerá da pressão de água intersticial no sedimento; o que implica que alta permeabilidade acarreta em rápida infiltração da água de degelo, permitindo que a água seja drenada mais rapidamente, provocando um aumento da tensão.

Boulton \& Hindmarsh (1987), através da análise dos dados apresentados em campo e nas equações 2 e 3 , estabeleceram como valor crítico a equivalência entre o esforço de cisalhamento e resistência a deformação $\left(\tau=\varphi_{c}\right)$. Consideração esta que implica num valor crítico para a pressão efetiva, expresso pela seguinte equação:

$$
P_{\theta}=(\tau-C) / \eta
$$

Consequentemente, foram elaboradas quatro situaçōes reológicas possíveis (Figura 4.1.2.2):

1) Substrato sem deformação, com apenas o Horizonte $B\left(0<(\tau-C) / \eta<P_{\theta}\right)-$ neste caso a potencialidade hidráulica da base do estrato $\left(\Psi_{\mathrm{e}}\right)$ é relativamente pequena e/ou a potencialidade é inferior à diferença de potencialidade entre a base do estrato e a base do gelo $\left(\Delta \Psi=\Psi_{i}-\Psi_{\theta}\right)$, de tal forma que a diferença entre a pressão de água imediatamente abaixo da geleira e a pressão do gelo é maior que o valor critico $((\tau-\mathrm{C}) / \eta)$. Desta forma, não há descontinuidades no sedimento subglacial, representado por um único horizonte sem deformação dúctil. Esta situação é favorecida por baixas taxas de degelo basal, baixos 
valores de potencialidade na base, baixos valores de esforço de cisalhamento e alta resistência do sedimento. Caso o sedimento apresente alta permeabilidade, pode-se esperar infiltração do gelo e a não ocorrência de deslizamentos.

2) Substrato com horizontes $A$ e $B$ estáveis $\left(0<P_{\theta}<(\tau-C) / \eta\right)$ - Nesta situação a pressão efetiva na interface gelo/substrato é menor que o valor crítico, resultando em deformação, dilatação e uma camada superior com permeabilidade mais alta.Sem a dilatação $e$, consequentemente, o aumento na permeabilidade, a pressão efetiva na base da geleira poderia ser nula ou negativa. Esta condição é favorecida por altos valores de influxo de água basal $(\mathrm{m})$, potencialidade hidráulica da base do estrato e esforço de cisalhamento, além de valores baixos de coesão dos sedimentos, coeficiente de fricção interna e permeabilidade no Horizonte B. Pode apresentar infiltração do gelo nos sedimentos com alta permeabilidade e inibição de deslizamentos.

3) Substrato com horizontes A e B instáveis $\left(P_{e}<0<(\tau-C) / \eta\right)-$ Nestas condições, apesar da dilatação dos sedimentos superiores, $\Psi_{e}$ ou $\Delta \Psi$ é tão alta, que a pressão hidráulica é igual a pressão do gelo. Este sistema é particularmente sensivel a pequenos aumentos na taxa de derretimento basal ou pequenas diminuições na permeabilidade. Não é provável que ocorra infiltração de gelo. É possível que aconteça deslizamentos na interface e que o sedimento ofereça pouca resistência ao movimento da geleira.

4) Apenas Horizonte $A$ instável - trata-se de uma situação cujos estratos estão completamente dilatados e, desta forma, a descarga de água de degelo pode ser impossibilitada enquanto suportar valores positivos de pressão efetiva. Se estiver em estado estável e se o coeficiente de fricção da interface entre o sedimento e o material em que se encontra for suficientemente baixo, deslizamentos podem ocorrer em baixas interfaces.

Se o sedimento apresentar camadas impermeáveis, não há drenagem vertical, a queda da potencialidade $(\Delta \Psi)$ tem que ser nula e o gradiente da pressão de água será totalmente gravitacional. Neste caso a água tem que ser descarregada horizontalmente. Para estratos de granulaçäo fina, descargas de comprimentos relativamente pequenos das linhas de fluxo será normalmente suficientes para produzir pressão efetiva nula e causar instabilidades (Boulton \& Jones, 1979). 


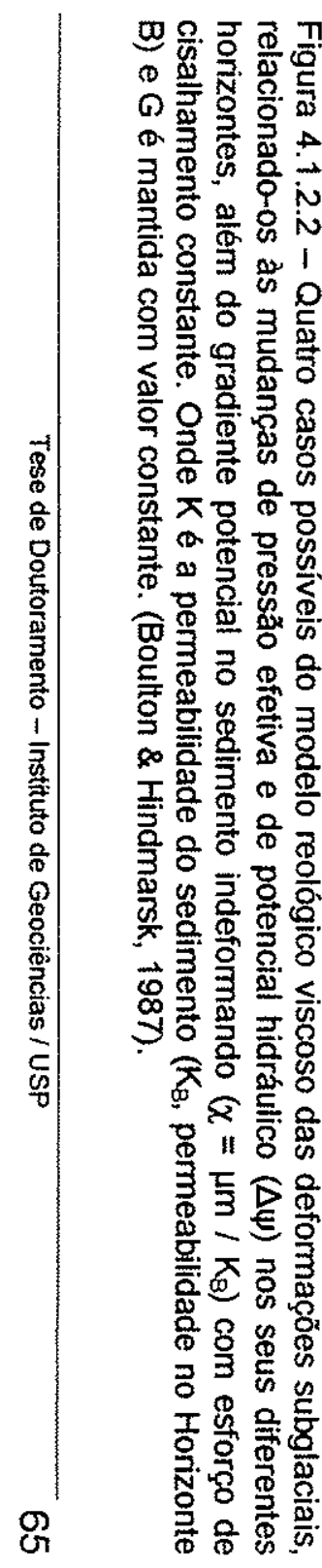

Caso 1

Apenas Horizonte $\mathrm{B}$ estável.

Infiltração, não há deslizamento.

Tensão principal concentrada na interface.

\section{Caso 2}

Horizontes A e B estáveis.

Um pouco de infiltração.

Não há deslizamento.

Caso 3

Horizontes $A$ e $B$ instáveis.

Não há infiltração.

Deslizamento.

\section{Caso 4}

Apenas horizontes A instáveis.

Năo há infiltração.

Possivel deslizamento no topo

e na base.
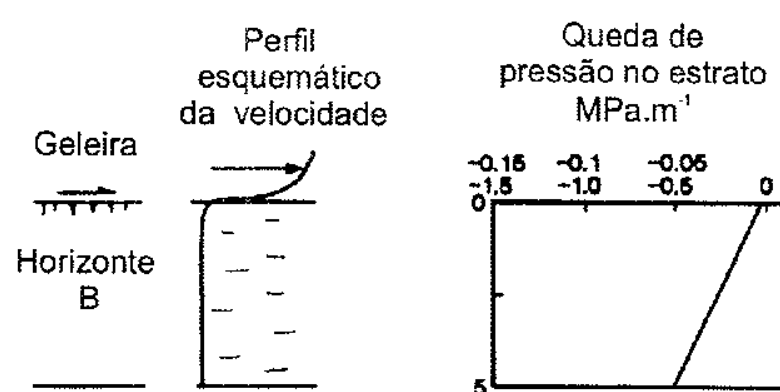

Pressão efetiva $\mathrm{MPa}$

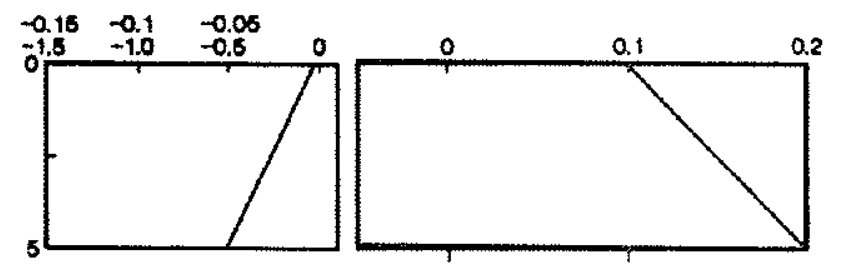

$\Delta \psi=0.15 \mathrm{MPa}$ $\dot{x}=10 \mathrm{kPa} \cdot \mathrm{m}^{-1}$

$\underline{\text { Horizonte }}$
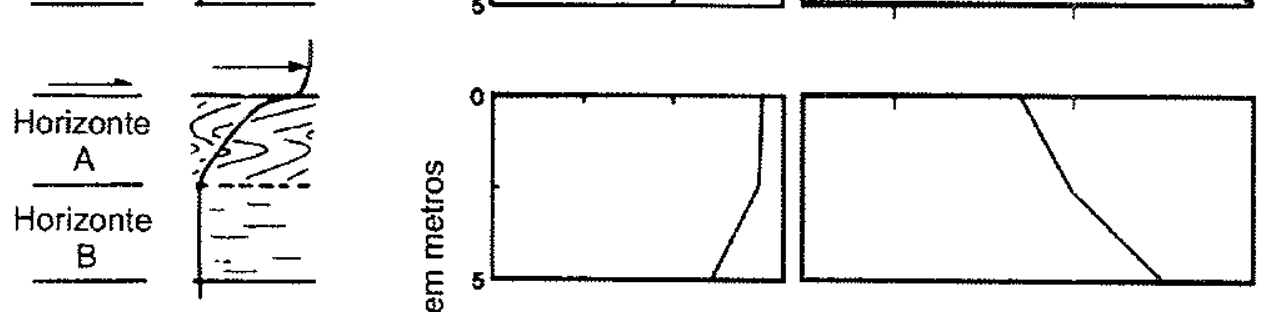

$\Delta \Psi^{\prime}=0.1 \mathrm{MPa}$ $x=10 \mathrm{kPa}$

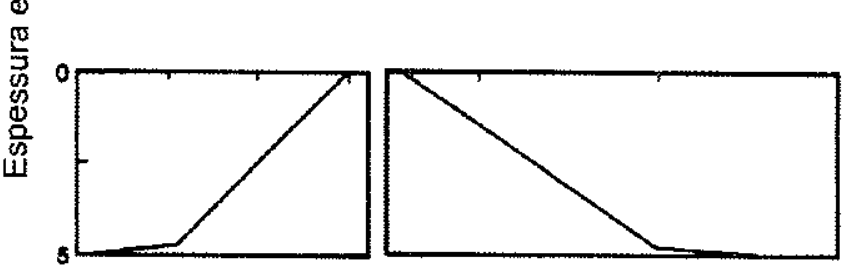

$\Delta \Psi=0.1 \mathrm{MPa}$

Horizonte

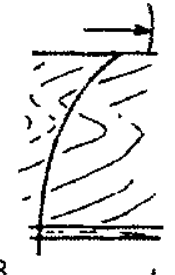

Horizonte 8 $\longrightarrow$
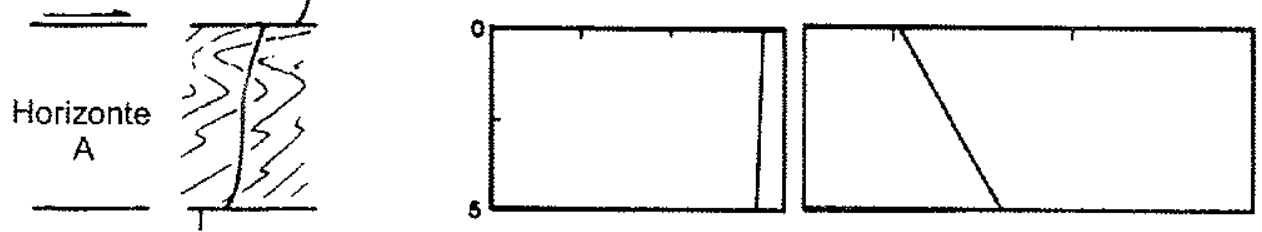
$\Delta \Psi=0.05 \mathrm{MPa}$
$\mathrm{x}=10 \mathrm{kPa} \cdot \mathrm{m}^{\prime}$

Em todos os casos $K=(\tau-C) / \eta=0,1 \mathrm{MPa}, G=(1-n)(P i-P w)=10 \mathrm{kPa} \cdot \mathrm{m}^{-1}$ 
Realmente, como já demonstraram anteriormente Boulton $(1975 ; 1982$; 1996) e Boulton \& Jones (1979), esta interação pode controlar as pressões efetivas de tal forma que, em geral, sedimentos de granulometria fina e mais ricos em argila respondem, para um dado valor de esforço, com razões de deformação bem mais altas. Esse processo ocorre por duas razões: a) a fricção intergranular é reduzida e o consequente dilatamento progressivo da fábrica do sedimento facilita o deslizamento interno interpartículas; b) sedimentos de granulometria fina possuem baixa permeabilidade e, consequentemente, para que a descarga de água através deles seja conservada é necessário que sejam mantidos altos gradientes piezométricos, os quais, por sua vez, produzem altas pressões intersticiais e baixas pressões efetivas.

Desta forma, o comportamento do fluxo gravitacional das geleiras é determinado por três fatores principais:

a) A interação da atmosfera com a superfície da geleira, que determina o balanço de massa superficial e, portanto, a efetividade do empuxo gravitacional;

b) A reologia do gelo, que depende da temperatura e, parcialmente, determina a resposta da massa de gelo ao empuxo gravitacional; $e$

c) A interação entre a geleira e seu substrato, a qual, juntamente com a reologia interna da geleira, determina a resposta total da massa de gelo à força de empuxo.

Tal sistema é altamente interativo e nenhuma de suas partes se comporta de forma completamente independente da outra.

Estudos experimentais dos dois primeiros fatores ( $a$ e b) derivam da observação de geleiras modernas. Contudo, o estabelecimento das condições físicas da interação entre a geleira e seu substrato (fator c) é muito mais difícil. Informações a respeito do substrato de geleiras modernas têm-se limitado a observações das condições subglaciais prevalentes em geleiras do tipo alpino (de vale), as quais correspondem a um componente volumetricamente insignificante da atual massa global de gelo $\mathrm{e}$, certamente, não são representativas das extensas áreas sedimentares continentais subjacentes às coberturas de gelo da Groenlândia e Antártica.

\section{Problemas do Modelo de Acamamento Viscoso}

Segundo Tulaczyk et al. (2001), existem vários problemas que o modelo de Acamamento Viscoso não consegue resolver, dentre eles destacam-se três fatos:

1) Resultados de testes geotécnicos mostram que a reologia dos sedimentos sob correntes de gelo não é viscosa, mas sim plástica, conforme o modelo de Coulomb (Kamb, 1991; Tulaczyk et al., 2000a); 
Experimentos com estacas cravadas no lce Stream B da Antártica demonstraram predominância de deslizamentos basais e/ou deformações rasas do substrato sedimentar (Engelhardt \& Kamb, 1998); e

Presença de hetereogenidades intra-till quanto à porosidade, composição e microfósseis (Rooney, 1998 apud Tulaczyk et al., 2001).

Inicialmente, testes de laboratório com amostras de tills subgiaciais coletadas em diversos pontos da lce Stream B da Antártica têm demonstrado um comportamento não viscoso (Kamb, 1991; Tulaczyk et al., 2000a). Em contrapartida, estes mesmos testes têm indicado que os tills subglaciais atuam como um material plástico "coulombiano", cuja resistência ao cisalhamento depende do esforço efetivo e praticamente independe da taxa de tensão. Além do mais, análises sobre o equilibrio de forças em correntes de gelo têm indicado que deformaçōes rápidas do gelo nas margens de cisalhamento da geleira contribuem mais para a resistência aos esforços do que a deformação subglacial do till (Echelmeyer et al., 1994; Jackson \& Kamb, 1997). Kamb (1991), por sua vez, demonstrou, através de testes diretos, que a resistência dos sedimentos inconsolidados abaixo de correntes de gelo e a magnitude do esforço cisalhante basal que este pode suportar é bem inferior do que a magnitude do esforço decorrente da gravidade que age sobre a corrente de gelo. Cálculos apresentados por Jackson \& Kamb (1997) indicam magnitudes aproximadas de $2 \mathrm{kPa}$ para o esforço cisalhante basal e de 14 a $20 \mathrm{kPa}$ para a ação da gravidade. Esta pequena resistência do till analisado tem muita relação com a porosidade, que varia de aproximadamente $39 \%$ a $45 \%$ (Tulaczyk et al., 2000a, 2000b; 2001), tornando-o rico em água. Contudo, as correntes de gelo não flutuam na água, mas movem-se sobre o sedimento inconsolidado, que não consegue suportar o esforço causado pela gravidade. Sendo assim, quanto menos rígido e mais fraco for o sedimento, mais rápido a corrente de gelo se moverá, visto que uma fração maior do esforço motriz deve ser suportada pela deformação do gelo nas margens de cisalhamento, ou seja, baixas resistências basais (ou mesmo nulas) são compensadas apenas pelo esforço gravitacional nas margens da geleira e pela parte expansivel do esforço motriz sobre o estiramento do gelo (Raymound, 1996, eq. 39; Tulaczyk et al., 2000a, 2000b; 2001). Estes resultados indicam que a resistência dos sedimentos inconsolidados sob correntes de gelo é praticamente independente da magnitude da tensão e da taxa de tensão de cisalhamento, porém depende, linearmente, do esforço efetivo (Kamb, 1991; Tulaczyk et al., 2000a, 2000b; 2001). Consequentemente, favorece-se o deslizamento basal e/ou a deformação rasa do sedimento subglacial como principais agentes responsáveis pelo movimento das correntes de gelo. 
4.1.3. Modelo de Aração (Tulaczyk et al., 2001)

O modelo de aração de Slawek M. Tulaczyk, Reed P. Scherer e Christopher D. Clark propõem uma modelagem reológica para camadas pouco resistentes de till sob correntes de gelo. Desta forma, pressupõem que as camadas apresentam poucos metros de espessura $e$ que teriam sido deformadas durante a formação dos sulcos no decorrer do deslizamento de um corpo de gelo com base irregular. Este tipo de modelagem já havia sido proposto por Bedget (1986) e Brown et al. (1987), contudo estes enfatizavam a ação dos clastos na formação dos sulcos, enquanto que Tulaczyk et al. (op cit.) salientam a importância das irregularidades da base da geleira (protuberâncias de gelo, ice bumps), (Figura 4.1.3.1).

Este modelo pode explicar casos como os apresentados por Scherer et al., (1998) e Tulaczyk et al. (1998) para correntes de gelo da Antártica Ocidental (West Antarctic) ou mesmo para os pavimentos múltiplos de Palmeira (Rocha-Campos et al., 1999; Trosdtorf Jr. et al., 2001). O pacote sedimentar em que ocorrem os quatro pavimentos múltiplos neopaleozóicos de Palmeira são formados basicamente por camadas de areias médias a grossas, com pouca variação granulométrica, e sem qualquer evidência da presença de clastos. Desta forma, uma das possibilidades seria que os sulcos e as deformações rúpteis presentes nestes pavimentos teriam sido formados pelas próprias irregularidades da base da geleira. Outra hipótese seria a intervenção de pontas de icebergs arando as camadas de areia, porém a linearidade dos sulcos sugere que sejam corpos de gelo maiores. $\mathrm{Na}$ Antártica Ocidental, por sua vez, constatou-se que os substratos sedimentares inconsolidados das correntes de gelo apresentam granulação fina com poucos clastos, porém não há evidência direta de aração. As inferências sobre a aração são baseadas apenas em dados de radar, como os apresentados por Novick et al. (1994) para a Ice Stream B, ou por estudos da topografia do fundo do mar Ross (Shipp \& Anderson, 1997a, 1997b; Shipp et al., 1999). Análises de dados geofísicos, satélites e fotos aéreas de localidades em que houve a passagem de corrente de gelo, mostram corpos alongados de amplitude, comprimento de onda e largura variáveis (Figura 4.1.3.2), formando megalineações (Clark, 1993), como, por exemplo, as formas de relevo pleistocênicas, formadas pela "paleo-corrente de gelo" M'Clintock Channel (Clark \& Stokes, 2001).

Segundo Tulaczyk et al. (2001), neste modelo plástico para o substrato de correntes de gelo não existe nenhuma resposta entre a velocidade da corrente de gelo e a resistência propiciada peio sedimento subglacial contra o deslocamento da corrente de gelo, visto que a resistência do sedimento não depende da taxa de cisalhamento. A resistência de um sedimento plástico é altamente suscetivel à quantidade de água contida no sedimento (e.g.: Tulaczyk et al, 2000a), e, sendo assim, é bem provável que o comportamento transiente da corrente de gelo seja causado pelo aumento ou pela diminuição da estocagem de água no sedimento (Tulaczyk et al, 2000b). 


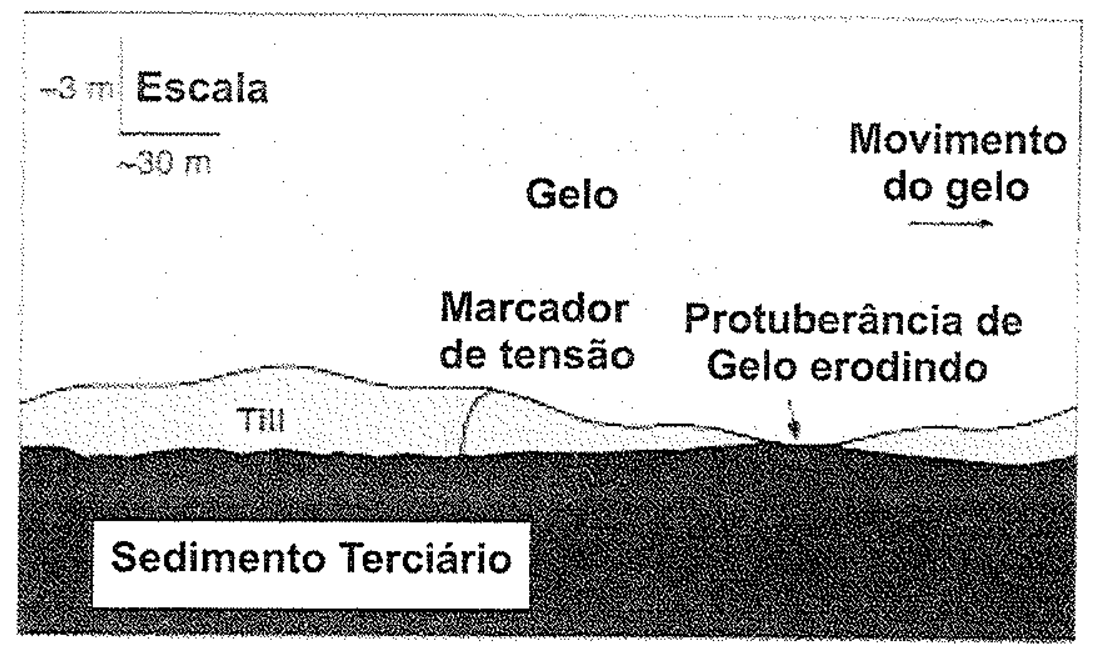

Figura 4.1.3.1 - Representação esquemática do modelo de aração, onde uma protuberância de gelo na base da geleira erode o till recém depositado, que, por sua vez, capeia sedimentos terciários (Tulaczyk et al., 2001).

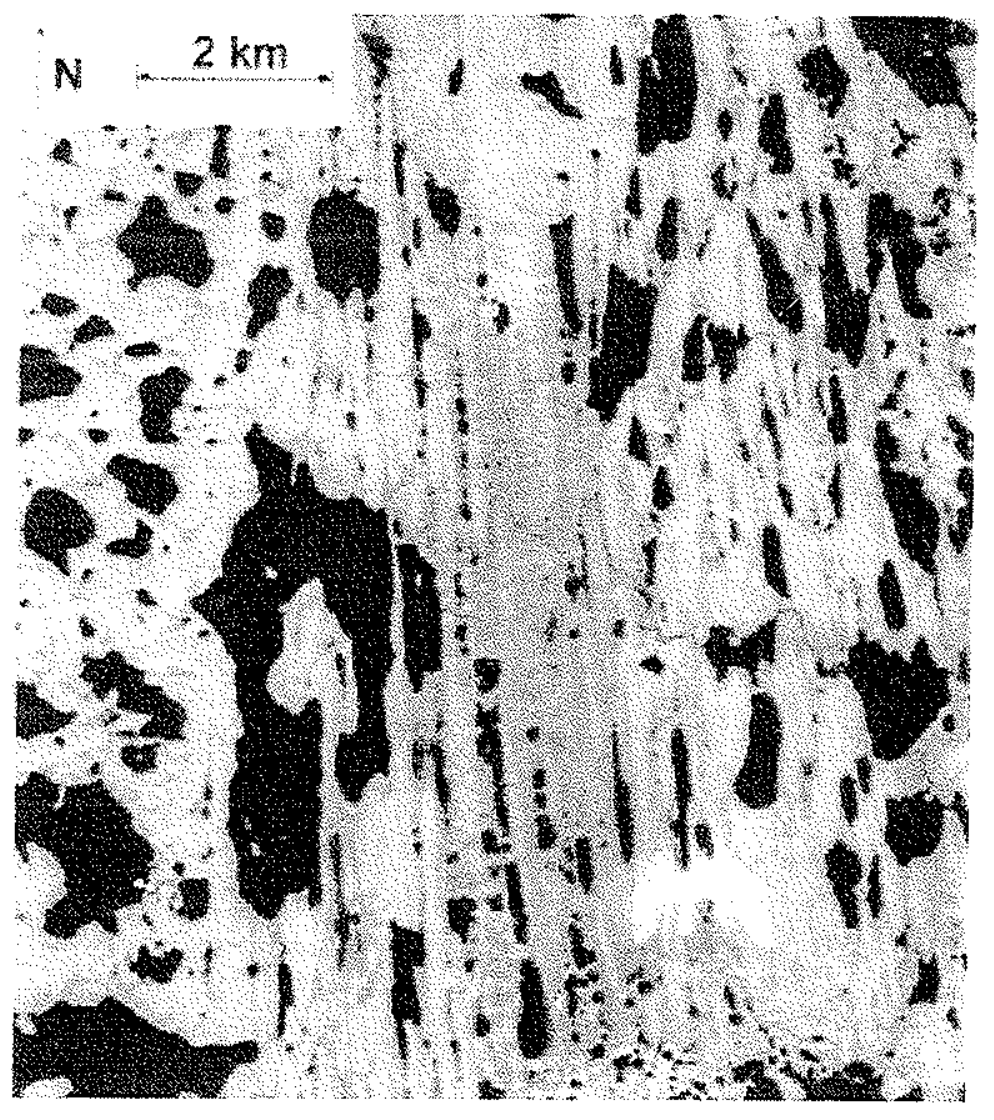

Figura 4.1.3.2 - Imagem de satélite (Landsat TM, banda 3) que mostra as estruturas de relevo alongadas na paleo-corrente de gelo M'Clintock, Ártico do Canadá. O centro da imagem encontra-se nas coordenada $72^{\circ} 14^{\prime} 21^{\prime \prime} \mathrm{N}$ e $106^{\circ} 11^{\prime} 22^{\prime \prime} \mathrm{W}$ (Clark \& Stoke, 2001). 
Como está sendo visto, a dinâmica da água nos sedimentos subglaciais é, realmente, fundamental para as considerações sobre as mudanças no comportamento da movimentação das geleiras. A "advecção" da água no sedimento transportado durante a aração é, possivelmente, um componente significativo no balanço hidráulico. Sabendo-se que o derretimento ou congelamento basal é da ordem de $1 \mathrm{~mm} / \mathrm{ano}$ na base de correntes de gelo, ou menos na Antártica Ocidental (Tulaczyk et ai., 2000b), e que em estágios estáveis, o derretimento basal é < 0,3 mm/ano, verifica-se que a "adveç̧ão" da água é um componente importante para determinar a escala de tempo apropriada para mudanças significativas na velocidade das correntes de gelo.

O degelo pode se concentrar nas irregularidades da base da geleira, visto que as tensões atuantes na aração devem ser várias vezes maiores do que as tensões associadas a uma base de gelo plana deslizando sobre sedimentos ou a cisalhamento em plano intrasedimento (Brown et al., 1987; Tulaczyk, 1999). O derretimento adicional devido ao aumento do calor causado pelo cisalhamento pode ser da ordem de $1 \mathrm{~mm} / a n o$ (para correntes de gelo com velocidade de $\sim 100 \mathrm{~m} / \mathrm{ano}$, resistência do sedimento de $\sim 1 \mathrm{kPa}$ e grande concentração de tensão, $\sim 10$ vezes), e, nestas condições, as protuberâncias de gelo na base da geleira com amplitude menor que $1 \mathrm{~m}$ podem ser derretidas. Contudo, deslocamentos rápidos da corrente de gelo podem auxiliar a minimizar a influência local do aumento do calor através do cisalhamento. Não obstante, verifica-se que correntes de gelo pretéritas deixaram registros de megalineamentos contínuos e muito longos (Clark, 1993; 1994; Shipp et al., 1999), indicando que estas irregularidades na base das geleiras foram preservadas em deslocamentos da ordem de 10 a $100 \mathrm{~km}$.

Cabe, contudo, acrescentar que as irregularidades do relevo por onde a geleira passa podem também contribuir para a formação de protuberâncias em geleiras com base plana ou que tenham sido aplainadas pelo derretimento das irregularidades da base de gelo. Assim, as irregularidades do relevo, antes que sejam desgastadas (erodidas), propiciam a formação de novas irregularidades na base da geleira, tornando possivel a sua sobrevivência, através da geração de novas protuberâncias de gelo, fazendo com que a aração seja mantida por distâncias que chegam a $100 \mathrm{~km}$.

Com relação às deformações nos sedimentos subglaciais, Tulaczyk et al. (2001) postulam que, no processo de aração subglacial, o sedimento é arrastado na direção do movimento do gelo e a protuberância de gelo envolta no sedimento auxilia na diminuição da desaceleração da geleira. A magnitude desta desaceleração é controlada pela relativa amplitude da irregularidade da base da geleira em relação à profundidade que penetrou no sedimento. Se atribuirmos que esta profundidade um valor $<0,3 \mathrm{~m}$, a desaceleração será aproximadamente $20 \%$ da velocidade inicial. Cada desaceleração na velocidade do deslizamento está associada ao um aumento na deformação do substrato sedimentar 
(Figura 4.1.3.3), e, consequentemente, estas deformaçôes seriam pontuais e atreladas à formação dos sulcos.

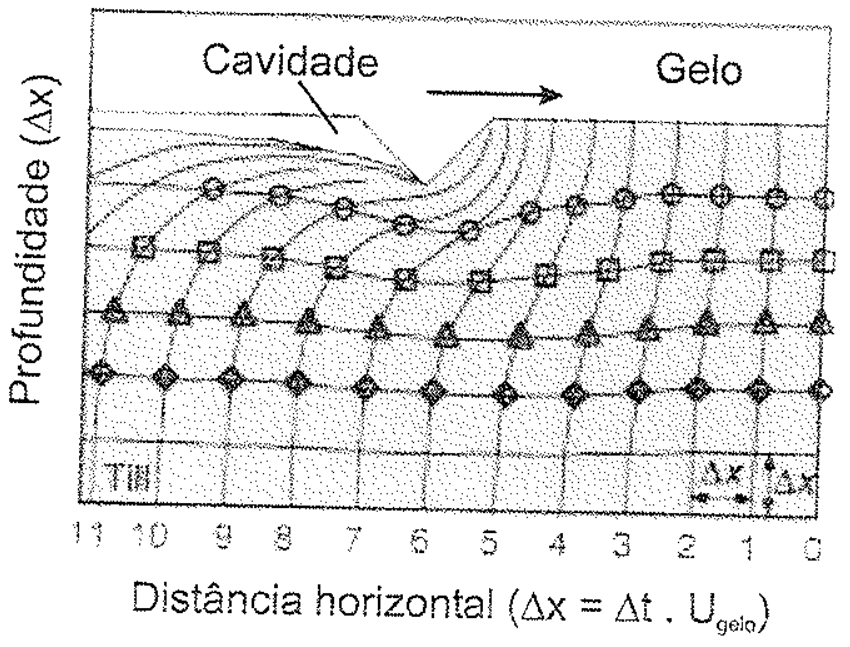

Figura 4.1.3.3 - llustração demonstrando as deformaçōes no substrato formadas pelas pelo deslocamento delo basal, de acordo com a profundidade do sedimento e a distância percorrida pelo deslocamento de uma geleira com velocidade de $U_{\text {gelo }}$ (Tulaczyk et al., 2001).

Piotrowski et al. (2001), que são favoráveis ao modelo plástico da aração, concordam que as deformações de sedimentos subglaciais são importantes processos glaciológicos, contudo, devido à inconsistência entre o modelo viscoso e os dados de campo, acreditam que este seja apenas aplicável a casos peculiares e que, a priori, não deva ser utilizado na maioria das geleiras. Apesar de aplicável a pequenas profundidades no sedimento, a deformação pervasiva das camadas subjacentes à geleira seria mais realista, estando inclusive de acordo com os experimentos em laboratório apresentados em lverson et al. (1997). É bem possivel, portanto, que estes pontos de deformação sejam transientes tanto com relação ao tempo quanto ao espaço (Fischer et al., 1999), fato que implicaria que uma determinada localidade subglacial pode sofrer múltiplas fases de deformação estabilidade. Esta deformação pode ocorrer em intervalos de tempo bem pequenos, com consequentes espessuras pequenas, e, em determinados casos, estes registros de esforços podem ficar acumulados, dando a impressão de um longo período de tempo (Piotrowski et al., 1999; Hoffmann \& Piotrowski, 2001). Segundo Piotrowski et al. (2001) alguns locais deformados também podem ser explicados pela existência de uma fina película de água separando a geleira do substrato, quando, então a pressão de água poderia atingir niveis de flutuação, favorecendo também os deslizamentos. No entanto, esses autores advertem que se deve ter cuidado ao assumir que todas as deformações preservadas em sedimentos foram desenvolvidas por deformações em sedimentos saturados em água. 
Em suma, o modelo reológico plástico de aração subglacial postula que:

- Os principais mecanismos de deslocamentos de antigos mantos de gelos caracterizaram-se por deslizamentos, em vez de deformações no substrato;

- Os detritos glaciais foram transportados englacialmente, e não através da deformação do acamamento; $\mathrm{e}$

- Deformações localizadas do sedimento causadas pela aração proporcionam explicaçöes suficientes para a existência de evidências sedimentares de cisalhamento subglacial. Não haveria necessidade de relacionar a ações continuas de deformação viscosa nos sedimentos basais.

Réplica Pró-Modelo Viscoso (Boulton et al., 2001)

Devido aos constantes questionamentos do grupo favorável ao modelo de aração, e em particular, ao trabalho de Piotrowski et al. (2001), G. S. Boulton, um dos idealizadores do modelo viscoso, através do artigo Boulton et al. (2001), faz uma réplica aos argumentos contrários ao modelo de fluxo Bingham (viscoso). Por pertinência com a temática quia tratada, julgou-se apropriado a elaboração de um resumo dos principais comentários de Boulton et al. (op cit.), onde, em itálico, são registrados os comentários de Piotrowski et al. (2001):

a) "O aumento da deformação de cisalhamento (shear strain) a jusante, observada em experimentos subglaciais, deve refletir uma transição de tills altamente deformados (no topo) a indeformados (na base)". Na verdade, a afirmação é falsa, a transição entre sedimentos altamente e sutilmente deformados é temporal e não espacial. Dependerá, por exemplo, na presença de irregularidades na superfície de descolamento (décollement) entre o horizonte deformado e o horizonte indeformado.

b) "Blocos de sedimentos inconsolidados encontrados dentro de um till devem apresentar nas suas bordas evidéncias de mistura com a matriz do till". É muito comum encontrar contatos bruscos entre clastos de sedimentos moles (soft sediments, que estavam inconsolidados, ou seja, intraclastos) e a matriz do till. Não se conhece precisamente o comportamento dos materiais, principalmente no que se refere às diferenças de rigidez e às propriedades de drenagem. No entanto, existem exemplos clássicos de materiais deformados, cujos clastos de greda (giz) e areia presentes na matriz argilosa do diamicto apresentam margens bruscas. 
c) "É necessário reconsiderar a capacidade de transportar conchas frágeis no till deformado, visto as amplas evidéncias de cominuição durante o transporte". O choque dos grãos ocorre, ou não, dependendo do esforço efetivo aplicado no material. Contudo, sabe-se que a pressão de água pode variar bastante, diariamente ou anualmente (Sharp et al., 1998 apud Boulton et al., 2001). Consequentemente, esta flutuação do esforço efetivo pode ou não promover choques entre os grãos. Também se espera variações espaciais na pressão efetiva, em parte devido à dinâmica das geleiras ou a diferenças na drenagem dos sedimentos. Desta forma, sedimentos finos subglaciais, incapazes de apresentar uma drenagem eficiente devido à sua baixa permeabilidade, podem sustentar pressões efetivas muito baixas durante longos periodos. Na realidade, a indagação correta seria: quais são os processos controladores da pressão efetiva nos sedimentos subglaciais? Além do mais, parece bizarro que ambientes com pressões criostáticas acima de $10^{4} \mathrm{kPa}$, preservem conchas delicadas.

d) "A rotação dos clastos é um importante critério na identificação de deformações subglaciais. No entanto, existem evidências de clastos que foram rotacionados e outros que permaneceram estáveis em pavimentos de clastos, o que os toma incompativeis com os substratos deformados". Não existe atualmente uma teoria baseada em critérios físicos sobre a orientação das fábricas dos clastos dos tills, além de Glen et al. (1957), que considera a rotação dos clastos em um fluído viscoso constante. Conforme mencionado anteriormente, a pressäo efetiva varia bastante e, desta forma, a viscosidade efetiva também flutua, dificultando a aplicação da teoria de Glen e colaboradores. Na realidade, Boulton et al. (2001) concorda com Bennett et al. (1999), que atribui à fábrica de clastos pouco suporte quantitativo para a interpretação dos sedimentos glaciogênicos.

e) "Em vánias áreas próximas do limite da glaciação, antigas formas de relevo sobrevivem abaixo do till, fato que não seria esperado se ocorressem espessos substratos deformados. O till deve ficar concentrado proximo ao limite glacial, enquanto que os frágeis sedimentos mais antigos devem ser preservados proximo deste limite, ao invés de serem destruídos". Esta observação é, contudo, compativel e prevista pelos conceitos dos substratos deformados. Boulton (1996), analisando o ciclo glacial durante processos glaciotectônicos, concluiu que em um único ciclo idealizado o till terá uma distribuição semelhante a uma curva sinusoidal, aumentando em direção ao ponto de máxima deposição e diminuindo próximo das margens. Na zona próxima à extensão máxima do gelo, não haveria erosão, privilegiando a deposição do till e a preservação dos sedimentos pré-existentes. 
f) "O sistema de drenagem associado aos substratos deformados deveria consistir de canais rasos com alta pressăo de água, e, contudo, existem evidências de que a drenagem da água de degelo subglacial correria principalmente através de canais subglaciais (tunnel valleys). Estes canais implicariam em substratos estáveis". Segundo Boulton et al. (2001), não existe razão para que canais subglaciais não sejam característicos de geleiras com substratos deformados, o que já teria sido sugerido por Boulton \& Hindmarsh (1987).

g) "A hipótese dos substratos deformados não pode explicar as camadas Heinrich". Neste caso Boulton et al. (2001) concordam, contudo os mecanismos relacionados aos substratos deformados podem implicar em eventos do tipo surge, que provocam liberação de icebergs de grande escala necessários para a formação das camadas Heinrich. Estas camadas Heinrich (Heinrich layers) são camadas sedimentares, encontradas em alguns testemunhos do Atlântico Norte, com baixo teores de $\delta^{18} \mathrm{O}$, pobres em foraminiferos plantônicos e ricas em fragmentos líticos e carbonáticos, que teriam sido arrastados pelo gelo. As camadas Heinrich, desta forma, correspondem a períodos de resfriamento intenso do clima e baixa salinidade das águas superficiais (Suguio, 1998).

h) "Exemplos modemos de substratos deformados são escassos e, por conseguinte, não suportam a importáncia dada às deformações subglaciais, visto a falta de representatividade". Apesar das camadas deformadas serem relativamente finas, as taxas de descarga são altas se comparadas com outros processos glaciais, sugerindo que os substratos deformados possuem uma alta capacidade de gerar tills subglaciais. As condições que determinam as respostas deformacionais dos sedimentos estão relacionadas ao esforço efetivo e ao esforço de cisalhamento, e apenas indiretamente à espessura do gelo e às propriedades dos sedimentos. Consequentemente, a espessura e a escassez de substratos subglaciais deformados não restringe a sua importância para a dinâmica da geleira.

Na realidade, o que se observa analisando essas argumentações, indagações e as possiveis explicações, tanto dos favoráveis ao modelo viscoso, quanto dos adeptos ao modelo de aração, é que ainda existe muita controvérsia e que as idéias de ambos os lados, aparentam ter fundamentos. Desta forma, presume-se que deva haver algum fator comum em ambos os modelos que possa explicar as virtudes de ambas as hipóteses. As considerações que se chegou neste trabalho sobre qual modelo apresenta maior eficácia, ou se haveria outra explicação, encontram-se discutidas em sequência às interpretações das localidades de Capivari e Jumirim, que representam ocorrências de estruturas subglaciotectônicas neopaleozóicas brasileiras. 
4.1.4. Modelo da Continuidade ou do Ciclo de Deslizamento-União, SlipStick Cycle (Alley, 2000; Boulton et al., 2001; Bennett, 2003)

Boulton et al. (2001) não só apresentaram uma réplica aos comentários de Piotrowski et al. (2001), conforme visto anteriormente, mas finalizaram-na com basicamente um "novo modelo", fundamentado em experimentos sobre o regime de drenagem em tills subglaciais e sobre a dependência dos esforços nos tills em relação ao tempo. Esta nova proposta pode ser denominada como o "Ciclo de Deslizamento-União" (Slip-Stick Cycle), ou como o "Modelo da Continuidade", visto que muitas idéias apresentadas por Boulton et al. (op cit.) coincidem com o trabalho prévio de Alley (2000), intitulado: "Continuity comes first:...".

Na realidade, Alley (2000), Boulton et al. (2001), assim como Bennett (2003), embora ainda de forma especulativa, acreditam que os processos relacionados ao deslocamento de corpos de gelo sobre sedimentos inconsolidados dependem da compreensão da hidrologia basal, relacionada principalmente às deformações subglaciotectônicas e aos deslizamentos, em função do tempo e do espaço. Baseado nas observações de Boulton et al. (2001), cujas interpretações foram complementadas por Bennett (2003), esta inter-relação pode ser resumida pela variação espacial e temporal da pressão de água. A pressão da água subglacial não apenas controla os esforços exercidos nos sedimentos, visto que o aumento da pressão de água intersticial reduz a friç̧ão interna e a coesão do sedimento, mas também controla a irregularidade/aspereza do substrato e a aderência entre a base do gelo e o substrato. Assim, desconsiderando a rusticidade do acamamento, é possivel estabelecer um ciclo de deslizamento-união (slip-stick) entre a geleira e o seu substrato associado à pressão de água (Figura 4.1.4.1):

1) Conforme a pressão de água aumenta, ela pode fazer com que o corpo de gelo flutue sobre o substrato, aumentando a lubrificação basal, e permitindo, desta forma, a formação de fluxos rápidos de gelo, com deformação mínima do sedimento. Segundo Boulton et al. (2001), este deslizamento será controlado pela lei de friç̧ão coulombiana. Quando a pressão crítica de água for alcançada, o deslizamento ocorrerá, ficando a taxa do deslizamento dependente da pressão de água.

2) Quando a pressão de água diminuir, a base da geleira começará a se unir com o substrato e o deslizamento ficará concentrado no horizonte sedimentar do acamamento. Neste caso inicia-se a formação de deformações no sedimento, próximo a sua superfície, visto que, em virtude do aumento da pressão efetiva, a resistência do sedimento aumenta de acordo com a profundidade.

3) Contudo, a localização da deformação máxima pode variar com o decorrer do tempo, já que a água é drenada verticalmente pelo sedimento. Desta forma, a 
pressão de água pode diminuir ou aumentar, variando o horizonte onde as deformações ficam concentradas. Segundo Alley (op cit.), os tills subgiaciais podem dilatar como materiais plásticos "coulombianos", e, desta forma, a taxa média de deformação no horizonte deformado pode aumentar mesmo com pouca força aplicada sobre o till. A deformação de tais sedimentos causará a expulsão da água e a consolidação do till. Consequentemente, a dilatação não pode ocorrer durante a expulsão da água e a consolidação do sedimento, embora, eventualmente, em condiçöes não estáveis possa haver a consolidação e a posterior dilatação dos sedimentos, conforme sugerido por Iverson et al. (1998).

4) Se a pressão de água diminuir a niveis inferiores aos necessários para a formação de deformação, o sedimento passará a se consolidar e a base da geleira ficará aderida ao substrato. Durante esta fase de união, segundo Bennett (2003), o fluxo do gelo só pode ocorrer via rastejamento (creep), permitindo o acumulo do esforço de cisalhamento basal, até que seja liberado pelo próximo aumento da pressão de água.

Se a pressão de água variar bastante, é possivel que se constate todos os estágios do ciclo de deslizamento-união. Alternativamente, se, em alguma destas etapas, a pressão de água é mantida ou sofre apenas uma variação limitada, segue que o ciclo pode não ter continuidade ou ficar restrito a um episódio, ou a algumas partes do ciclo.

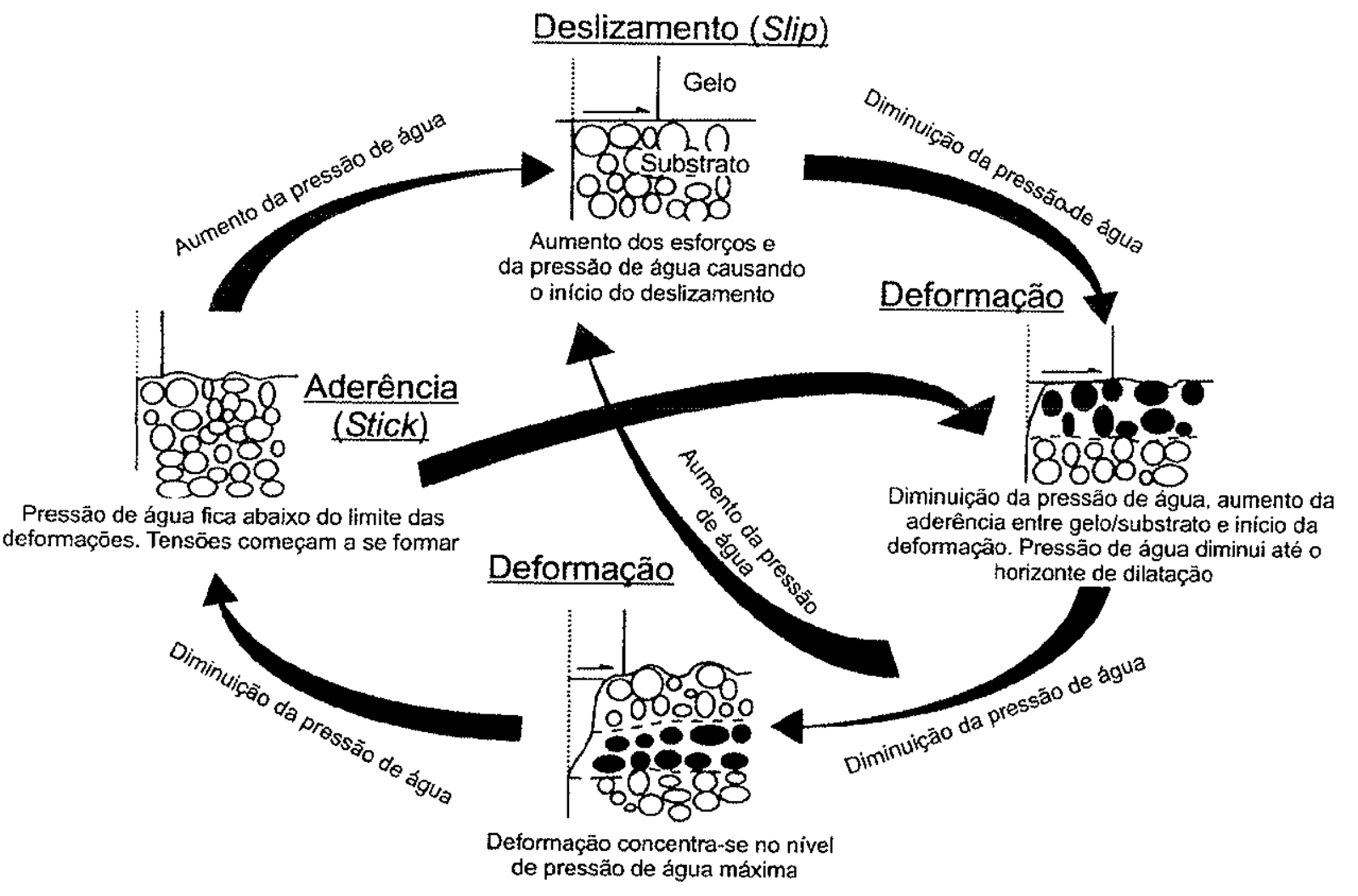

Figura 4.1.4.1 - Ciclo Slip-Stick (Deslizamento-Aderência), (Bennett, 2003). 


\subsection{DESCRIÇÃO DOS AFLORAMENTOS E ESTRATIGRAFIA DE CAPIVARI}

O afloramento de Capivari (Figura 4.2.1) apresenta 4 (quatro) intervalos estratigráficos distintos (Figura 4.2.2). A porção inferior é composta por arenito e siltito, com no mínimo $5 \mathrm{~m}$ de espessura (contato basal não aflorante), coloração amarelada a esverdeada, exibindo localmente estratificações plano-paralelas ou cruzadas, intercalado com corpos lenticulares, de espessura decimétrica e comprimento métrico, de conglomerado e arenito feldspático e conglomerático, descontínuos e deformados. Clastos neste nível são relativamente raros predominando o arenito fino a muito fino, que, de acordo com análise granulométrica realizada, apresenta uma composição com 45 a $66 \%$ de areia e possui lentes de argila próximas ao contato superior.

Sobrepondo-se discordantemente a essa unidade inferior, encontram-se 3 (três) corpos de diamictito (A, B e C, Figura 4.2.3), com aproximadamente $2 \mathrm{~m}$ de espessura cada um deles, com coloração amarelo-esverdeada, aparentemente maciços. As análises granuiométricas efetuadas por Salvetti (2000), mostraram que os diamictitos A, B e C (Figura 4.2.3) possuem uma proporção similar de areia e silte (médias de $17 \%$ e $55 \%$, respectivamente), exceto por uma discreta diminuição na porcentagem de areia no Diamictito $C$. No entanto, as análises granulométricas efetuadas neste trabalho forneceram valores distintos para o Diamictito $A$, enquanto que os demais coincidiram. Uma nova análise granulométrica da matriz do Diamictito $A$ apresentou um teor arenoso bem mais elevado ( $40 \%$ de areia) do que os encontrados anteriormente. Esta aparente discordância pode, na realidade, estar relacionada a um padrão geral de granodecrescência ascendente da matriz deste diamictito, haja vista a amostra ter sido coletada próximo ao contato inferior, enquanto que a utilizada por Salvetti foi coletada numa posição estratigráfica mais elevada. Em suma, considera-se que a matriz do Diamictito A passa gradativamente de areno-siltosa, na base, para argilo-siltosas, no topo, enquanto que as dos diamictitos $B$ e $C$ são argilosiltosas.

No contato inferior do Diamictito A com o arenito da base da sequência ocorre um horizonte onde ambas as litologias encontram-se deformadas por estruturas rúpteis, constituídas por pequenas fraturas e falhas de cisalhamento, e aqui denominado de Horizonte Falhado e Fraturado (HFF), (figuras 4.2 .2 e 4.2.3). Infelizmente, não se tem certeza da espessura deste horizonte, pois praticamente todo 0 arenito afiorante aparenta estar fraturado. Este horizonte deformado misturou blocos angulosos de arenito e da base do Diamictito $A$, demonstrado que os esforços que geraram as estruturas rúpteis foram exercidos após a deposição do Diamictito $A$, ou pelo menos da porção inferior, haja vista a ausência de deformação nas camadas superiores. Posteriormente, na análise conjunta com o afloramento de Jumirim (no Subcapitulo 4.4.), a discussão sobre este horizonte deformado será retomada. 


\section{Mapa geológico simplificado do afloramento de Capivari (SP)}

\section{Legenda}

Diamictito de matriz silto-argilosa, polimítico

Arenitos maciços ou tenuamente estratificados, deformados e fraturados

$\therefore \quad$ Pontos de ocorrência do pavimento de clastos

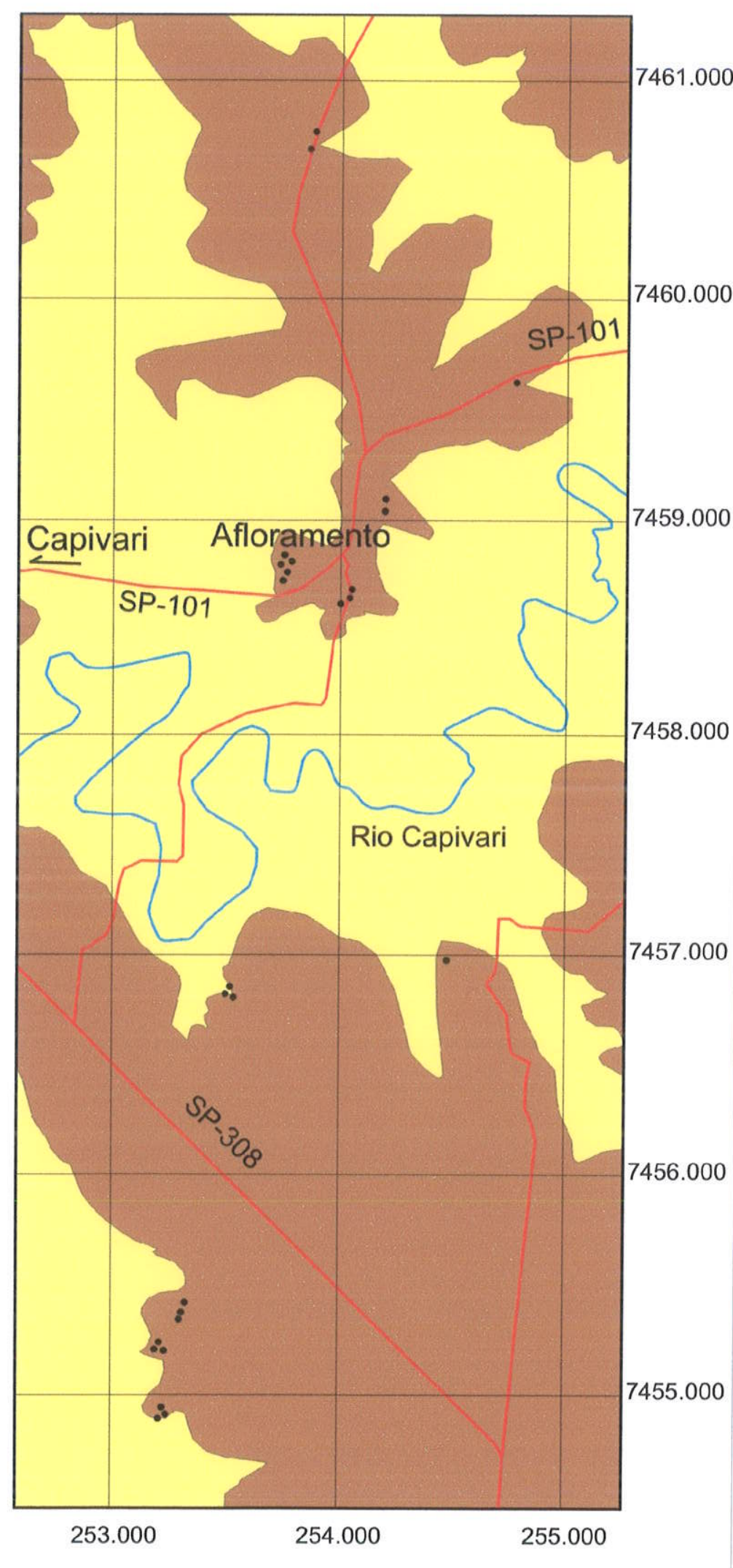

Figura 4.2.1 - Mapa geológico simplificado próximo da localidade de estudo de Capivari (Salvetti, 2000). 


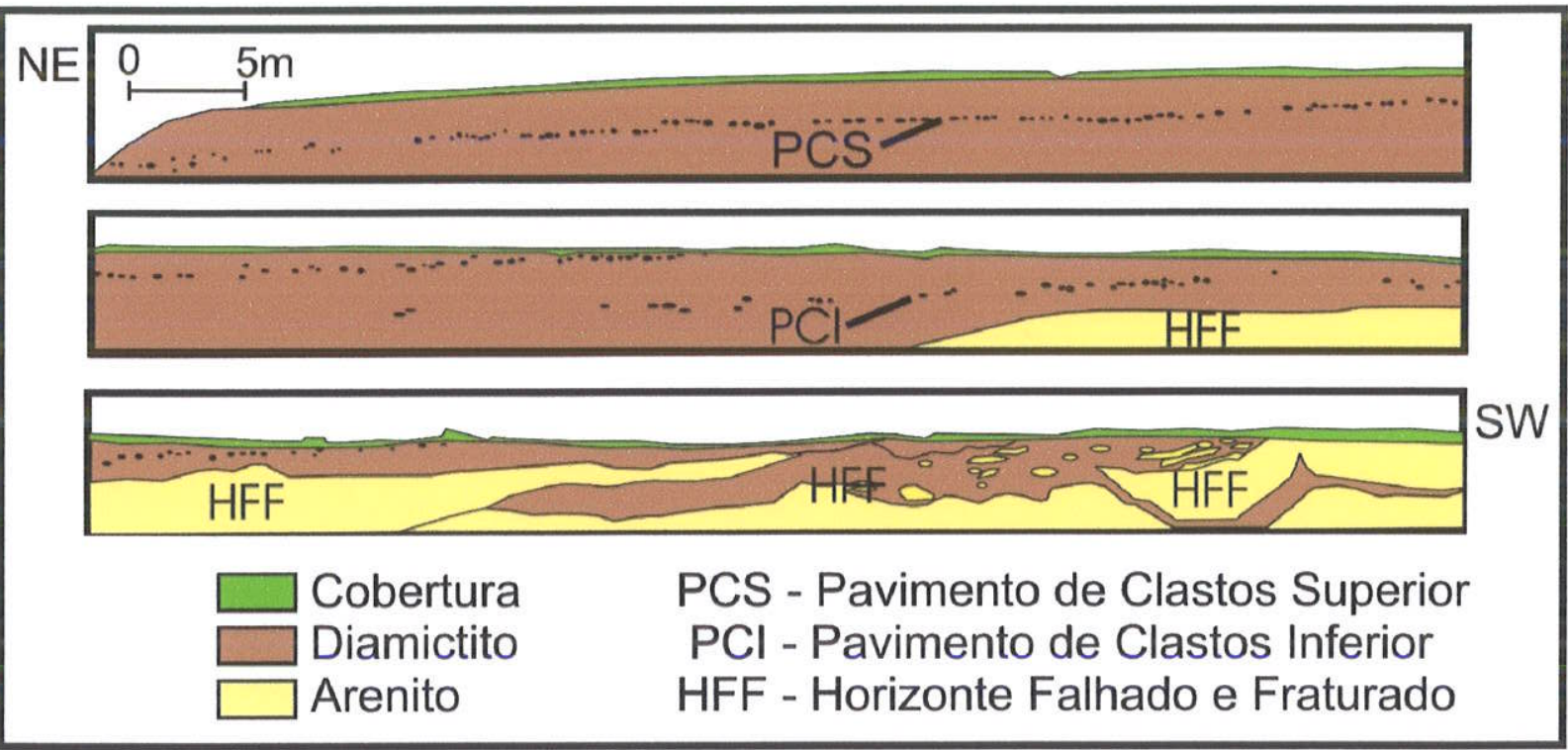

Figura 4.2.2 - Seção esquemática de Capivari (adaptado de Rocha-Campos et al., 1976).

\begin{tabular}{|l|l|l|} 
Fábrica Eigen Estrias & Pavimento de Clastos Superior \\
Pavimento de Clastos Inferior \\
Diamictito A
\end{tabular}

Figura 4.2.3 - Orientações das estrias sobre os pavimentos de clastos e das fábricas de clastos dos diamictitos, tanto pelo método tradicional da média dos valores das fábricas, quanto pelo método autovetores, de Capivari. Estes valores foram obtidos por Rocha-Campos et al. (1976) e Salvetti, (2000), enquanto que a coluna estratigráfica foi modificada de Salvetti (op cit.), com a inclusão do Horizonte Falhado e Fraturado. 
A composição litológica dos clastos nos diamictitos é bem variada em cada nível (pavimento ou diamictito), existindo pelo menos 18 (dezoito) tipos litológicos diferentes. Contudo, o Diamictito $C$ difere dos $A$ e $B$ por possuir clastos com uma menor variedade de tipos litológicos. Segundo Salvetti (2000), que está condizente com o que foi verificado neste trabalho, as litologias dos clastos presentes nos pavimentos de clastos e nos diamictitos indicam que as possiveis áreas-fonte destes clastos correspondiam às rochas précambrianas situadas na borda leste da bacia, tais como as rochas do Complexo Costeiro, do Grupo São Roque e do Complexo Amparo. Todavia, existem também litologias exóticas (e.g.: quartzito aroxeado), cujos clastos já foram constatados em vários outros locais e podem, alternativamente, ser interpretados como originários do continente africano ou de formações rochosas que foram totalmente erodidas em território nacional.

Nos contatos entre os corpos $A / B$ e $B / C$ de diamictitos desenvolvem-se dois pavimentos de clastos associados com intercalações de arenitos e siltitos com aspecto acanalado ou de corte e preenchimento, que ocorrem sempre abaixo do limite superior de cada pavimento. $O$ contato entre cada um dos pavimentos e o diamictito imediatamente superior corresponde a uma superficie de descontinuidade levemente ondulada, provavelmente de natureza erosiva. Os clastos do pavimento inferior estão melhor alinhandos, são menos espaçados e maiores, destacando-se um matacão de $0,5 \mathrm{~m}$ de diâmetro, de quartzito aroxeado, facetado e estriado (Figura 4.2.4).

Pavimentos de clastos podem ser gerados de diversas formas, como, por exemplo, pelo avanço de corpos de gelo que, inicialmente, depositam sedimentos em áreas continentais, plataformais rasas ou costeiras, os quais, posteriormente, por seleção por processos subaéreos ou através de ondas, correntes de marés, deixam um depósito de concentrado residual de clastos pela retirada seletiva dos sedimentos finos. Um novo avanço da geleira aplaina e estria esta concentração de clastos, que é então recoberta por um novo till depositado pela geleira (Bennett \& Glasser, 1996; Figura 4.2.5), ou, alternativamente, por lamitos ou sequência de deglaciação, como diamictito estratificado ou fluxo de detritos (informação verbal de John Visser a Paulo Roberto dos Santos). Este tipo de pavimento de clastos é denominado pavimento de clastos inter-tills, ou seja, entre dois tills diferentes. Exemplos deste tipo de pavimento de clastos foram descritos por Eyles (1988) na Formação Yakataga, Terciário do Alasca, e por McCabe \& Haynes (1996) em sequências sedimentares quaternárias da Irlanda.

Outra explicação para origem de alguns pavimentos de clastos foi reportada por Clark (1991), cujo modelo leva em consideração o peso dos clastos e a deformação do till em que os mesmos estão incluidos. Neste caso, grandes clastos imersos em camadas passiveis de deformação tendem a afundar no till até que atinjam niveis em que a matriz apresente resistência suficiente para suportar o peso destes clastos. Clark (1991) explica, desta forma, 

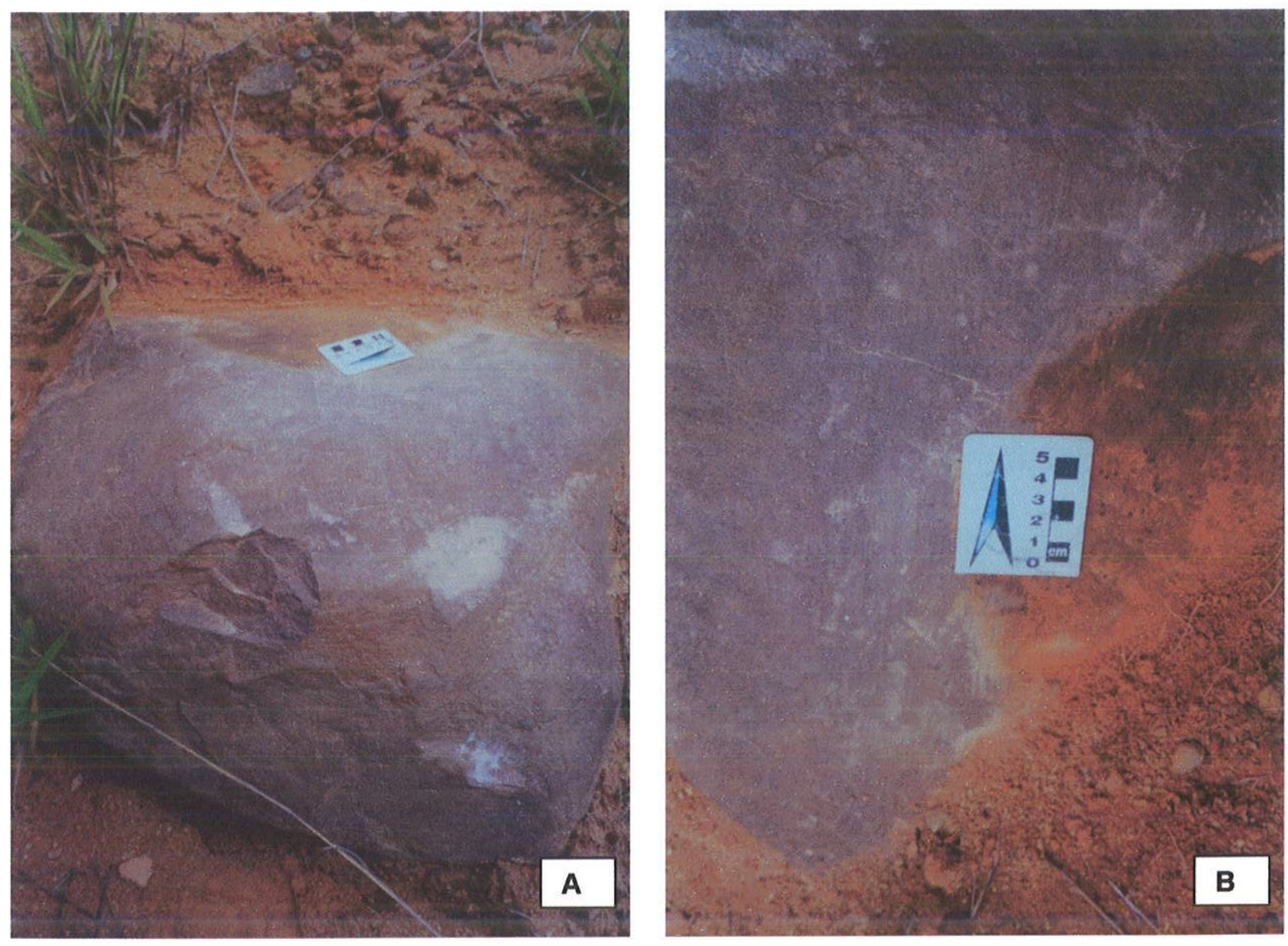

Figura 4.2.4 - Clasto de quartzito aroxeado, exótico, facetado e estriado, integrante do Pavimento de Clastos Inferior de Capivari. A) clasto subarredondado facetado na porção superior; B) Detalhe das estrias presentes no plano facetado do clasto.

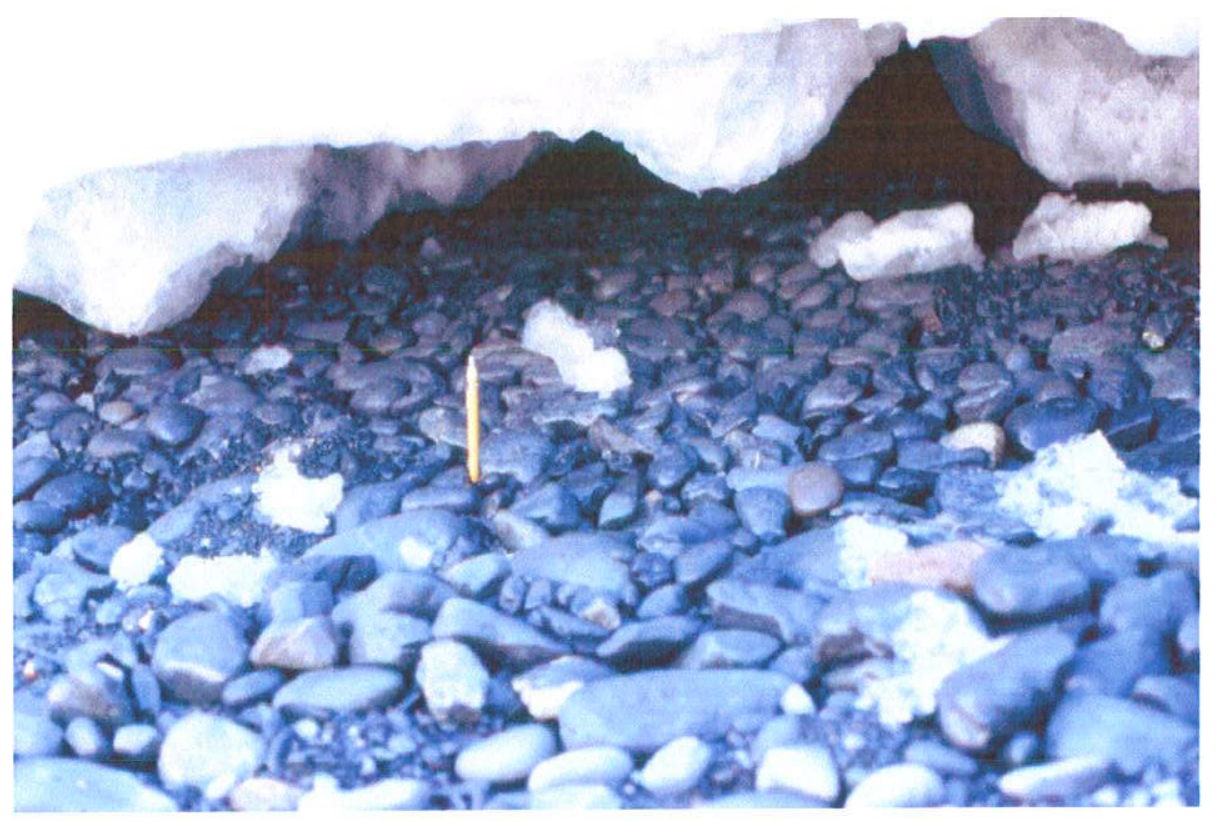

Figura 4.2.5 - Pavimento de clastos sendo formado embaixo de uma geleira do Alasca, EUA. Foto do Prof. Paulo Roberto dos Santos. Escala: lapiseira. 
a origem da concentração de clastos em um determinado nível de um mesmo till, para o qual usa-se a denominação pavimento de clastos intra-till.

Boulton (1996), por sua vez, argumentou que próximo da máxima extensão alcançada pelo avanço ou re-avanço da geleira, seria esperado o desenvolvimento de uma zona em que o till depositado pelo avanço da geleira (Figura 4.2.6A) é parcialmente erodido. Esta erosão estaria relacionada à deformação dos sedimentos, que ocorre devido ao rebaixamento da interface entre o Horizonte A deformável e o Horizonte B estável (Figura 4.2.6B). Com o rebaixamento dessa interface, a porção superior do Horizonte B começa a dilatar e a apresentar deformações, enquanto que a densidade do till diminui. Com a diminuição da densidade, a matriz do till não consegue mais sustentar os clastos, provocando o deslocamento destes para camadas mais inferiores do sedimento.

Durante a deposição do till (Figura 4.2.6A), não é possível que se desenvolva concentrações de clastos em um determinado horizonte, porque todos os horizontes foram, em algum momento, semelhantes à interface $A / B$, a qual, com o decorrer a deposição, sobe gradativamente. No decorrer da erosão, as condições reológicas do Horizonte B mudam bruscamente e os clastos que não conseguem mais ser sustentados pela matriz e acabam se concentrando próximo à nova interface $A / B$, já que, abaixo desta interface, as condições reológicas ainda não foram alteradas (Figura 4.2.6B). A subsequente deposição de sedimentos durante a fase de recuo da geleira possibilita a preservação desta interface erosiva e a concentração dos clastos (o pavimentos intra-till), mesmo com a posterior alteração da posição da interface dos horizontes A e B (Figura 4.2.6C). Por conseguinte, a presença ou não de um pavimento de clastos relacionado à variação da interface $A / B$, depende da densidade dos clastos e da matriz durante a fase de deformação, como também do desenvolvimento de dobramentos que alterem as condições físicas do meio ao acrescentarem esforços direcionais distintos, permitindo, assim, a sustentação de clastos mais densos que a matriz.
A) Fase de avanço
B) Fase Erosiva
C) Fase de recuo Deposição Deposição
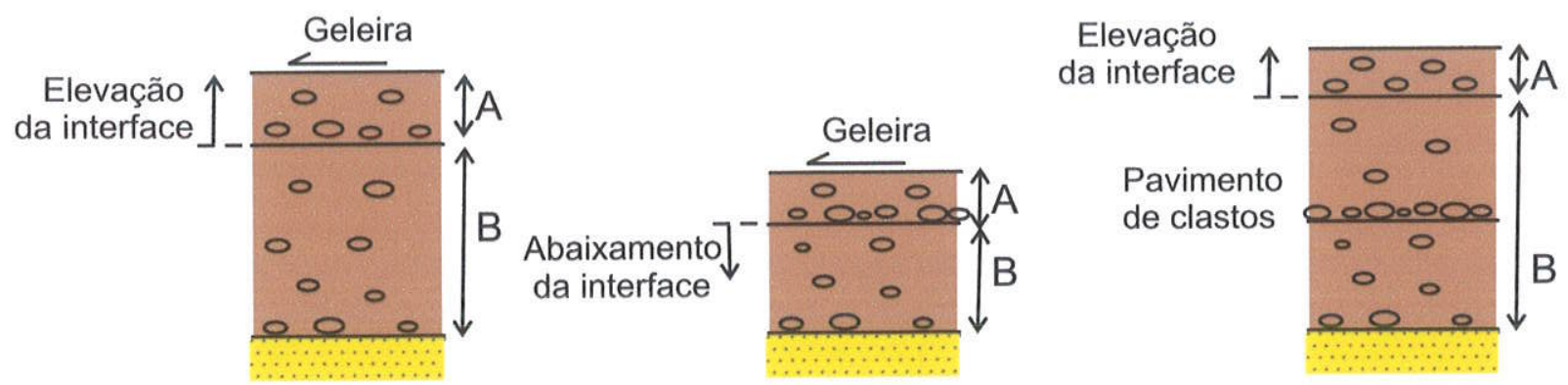

Figura 4.2.6 - Esquema ilustrativo do desenvolvimento de um pavimento de clastos intra-till, através do rebaixamento da interface dos horizontes A e B. A) fase deposicional; B) fase erosiva; e C) nova fase deposicional durante o recuo (Boulton, 1996). 
O modelo de Boulton, portanto, prevê que os clastos dos pavimentos serão litologicamente similares aos dos sedimentos subjacentes, enquanto que o modelo de Clark prevê que estes clastos serão similares aos dos sedimentos sobrejacentes. Cabe, contudo, considerar que nestes dois modelos (Clark, 1991 e Boulton, 1996), os clastos não são estriados e aplainados durante a formação do pavimento e o alinhamento dos clastos é mais descontínuo, visto que seu desenvolvimento depende das propriedades reológicas e hidráulicas que variam com o decorrer do tempo. Logo, é possível considerar que as estrias presentes nos clastos dos pavimentos intra-tills foram geradas em outro episódio e, como foram retransportados, tendem a apresentar uma grande dispersão nos seus direcionamentos.

Para se estabelecer, de forma confiável, a origem dos pavimentos de clastos, faz-se necessário um estudo cuidadoso das fábricas dos clastos dos pavimentos, assim como os dos diamictitos sub- e sobrejacentes (Hicock, 1991). Desta forma, cotejando-se os pavimentos de clastos e as fábricas de clastos de Capivari com as de Jumirim, nota-se uma grande semeihança entre estes dados. Em ambos os casos, o Pavimento de Clastos Inferior é muito bem alinhado, os clastos encontram-se bem próximos uns dos outros, enquanto que - Pavimento de Clastos Superior é descontínuo e desalinhado, mostrando uma irregularidade no horizonte em que foram depositados.

Em Capivari, estes dados foram inicialmente descritos por Rocha-Campos et al. (1976) como dois pavimentos de clastos ocorrentes em dois níveis estratigráficos diferentes dentro de um único diamictito, ou seja, ambos os pavimentos seriam do tipo intra-tillito. Análises posteriores permitiram constatar que se tratava de pavimentos de clastos do tipo inter-tilito (Rocha-Campos et al., 1992, 1993; Cotter et al., 1992), e que os registros estratigráficos preservados representam, pelo menos, 3 (três) fases de avanço e recuo da margem de um corpo de gelo em condições terrestres. Segundo o modelo da gênese dos pavimentos de Capivari proposto por Rocha-Campos et al. (1992) e Cotter et al. (1992), os pavimentos resultariam de múltiplos avanços de geleiras com a deposição de till basal, e dos consequentes recuos das margens dessas geleiras. Após cada recuo estes tills foram expostos subaereamente, foram erodidos e seus clastos concentrados seletivamente e relocados por um novo avanço glacial.

Um mapeamento da área de ocorrência nas cercanias do afioramento indicou que o pavimento se estende por uma área superior a $17 \mathrm{~km}^{2}$ (Salvetti, 2000, Figura 4.2.1). Os clastos que definem os pavimentos variam de pequenos seixos a calhaus (predominantemente) e matacões (alguns com $1,5 \mathrm{~m}$ de diâmetro), são normalmente arredondados e subarredondados, e apresentam as porções superiores biseladas, nas quais geralmente se observam estrias. 
A fim de aferir os valores direcionais anteriormente obtidos por Rocha-Campos et al. (1976), os dados foram reinterpretados pelo método dos autovetores (Mark, 1973), através do software QuickPlot. Na Figura 4.2.3 estão apresentados os resultados de Salvetti (2000) que comparou os dados então obtidos com os valores médios das fábricas descritas por Rocha-Campos et al. (1976). A orientação dos eixos dos clastos dos diamictitos A, B e C foi analisada por Salvetti (2000) através da medição da fábrica dos clastos e os resultados obtidos foram, N274, N253 e N155, respectivamente. No entanto, ao utilizar as mesmas medidas de fábrica dos clastos de Salvetti (op cit.) e Rocha-Campos (op cit.) no software StereoNett, constata-se a ocorrência de alguns equívocos nos procedimentos para o cálculo das fábricas.

Inicialmente, cabe enfatizar que, embora os autovetores obtidos para os diamictitos A, B e C através dos dois programas computacionais (StereoNett e QuickPlot) foram semelhantes (no caso do StereoNett, N274, N253 e N046, respectivamente), a direção dos vetores médios (vector mean direction) apresentou algumas diferenças, sendo respectivamente N223, N294 e N209 (Figura 4.2.7), valores estes relativamente semelhantes aos apresentados por Rocha-Campos et al. (1976). No entanto, cabe mencionar a caracterização de dois problemas: a aplicação inadequada dos autovetores; e a grande dispersão dos dados apresentados. Por pertinência, vale a pena ainda mencionar que, na elaboração do diagrama de rosáceas do Diamictito $\mathrm{C}$, a partir dos dados de RochaCampos (op cit.) e Salvetti (2000), não foram considerados os clastos com inclinação superior a 70 graus (subverticais), visto que dificilmente os clastos teriam alcançado tal inclinação como resultado da passagem da geleira em um ambiente subglacial e, portanto, possivelmente representem outro processo deposicional.
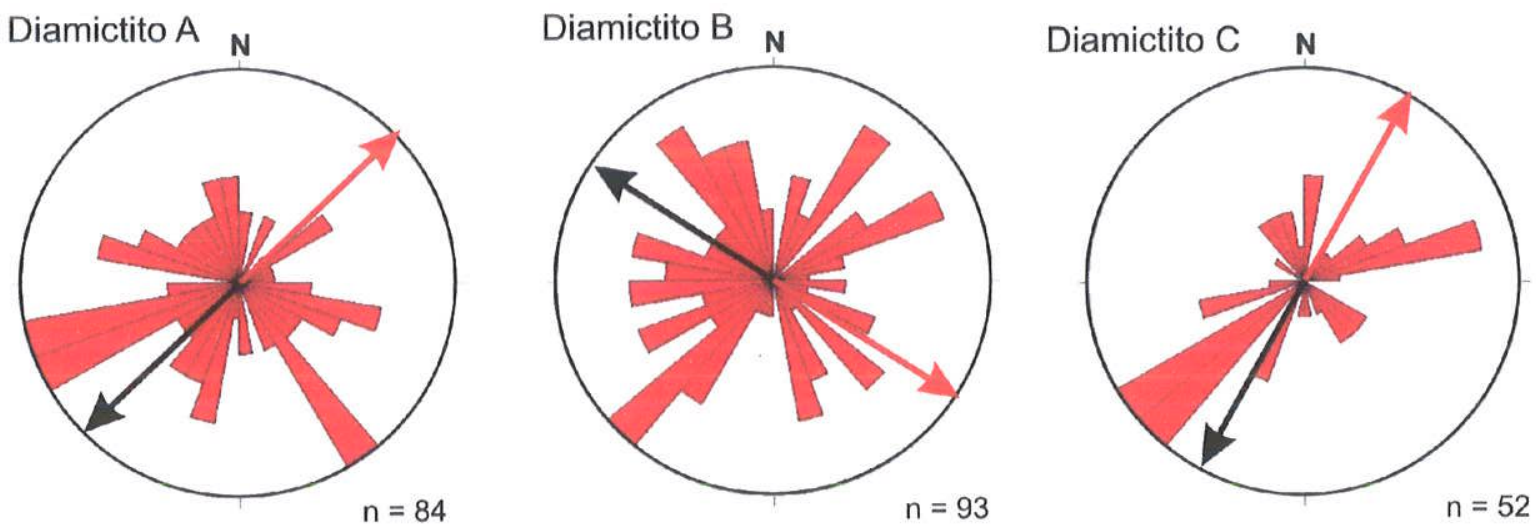

Figura 4.2.7 - Diagrama de rosáceas dos diamictitos de Capivari, baseada em dados obtidos por Rocha-Campos et al. (1976) e Salvetti (2000). Os resultados das re-análises destas fábricas estão representados por setas, sendo que as setas em preto indicam o sentido do vetor médio das fábricas e as setas vermelhas o sentido do movimento da geleira, caso as fábricas tenha sido geradas pelo deslocamento de um corpo de gelo; enquanto que n é o número de medidas analisadas. 
Consequentemente, nota-se, claramente, que o método do autovetor não deve ser usado nestes casos, pois este método estatístico busca calcular três eixos ortogonais entre si: o eixo médio das maiores concentrações de vetores (autovetor principal); um eixo intermediário a $90^{\circ}$ do vetor principal e com concentrações intermediárias de vetores; e um terceiro eixo com concentrações baixas de vetores, de forma que os três eixos fiquem a $90^{\circ}$ uns dos outros. Em outras palavras, o autovetor principal pode até coincidir com a direção do vetor médio, ou seja, com as maiores concentraçōes de vetores, mas quando os valores estiverem muito dispersos dificilmente será verificada a sua eficácia.

Analisando em detalhe os dados apresentados na Figura 4.2.7, observa-se uma grande dispersão dos sentidos do eixo maior dos clastos, evidenciando que não existe um direcionamento preferencial que indique, com precisão, qual foi o sentido do deslocamento da geleira. Utilizando outra ferramenta estatística do StereoNett, observa-se que, nos diamictitos A, B e C, o paralelismo entre os vetores $(21,26 \%, 7,63 \%$ e $3,89 \%$, respectivamente) e a concentração dos vetores $(2,51 ; 2,14$ e 1,89 , respectivamente) é muito baixa, havendo, inclusive, uma diminuição gradativa destes parâmetros.

Uma possível explicação seria a de que um corpo de diamictito pode ter sido depositado por uma geleira que, com o decorrer do tempo, teria mudado de sentido quando se deslocava. Neste sentido, nota-se, claramente, que no Diamictito A, por exemplo, os eixos não estão somente concentrados no sentido N223, ou seja, para SW, mas que existe outra concentração na direção NW-SE. Esta segunda concentração (NW-SE) é, contudo, semelhante à apresentada pelo Diamictito $\mathrm{B}$, mostrando que pode ter havido uma mudança na direção do desiocamento do corpo de gelo, embora esta afirmação seja dotada de certa subjetividade.

Em tais situações o ideal seria que fosse feito um detalhamento faciológico prévio, procurando assim identificar depósitos sedimentares distintos associados ao diamictito, como, por exemplo, uma lente com clastos subverticalizados ou a variação das fábricas entre horizontes distintos do diamictito analisado. No entanto, este nivel de detalhamento nem sempre é possível de ser alcançado devido ao estado de conservação dos afloramentos, como é o caso de Capivari. Conforme foi mencionado no Subcapítulo 1.4.3. (Análise de Fábrica de Clastos), embora em muitos tills os clastos apresentem a orientação do eixo maior paralela ao deslocamento do fluxo de gelo (e.g.: till de alojamento subglacial), os padrões raramente são bem definidos. Além do mais, o desconhecimento do controle do ambiente e dos processos deposicionais, bem como dos efeitos da compactação pósdeposicional colocam em risco o uso irrestrito deste método.

Consequentemente, neste trabalho, devido à falta de detalhamento faciológico prévio, foi apenas considerado que os dados apresentados pelo método estatístico são equivalentes apenas ao sentido do vetor médio dos eixos de todas as medidas dentro dos 
diamictitos, ou seja, N223, N294 e N209 (diamictitos A, B e C, respectivamente). Tentativamente, e apesar de todas as ressalvas consideradas, estes vaiores podem ser utilizados para indicar a direção média da variação do deslocamento da geleira, a fim de que se possa ter algum elemento comparativo entre os diamictitos e as estrias presentes no topo do arenito e nos pavimentos de clastos. Neste caso, presume-se que a direção do deslocamento do corpo de gelo variou com o decorrer do tempo e que não ocorreu apenas imbricamentos típicos, visto que os clastos encontram-se inclinados nos dois sentidos.

Esta tentativa de utilização dos dados obtidos pela análise da fábrica dos clastos, assim como uma análise mais detalhada das feições subglaciotectônicas e dos pavimentos de clastos das duas localidades, encontram-se no tópico: "Discussão sobre as estruturas subglaciotectônicas de Capivari e Jumirim", que segue após o próximo subcapítulo.

\subsection{DESCRIÇÃO DOS AFLORAMENTOS E ESTRATIGRAFIA DE JUMIRIM}

O nivel de conhecimento alcançado até o momento, permite considerar a hipótese que o afloramento de Jumirim pode se constituir em mais um exemplo de estruturas subglaciotectônicas rúpteis registradas no Subgrupo Itararé. Este afloramento não só possibilita o seu cotejamento com o afloramento de Capivari, e permitindo, desta forma, compreender melhor, e de modo mais claro, os eventos que influenciaram a gênese dos pavimentos de clastos ocorrentes em ambas as localidades, mas também se tomou um fator importante em termos da sua estratigrafia e das novas ocorrências de fósseis de plantas descobertas através deste estudo.

O contexto estratigráfico do sítio, como o aqui proposto, foi definido através da observação das seções estratigráficas e do mapeamento geológico de suas cercanias, procedimento este que permitiu a identificação de 6 (seis) distintas associaçōes de litofacies. A estratigrafia local pode ser observada nas seções 1 e 2 do quadro de correlação da Figura 4.3.1A. A Seção 1, que representa uma área de empréstimo próxima à primeira entrada de Jumirim, km 166,7 da SP-300 e afloramentos a leste deste ponto da rodovia (Sítio do Pedro Bertola), corresponde, em parte, à Seção B (NW-SE) de Lucio (1999), enquanto que a Seção 2, encontra-se cerca de $1.100 \mathrm{~m}$ a oeste da Seção 1, estando situada no outro flanco do vale que as separa (Figura 4.3.1C). A Seção 2, por sua vez, seria análoga à Seção $A$ de Lucio (1999) e corresponde à representação de pequenos afloramentos parcialmente encobertos no leito de uma estrada secundária de terra e, infelizmente, não foi possivel descrevê-la com o mesmo nivel de detalhamento da Seção 1; contudo, notou-se a possibilidade de se estabelecer uma correlação entre elas, $e$, nesse sentido, os dados de Lucio (1999) foram reinterpretados (e.g.: Associação II). A sequência estratigráfica da Seção 1 apresenta, da base para o topo, as seguintes associações de litofacies (Figura 4.3.1A): 
A) Correlação estratigráfica de Jumirim

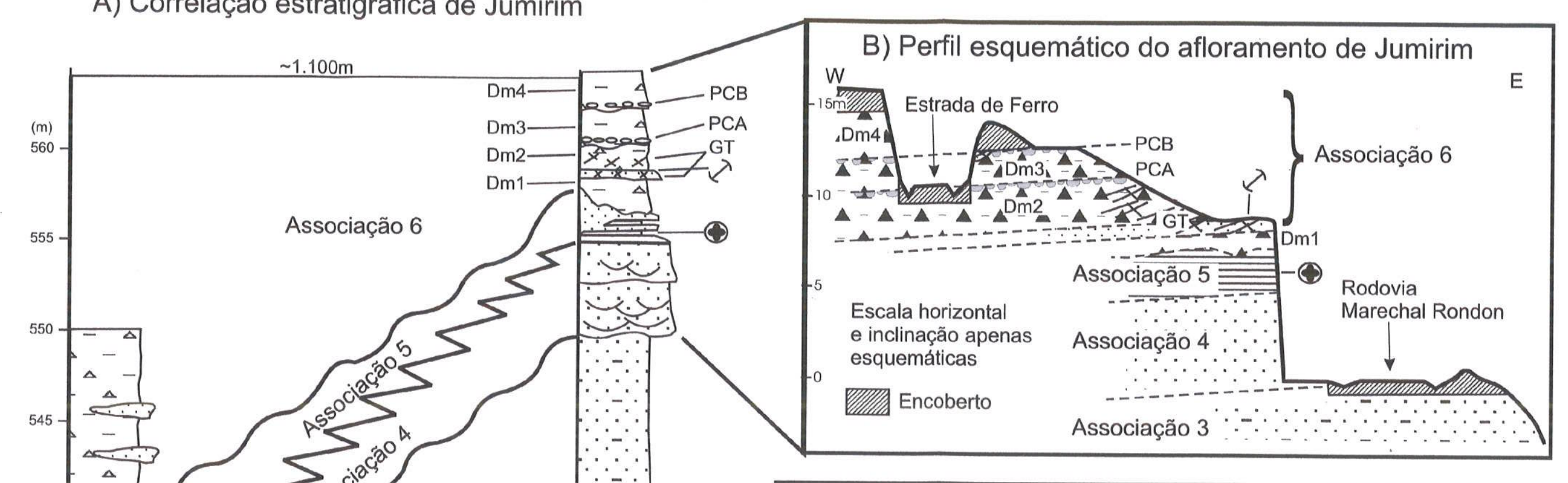

C) Mapa do afloramento de Jumirim

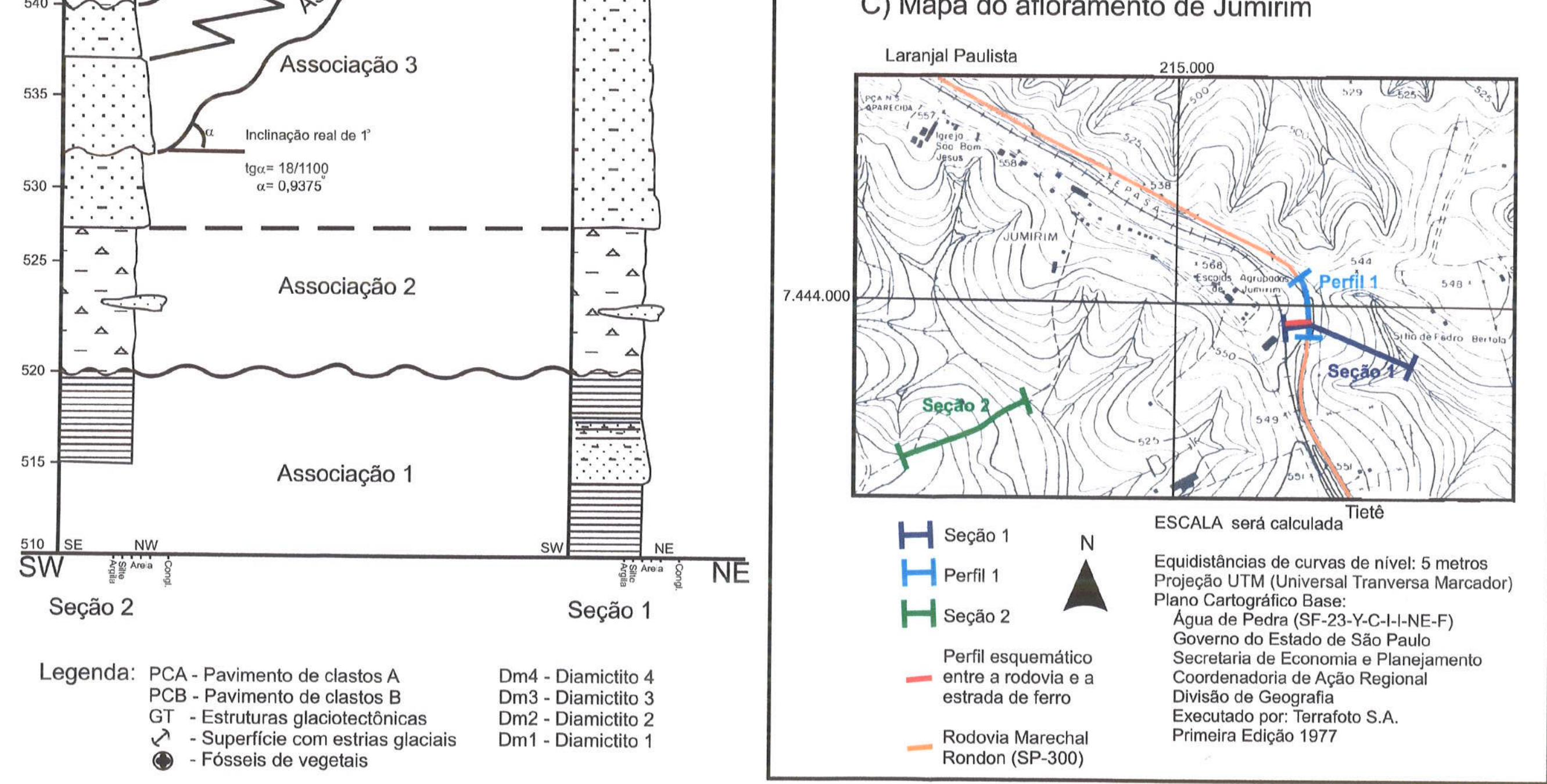

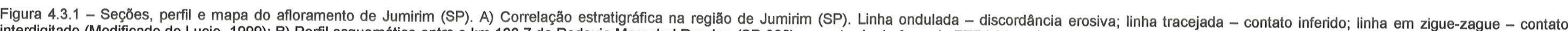

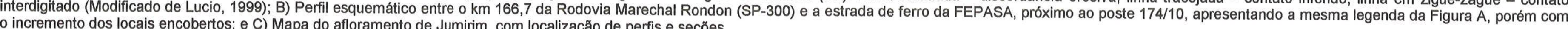


Associação 1 - é composta por ritmitos irregulares silto-arenosos e argilo-siltosos, arenitos finos, silto-argilosos, estratificados, e arenitos finos a médios, maciços. Embora o contato inferior não tenha sido observado, foi possivel constatar que, nesta localidade, a Associação 1 apresenta, pelo menos, $10 \mathrm{~m}$ de espessura.

A Seção 1 inicia-se com mais de $1 \mathrm{~m}$ de espessura de ritmitos (Figura 4.3.2), às vezes com acamamentos ondulados, que alternam tonalidades entre 0 amarelado típico dos arenitos finos e os tons avermelhados (cinza quando menos intemperizado) dos sedimentos mais finos (argilitos e siltitos) e são sucedidos, bruscamente, por um pacote de arenito fino, maciço, amarelado, com espessura superior a $2 \mathrm{~m}$, exibindo granodecrescência ascendente, que grada para um arenito mais fino com estratificação plano-paralela. Após um intervalo sem registros, no topo desta associação ocorrem novamente os ritmitos ondulados.

A sequência de litofacies enfeixadas nesta associação pode, alternativamente, representar o registro de um ciclo incompleto de turbidito. Segundo a sequência clássica de Bouma (Bouma, 1962), que será mais detalhadamente comentada no Capítulo 6 , os sedimentos da Associação 1 representariam, da base para o topo, os intervalo A (material arenoso com estratificação gradativa relativamente desenvolvida), B (material arenoso com estrutura geralmente laminar horizontal) e C (sedimento arenoso fino corn laminações cruzadas originadas pela migração de formas de leito onduladas e eventuais estruturas convolutas). Os intervalos D (material lamítico com laminação horizontal distinta) e $E$ (sedimentos argilosos), possivelmente foram erodidos pelos processos deposicionais dos diamictitos da Associação 2. Esta hipótese é reforçada pela ocorrência de lamitos na base da seção estratigráfica B de Lucio (1999), os quais, contudo, não foram identificados.

Associação 2 (Associação I, de Lucio, 1999) - composta por diamictito maciço, siltoargiloso, que chega a atingir $7 \mathrm{~m}$ de espessura na seção, apresentando um caráter homogêneo e com intercalações de lentes pouco espessas e deformadas de arenito fino. $O$ contato inferior com os ritmitos é abrupto e erosivo, enquanto que o contato superior com sedimentos mais finos, aparentemente, é concordante. A interpretação mais plausivel que pode ser considerada no momento identifica o diamictito como um depósito de sedimentos finos, derivados da decantação de plumas de detritos introduzidos em ambiente subaquático a partir de fluxos gravitacionais de massa, ou mesmo a partir de fluxo subglacial de água de degelo associados a materiais caidos de icebergs (rain out).

$\mathrm{Na}$ Seção 1, o contato infeiror entre as associações 1 e 2 encontra-se inclinado e representa uma aparente discordância erosiva (Figura 4.3.3). Contudo, na Seção 2, onde o acesso ao afloramento é melhor, os ritmitos encontram-se ondulados e as duas litologias estão sutilmente misturadas numa zona de contato com aproximadamente $20 \mathrm{~cm}$ de espessura. Nesta zona notam-se clastos centimétricos e de litologias variadas no ritmito e 
intraclastos $^{11}$, compostos por fragmentos retrabalhados do ritmito no diamictito (Figura 4.3.4). Uma possível explicação seria a de representarem eventos glaciotectônicos em condições subaquáticas. No entanto, seria mais realista considerar que o diamictito é resultante de um deslocamento gravitacional de massa do tipo fluxo de detriticos, visto que a espessura $(7 \mathrm{~m})$ do diamictito não é usual para um tilito subglacial e o contexto estratigráfico sub-e sobrejacente indica tratar-se de um ambiente subaquoso (marinho?) relativamente profundo.

Associação 3 (Associação II, de Lucio, 1999) - prevalece arenito fino, siltoso a argiloso, alaranjado a avermelhado, maciço e ocasionalmente estratificado, com poucos clastos decimétricos, de composiçăo variada, dispersos caoticamente na matriz. A despeito do fato do terreno em que ocorre a associação ser de topografia suave e coberto por pastagens, e, consequentemente, não favorecer o seu exame contínuo devido a existência de poucos e esparsos afloramentos, foi possível constar algumas evidências que levantam a possibilidade de que a associação possa corresponder ao registro de uma regressão marinha. $O$ espesso pacote de arenito, com no mínimo de $20 \mathrm{~m}$ de espessura, apresenta uma aparente granocrescência geral ascendente, com algumas lentes decimétricas de lamitos intercaladas no arenito fino, principalmente próximos à base, e de arenitos grossos, que aumentam em número para o topo. $O$ contato inferior não foi observado, enquanto que o superior é abrupto, erosivo e localmente possui estruturas de sobrecarga possivelmente associadas ao alto aporte de sedimentos depositados bruscamente sobre um material menos denso. Cabe esclarecer que esta associação possivelmente corresponde, lateraimente, ao lamito da Associação II de Lucio (1999), dela diferenciando-se apenas pela variação granulométrica dos sedimentos. Com relação à interpretação do ambiente deposicional, como já foi acima antecipado, esta associação pode representar uma regressão marinha, com pulsos descontínuos de sedimentos transportados por fluxos de água de degelo. Os clastos dispersos na matriz possiveimente representem clastos caídos de icebergs.

Associação 4 (parte da Associação IV de Lucio, 1999) - arenito feldspático, facilmente reconhecível devido a sua tonalidade amarelada a esbranquiçada, a sua granulometria de média a grossa, por formar espessos bancos e por exibirem estratificações cruzadas acanaladas, de médio a grande porte, que chegam a apresentar canais de $3 \mathrm{~m}$ de comprimento de seção e espessuras de $0,5 \mathrm{~m}$. Os clastos arredondados presentes nesta

\footnotetext{
11 Adotou-se aqui o termo intraclasto, para fragmentos retrabalhados de rochas sedimentares, por não se encontrar um termo mais apropriado e de igual significado, apesar de Suguio (1998) considerar que o termo só pode ser empregado para fragmentos calcários retrabalhados, de deposiçăo penecontemporânea, que foi erodido e redepositado nas cercanias e incorporado a calcários de idade mais nova.
} 


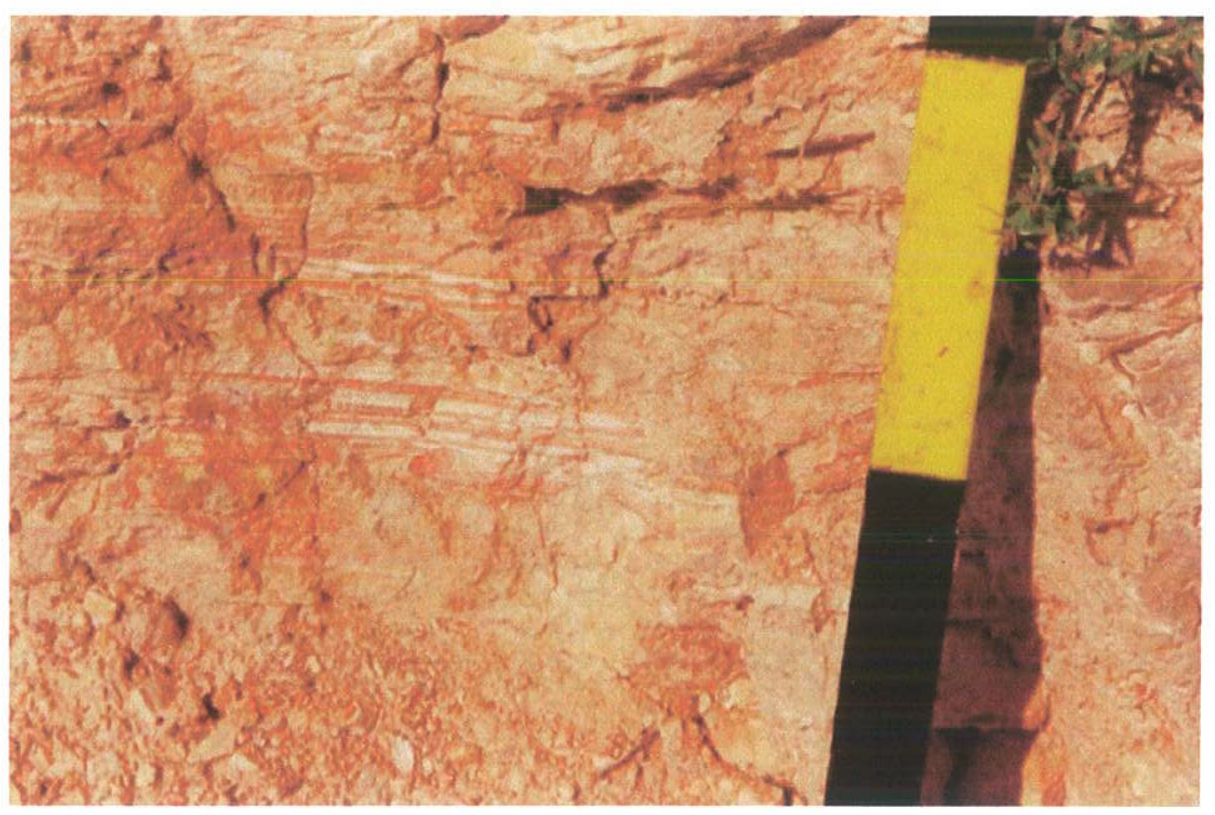

Figura 4.3.2 - Detalhe das camadas rítmicas da Associação 1, na base da Seção 1 de Jumirim. Escala: tala de madeira dividida a cada $10 \mathrm{~cm}$.

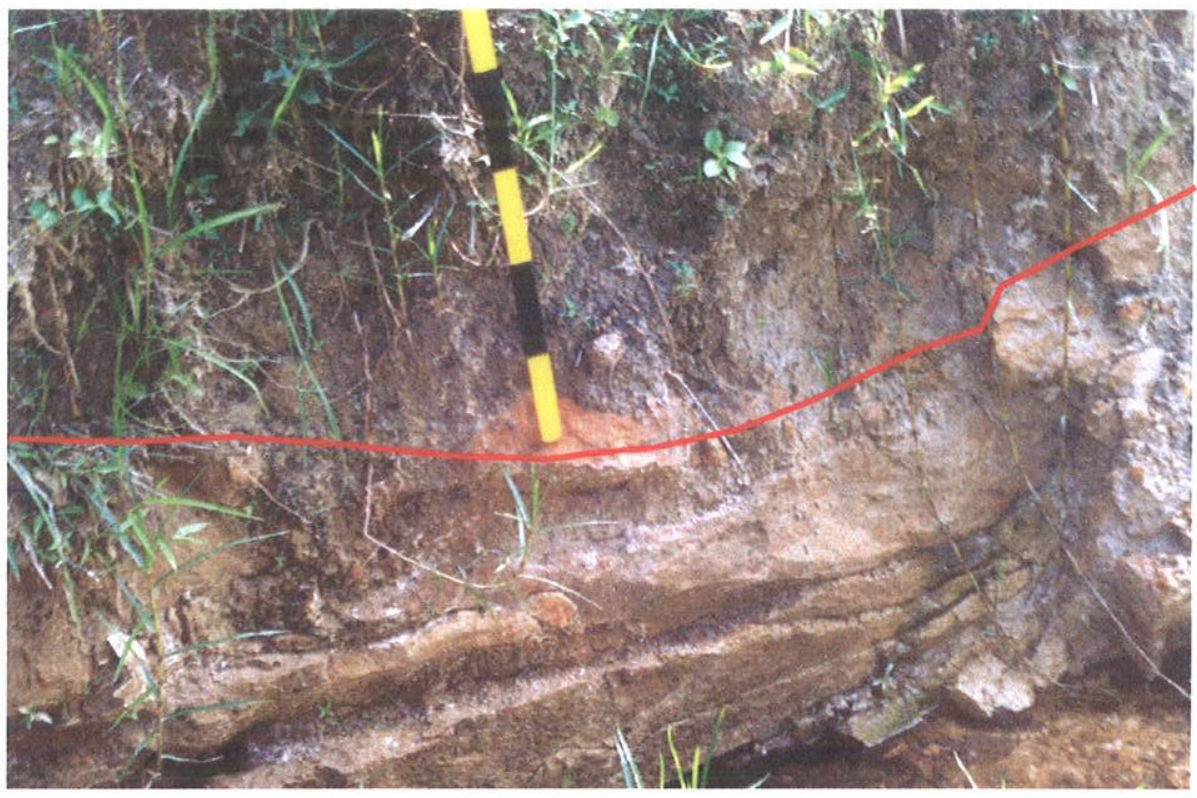

Figura 4.3.3 - Contato irregular inclinado entres as associações 1 e 2 (linha vermelha), na Seção 1 de Jumirim. Escala: tala de madeira dividida a cada $10 \mathrm{~cm}$. 


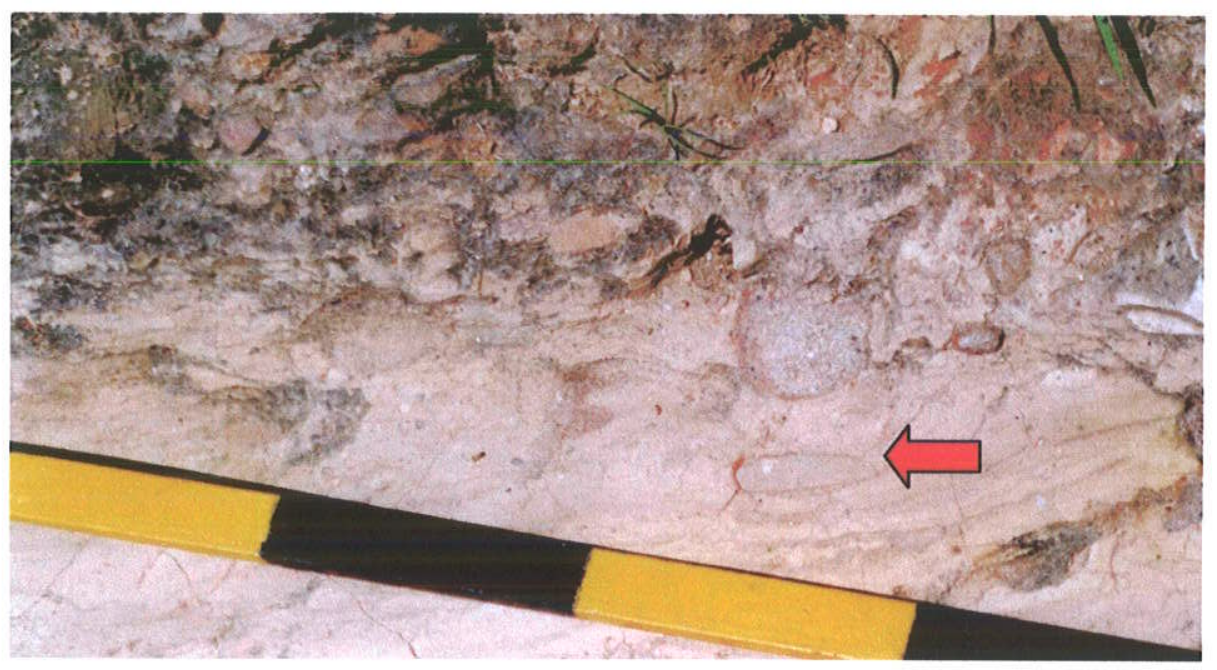

Figura 4.3.4 - Intraclasto de argilito (seta) na zona de contato entre as associações 1 e 2, na Seção 2 de Jumirim. Escala: tala de madeira dividida a cada $10 \mathrm{~cm}$.

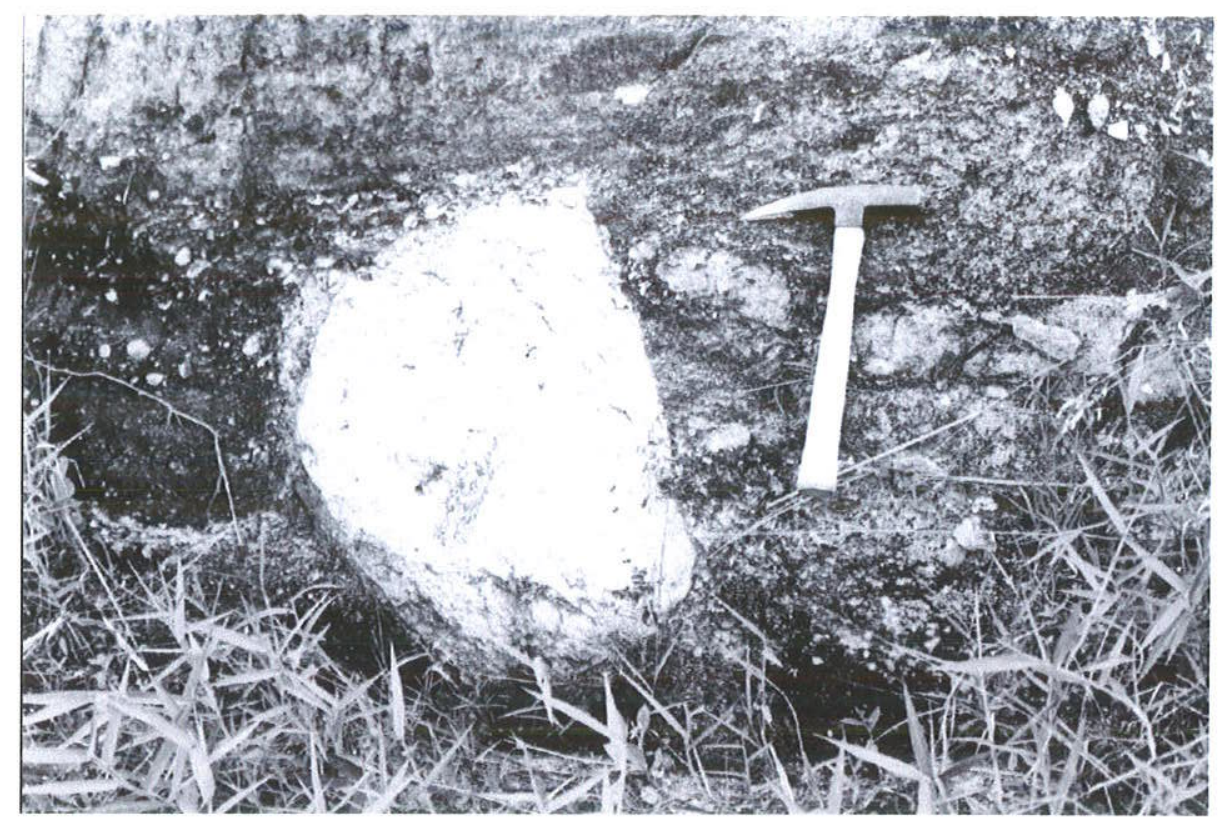

Figura 4.3.5 - Clasto de granito hololeucocrático, presente na base da Associação 4 de Jumirim. Escala: martelo geológico. 
associação raramente excedem $5 \mathrm{~cm}$ ao longo do eixo maior, sendo mais comuns os de 1 $\mathrm{cm}$ de diâmetro. No entanto, merece aqui uma menção a respeito de um clasto de granito hololeucocrático, com $45 \mathrm{~cm}$ de diâmetro e forma de "mata-borrão", ocorrente na base da associação (Figura 4.3.5). Os sedimentos depositados posteriormente no entorno e sobre este clasto, formam uma sombra de materiais, que, aparentemente, sugere um fluxo para norte. Este pacote possui, localmente, um pouco mais de $5 \mathrm{~m}$ de espessura, sendo que a incidência de estratificações cruzadas acanaladas tende a diminuir para o topo, associadamente a uma granodecrescência ascendente, que é truncada por um novo ciclo de canais com granulometria um pouco mais grossa, próximo ao topo da sequência.

$\mathrm{Em}$ termos interpretativos a ocorrência restrita da Associação 4, assim como sua faciologia e geometria, sugerem tratar-se de um depósito do tipo flúvio-deltáico, compativeis com os elementos do modelo de deposição do tipo outwash de Rust (1977), também conhecido, principalmente na Islândia, como sandur; ou seja, um depósito subaquático ou subaéreo de degelo em que se altemam acumulações de areia e conglomerados em canais distributários de um leque deltáico. Nesse modelo, alguns clastos relativamente grandes são encontrados dispersos e interpretados como representando clastos caídos de icebergs, ou mesmo rolados gravitacionalmente a partir de locais mais ingremes (e.g.: de morainas proglaciais), sendo esta última possibilidade mais viável para a origem do clasto com a forma de um mata-borrão (Figura 4.3.5).

Associação 5 (parte da Associação IV, de Lucio, 1999) - corpo de arenito fino a médio, amarelado, relativamente homogêneo, com estratificação plano-paralela a cruzada tabular de porte médio, interdigitado concordantemente com siltitos, exibindo, inclusive, um aspecto geral de um ritmito. A espessura total da associação é de aproximadamente $1,7 \mathrm{~m}$. Os siltitos possuem raras lentes de argila de coloração acinzentada, que, quando intemperizados, adquirem uma tonalidade alaranjada a avermelhada. $O$ contato inferior com a Associação 4 é gradativo e concordante. A presença de caules fósseis (Figura 4.3.6) e de sementes nos siltitos revela um ambiente de deposição transicional ou subaquático (marinho ou lagunar?) de baixa salinidade (informação verbal da Profa. Dra. Mary Elizabeth Cerruti Bernardes de Oliveira), próximo ao continente, que permitiu a sua acumulação e preservação.

Associação 6 (Associação V de Lucio, 1999) - é nesta associação que se encontram os pavimentos de clastos e as deformações glaciotectônicas (figuras 4.3.1A, Seção $1 \mathrm{e}$ 4.3.1B). Em termos estratigráficos, de baixo para cima, ocorre um corpo alongado de diamictito acinzentado (Dm1), com clastos centimétricos, subarredondados, de composição variada, que chega a medir $3 \mathrm{~m}$ de espessura. Apresenta contatos erosivos e, localmente, 

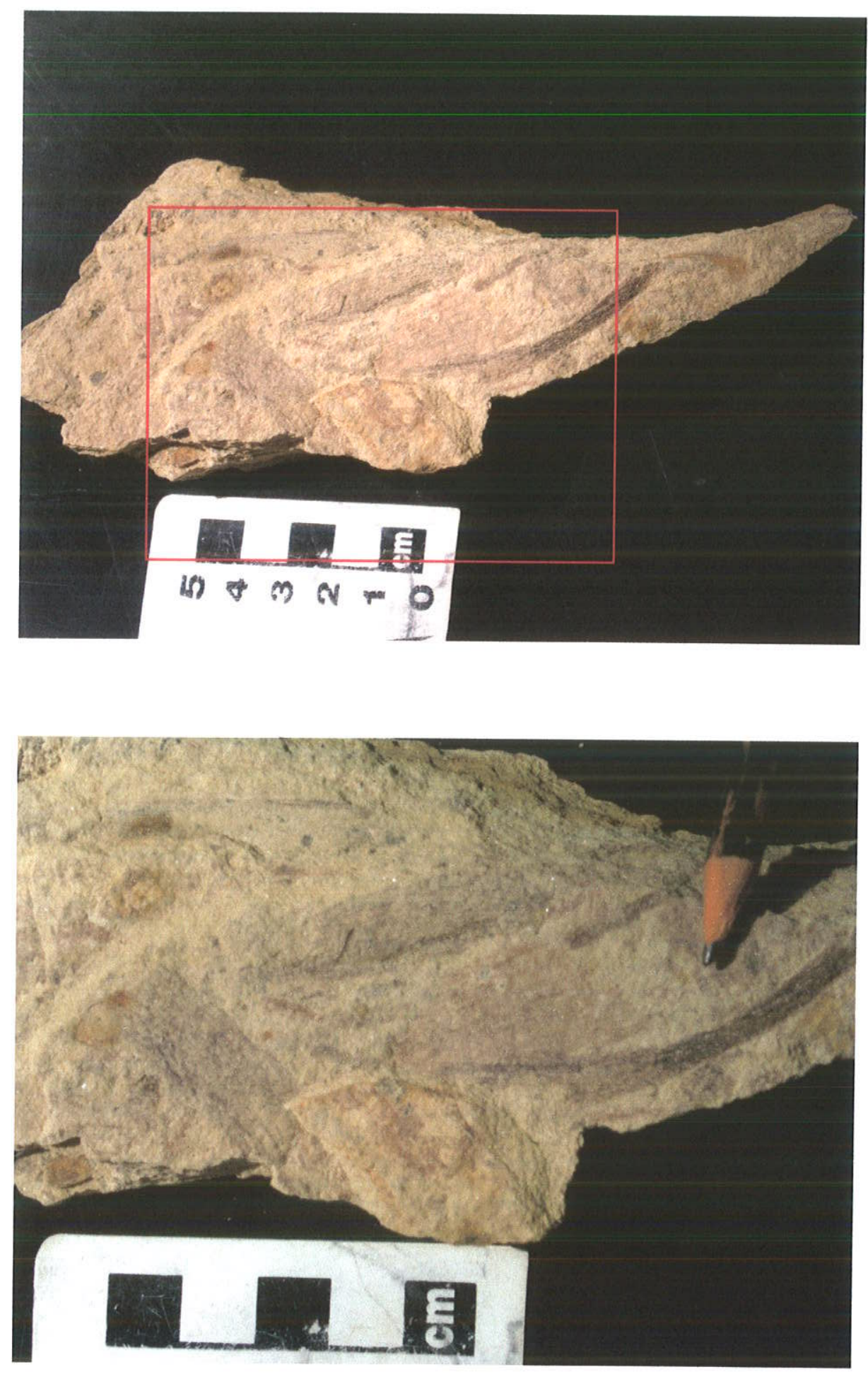

Figura 4.3.6 - Fósseis de vegetal, provavelmente paracalamites, coletados in situ na Associação 5 de Jumirim. Foto inferior detalhe da superior delimitada pelo quadro vermelho. 
irregulares e truncantes, com os arenitos da Associação 5 sotoposta. Em cima dos diamictitos ocorre uma fina camada de arenito fino a médio (centimétrica, no máximo $0,5 \mathrm{~m}$ ), com estratificação plano-paralela e cruzada na base e estruturas rúpteis de pequena escala, no topo. Este arenito, por sua vez, é capeado por um diamictito de matriz argilosa e laminada (Dm2), acinzentado, também deformado, com poucos clastos centimétricos e com espessura de aproximadamente 1,5 m. Estas deformações rúpteis limitam-se ao arenito e ao Dm2, não tendo sido observadas tanto nas camadas subjacentes, quanto sobrejacentes.

Sobrepondo-se ao Dm2 encontra-se um alinhamento bem desenvolvido de clastos, 0 Pavimento de Clastos A (PCA, Figura 4.3.1A, Seção 1), bem exposto por mais de $5 \mathrm{~m}$ ao longo da face leste do corte da estrada de ferro (Figura 4.3.7), embora parcialmente encoberto. Os clastos do PCA apresentam facetas superiores e estrias com orientação N300. Acima deste pavimento ocorre um terceiro diamictito (Dm3), que, por sua vez, é maciço, de matriz areno-siltosa, cinza claro, de $1 \mathrm{~m}$ de espessura, com estratificação local pouco nítida, evidenciada por intercalações de lâminas descontínuas de siltito e arenito fino, além de corpos esféricos e deformados de arenito com evidências de estratificação concêntrica, imersos na matriz do diamictito. No topo do Dm3 existe um segundo pavimento de clastos, o Pavimento de Clastos $B$ (PCB), com maior espaçamento horizontal entre os clastos (decimétrico) e clastos bem maiores (decimétricos) que os do PCA. Os clastos do PCB possuem composição litológica pouco variada e encontram-se facetados e estriados (N007). Capeando topo o pacote sedimentar ocorre um quarto diamictito (Dm4), com matriz argilo-siltosa, acinzentada e clastos centimétricos a decimétricos, intercalado por lentes métricas de arenito fino com estratificações cruzadas.

Analisando somente os pavimentos de clastos de Jumirim, nota-se que Rocham Campos et al. (1968), no primeiro trabalho sobre esta ocorrência, descreveram um único pavimento de clastos aflorante ao longo da Estrada de Ferro Sorocabana e da rodovia Marechal Rondon (SP-300). Contudo, conforme será detalhado nos próximos parágrafos, trata-se, na realidade, de dois pavimentos de clastos distintos. Posteriormente, as informações sobre esta ocorrência foram acrescidas com descrições detalhadas das estrias glaciais, com direção N300, e marcas em crescente, formadas por sulcos em crescente (crescentic gouges), fraturas lunadas (lunate fractures) e fraturas em crescente (crescentic fractures), sobre a face superior aplainada de um dos matacões de $90 \mathrm{~cm}$ de diâmetro do pavimento (Rocha-Campos et al., 1969; Figura 4.3.8). Este segundo trabalho teve o mérito adicional de reforçar as evidências de origem glacial dos pavimentos de clastos, visto que estruturas semelhantes foram reportadas por Dreimanis (1953) em sedimentos do Pleistoceno da América do Norte. 


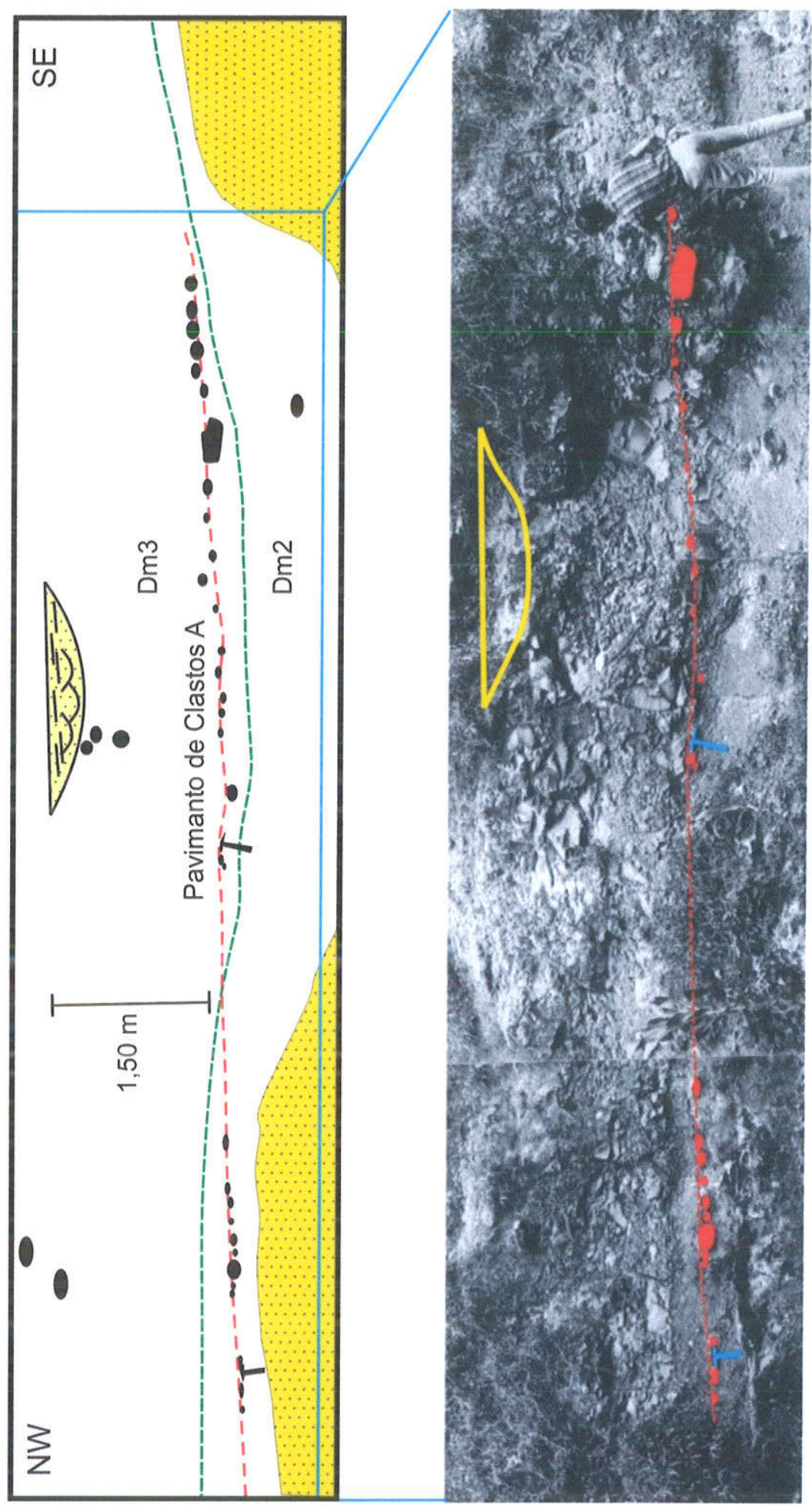

Figura 4.3.7 - Diagrama esquemático e mosaico de fotos do corte leste na estrada de ferro próximo a entrada da cidade de Jumirim. No mosaico de fotos, o Pavimento de Clastos A está destacado em vermelho e o canal delimitado por linhas amarelas. O diagrama esquemático deste afloramento foi adaptado de Rocha-Campos et al. (1968), onde os dados acrescentados foram: quadrado azul = localização do mosaico de fotos no esquema de Rocha-Campos et al. (1968); Dm2 = Diamictito 2; Dm3 = Diamictito 3; linha tracejada vermelha = alinhamento aproximado do Pavimento de Clastos A; linha tracejada verde = limite atual dos detritos que soterraram parte do afloramento, ou seja, a área abaixo desta linha está coberta por sedimentos; áreas pontilhadas em amarelo $=$ arenitos, onde os inferiores são os arenitos deformados e o superior representa uma lente de arenito fino com estratificações cruzadas e deformado acima do Dm3. Mosaico de fotos gentilmente cedidas pelo Prof. Antonio Carlos Rocha-Campos. Escalas do mosaico: martelo geológico e uma pessoa. 


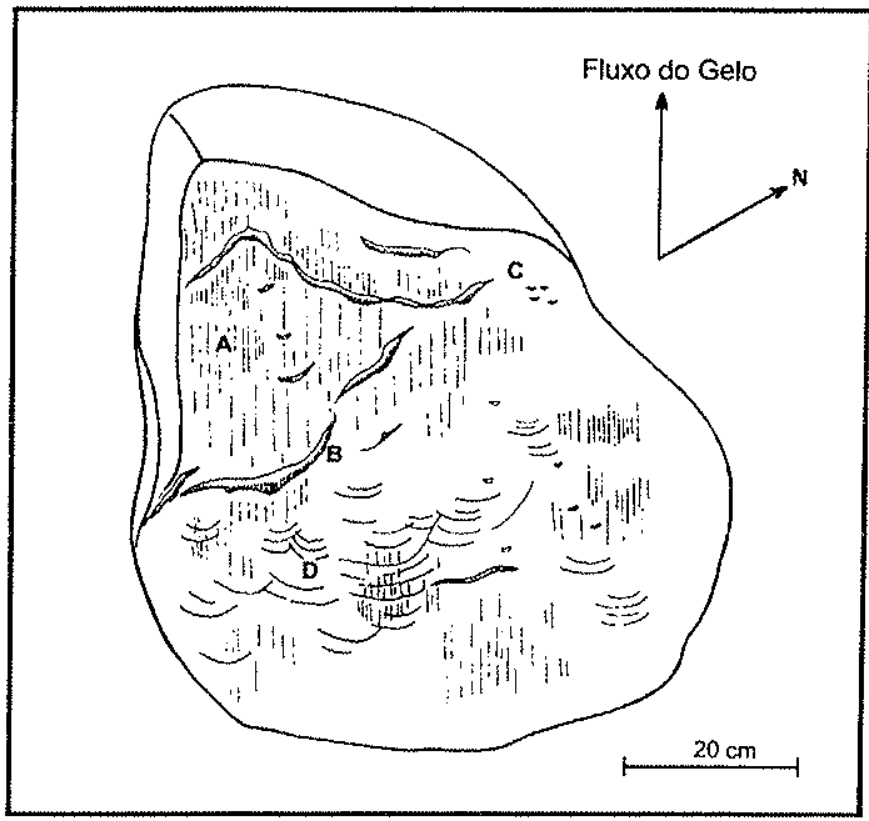

Figura 4.3.8 - Matacåo com marcas em crescente e estrias glaciais, presente no Pavimento de Clastos A de Jumirim, onde A) estrias glaciais; B) sulcos em crescente; C) fraturas lunadas; $e$ D) fraturas em crescente. O fluxo do gelo apresenta direção de N300 (Rocha-Campos et al., 1969).

Mais recentemente, os professores Antonio Carlos Rocha-Campos, Paulo Roberto dos Santos, José Roberto Canuto e James F. P. Cotter (informação verbal de Rocha-Campos e Santos) reconheceram a existência de um segundo pavimento descontínuo de clastos e outro nivel de diamictito entre os dois pavimentos de clastos. Todavia, eles não publicaram tal constatação, em virtude da ausência de estudos detalhados desta segunda ocorrência.

No trabalho de Rocha-Campos et al. (1968) os dois pavimentos de clastos foram descritos como um só, visto que estes ocorrem em afloramentos distintos. Desta forma, achou-se, em primeira instância, que se tratava apenas de um único pavimento de clastos. Contudo, analisando-se as fotos, os esquemas desenhados dos afloramentos e com base em informações do Prof. Dr. Antonio Carlos Rocha-Campos concluiu-se que o matacão estriado pertencia ao Pavimento de Clastos A.

Atualmente, a parte inferior do afloramento no corte leste da estrada de ferro, onde é possível observar o pavimento inferior, está parcialmente encoberta por detritos. Entretanto, em áreas não encobertas do afloramento alguns clastos do pavimento que aparecem ilustrados na foto da Figura 4.3.7 não foram encontrados, dificultando a análise deste pavimento. Este pavimento foi também identificado acima dos diamictitos deformados (Dm2), do outro lado do morrote, próximo à rodovia Marechal Rondon, onde também foi possível analisá-1o (Figura 4.3.1B). O Pavimento de Clastos A (PCA, Figura 4.3.7) apresenta um alinhamento bem definido e os clastos estão bem próximos uns dos outros, com afastamento centimétrico entre eles. Não foram encontradas novas estrias glaciais, registrando-se apenas a direção N300 medida no matacão descrito por Rocha-Campos et 
al. (1969). Cogitou-se que poderia ser um pavimento intra-till, visto a sua ocorrência acima de um diamictito com deformação subglaciotectônica rúptil. Contudo, o perfeito alinhamento dos clastos, a pouco distância entre eles, o aplainamento superior de muitos clastos e a presença de estrias glaciais dificultam a confirmação desta hipótese.

Já o Pavimento de Clastos B (PCB, figuras 4.3.1B e 4.3.9) que apresenta alinhamento irregular e afastamento decimétrico entre os clastos, poderia ser facilmente confundido com um do tipo intra-till, pois a granulometria da matriz dos diamictitos sub-e sobrejacentes é semeihante. No entanto, uma análise mais detalhada permitiu verificar que o intervalo contendo o pavimento exibe uma estratificação plano-paralela incipiente com (Figura 4.3.9). Estes três intervalos incipientes distam de 10 a $20 \mathrm{~cm}$ entre si, contudo, só a do meio apresenta clastos com a superfície aplainada ao longo da estratificação, grande quantidade de clastos decimétricos, e, pelo menos, um clasto com estrias glaciais, com direção N007, tornando possivel designá-lo como um pavimento de clastos. $\mathrm{Na}$ porção plano-paralela inferior, por outro lado, existem alguns clastos que aparentam ter sido depositados ao longo dela, embora não estejam aplainados e/ou estriados, mas podem facilmente ser confundidos com os pertencentes ao pavimento relacionado ao intervalo intermediário. A estratificação incipiente superior não aparenta ter clastos associados. Desta forma, é possível concluir que o Pavimento de Clastos $B$ não é irregular e constitui, realmente, um alinhamento de clastos.

No afioramento em que é avistado o Pavimento de Clastos $A$, na estrada de ferro (Figura 4.3.7), não foi constatada a presença do PCB, mas, aproximadamente $2 \mathrm{~m}$ acima do PCA, capeando o diamictito Dm3, encontrou-se um corpo em forma de canal de arenito fino com estratificações cruzadas e acanaladas e deformações rúpteis (fraturas; figuras $4.3 .1 \mathrm{~B}$ e 4.3.10). Como as deformações rúpteis só ocorrem na porção inferior deste corpo arenoso e - horizonte que separa a porção deformada da não deformada apresenta-se aplainado (Figura 4.3.10C), concluiu-se que, possivelmente, este horizonte corresponda a um depósito sedimentar (um canal subaéreo) adjacente ao Pavimento de Clastos B. Consequentemente, a porção do arenito sobrejacente a este horizonte erosivo, sem vestígios de fraturas ou falhas, representaria um segundo canal, provavelmente subglacial associado ao Dm4.

Esta associação parece representar um conjunto de litofacies de origem marcadamente glacial, com exceção do Dm1, que se afigura ser resultante de fluxos gravitacionais de massa. Os diamictitos Dm2 e Dm3 representam, provavelmente, tilitos subglaciais, como parecem indicar sua associação com as deformações e as estrias glaciais presentes na superfície do substrato arenoso, além da presença de clastos comprimidos contra esse substrato arenoso. Podem, portanto, representar tilitos de alojamento ou de deformação. Já o diamictito superior (Dm4) representaria um depósito de till de degelo (meltout), originado pelo lento acúmulo subglacial de partículas liberadas pelo derretimento do gelo, com canais localizados formados por arenitos finos com estratificações cruzadas. 

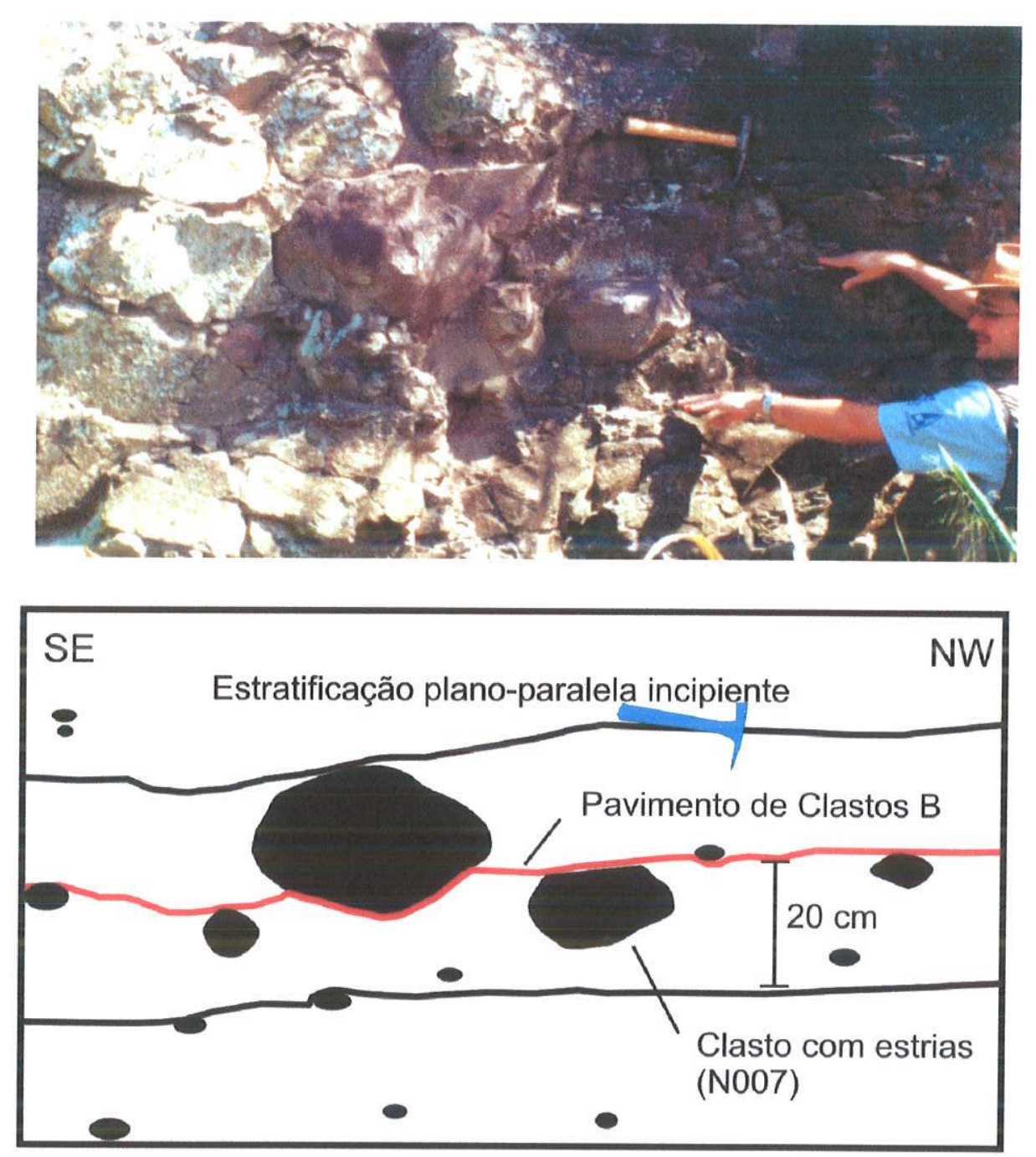

Figura 4.3.9 - Foto do Pavimento de Clastos B de Jumirim e diagrama explicativo da foto, com destaque para o Pavimento de Clastos $\mathrm{B}$ em vermelho e o clastos estriado. 
A)

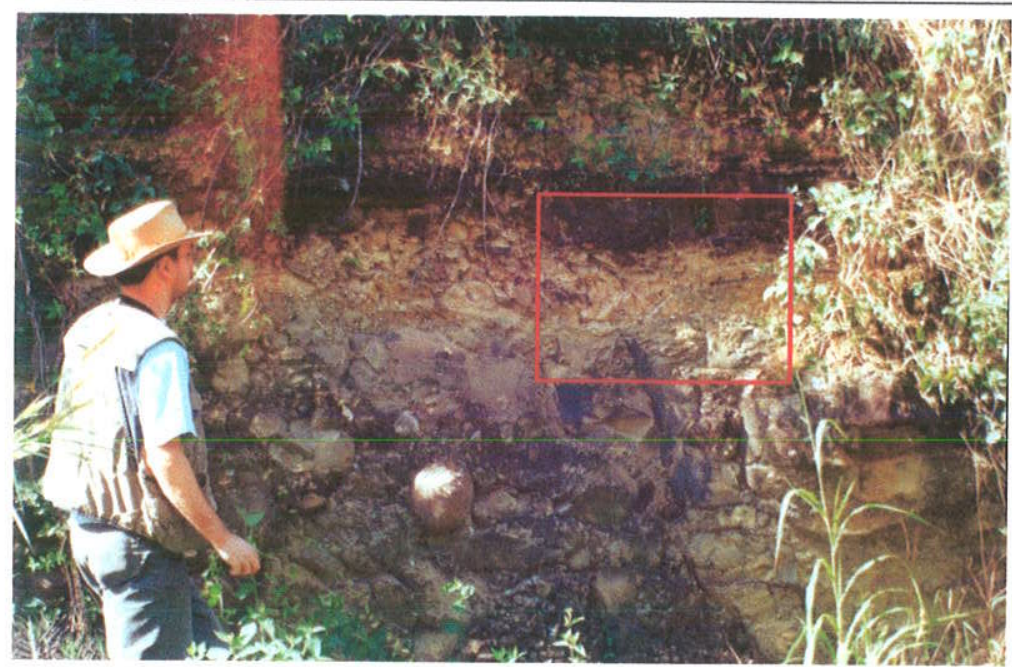

B)

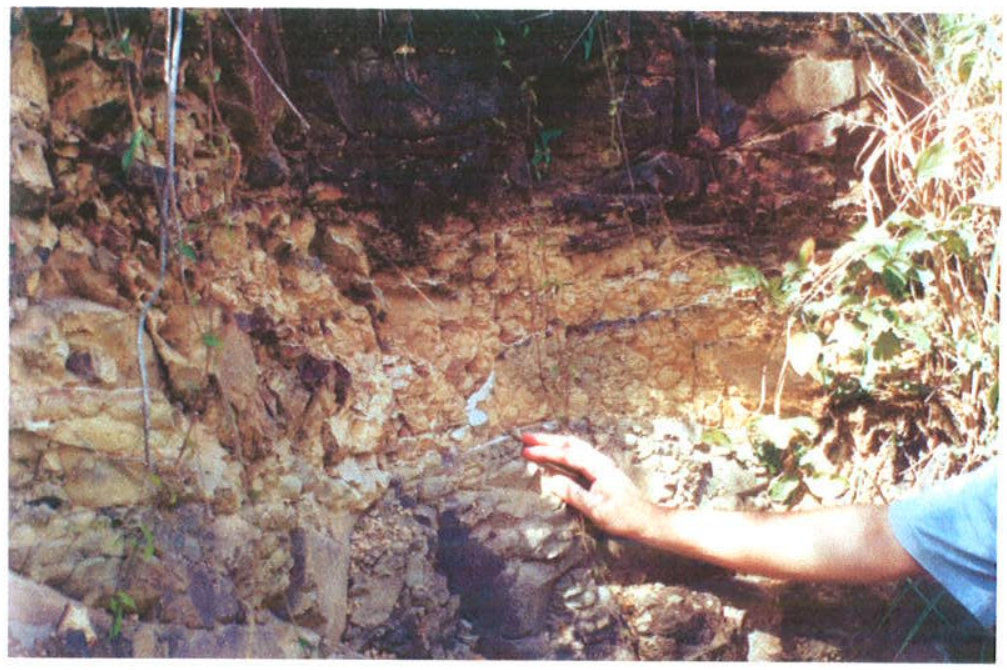

C)

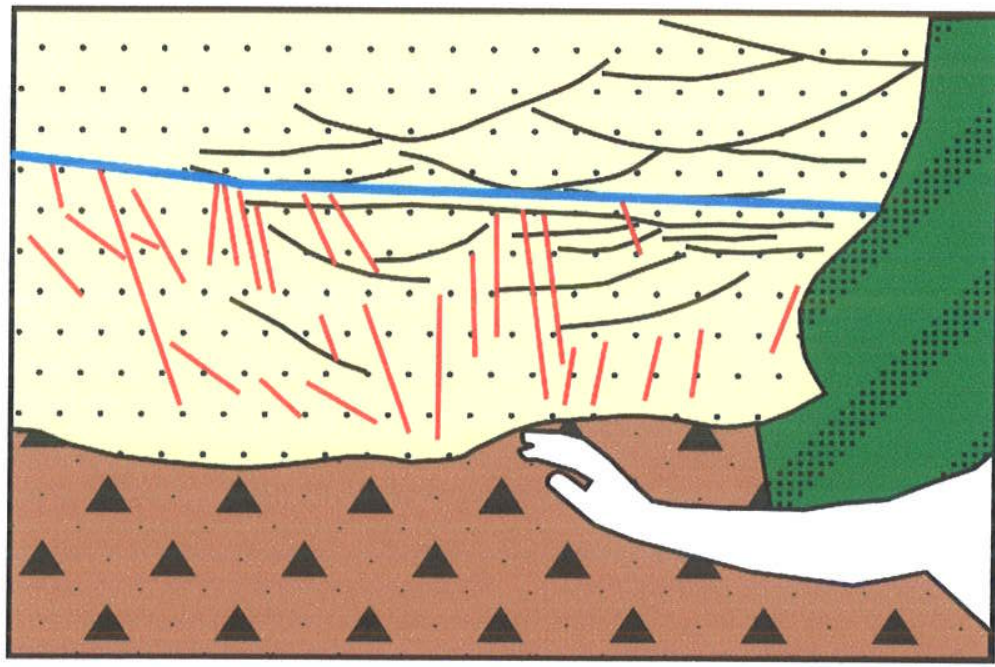

Figura 4.3.10 - Canal de arenito fraturado e falhado, acima do Diamictito 3, na Associação 6 de Jumirim. A) Foto ampla da ocorrência. B) Foto detalhando as estratificações, fraturas e pequenas falhas presentes no retângulo vermelho na foto $A$. C) llustração esquemática da foto $B$, onde as linhas pretas = estratificações; linhas vermelhas = fraturas e pequenas falhas; área marrom com triângulos = Diamictito 3; área amarela pontilhada = arenito fraturado; área em verde com linhas pontilhadas na diagonal = encoberta; e linha azul $=$ horizonte aplainado adjacente ao lineamento de clastos do PCB. 


\section{Perfil 1}

As associações 4 e 5 podem também ser observadas no Perfil 1 (Figura 4.3.11), que estende lateralmente a Seção 1, na direção N-S (Figura 4.3.1C), em mais de $60 \mathrm{~m}$ de comprimento ao longo da rodovia Marechal Rondon (SP-300), incluindo a área de empréstimo e a curva da estrada no km 166,7, aproximadamente. Neste perfil é possível constatar as interações dessas duas associações, assim como a variação lateral das litologias que as compõem. Nota-se que, na porção sul, foi constatada a presença de, no mínimo, duas camadas de siltito intercaladas no arenito fino da Associação 5, embora a camada superior seja gradativamente substituída por arenitos finos na porção central do perfil. Duas outras constatações ainda merecem ser mencionadas: a ocorrência de fósseis de plantas e evidências de escorregamento.

Com relações à ocorrência de fósseis de vegetais (Figura 4.3.6), uma análise preliminar permitiu identificar inúmeros exemplares de caules (paracalamites) e algumas poucas sementes. Estes exemplares foram e estão sendo analisados pela equipe da Profa. Mary Elizabeth Cerruti Bernardes de Oliveira, inclusive através de estudos palinológicos, que, provavelmente, fornecerão importantíssimas informações paleoambientais e para datação da unidade, contribuindo, também, para possíveis biocorrelações com outras localidades (e.g.: Cerquilho e o poço J-IG-93).

Segundo uma correlação tentativa com a coluna litoestratigráfica do poço J-IG-93 (Figura 4.3.12), perfurado pelo IG/SMA para captação de água no município de Jumirim, localizado na coordenadas UTM 7444950 / 214150 (Petri et al., 1996) e distante aproximadamente 1,5 km do afloramento principal de Jumirim, os siltitos analisados neste trabalho estariam a aproximadamente $21 \mathrm{~m}$ de profundidade, mas infelizmente, não foram feitas lâminas petrográficas de amostras dos testemunhos de sondagem desta camada. No entanto, as lâminas IG-P-151 A e B de amostras do intervalo a 26,2 m de profundidade correspondem, aparentemente, ao topo da Associação 3 e as lâminas IG-P-150 A e B de 18,2 m de profundidade ao contato entre o Subgrupo Itararé e a Formação Tatuí. Nas lâminas IG-P-150 não foram constatados palinomorfos, enquanto que as lâminas IG-P-151 apresentaram, segundo Souza (2000), grãos de pólen de Vittatina costabilis Wilson 1962 (Callegari, 2001). Esta espécie de grãos de pólens poliplicados distribui-se estratigraficamente na Bacia do Paraná no Subgrupo Itararé (Zona Vittatina, Subzona Protohaploxypinus goraiensis), formações Rio Bonito e Palermo e Subgrupo Irati. No trabalho de Callegari (2001), foram analisados bioestratigraficamente 64 espécies de palinomorfos do poço J-IG-93 e de um afloramento localizado na margem esquerda do rio Capivari, estendendo-se ali por mais de $100 \mathrm{~m}$, rumo nordeste a partir das coordenadas $22^{\circ} 59,3^{\prime} \mathrm{S} / 47^{\circ} 45^{\prime} \mathrm{W}$. Esses palinomorfos foram correlacionados entre si e posicionados na base da Zona Vittatina, Subzona Protohaploxypinus goraiensis, que indica o Permiano Inferior (possivelmente Asseliano/Sakmariano, 295 a 275 Ma.). 
Perfil 1 de Jumirim
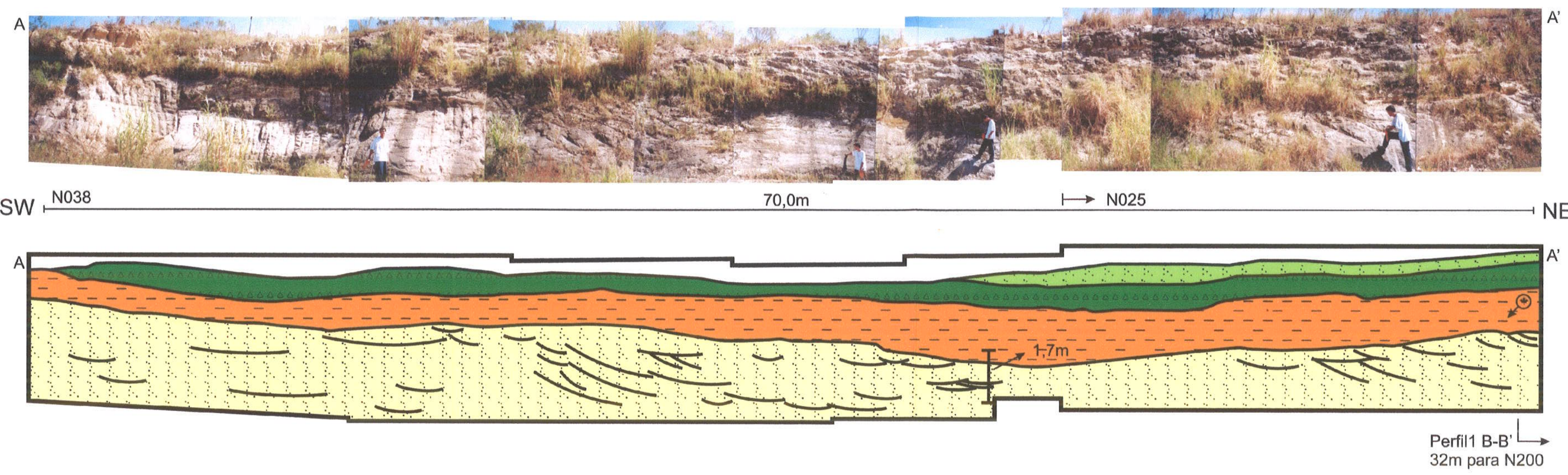

$\longleftarrow \begin{aligned} & \text { Perfil1 A-A' } \\ & 32 \mathrm{~m} \text { para N200 }\end{aligned}$

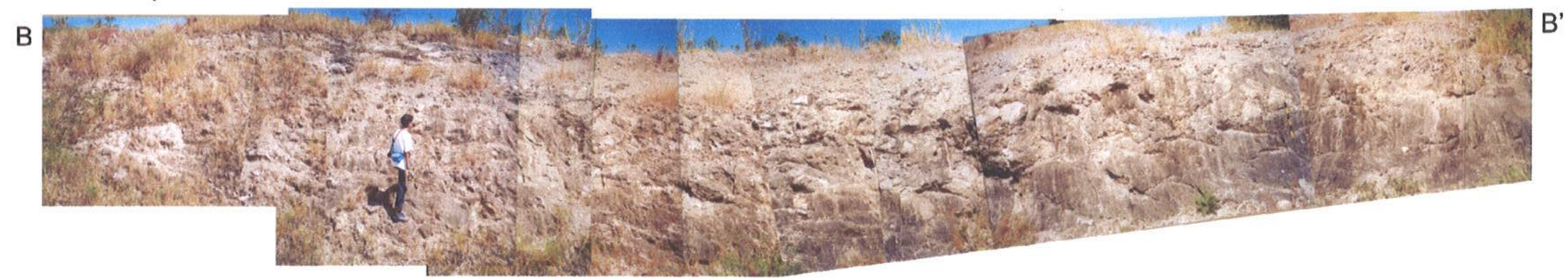

SE

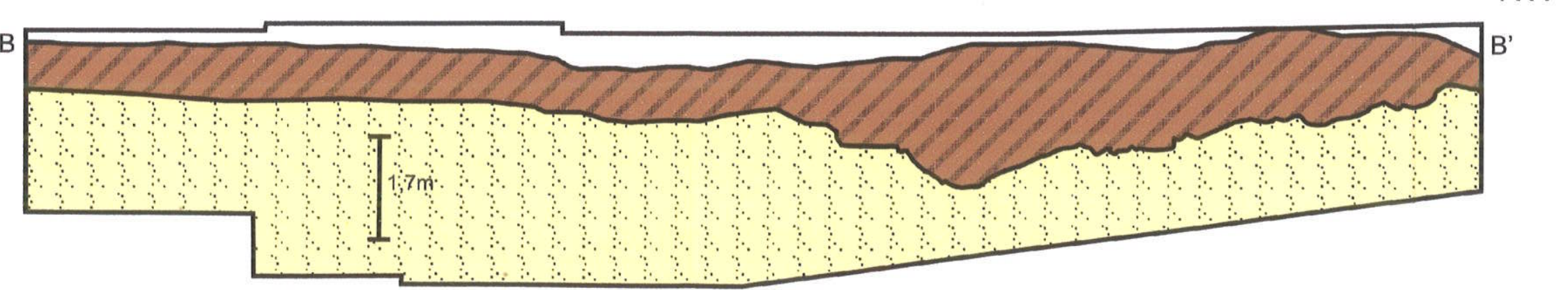

\section{LEGENDA}

$\left.\begin{array}{l}\text { Escorregamento } \\ \text { Arenitos } \\ \text { Diamictito 1 }\end{array}\right\}$ Associação 6

Associação 5

Associação 4

(-) Ocorrência de fósseis de plantas

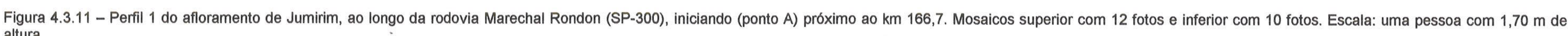




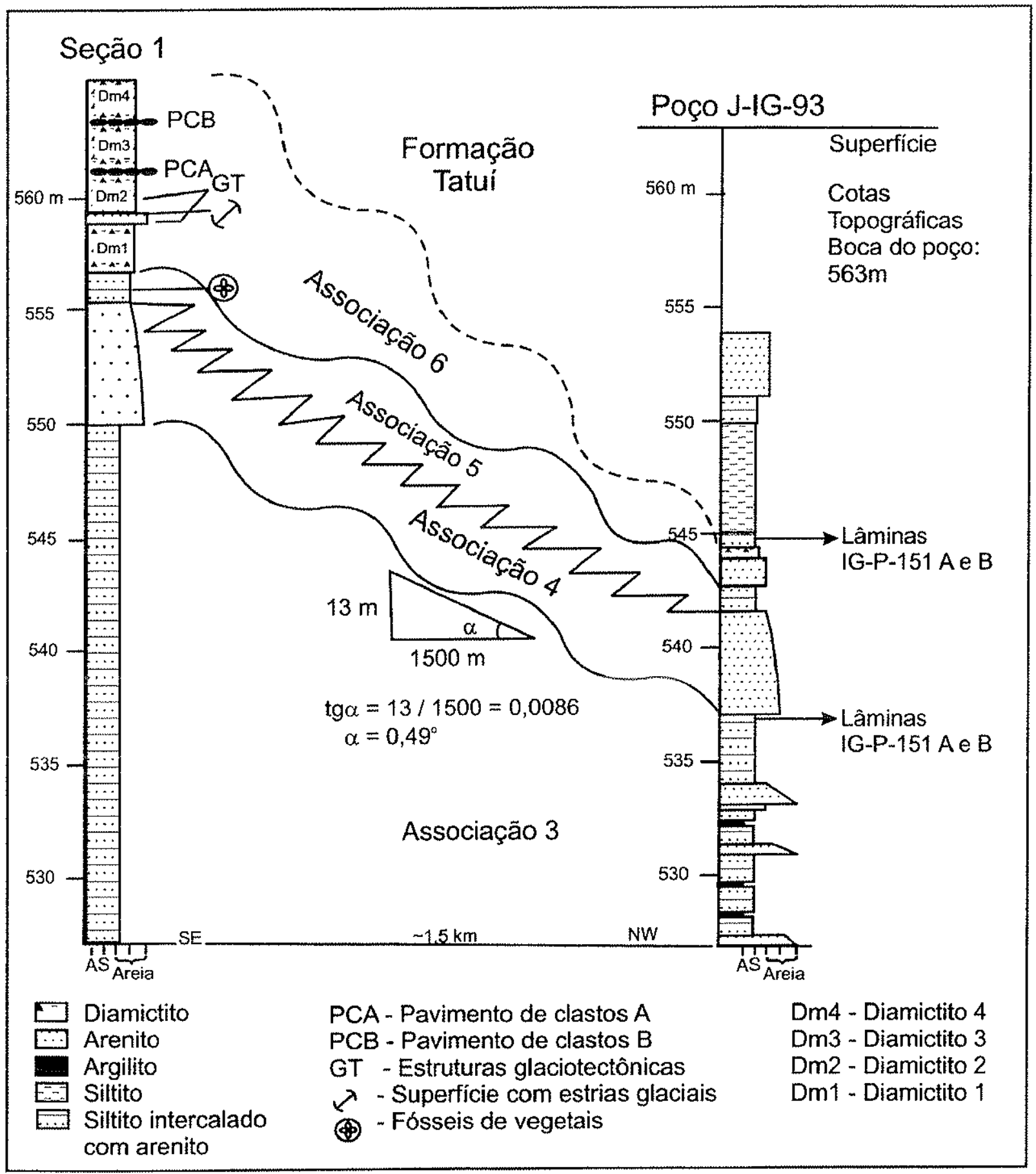

Figura 4.3.12 - Correlação estratigráfica entre o Poço J-IG-93 (atual denominação: número 25) e a Seção 1 de Jumirim. O Poço J-IG-93 foi adaptado de Caliegari (2001), que apresenta uma seção de subsuperfície do topo do Subgrupo Itararé. 
No que concerne às estruturas de escorregamento (s/ump), identificadas na porção norte do perfil, foi possível constatar que os arenitos de outwash das associações 4 e 5 foram nitidamente escavados (erodidos) por um corpo de diamictitos resultante de um esporádico fluxo gravitacional de massa, do tipo fluxo de detritos. Corroboram esta interpretação as constatações de que os diamictitos apresentam estruturas internas caóticas e que incorporaram fragmentos de fósseis ocorrentes nos siltitos sotopostos (Figura 4.3.13). Adicionalmente, verifica-se que alguns fragmentos decimétricos de ritmitos da Associação 5 encontram-se dobrados (Figura 4.3.14), demonstrando que foram remobilizados, deformados e incorporados pelo escorregamento. Enfatiza-se, ainda, que o topo dos sedimentos que compõem o escorregamento é aplainado e apresenta dois conjuntos de estrias glaciais bem definidas com alguns centímetros de comprimento, orientadas na direção NW-SE (N309 e N321, Figura 4.3.15), semelhantes, portanto, às estrias direcionadas em média para N-S sobre o arenito deformado da Associação 5 , que se encontram no mesmo horizonte a $7 \mathrm{~m}$ para sul das estrias sobre o escorregamento. Desta forma, o aplainamento e as estrias glaciais sobre o arenito deformado e o diamictito relacionado ao escorregamento estariam associados ao mesmo evento glacial, ou seja, ao mesmo avanço de um corpo de gelo. Faz-se necessário comentar que o escorregamento apresenta direção leste-oeste e contato basal erosivo, com formato geral acanalado.

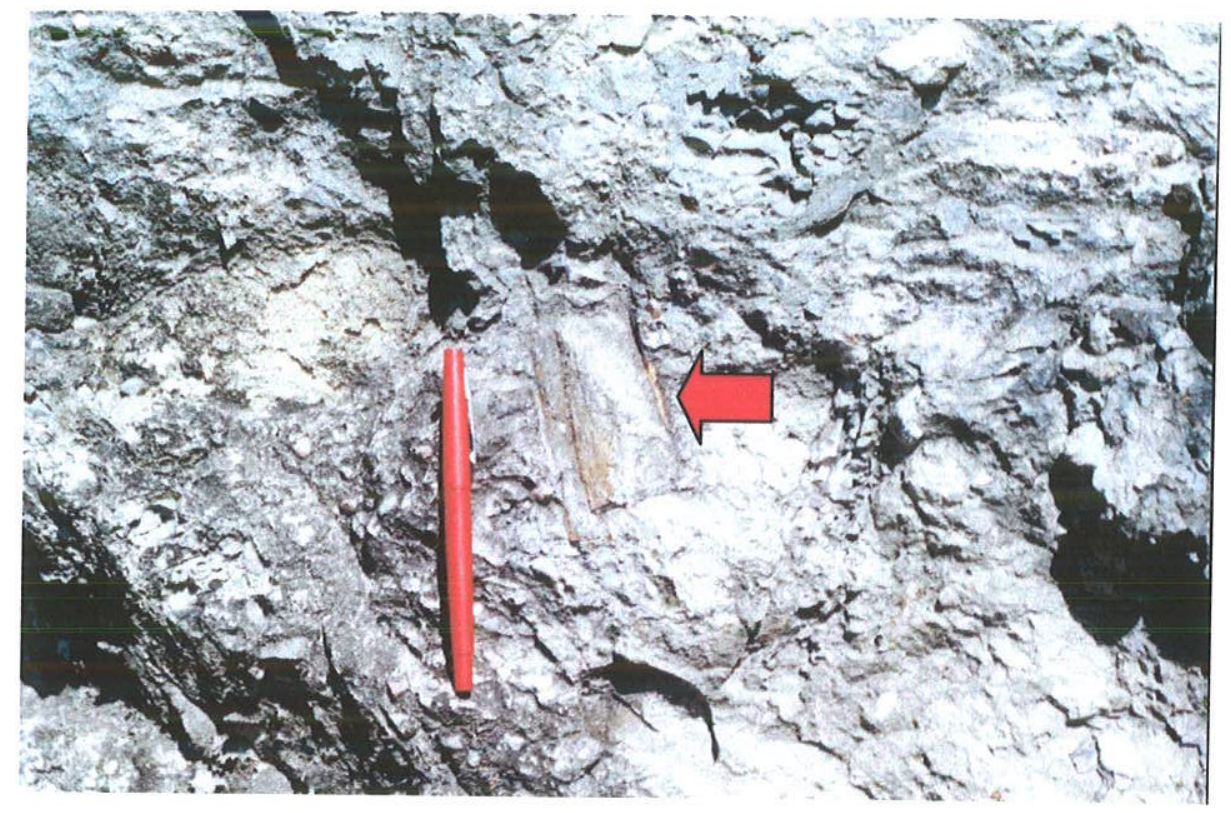

Figura 4.3.13 - Fóssil de caule incorporado pelo escorregamento, possivelmente oriundo da Associação 5 de Jumirim. Escala: caneta. 


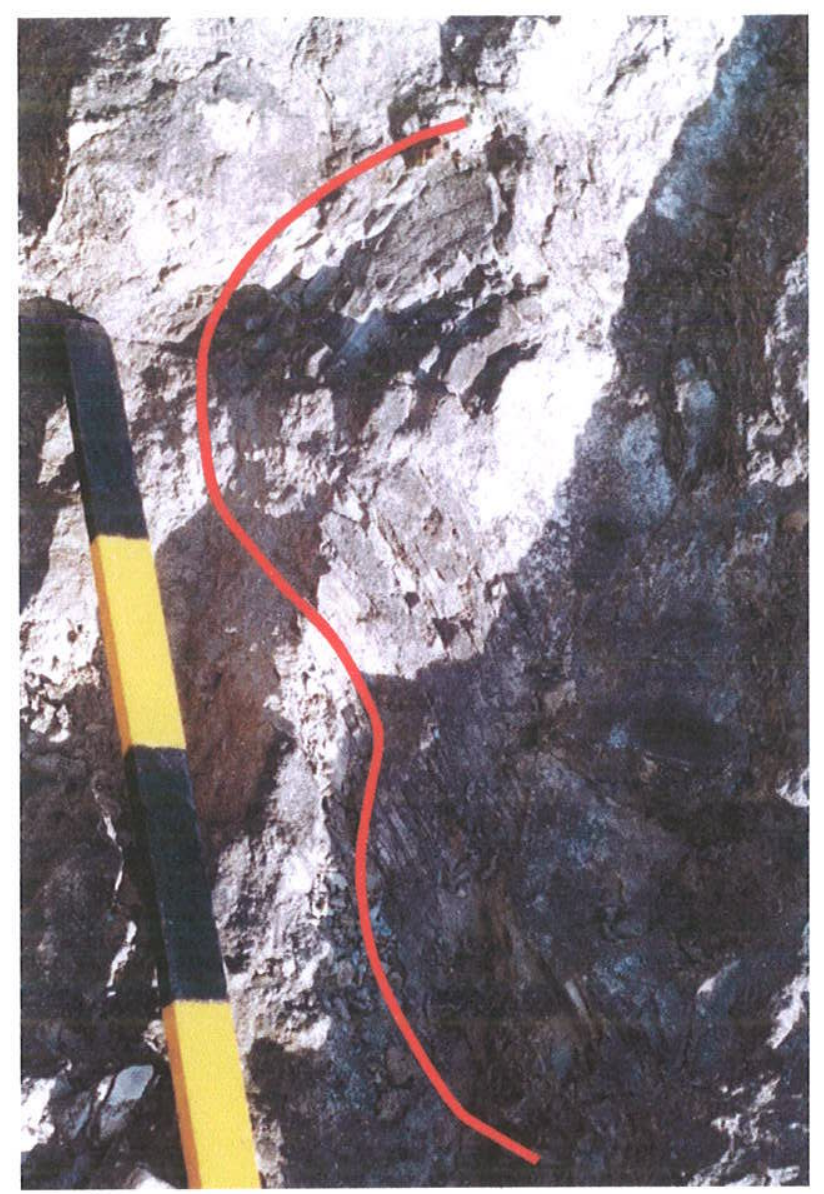

Figura 4.3.14 - Clasto de ritmitos dobrados incorporados no escorregamento da Associação 5 de Jumirim. Linha vermelha demonstra a deformação das camadas do ritmito. Escala: tala de madeira dividida a cada $10 \mathrm{~cm}$.

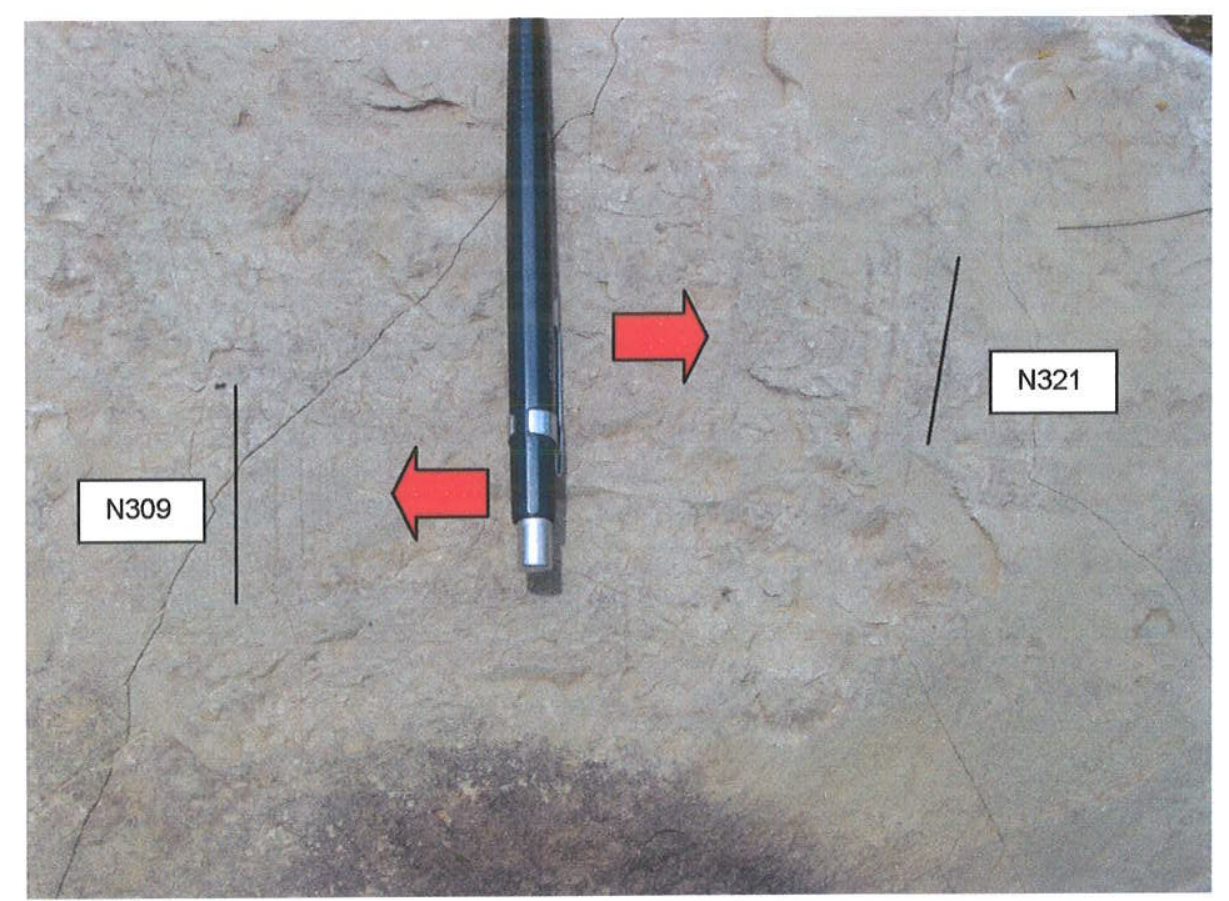

Figura 4.3.15 - Superfície sobre sedimentos do escorregamento da Associação 5 de Jumirim, com dois conjuntos de estrias glaciais, centimétricas, finas e paralelas, com direções N309 e N321. Seta e linhas indicam a posição dos respectivos conjuntos de estrias. Escala: lapiseira. 


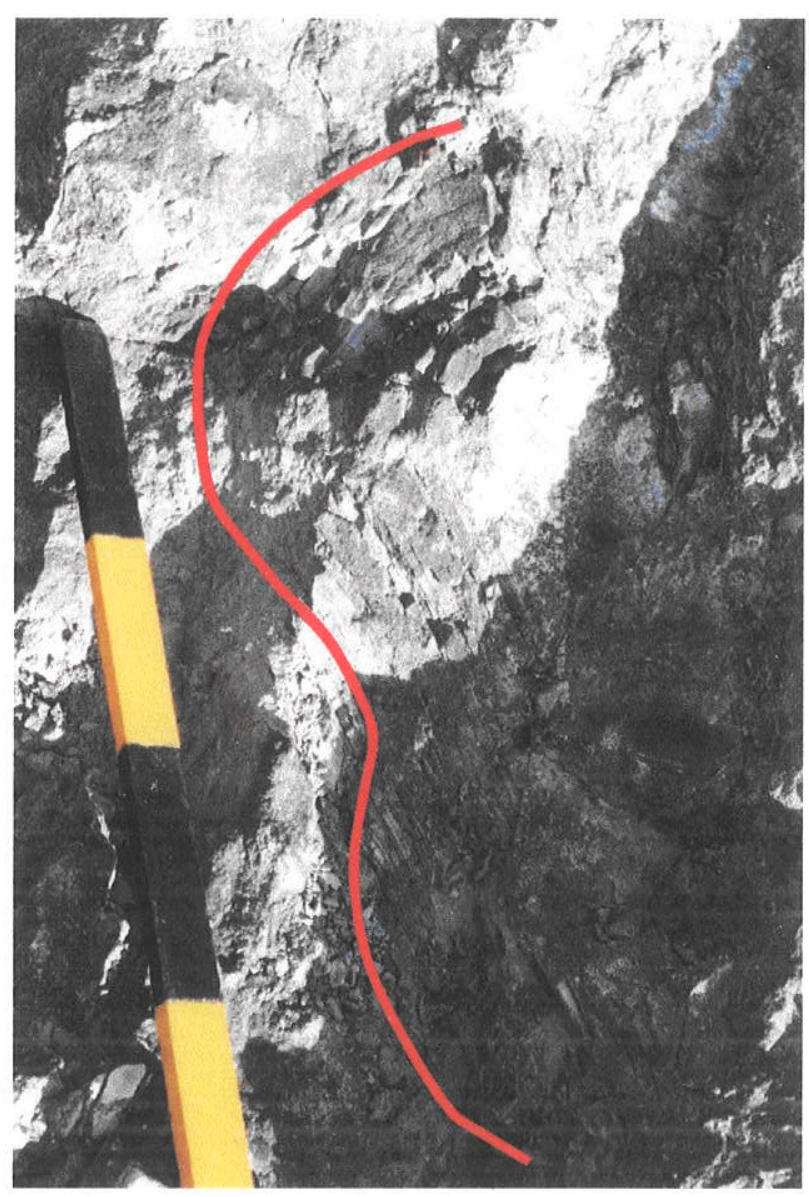

Figura 4.3.14 - Clasto de ritmitos dobrados incorporados no escorregamento da Associação 5 de Jumirim. Linha vermelha demonstra a deformação das camadas do ritmito. Escala: tala de madeira dividida a cada $10 \mathrm{~cm}$.

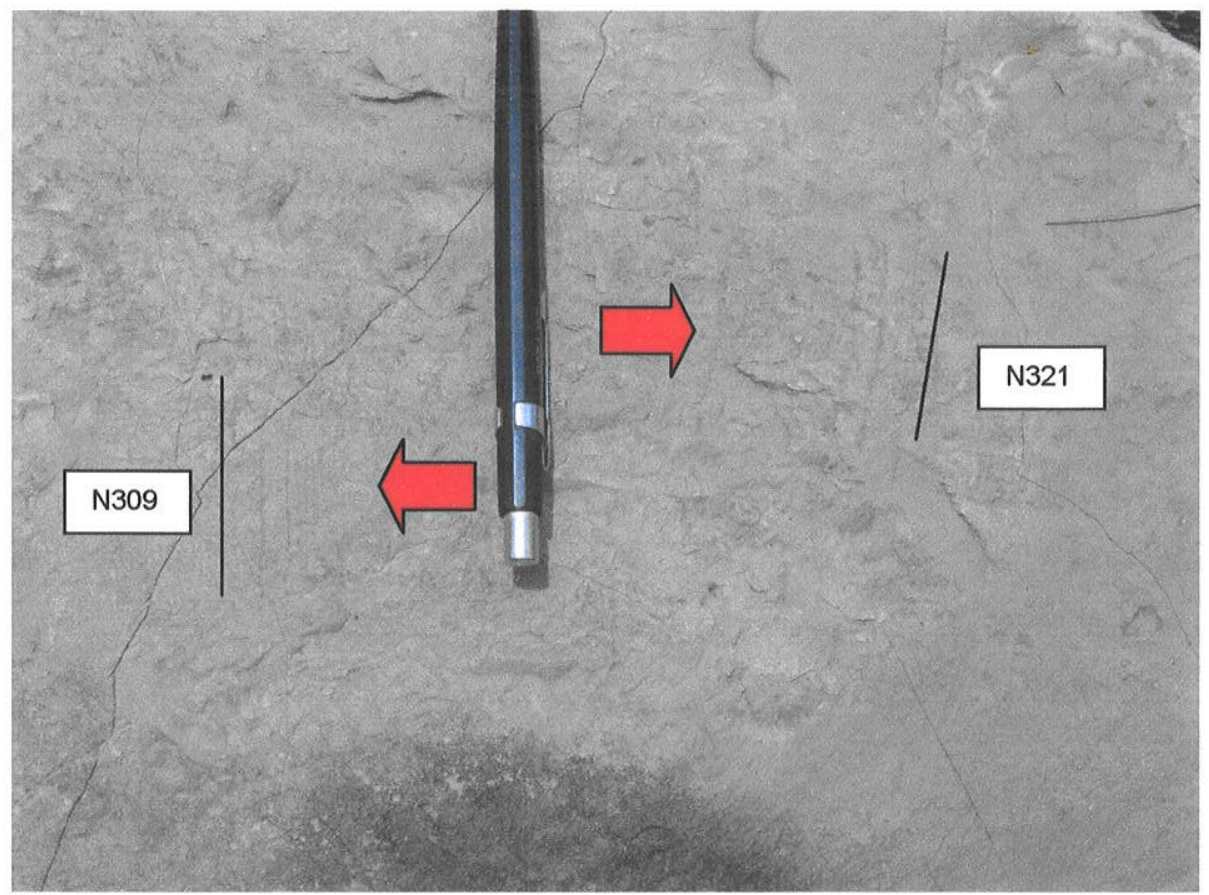

Figura 4.3.15 - Superfície sobre sedimentos do escorregamento da Associação 5 de Jumirim, com dois conjuntos de estrias glaciais, centimétricas, finas e paralelas, com direções N309 e N321. Seta e linhas indicam a posição dos respectivos conjuntos de estrias. Escala: lapiseira. 


\subsection{CONSIDERAÇÕES SOBRE AS ESTRUTURAS SUBGLACIOTECTÓNICAS E} AS IMPLICAÇÖES NA ESTRATIGRAFIA DE CAPIVARI E JUMIRIM

Inicialmente, serão analisadas, conjuntamente, as deformações presentes no arenito basal da seção de Capivari, e no arenito e no diamictito Dm2 da Associação 6 de Jumirim e, posteriormente, no subcapitulo subsequente versar-se-á sobre os pavimentos de clastos, permitindo, também, a comparação entre os pavimentos destas localidades.

\subsubsection{Estruturas Subglaciotectônicas}

As estruturas subglaciotectônicas, tanto em Capivari, como em Jumirim, compreendem estruturas típicas de esforços rúpteis, incluindo numerosas fraturas e pequenas falhas, em arenitos finos a médios, homogêneos e coesos. Cabe, primeiramente, acrescentar, que, abaixo das zonas deformadas em ambos os arenitos (de Capivari e Jumirim), foram observadas pequenas estratificações cruzadas e mesmo nas zonas deformadas dos arenitos foram constatadas estratificações sutis em lâminas delgadas, demonstrando, que os arenitos, antes de terem sido deformados, foram formados por processos sedimentares subaquáticos (e.g.: canais subglaciais). Outros fatores importantes a serem enfatizados de início são os aplainamentos dos contatos superiores entre os arenitos deformados e os diamictitos sobrejacentes, além da presença de estrias glaciais nestas superfícies. No caso de Capivari não foram encontradas estas estrias, mas existem registros de sua ocorrência (Rocha-Campos et al., 1976; Salvetti, 2000).

As deformações presentes em Capivari e em Jumirim são rúpteis e compreendem numerosas fraturas e pequenas falhas normais e de acavalamento com baixo ângulo que deslocam camadas de siltito e arenito (Tomio et al., 2000, Figura 4.4.1.1), além de pequenas (milimétricas) zonas de cisalhamento. Estas camadas falhadas, deformadas e descontinuas apresentam vários tamanhos (milimétricas a decimétricas) e espessuras (centimétricas a métricas), e encontram-se nas porções superiores do arenito basal da seção. As deformaçōes ocorrem no arenito deformado e no respectivo diamictito sobrejacente (DmA em Capivari e Dm2 em Jumirim) e são, basicamente, estruturas rúpteis de pequena escala (small-scale brittle structures). Estas estruturas rúpteis são semelhantes às mencionadas por Menzies (1987) e Eyles \& Boyce (1998), compreendendo, inclusive, pequenas falhas de acavalamento no contanto entre os arenitos e diamictitos deformados, que devido ao intenso fraturamento e cisalhamento acarretou a individualização em pequenos blocos angulosos e aplainados de arenito dispersos nas porções basais dos diamictitos deformados. Infelizmente, não foi possivel estudar estas fraturas e pequenas falhas presentes no diamictito laminado, devido à sua característica friável. Consequentemente, a maior parte das análises em Jumirim, que se seguem, provieram do arenito deformado da Associação 6. 


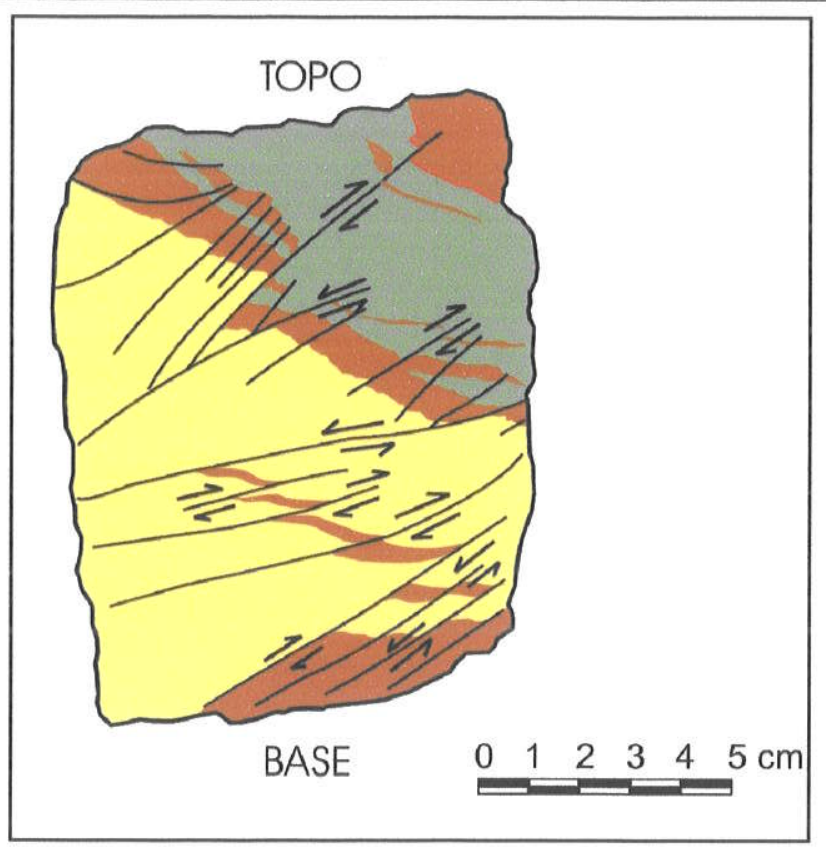

Figura 4.4.1.1 - Seção polida de amostra do arenito, obtida próximo ao contato com o Diamictito A (Figura 4.2.3), mostrando fraturas e pequenas falhas de baixo ângulo que deslocam camadas de siltito e arenito (Tomio et al., 2000).

A)

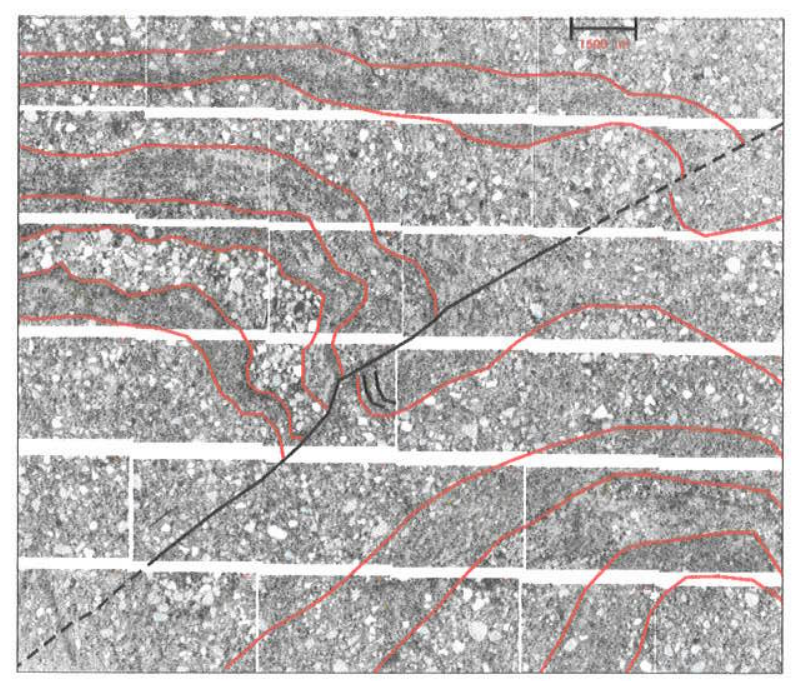

B)

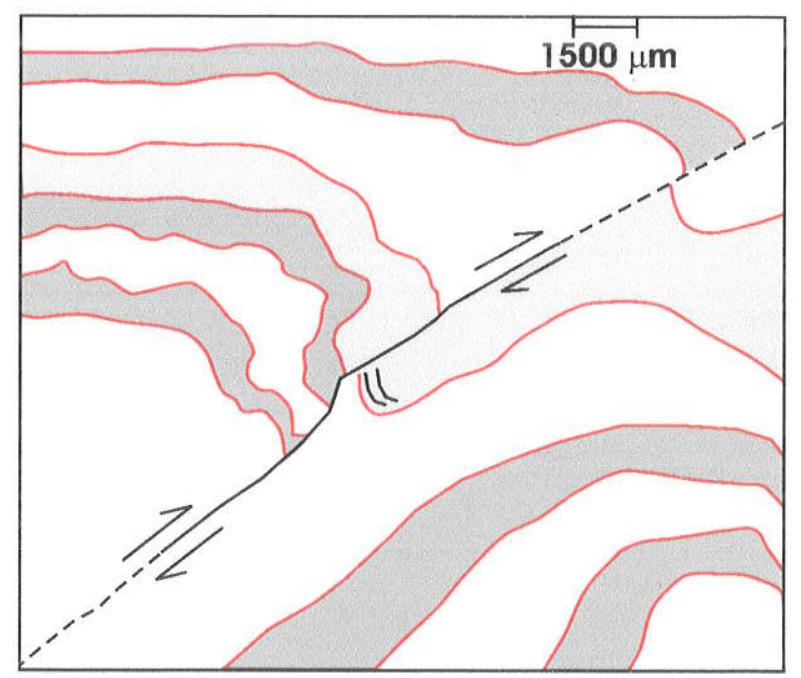

Figura 4.4.1.2 - A) Plasma bandado formando dobras de arrasto ao longo de micro-falha de empurrão em lâmina delgada de amostra de Capivari. Linhas vermelhas representam os limites das bandas. No diagrama interpretativo (B) as bandas com granulometria maior estão representadas em branco, enquanto que as que apresentam menor granulometria estão em cinza-escuro. Mosaico de $\mathbf{4 8}$ fotos. Escala no mosaico igual à apresentada na ilustração explicativa. 
Análises em micro-escala (lâminas delgadas) permitiram diagnosticar que as amostras de ambas as localidades possuem baixa porosidade $(\sim<15 \%)$ e pouquíssimo cimento (quase nulo). Os grãos que formam o arcabouço sedimentar são, essencialmente, de quartzo (95\% em Capivari e $99 \%$ em Jumirim), sub-angulares a angulares e apresentam baixa esfericidade, sendo que, em Jumirim, algumas porções das lâminas apresentaram grãos com esfericidade média. Em determinadas zonas das amostras, estes grãos estão bem orientados, formando, inclusive, dobras bandadas de arrasto (Figura 4.4.1.2). Este plasma $^{12}$ bandado, dobrado, milimétrico, ocorre em raras falhas reversas, com pequeno rejeito (milimétrico), orientadas na direção norte-sul. Possivelmente, este plasma bandado corresponde a estratificações prévias do sedimento que foram deformadas pelas falhas. Outras estruturas observadas em micro-escala foram fraturas e pequenas (milimétricas) zonas de cisalhamento, principalmente nas porções superiores das amostras, nas quais os grãos também estão orientados, aproximadamente na direção N-S.

\section{Análises de paleoesforços em Jumirim}

Análise do paleoesforço responsável pela gênese das estruturas rúpteis de pequena escala (small-scale brittle structures) foram desenvolvidas no arenito da Associação 6 de Jumirim . O caráter homogêneo e coeso desta litologia permitiu a preservação das fraturas e da superfície aplainada no contato com o diamictito sobrejacente $e$, desta forma, facilitou a investigação das fraturas e a própria exposição das estrias glaciais. A grande quantidade de fraturas no arenito deformado possibilitou a determinação dos campos de esforços responsáveis pela geração das estruturas rúpteis, seguindo os conceitos de Hancock (1985), Hancock \& Engelder (1989), Dunne \& Hancock (1994) e Pollard \& Aydin (1988). Neste método de determinação dos paleoesforços, as fraturas são representadas graficamente em estereogramas Schmidt-Lambert (hemisfério inferior) e apresentadas em diagramas de pólos de plano, contornos de pólos e diagramas de rosáceas com azimutes dos planos e seus mergulhos, procedimento este que tem sido aperfeiçoado e vem apresentando bons resultados (e.g.: Caputo, 1995; Salvador \& Riccomini, 1995; Riccomini, 1997; Sales, 1999). Os planos e lineações analisados foram medidos em campo com bússolas Clar e Brunton. No tratamento dos dados estruturais e apresentação dos dados adotou-se os programas FP Tectonics.1.6.1155-DEM e StereoNett 2.46.

Os sistemas de fraturas podem ser classificados, quanto a sua arquitetura, associando-se as formas dos traços das fraturas às letras do alfabeto latino. Desta forma, as fraturas de Jumirim podem ser consideradas com do tipo $Y$ (predominantemente), e, em menor quantidade, 1 e $H$, e raros traços do tipo $X$ e $V$, de acordo com as formas

\footnotetext{
12 Plasma: matriz argilosa microcristalina a criptocristalina, que em exames microscópicos é vista preenchendo os espaços intersticiais deixados pelo esqueleto, que é composto pelos minerais residuais da rocha matriz (Suguio, 1998).
} 
apresentadas pelos seus traços centimétricos (com no máximo um metro). Segundo Dunne \& Hancock (1994), os traços na forma de $Y, V$ e $X$ são característicos de fraturas conjugadas hibridas e de cisalhamentos, sendo as em $Y$ mais comuns e as em $X$ mais raras. Já os tipos geométricos com formas de $Y, K$ e I representam um fraturamento extensional, enquanto que uma forma do tipo $\mathrm{H}$ ocorre quando as fraturas são curtas, não sistemáticas, mais jovens, e começam e finalizam em fraturas maiores e sistemáticas.

Em Jumirim nota-se que, na maior parte do afloramento que contem o aplainamento do contato superior do arenito da Associação 6 (Figura 4.4.1.3), prevalece uma arquitetura que estaria relacionada a fraturas extensionais, inclusive, uma maior quantidade de fraturas sistemáticas maiores (decimétricas) e mais contínuas na direção NNW-SSE, que raramente demonstram deslocar, no sentido destral, as fraturas mais jovens, menores (centimétricas) e menos continuas, de direção NNE-SSW. Segundo Dunne \& Hancock (op cit.), as fraturas de extensão tem uma tolerância de variabilidade de $10^{\circ}$, enquanto que as híbridas apresentam valores superiores a $10^{\circ}$. No entanto, havendo dois conjuntos de fraturas torna-se possivel a formação de um espectro de fraturas entre estes conjuntos, e, consequentemente, o eixo de tensão principal estará na bissetriz deste espectro.

Nos trabalhos realizados através de programas de informática aplicados à Geologia Estrutural, os dados obtidos em Jumirim foram inicialmente representados em diagramas de rosáceas e de contomos de pólos de fraturas, de acordo com os pólos de planos das fraturas, acrescendo-se as lineaçöes das estrias glaciais (Figura 4.4.1.4). Em termos gerais, as análises das fraturas conjugadas indicaram que os planos de fraturas variam de N310 a N040. Neste contexto o ângulo diedral $(2 \theta)$ das fraturas é de $90^{\circ}, 0$ que, como será visto adiante, dá a falsa impressão de se tratar de fraturas conjugadas de cisalhamento compressional (Hancock, 1985; Figura 4.4.1.5). O aparente esforço principal máximo $\left(\sigma_{1}^{\prime}\right)$ encontra-se na direção N355, dado condizente com a média das medidas de estrias no horizonte sobre 0 arenito e a orientação do escorregamento $\left(\mathrm{N} 350^{13}\right)$. No entanto, considerando apenas as estrias presentes na superfície do arenito, 0 vetor principal identificado foi na direção de N004, novamente condizente com o valor de esforço principal das fraturas.

A variação das direções das estrias (de N321 a N027) resultou no questionamento sobre o seu significado no fraturamento do arenito. Para tanto, o horizonte em que ocorrem as estrias e a deformação rúptil foi dividido em três blocos ( $A, B$ e $C$ ). Cada bloco é representado por uma ou mais estrias e o conjunto de fraturas que as cercam (Figura 4.4.1.6). O bloco A, encontra-se na porção sul do afloramento e apresenta 10 estrias finas com alguns centímetros de comprimento, com a mesma direção (N021), enquanto que o

\footnotetext{
${ }^{13}$ Nos cálculos do vetor principal foi utilizado o método estatistico de Fisher (Fisher, 1953), disponivel como uma das ferramentas do software TectonicsFP.
} 
bloco B, dista $10 \mathrm{~m}$ para norte das presentes no bloco $\mathrm{A}$. No bloco B encontram-se duas estrias glaciais (N339 e N351), ambas finas e com comprimentos centimétricos. O bloco C, por sua vez, encontra-se na porção norte, a $5 \mathrm{~m}$ do bloco $B$. Quanto às estrias deste bloco, ambas são centimétricas, sendo a direcionada para N027, mais continua, enquanto que a N002 apresenta-se mais larga.

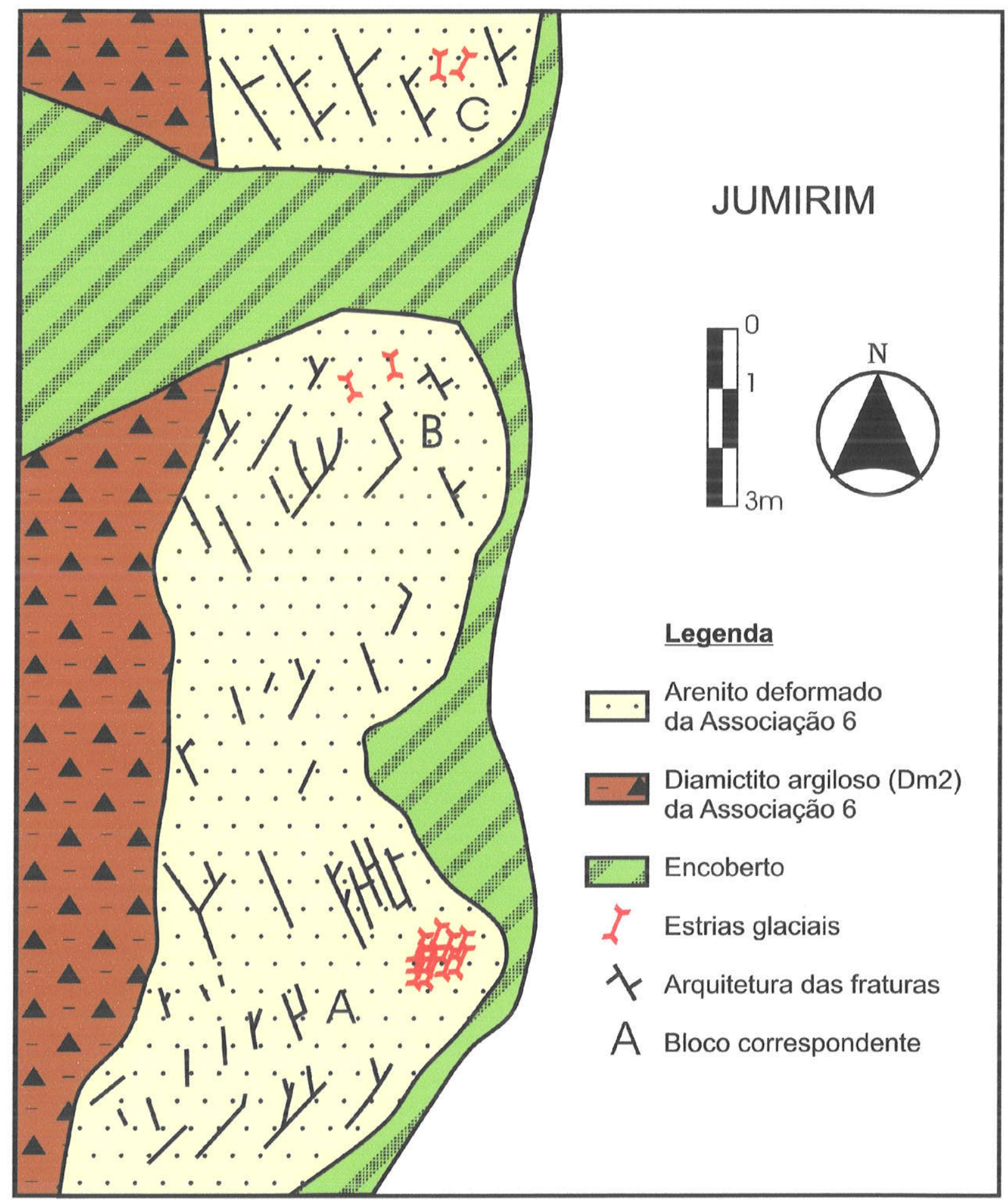

Figura 4.4.1.3 - Desenho esquemático em planta da arquitetura das fraturas presentes na superfície aplainada formada no contato entre o arenito deformado e o diamictito Dm2 da Associação 6 de Jumirim. 


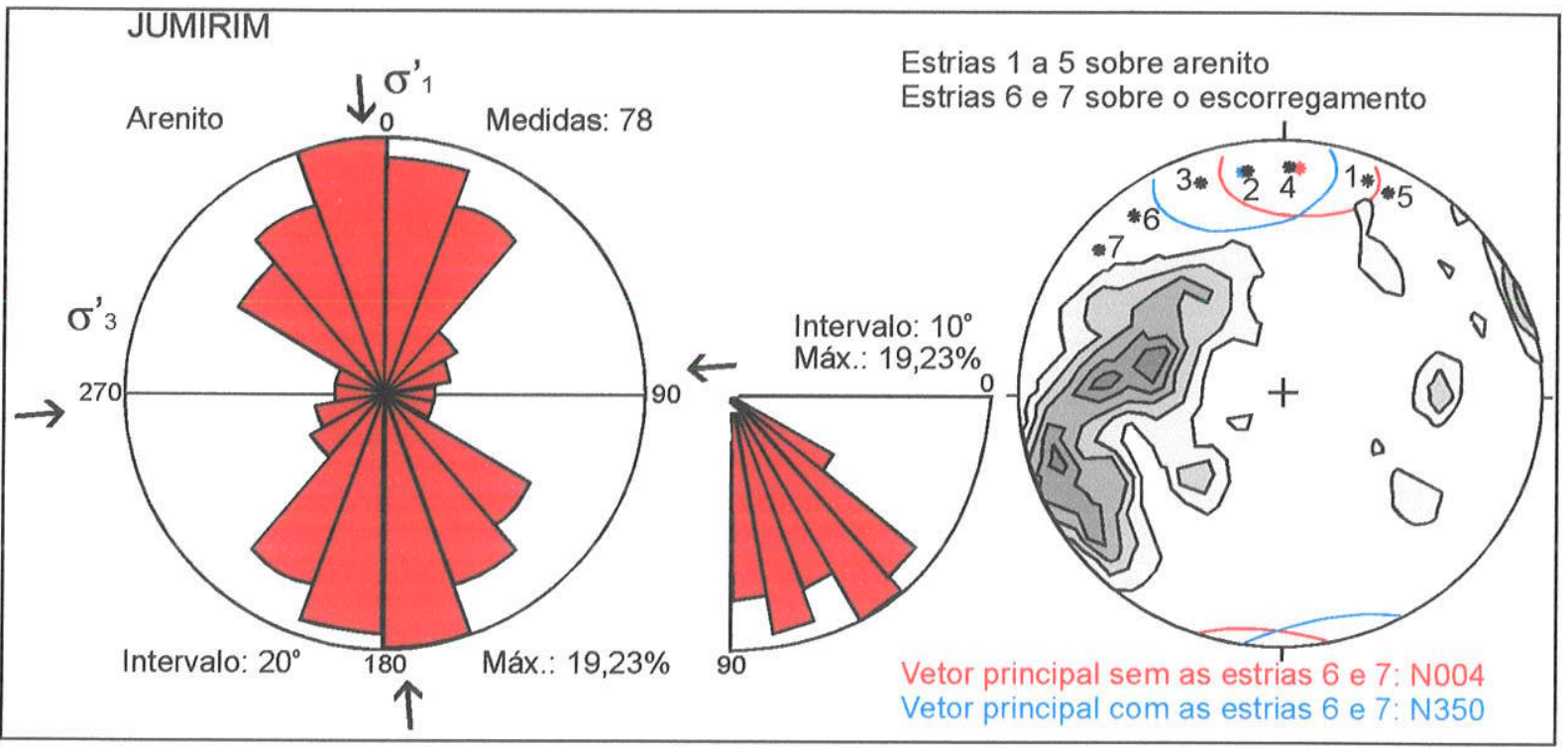

Figura 4.4.1.4 - Diagrama de rosáceas, com a indicação dos aparentes esforços principais máximo e mínimo ( $\sigma_{1}^{\prime}$ e $\sigma_{3}^{\prime}$, respectivamente), atuantes no arenito deformado da Associação 6 de Jumirim, cuja direção do $\sigma_{1}^{\prime}$ é N355, e diagrama de contornos dos pólos das fraturas, acrescidos das direções das estrias sobre o arenito e o escorregamento e o resultado do cálculo do vetor principal das estrias com e sem os dados sobre o escorregamento.

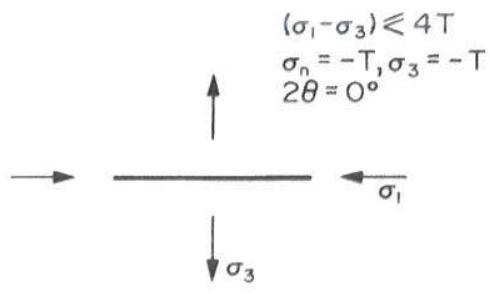

Fraturas de extensionais

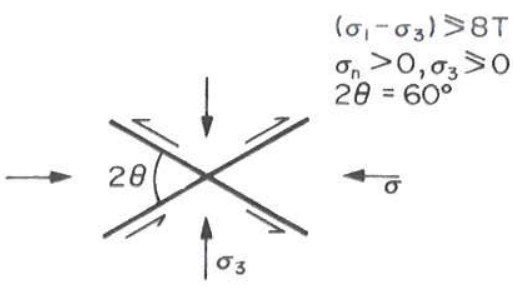

Fraturas de cisalhamento conjugadas
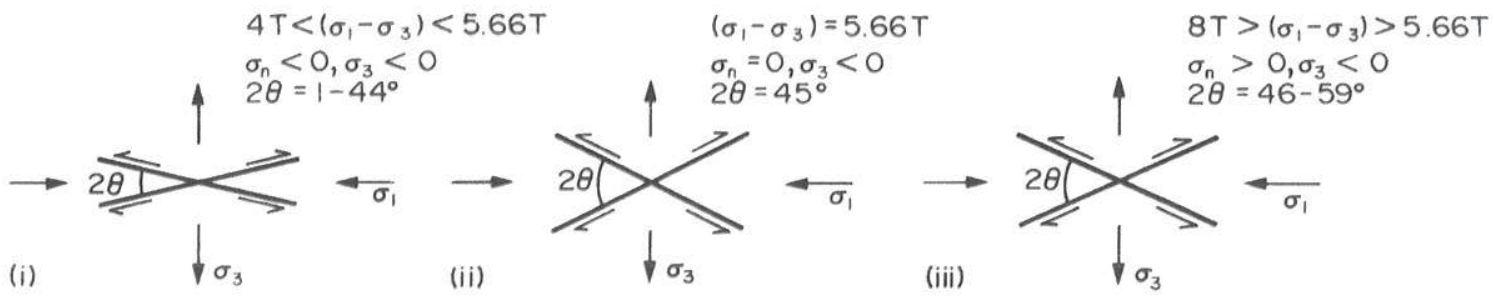

Fraturas híbricas conjugadas

Figura 4.4.1.5- Condições de esforços durante a formação de fraturas em rochas intactas. a) Fraturas extensionais. b) Fraturas de cisalhamento conjugadas. c) Fraturas híbridas conjugadas. Onde, $\sigma_{1}$ e $\sigma_{3}$ são os esforços principais máximo e mínimo, respectivamente; $\sigma_{n}$ é o esforço normal atuando na fratura durante o falhamento; $2 \theta$ é o ângulo diedral de cisalhamento conjugado; e T é a resistência a tensão da rocha (Hancock, 1985). 


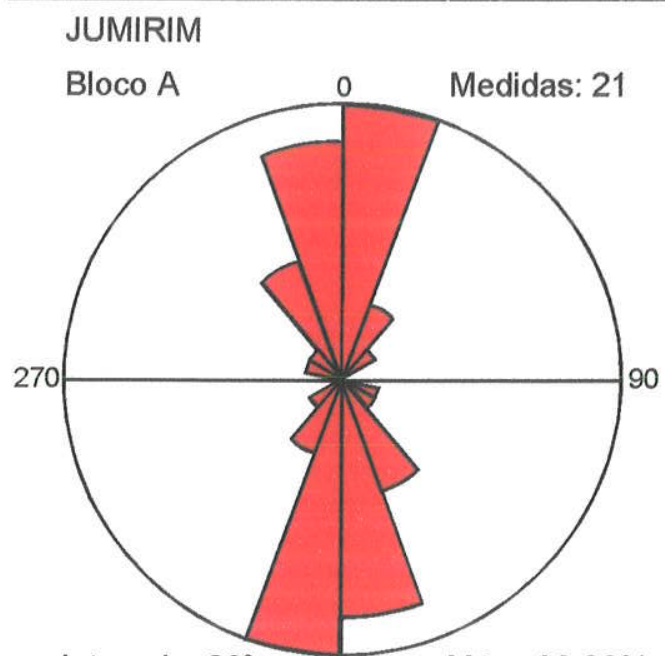

Intervalo: $20^{\circ}$

180

Máx.: 33,33\%

Intervalo: $10^{\circ}$

Máx.: $28,57 \%$

\section{JUMIRIM}

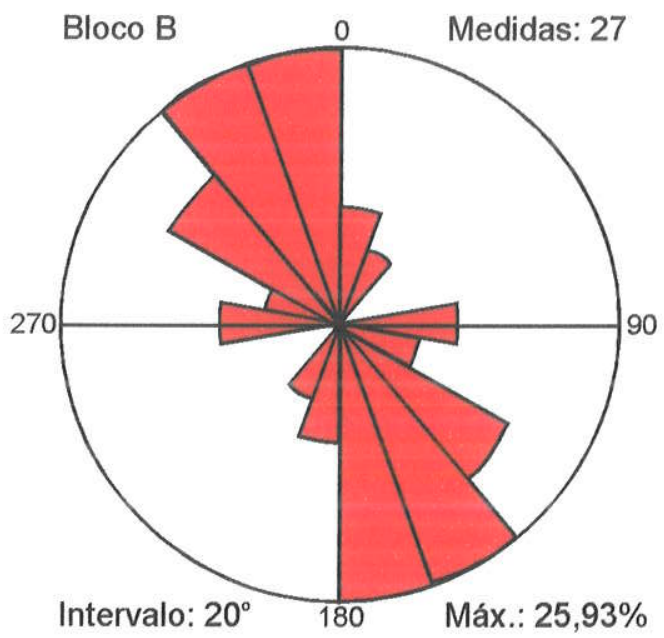

\section{Intervalo: $10^{\circ}$}

Máx.: $37,04 \%$
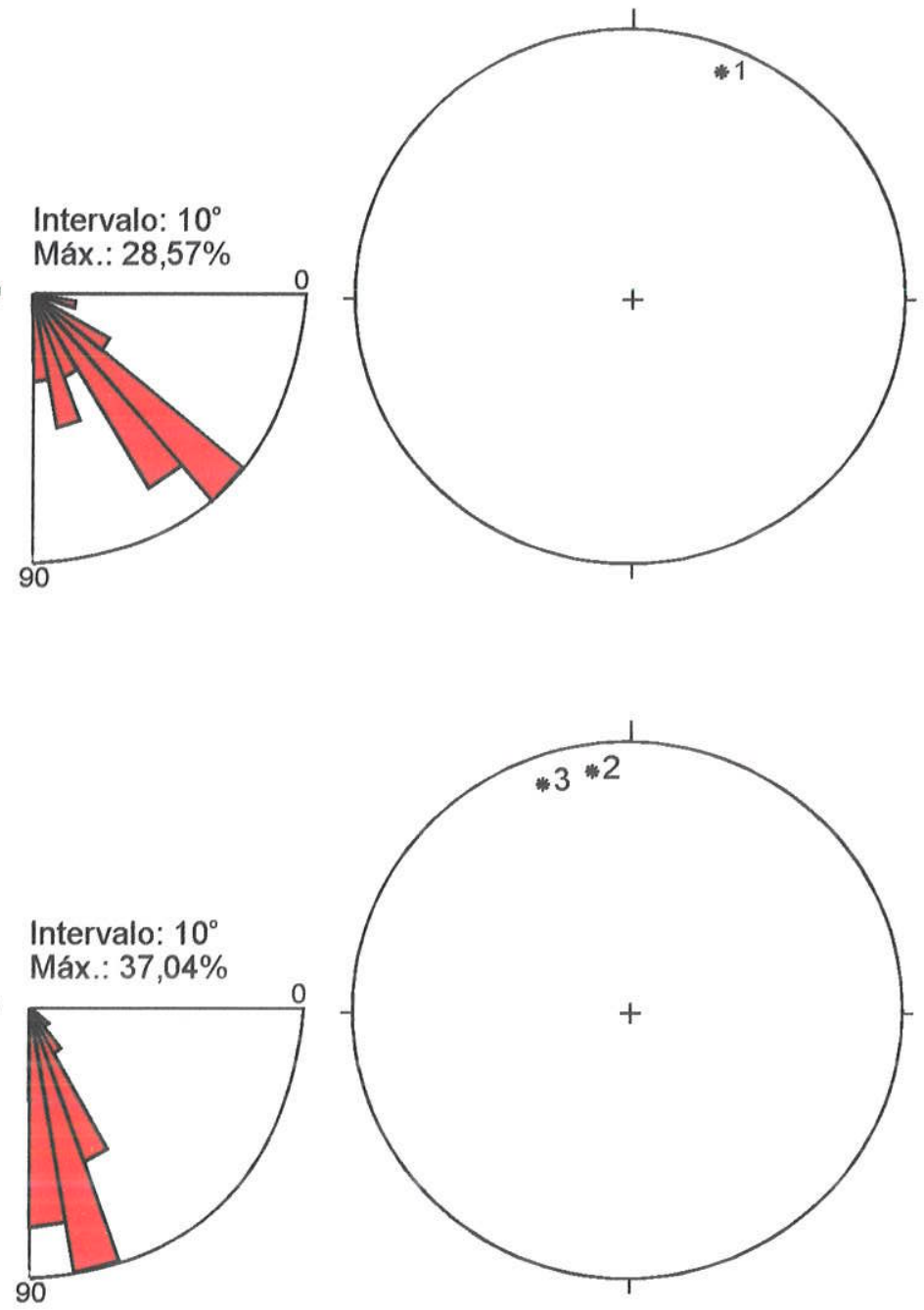

\section{JUMIRIM}
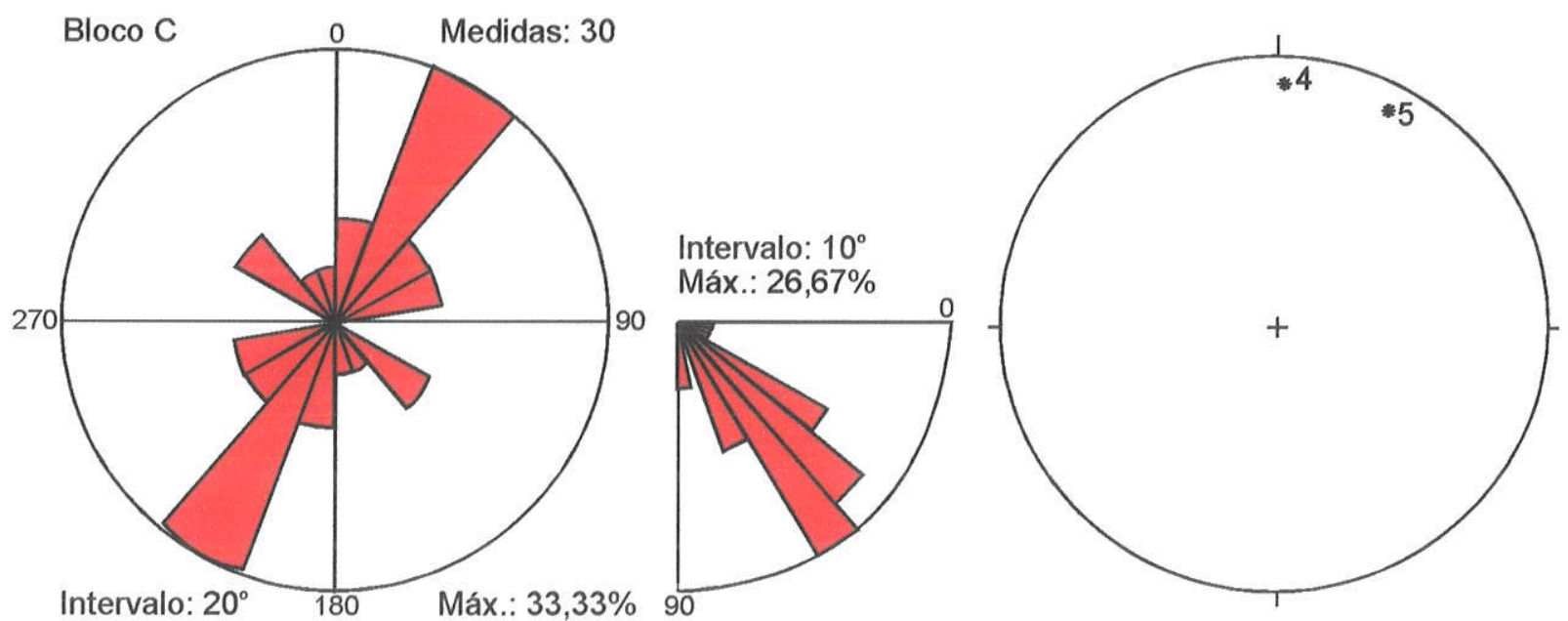

Figura 4.4.1.6 - Diagramas de rosáceas das fraturas presentes nos blocos (A, B e C), em que o arenito deformado da Associação 6 de Jumirim foi subdividido, e respectivas direções de estrias glaciais presentes em cada bloco. 
$\mathrm{Na}$ Tabela 4.4.1.1 observa-se que as direções principais para os esforços atuantes no arenito, tanto relacionados ao fraturamento, quanto às estrias glaciais, estão condizentes com o valor apresentado inicialmente (N355), apesar da maioria dos valores variarem entre N340 e N355 (NNW). Todavia, fica clara a presença de um outro esforço, direcionado entre N021 e N035 (NNE), só aferido através das fraturas no bloco C. Não é possível, contudo, determinar se foram causados por dois eventos glaciais independentes ou pela alteração na direção de movimentação de uma única geleira. Salienta-se que, o bloco $\mathrm{C}$ encontra-se na porção norte do afloramento, sendo, portanto, o bloco mais próximo do escorregamento (aproximadamente $10 \mathrm{~m}$ ) e que a mudança no direcionamento do gelo e, consequentemente, dos esforços principais, representaria a tendência deste a contornar o obstáculo, além de também ser uma informação pontual dos esforços. Esta mesma explicação serve para as direções das estrias observadas sobre o escorregamento, que se orientam entre N309 e N321.

Tabela 4.4.1.1 - Comparações entre os valores apresentados pelas fraturas e as estrias glaciais.

\begin{tabular}{|ccccc|}
\hline Blocos & $\begin{array}{c}\text { Variação das direções das } \\
\text { fraturas }\end{array}$ & $\begin{array}{c}\text { Ángulo diedral } \\
(2 \theta)\end{array}$ & $\begin{array}{c}\text { Direção do esforço } \\
\text { principal máximo }\left(\sigma_{1}\right)\end{array}$ & $\begin{array}{c}\text { Direção das estrias } \\
\text { glaciais }\end{array}$ \\
\hline A & N330 a N020 & $50^{\circ}$ & N355 & N021 \\
\hline B & N310 a N010 & $60^{\circ}$ & N340 & N339 e N351 \\
\hline C & N350 a N080 & $90^{\circ}$ & N035 & N002 e N027 \\
\hline Geral & N310 a N040 & $90^{\circ}$ & N355 & N004* e N350** \\
\hline
\end{tabular}

*Direção principal sem considerar as estrias sobre o escorregamento; $e^{\text {*^ }}$ acrescendo-se estas estrias.

Outro método que se julgou conveniente para a determinação da direção do esforço principal, e que mostrou resultados satisfatórios, foi na determinação da direção principal das fraturas através do método estatístico de Fisher (Fisher, 1953). Desta forma, foi possível determinar, numericamente, o eixo normal da média dos planos de fraturas, que, por sua vez, é ortogonal ao plano mediano entre as fraturas e ao esforço principal máximo $\left(\sigma_{1}\right)$. Logo, ao rotacionar este eixo em $90^{\circ}$, encontrar-se-á a direção do esforço principal máximo com maior precisão, conforme ilustrado na Tabela 4.4.1.2. Estes valores são mais especialmente condizentes com o esforço de direção NNE no bloco $\mathrm{C}$, demonstrando que este esforço variou entre o esforço geral (N355) e N027.

Somando-se a estes dados a possibilidade de se observar três conjuntos de fraturas presentes nos blocos através dos diagramas de rosáceas da Figura 4.4.1.6, fica clara a relação entre os conjuntos de fraturas e o direcionamento das estrias glaciais. Ao analisar separadamente cada bloco, nota-se que no bloco A existe uma concentração das fraturas na direção N-S, mesma orientação das estrias glaciais. A mesma coincidência entre a concentração das fraturas e o direcionamento das estrias glaciais pode ser observada nos 
blocos B e C, cujos direcionamentos são NNW-SSE e NNE-SSW, respectivamente. Consequentemente, o que se imaginava serem fraturas conjugadas são, na realidade, fraturas extencionais que sofreram alterações no direcionamento dos esforços principais ao longo do tempo. Alia-se à esta conclusão a observação de fraturas NNE-SSW sendo deslocadas pelas NNW-SSE.

Tabela 4.4.1.2 - Comparação dos resultados obtidos para a determinação do esforço principal máximo aplicando-se o método de Fisher e pelas rosáceas, assim como os valores das estrias glaciais.

\begin{tabular}{|ccccc|}
\hline Blocos & $\begin{array}{c}\text { Normal do plano } \\
\text { mediano através do } \\
\text { método de Fisher }\end{array}$ & $\begin{array}{c}\text { Direção do esforço } \\
\text { principal máximo por } \\
\text { Fisher }\end{array}$ & $\begin{array}{c}\text { Direção do esforço } \\
\text { principal máximo pelas } \\
\text { rosáceas }\end{array}$ & $\begin{array}{c}\text { Direção das } \\
\text { estrias glaciais }\end{array}$ \\
\hline A & $\mathrm{N} 085 / 37$ & $\mathrm{~N} 355$ & $\mathrm{~N} 355$ & $\mathrm{~N} 021$ \\
\hline B & $\mathrm{N} 079 / 46$ & $\mathrm{~N} 349$ & $\mathrm{~N} 340$ & $\mathrm{~N} 339$ e N351 \\
\hline C & $\mathrm{N} 105 / 38$ & $\mathrm{~N} 015$ & $\mathrm{~N} 035$ & $\mathrm{~N} 002$ e N027 \\
\hline Geral & $\mathrm{N} 093 / 39$ & $\mathrm{~N} 003$ & $\mathrm{~N} 355$ & $\mathrm{N004}^{*}$ e N350 \\
\hline
\end{tabular}

Desta forma, conclui-se que as fraturas são extencionais e que foram provocadas pelo deslocamento de um corpo de gelo gerador das estrias glaciais. A interpretação prévia da direção principal da geleira através das fraturas (N355) não seria afetada, pois o eixo de tensão principal está na bissetriz do espectro de fraturas, que coincide com o vetor médio das fraturas. Esta geleira, conforme mencionado anteriormente, não apresentou um direcionamento constante nesta localidade; a dispersão dos direcionamentos pode, portanto, ter sido gerada por mudanças gradativas na direção do deslocamento da geleira, ou pela irregularidade do substrato, relacionada ao efeito local da topografia. Cabe enfatizar, também, que o arenito deformado, assim como da mesma forma ocorre em Capivari, se comportou como um substrato rígido, possibilitando a formação de fraturas extencionais e estrias glaciais, com direcionamento principal norte-sul. Para tanto, estes substratos rígidos arenosos devem ter apresentado uma boa drenagem subglacial (Boulton \& Hindmarsh, 1987), conforme será discutido a seguir.

\subsubsection{Hidrologia dos Sedimentos com Estruturas Subglaciotectônicas de Capivari e Jumirim}

Como foi visto anteriormente, as estruturas glaciotectônicas como as registradas nos arenitos descritos em Capivari e Jumirim ocorrem em sedimentos que, no momento de sua deformação, estavam inconsolidados, porém se comportaram como substrato rígido (hardbeds), ou seja, como Acamamentos $\mathrm{H}$ (H-beds). Desta forma, as condições hidrológicas vigentes durante a gênese destas estruturas certamente foram peculiares, principalmente considerando que o deslocamento de uma geleira sobre estes sedimentos causa mudanças 
bruscas nas pressões exercidas nestes sedimentos e alteraram, consideravelmente, o seu conteúdo de água intersticial. Inicialmente, conforme mencionado no Subcapítulo 4.1.1. (Tipos de Acamamentos), existem cinco possibilidades do substrato de uma geleira se comportar como rígido. A primeira refere-se a um embasamento rochoso e, portanto, não se aplica neste caso. A segunda possibilidade refere-se a um substrato constituido por sedimentos congelados, e, neste caso a geleira, mesmo que parcialmente, teria base fria e dificilmente haveria deslocamentos na base da geleira para estriar o substrato e deformá-lo.

As outras três condiçōes reológicas envolvem as características da variável condutividade hidráulica dos sedimentos subjacentes à geleira. Com efeito, no que se refere às condições hidrológicas associadas aos sedimentos afetados pelas deformações subglaciotectônicas de Capivari e Jumirim, é difícil afiançar que os arenitos em questão, com expressiva porosidade, apresentavam baixa condutividade hidráulica. Desta forma, $e$ com exceção do sedimento congelado, restam as possibilidades de desenvolvimento de um substrato rigido relacionadas às condições peculiares de alta condutividade hidráulica dos sedimentos. Como existem estrias glaciais na superficie superior destes arenitos, a presença de um aquitarde no seu contato superior não se aplica. A única opção viável é a que considera a prevalência de um substrato constituido por sedimentos com alta condutividade hidráulica $\left(K>10^{-6} \mathrm{~m} \cdot \mathrm{s}^{-1}\right)$, formando um aquifero com condutividade hidráulica semelhante, ou superior, permitindo uma alta taxa de percolação intersticial de água na camada superior. Neste caso, a água de degelo não produziria descargas superiores ao fluxo de água intersticial na camada superior, mantendo esta camada inativa hidraulicamente.

Outra evidência a favor da existência dos Acamamentos " $H_{e}$ " (Menzies, 1989) é a inexistência de depósitos sedimentares típicos de canais subglaciais. Com efeito, a camada superior dos demais tipos de acamamentos rigidos tende a isolar as camadas inferiores da água de degelo presente na interface gelo/substrato, de tal forma que possibilita a formação de instabilidades na interface e, consequentemente, de canais subglaciais (Walder, 1986; Weertman, 1986; Boulton \& Dobbie, 1993). Todavia, como os arenitos deformados apresentam estratificações cruzadas prévias à deformação, é possível que estes sedimentos tenham sido gerados inicialmente em canais subglaciais, que, por causa de alguma mudança hidrológica (que será discutida no final deste subcapítulo), foram se consolidando a ponto de se deformarem originando estruturas rúpteis.

Consequentemente, em consonância com os argumentos alinhavados no trabalho de Boulton \& Dobbie (1993), um sedimento inconsolidado consiste de partículas que não podem ser comprimidas, com espaços intersticiais (poros) preenchidos por água, e, assim, se não for exercida carga sobre o sedimento e se não houver entrada ou saída de fluxos de água no sedimento, não existirá uma componente de pressão potencial, e a pressão 


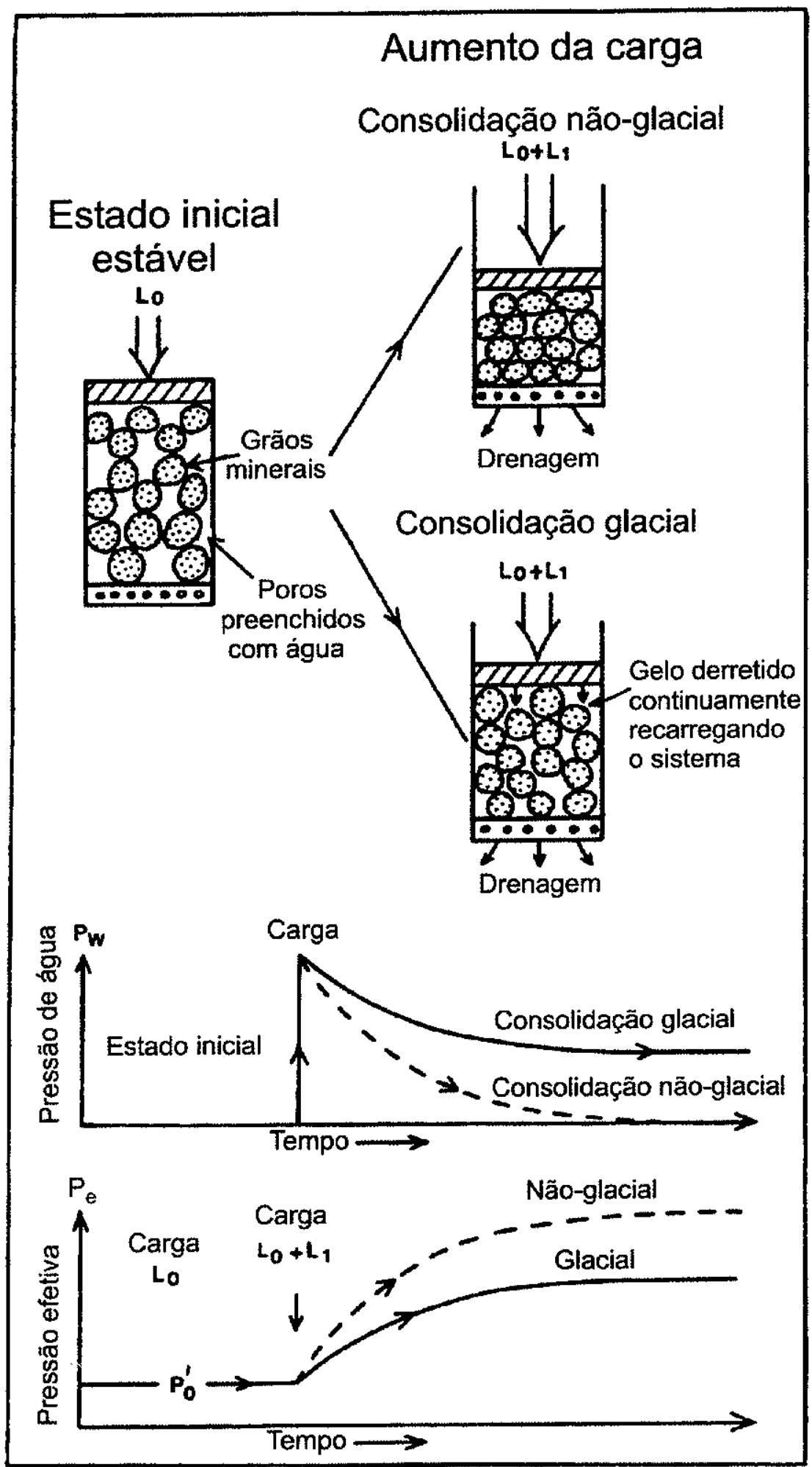

Figura 4.4.2.1 - Consolidaçăo de sedimentos não-glaciais e glaciais. Neste esquema, foi exercido um incremento na carga $\left(L_{1}\right)$ sobre uma célula sedimentar, que se encontrava estável sob a ação de uma carga prévia $\left(L_{0}\right)$. Após o aumento da carga desenvolve-se uma pressão potencial na água intersticial, fazendo com que ela flua para fora da célula e permita a compacłação dos grãos. Este aumento na carga favorece, deste modo, mudanças nas pressões da água e efetiva, com considerada diferença caso este esforço compressivo seja causado pela passagem ou não de uma geleira (Boulton \& Dobbie, 1993). 
efetiva será gravitacional. Mas, se for exercida uma carga sobre o sedimento, os grãos minerais responderão com o fechamento do arcabouço sedimentar que conduz a um sedimento mais compactado, o que fará com que parte da água intersticial seja relocada (Figura 4.4.2.1). Neste processo de consolidação, o esforço compressivo adicional $\left(\sigma_{c}\right)$ aplicado será, inicialmente, equivalente à pressão intersticial.

$$
\sigma_{c}=P_{i}
$$

Consequentemente, nessas condições, gera-se uma pressão potencial vertical $(\partial \psi / \partial z)$, resultante do escoamento da água intersticial através do contato basal do pacote sedimentar. Nestas condições:

$$
\partial P_{i} / \partial z=(\partial \psi / \partial z)+\rho_{w} g
$$

onde, $g$ é a aceleração gravitacional e $\rho_{w}$ é a densidade da água. Comparando esta fórmula com a lei de Darcy, o gradiente potencial fará com que a água escape com a seguinte velocidade $\left(u_{\theta}\right)$ :

$$
u_{\theta}=-\left(k / \rho_{w} g\right)(\partial \psi / \partial z)
$$

onde, $\mathrm{k}$ é a permeabilidade intrínseca.

Conforme a água escapa, o sedimento torna-se cada vez mais consolidado e o esforço compressivo causado pelo peso da geleira é progressivamente transferido da água intersticial para o arcabouço dos grãos minerais. A pressão de água diminui e a pressão efetiva aumenta progressivamente até que o gradiente potencial se torne nulo (Figura 4.4.2.1), ou seja, até que não haja mais evasão de água.

Ainda segundo Boulton \& Dobbie (1993), nos casos de regiões temperadas, as bases das geleiras sofrem derretimento, como consequência do aquecimento geotérmico e da friç̧ão causada pelo deslocamento da geleira. Desta forma, a consolidação destes sedimentos deve considerar o influxo de água de degelo provinda da interface gelo/substrato. Nestes casos, um substrato pode mesmo assim ficar consolidado, contudo, em lugares que não apresentam canais subglaciais, existe a necessidade que a água de degelo percole pelo sedimento com uma velocidade a ponto de permitir que seja rapidamente descarregada pela extremidade basal. A pressão de água final, imediatamente abaixo da geleira, não é simplesmente uma pressão gravitacional estática, mas inclui componentes de pressão potencial resultante do gradiente potencial necessário para decarregear a água de degelo basal com velocidade $u_{d}$, que é igual à velocidade de escape $\left(u_{e}\right)$, ou seja, $u_{d}=-\left(k / \rho_{w} \cdot g\right)(\partial \psi / \partial z)$. Por conseguinte, a pressão efetiva será menor do que seria em condições não glaciais e o gradiente da pressão efetiva será:

$$
\partial P_{e} / \partial z=(1-n)\left(\rho_{s}-\rho_{w}\right) g-\left(u_{d} \rho_{w} g\right) / k
$$


Desta forma, comprova-se que a permeabilidade e a porosidade dos sedimentos são fundamentais para a sua consolidação. Quanto menor a porosidade e a permeabilidade, maior será a pressão efetiva. Cabe ainda lembrar que, à medida que esforço compressivo é transferido da água intersticial para 0 arcabouço dos grãos minerais, o sedimento passa a ficar, progressivamente, mais compactado, e, desta forma, principalmente na porção superior, vai gradativamente diminuindo a sua porosidade e permeabilidade, aumentado assim a pressão efetiva. Neste caso a porção do sedimento menos porosa se torna um aquitarde, enquanto que a porção inferior permanece como um aquífero de alta transmissibilidade, drenando a água que passa verticalmente pela zona de baixa permeabilidade (Figura 4.4.2.2).

Tomando como ponto de consideração o modelo de drenagem subglacial de Boulton \& Dobbie (1993), é razoável considerar que os arenitos deformados de Capivari e Jumirim se comportaram hidraulicamente tanto como um substrato com alta transmissibilidade hidráulica (na porção inferior, pouco compactada), quanto como um aquitarde nas camadas superiores onde a porosidade foi reduzida pela compactação (Figura 4.4.2.2). Ainda segundo Boulton \& Dobbie (op cit.), assumindo que a pressão da água no topo do aquífero (porção porosa do arenito) seja nula nas áreas que não estejam abaixo do corpo de gelo, assim como valores constantes para a taxa de derretimento basal $\left(u_{d}\right)$, numa zona de derretimento que começa em $x_{0}$ e um aquifero com permeabilidade $\left(k_{a}\right)$ e espessura $(H)$ constantes, a descarga subglacial do aquífero $\left(Q_{H}\right)$ no ponto $x$ será:

$$
Q_{H}=\left(x-x_{0}\right) u_{d}
$$

Aplicando a lei de Darcy, o gradiente potencial do aquífero será:

$$
\partial \psi / \partial z=\left(x-x_{0}\right) u_{d} \rho_{w} g
$$

Assumindo que o derretimento subglacial termina nas margens da geleira $\left(x_{1}\right)$, neste ponto a pressão potencial no topo do aquifero será zero e o gradiente potencial será:

$$
\partial \psi / \partial z=-\left[\left(x_{1}-x_{0}\right) u_{d} \rho_{w} g\right] / k_{a} H
$$

Consequentemente, a pressão da água no topo do aquifero irá gradativamente aumentando de zero, na margem da geleira, até $\psi_{\mathrm{e}}$ no ponto $x_{0}$, sendo $\psi_{\mathrm{e}}$ igual a pressão potencial resultante da perda de potencialidade no aquitarde no ponto $x_{0}$ (Figura 4.4.2.2). 


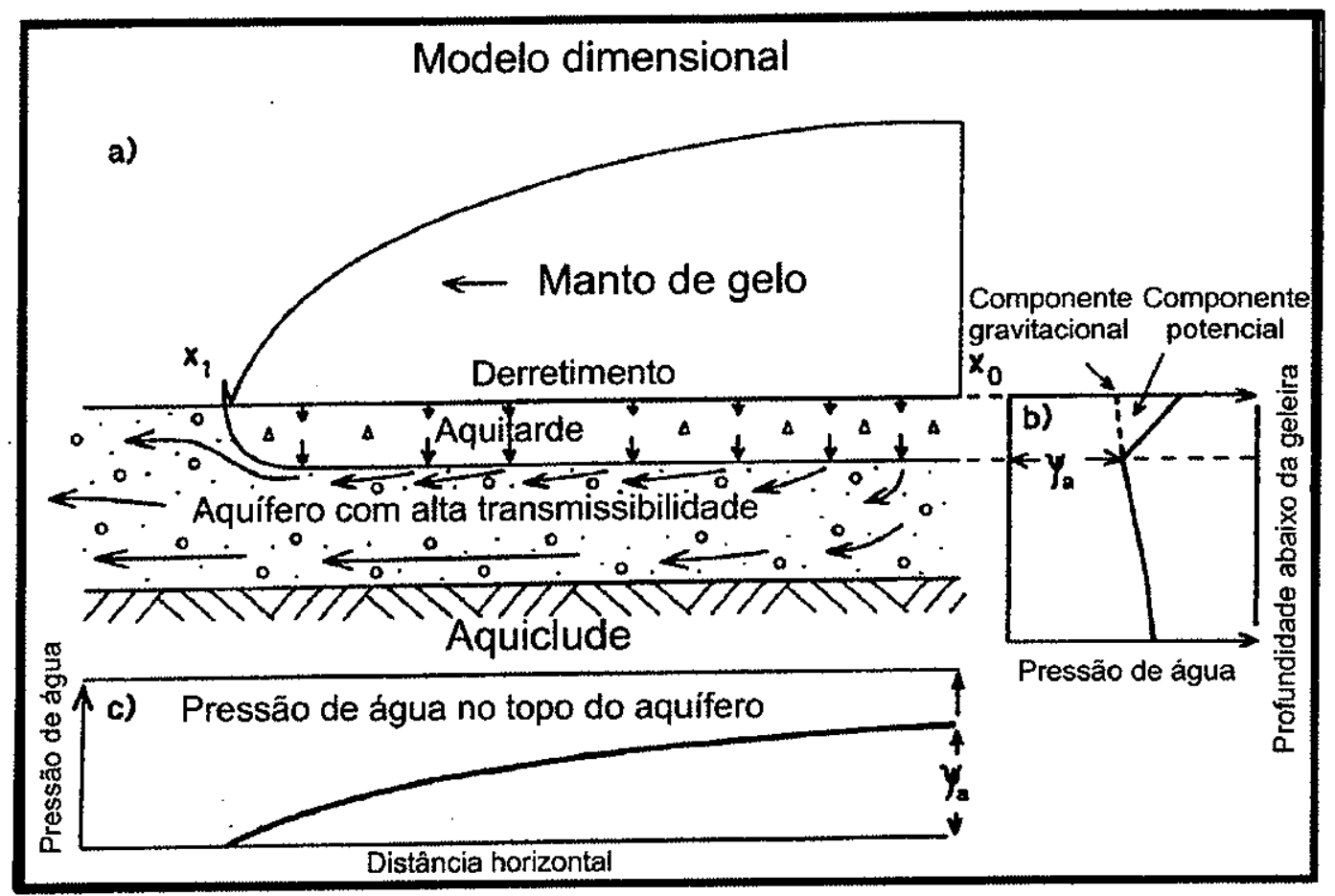

Figura 4.4.2.2 - Modelo esquemático da drenagem da água de degelo passando por um aquitarde (sedimento com baixa porosidade, no caso o arenito deformado da Associação 6) até chegar ao aquífero subjacente (o mesmo sedimento, contudo com alta porosidade), além da variação da pressão da água, tanto no deslocamento vertical, quanto no horizontal. Sendo que $\psi_{\mathrm{e}}$ é o potencial hidráulico na base do aquitarde (Modificado da Figura 4 de Boulton \& Dobbie, 1993).

Estes dados implicam na formação de um horizonte do tipo B de Boulton \& Hindmarsh (1987) no topo de um aquifero, horizonte este também denominado por Boulton (1987) como Horizonte $B_{1}$. Para tanto, como foi mencionado no subcapitulo introdutório sobre as estruturas subglaciaotectônicas (4.1.2 Modelo de Acamamento Viscoso), o desenvolvimento apenas do Horizonte $B$ requer que:

a potencialidade hidráulica da base do estrato $\left(\Psi_{\mathrm{e}}\right)$ seja relativamente pequena;

$>$ a diferença de potencialidade entre a base e o topo do estrato $\left(\Delta \Psi=\Psi_{i}-\Psi_{e}\right)$ tem que ser menor que o gradiente potencial, ou seja, $\partial \Psi / \partial z<\Delta \Psi$, que nada mais é do que a potencialidade perdida no aquitarde ou no Horizonte $B$;

$D$ a pressão efetiva $\left(P_{e}=P_{i}-P_{w}\right)$ seja menor que o valor crítico $((\tau-C) / \eta)$; e

$>$ haja baixas taxas de degelo basal $\left(u_{d}\right)$, implicando na diminuição do gradiente potencial (equações 9 e 10), assim como baixos valores de esforço de cisalhamento e alta resistência do sedimento, aumentando o valor crítico, e favorecendo que este valor supere a pressão efetiva.

Considerando que as deformações subglaciotectônicas rúpteiș de Capivari e Jumirim só seriam possiveis de serem geradas se os arenitos e diamictitos apresentassem 
características de substrato rigido, torna-se lícito considerar a seguinte questão: será que os arenitos e diamictitos deformados destas localidades não apresentaram condições hidrológicas semelhantes às necessárias para a formação de acamamentos rígidos do tipo $\mathrm{He}_{\mathrm{e}}$ ?

Neste sentido, cabe lembrar que, sobre estes arenitos deformados, ocorrem, tanto em Capivari como que em Jumirim, diamictitos de matriz argilosa, com estruturas subglaciotectônicas rúpteis, semelhantes às presentes nos arenitos, porém mais friáveis e com maior quantidade de fraturas e falhas. Além disso, não foi constatada, nos diamictitos deformados, qualquer evidência de estruturas dúcteis, ou seja, da gênese de um horizonte do tipo A de Boulton \& Hindmarsh (1987). Logo, pode-se considerar que estes diamictitos também foram gerados em condições hidráulicas semelhantes aos arenitos deformados.

Esta "coincidência" hidrológica entre os arenitos e os diamictitos deformados possibilita uma avaliação dos fatores fundamentais para este caso específico, onde a consolidação não se alterou, apesar da variação litológica. É claro que muitas propriedades hidráulicas seriam modificadas, visto que, como as litologias são distintas, a porosidade, a resistência dos sedimentos ao cisalhamento, a coesão e a friç̧ão interna dos sedimentos, e, consequentemente, o valor critico $((\tau-C) / \eta$, equação 5), certamente são propriedades que iriam variar. No entanto, a modificação destas características litológicas não teria sido suficiente para alterar a consolidação dos sedimentos, mantendo-os rígidos. Resta, desta forma, considerar os fatores pressão efetiva e taxa de degelo basal. Caso tenha havido baixo influxo de água de degelo nos sedimentos, existiriam poucas condições para a formação de horizontes do tipo $A$, ou seja, horizontes dúcteis, menos consolidados. Consequentemente, deduz-se daí que as estruturas subglaciotectônicas rúpteis foram geradas em avanços glaciais com baixas taxas de água de degelo, possivelmente subglaciais, com temperaturas baixas o suficiente para consolidar os sedimentos subjacentes e, ao mesmo tempo, permitir o deslocamento da geleira.

Neste sentido, outra pergunta que pode ser feita é: poderiam as estruturas subglaciotectônicas de Jumirim e Capivari ter sido formadas pela compressão operada pela geleira sobre sedimentos congelados? Afirmar que os sedimentos estavam congelados não é a mesma coisa que dizer que a base da geleira era fria e, portanto, é possivel que tenha havido movimentação significativa na interface gelo/substrato, suficiente, inclusive, para estriar a superfície superior do arenito, além de deformar o próprio arenito e o diamictito. Por conseguinte, não há evidências suficientes para discernir se o sedimento estava congelado ou foi consolidado pelas condições hidráulicas, mais especificamente da taxa de degelo, como explicação plausivel para as deformações rúpteis em Capivari e Jumirim. 
4.4.3. Implicações no Contexto Subglaciotectónico e Estratigráfico e Interpretações Paleogeográficas e Paleoambientais

Outras possiveis indagações que podem ser aventadas com relação à interpretação das informações descritas anteriormente: Como foi a evolução paleogeográfica e paleoambiental de Capivari e Jumirim? Qual a origem dos diamictitos deformados destas localidades? Como foram produzidas as estrias sobre os arenitos deformados? Quantos avanços glaciais teriam ocorrido?

Tendo como base inicialmente apenas a estratigrafia de Jumirim, visto que não foi possivel obter dados sobre os sedimentos subjacentes ao arenito deformado de Capivari, verifica-se que, após a deposição de sedimentos aparentemente glácio-marinhos da Associação 3 , seguiram-se os depósitos sedimentares com características mais costeiras (as planícies de lavagem, provavelmente subaquáticas, da Associação 4) e o intervalo contendo a ocorrência de plantas fósseis em siltitos da Associação 5 , indicando um ambiente mais redutor em contextos transicionais e/ou continentais. Esta sucessão pode ser alternativamente interpretada como o registro de um evento de regressão marinha, que, possivelmente, foi acompanhada pelo avanço do lobo glacial responsável pela deposição dos sedimentos da Associação 6.

A partir da Associação 6 de Jumirim, a sucessão estratigráfica se assemelha bastante à de Capivari, permitindo a análise simultânea de ambas as localidades em termos de eventos e processos. A base da Associação 6, assim como a do pacote sedimentar de Capivari onde ocorre o Horizonte Falhado e Fraturado (figuras 4.2.2; 4.2 .3 e 4.4.3.1), iniciam-se com arenitos deformados, com estratificações plano-paraleias e cruzadas que, possivelmente, foram depositados em ambiente subaquático. Em seguida houve o avanço de um corpo de gelo sobre os arenitos, na direção Norte-Sul em ambas as localidades, conforme indicam as direções das estrias e das estruturas glaciotectônicas (Figura 4.4.3.1). Durante este avanço glacial, 0 arenito se comportou como um acamamento rígido, o que leva à consideração de que as condições hidrológicas eram favoráveis a este tipo de comportamento (baixa taxa de influxo de água) ou o arenito encontrava-se previamente congelado. Este segundo caso pode implicar na prevalência de condições de permafrost, contudo não existem evidências contexturais e/ou locais que comprovem esta hipótese. A medida que a geleira avançou sobre o arenito, ela deformou-o, com a formação de fraturas e pequenas falhas, e estriou-o na sua superfície superior. As deformações subglaciotectônicas seriam, desta forma, oriundas do gradativo deslocamento da geleira, enquanto que as estrias seriam geradas nos episódios de acelerações do deslocamento da geleira. 


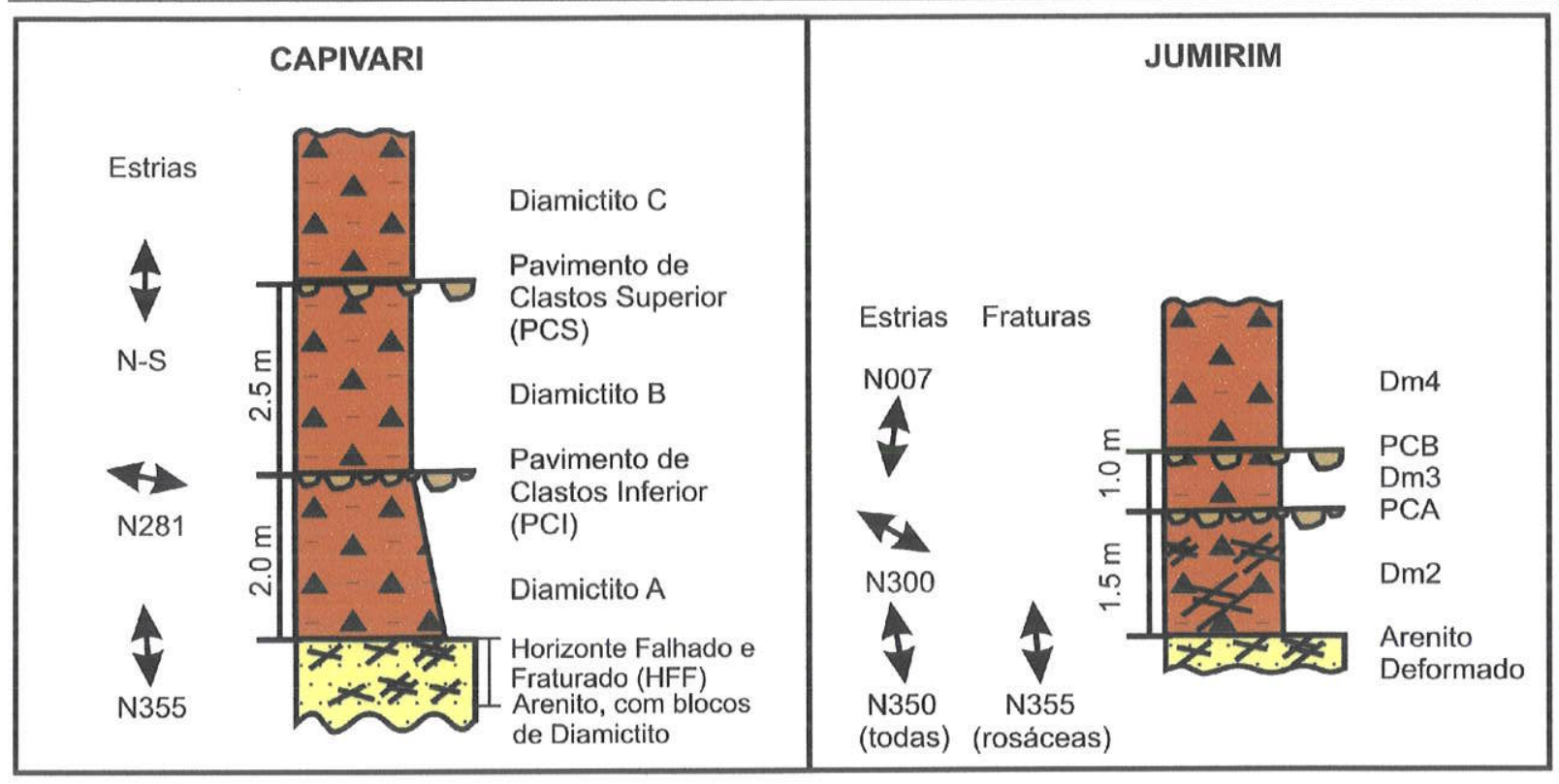

Figura 4.4.3.1 - Comparação entre a estratigrafia e dados sobre as direções das estrias e dos esforços das deformações nos arenitos em Capivari e Jumirim, onde Dm2 = Diamictito 2; Dm3 = Diamictito 3; Dm4 = Diamictito 4, PCA = Pavimento de Clastos A e PCB = Pavimento de Clastos B.

A deposição do diamictito sobre o arenito deformado pode ter decorrido através de dois processos possíveis: ou as condições subglaciais passaram a favorecer a acumulação de detritos, originando assim um till de alojamento subglacial, ou houve uma oscilação da frente da geleira, permitindo o seu recuo, possivelmente momentâneo, e, por conseguinte, a deposição de um till de degelo por ablação (meltout).

Till de degelo (melt-out) corresponde a um depósito de detritos rochosos depositados por geleiras estagnadas, ou em movimento, através do degelo de camadas de gelo muito ricas em fragmentos líticos, sem que haja subsequente transporte ou deformação (Benn \& Evans, 1998). Este degelo pode ocorrer em camadas subglaciais (till de degelo subglacial), em geleiras estagnadas ou zonas estagnadas embaixo de geleiras ativas; ou supraglaciais, também denominado por alguns pesquisadores como till de degelo por ablação (Suguio, 1998), e, neste caso, o derretimento ocorre no topo da geleira, normalmente de baixo de uma capa de detritos (Boulton, 1971; Dreimanis, 1989). Segundo Benn \& Evans (1998), existem poucos trabalhos sobre tills de degelo, mesmo em registros recentes, o que limita a possibilidade de uma análise mais detalhada de sua gênese. Desta forma, a interpretação de tills de degelo antigos é sempre acompanhada de muita controvérsia e muitos critérios são baseados em evidências geológicas (e.g.: análises de fábricas dos clastos) que não são amplamente aceitos pelos pesquisadores. Consequentemente, além dos argumentos relacionados à falta de orientação dos clastos observada nos diamictitos, adotou-se neste trabalho a própria estratigrafia do pacote sedimentar em questão como referência para uma possível interpretação destes diamictitos como sendo tills de degelo. Também deve-se frisar que, no caso dos diamictitos deformados, o emprego do termo till de degelo se refere apenas à interpretação da gênese anterior à deformação, pois, conforme dito anteriormente, 
não deve haver subsequente deformação e transporte para o uso sensu strito do termo em questão.

Na primeira hipótese, as deformações subglaciais presentes no diamictito estariam relacionadas a mudanças dinâmicas locais da base da geleira, passando de uma zona de acumulação de sedimentos para uma fase de deformação associada com baixa taxa de influxo de água no sedimento. Desta forma, pode-se considerar que, durante a acumulação dos detritos subglaciais, a interface geleira/substrato apresentava uma quantidade maior de influxo de água no sedimento. Esta variação local das condições hidrológicas é perfeitamente cabivel e compativel com um avanço gradativo da frente da geleira (Bennett, 2003).

No entanto, a confirmação da segunda hipótese necessita que tenha havido um novo avanço da frente da geleira e, posteriormente, o estabelecimento de condições hidrológicas semelhantes às relacionadas à deformação rúptil do arenito, visto que também seria indispensável um baixo influxo de água no diamictito. Consequentemente, a variação hidrológica da base da geleira teria sido bem mais acentuada do que no primeiro caso.

O principal problema para interpretar a estratigrafia de Capivari e Jumirim é, na realidade, o entendimento da relação entre o diamictito deformado e o primeiro pavimento de clastos de cada localidade (Figura 4.4.3.1). Para a formação dos pavimentos de clastos, que, em ambos os casos aqui considerados são interpretados como correspondentes a pavimentos de clastos inter-till, seria necessário presumir o recuo da frente da geleira, possibilitando a deposição de detritos, principalmente till de degelo. Posteriormente, estes sedimentos seriam expostos subaereamente e parcialmente retrabalhados e erodidos, fato que permitiria a subsequente eliminação dos sedimentos finos e concentração seletiva da fração mais grossa. Após esse processo de lavagem seletiva, o pavimento de clastos seria produzido como resultado de um novo avanço da geleira que sobrepassaria a superfície de detritos.

Entretanto, a duvida que ainda permanece refere-se aos registros resultantes deste possivel primeiro recuo da frente da geleira, que deveriam estar presentes após a deformação do diamictito subjacente (DmA e Dm2). Os diamictitos deformados de Capivari e Jumirim diferem pela ausência de deformação no topo do DmA, fato não observado em Jumirim, pela matriz do diamictito Dm2 ser mais argilosa e pelas espessuras, respectivamente, 2,00 m (DmA) e 1,50 m (Dm2). No caso de Capivari existe, na base do DmA, um Horizonte Falhado e Fraturado, onde verifica-se uma mistura de blocos angulosos de ambas as litologias (arenito e diamictito), contudo é difícil encontrar novas estruturas de deformações acima desta zona falhada (figuras 4.2.2; 4.2.3 e 4.4.3.1). Como existe uma mudança granulométrica da matriz do DmA, indo de arenosa na base para argilosa no topo, 
é possivel considerar que o DmA corresponda, na realidade, a dois diamictitos, um subglacialmente deformado e outro um till de degelo.

Com relação a Jumirim, permanecem ainda algumas dificuldades com relação a tal explicação, visto que, praticamente, 0 diamictito deformado está em contato com 0 pavimento de clastos (pelo menos no afloramento analisado, próximo das estrias sobre o arenito deformado, figuras 4.4.1.3 e 4.4.3.1). Para este caso foram cogitadas duas explicações: a deformação do Dm2 ocorreu conjuntamente com o segundo avanço da frente da geleira; ou os sedimentos depositados após o recuo da frente da geleira foram, em grande parte, seletivamente erodidos, restando, basicamente, apenas a concentração residual de clastos presentes atualmente no pavimento inferior. $\dot{E}$ difícil aceitar, como provável, a primeira hipótese em virtude da inexistência de registros semelhantes nas sequências glaciogênicas recentes ou pré-pleistocênicas do mundo, assim como não existem deformações no diamictito (Dm3) abaixo do pavimento de clastos superior. Além do mais, a segunda hipótese parece mais factivel visto ser favorecida pelo fato do Dm2 ter se comportado como um sedimento consolidado e, portanto, menos susceptivel a erosão.

Embora ainda um tanto especulativo pode-se considerar que os novos avanços das frentes das geleiras, que originaram os pavimentos de clastos inferiores, tanto em Capivari como em Jumirim, tenham mudado de direção, passando para WNW-ESE. Após a formação do pavimento de clastos inferior teria havido a repetição da oscilação das frentes dos corpos de gelo em ambas as localidades, permitindo a formação de um segundo pavimento de clastos. Contudo, desta vez, o diamictito entre os dois pavimentos não apresenta deformação, demonstrando que não houve outro avanço da frente das geleiras neste periodo, o qual poderia ocasionar estruturas subglaciotectônicas. Desta forma, parece mais razoável considerar que teria havido um recuo da frente das geleiras e novamente a seleção granulométrica (winnowing), através da exposição subaérea dos sedimentos, e a formação de um novo pavimento de clastos, após um novo avanço da frente das geleiras. Este último avanço também apresentou um direcionamento semelhante (Norte-Sul) em ambas as localidades. Com o recuo deste último avanço glacial, o pacote sedimentar acima do pavimento superior parece representar um till de degelo, associado com lentes e/ou camadas de canais flúvio-glaciais, que se intensificam gradativamente para o topo da unidade, culminando nos arenitos com estratificação cruzada e acanalada que capeiam o Diamictito 4 de Jumirim, fato observado perto da Estação Férrea de Jumirim.

Apesar das várias hipóteses apresentadas para cada situação, que se mostram, em princípio, conflitantes, acredita-se que as respostas mais prováveis sejam as seguintes:

Ocorreram 3 (três) avanços dos corpos de gelo sobre os sedimentos tanto em Capivari, quanto em Jumirim. O primeiro foi responsável pela geração das estruturas glaciotectônicas rúpteis registradas nos arenito e diamictitos 
deformados, além das estritas no contato destas litologias. O segundo e 0 terceiro avanços das geleiras seriam responsáveis, respectivamente, pela gênese dos pavimentos de clastos inferiores e superiores;

$>$ As estritas sobre os arenitos deformados teriam sido produzidas durante acelerações no deslocamento da geleira durante o primeiro avanço;

$>$ Os diamictitos deformados seriam sedimentos subglaciais depositados em períodos em que houve condições propícias à acumulação de sedimentos na interface geleira/substrato, sendo posteriormente deformados em virtude da mudança das condiçōes hidrológicas; e

$>$ Em Jumirim, o till de degelo, que teria sido depositado após o recuo da frente da geleira que teria antecedido a formação do pavimento de clastos inferior, e, portanto, após a deposição do diamictito deformado (Dm2) e antes do PCA, provavelmente foi erodido e retrabalhado pelo re-avanço que gerou o referido pavimento.

Vale a pena, ainda, mencionar que, em sequências glaciogênicas recentes e antigas, näo existe outro registro semelhante a estas ocorrências de Capivari e Jumirim, com associações entre estruturas subglaciotectônicas rúpteis em arenitos e diamictitos, estrias glaciais e pavimentos de clastos, o que torna estes afloramentos únicos e importantíssimos ao desenvolvimento dos conhecimentos sobre a dinâmica das geleiras, tanto nacionalmente, quanto internacionalmente, conforme comentado pessoalmente por Matthew R. Bennett.

\section{Correlaçőes entre os afloramentos analisados e o Modelo Slip-Stick}

As informações reológicas obtidas a partir da análise dos sedimentos de Capivari e Jumirim podem contribuir, substancialmente, para suporte à recente proposta de Alley (2000), Boulton et al. (2001) e Bennett (2003), de um modelo reológico continuo, o Modelo da Continuidade ou Modelo do Ciclo Slip-Stick (Modelo do Ciclo de DeslizamentoAderência), já comentado no Subcapitulo 4.1.4.. Este modelo, ainda preliminar, baseia-se na variação da pressão de água, um dos principais fatores relacionados às mudanças reológicas identificadas no primeiro avanço das geleiras sobre Capivari e Jumirim, e, desta forma, responsável pelas estruturas subglaciotectônicas rúpteis. Baseando-se no modelo Slip-Stick, e sob a ótica deste, teria havido a seguinte sequência de eventos no primeiro avanço das geleiras de ambas as localidades em questão:

1) As deformações rúpteis nos arenitos teriam sido geradas no estágio Stick (da aderência), do modelo, ou seja, em que a base da geleira e o substrato encontramse aderidos devido às condições hidrológicas. $O$ fato da pressão de água ser muito 
baixa, teria possibilitado o enrijecimento do substrato, permitindo, assim, a formação de estruturas rúpteis.

2) O aplainamento do contato entre os arenitos e os diamictitos deformados e a presença de estrias glaciais representariam o estágio Slip (do deslizamento). Neste caso a pressão de água teria aumentado a tal ponto que lubrificou a interface geleira/substrato, possibilitando $\circ$ deslizamento súbito das geleiras. Consequentemente, este deslizamento teria sido responsável pelo aplainamento, pela geração das estrias e pela formação e acumulo de sedimentos basais de um till (os diamictitos deformados).

3) Caso a diminuição da pressão de água tivesse sido gradativa, esperar-se-ia a formação de deformações dúcteis nos diamictitos, mas, a presença de estruturas rúpteis demonstra que a pressão de água voltou a ser muito baixa, sem que houvesse a necessidade de passar pela etapa de Deformação do ciclo Slip-Stick. A granulometria argilosa das matrizes dos diamictitos e a escassez de clastos nos diamictitos devem ter contribuído para a ocorrência desta situação atípica, conforme já previsto por Bennett (2003).

Consequentemente, destacam-se as seguintes contribuições deste trabalho para a teoria do Modelo Slip-Stick:

o modelo do ciclo Slip-Stick é extremamente útil para explicar vários problemas de reologia subglacial, inclusive para as ocorrências de Capivari e Jumirim;

$>\quad$ o ciclo Slip-Stick não é um "caminho de mão única", podendo haver situações em que algumas etapas não sejam realizadas ou que tenham apresentado, ocasionalmente, pouco registro geológico (Figura 4.4.3.2), conforme previsto por Bennett (2003) e observado em Capivari e Jumirim;

$>$ Durante a fase de aderência (stick), teoricamente não há deformação, contudo a tensão efetiva sobre o substrato toma-se tão concentrada, que atingirá um ponto critico $(\alpha)$ para a formação de estruturas rúpteis. Neste sentido, vale lembrar que o valor crítico estabelecido pela equação $5\left(P_{e}=(\tau-C) / \eta\right)$, refere-se à pressão efetiva necessária para a formação de substratos rígidos e não ao citado ponto crítico $\alpha$; $e$ que a aderência é obtida por processos hidrológicos e não térmicos, e, desta forma, a geleira ainda era de base temperada.

$>$ A formação das estruturas subglaciotectônicas rúpteis no estágio de aderência ocorreria pouco antes da passagem para a fase de deslizamento (slip), sendo, inclusive, um dos fatores responsáveis pelo seu início. Assim, à medida que surgem 
as fraturas e falhas nos sedimentos enrijecidos, o aumento da pressão de água é favorecido, o que resulta no início da fase de deslizamento.

$>$ As tensões responsáveis pela formação das estruturas subglaciotectônicas rúpteis podem estar relacionadas com o balanço de massa da geleira, e, nesse sentido, vale aqui lembrar que a etapa de deslizamento (slip) pode ser, em parte, considerada como um surge (avanço rápido dos corpos de gelo), visto que, como comenta Benn \& Evans (1998), um surge pode ser ocasionado por oscilações internas na geleira, principaimente relacionadas a aparentes reorganizações do sistema de drenagem subglacial. Além da relação com a hidrologia subglacial, um avanço rápido de uma geleira também pode ser ocasionado por mudanças climáticas, em virtude das mudanças no seu balanço de massa, conforme sugerido por Budd (1975). Como ainda não se conhece o suficiente sobre a gênese dos surges, torna-se possivel sugerir e/ou considerar uma combinação de ambas as explicações. Neste caso, e dependendo dos fatores climáticos, é possível que, em uma geleira que esteja aderida a seu substrato (sticked), o acumulo de massa supere a sua capacidade de escoar o gelo acumulado apenas por fluxos lentos. Consequentemente, 0 acumulo de tensões tornaria factivel as deformações rúpteis do substrato enrijecido $e$, por conseguinte, aumentaria a pressão de água, dando início assim à fase de deslizamento (slip) que, no caso, também pode ser denominado como surge.

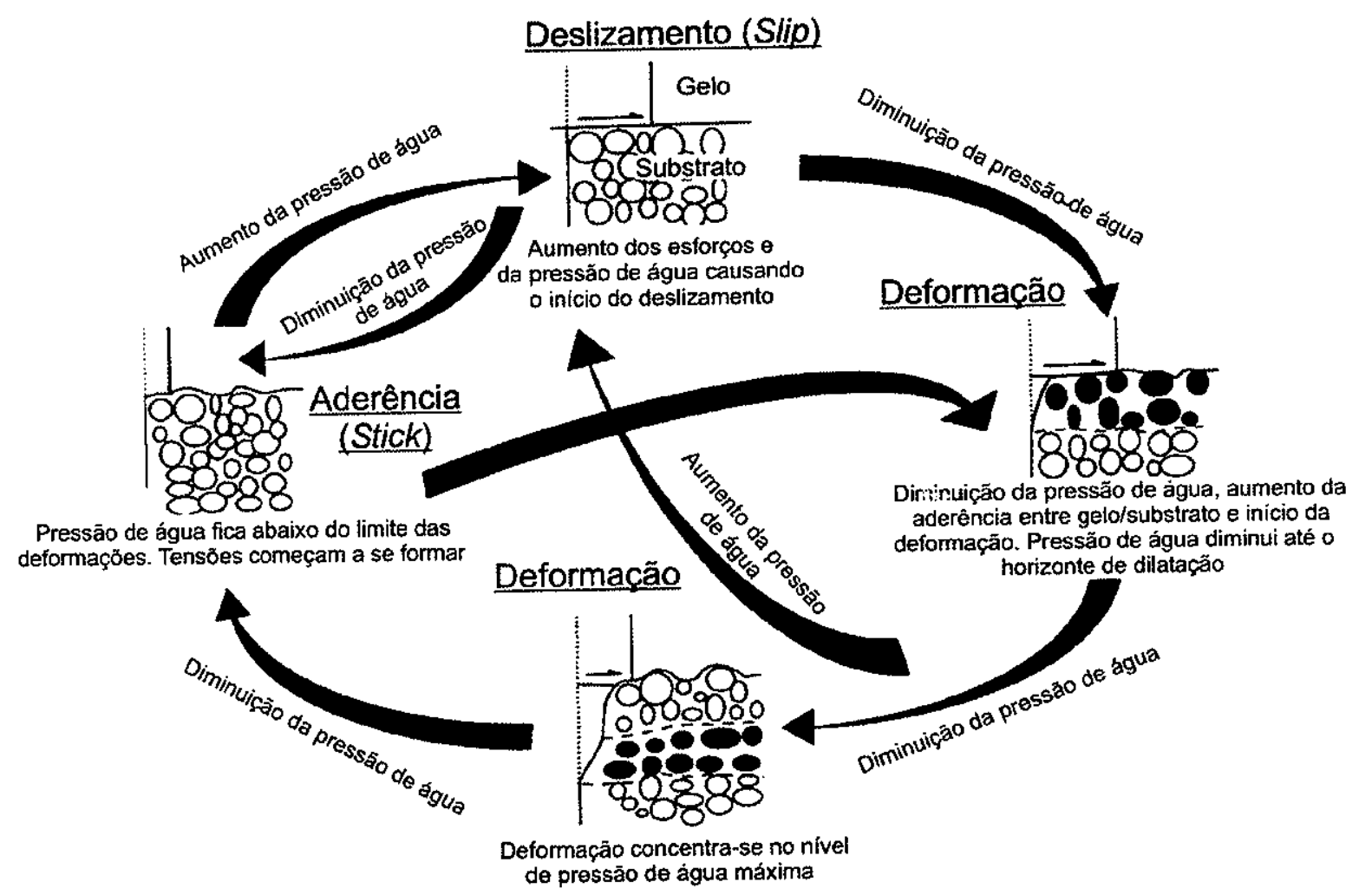

Figura 4.4.3.2 - Ciclo Slip-Stick (Deslizamento-Aderência), adaptado de Bennett (2003). 


\section{Problemas na análise conjunta de Capivari e Jumirim}

Conforme observado anteriormente, no Subcapítulo 4.2, as fábricas dos clastos dos diamictitos de Capivari, assim como nos dados obtidos em Jumirim, não foram utilizados, pois apresentaram uma grande dispersão, passivel de falsas interpretações. Deste modo, esta metodologia, embora muito aplicada para distinguir os diamictitos sub- e sobrejacentes de um pavimento de clasto, não foi aproveitada neste estudo, devido a falta de detalhamento faciológico específico.

Enfatiza-se também, mais uma vez, que, embora ao que tudo parece indicar, as sucessões de Jumirim e Capivari representam diferentes intervalos estratigráficos (Saad, 1977; Santos, 1979), a interpretação de ambas as regiões foi feita de forma conjugada, já que os dados de ambas as localidades são muito semelhantes. Além disso, é difícil correlacionar Capivari e Jumirim, visto as distâncias geográfica e estratigráfica entre elas e, principalmente, às grandes mudanças faciológicas verticais e laterais, que não permitem reconhecer uma camada-guia, e à presença de inúmeros falhamentos e intrusões de diques e sills mesozóicos. Não obstante, há carência de informações confiáveis a respeito da posição estratigráfica do afloramento de Capivari assim como de levantamentos detalhados da estratigrafia entre estas duas localidades. Por conseguinte, apesar da grande coincidência entre os dados obtidos nestas localidades, não é possivel afirmar que sejam contemporâneos, fato que remeteria o afloramento de Capivari ao topo do Subgrupo Itararé. Contudo, certamente demonstram que os avanços e recuos glaciais do Subgrupo Itararé ocorreram com padrões semelhantes nestas regiōes do Estado de São Paulo e que, não sendo contemporâneos, estão a indicar que estes padrões se repetiram de forma análoga nos sucessivos ciclos glaciais já reconhecidos ao longo de toda a sucessão estratigráfica do Subgrupo Itararé (Santos, 1979; Santos et al., 1996). 


\section{DEFORMAÇÕES PROGLACIOTECTÓNICAS}

\subsection{AS ESTRUTURAS PROGLACIOTECTÓNICAS E AS MORAINAS DE EMPURRÃO}

As deformações proglaciotectónicas compreendem todas as deformações provocadas nos sedimentos, rochas e gelos nos âmbitos frontais e laterais de um corpo de gelo em deslocamento. Esta definição é muito semelhante à apresentada por Bennett (2001) para distinguir as morainas de empurrão ou "stauch-morainen" (Gripp, 1938 apud Hart \& Boulton, 1991), porém em um sentido mais amplo já que engloba neste conceito as morainas sub-marginais. No entanto, historicamente, na Geologia Glacial do Quaternário e Recente o termo "moraina" tem conotaçöes restritas, limitadas às formas de relevo, fato que, face ao seu baixo potencial de preservação, dificulta a sua utilização em sedimentos prépleistocênicos. Ainda Bennett (2001) também aplica o termo "moraina de empurrão" para morainas poligéticas, referindo-se àquelas que apresentam deformaçöes geradas em mais de um ambiente sedimentar, como, por exemplo, deformações desenvolvidas em ambiente proglacial associadas a estruturas subglaciotectônicas, e, nestes casos, a designação adjetiva mais adequada para as deformações seria poliglaciotectônica. Entretanto, nesses casos, e devido às condições de preservação e à dificuldade natural de se determinar a gênese de sedimentos pré-pleistocênicos, dificilmente todos os fatores envolvidos na gênese de uma deformação poligenética serão identificados por completo, prevalecendo, em muitos casos, o ambiente gerador das deformações glaciotectônicas mais proeminentes ou mais jovens.

Como a definição utilizada para as estruturas proglaciotectônicas, descrita no Subcapítulo 3.2 (Tipos de estruturas glaciotectônicas), tem como base as deformações glaciotectônicas proglaciais de Hart \& Boulton (1991), acrescidas de suas características tectônicas descritivas (dúctil ou rúptil), a abrangência destas compreende estilos de deformações que vão dos compressivos contínuos, nas margens das geleiras, a dobras (deformação dúctil) e empilhamentos tectônicos através de acavalamentos (deformação rúptil), em sedimentos ou rochas locais ou transportados por longas distâncias. Normalmente, o resultado final depende da reologia, da competência do substrato e do comportamento do manto de gelo.

$\dot{E}$ indubitável que a principal forma de relevo proglacial que apresenta estruturas glaciotectônicas são as morainas de empurrão, e, na falta de outras estruturas proglaciotectônicas pré-pleistocênicas, cabe aqui utilizá-las na forma de análogos de estruturas contemporâneas. Segundo van der Wateren (1995a), desde o século 17, as morainas de empurrão têm sido descritas através de vários nomes, como, por exemplo, shoved moraines, ice-pushed moraines (morainas empurradas por gelo), ice-thrust ridges 
(cristas acavaladas por gelo), pseudo-moraines (pseudo-morainas), push or thrust ridges (cristas empurradas ou acavaladas), push endmoraines (morainas terminais empurradas). $\mathrm{Na}$ verdade estas denominações mostram que elas têm distribuição restrita e associação especifica com cenários glaciotectônicos e glaciológicos nas margens das geleiras. Por outro lado, esta distribuição e ocorrência ambíguas proporcionam um potencial considerável para investigaçōes paleoambientais e paleoglaciológicas, com importantes dados sobre a glaciodinâmica (Bennett, 2001), além de ser um ótimo análogo para estudos sobre cinturões orogênicos de pequena espessura (thin-skin tectonics within orogenic belts, e.g.: Pedersen, 1987; Aber et al., 1989; van der Wateren, 1995a). A grande afinidade das morainas de empurrão com o balanço de massa glacial faz com que sejam consideradas indicadoras confiáveis de mudanças climáticas (van der Wateren, 1995a). Consequentemente, são também importantes nas reconstruções dos mantos de gelo (e.g.: Boulton \& Clark, 1990a, 1990b; Kleman \& Borgström, 1996; Kleman et al., 1997) e nas comparações entre o comportamento dos mantos de gelo pleistocênicos e os dados ambientais obtidos por perfurações no gelo e marinhas (e.g.: Dansgaard et al., 1993; Keigwin et al., 1994), além de serem de grande valor na confeç̧ão de modelos sobre mudanças ambientais (e.g.: Boulton, 1996).

As morainas de empurrão apresentam tipos morfológicos que variam de poucos metros a quilômetros de extensão, composições com sedimentos e/ou rochas diversas, e cristas que podem variar de apenas uma pequena e discreta elevação marginal a várias cristas complexas. Segundo Bennett (2001), que tomou como base Boulton et al. (1999), apesar da ampla variedade de combinações de morfologias, estilos de deformaçöes e escalas de encurtamento da margem frontal, as morainas de empurrão podem ser divididas nas seguintes categorias, de acordo com o incremento no esforço compressivo:

1) Morainas de Empurrão Pequenas ( $\leq 5 \mathrm{~m}$ de altura), com uma crista simples orientada paralelamente à margem da geleira. As deformações ocorrem perto da margem do gelo em uma zona estreita, normalmente como consequência de flutuações sazonais da posição da margem do gelo. Estas morainas de empurrão também são denominadas de sazonais ou anuais (Sharp, 1984; Boulton 1986). Comumente, as cristas apresentam perfis assimétricos, possuindo inclinações mais suaves na face próxima da geleira e mais íngreme na face mais distal, além de estarem comumente associadas a flutes (van der Meer, 1997).

2) Morainas de Empurrão Grandes ( $\geq 5 \mathrm{~m}$ de altura), com uma crista simples orientada paralelamente à margem da geleira. São decorrentes de avanços mais efetivos da margem de gelo, usualmente causados por mudanças marcantes no balanço de massa da geleira. 
3) Morainas de Empurräo, com várias cristas estreitas, nas quais deformações significativas ocorrem horizontalmente entre 50 a $300 \mathrm{~m}$ da margem da geleira e por uma espessura de 10 a $20 \mathrm{~m}$. O estilo das deformações pode envolver dobras múltiplas ou acavalamentos listricos.

4) Morainas de Empurrão, largas e com várias cristas, nas quais as ocorrências de deformações relacionadas superam, horizontalmente, $300 \mathrm{~m}$ da margem da geleira e por uma espessura de 10 a $20 \mathrm{~m}$. O estilo das deformações, normalmente, apresenta acavalamentos imbricados ou nappes subhorizontais superimpostas, produzidas pelos acavalamentos.

Com base nesta classificação, as estruturas proglaciotectônicas, pré-pleistocênicas, também podem ser classificadas com base nas dimensões das deformações. Havendo a possibilidade de medir-se a altura e a abrangência horizontal das deformações, seja por métodos diretos ou indiretos (e.g.: através da utilização de GPR, quando houver pouca argila associada), poder-se-á classificá-las, respectivamente, em estruturas proglaciotectônicas pequenas (sazonais); grandes; múltiplas e estreitas; e múltiplas e largas. No entanto, em depósitos sedimentares antigos, nem sempre é possivel mensurar as dimensões exatas destas ocorrências, sendo, portanto, aconselhável a sua generalização, denominando-as apenas como estruturas proglaciotectônicas. Em outras palavras, a classificação destas estruturas proglaciotectônicas pré-pleistocênicas deve ser aplicada apenas em ocorrências indubitáveis.

\subsection{DESCRIÇÃO DOS AFLORAMENTOS E ESTRATIGRAFIA DE WITMARSUM}

Os afloramentos estudados na Colônia Menonita de Witmarsum, Palmeira (PR), possuem um caráter singular, por não terem sido até então documentados e por representarem, possivelmente, as primeiras ocorrências de deformação proglaciotectônica afetando sedimentos do Neopaleozóico. Os estudos realizados nesta região foram divididos em três partes. $\mathrm{Na}$ primeira etapa, foram realizados o mapeamento geológico e 0 levantamento estratigráfico da área estudada. Esta fase contou com a colaboração do geólogo Ivo Trosdtorf Junior, que estudou concomitantemente a geologia glacial desta região. Os dados desta primeira etapa foram apresentados e estão pormenorizados na sua dissertação de mestrado, Trosdtorf $\mathrm{Jr}$. (2002), tendo sido sintetizados no próximo tópico. $\mathrm{O}$ segundo tópico caracterizou-se pela análise estrutural de uma falha tectônica, associada à área estudada, que produziu uma série de novos dados e que serviram para modificar as interpretações iniciais. Já a terceira etapa consistiu no detalhamento das estruturas proglaciotectônicas, o qual abrangeu principalmente análises estruturais e interpretações quanto à origem daquela estrutura. 


\subsubsection{Mapeamento Geológico e Estratigrafia}

A região já havia sido mapeada anteriormente na escala 1:50.000 por Fuck et al. (1965), Folha Geológica de Quero-Quero, e abrange o célebre pavimento estriado descrito por Bigarella et al. (1967). Contudo, no decorrer dos estudos, contatou-se que a estratigrafia do Subgrupo Itararé na localidade era mais complexa e variada do que a representada nesse trabalho pioneiro. A quantidade e as características dos diamictitos, assim como as suas relações mútuas de contato com outras rochas associadas, tornaram necessário um estudo mais pormenorizado da geologia local, resultando no mapa geológico da Colônia Menonita de Witmarsum, com escala de 1:25.000 (Anexo I; Trosdtorf Jr., 2002).

As rochas sedimentares reconhecidas nesta região estão relacionadas à Formação Furnas (Devoniano) e ao Subgrupo Itararé (Permo-Carbonífero), sendo que, no contexto deste trabalho, a Formação Furnas foi considerada como embasamento local do Subgrupo Itararé. No perfil geológico levantado ao longo de $6 \mathrm{~km}$ da estrada de ligação entre Witmarsum e a BR-277 (Figura 5.2.1.1), o Subgrupo ltararé apresenta aproximadamente $114 \mathrm{~m}$ de espessura exposta, onde predominam pacotes alternados de diamictitos $\mathrm{e}$ arenitos de diversos tipos e, subsidiariamente, de siltitos e arenitos conglomeráticos. Essa disposição resulta em uma topografia atual escalonada, com os arenitos sustentando as escarpas sobre os diamictitos. Com base nas análises estratigráficas, que consistiram no levantamento de algumas seções geológicas e perfis estratigráficos, foi possivel ordenar a sucessão litológica exposta em 5 (cinco) associações faciológicas, denominadas como unidades por Trosdtorf Jr. (2002), que se seguem, ordenadas da base para o topo:

Unidade 1 (Formação Furnas) - Composta por arenitos finos a grossos, quartzosos, frequentemente feldspáticos, com pouca matriz e, geralmente, mal selecionados. Formam bancos de espessura variando de decímetros a metros, normalmente com estratificação cruzada de porte médio a grande, tabular, tangencial na base e com granodecrescência ascendente. Nota-se entre esses bancos a ocorrência de intercalações de lentes e camadas centimétricas silto-argilosas. Conforme já comentado por Bigarella et al. (1967), nem sempre é fácil distinguir os arenitos da Formação Furnas dos do Subgrupo Itararé, quando imediatamente superpostos, o que justifica algumas modificações aqui propostas à geologia da Folha Quero-Quero. Como forma de diferenciar os arenitos utilizou-se a orientação das paleocorrentes, visto que são distintas nas duas unidades, e a presença ou não de deformações, feição esta presente apenas nos sedimentos do Subgrupo Itararé nesta localidade; visto que através das características sedimentológicos não foi possível tal diferenciação. O contato superior apresenta uma descontinuidade erosiva, em muitos casos correspondendo a uma discordância angular, com ângulo apertado, podendo, inclusive, caracterizar numa paraconformidade. Já o limite inferior não foi observado na região. 


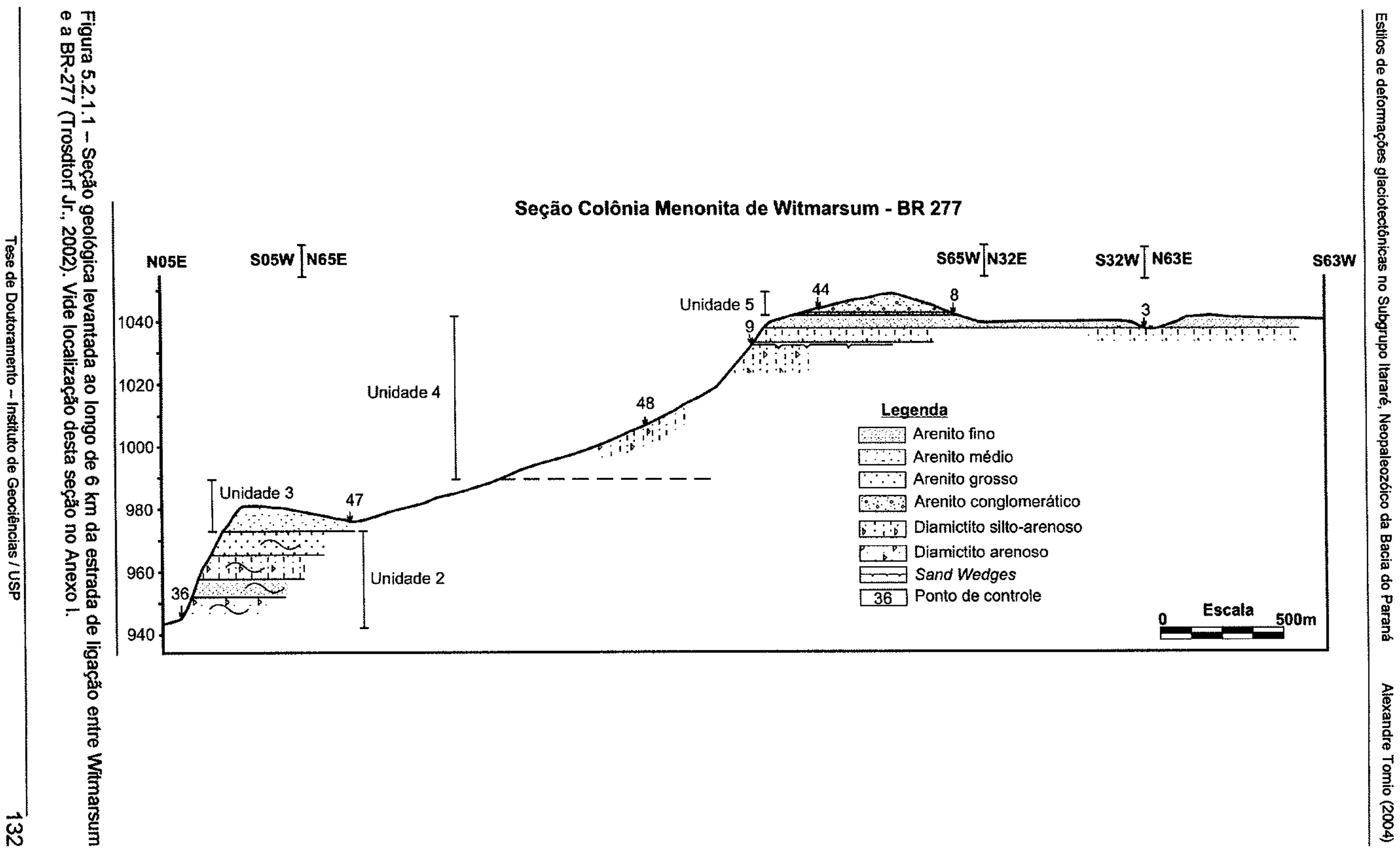


Merecem especial ênfase as diversas superfícies estriadas, subhorizontais, entalhadas nos contatos superiores desta unidade, caracterizadas, historicamente, pelo clássico "pavimento estriado de Witmarsum". Ao todo existem dezessete exposições de superficies estriadas que foram identificadas na regiäo (Bigarella et al., 1967; Fuck \& Bigarella, 1967; Canuto, 1985; Trosdtorf Jr., 2002), onde se desenvolvem estrias e sulcos retilineos e paralelos. A orientação média das feições é de N348 e as superfícies que as hospedam encontram-se localmente basculadas por falhamento. Outra caracteristica marcante desse nivel é a impregnação de limonita nos arenitos Furnas, fato que pode ter auxiliado na preservação das estruturas. Com relação, especificamente, ao clássico "pavimento estriado de Witmarsum", aflorante junto à cooperativa da colônia, prevalecem os sulcos, cujo comprimento máximo visivel é de $10 \mathrm{~m}$, largura e profundidade máximas de 40 $\mathrm{cm}$ e $10 \mathrm{~cm}$, respectivamente, embora também ocorram estrias dentro dos sulcos e sobre as cristas intermediárias.

Unidade 2 (Subgrupo Itararé) - Formada predominantemente por diamictitos e secundariamente por arenitos. Os diamictitos apresentam-se sob a forma de corpos com espessura variando de decímetros a metros, com matriz de composição arenosa, siltoarenosa ou silto-argilosa e coloração avermelhada, branca, amarela e cinza. Os clastos encontram-se dispersos na matriz e possuem normalmente granulometria milimétrica a centimétrica, raramente atingindo dimensões decimétricas. Com relação à estrutura interna, os corpos apresentam-se maciços, estratificados, laminados, "foliados" (com estratificação descontínua) e cisalhados. A geometria destes corpos de diamictito varia entre: tabulares, com contatos bruscos e erosivos; anticlinais maciços, irregulares, complexamente interdigitados, deformados e intercalados por camadas centrimétricas a decimétricas de arenito fino; e feições morfológicas coliniformes de 4-5 $\mathrm{m}$ de altura e 5-8 $\mathrm{m}$ de largura, onde o diamictito encontra-se bem estratificado e deformado por falhas normais e reversas, fraturas e dobras (Figura 5.2.1.2). Outras estruturas importantes para este trabalho, identificadas atrás da Companhia de Laticínios Cancela e pertencentes a esta unidade, são os diques clásticos de origem subglacial, que serão detalhados no Subcapítulo 5.2.3.

Arenitos encontram-se deformados, intercalados nos diamictitos e capeando as estruturas anticlinais e coliniformes. Sua coloração varia entre ocre e amarela e a sua espessura chega a $5 \mathrm{~m}$ na porção superior da unidade. Estratificações cruzadas acanaladas de pequeno porte e pequenas dobras de vergência para NW e/ou NE são comuns.

Unidade 3 - Constituída por bancos de arenito de características diversificadas e aproximadamente 10,84 m de espessura total. Esta unidade é composta por 3 (três) pacotes de arenito, com uma camada fina ou lente de diamictito intercalada. 
Esta unidade foi detalhada no segundo intervalo da seção aflorante no morro "Siebert" (Figura 5.2.1.3), localizado próximo à Gástehaus (Pousada) Siebert (Anexo I). Nesta seção, o intervalo inferior representa a Unidade 2, com exposiçöes descontínuas de camadas decimétricas a métricas de diamictitos arenosos estratificados e camadas menos espessas de arenito fino, laminado, e um arenito médio-grosso, com estratificação cruzada acanalada e tangencial, lentes conglomeráticas e dobras de pequeno porte (Figura 5.2.1.3; banco A).

O segundo intervalo da seção (Unidade 3), consiste, basicamente, de três bancos de arenito. $\mathrm{Na}$ porção basal da seção, encontram-se arenitos grossos, brancos, com estratificação cruzada tabular de grande porte (Figura 5.2.1.4; banco B), seguido por uma camada ou lente de diamictito de $45 \mathrm{~cm}$ de espessura, maciço, matriz arenosa, vermelho a amarelo esbranquiçado, com clastos milimétricos a centimétricos; seguem arenitos finosmédios, ocres a amarelados, feldspáticos, com raros clastos milimétricos dispersos e estratificação cruzada acanalada e tangencial na base (2,46 m de espessura; Figura 5.2.1.3; banco $\mathrm{C}$ ); e arenito médio, ocre, com lentes métricas de arenito grosso até conglomerático intercaladas, estratificação plano-paralela e/ou cruzada longa e de baixo ângulo $(6,8 \mathrm{~m}$ de espessura; 5.2.1.3; banco D).

Unidade 4 - Apresenta uma grande variedade de litofacies, onde predominam arenitos finos a conglomeráticos e diamictitos, $e$, secundariamente, siltitos. Os diamictitos têm matriz siltosa a arenosa, encontram-se estratificados ou maciços e suas cores variam entre vermelho, ocre e amarelo, além de conterem clastos dispersos variando de milimétricos a centimétricos. Os arenitos variam de finos a médios, feldspáticos, normalmente com estratificação cruzada de pequeno porte e tangencial na base, podendo, em alguns lugares, apresentar granodecrescência ascendente. Os siltitos apresentam laminações finas, planoparalelas, cor ocre e podem apresentar estruturas de corte e preenchimento.

Unidade 5 - Formam esta unidade três litofacies: um diamictito amarelo, arenoso, aparentemente maciço, com clastos milimétricos a centimétricos; arenito conglomerático, branco, maciço, com clastos milimétricos subangulosos; e siltito, branco, maciço e silicificado, com aureolas de liesegang, aqui denominado informalmente de porcelanito. Geometricamente essas litofacies podem apresentar formas lenticulares e tabulares de contatos normalmente bruscos.

\footnotetext{
${ }^{14} \mathrm{O}$ referido morro é localmente denominado pela comunidade como o morro da Imandade, contudo antes de obter esta informaçăo, já estava sendo empregado informalmente o nome de Siebert (e.g.: Trosdtorf Jr., 2002) e, consequentemente, foi mantido para facilitar as correlações com outros trabalhos.
} 


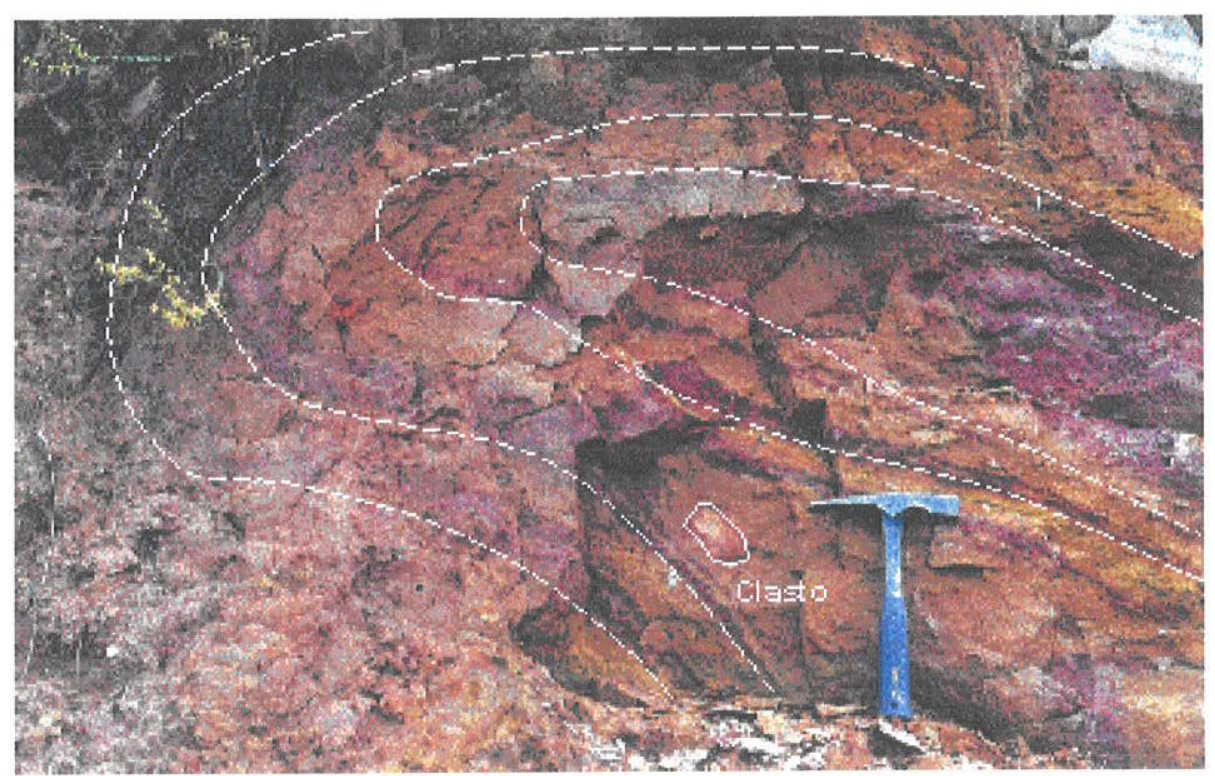

Figura 5.2.1.2 - Diamictito dobrado, silto-arenoso, amarelo, estratificado com bandas avermelhadas, aflorando cerca de $350 \mathrm{~m}$ atrás da casa da Fazenda Schoeder. Foto de Ivo Trosdtorf Junior. Escala: martelo geológico.

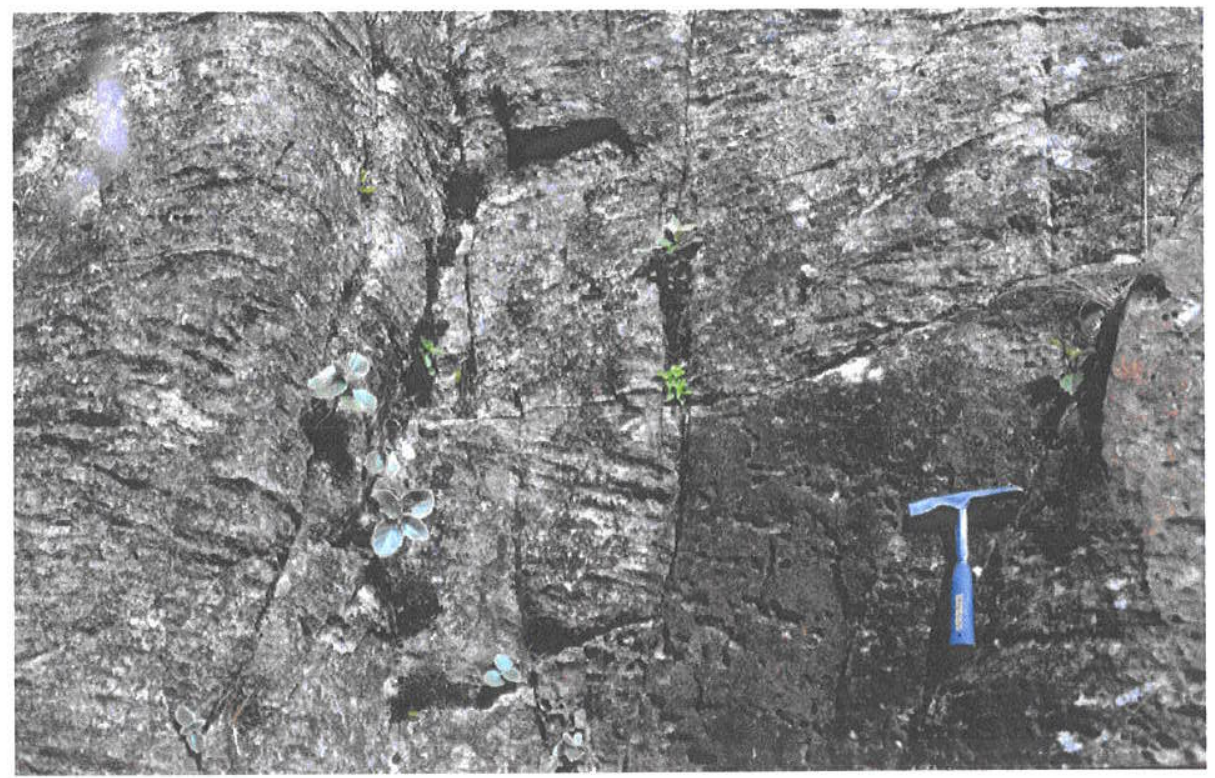

Figura 5.2.1.4 - Estratificação cruzada de grande porte, seção do morro Siebert (Figura 5.2.1.3; banco B). Foto de Ivo Trosdtorf Junior. Escala: martelo geológico. 


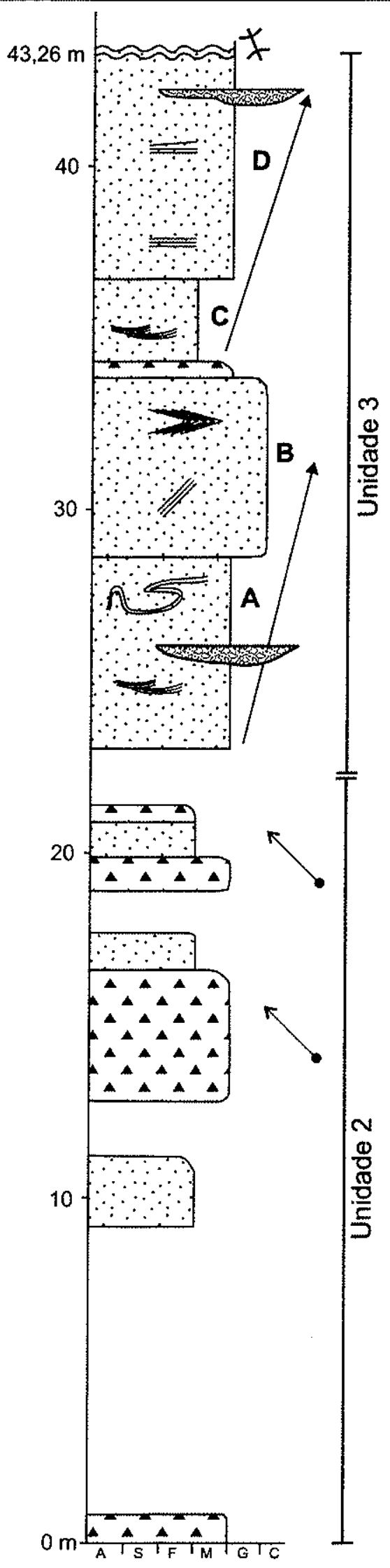

\section{LEGENDA}

$\because \because \because \quad$ Arenito

Diamictito

凡 Dobras decimétricas

× Superficie estriada e sulcada

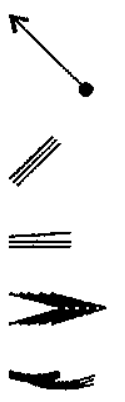

Direção do mergulho dos estratos

Estratificação cruzada tabular

Estratificação cruzada de baixo ângulo

Estratificação cruzada de grande porte

Estratificação cruzada acanalada

A, B, C e D Bancos de arenito

Figura 5.2.1.3 - Seção levantada no morro atrás da Pousada Siebert em Witmarsum (Trosdtorf Jr., 2002). Vide localização desta seção no Anexo $\mathrm{I}$. 


\subsubsection{Tectônica Local de Witmarsum (Falha Cancela)}

A análise dos mapas geológicos disponiveis da região e adjacências (folhas de Quero-Quero, Porto Amazonas, Campo Limpo e Contenda, respectivamente, Fuck et al., 1965; Palka et al., 1965; Muratori et al., 1965; Trein et al., 1965), permite observar dois sistemas de fraturas (NW-SE e NE-SW) controlando as principais drenagens. Diques de diabásio (NW-SE) e falhas NW-SE e NE-SW são raros.

A principal estrutura presente na área estudada é a Falha Cancela (Anexo 1), cuja direção é aproximadamente $E-W$, na qual se instalou o rio de mesmo nome. Inicialmente, Biagella et al., (1967) interpretaram esta falha como normal e de pequeno rejeito, porém análises mais detalhadas em vários pontos aflorantes revelaram uma complexidade maior.

Com base nos estudos realizados verifica-se que a Falha Cancela seria, na realidade, um falhamento do tipo transcorrente destral (right-hand strike-slip fault), com componentes transtrativas e transpressivas. Sua caracterização é de suma importância já que existem poucos registros de falhamento transcorrentes significativos na Bacia do Paraná estudados como detalhe. No intuito de caracterizar tal regime de esforços, foram desenvolvidas várias análises estruturais ao longo da falha, com destaque para os afloramentos aqui denominados "Paredão Cancela", localizado atrás da Companhia de Laticinios Cancela, e "Schroeder", situado na fazenda homônima (Anexo l).

No Paredão Cancela observa-se em uma espessa camada de arenito, intercalada por finas camadas de argila (milimétricas) da Formação Furnas, planos de acamamento dobrados, além de uma intensa malha de fraturamentos e falhamentos (Figura 5.2.2.1). Foram constatados pequenos falhamentos normais, com rejeito decimétrico, observados no topo da seção, possivelmente relacionados ao alivio de tensões.

A dobra presente no Paredão Cancela forma uma grande anticlinal aberta e, como as camadas praticamente não mudam de espessura, pode-se classificá-la como do tipo $1 \mathrm{~B}$ (Ramsay, 1967; Ramsay \& Huber, 1987), também denominada como dobra paralela (Figura 5.2.2.1). Medições indiretas (calculadas através dos acamamentos) indicaram que o eixo axial da dobra é subhorizontal caindo suavemente para sul (N300/56) e o seu plano axial é subvertical (N256/64, Figura 5.2.2.2). Os dados oriundos das fraturas conjugadas foram plotados no estereograma de Schimdt-Lambert (Figura 5.2.2.2) e indicam que o esforço compressivo máximo, aparentemente relacionado à dobra, foi horizontal e de direção $E-W$ (N076/26) e ângulo diedral (20) de $72^{\circ}$, o que, de acordo com Hancock (1985), é sugestivo de fraturamento cisalhante compressional. Contudo, segundo Ramsay \& Huber (1987), as falhas transpressionais normalmente apresentam dobramentos e acavalamentos associados, onde o eixo axial dispõe-se entre 40 e $45^{\circ}$ da direção do plano da falha transcorrente, caso o cisalhamento seja simples, orientação esta diferente das falhas de acavalamento, o que demonstra possiveis rotações entre os blocos. 

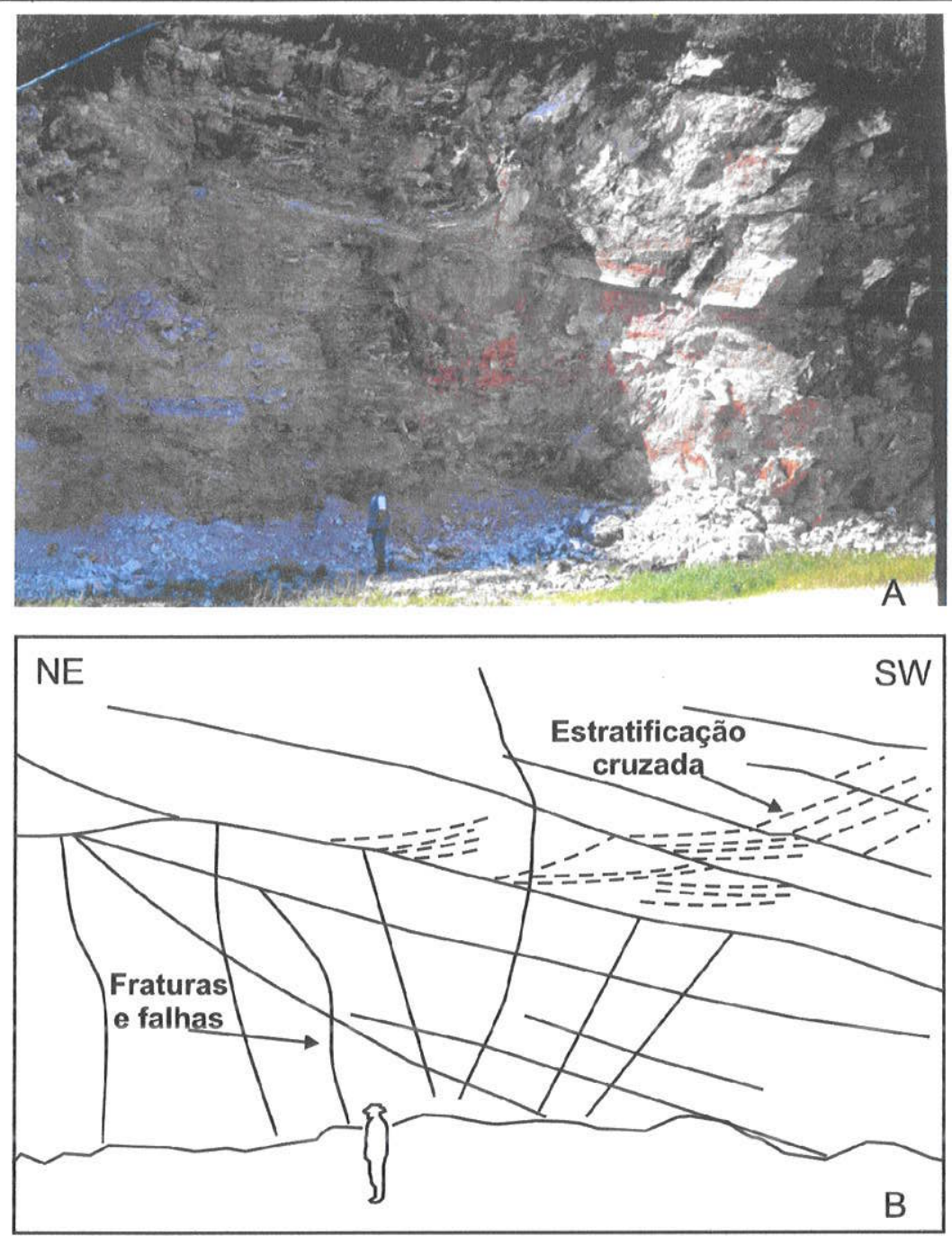

Figura 5.2.2.1 - "Paredão Cancela", atrás da Companhia de Laticínios Cancela. A) Foto ilustrando o arenito da Formação Furnas intensamente fraturado, em virtude do regime de esforços compressivos decorrentes da Falha Cancela; B) interpretação da foto. Escala: uma pessoa com 1,80 m de altura.

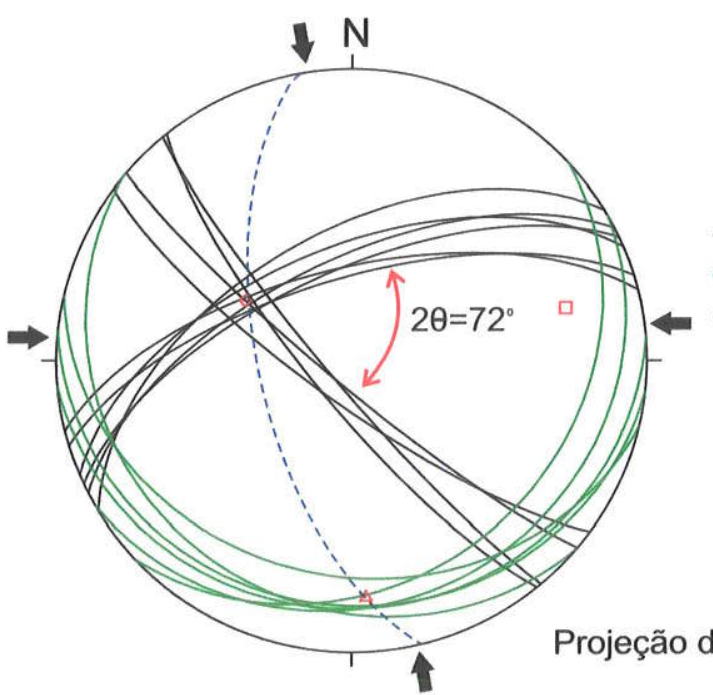

Figura 5.2.2.2 - Estereograma com fraturas e acamamentos obtidos em campo e eixo de dobra, plano axial e eixos de esforços adquiridos indiretamente, mostrando o regime de esforços compressivos sub-horizontal nos arenitos da Formação Furnas. 
Deslocando-se $100 \mathrm{~m}$ para leste, ao longo do paredão, o traço do plano de falha adquire uma feição ondulada (Figura 5.2.2.3), variando de vertical a inclinado, com ocorrências de brecha de falha composta por fragmentos angulosos do diamictito e do arenito, que chega a medir $33 \mathrm{~cm}$ de espessura, formada pelo acavalamento dos diamictitos do Subgrupo Itararé pelos arenitos da Formação Furnas (Figura 5.2.2:4). Uma das componentes reversas da falha transcorrente encontra-se ao lado do refeitório da Companhia de Laticineos Cancela (Figura 5.2.2.3, Anexo I), cuja direção é N063 (atitude do plano de falha N333/67). Ressalta-se que esta situação encontra-se muito próxima do célebre pavimento estriado de Witmarsum (Bigarella et al., 1967), que ocorre sobre os arenitos da Formaçăo Furnas. A $10 \mathrm{~m}$ para leste do citado pavimento, encontra-se o outro plano de falha, este, porém, subvertical (atitude de N328/83, ou seja, direção de N068) e sentido destral (Figura 5.2.2.4), deduzido através de lineações incipientes no plano de falha (N243/33).

Outro plano de falha foi observado $10 \mathrm{~m}$ para sul da frente do Paredão Cancela (Anexo 1), num pequeno curso d'água, que formou uma pequena ravina. Nesta ravina, novamente, se observa o acavalamento citado anteriormente, onde os arenitos da Formação Furnas encontram-se sobre os diamictitos do Subgrupo Itararé. Este falhamento, todavia, apresenta o plano de falha com atitude de N004/73.

A presença dos falhamentos, tanto inversos quanto transcorrentes, em uma distância de poucos metros, associados com o fraturamento conjugado do Paredão Cancela, demonstra que se trata de um falhamento transcorrente, destral, com componentes transpressivas (nesta localidade). Além do mais, trata-se de um falhamento com plano de falha irregular, embora com direçăo aproximada leste-oeste, visto a variação da atitude dos planos de falha, entre N328 e N004.

$\mathrm{Na}$ Fazenda Schroeder, a aproximadamente $1,5 \mathrm{~km}$ do afloramento do Paredão Cancela (Anexo 1), uma série de falhas cortam a Formação Fumas, provocando o deslocamento e escalonamento de blocos contendo um pavimento estriado (Figura 5.2.2.5), que, neste caso, serviram como camada-guia para o reconhecimento da estratigrafia local. Nas figuras 5.2.2.6, 5.2.2.7 e 5.2.2.8 observamse um pequeno acavalamento dos sedimentos devonianos sobre os permo-carboníferos, fato também observado em outras porções do afloramento. $\mathrm{Na}$ realidade, estas estruturas demonstram o soerguimento de parte de um bloco contendo rochas da Formação Furnas, através de falhas inversas que representam esforços transpressivos, e o abatimento da outra porção do bloco, evidenciado pelas sistemáticas falhas normais estabelecidas por esforços transtensionais. Esta combinação de esforços é interpretada como tendo sido ocasionada por uma intensa rotação do bloco, semelhante ao apresentado por Ramsay \& Huber (1987, Figura 5.2.2.9). 
Deslocando-se $100 \mathrm{~m}$ para leste, ao longo do paredão, o traço do plano de falha adquire uma feição ondulada (Figura 5.2.2.3), variando de vertical a incliriado, com ocorrências de brecha de falha composta por fragmentos angulosos do diamictito e do arenito, que chega a medir $33 \mathrm{~cm}$ de espessura, formada pelo acavalamento dos diamictitos do Subgrupo Itararé pelos arenitos da Formação Fumas (Figura 5.2.2.4). Uma das componentes reversas da falha transcorrente encontra-se ao lado do refeitório da Companhia de Laticineos Cancela (Figura 5.2.2.3, Anexo 1), cuja direção é N063 (atitude do plano de falha N333/67). Ressalta-se que esta situação encontra-se muito próxima do célebre pavimento estriado de Witmarsum (Bigarella et al., 1967), que ocorre sobre os arenitos da Formação Furnas. A $10 \mathrm{~m}$ para leste do citado pavimento, encontra-se o outro plano de falha, este, porém, subvertical (atitude de N328/83, ou seja, direção de N068) e sentido destral (Figura 5.2.2.4), deduzido através de lineações incipientes no plano de falha (N243/33).

Outro plano de falha foi observado $10 \mathrm{~m}$ para sul da frente do Paredão Cancela (Anexo 1), num pequeno curso d'água, que formou uma pequena ravina. Nesta ravina, novamente, se observa o acavalamento citado anteriormente, onde os arenitos da Formação Furnas encontram-se sobre os diamictitos do Subgrupo Itararé. Este falhamento, todavia, apresenta o plano de falha com atitude de N004/73.

A presença dos falhamentos, tanto inversos quanto transcorrentes, em uma distância de poucos metros, associados com o fraturamento conjugado do Paredão Cancela, demonstra que se trata de um falhamento transcorrente, destral, com componentes transpressivas (nesta localidade). Além do mais, trata-se de um falhamento com plano de falha irregular, embora com direção aproximada leste-oeste, visto a variação da atitude dos planos de falha, entre N328 e N004.

$\mathrm{Na}$ Fazenda Schroeder, a aproximadamente $1,5 \mathrm{~km}$ do afloramento do Paredão Cancela (Anexo 1), uma série de falhas cortam a Formação Furnas, provocando o deslocamento e escalonamento de blocos contendo um pavimento estriado (Figura 5.2.2.5), que, neste caso, serviram como camada-guia para o reconhecimento da estratigrafia local. Nas figuras 5.2.2.6, 5.2.2.7 e 5.2.2.8 observa-se um pequeno acavalamento dos sedimentos devonianos sobre os permo-carboniferos, fato também observado em outras porções do afloramento. Na realidade, estas estruturas demonstram o soerguimento de parte de um bloco contendo rochas da Formação Furnas, através de falhas inversas que representam esforços transpressivos, e o abatimento da outra porção do bloco, evidenciado pelas sistemáticas falhas normais estabelecidas por esforços transtensionais. Esta combinação de esforços é interpretada como tendo sido ocasionada por uma intensa rotação do bloco, semelhante ao apresentado por Ramsay \& Huber (1987, Figura 5.2.2.9). 


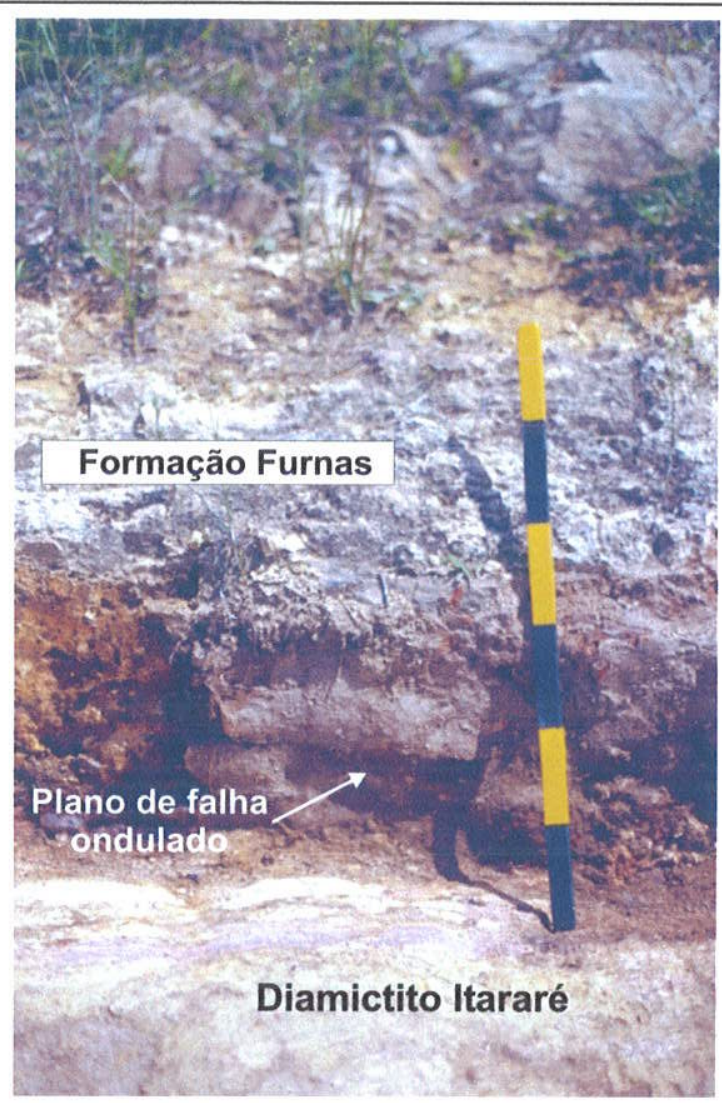

Figura 5.2.2.3 - Plano de falha subvertical, ondulado, sugerindo uma componente horizontal (falha transcorrente destral). Este falhamento coloca em contato lateral a Formação Furnas e o Subgrupo Itararé. Escala: tala de madeira dividida a cada $10 \mathrm{~cm}$.

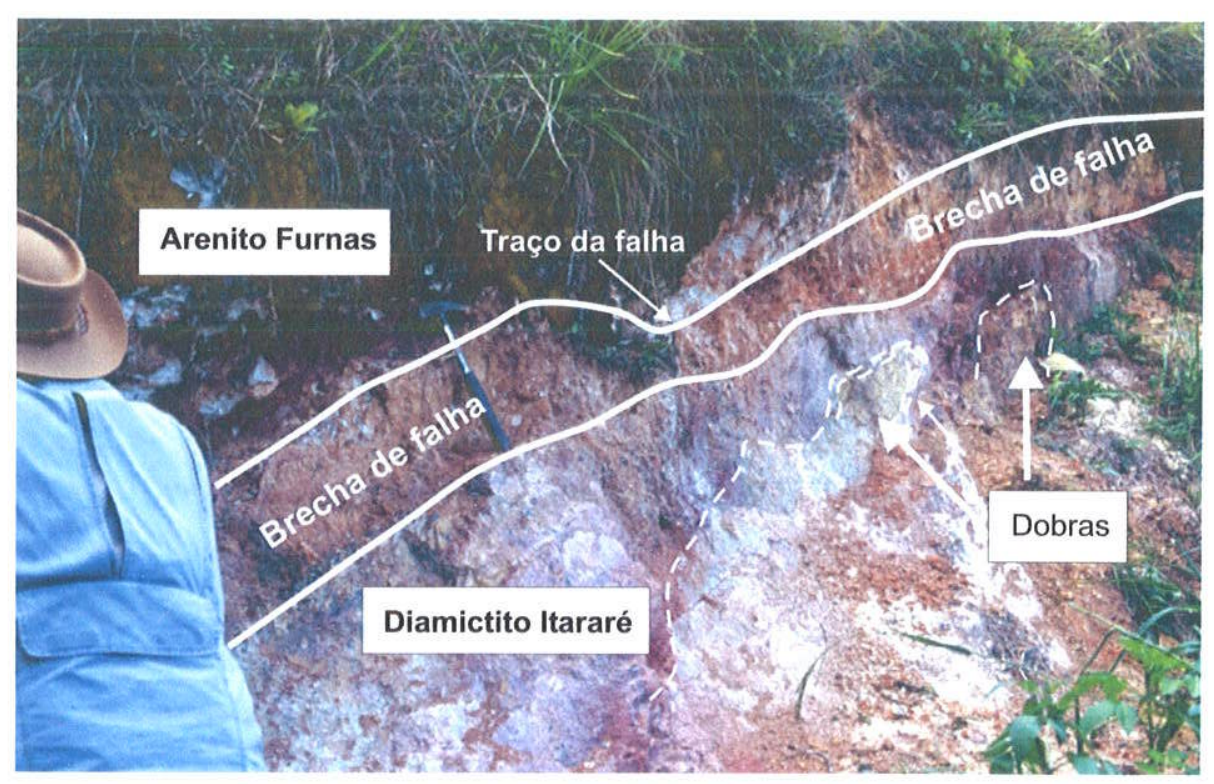

Figura 5.2.2.4 - Brecha de falha produzida pelo acavalamento dos arenitos Furnas sobre os diamictitos Itararé no falhamento Cancela, ao lado do refeitório da Companhia de Laticínios Cancela. 


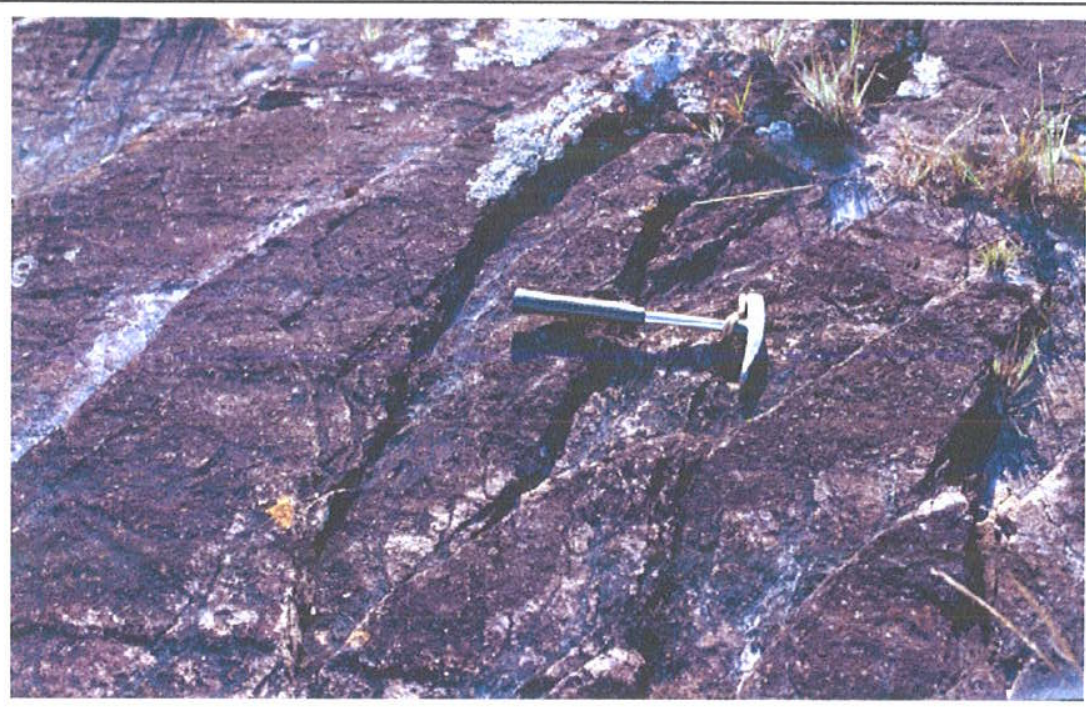

Figura 5.2.2.5 - Pavimento estriado, sobre a Formação Furnas, intensamente fraturado, formando degraus (Fazenda Schroeder). Foto de Ivo Trosdtorf Junior. Escala: martelo geológico.

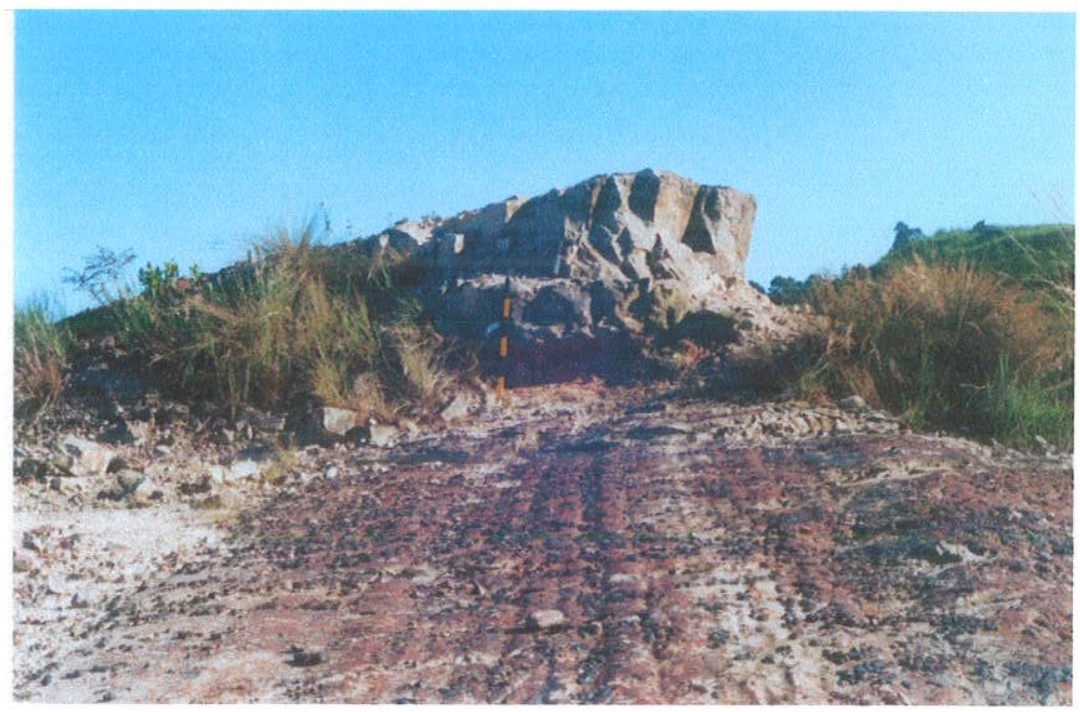

Figura 5.2.2.6 - Arenito Furnas cavalgando o diamictito Itararé. Observar que sobre o pavimento estriado, ao lado da escala, ocorre um diamictito em baixo de um bloco de arenito Furnas. Escala: tala de madeira dividida a cada $10 \mathrm{~cm}$.

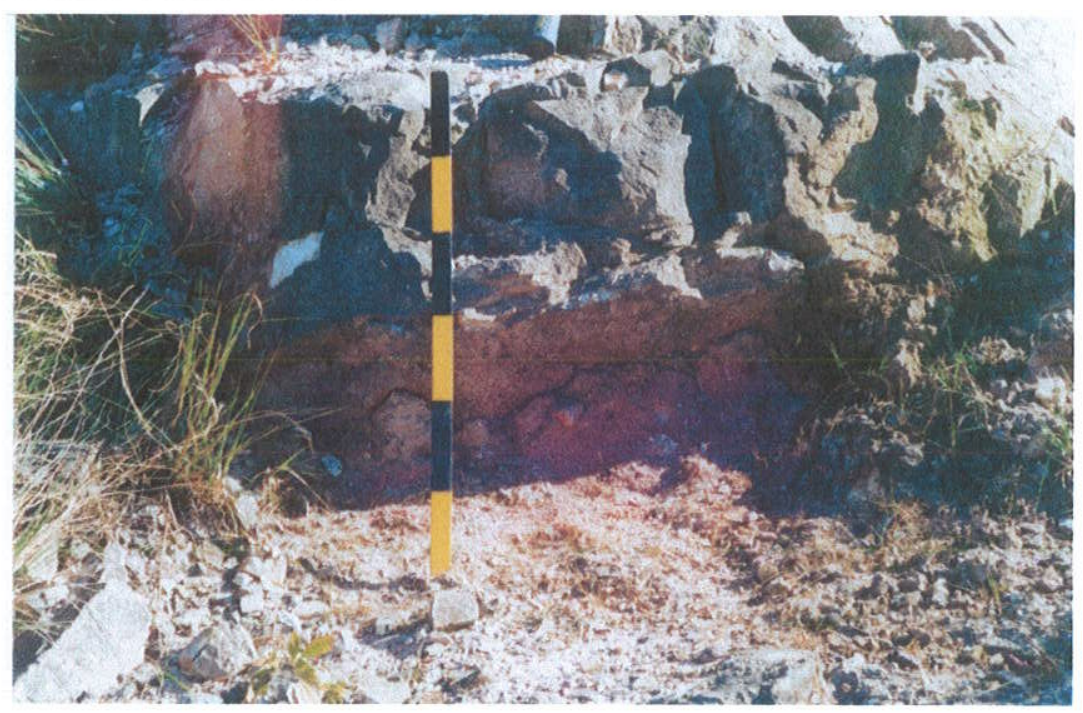

Figura 5.2.2.7 - Detalhe do diamictito Itararé que foi cavalgado por um bloco de arenito Furnas. Escala: tala de madeira dividida a cada $10 \mathrm{~cm}$. 


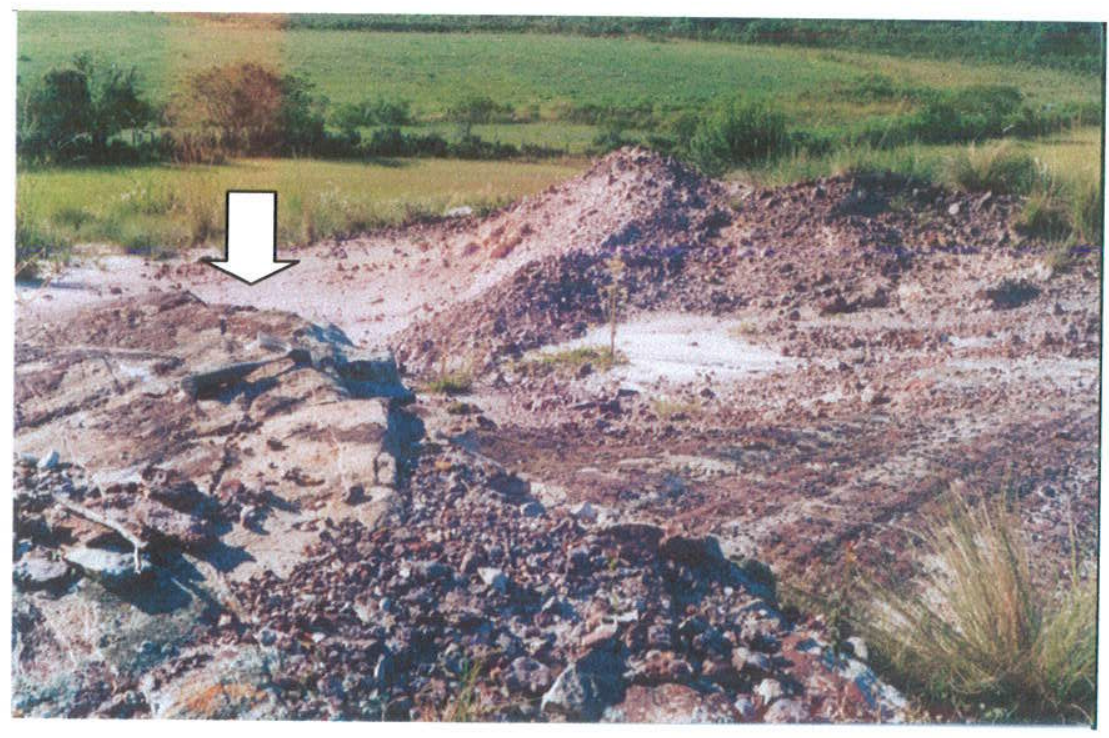

Figura 5.2.2.8 - Falha de empurrão da Fazenda Schroeder, semelhante a da Figura 5.2.2.6, porém vista de cima do bloco acavalado. Notar o pavimento estriado e sulcado sobre o bloco superior (indicado pela seta), com direção dos sulcos similar aos do pavimento inferior. Escala: martelo geológico, localizado no bloco de cima, abaixo da seta.

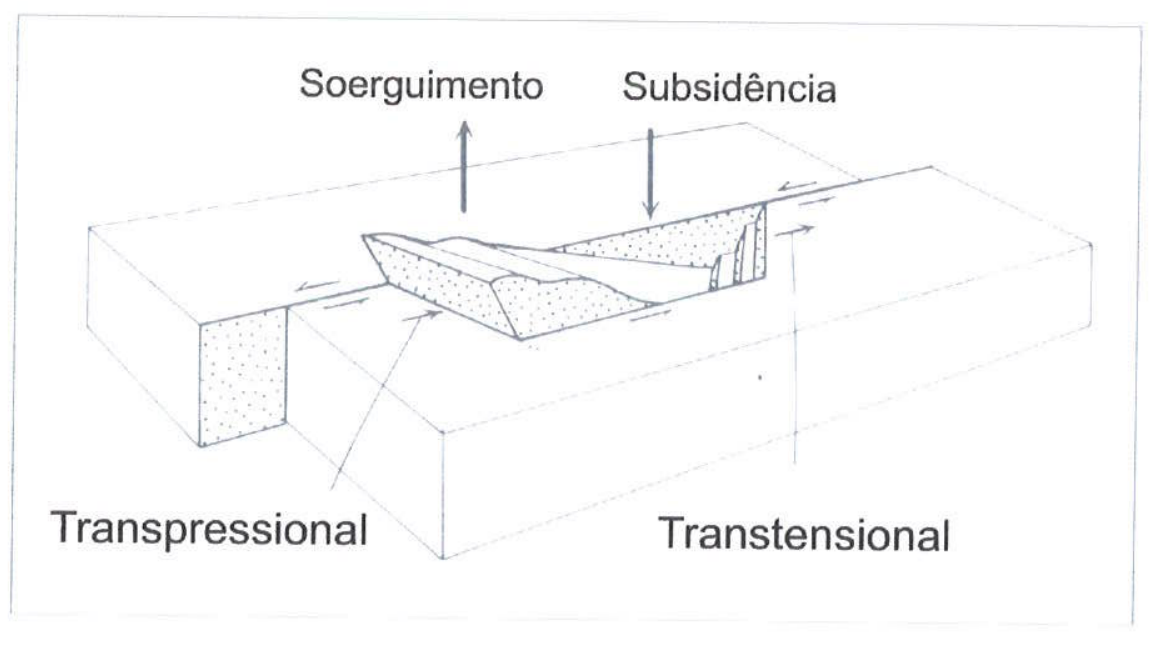

Figura 5.2.2.9 - Rotação de um bloco como resultado de esforços transpressionais e transtensionais combinados, em um falhamento transcorrente sinistral (adaptado de Ramsay \& Huber, 1987). 


\section{Clastos Partidos e Selados de Witmarsum (PR)}

Ainda neste mesmo afloramento da Fazenda Schroeder foram encontrados vários clastos partidos por fraturas paralelas ou obliquas aos seus eixos maiores, porém com as fatias de rochas aderidas umas as outras ("seladas") pela deposição secundária de cimento silicoso (Figura 5.2.2.10). Nota-se que em raros clastos houve um deslocamento relativo das fatias e posterior cimentação que as manteve unidas (Figura 5.2.2.11). A maioria dos clastos é de arenito, provavelmente da Formação Furnas, e de quartzito; são geralmente facetados, centimétricos, tabulares (ou oblatos), isoaxiais, alguns com lineações. As fraturas normalmente acompanham a estratificação da rocha, $e$, em apenas um caso, o fraturamento é independente da estrutura. Estes clastos partidos encontram-se em um fino corpo de diamictito arenoso, rico em clastos centimétricos a milimétricos, situado sobre uma extensa superficie estriada sobre o arenito Furnas.

A ocorrência destes clastos partidos foi inicialmente conexa a campos de blocos (block fields) segundo a literatura européia e a kurums, de acordo com a literatura russa (Trosdtorf Jr., 2002), e estariam associados a extensas superfícies de fragmentos angulosos de rocha, comumente relacionados à desintegração e partição mecânica de rochas por congelamento da água presente nos poros, juntas e planos de acamamento (French, 1996). No entanto, em virtude da magnitude do cisalhamento da Falha Cancela, parece mais plausivel considerar que tenham sido gerados tectonicamente, formando cracked-sealed clasts (clastos partidos e selados).

Em lâminas delgadas verificou-se que o material selante (o cimento) é formado, basicamente, por grãos de quartzo, além de raros grãos de feldspato e mica. A extinção ótica se distingue do restante da amostra e não se observa crescimento secundário no cimento, demonstrando ter havido um processo de recristalização. As paredes das fraturas e falhas são praticamente retilineas, sendo que alguns grãos aparentam terem sido cortados, enquanto que outros que não o foram, e possuem microfraturas internas exatamente onde estaria fratura principal. Notou-se, também, que há dois tipos de partição e selamento nas amostras desta localidade: em aiguns casos o clasto simplesmente foi fraturado e posteriormente foi selado com minerais oriundos dele mesmo, onde os grãos do material selante encontram-se irregulares; já outros clastos apresentam deslocamento formando grãos alongados no cimento, demonstrando que houve cisalhamento no momento da recristalização. Nestes clastos, são mais comuns a formação de uma zona de falha, visto a presença de mais de um plano de fraqueza que apresentou deslocamento. Estes dados não só tornam improvável a interpretação da intervenção de clima periglacial no processo de partição e selagem, como também descartam a hipótese de ação hidrotermal como agente selante dos clastos. 


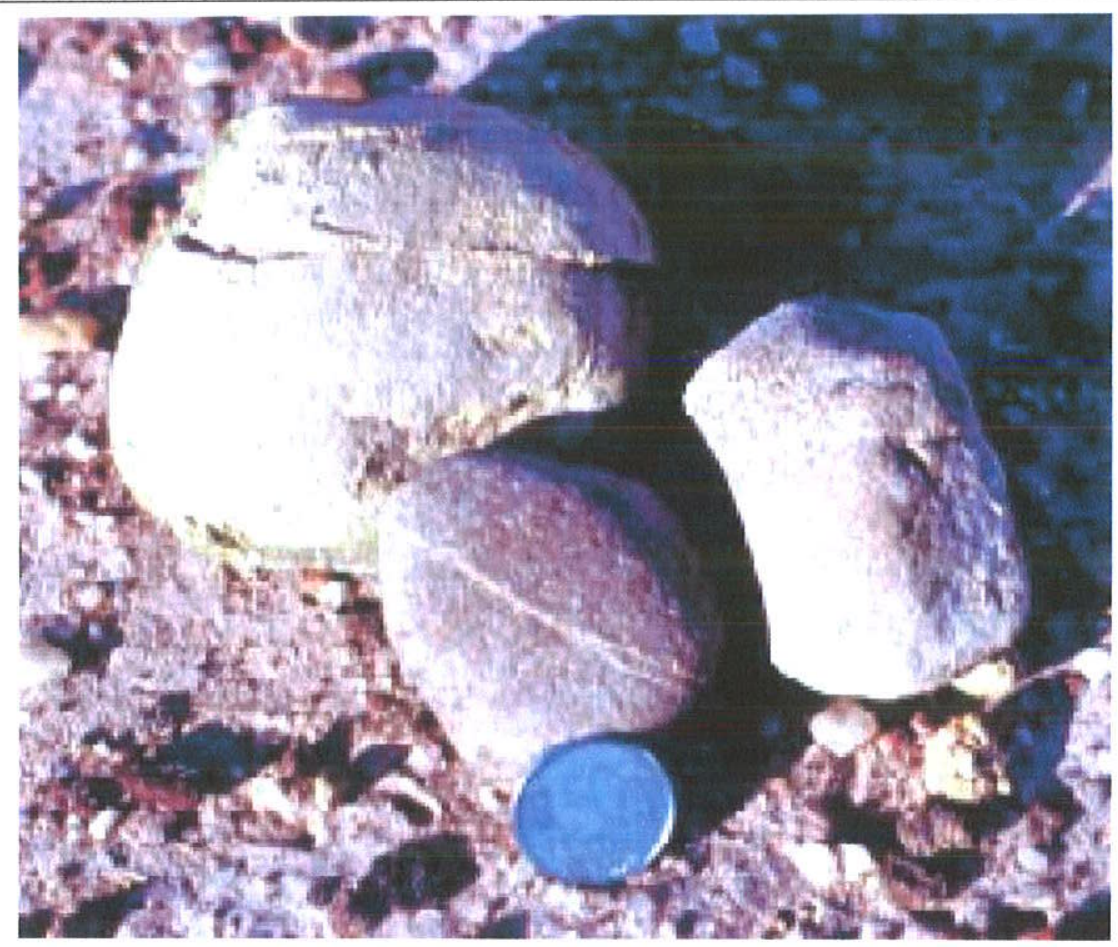

Figura 5.2.2.10 - Clastos partidos observados em campo na Fazenda Schroeder (Unidade 2), observar ligeiro deslocamento entre as parte do clasto maior à esquerda (Trosdtorf Jr., 2002). Escala: tampa da objetiva de uma câmera fotográfica.

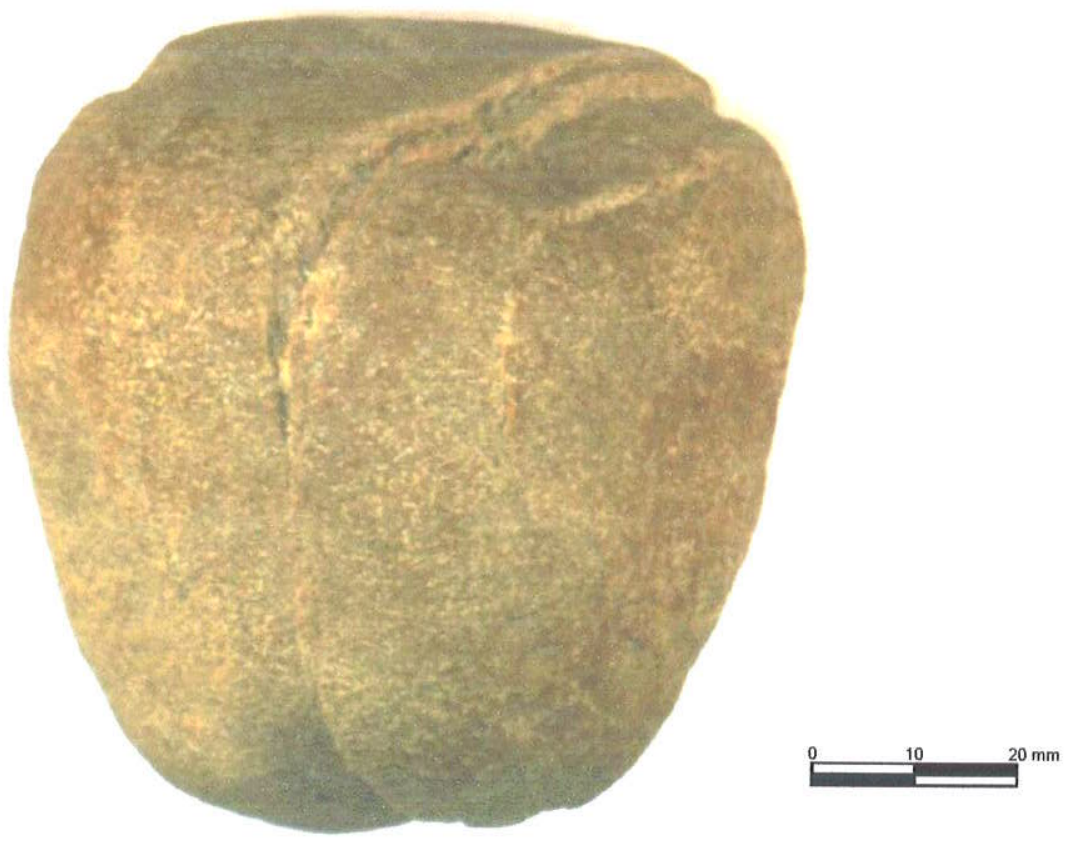

Figura 5.2.2.11 - Detalhe do clasto partido que sofreu deslocamento no plano de fraturamento. Notar que o fraturamento acompanha a incipiente estratificação da rocha da Unidade 2 (Trosdtorf Jr., 2002). 
Segundo Ramsay \& Huber (1987, p. 574), mecanismos de partição e selamento (crack-seal) podem ocorrer relacionados às atividades tectônicas locais. Durante um terremoto, por exemplo, mudanças bruscas e severas na pressão d'água intersticial podem ser geradas, fazendo com que, iniciaimente, a água intersticial diminua consideravelmente e após o terremoto aumente drasticamente em direção à superficie. Este repentino influxo (recarga) de água (normalmente quente e podendo conter saimouras) pode ocasionar a liquefação de sedimentos inconsolidados, a formação de diques clásticos e vulcões sedimentares, assim como o desenvolvimento de fluxos gravitacionais de massa dos sedimentos inconsolidados sobrejacentes, além de fissuras nas rochas em decorrência da variação na pressão d'água, o que poderia explicar a partição observada nos clastos.

Desta forma, com o aumento da pressão d'água, os três esforços principais do círculo de Mohr aumentariam igualitariamente, conforme a Figura 5.2.2.12, onde este acréscimo é representado por $\sigma$ (esforço decorrente do aumento da pressão). Esse incremento é funçäo do esforço efetivo e, por conseguinte, da pressão dos fluidos nos poros da rocha em questão. Este esforço adicional pode ser suficiente para atingir ponto $P$ do envoltório de Mohr e, consequentemente, falhar a rocha, no presente caso o diamictito e os seus clastos, de acordo com o ângulo $\theta$ (ângulo que a falha de cisalhamento faz com o sentido do esforço compressivo principal). Estas fissuras se expandem pouco, normalmente se distanciando 10-100 $\mu \mathrm{m}$, enquanto a deformação elástica se dissipa.

Desta forma, se o aumento do esforço for substancial e a rocha estiver litificada, apesar das diferenças internas quanto à porosidade e a resistência ao cisalhamento do diamictito, visto que é uma rocha heterogênea, tanto a matriz quanto os clastos atingiriam o ponto crítico e falhariam, contudo, formando ângulos distintos com o eixo compressivo principal $(\theta)$. Os pequenos deslocamentos nas superfícies de partição observados nos clastos (figuras 5.2.2.10 e 5.2.2.11), demonstram também que houve esforços obliquos ao plano de partição ou, alternativamente, estes esforços provocados pela água intersticial também apresentavam componentes direcionais, fato este muito provável, pois são fluxos ascendentes próximos ao falhamento que ocasionam o terremoto. Além do mais, estes fluxos não são providos apenas de água intersticial, mas podem também conter fluídos semelhantes aos presentes nas paredes da partição, ou totalmente diferentes dos presentes na rocha, ou mesmo uma mistura de líquidos com materiais provenientes da própria rocha e de outras fontes. Consequentemente, estes materiais podem se cristalizar nas superficies de partição, selando o clasto ou a rocha em questão (Figura 5.2.2.13). Nos clastos partidos e selados de Witmarsum, como a solução depositada nas paredes das fissuras foi silicosa $e$, ainda, como a maioria dos clastos é de arenito e quartzito, essas soluções seriam possivelmente provenientes dos próprios clastos ou mesmo dos arenitos da Formação Fumas subjacentes. 


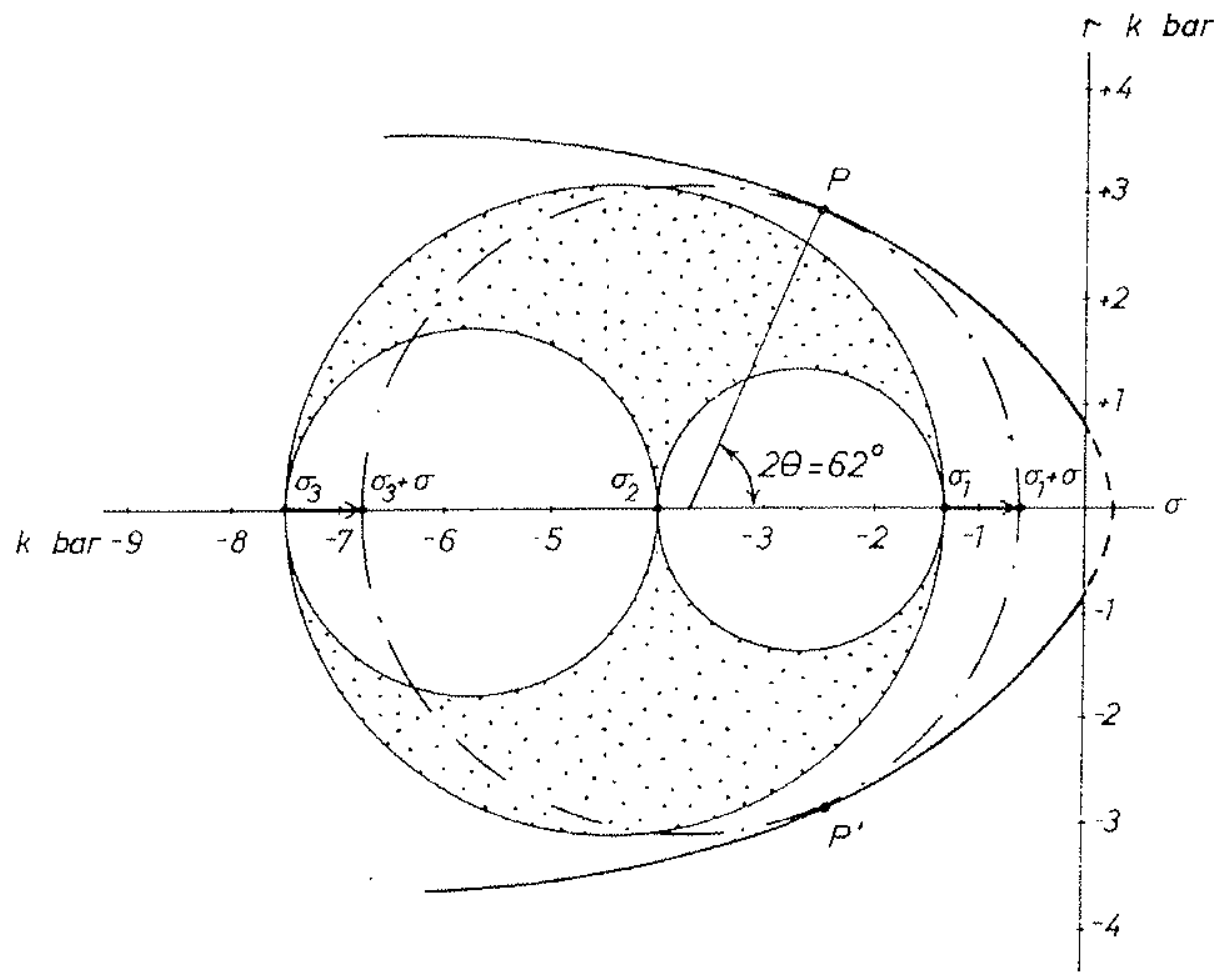

Figura 5.2.2.12 - Círculo de Mohr para estágios de esforços, onde $\sigma_{1}>\sigma_{2}>\sigma_{3}$, demonstrando as implicações de se aumentar igualmente um valor qualquer, representado por $\sigma$, em todos os esforços. Com o incremento os esforços deslocam-se para a direita e atingem a Envoltória do Círculo de Mohr em P (Ramsay \& Huber, 1987).
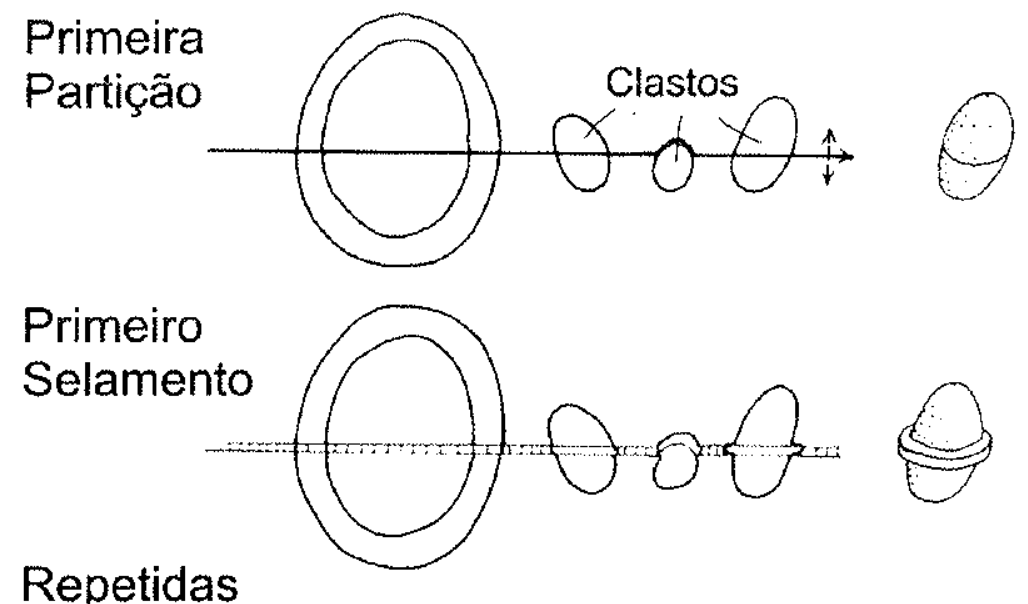

\section{Partições e Selamentos}
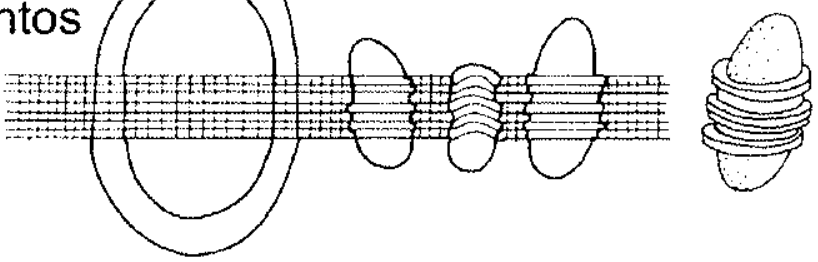

Figura 5.2.2.13 - Sequẽncia de eventos de partições e selamentos. Adaptado de Ramsay \& Huber (1987). 


\subsubsection{Estruturas Glaciotectónicas de Witmarsum}

Evidências de processos glaciotectônicos reconhecidas encontram-se basicamente restritas à Unidade 2 (Anexo l; figuras 5.2.1.1 e 5.2.1.3). Entre as estruturas glaciotectônicas de Witmarsum, merecem destaque as estruturas proglaciotectônicas, as quais, possivelmente, seriam correspondentes a morainas de empurrão (push moraines), relacionadas às colinas deformadas de diamictito e deformações em diamictitos associados a diques clásticos de origem subglacial.

\section{Diques Clásticos de Origem Subglacial}

Os diques clásticos de origem subglacial ocorrem alguns metros a oeste do Paredão Cancela, atrás da Companhia de Laticínios Cancela, em rochas da Unidade 2. Neste afloramento encontrou-se dois diques clásticos verticais, distando $5,25 \mathrm{~m}$ entre si e apresentando 65 e $95 \mathrm{~cm}$ de espessura e paredes bem planas com orientações de N335 e N338, respectivamente (Figura 5.2.3.1). Ambos os diques são de arenito fino e possuem, na região central, planos de fraturas paralelos ao comprimento dos diques, onde foi depositado óxido de manganês. Entre os diques clásticos ocorrem camadas de arenito limonitizado, com espessura constante de $3 \mathrm{~cm}$ e intensamente redobradas (Figura 5.2.3.2). Com a finalidade de calcular a compressão que provavelmente a intrusão dos diques clásticos exerceu sobre a camada, foram medidos os comprimentos das camadas retorcidas $(2,75$ e $3,00 \mathrm{~m})$ de duas dobras e seus respectivos espaçamentos entre os diques $(1,90$ e 1,75 m), ou seja, os comprimentos dos horizontes em que as camadas de arenito foram comprimidas. Com base nestes dados foi possivel deduzir que as camadas de arenito sofreram um encurtamento aparente de $30,91 \%$ e $41,61 \%$, respectivamente, orientada aproximadamente segundo $E-W$ e, principalmente, que os sedimentos estavam inconsolidados no momento em que os diques clásticos foram gerados.

Estes diques clásticos foram vinculados, por Trosdtorf Jr. (2002), a eventos glaciotectônicos, visto que apresentam orientação paralela (NNW) aos sulcos e estrias de pavimentos sobre o contato Furnas/ltararé e em sedimentos inconsolidado no topo da Unidade 2 (Seção do morro Siebert). Deve-se acrescentar, por pertinência, que, segundo Brodzikowski \& van Loon (1985), é amplamente aceito que tais estruturas intrusivas ocorrem em condições subglaciais caracterizadas por saturação de água, com movimentos intergranulares como principal mecanismo deformador. Exemplos de diques clásticos glaciotectônicos existem no Kansas Drift (EUA), Morainas Herdla (Noruega), Systofte (Dinamarca) Catfish Creek Drift (Canadá; Dreimanis \& Rappol, 1997) e Killiney Bay (Irlanda, Rijsdijk et al., 1999). 
Outra possivel explicação relaciona os diques clásticos aos esforços ascendentes dos líquidos intersticiais contidos em condições de alta pressão. Neste caso, seriam originados por fluídos que aproveitariam as juntas ou planos de falhas ocasionados pela Falha Cancela, fato que teria facilitado o carreamento de sedimentos de niveis inferiores em busca zonas de pressões mais baixas. Vale ressaltar que a localização dos diques é próxima à Falha Cancela e que, segundo esta interpretação, o tectonismo que originou os diques clásticos teria a mesma idade que os sedimentos inconsolidados do Subgrupo Itararé.

$\mathrm{Na}$ realidade se forem considerados apenas os atributos reológicos e de orientação dos diques clásticos, não é possivel definir qual origem seria mais provável, haja vista que, na possibilidade tectônica, o ângulo que os diques podem formar com a falha varia muito. Por outro lado, se uma geleira sofre uma inflexão no seu deslocamento devido a um desnível do substrato, no local desta inflexão são gerados esforços extensionais e, consequentemente, uma segunda familia de diques clásticos perpendicular ao movimento real do corpo de gelo se desenvolve.

Contudo, mesmo assim, dois fatores prejudicam a interpretação tectônica para a origem dos diques: a extensa exumação que a região sofreu antes da deposição dos sedimentos do Subgrupo Itararé, e, sobretudo, o fato de não terem sido encontrados sismitos ou qualquer outra evidência tectônica nos sedimentos, os quais estariam inconsolidados no momento da formação dos diques clásticos. Não obstante, vale lembrar que não foi encontrada, até o momento, nenhuma evidência tectônica em sedimentos não litificados em toda a região estudada, assim como näo há relatos prévios em trabalhos científicos realizados nesta localidade.

Desta forma, toma-se possível concluir que os diques clásticos foram produzidos pela compressão causada por uma massa de gelo sobre estratos inconsolidados, constituídos por sedimentos de baixa densidade e capeados por sedimentos de alta densidade. Esta condição, vinculada à densidade das camadas, pode ser considerada consistente para justificar também a ausência de outros diques clásticos, além da sua dificil preservação e/ou reconhecimento em depósitos antigos. 

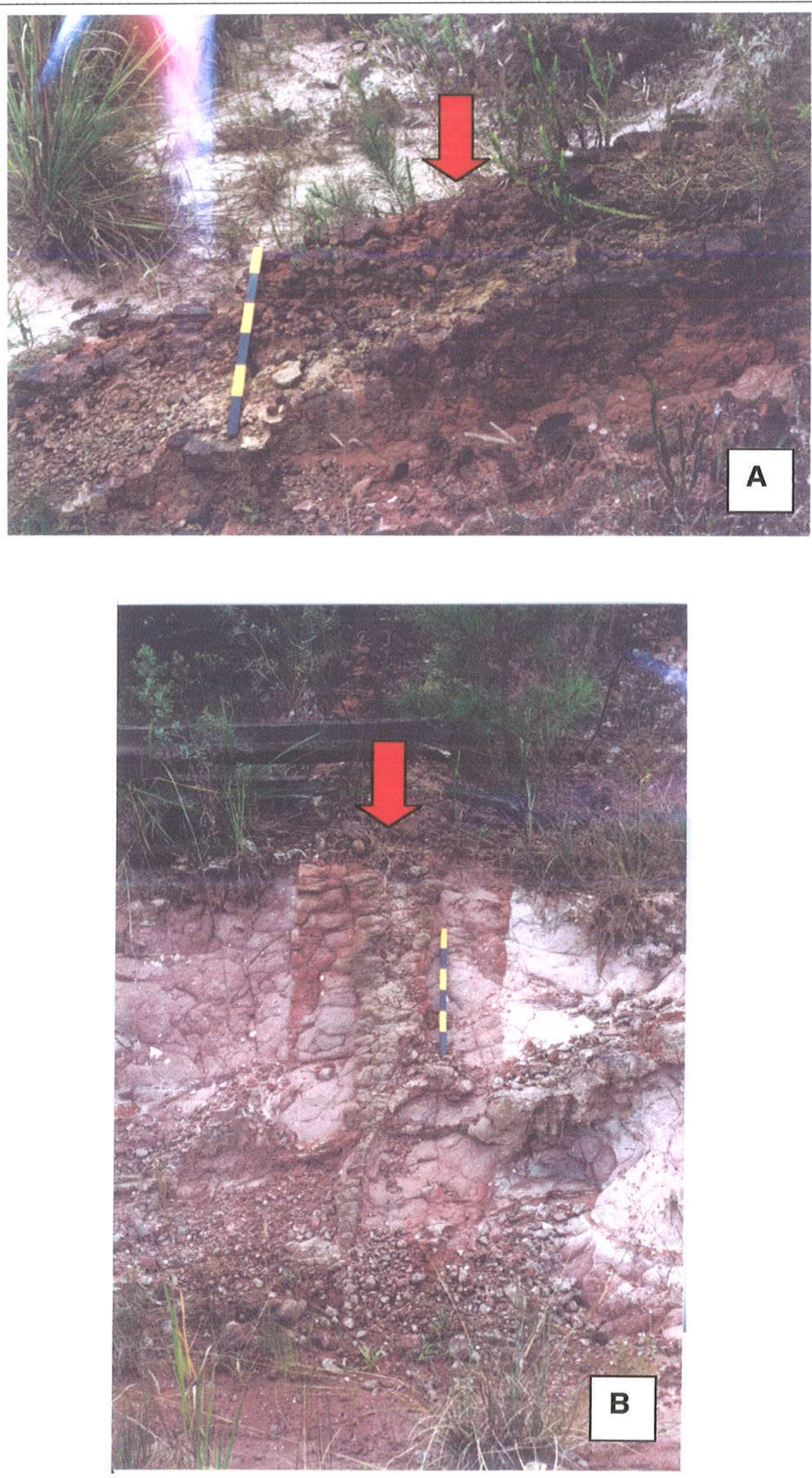

Figura 5.2.3.1 - Diques clásticos localizados atrás da Companhia de Laticínios Cancela. A) vista vertical da intrusão de um dos dique clástico no diamictito da Unidade 2, escala oblíqua a espessura do dique; e B) visão do corte superior do dique clástico. Setas vermelhas indicam o dique clástico nas fotos. Escala: tala de madeira com divisões a cada $10 \mathrm{~cm}$. 


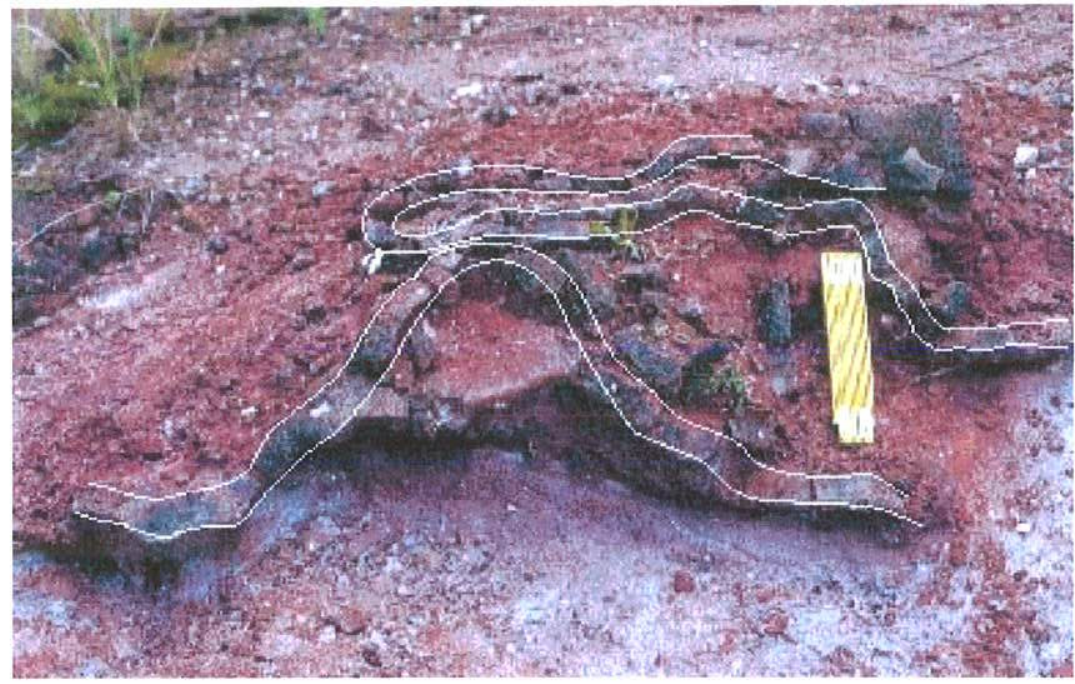

Figura 5.2.3.2 - Camada deformada de arenito médio limonitizado da Unidade 2 entre os diques clásticos. Afloramento atrás da Companhia de Laticínios Cancela. Escala: régua de madeira com 10 $\mathrm{cm}$.

\section{Colinas Deformadas (Estruturas Proglaciotectônicas de Witmarsum)}

A aproximadamente $1,5 \mathrm{~km}$ ao sul do Paredão Cancela, em sua grande maioria na Chácara Lótus (Anexo I), afloram estruturas sob a forma de colinas baixas, alongadas na direção E-W, agrupadas descontinuamente ao longo de pelo menos três faixas paralelas distintas, de até $250 \mathrm{~m}$ de extensão, separadas entre si por regiões mais ou menos planas. As dimensões individuais variam entre 3 e $8 \mathrm{~m}$ de altura e $30 \mathrm{~m}$ de extensão. Possuem perfil arredondado e assimétrico, com o flanco sul mais suave e o norte mais abrupto. As colinas e os terrenos que as separa são formados por diamictitos areno-argilosos, maciços e com estratificações plano-paralelas dobradas, ocres, com frequentes clastos dispersos de tamanho milimétrico a decimétrico (Figura 5.2.3.3). Esses corpos mostram-se intensamente dobrados, falhados e fraturados, localmente com lentes centimétricas de arenito fino cisalhadas. No topo das estruturas encontram-se camadas descontínuas de arenito fino deformado, que podem ter protegido as colinas da erosão, preservando assim sua forma. As camadas de arenito que não se encontram deformadas apresentam estratificações acanaladas, cruzadas e plano-paralelas, sugestivas de fluxos d'água e de pequenos canais.

A fim de identificar a vergência dos esforços atuantes nos corpos sedimentares em questão foram analisados estruturalmente 4 (quatro) afloramentos com diamictitos deformados, que encontram-se expostos em cortes dos morros ao longo da estrada de terra que cruza a chácara e no próprio piso deste acesso. Inicialmente, foram medidos os acamamentos e as laminações presentes nos diamictitos e arenitos deformados, aliando-as à descrição das formas das deformações. Posteriormente, adicionou-se as informações das fraturas, falhas, eixos de dobras e outros dados que poderiam auxiliar na interpretação das estruturas, tanto do sentido dos esforços a que foram submetidos, quanto da sua gênese. 


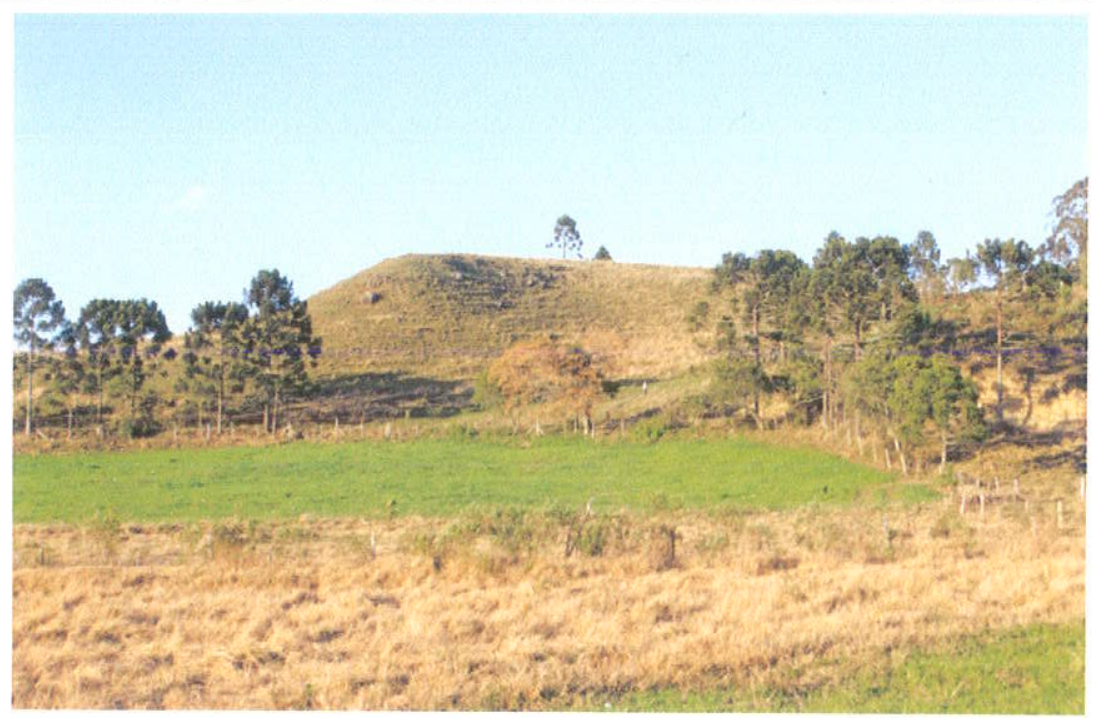

Figura 5.2.3.3 - Colinas, alongadas na direção E-W (vista para sudeste), com diamictitos deformados e falhados na base, capeados por arenitos. Foto de Ivo Trosdtorf Junior.
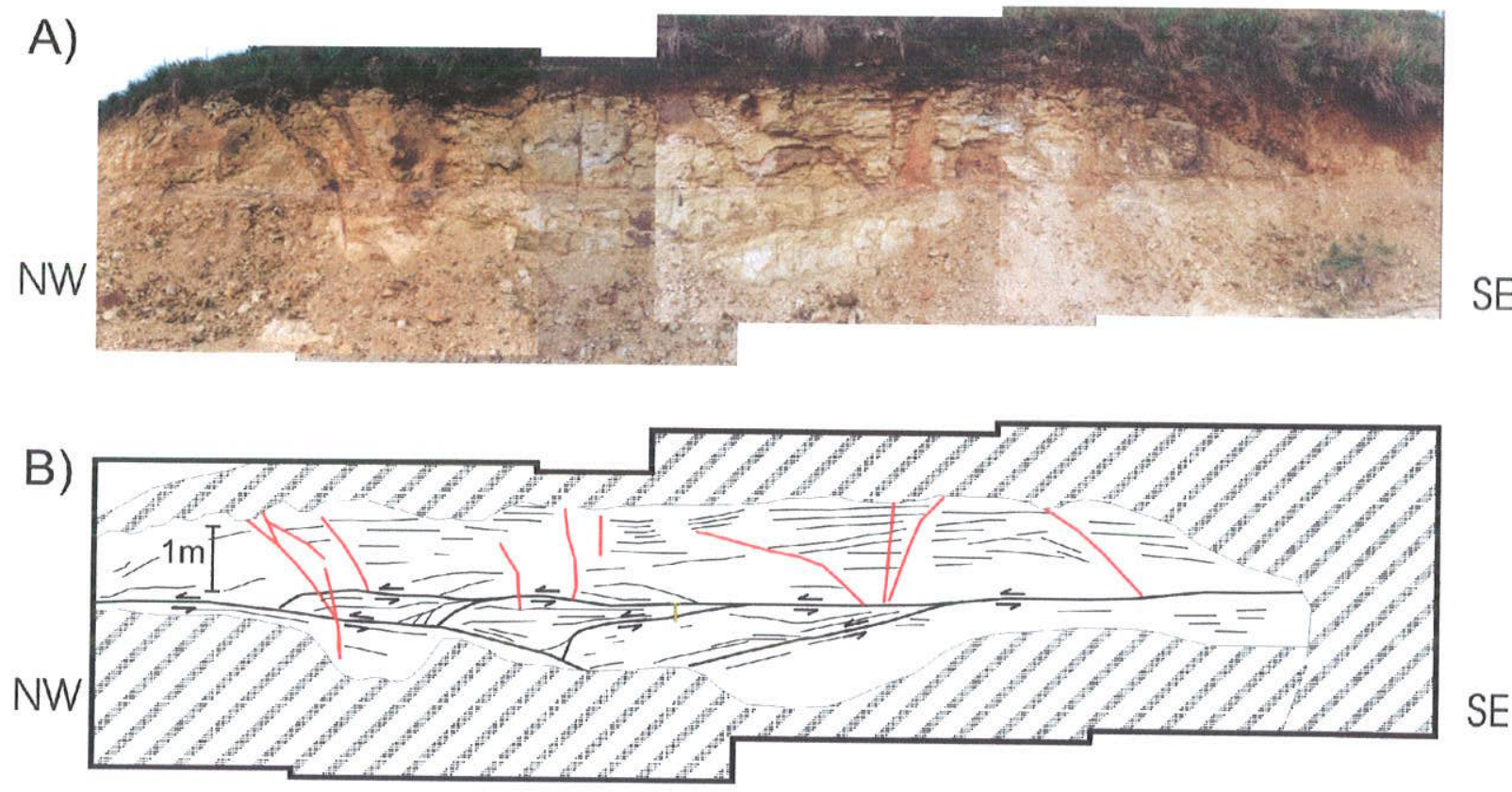

Figura 5.2.3.4 - Diamictito Deformado A (DDA), da Unidade 2, presente próximo do açude da Chácara Lótus. A) mosaico de fotos das "deformações do DDA; e B) ilustração interpretativa das estruturas observadas no mosaico de fotos. Escala no mosaico igual a da ilustração explicativa. 


\section{Diamictito Deformado A (DDA) (Anexo I)}

De oeste para leste, a primeira estrutura estudada localiza-se ao lado de um pequeno açude, distando aproximadamente $150 \mathrm{~m}$ para oeste da entrada da chácara. Este afloramento apresenta um extenso corte $\mathrm{N}-\mathrm{S}$, com aproximadamente $30 \mathrm{~m}$ de comprimento e 2,5 m de altura (Figura 5.2.3.4), além de uma pequena exposição $E-W$ no canto norte. Neste local afloram diamictitos areno-siltosos, ocres, com frequentes clastos dispersos de tamanho centimétrico a decimétrico, com porçöes maciças e outras apresentando estratificações plano-paralelas contorsidas e falhadas. Na porção intermediária observa-se uma superfície sub-horizontal que trunca as laminações inferiores do afloramento, demonstrando ser um plano de falha inversa que tende a se tornar mais inclinado para oeste. Embora os diamictitos tanto acima como abaixo do plano de falha sejam semelhantes composicionalmente, o inferior apresenta uma menor quantidade de clastos e estratificaçōes (ou laminações) plano-paralelas sub-horintais e inclinações para oeste próximas do contato (Figura 5.2.3.4B). Em contrapartida, o diamictito superior encontra-se intensamente deformado, configurando dobras recumbentes, com eixo horiziontal e plano axial subhorizontal (N185/01 e N095/29, respectivamente, valores estes calculados com base nos autovetores obtidos, Figura 5.2.3.5A) e charneira voltada para leste. Baseando-se no direcionamento das dobras recumbentes superiores, é plausível interpretar que houve um acavalamento de sedimentos superiores com sentido de deslocamento para leste.

\section{Diamictito Deformado B (DDB) (Anexo l)}

A $90 \mathrm{~m}$ para leste do açude, novamente ocorre um diamictito ocre, com clastos centimétricos, laminado e deformado, capeado por um corpo de arenito grosso deformado. Este afloramento, contudo, é bem modesto, apresentando menos de $1 \mathrm{~m}$ de altura e $3 \mathrm{~m}$ de comprimento. Na realidade, consiste de deformaçöes observadas no chão e na lateral da estrada da chácara. Este diamictito é muito semelhante ao diamictito da porção superior do afloramento próximo ao açude (DDA), embora a direção do deslocamento, baseada nos acamamentos, seja N-S (Figura 5.2.3.5B). O diamictito forma uma grande dobra recumbente, com eixo sub-horizontal, orientado na direção E-W e plano axial subhorizontal, suavemente inclinado para sul. Capeando os diamictitos ocorre outra dobra recumbente, a qual, contudo, afeta arenitos médios, estratificados. Esta dobra no arenito, por sua vez, indica uma movimentação para NE, haja vista o direcionamento da charneira da dobra. Possivelmente, sua orientação distinta se deva aos sedimentos previamente depositados (diamictitos), os quais teriam servido de obstáculo, acarretando o desvio destas dobras. Em virtude do afloramento ser pequeno e, portanto, apresentar poucos dados, não se julgou aconselhável considerar os autovetores 1 e 3 como sendo similares aos plano axial e o eixo das dobras, respectivamente. 

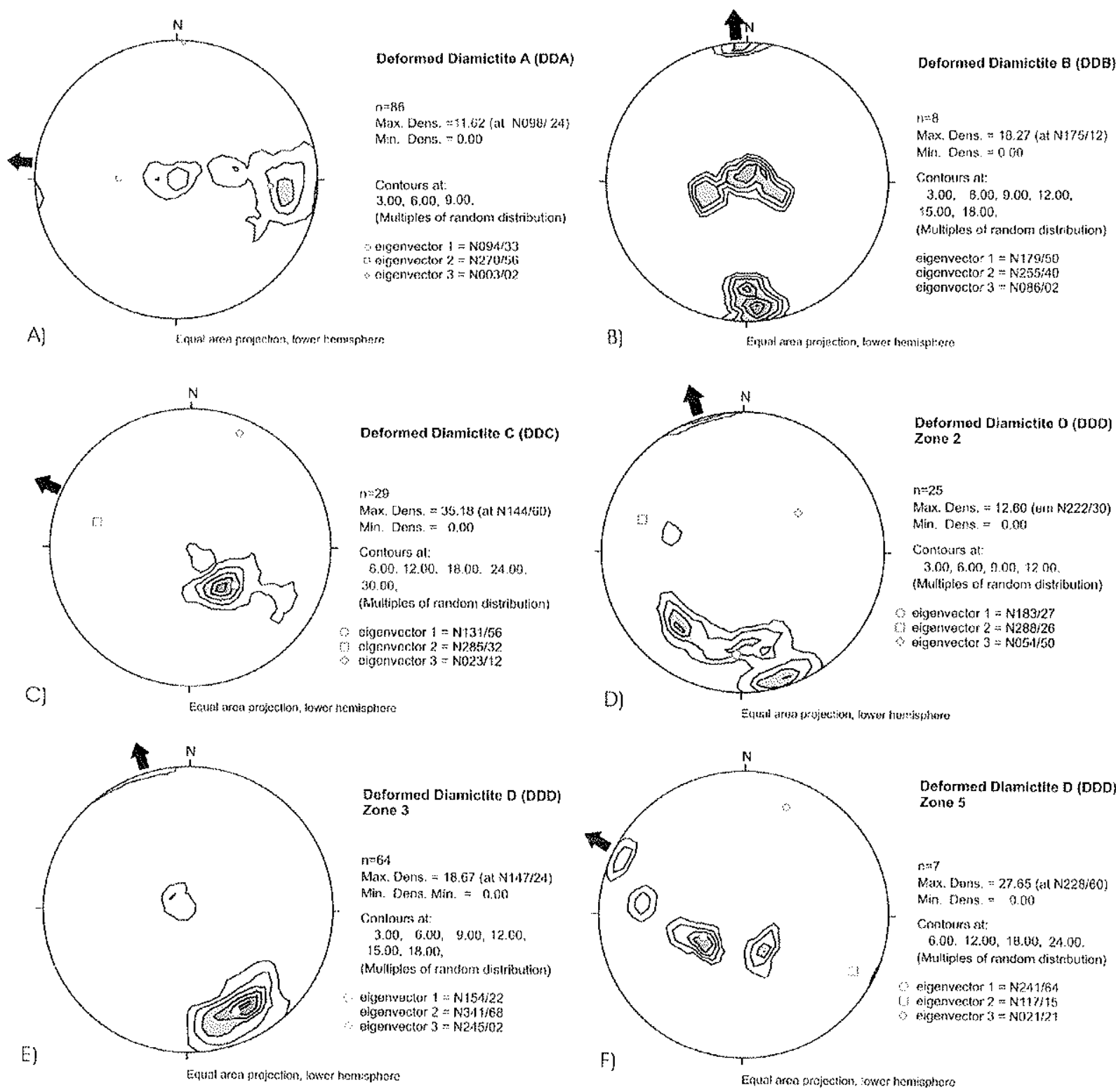

Figura 5.2.3.5 - Diagrama Schmidt-Lambert, hemisfério inferior, com o contorno das concentrações dos pólos das laminações presentes e a projeção dos seus autovetores, assim como o cálculo das densidades máximas e minimas, das dobras presentes nos diamictitos deformados. a) Dobras na porção superior do Diamictito Deformado A; b) Dobras no Diamictito Deformado B; c) Dobras no Diamictito Deformado $C$; d) Dobras na Zona 2 do Diamictito Deformado $D$; e) Dobras na Zona 3 do Diamictito Deformado D; f) Dobras na Zona 5 do Diamictito Deformado D. 


\section{Diamictito Deformado C (DDC) (Anexo I)}

Este afloramento está localizado do lado da casa do Sr. Jair dos Santos, pertencente à Chácara Lótus, no início da estrada de terra que cruza a chácara. As estruturas encontramse no piso e no corte da estrada. Inicialmente, observa-se um contato subvertical entre um diamictito maciço, avermelhado, com matriz silto-argilosa e com clastos centimétricos (inclusive de rochas metamórficas) e outro diamictito estratificado, amarelado, com matriz areno-siltosa e clastos que chegam a ser decimétricos, formando uma dobra recumbente semelhante às presentes no Diamictito Deformado $D$.

Assim como nos demais diamictitos deformados, foram também medidos os flancos da dobra com o objetivo de definir o eixo da mesma, cuja chaneira está voltada para norte. Como base nos dados obtidos verificou-se sua consonância com a dobra recumbente da zona 5 do Diamictito Deformado D, apresentando eixo de N023/12 e vergência para óesnoroeste (Figura 5.2.3.5C).

\section{Diamictito Deformado D (DDD) (Anexo I)}

Outra estrutura analisada e denominada "Diamictito Deformado D", encontra-se próxima à entrada da chácara, cerca de $30 \mathrm{~m}$, e, portanto, a mesma distância do Diamictito Deformado C, ou seja, a leste das demais estruturas analisadas. A Seção Geral (Figura 5.2.3.4) abrange todo o morro onde ocorre, num corte transversal com $17 \mathrm{~m}$ de comprimento e $5 \mathrm{~m}$ de altura em sua base, diamictitos, ocres, deformados, de matriz argilosa a arenosa fina e rica em clastos de várias litologias (inclusive granitos), centimétricos a decimétricos, subarredondados a subangulosos, com faces por vezes aplainadas e com raras estrias. Estes diamictitos apresentam intercalações de arenitos finos a médios, que, em muitos casos, encontram-se deformados. $O$ corpo de diamictito constitui uma dobra recumbente direcionada para norte, conforme será detalhado posteriormente. Apresenta-se amplamente falhada e fraturada, além de deformada tanto lateralmente quanto na porção superior.

Medindo uma seção N-S (Figura 5.2.3.6), no morro em que se encontra a parede mencionada, foi possivel constatar que o diamictito possui no mínimo $10,44 \mathrm{~m}$ de espessura, sendo capeado por arenitos finos a médios, com intervalos deformados de $5,30 \mathrm{~m}$ de espessura. Infelizmente, os arenitos encontram-se parcialmente encobertos na maior parte da seção. Os contatos inferiores e superior deste arenito são erosivos e irregulares. Acima dos arenitos ocorre outro corpo muito intemperizado de diamictito acinzentado e avermelhado, com matriz mais argilosa, menor quantidade de clastos decimétricos, aparentemente maciço, apesar da presença de pequenos cisalhamentos em lentes argilosas. Estes diamictitos possuem 4,18 m de espessura e apresentam contato novamente erosivo e irregular com arenitos, além de um pequeno escorregamento lateral de material arenoso. Este segundo corpo de arenito fino a médio não aparenta estar 
deformado, mas possui estratificação acanalada, formando vários canais que truncam os diamictitos subjacentes (Figura 5.2.3.7), e são substituídas gradativamente, para o topo da sequência, por estratificações plano-paralelas, além de uma sutil granodecrescência ascendente. Estes arenitos ocorrem até o topo do morro, totalizando no mínimo $8,60 \mathrm{~m}$ de espessura.

Voltando ao afloramento do diamictito inferior, foram ali definidas 5 (cinco) zonas de estudo, conforme a Figura 5.2.3.8. A primeira estrutura que aflora no canto leste inferior da parede é maciça (zonas 1 - diamictito maciço), apesar da composição similar dos diamictitos. A deposição deste diamictito maciço deve ter precedido os demais, correspondendo, possivelmente, a um till de alojamento. O contato com o segundo corpo é abrupto, obliquo e demonstra um aparente deslocamento sinistral do bloco sobrejacente, como se estivesse cavalgando o diamictito da base.

\section{Seção Geral dos Diamictitos Deformados}

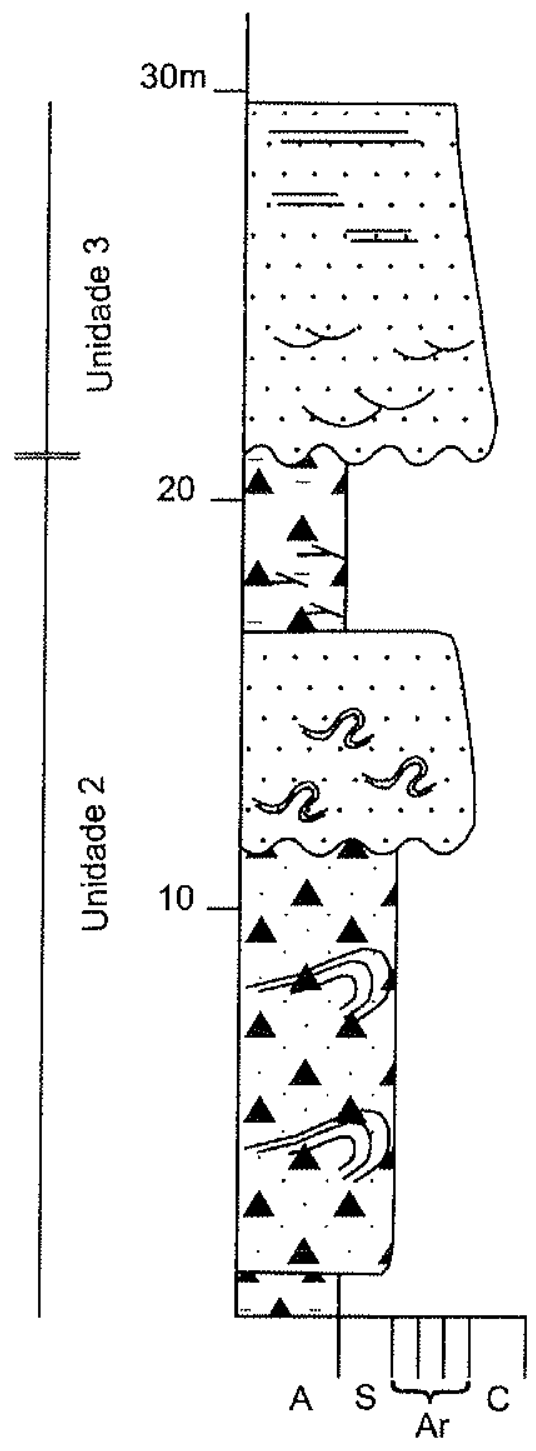

Arenito fino com estratificacao plano-paralela

Arenito grosso com estrtificacao acanalada

Diamictito macico com matriz argilosa e cisalhado

Arenito deformado

Diamictito laminado e deformado com matriz arenosa

Diamictito macico com matriz argilosa

Figura 5.2.3.6 - Seção Geral do Diamictito Deformado D. Localização no Anexo H-B. 

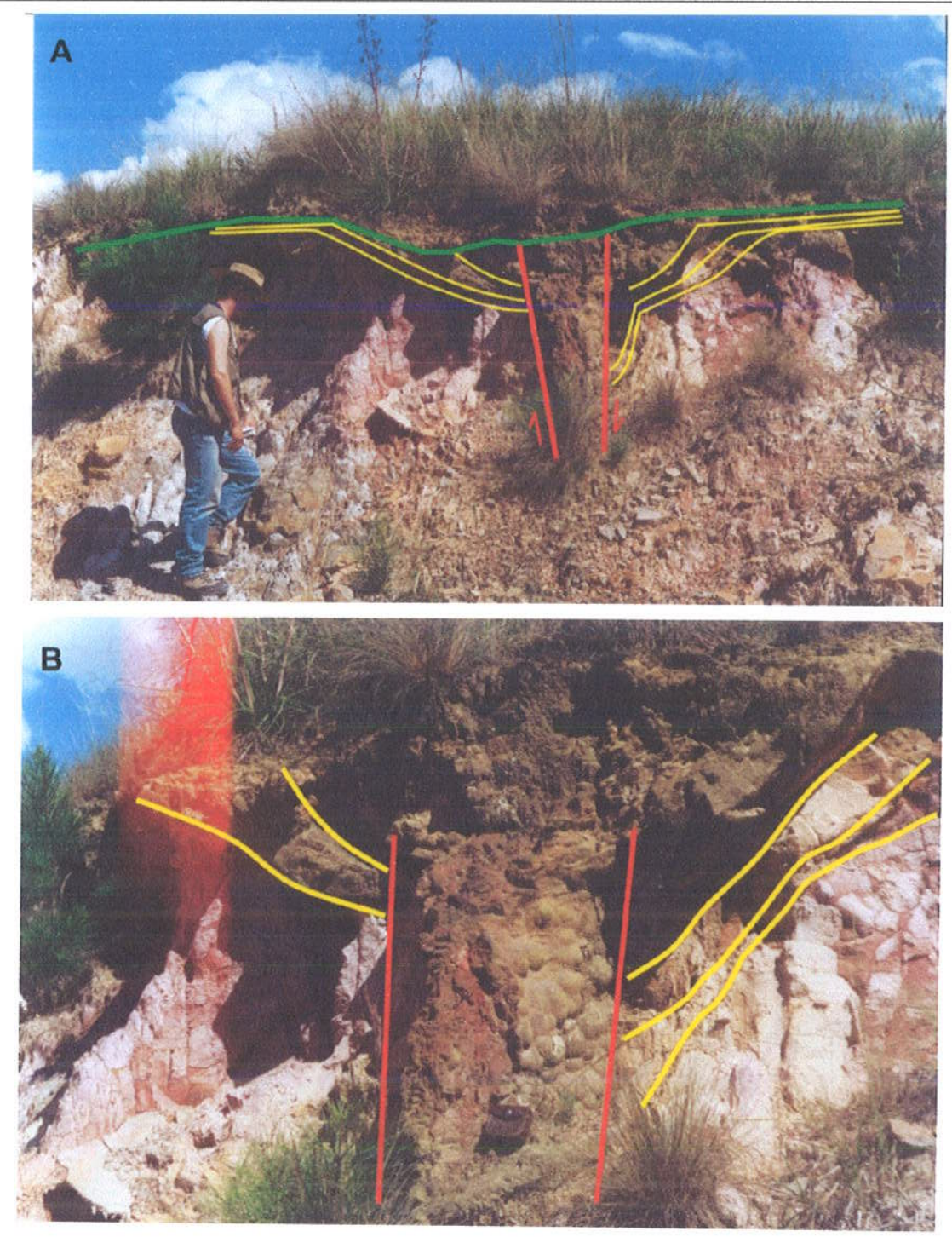

Figura 5.2.3.7 - Fotos do Diamictito Superior da seção do Diamictito Deformado D, orientados com o lado esquerdo para leste e o direito para oeste. A) Observar os canais de arenito no topo do afloramento (linhas amarelas) e falha normal preenchida por limonita que corta o diamictito e o arenito sobrejacente (delimitada pelas linhas vermelhas); e B) Detalhe dos canais e da falha. Escala: uma pessoa de 1,80 $\mathrm{m}$ de altura.

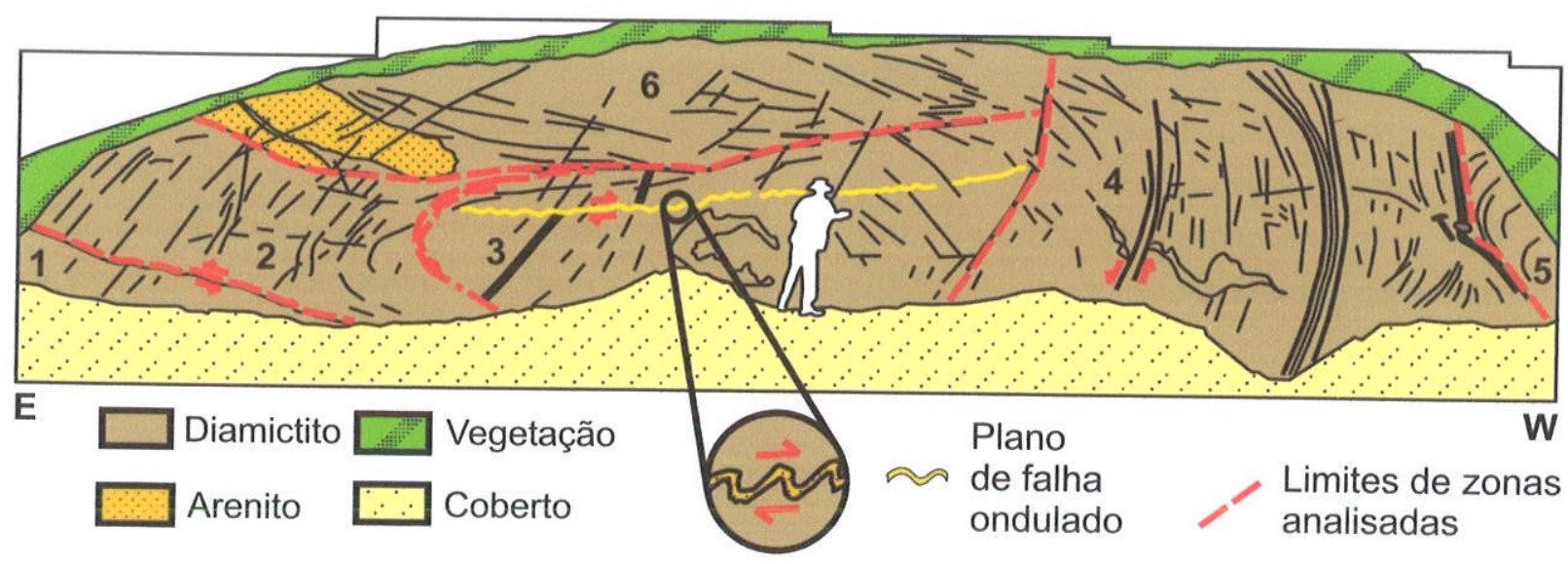

Figura 5.2.3.8 - Esquema ilustrativo das feições presentes no Diamictito Deformado D. Nota-se também a divisão das zonas analisadas, onde os números representam: 1 - diamictito maciço; $2,3,4$ e 5 - subdivisões do diamiactito deformado segundo uma dobra recumbente, de acordo com a inclinação do eixo e intensidade de falhamentos e fraturamentos; e 6 - diamictito e arenito com estratificações cruzadas e plano-paralelas. Escala: uma pessoa de 1,80 m de altura. 
O segundo diamictito, que constitui as zonas 2 a 5 , é formado, em termos gerais, por dobras recumbentes, abertas, do tipo $1 \mathrm{C}$ (com isógonas fracamente convergentes), cujo eixo varia localmente de inclinado a subhorizontal. A zona 4 se distingue das demais por estar altamente fraturada e falhada, e, portanto, os dados apresentam uma forte interferência tectônica. Na zona 2 (Figura 5.2.3.5D), o eixo da dobra encontra-se inclinado (N054/50, considerando ser equivalente ao autovetor 3 ), enquanto que na zona 3 apresentase subhorizontal (N245/02, Figura 5.2.3.5E) e na zona 5, novamente inclinado (N021/21, Figura 5.2.3.5F). Estes dados indicam que, provavelmente, as zonas 2 e 3 fazem parte de uma mesma estrutura de deformação, visto que apresentam o mesmo direcionamento; porém na zona 2 encontra-se mais inclinada devido a irregularidade do substrato, causada pelo diamictito inferior (zona 1). A zona 4, além de representar uma zona com grande interferência tectônica, configura o contato com outra dobra recumbente localizada a oeste do afloramento, que foi constatada na zona 5. Esta interface é evidenciada por um sistema irregular de fraturas paralelas, inclusive com um clasto situado no traço deste fraturamento sem que tenha sido fragmentado (Figura 5.2.3.9). Na zona 5 , a dobra não possui um direcionamento para nor-noroeste, conforme a zonas 2 e 3 , mas sim oés-noroeste. No entanto, todas as dobras recumbentes aparentam ter sido geradas concomitantemente por um mesmo evento de cavalgamento, havendo, inclusive, um plano de falha inversa subhorizontal ondulado (Figura 5.2.3.10), com dobras recumbentes acima e abaixo. Posteriormente, nessa sequência de eventos, ter-se-ia depositado a zona 6 , formada por diamictitos estratificados, com matriz argilosa e clastos milimétricos a centimétricos, intercalados por arenitos, ambos apresentando estratificação cruzada e plano-paralela, em contato abrupto erosivo.

Com relação às fraturas e falhas, além da falha inversa subhorizontal, nota-se três outros conjuntos de falhas e fraturamentos subverticais (Figura 5.2.3.11), que, em alguns casos, apresentam um sistema de falhas paralelas normais. As fraturas extensionais N-S seriam decorrentes dos acavalamentos que originaram as dobras recumbentes com vergência para norte. As demais falhas e fraturas (E-W e NE-SW) fazem parte de um sistema de falhas e fraturas conjugadas, cujo esforço compressivo principal estaria a ENEWSW e teria sido ocasionado pela Falha Cancela. Como o eixo da ondulação no plano da falha inversa subhorizontal varia de N-S a NNW-SSE, e, portanto de perpendicular a sutilmente perpendicular à direção do segundo esforço compressivo, conclui-se que esta ondulação também se deve ao falhamento transcorrente pós-deposição e litificação das rochas do Subgrupo Itararé. Cabe ainda ressaltar que estes três conjuntos de falhas e fraturas subverticais foram verificados em todos os afloramentos analisados, contudo, curiosamente, somente no Diamictito Deformado D foram constatadas as ondulações aqui descritas. 


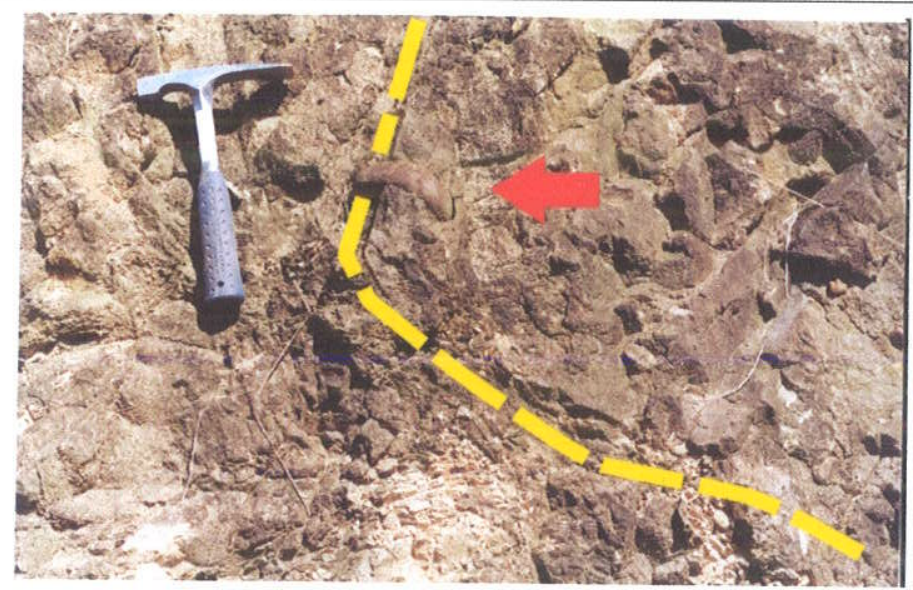

Figura 5.2.3.9 - Clasto decimétrico no meio de um sistema irregular de fraturas paralelas no Diamictito Deformado D. Linha tracejada ao longo das fraturas e seta indicando a posição do clasto. Escala: martelo geológico.

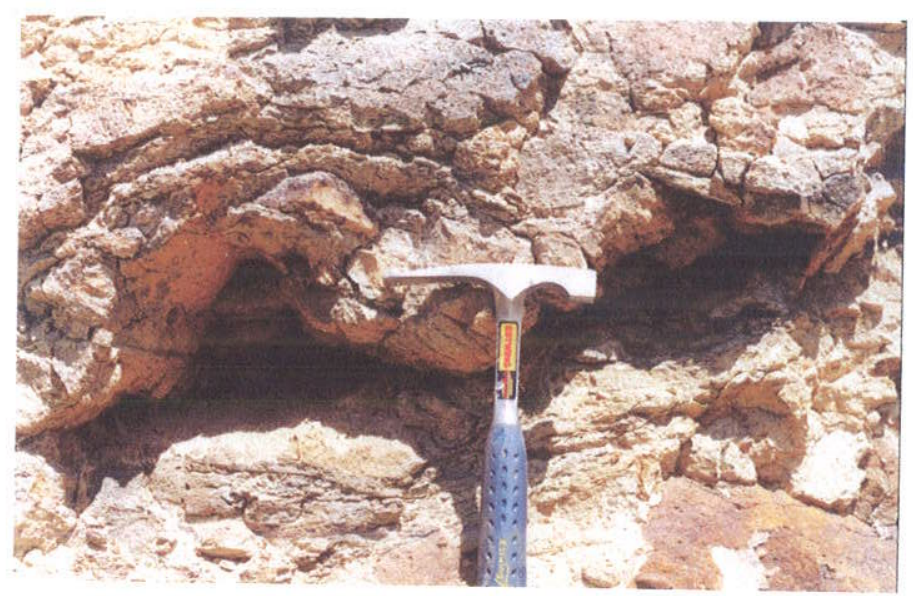

Figura 5.2.3.10 - Plano de falha inversa subhorizontal ondulado no Diamictito Deformado D. Escala: martelo geológico.

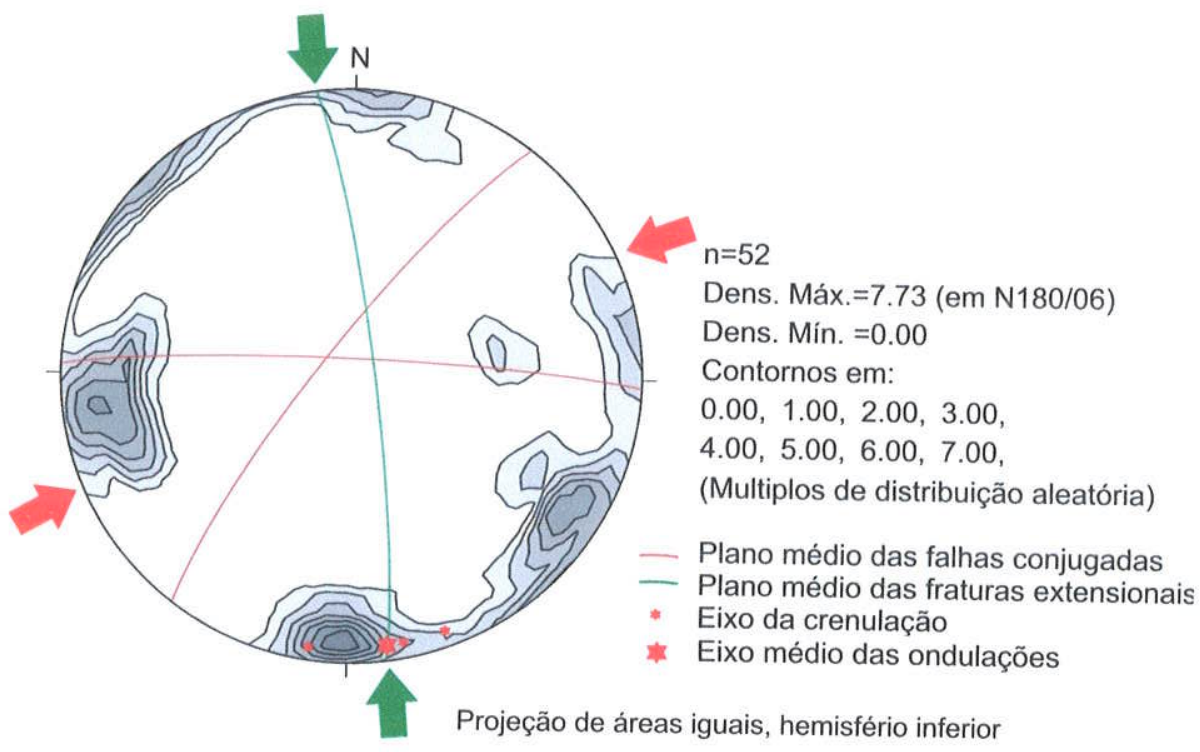

Figura 5.2.3.11 - Diagrama Schmidt-Lambert com o contorno das concentrações dos pólos das fraturas e das falhas verticais presentes no afloramento do Diamictito Deformado $D$ e a projeção dos planos médios dos agrupamentos, assim como eixo de ondulação presente na falha inversa. Setas indicam os prováveis sentidos dos esforços, em verde - esforços concomitante às dobras recumbentes; e em vermelho - esforços tectônicos posteriores. 


\subsubsection{Consideraçס̃es e interpretações de Witmarsum}

Em consonância com o que foi comentado anteriormente é possivel considerar que na região da Colônia Menonita de Witmarsum (PR), houve, inicialmente, um avanço de uma geleira com sentido geral de deslocamento para norte (orientação média N348), sobre, principalmente, um substrato consolidado formado pelas rochas da Formação Furnas. Este fato pode ser demonstrado pelos pavimentos estriados e sulcados que ocorrem, não somente na localidade do clássico pavimento estriado de Witmarsum, mas também em muitos outros afloramentos da região (e.g.: na Fazenda Schroeder). Outro evento associado a esse avanço seria a deposição de tills de alojamento, hoje representados pelos diamictitos (tilitos) maciços, pouco espessos, que ocorrem sobre as superfícies estriadas entalhadas no arenito da Formação Furnas (Figura 5.2.4.1).

Com o recuo do corpo de gelo, ocorreu a deposição de tills de degelo (melt-out tills), que, posteriormente, foram deformados por um novo avanço da geleira. Desta forma, estes diamictitos deformados e os diques clásticos da Unidade 2 teriam sido originados pela ação direta do lobo glacial Paraná (Martin, 1961; Frakes \& Crowell, 1969, 1972; Visser, 1987; Santos, 1987; Santos et al., 1996). Os diamictitos deformados corresponderiam a estruturas proglaciotectônicas no conceito de Hart \& Boulton (1991), e poderiam corresponder a morainas de empurrão (push moraines), visto que as características composicionais, estruturais e das orientações das estruturas aqui descritas são compativeis com as descritas na literatura de Geologia Glacial do Pleistoceno e Recente (van der Wateren, 1995a; Bennett \& Glasser, 1996). A distribuição das estruturas em faixas transversais ao sentido do fluxo do gelo reforça esta interpretação. Ademais, a formação de dobras recumbentes, com vergências semelhantes ao do deslocamento da geleira, assim como a presença de planos de acavalamento, assemelham-se muito às morainas de empurrão descritas por Krüger $(1985,1994)$ e localizadas a frente da geleira Höfdabrekkujökull (sul da Islândia, Figura 5.2.4.2). Outra informação importante que merece ser enfatizada é que os pavimentos estriados e sulcados da base da unidade, nos quais se põe de permeio a moraina de empurrão, assim como todas as camadas sobrejacentes e subjacentes destas estruturas, encontram-se subhorizontais, demonstrando que dificilmente as deformações seriam decorrentes de fluxos gravitacionais de massa. Além disso, tratam-se de estruturas de empurrão e, portanto, necessitam de um agente que as impelisse, e, no presente caso, este teria sido a geleira. Na realidade, a própria inclinação incipiente dos acamamentos é uma condição favorável para o desenvolvimento de morainas de empurrão de pequeno porte (aproximadamente, $5 \mathrm{~m}$ de altura), conforme ilustrado na Figura 5.2.4.3. 

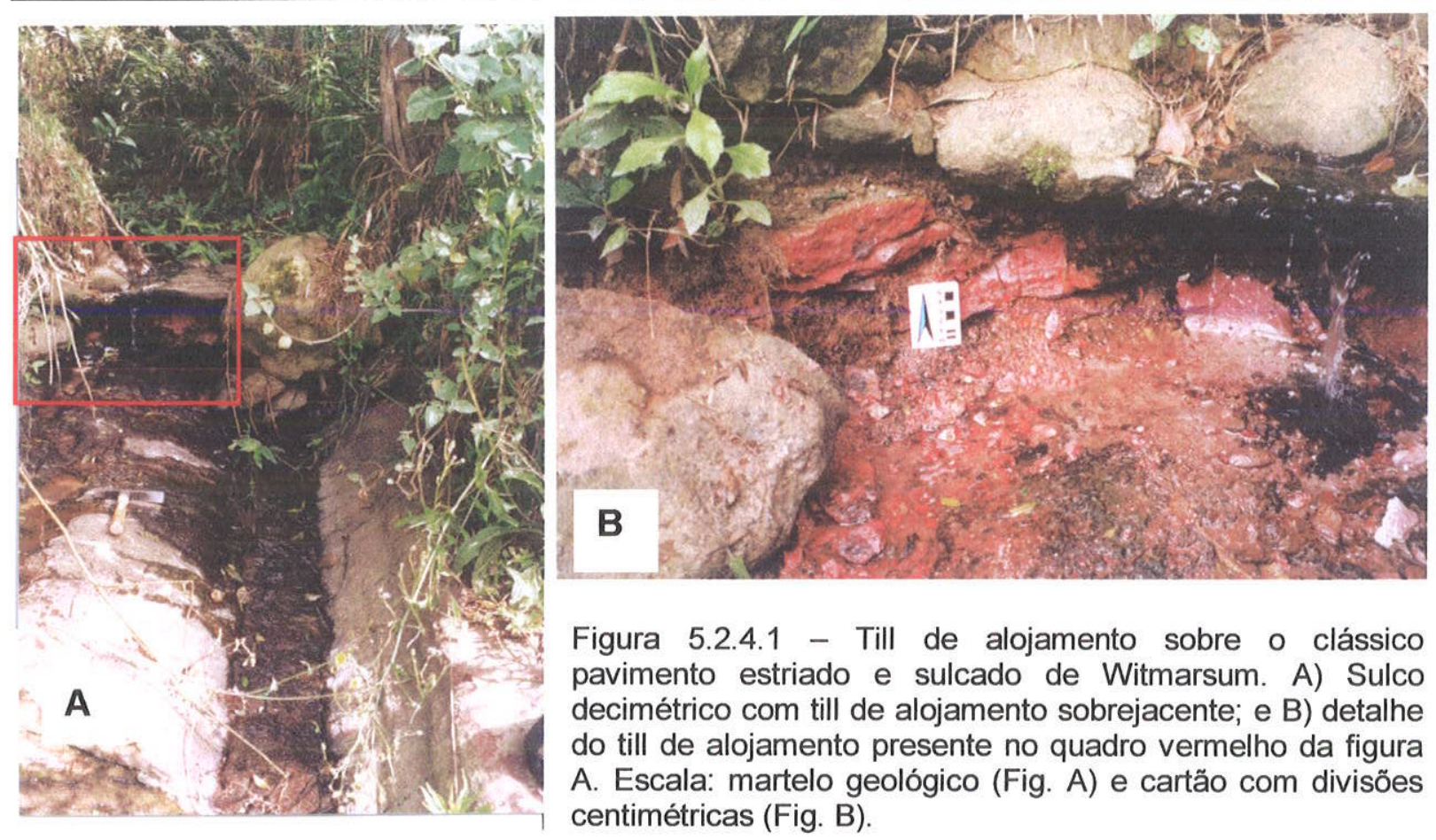

Figura 5.2.4.1 - Till de alojamento sobre o clássico pavimento estriado e sulcado de Witmarsum. A) Sulco decimétrico com till de alojamento sobrejacente; e B) detalhe do till de alojamento presente no quadro vermelho da figura A. Escala: martelo geológico (Fig. A) e cartão com divisões centimétricas (Fig. B).

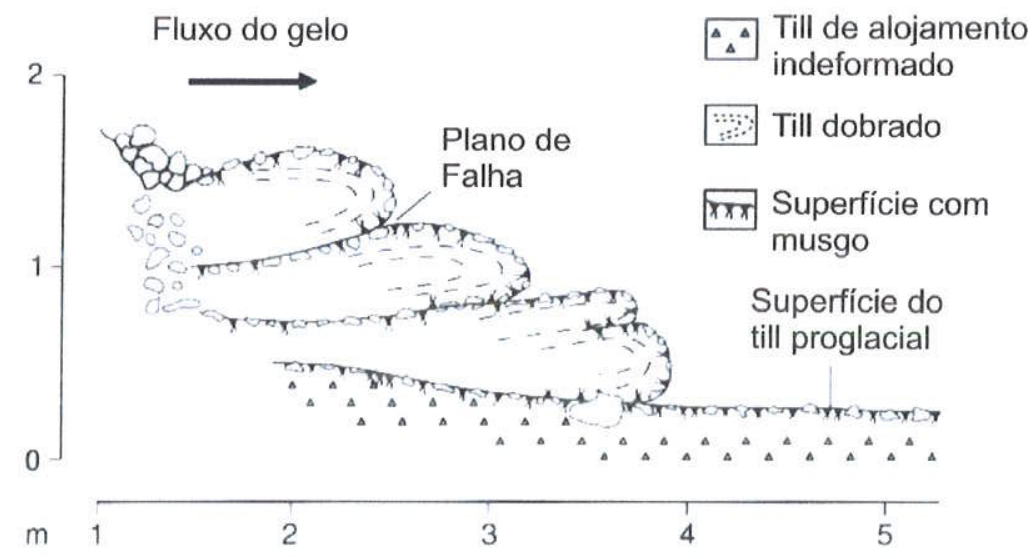

Figura 5.2.4.2 - Moraina de empurrão localizada a frente da geleira Höfdabrekkujökull (Krüger, 1985, 1994).

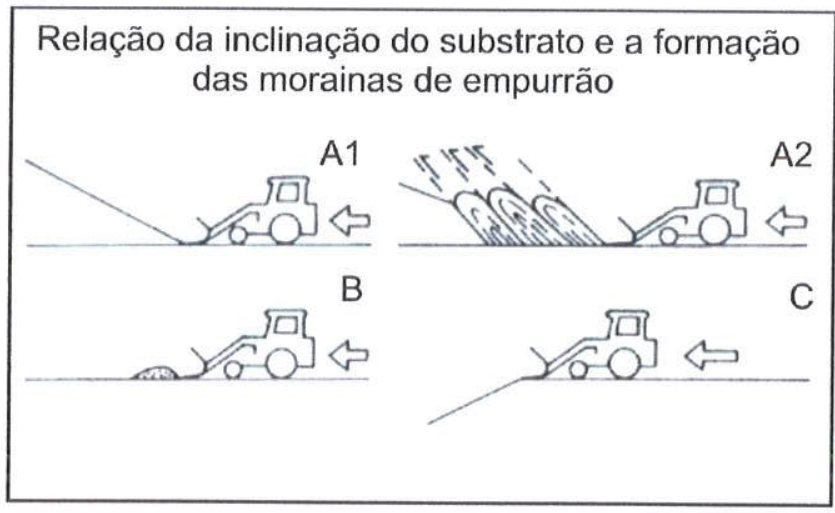

Figura 5.2.4.3 - Relação da inclinação do substrato e a formação de morainas de empurrão. Em A1 o substrato serve de obstáculo à passagem da geleira (representada por um trator e deslocando-se para a esquerda), gerando morainas complexas de grande porte (A2). A figura B representa um substrato pouco inclinado formando morainas de empurrão pequenas e em $\mathrm{C}$ um declive que não acarretaria no desenvolvimento de morainas de empurrão (Bennett \& Glasser, 1996). 
Com relação ao tipo de morainas de empurrão, entre as classificações apresentadas por Bennett (2001) é plausível que sejam correspondentes às denominadas Morainas de Empurrão Pequenas ou Sazonais ou Anuais, em virtude da sua altura ( $\leq 5 \mathrm{~m}$ de altura) e organizaçäo, com uma crista simples orientada paralelamente à margem da geleira. Estas morainas de empurrão também são denominadas de sazonais ou anuais (Sharp, 1984; Boulton 1986), mas, no presente caso, como não é possivel determinar, com a mesma eficácia e como acontece com os depósitos quaternários, o padrão temporal da sua gênese, crê-se que a melhor nomenclatura seria a referência ao padrão descritivo (Paleo-Morainas de Empurrão Pequenas), ou ainda, de maneira mais correta, "Estruturas Proglaciotectônicas de Pequena Escala". Como pode ser verificado atualmente, as deformações ocorrem próximas da margem do gelo de uma geleira, em uma zona estreita, normalmente como consequência de flutuações sazonais da margem de gelo. Comumente, estas cristas apresentam perfis assimétricos, possuindo inclinações mais suaves na face próxima da geleira e mais ingreme na face mais distal, além de estarem comumente associadas a flutes (van der Meer, 1997).

Representando-se graficamente as vergências médias das dobras recumbentes de Witmarsum (Figura 5.2.4.4), nota-se duas nítidas vergências: uma para noroeste e outra para norte. Esta variação das vergências pode refletir mudanças estruturais locais na frente das morainas, que normalmente são corpos lobados. No entanto, no afloramento do Diamictito Deformado $D$, ambos os flancos da parede apresentam dobras recumbentes direcionadas para NW e que estão truncadas na porção central por dobramentos voltados para norte. Desta forma, interpretou-se que, num primeiro estágio, teria se formado um arco de morainas de empurrão, que nesta localidade apresentaria vergência para NW e, posteriormente, durante um segundo avanço, ter-se-iam gerado as deformações com vergência para norte, destruindo, em parte, o arco de morainas previamente depositadas. Ressalta-se, inclusive, que no contato oeste entre estas estruturas o fraturamento decorrente não foi suficiente para fragmentar um clasto, conforme anteriormente descrito, 0 que pode ser interpretado como demonstrativo do caráter plástico da deformação.

Em suma, possivelmente, estas morainas de empurrão seriam sazonais, formadas durante curtos avanços da frente da geleira, durante as oscilações de primavera-verão, sobre a paisagem deglaciada, provocando, nas áreas proglaciais, o desenvolvimento de cristas de tilitos e de sedimentos flúvio-glaciais subsidiários, dispostos na frente da geleira. Em seguida, teria havido a formação de um ambiente subaquoso, lacustre ou marinho, propiciando a deposição das areias e do diamictito de fluxo, finalizando a Unidade 2 com arenitos de plataforma rasa, de acordo com a seção levantada no morro atrás da Pousada Siebert. 
Segundo observações feitas em conjunto com o geólogo Ivo Trosdtorf Jr. e divulgadas na sua dissertação de mestrado (Trosdtorf $\mathrm{Jr}$., 2002), as unidades 3 e 4, respectivamente, formam um platô relativamente extenso, com predominância de processos deposicionais interpretados como ligados à planície de lavagem glacial (outwash ou sandur). No que concerne ao restante da Unidade 4, verifica-se que a superposição de diamictitos é possivelmente decorrente dos sucessivos avanços da frente glacial. Observou-se, inclusive, a incorporação, em diamictitos, de fragmentos de outro diamictito subjacente, fato este que sugere um caráter erosivo e ativo de sua deposição, caracterizando um possível ambiente subglacial (Figura 5.2.4.5). Posteriormente, teriam se formado platôs ou zonas de relevo baixo, sugerindo tratar-se de diversas superfícies glaciais exumadas, inclusive com feiçöes morfológicas do tipo morainas de empurrão preservadas. Com relação aos pacotes sedimentares da Unidade 5, estes aparentam representar um ambiente glácio-lacustre, estando o arenito conglomerático associado a fluxo subaquático de detritos dentro do mesmo contexto.

Consequentemente, uma possivel interpretação dos eventos que atingiram a região, considera que, após a deposição dos corpos rochosos de origem francamente glácioterrestre, associados a depósitos subglaciais e proglaciais, flúvio-glaciais e lacustres da Unidade 2, a região assistiu a um recuo da geleira, com simultânea elevação do nível do corpo de água local e instalação de uma plataforma (marinha?) rasa. O posterior rebaixamento do nivel da água, provavelmente foi uma resposta à compensação glácioisostática do continente, seguida de novo avanço glacial e instalação de condições deposicionais proglaciais. Em seguida, novos ciclos de avanço e recuo da frente da geleira ocorreram, sendo evidenciados pelo empilhamento de diamictitos e sedimentos proglaciais.

A confirmação da ocorrência de morainas de empurrão em depósitos glaciais prépleistocênicos brasileiros, constitui um fato raro, se não único, e será de grande repercussão no âmbito da Geologia Glacial. O valor intrínseco de tal descoberta tem o seu significado ampliado na medida em que se constata que, atualmente, não existe na literatura internacional e nacional qualquer referência sobre ocorrências deste tipo de estruturas no registro geológico antigo.

Sob o ponto de vista da Geologia Glacial, a região de Witmarsum também é de fundamental interesse devido à ocorrência de feiçöes tectônicas peculiares, pouco descritas nos sedimentos neopaleozóicos da bacia do Paraná, como, por exemplo, os clastos partidos e selados e o próprio caráter transcorrente da Falha Cancela. 


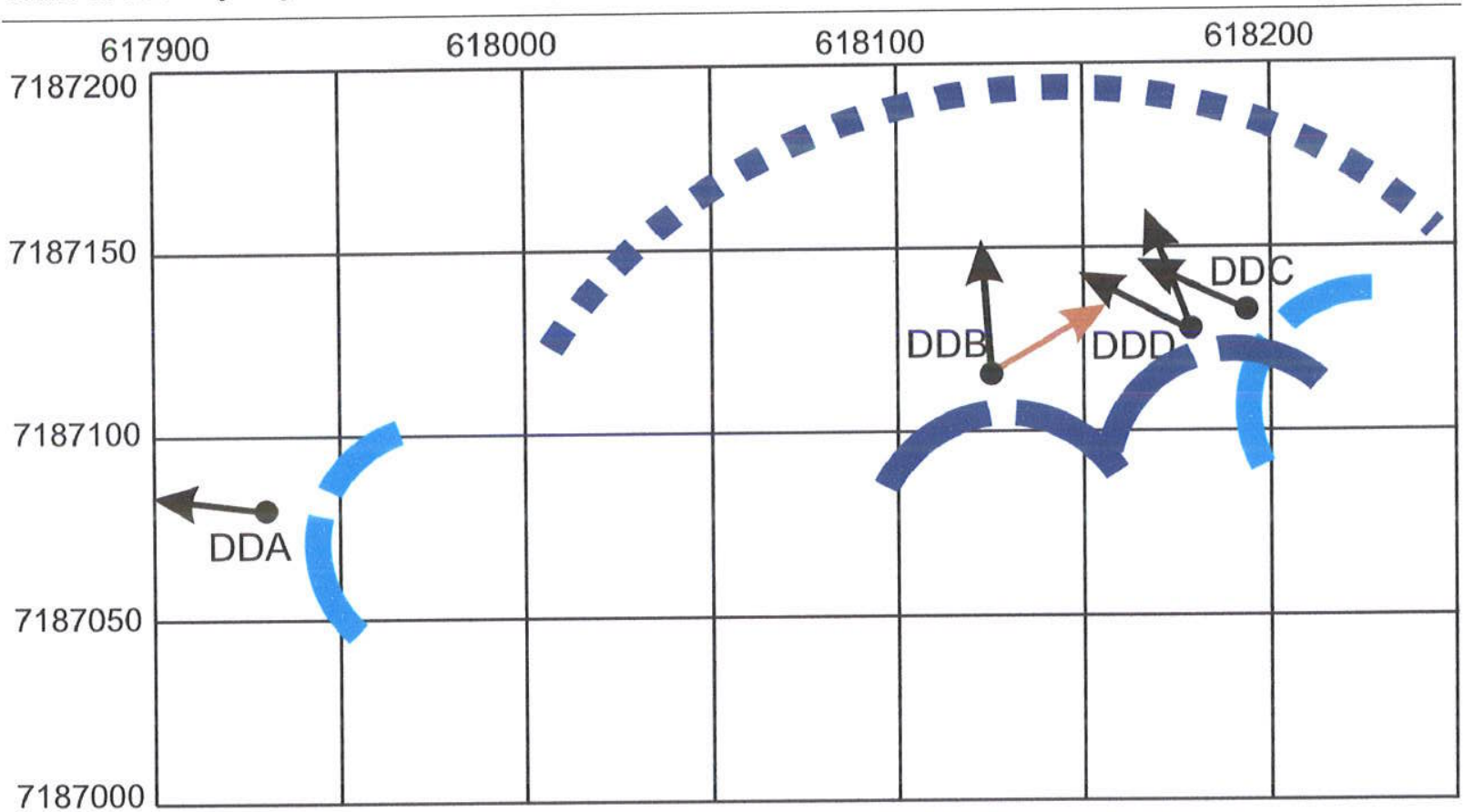

Figura 5.2.4.4 - Mapa com as vergências médias das dobras recumbentes presentes nos diamictitos deformados, onde: DDA - Diamictito Deforma A; DDB - Diamictito Deformado B; DDC - Diamictito Deformado C; DDD - Diamictito Deformado D; arcos tracejados azul claro - esquema da forma do primeiro arco de morainas de empurrão com vergência para noroeste; arcos tracejado azul escuro esquema da forma do segundo arco de morainas de empurrão; e arco pontilhado azul escuro - forma esquemática do lobo da geleira que ocasionou as deformações.

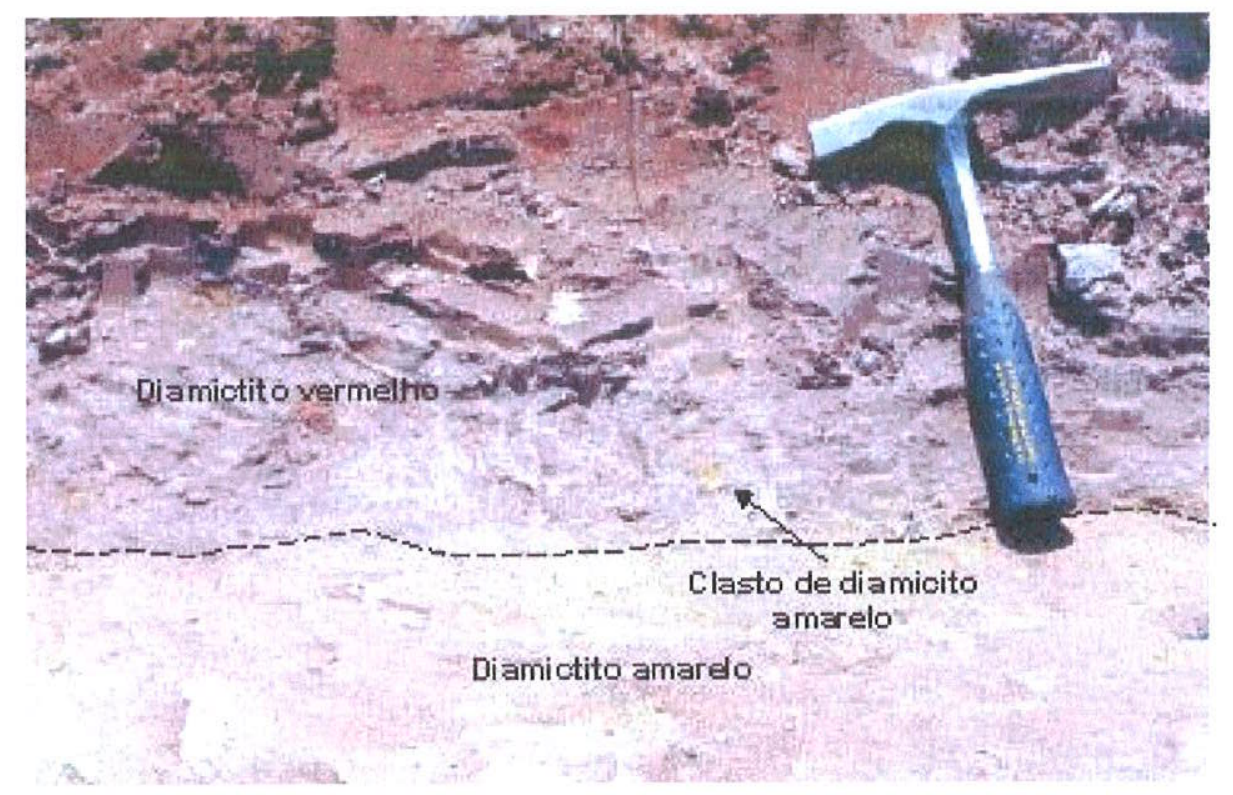

Figura 5.2.4.5 - Contato entre diamictito vermelho de matriz síltica e diamictito amarelo de matriz arenosa, ambos finamente estratificados, da Unidade 4. Intercalações arenosas centimétricas no diamictito inferior perecem deformadas por cisalhamento. Notar clastos amarelados (seta) imersos no diamictito vermelho que foram arrancados do diamictito inferior. Este afloramento localiza-se na estrada de acesso à Colônia Menonita de Witmarsum, próximo à BR-277. Foto de Ivo Trosdtorf Junior. Escala: martelo geológico. 


\subsection{ESTRUTURAS PROGLACIOTECTÓNICAS DA ISLÂNDIA}

O estudo realizado na Islândia visou, através de uma abordagem contra-atualística, comparar as estruturas glaciotectônicas do Neopaleozóico brasileiro com estruturas de mesma origem formadas recentemente na Isiândia. Para tanto, os estudos de escritório foram desenvolvidos na University of Greenwich (inglaterra), enquanto que as atividades de campo na região de Hagafellsjökull-Eystri, que faz parte do manto de gelo de Langjökull, no centro da Islândia.

Na região de Hagafellsjökull-Eystri, que compreende não somente as margens desta geleira, mas, também, o lago Hagavatn e o vale Jarthettukvisl, enfatizou-se as análise sobre a geometria interna (através de escavaçőes e métodos de geologia estrutural e geofísicos) e externa (dados geomorfológicos), a sedimentologia e a estratigrafia das morainas de empurrão (push moiranes). Deste modo, com os dados obtidos nos trabaihos de campo pôde-se verificar e deduzir a gênese das morainas de empurrão.

Esta região foi escolhida por registrar vários avanços e recuos da frente da geleira, em alguns casos envolvendo fenômenos do tipo "surge" (avanço acelerado). O último avanço acelerado da geleira Hagafellsjökull-Eystri ocorreu entre 1998 e 1999, mais precisamente no outono de 1998 (ou seja, por volta de setembro e outubro), através de avanços laterais dos lobos de piedmonte na direção do vale Jarlhettukvísl. A porção frontal da geleira, no entanto, começou a se deslocar somente no inverno de 1999 e, em abril de 1999, a margem frontal da geleira se moveu mais de 30 metros em 24 horas. A geleira parou de avançar em julho de 1999 , tendo apresentado um deslocamento máximo de $1165 \mathrm{~m}$. Este deslocamento "brusco" da geleira gerou um sistema complexo de arcos de morainas de empurrão na porção terminal da geleira e deformações subglaciais, que foram apresentados nos trabalhos Bennett et al. (2003; 2004), que fizeram parte deste estudo.

Com relação às morainas de empurrão relacionadas a este surge (as morainas de empurrão de 1998/99), no verão (junho) de 2002, encontravam-se elas separadas da margem lateral da geleira por um sistema de canais de água de degelo (Figura 5.3.1). As morainas de empurrão de 1998/99 são simples, pequenas (de 2 a $5 \mathrm{~m}$ de altura), alinhadas ao longo da margem lateral a sudeste da geleira e compostas pelas seguintes fácies: areias finas com laminação paralelas, intercaladas com siltes; camadas de grânulos, bem selecionados; intercalações de areias médias e grânulos; camadas de grânulos, mal selecionados, ricos em matriz, com lentes de silte e, ocasionalmente, lentes de seixos; areias grossas, maciças, com lentes de grânulos; e siltes e areias finas com laminação paralela. Estes sedimentos são consistentes com depósitos formados em condições gláciofluviais, formando, inclusive, os ocorrentes em uma pequena planicie de lavagem (outwash) lateral, sujeita às variações do regime de fluxo da geleira. 

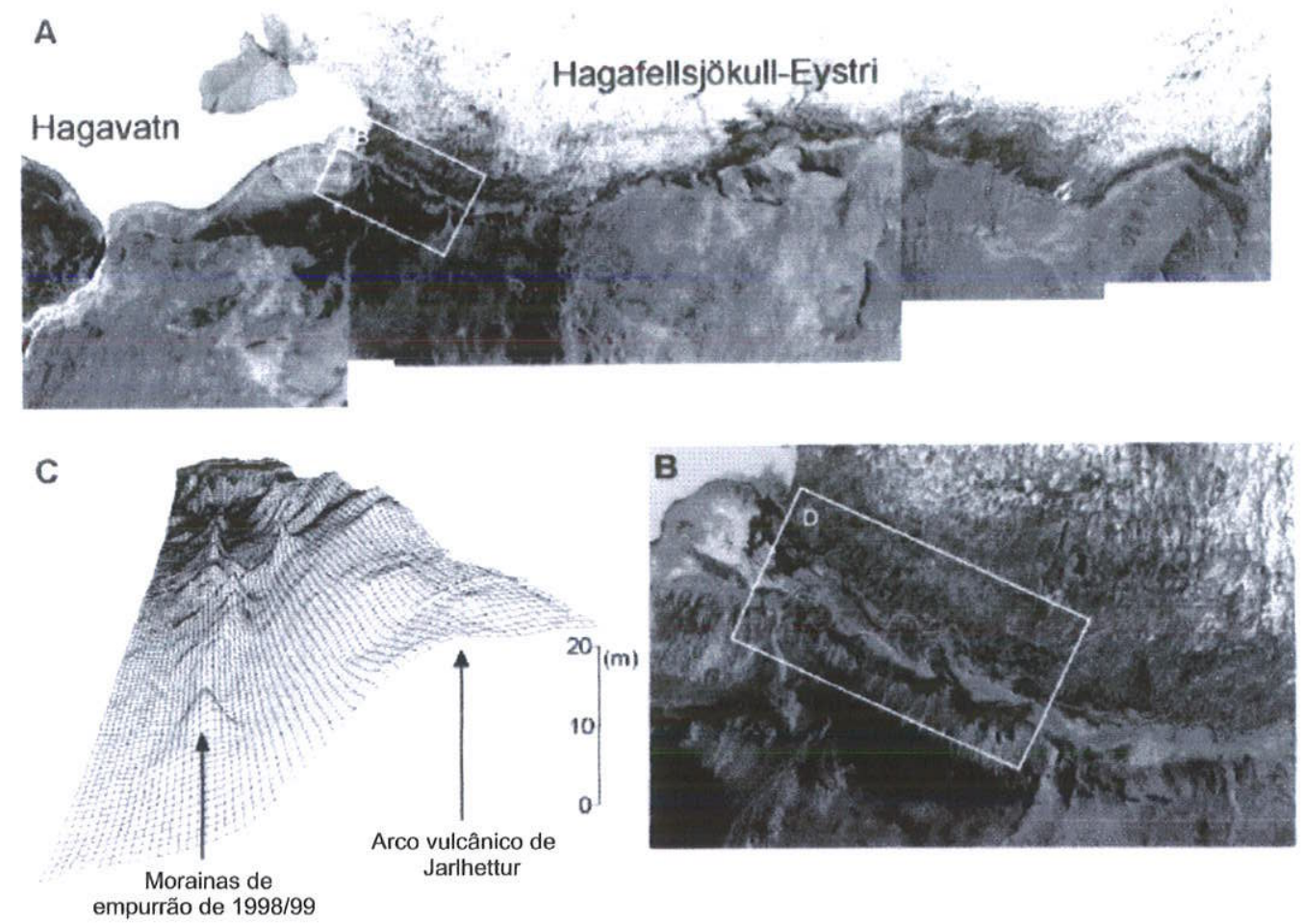

empurrão de 1998/99
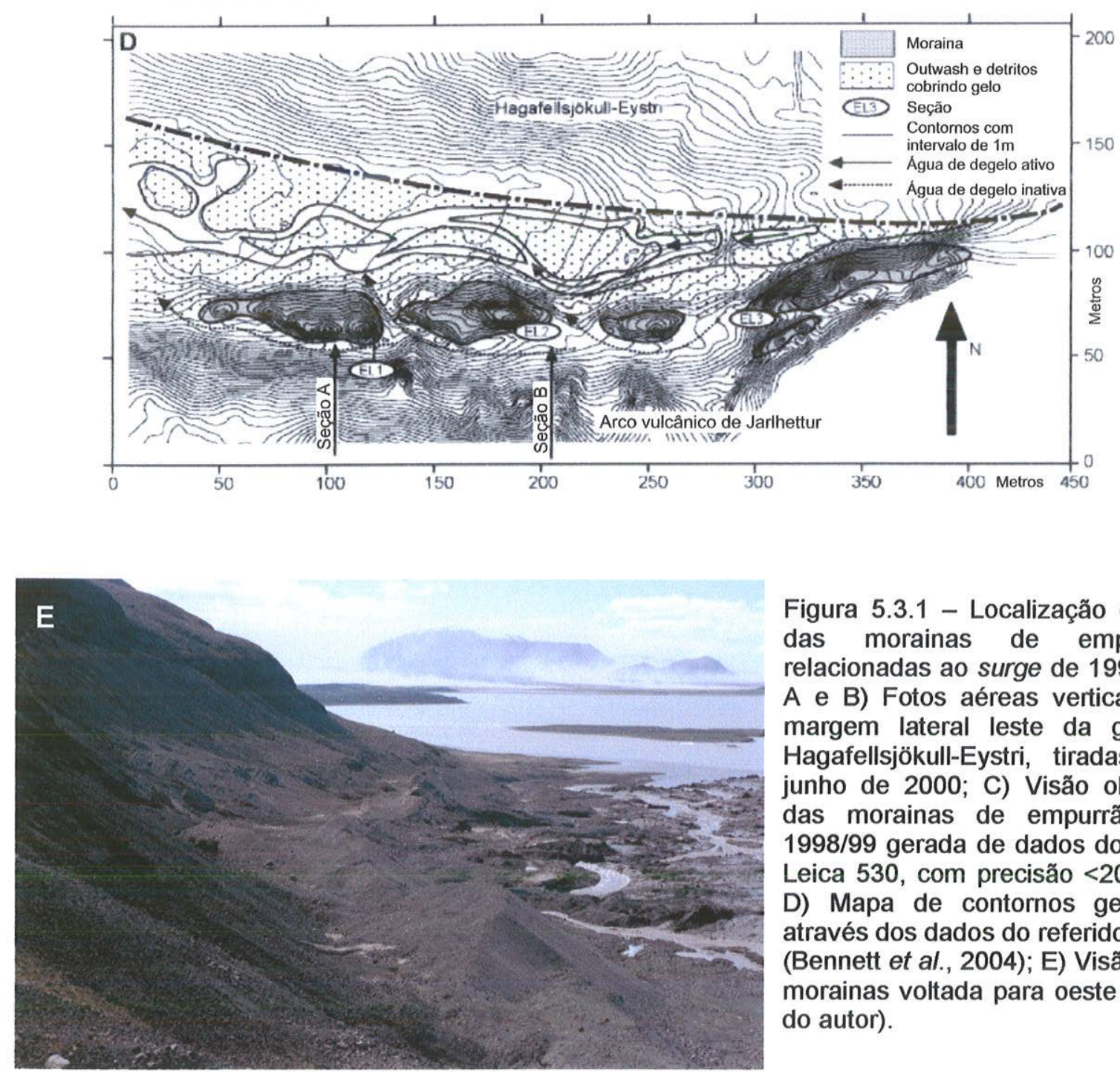

Figura 5.3.1 - Localização e foto das morainas de empurrão relacionadas ao surge de 1998/99. A e B) Fotos aéreas verticais da margem lateral leste da geleira Hagafellsjökull-Eystri, tiradas em junho de 2000; C) Visão oblíqua das morainas de empurrão de 1998/99 gerada de dados do GPS Leica 530 , com precisão $<20 \mathrm{~mm}$; D) Mapa de contornos gerados através dos dados do referido GPS (Bennett et al., 2004); E) Visão das morainas voltada para oeste (Foto do autor). 
A arquitetura das morainas de empurrão de 1998/99 consiste de um empilhamento de blocos de sedimentos depositados antes do avanço da geleira sobre sedimentos similares subhorizontais. Os sedimentos que foram empurrados apresentam na face voltada ao corpo de gelo estratos com grande inclinação $\left(20-90^{\circ}\right)$. O plano de descolamento entre o bloco que cavalgou e o sedimento que resistiu ao empurrão é irregular e formado por uma fina camada de argila siltosa, com inúmeros planos de cisalhamento bem definidos. Em alguns casos, com apresentado na Figura 5.3.2, prevalecem deformações dúcteis, com dobras abertas e eixos paralelos à crista das morainas, porém, na maioria dos casos, são as estruturas rúpteis que dominam, através de inúmeras fraturas e falhas, sendo que ambos os estilos de deformação ocorrem conjuntamente em todas as seções estudadas. Embora hajam inúmeras fraturas e falhas, mesmo onde prevalecem estruturas dúcteis (Figura 5.3.3). Estas estruturas refletem a natureza transpressiva do regime de esforços na margem lateral da geleira, merecendo destaque a presença de sedimentos ainda congelados (Figura 5.3.4) na base das faces voltadas para a geleira, onde, coincidentemente, também prevalecem estruturas rúpteis.

Para um maior detalhamento deste sistema de morainas de empurrão formadas durante o avanço acelerado de 1989/1999, sugere-se a leitura do trabalho Bennett et al., (2004), que, inclusive, descreve três seções escavadas perpendicularmente à crista destas morainas. No entanto, o que chama a atenção são as conclusões obtidas através destas seções para a gênese destas estruturas proglaciotectônicas de 1998/99, em particular a presença de sedimentos congelados (Figura 5.3.4).

Neste sentido verifica-se que existem quatro explicações possiveis para a rápida alternância entre os estilos de deformação rúpteis e dúcteis: variação na granulometria e nas fácies; variações dos esforços de compressão; variações na hidrologia dos sedimentos (pressão de água); ou variações na resistência dos sedimentos, caso estivessem congelados ou não. Contudo, é possivel eliminar, de início, as primeiras três explicações, visto que a sedimentologia é semelhante em todo o arco de morainas de empurrão, mesmo nos locais em que há estilos de deformação distintos. Além do mais, dificilmente os esforços atuantes iriam variar tanto em distâncias tão pequenas (e.g.: $20 \mathrm{~m}$ ). Adicionalmente, para que os fatores hidrológicos condicionassem os estilos de deformação, seria necessário um sistema hidrologicamente fechado, em que a água intersticial não pudesse escapar, fator este que permitiria, em termos, a formação de estruturas rúpteis. Porém, tal confinamento não existe, o que dificulta a interpretação destas estruturas através da pressão de água. 


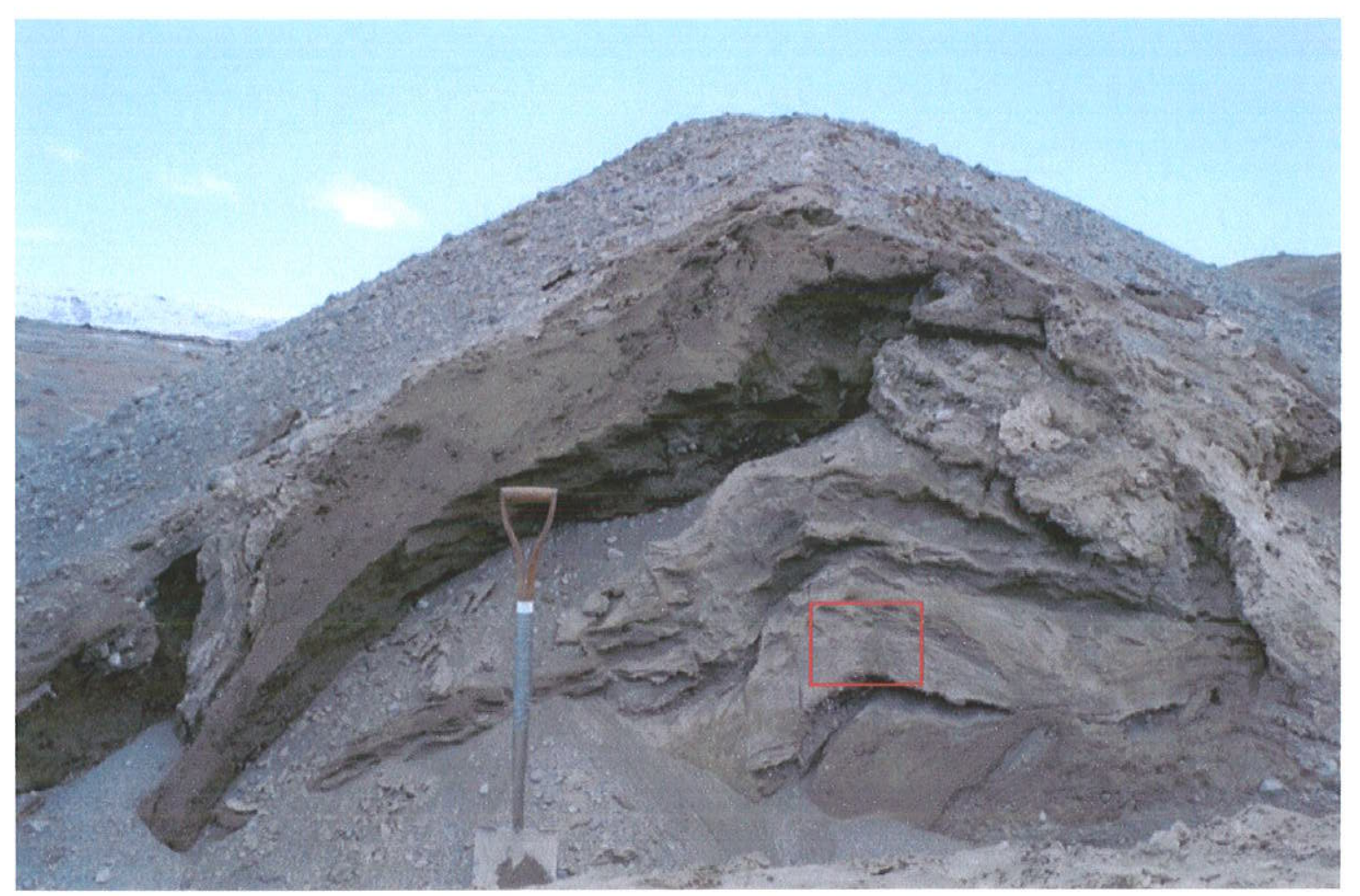

Seção EL3 da moraina de empurrão de 1998/99

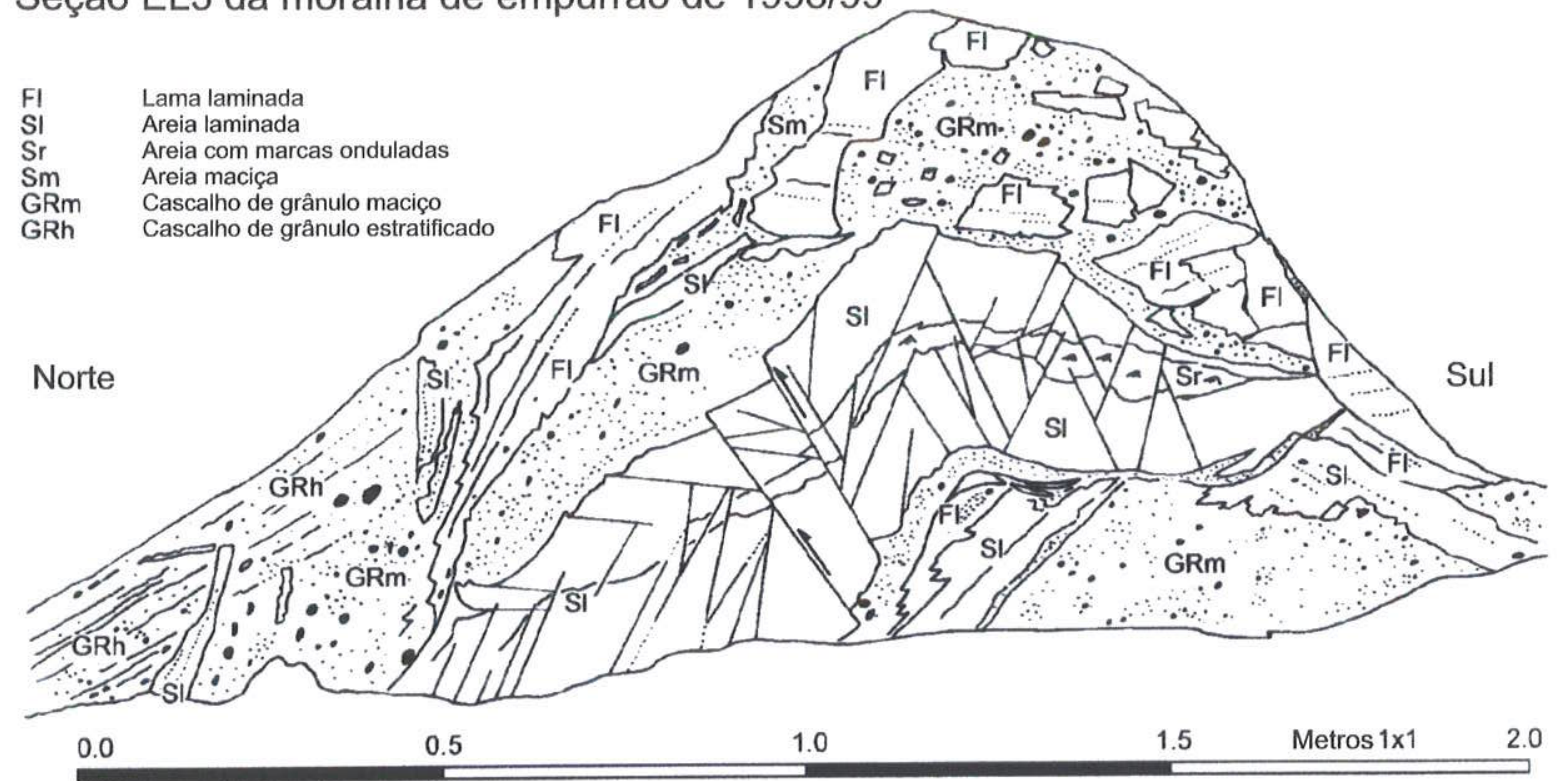

Figura 5.3.2 - Foto e ilustração explicativa da parte superior da Seção EL3 da moraina de empurrão de 1998/99. Foto do autor e ilustração explicativa apresentada em Bennett et al. (2004). Localização da Seção EL3 na Figura 5.3.1. Escala da foto: pá com $70 \mathrm{~cm}$ de comprimento. Retângulo vermelho referente à Figura 5.3.3. 


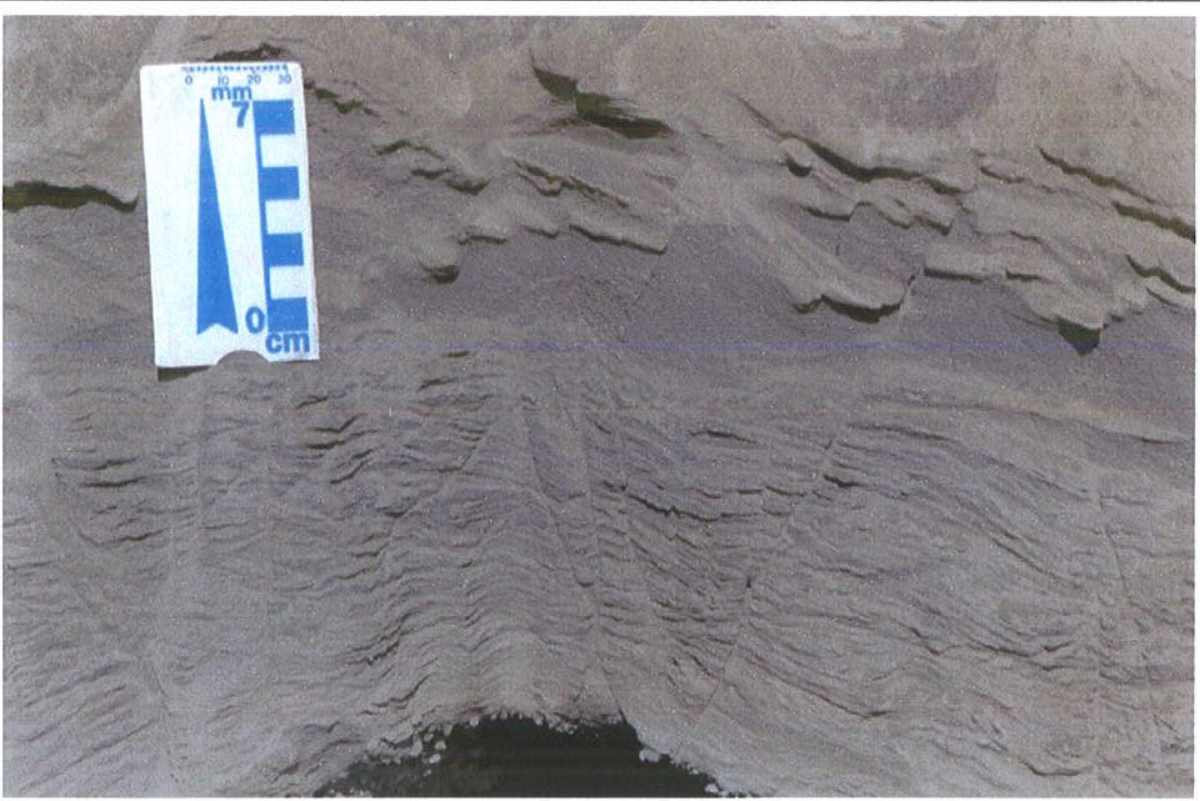

Figura 5.3.3 - Foto de detalhe das estruturas rúpteis presente na porção superior da Seção EL3 da moraina de empurrão de 1998/99. Localização da foto demarca por retângulo vermelho na Figura 5.3.2.

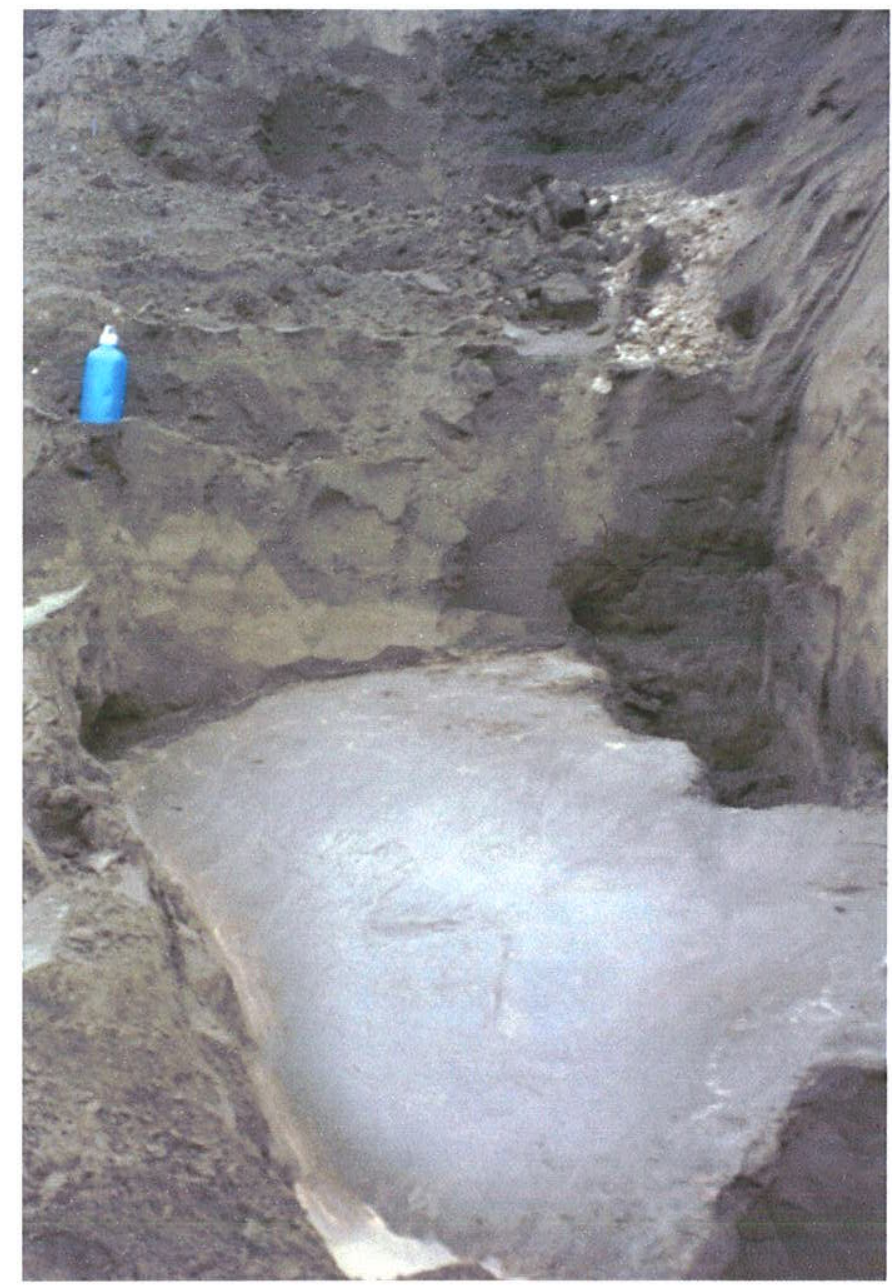

Figura 5.3.4 - Sedimento congelado escavado na base de uma moraina de empurrão na região de Hagafellsjökull-Eystri. O sedimento congelado está mais claro em virtude do reflexo da luz solar. Escala: cantil. 
Por conseguinte, é bem possivel que as mudanças observadas no estilo tectônico das estruturas sejam decorrentes da prevalência, ou não, de processos de congelamento dos sedimentos proglaciais no momento da deformação. Locais em que os sedimentos encontravam-se congelados e com pequenas quantidades de água intersticial apresentariam altos índices de coesão interna e de resistência à deformação, provocando o surgimento de estruturas rúpteis. Em contraste, nos sedimentos que não sofreram congelamento, especialmente nas adjacências de sedimentos congelados, onde a drenagem é dificultada, as pressões de água intersticial seriam maiores favorecendo a formação de estruturas dúcteis.

Segundo Krüger (1994), estas variações abruptas entre sedimentos congelados e outros que não foram congelados se deve à variação na distribuição espacial da neve, causadas pelos fortes ventos catabáticos provindos do manto de gelo de Langjökull. $O$ impacto das coberturas de neve no regime térmico do substrato e na profundidade de congeiamento depende de quando ocorre a nevasca e da espessura da neve acumulada que permanecerá sobre os sedimentos (Williams \& Smith, 1989). Se a neve cair no início do inverno, os sedimentos ficaram isolados das temperaturas mais baixas do inverno, $e$, consequentemente, a profundidade de congelamento dos sedimentos fica limitada. No entanto, se a nevasca cair no final do inverno, os sedimentos ficam isolados das temperaturas em elevação por mais tempo, permitindo a conservação de uma camada mais espessa de sedimento congelado. Adicionalmente, a alta quantidade de água também limita o congelamento sazonal, visto que aumenta o volume de água a ser congelada, juntamente com a água intersticial. Desta forma, a presença de neve agindo como isolante térmico e a quantidade de água no ambiente são provavelmente as melhores explicações para a variação nos estilos de deformação presentes nas morainas de empurrão formadas no surge de 1998/99 em Hagafellsjökull-Eystri.

Outro dado interessante e importante fornecido por este avanço rápido da geleira foi discutido no trabalho Bennett et al. (2003), onde é reportada a descoberta de possiveis deformações subglaciotectônicas de blocos de gelo e sedimentos congelados em temperaturas de sub-congelamento (sub-freezing) abaixo da geleira Hagajellsjökull-Eystri (Figura 5.3.5). Na porção basal de um lobo do tipo piedmonte desta geleira (Figura 5.3.6), que avançou durante o surge de 1999, foram encontrados blocos de gelo deformados em sedimentos congelados (Figura 5.3.7). Estes blocos de gelo podem ter sido gerados nas margens da geleira através da fragmentação do corpo de gelo, que caracterizam os lobos de piedmonte durante um surge. Estes fragmentos de gelo podem ter alcançado o substrato da geleira, por colapso dentro de crevasses abertas ou caindo em sedimentos proglaciais que, posteriormente, foram sobrepassados pela geleira (Figura 5.3.8, estágios 1 e 2). 

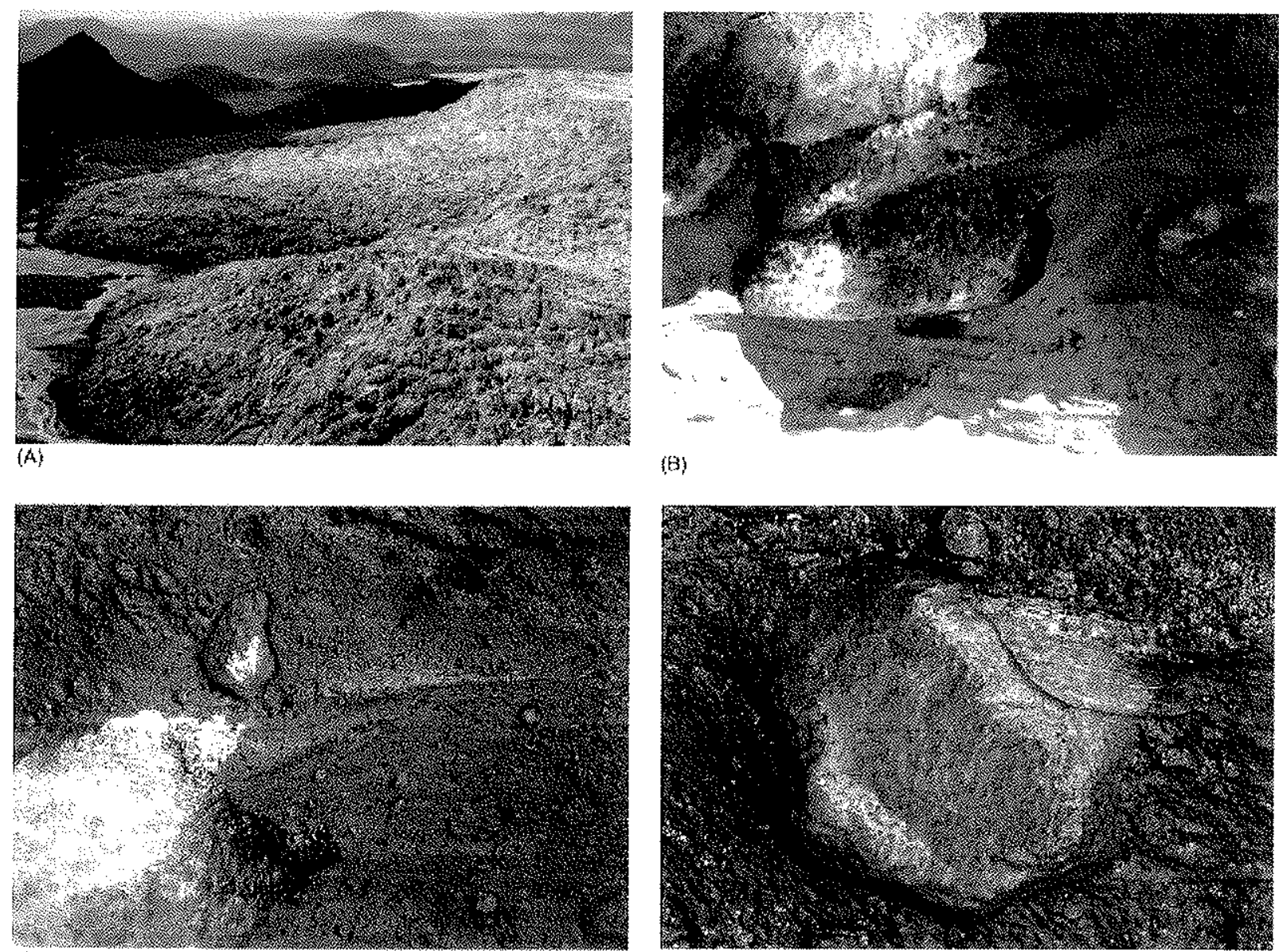

(C)

(b)

Figura 5.3.5 - Blocos de gelo e sedimentos congelados deformados. A) Lobos piedmonte da geleira Hagafellsjökull-Eystri após o surge de 1998/99. O Lobo 3 encontramse no meio da foto. B) Blocos de gelo da geleira imbricados presentes na Seção B. C) Atenuação de um bloco de gelo no diamicto congelado circundante. D) Lentes de gelo segregados no Lee de um clasto da Seção B (Bennett et al., 2003). Localização dos lobos e da Seção B na Figura 5.3.6. 


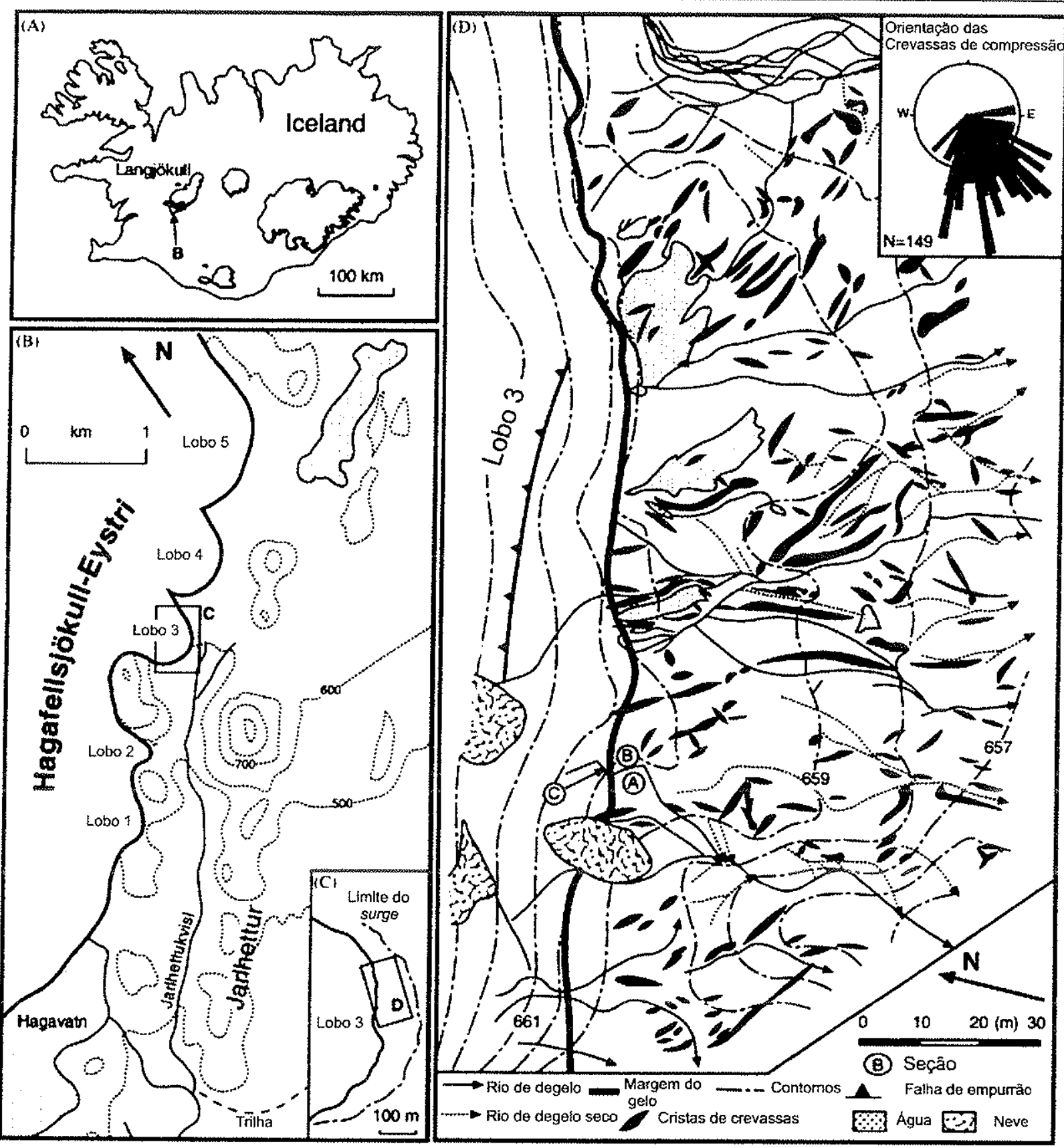

Figura 5.3.6 - Mapa de localizaçåo e geomorfológico do Lobo 3 situado na margem lateral leste da geleira Hagafellsjökull-Eystri, além da orientação das crevasses de compressão (crevasse-squeeze). O mapa geomorfológico (D) foi elaborado como auxílio do GPS Leica 520 , com precisão $<20 \mathrm{~mm}$. (Bennett et al., 2003). 


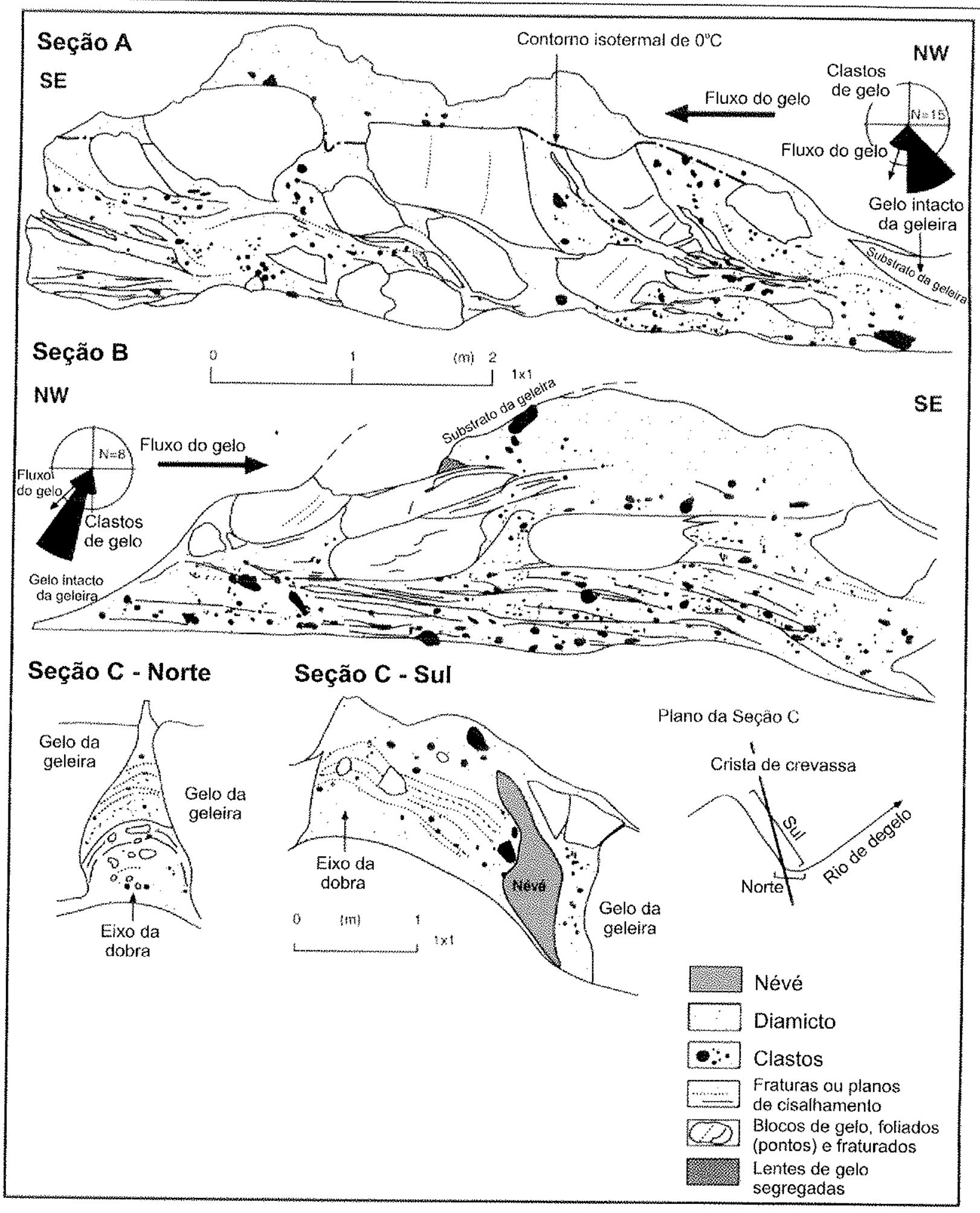

Figura 5.3.7 - Seções dos blocos de gelo e sedimentos congelados presentes no Lobo 3 da geleira Hagafellsjökull-Eystri e diagramas de rosáceas com dados sobre a fábrica dos clastos de gelo. Localizações das seções encontram-se na Figura 5.3.6 (Bennett et al., 2003). 


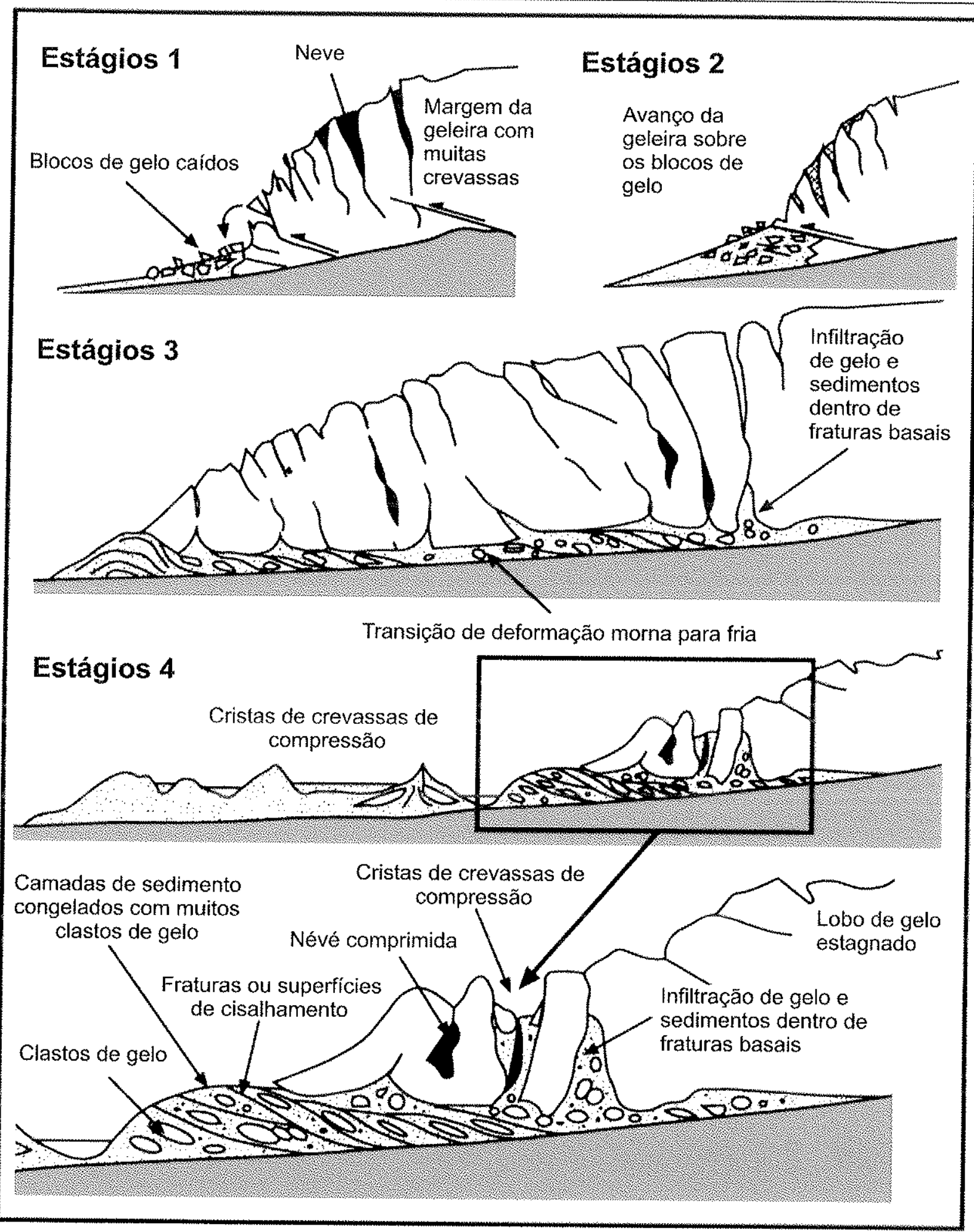

Figura 5.3.8 - Modelo esquemático da deformação de sub-congelamento no Lobo 3, da geleira Hagafellsjökull-Eystri, gerada durante o surge de 1998/99 (Bennett et al., 2003).

Com relação aos estilos de deformação, existem evidências de duas fases, as quais estão associadas a condições reológicas e térmicas contrastantes. Inicialmente, verifica-se que os blocos de gelo apresentam evidências de condições térmicas subglaciais e/ou 
erosão mecânica, fazendo com que os blocos se apresentassem com formas subarredondadas e padrões de imbricamentos consistentes com os pavimentos de clastos subglaciais, sugerindo que os blocos de gelo atuaram como se fossem massas competentes, desiocando-se dentro de uma matriz temperada, dúctil, e com camadas de sedimentos facilmente deformadas. $O$ preenchimento de crevasses e fraturas, que ficam mais espaçadas na direção da base da geleira, por sedimentos e blocos de gelo, só poderia ocorrer nestas condições térmicas e reológicas. Posteriormente, surgem na matriz evidencias de deformação rúptil na forma de fraturas ricas em gelo. A concentração de gelo dentro destas fraturas pode refletir a expulsão da água intersticial em excesso para dentro destas fraturas, associadas à formação e expansão volumétrica de gelo nos poros dos sedimentos. Este processo requer a transformação para condições sub-congeladas que resultam em mudanças reológicas. O progressivo congelamento da água contida na matriz, produzindo gelo intersticial, aumentaria a resistência ao cisalhamento do sedimento, permitindo a formação de deformações rúpteis. Em suma, no processo de deformações subglaciotectônicas de sub-congelamento existem evidências de deformações dúcteis e rúpteis, demonstrando variações térmicas e reológicas na base da geleira (Figura 5.3.8, estágios 3 e 4).

A temática destes dois trabalhos (Bennett et al., 2003; 2004) têm forte implicações na teoria dos regimes reológicos e nas gêneses das deformações glaciotectônicas, e foram úteis nas considerações relacionadas às estruturas descritas no Neopaleozóico brasileiro. A constatação da variação entre condições térmicas e reológicas da geleira Hagafellsjökull pode, inclusive, contribuir para o aperfeiçoamento do modelo Slip-Stick. Na realidade, os processos mencionados por Bennett et al. (2003) podem refletir as alternâncias de regimes hidrológicos, nos quais a pressão de água teria sido a responsável pelo avanço súbito da geleira (através da etapa de deslizamento, slip, do referido modelo). Todavia, também demonstra que, após um surge, a base da geleira pode voltar a ficar aderida ao substrato, provocando condições sub-congelantes. Estas interpretações são semelhantes às apresentadas para as deformações subglaciotectônicas rúpteis de Capivari e Jumirim, de forma que verifica-se assim que o contexto apresentado para explicar as deformações neopaleozóicas brasileiras tem possiveis equivalentes atuais.

Outra importante constatação foi a possibilidade de sedimentos congelados serem gerados em ambientes progiaciais de geleiras temperadas, numa região com altas taxas de precipitação de neve, como é o caso da Islândia. Mesmo considerando que a neve depositada sobre os sedimentos age como um isolante térmico, prevenindo assim a formação de sedimentos congelados, foi possível constatar a presença de sedimentos congelados, devido à formação de "ilhas" sem concentração de neve. Nos locais em que não há cobertura por neve ou por água, os sedimentos podem ficar sujeitos às baixas 
temperaturas do inverno, possibilitando a formação de sedimentos congelados. Este pode ser mais um motivo para a geração de estruturas glaciotectônicas rúpteis, pois os sedimentos estariam mais enrijecidos, e, assim, no caso das estruturas subglaciotectônicas rúpteis, próximas ao contato entre os arenitos e os diamictitos deformados de Capivari e Jumirim, é mais provável que tenham sido provocados, conforme acima discutido, pelas condições hidrológicas. No entanto, cabe lembrar que, em Jumirim, há também a presença de um canal arenoso com estruturas rúpteis (Figura 4.3.10), situado, aproximadamente, no mesmo horizonte que o Pavimento de Clastos Superior. Desta forma, torna-se pertinente considerar a possibilidade dos sedimentos terem se congelado durante o inverno que antecedeu o avanço da frente da geleira. Para tanto, faz-se necessário considerar que o canal tenha secado durante o inverno e que não tenha havido deposição de neve sobre este sedimento. Caso o inverno tenha sido, realmente, rigoroso, a disponibilidade de água de degelo, que, possivelmente, alimentava este canal, pode ter cessado, permitindo, assim, o congelamento do sedimento antes do avanço da frente da geleira e a sua posterior deformação.

Finalmente, vale a pena por em evidência que estes estudos demonstram a importância do permafrost na formação das estruturas glaciotectônicas rúpteis. Contudo, cabe também lembrar que as morainas de empurrão de Witmarsum são muito semelhantes às da geleira Höfdabrekkujökull (Islândia), descritas por Krüger (1985, 1994) como decorrentes de avanços abruptos da geieira sobre um substrato parcialmente congelado. No entanto, ressalvamse que as morainas de Witmarsum não demonstram a mesma gênese, visto que apresentam deformações dúcteis e "canibalismo", já que o segundo sistema de morainas de empurrão destrói, em parte, o sistema previamente depositado. Caso houvesse condições para o desenvolvimento de permafrost antes do segundo avanço da geleira, o substrato (no caso, o primeiro sistema de morainas de empurrão) se comportaria, reologicamente, como um sedimento rígido, intensificando a geração de estruturas rúpteis e dificultando a sua parcial destruição, servindo, assim, como um obstáculo para um novo avanço da frente da geleira. 


\section{OUTROS TIPOS DE DEFORMAÇÕES ANALISADAS}

Tendo em vista a constatável semelhança entre as estruturas glaciotectônicas e as decorrentes de fluxos gravitacionais de massa, tornou-se necessário um estudo sobre os procedimentos para distingui-las, visto que estes dois processos deformacionais dominam as deformações adiastróficas em ambientes glaciomarinhos ou glaciolacustres, possibilitando, desta forma, a confusão entre ambos. As deformações decorrentes de fluxos gravitacionais de massa em ambientes afetados por geleiras são dominadas, inicialmente, por processos sedimentares relacionados com a taxa de aporte de sedimentos, à quantidade de água contida nos sedimentos e a distância da margem da geleira, enquanto que nas deformações subglaciotectônicas dominam os processos deformadores associados à pressão efetiva, à deformação por cisalhamento, ao tipo de material subglacial envolvido e à distância da margem da geleira. Apesar da semelhança entre as estruturas resultantes de deformação desenvolvidas nestes dois ambientes, é possivel tentar estabelecer alguns critérios sedimentares e estruturais de diferenciação.

Para tanto, foram desenvolvidos estudos sedimentológicos, estratigráficos e estruturais no afloramento conhecido pela denominação "Boituva". Conforme mencionado anteriormente, este afloramento já foi considerado como de origem glaciotectônica (Washburne, 1930; Almeida, 1953; Martin, 1964) e, atualmente, é tido como decorrente de fluxo gravitacional de massa (Rocha-Campos, 1963, 1967; Rocha-Campos et al., 1972; Gama Jr. et al., 1992). Para tanto, e visando verificar quais procedimentos apresentam maior eficácia, os dados obtidos neste estudo foram confrontados com os conhecimentos que se tem no presente momento sobre os métodos para diferenciar estes dois processos deformacionais.

\subsection{DESCRIÇÃO DOS AFLORAMENTOS E ESTRATIGRAFIA DE BOITUVA}

Este afloramento apresenta uma associação faciológica característica, que compreende uma sucessão de altemâncias centimétricas de sedimentos silto-argilosos, intercalados com arenitos finos, maciços, raramente estratificados, normalmente subhorizontais. Estes sedimentos silto-argilosos compreendem, basicamente, folhelhos e ritmitos irregulares, semelhantes às litofacies reconhecidas por Setti (1998) para a porção proximal de bacia do Subgrupo Itararé, próximo a Itu. Em Boituva, contudo, estas litofacies possivelmente seriam equivalentes a registros de condições distais, visto a escassez de clastos caídos e praticamente ausência de evidências de correntes de tração. 
Rocha-Campos et al. (1972) inicialmente descreveu 13 unidades faciológicas nos afloramentos de Boituva. Contudo, no presente trabalho, esses sedimentos foram reinterpretados e associados em duas unidades faciológicas (Unidades A e B), devido à presença de características semelhantes entre elas (Figura 6.1.1). Assim, as unidades faciológicas A e B são representadas, respectivamente, pelas unidades $1-7$ e $8-13$, segundo a nomenclatura de Rocha-Campos et al. (op cit.).

Vale a pena mencionar, também, que, embora tenha sido feita uma alteração nos agrupamentos faciológicos das unidades, não foi dada ênfase à descrição das litofacies em virtude da existência de vários trabalhos que descrevem este afloramento com detalhe, sugerindo-se a leitura dos trabalhos de Rocha-Campos et al. (1972) e Gama Jr. et al. (1992) para um detalhamento sedimentógico e estratigráfico sobre este afloramento. Além do mais, praticamente todas as estruturas sedimentares e feições estruturais descritas em trabalhos anteriores sobre a localidade foram reconhecidas e analisadas nos trabalhos de campo, entre elas, dobras recumbentes, falhas de acavalamento, estruturas em constrição e de recalque.

Conforme apresentado na Figura 6.1.1, a sequência estratigráfica inicia-se, da base para o topo, com a unidade faciológica $A$, formada predominantemente por folhelhos escuros (acinzentados), quando não intemperizados, relativamente mal laminados, que, localmente, chegam a ser siltosos e, em muitos casos, extensivamente dobrados e fraturados, por vezes, intercalados por arenitos finos, amarelados. Esta Unidade A possui, no mínimo, $25,5 \mathrm{~m}$ de espessura e inicia-se com alternâncias entre folhelhos horizontais e dobrados, intercalados por camadas de arenito. Esta sequência basal, caracterizada por dobramentos, é interrompida, na altura dos $8 \mathrm{~m}$, por uma estrutura de sobrecarga, que é capeada por folhelhos maciços. Estes folhelhos maciços, horizontais, apresentam aproximadamente $2,5 \mathrm{~m}$ de espessura, acima dos quais ocorre, novamente, uma sequência, com cerca de $1,5 \mathrm{~m}$ de espessura, de folhelhos onde se alternam camadas horizontais e dobradas, com intercalações de arenitos finos. Estas deformações e intercalações de arenito aumentam gradativamente de frequência, e passam a exibir, na altura dos $12 \mathrm{~m}$ da seção, estruturas caoticamente deformadas ao longo de um intervalo de, no máximo, $9 \mathrm{~m}$ de espessura. Acima destas camadas com estruturas caóticas da Unidade A, ocorrem, em contato brusco e erosivo com as camadas subjacentes, um intervalo de arenitos finos, estratificados, que, devido à falta de registros nos afloramentos, não foi possivel constatar a sua espessura, mas que pode apresentar no mínimo $1,5 \mathrm{~m}$ de espessura. $A$ Unidade $A$ termina com uma camada de folhelhos maciços com no minimo $1 \mathrm{~m}$ de espessura. 


\section{Seção Estratigráfica de Boituva}

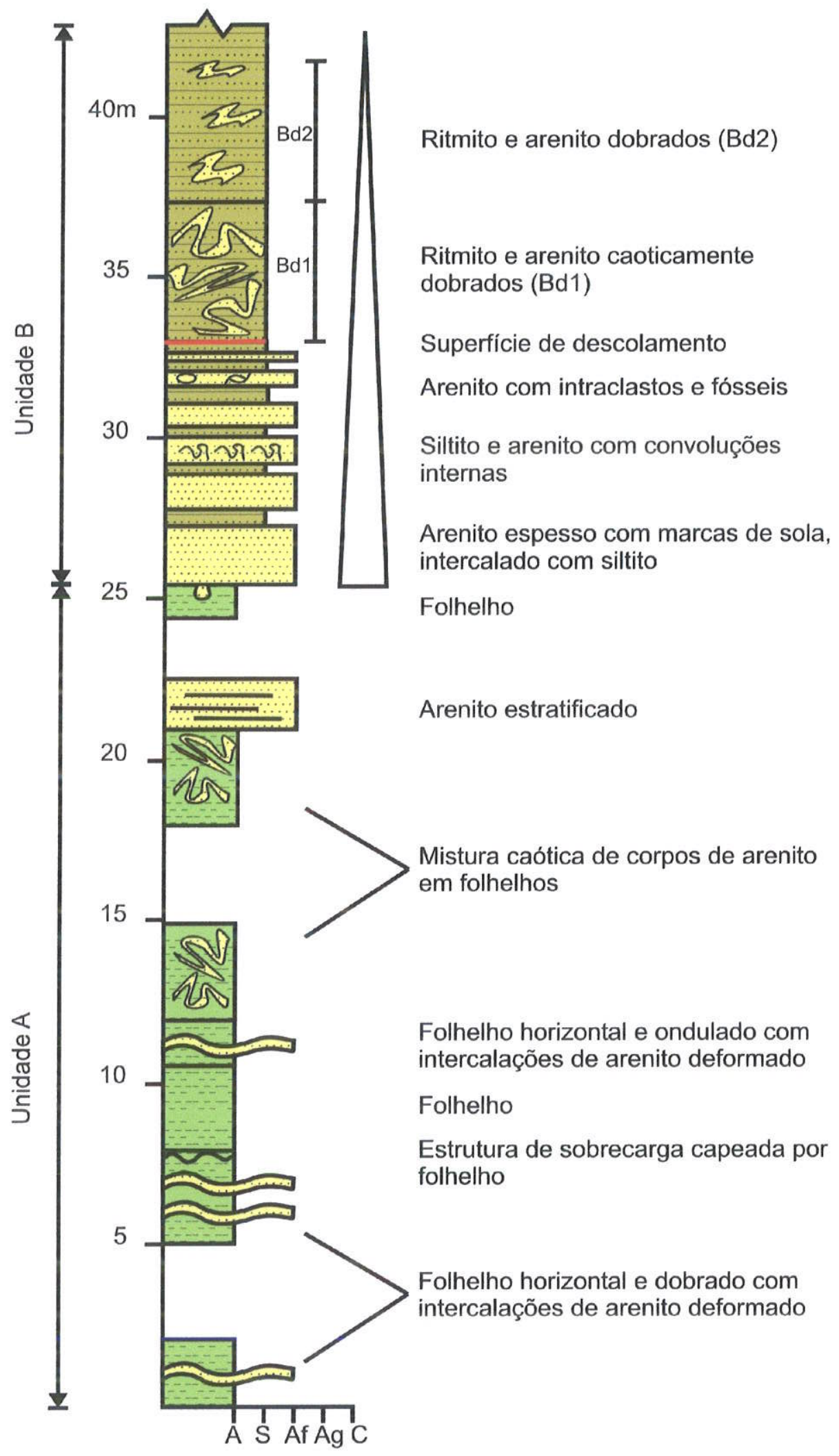

Figura 6.1.1 - Seção estratigráfica do lado esquerdo, no sentido Porto Feliz para Boituva, do afloramento locado no $\mathrm{km} \mathrm{0,5}$ da rodovia Vicente Palma, SP-129. Linha grossa vermelha representa a superfície de descolamento (adaptado de Rocha-Campos et al, 1972). 
As deformações registradas nos folhelhos da Unidade A, constituidas, em parte, por dobramentos e ondulações, são resultantes, ao que tudo indica, de compactação diferencial e/ou consequentes de reajustes hidroplásticos (e.g.: laminações convolutas, estruturas de sobrecarga e pseudonódulos), provavelmente relacionadas à deposição rápida de sedimentos arenosos com retenção de alto conteúdo de água.

A unidade faciológica $B$, que possui no mínimo $17,5 \mathrm{~m}$ de espessura, inicia-se com um corpo de arenito, maciço, amarelado, que apresenta na sua base marcas de sola, evidenciando um contato brusco e erosivo com o topo da Unidade A. Acima deste arenito começa a haver uma frequente alternância entre arenitos finos a médios, siltitos e ritmitos irregulares de siltitos e argilitos, cujas espessuras diminuem para o topo, onde são seccionados por uma superficie de descolamento. Os siltitos são maciços, de coloração ocre ou bege, enquanto que os ritmitos irregulares são definidos por pares litológicos formados por camadas/lâminas, milimétricas a centimétricas, de siltito, cinza-claro, ou arenito fino, amarelado, e lâminas centimétricas de argilitos ou folhelhos cinza-escuros, com estratificações plano-paralelas. Contatos transicionais e bruscos foram observados entre as camadas claras e escuras dos ritmitos.

Abaixo da superficie de descolamento os sedimentos apresentam poucas deformações internas, predominando estruturas de sobrecarga e de amalgamação de camadas e lentes de arenito muito fino/fino, maciço, separadas por niveis de argilito, siltito ou ritmito. A porção situada acima da superfície de descolamento, com no mínimo $10 \mathrm{~m}$ de espessura, constitui-se, basicamente, de ritmitos irregulares com espessura variável dos pares litológicos, e camadas arenosas maciças intensamente dobradas, fraturadas e falhadas, além de localmente redobradas (primeiros 5,5 m, Unidade Bd1, Figura 6.1.1). Essas estruturas deformadas acima da superfície de descolamento serão detalhadas no próximo tópico deste subcapitulo.

Como foi visto anteriormente, intercalados, subordinadamente, nos sedimentos, tanto na Unidade A como na Unidade B, ocorrem arenitos maciços, amarelados, de granulometria fina a média, normalmente com granodecrescência ascendente, passando, gradativamente, em alguns casos, para siltitos e argilitos laminados, formando, inclusive, uma "cauda de argila", no topo. Estes arenitos, que, por vezes, encontram-se deformados (principalmente dobrados), apresentando, inclusive, estruturas de sobrecarga na base ou marcas de sola, são normalmente atribuídos a turbiditos.

Correntes de turbidez, ou simplesmente turbiditos, de modo geral, são correntes densas de reologia fluidal e estado turbulento, que se movem declive abaixo, junto ao assoalho da bacia, sob ação direta da gravidade, que conduz a corrente de acordo com as variações de densidade entre a corrente e as águas circundantes (Shanmugam, 1996). A 
Sequência de Bouma (Bouma, 1962) é o principal modelo genético utilizado para a compreensão dos depósitos de "turbiditos verdadeiros", ou seja, depósitos originados por correntes de turbidez típicas, com reologia fluidal ou Newtoniana, na qual os sedimentos são suspensos pela turbulência do fluido.

Sucintamente, a Sequência de Bouma é uma sequência vertical apresentando cinco subdivisões (A, B, C, D e E; da base para o topo, Figura 6.1.2). O nível $A$, dependendo do tipo de material iniciaimente disponivel, é constituído pela granulometria mais grossa, areias ou conglomerados maciços ou com gradação normal, e é produto de uma deposição rápida a partir do material transportado em tração na base do fluxo. As areias com laminações paralelas do nivel $B$ são depositadas como parte das camadas de recarga da corrente. Ao continuar a desaceleração do fluxo, depositam-se areias e siltes com laminações cruzadas (nivel $\mathrm{C}$ ), às quais podem se associar laminações convolutas

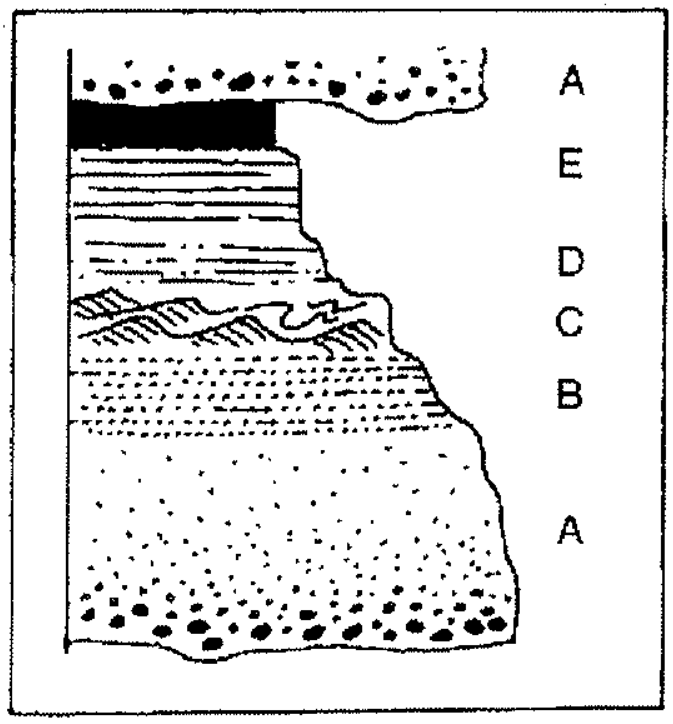

Figura 6.1 .2 - Sequência clássica de Bouma, sem escala e com as letras representando as determinadas subdivisões (Benn \& Evans, 1998). resultantes da eliminação do excesso de água intersticial. No nivel $D$, as interlaminações de siltes e/ou argilas são formadas pela decantação do material fino suspenso durante os estágios terminais do fluxo, com as laminações refletindo os pulsos da velocidade do fluxo. Finalizando, o nivel $\mathrm{E}$, com argilas ou siltes maciços, representa a decantação gradual do material de recarga residual em condições de água calma. Dependendo das condições do fluxo turbidítico, várias combinações podem ser obtidas com a ausência ou a repetição de alguns niveis desta sequência. Fluxos altamente concentrados podem apresentar espessas unidades $A$ e $B$, tendo as demais unidades apenas subordinadamente, caso apresentem estas unidades. Situações opostas (e.g.: com fluxos pouco concentrados) ou repetições de niveis, devido a variações nos pulsos do fluxo, ou mesmo fluxo reversos, decorrentes da inversão da direção do fluxo após refletir em altos topográficos, também são passiveis de serem desenvolvidas.

Consequentemente, nota-se que as litofacies formadas por arenitos maciços $\mathrm{e}$ "caudas de argilas" seriam, na verdade, sequências incompletas de Bouma, nas quais ocorreriam apenas os niveis $A$ e $E$, assim como $o$ nivel $D$ em raras sequências. Por conseguinte seriam, predominantemente, correntes de turbidez de alta densidade, em que 
prevalecem os processos de tração (com estratificações horizontais e obliquas, ou cruzadas) e suspensão (Lowe, 1982).

No entanto, em algumas camadas do afloramento de Boituva, foram encontrados raros clastos de argilitos e lamitos e/ou ritmitos finos (intraclastos, Figura 6.1.3) e fósseis centimétricos dispersos na matriz (Figura 6.1.4). Verifica-se, desta forma, que estas constatações não condizem com um depósito gerado por correntes de turbidez, que são caracterizadas pela reologia fluidal e pelo estado de turbulência do fluxo, mas sim por um fluxo em estado laminar com comportamento reológico plástico. Desta forma, pelo menos algumas camadas de arenito maciço, em particular as que apresentam intraclastos e/ou fósseis, ocorrentes poucos decímetros abaixo da superfície de deslocamento (Figura 6.1.1), seriam, altamente, resultantes de fluxos arenosos de detritos ou de correntes de fundo (bottom current). O uso do termo fluxo arenoso de detrito (sandy debris flow) foi proposto por Shanmugam (1996), em detrimento à designação que, às vezes, é adotada por alguns pesquisadores, "corrente de turbidez de alta densidade", para se referir ao processo formador de areias maciças contendo clastos suspensos. Segundo Shanmugam (op cit.), uma corrente com estas características se comportaria muito mais plasticamente, com menor influência da turbulência e maior importância da coesão da matriz no transporte dos grãos. Este processo, geralmente associado a fluxos de reologia plástica, possui um comportamento temporal e espacialmente variável, podendo passar de fluxos coesivos a não-coesivos. Os mecanismos de suporte dos sedimentos nos fluxos arenosos de detritos incluem pressão dispersiva, coesão da matriz e fluxos ascendentes. Podem apresentar, da mesma forma, caudas tardias de material em suspensão, cujo registro seria algo semelhante ao que foi observado nos depósitos ditos "clássicos" de turbiditos (Salvetti, em preparação). Contudo, o objetivo desta tese não é a análise das controvérsias relacionadas aos mecanismos de fluxos gravitacionais de massa, porém faz-se necessário esclarecer que, face aos recentes estudos e aos clastos e fósseis encontrados dispersos na matriz, o modelo proposto por Bouma deve ser utilizado com cautela, ou, se o enfoque desejado for estes fluxos de massa, cabe estabelecer um novo estudo mais detalhado para que a caracterização dos atributos que definem a porção basal seja estabelecida sem que haja erros de interpretação. 


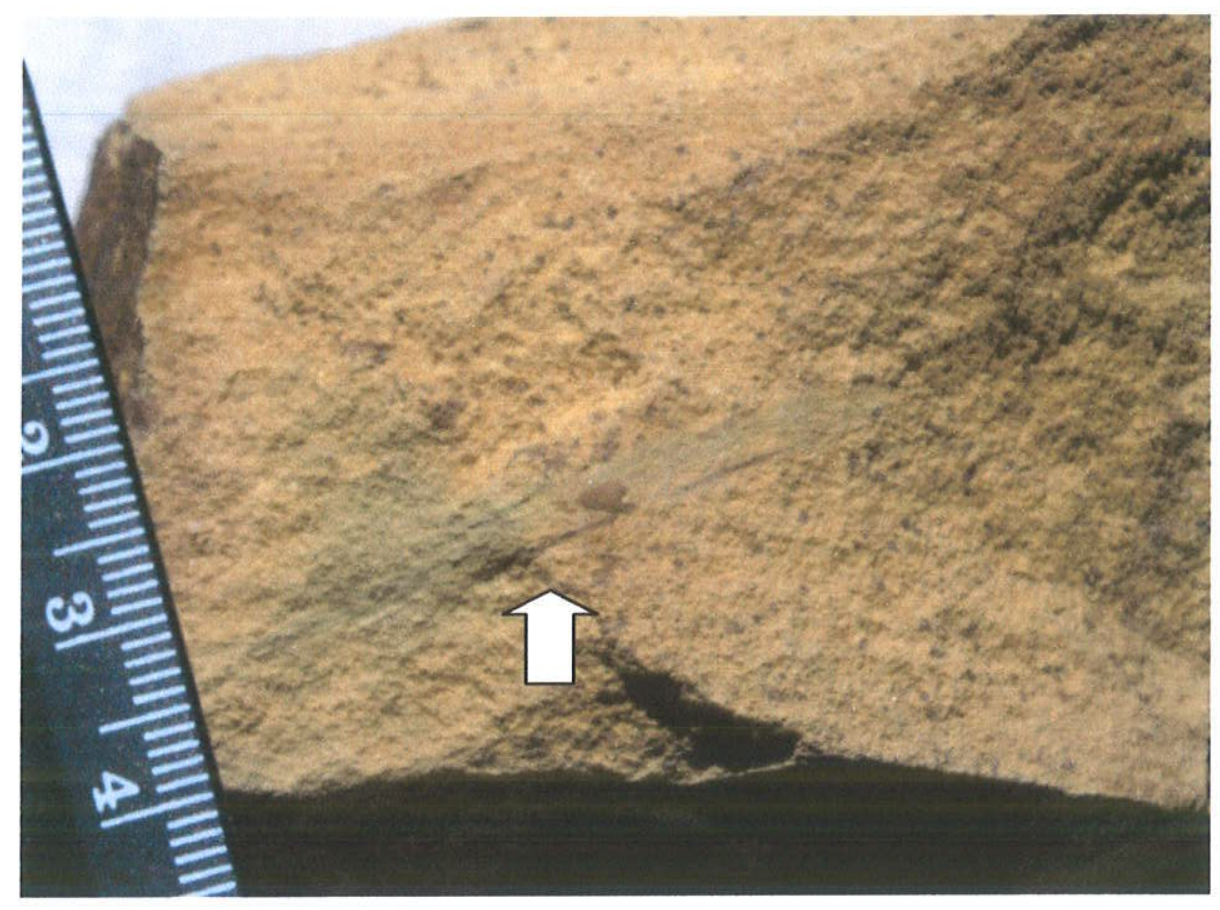

Figura 6.1.3 - Intraclastos argilosos dispersos na matriz de arenito maciço de Boituva. Seta indica a posição.

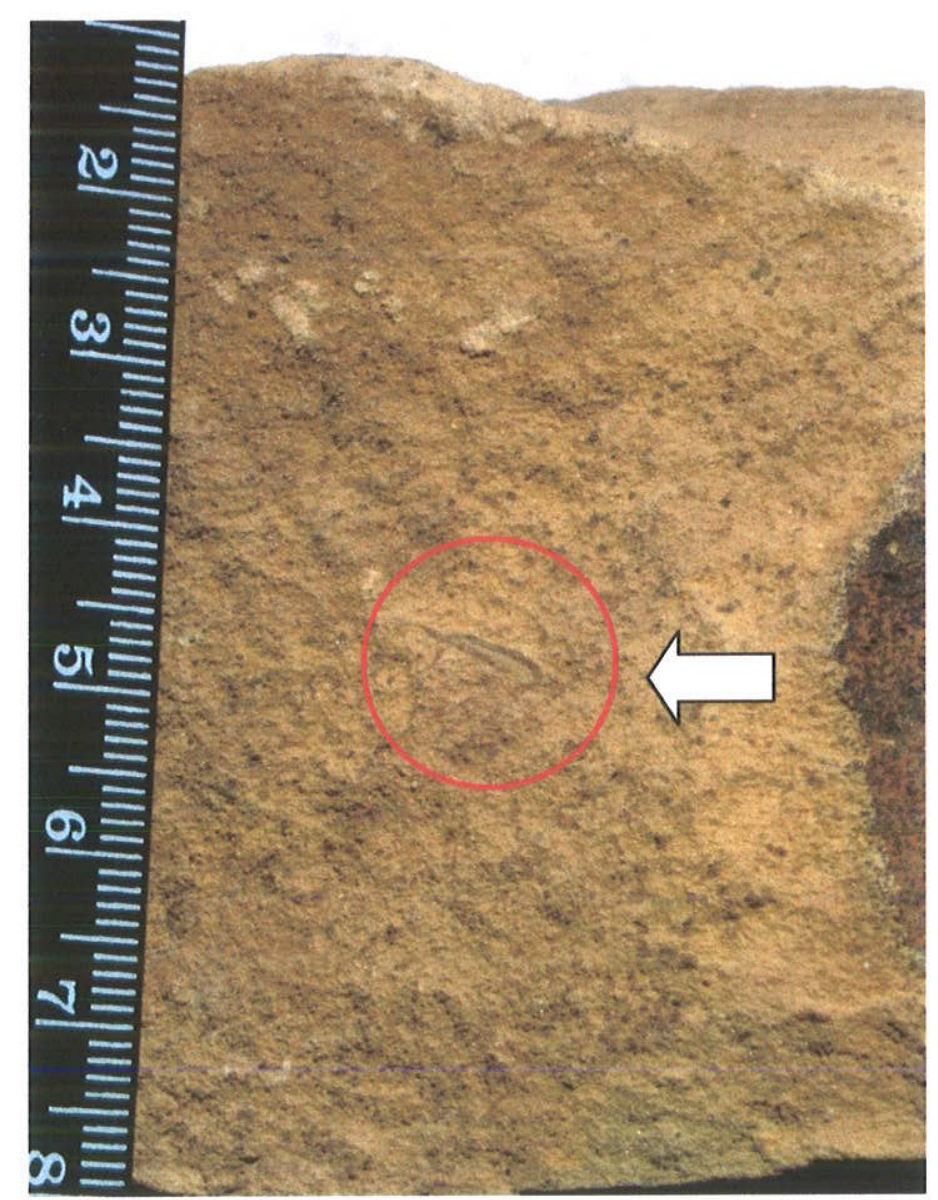

Figura 6.1.4 - Fóssil de bivalve disperso na matriz de arenito maciço de Boituva. Seta e círculo vermelho indica a posição. 
Em consonância com Gama Jr. et al. (1992), notou-se que, como característica geral, a Unidade B apresenta, como um todo, uma granodecrescência ascendente (fining upward) e diminuição na espessura das camadas (thinning upward) psamíticas. Tais características suportam a consideração de que representaria uma sequência subaquática distal (possivelmente marinha), composta, predominantemente, por siltitos e ritmitos irregulares, interdigitados por fluxos turbidíticos e/ou outros tipos de fluxos de alta densidade, que passam, no sentido ascendente e gradativamente, a se tomarem mais distais. Esta ciclicidade de eventos de deposições por suspensão, normal da bacia sedimentar, e por fluxos gravitacionais de massa ocorre em todo o pacote sedimentar, inclusive nas camadas acima da superfície de descolamento (decollement), onde encontram-se intensamente deformadas.

\section{Estruturas de deformação acima da superfície de descolamento}

Neste tópico serão analisadas as estruturas de deformação que ocorrem acima da superfície de descolamento, (figuras 6.1.1, 6.1.5 e 6.1.6). Esta superfície apresenta-se em disposição subhorizontal, assim como os planos de acamamento das camadas que se encontram abaixo. Nas camadas superiores da Unidade B, ou seja, na Unidade Bd1 (Figura 6.1.1), que possuem no mínimo $10 \mathrm{~m}$ de espessura, foram constatadas várias estruturas de deformação dúctil-rúptil previamente descritas por outros autores (e.g. Aimeida, 1953; Rocha-Campos, 1963; Martin, 1964; Rocha-Campos et al., 1972), expostas numa extensão superior a $400 \mathrm{~m}$ ao longo do afloramento.

Na porção superior dos sedimentos intensamente deformados da Unidade Bd2 (a partir de $4 \mathrm{~m}$ acima da superfície de descolamento, Figura 6.1.1; Unidade 13 de Rocha-Campos et al., 1972), o sistema de dobras é caracterizado por dobras flexurais sinclinais e anticlinais assimétricas, com espessamento nas charneiras curvilineares e flancos adelgaçados (Figura 6.1.7), planos axiais geralmente inclinados para NE, variando normalmente de $45^{\circ}$ a subverticais, e eixos de dobras subhorizontais (com no máximo $40^{\circ}$ de inclinação) na direção NNW-SSE, que, por sua vez, indicam um sistema de dobras inversas cônicas horizontais (overturned fold ou overfold), conforme pode ser constatado na Figura 6.1 .8 , onde os pólos dos planos medidos nos flancos das dobras podem ser traçados dentro de uma guirlanda máxima, e demonstrando também que não sofreram redobramento. 

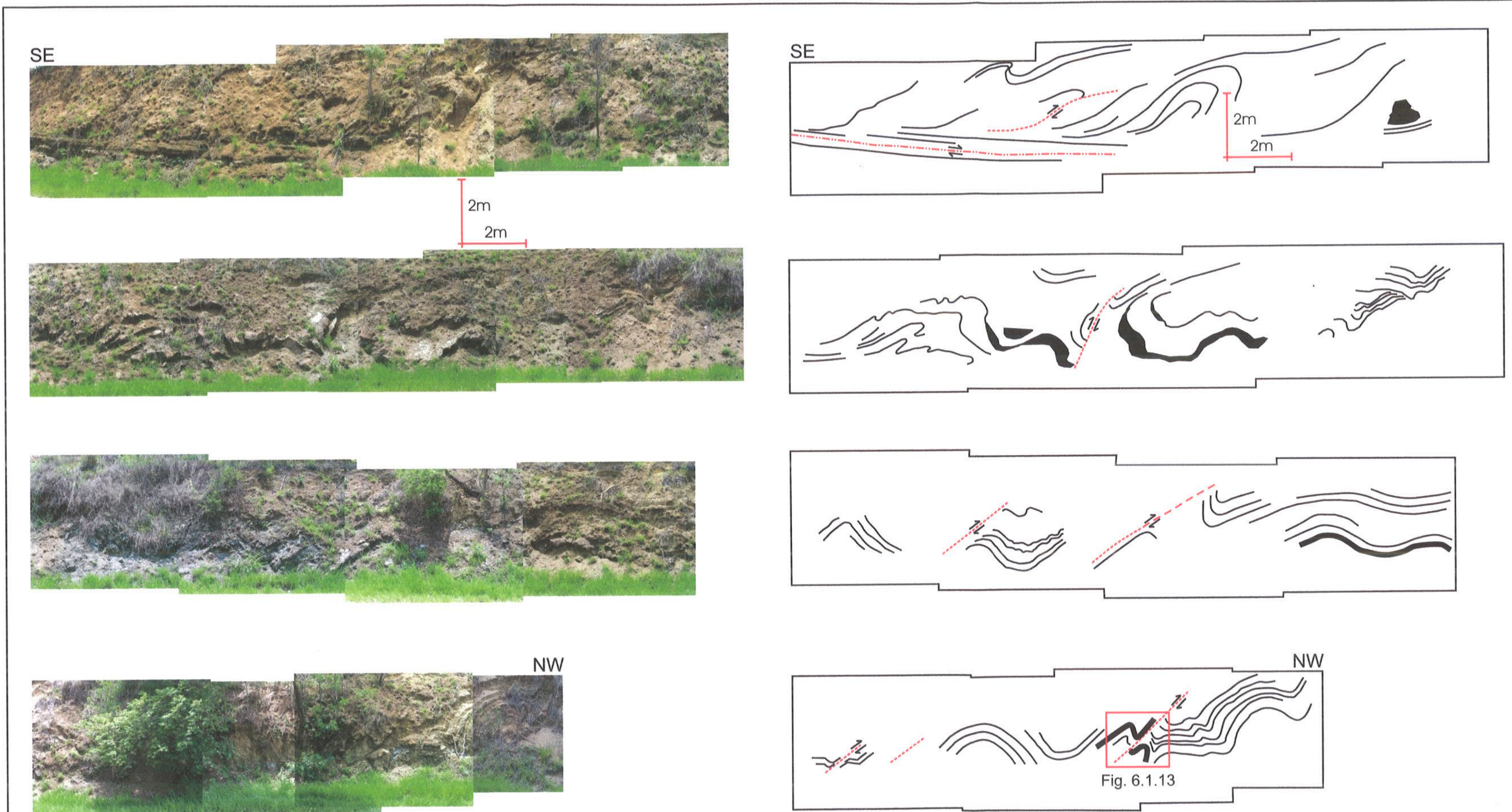

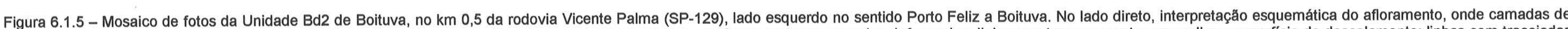

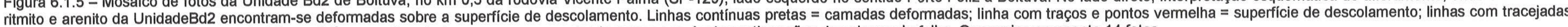
com espaçamentos curtos = planos de falha; e linhas com tracejadas com espaçamentos longos = prováveis continuações dos planos de falha. 0 mosaico apresenta 14 fotos 


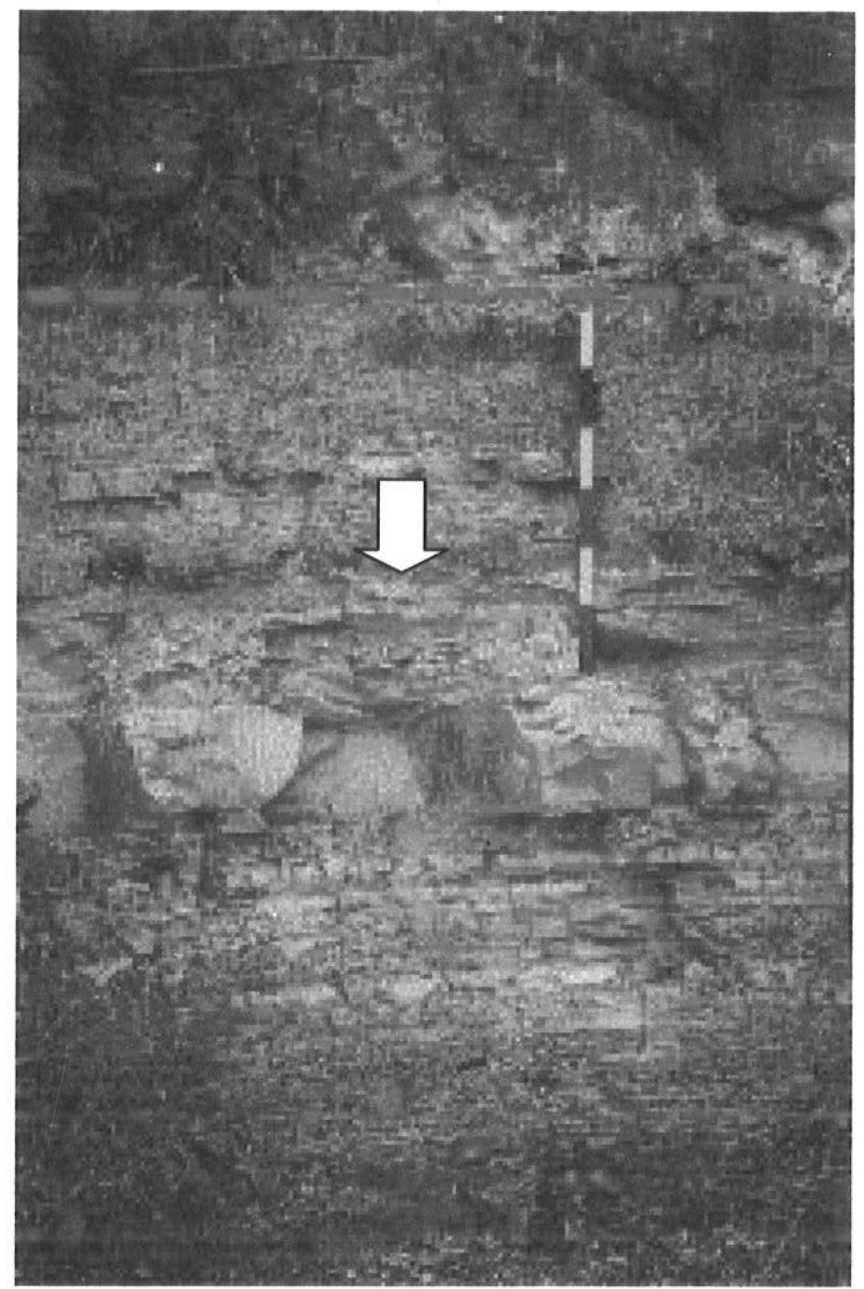

Figura 6.1.6 - Camadas horizontais plano-paralelas de ritmito e arenito abaixo da superfície de descolamento (tracejada em vermelho), na Unidade B. Seta indica uma estrutura de sobrecarga. Escala: $60 \mathrm{~cm}$.

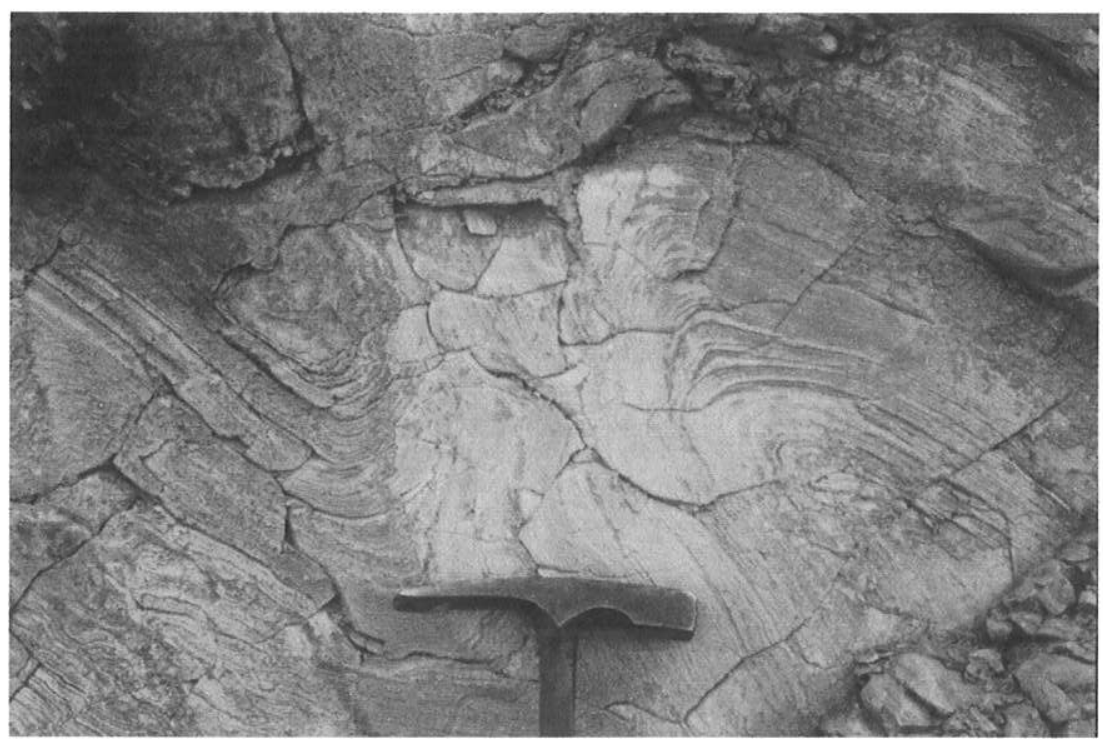

Figura 6.1.7 - Dobras flexurais sinclinais e anticlinais assimétricas, com espessamento nas charneiras curvilineares e flancos adelgaçados da Unidade Bd2. Escala: martelo geológico. 

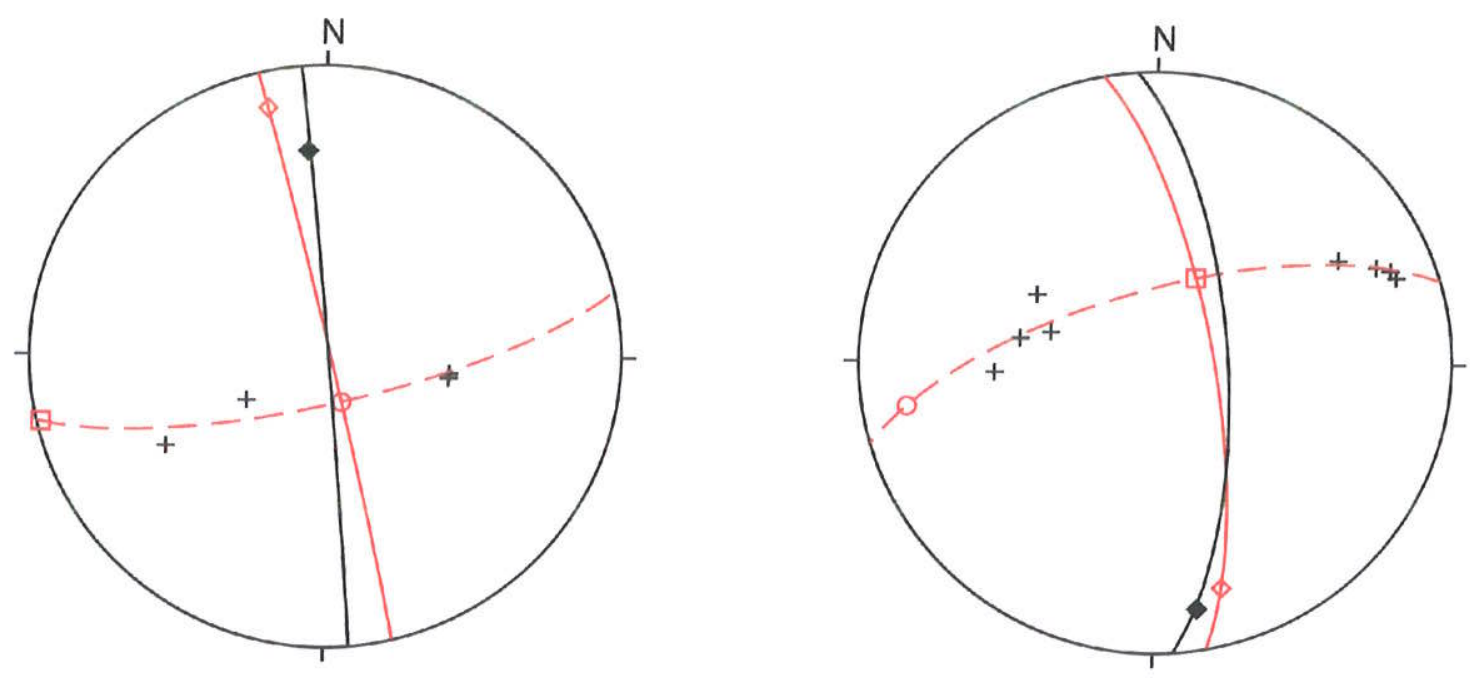

$\mathrm{N}=4$

+ Pólos dos planos nos flancos da dobra

- Eixo da dobra medido (N355/30)

Plano axial medido (N085/89)

- Autovetor 1 (N160/76)

$\square \quad$ Autovetor 2 (N256/02)

$\diamond \quad$ Autovetor 3 (N347/14)

Autovetor 3 = Eixo da dobra indireto

Plano axial indireto (N076/88)

- Guirlanda média com pólos dos flancos
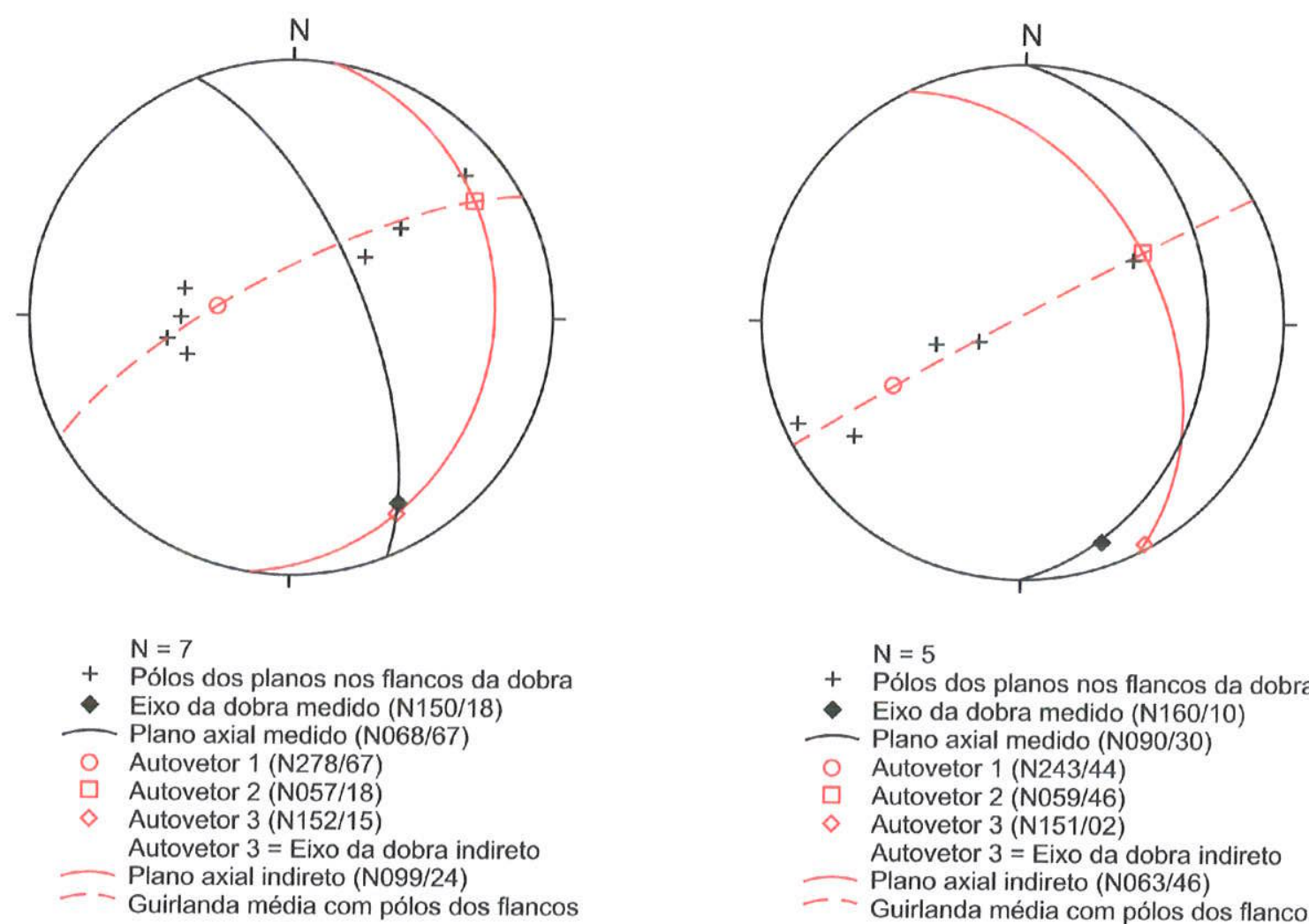

$N=5$

+ Pólos dos planos nos flancos da dobra

- Eixo da dobra medido (N160/10)

Plano axial medido (N090/30)

- Autovetor $1(\mathrm{~N} 243 / 44)$

Autovetor 2 (N059/46)

$\diamond \quad$ Autovetor 3 (N151/02)

Autovetor 3 = Eixo da dobra indireto

Plano axial indireto (N063/46)

- Guirlanda média com pólos dos flancos

Figura 6.1.8 - Diagramas Schmidt-Lambert, hemisfério inferior, de quatro dobras da Unidade Bd2, com dados obtidos em campo (eixos de dobra, plano axial e os pólos dos planos medidos nos flancos das respectivas dobras) e calculados estatisticamente (autovetores e planos axiais indiretos, ou seja, o plano axial obtido através dos autovetores), além da guirlanda máxima que contem os pólos dos planos medidos para cada dobra, caso sejam dobras cônicas. Acrescenta-se que o autovetor 3 normalmente coincide com o eixo axial quando a dobra é cônica. 
Adotando-se a classificação de dobras de Ramsay (1967), que se baseia nas isógonas de mergulho, a maioria das dobras seriam da Classe 2, ou seja, com isógonas paralelas. Eventualmente ocorrem dobras com isógonas fracamente convergentes (Classe 1C) e divergentes (Classe 3). No presente caso torna-se difícil generalizar, pois que existe um grande contraste no estilo das dobras formadas entre camadas arenosas, siltosas e argilosas, e, dentro de uma mesma estrutura, camadas com granulometria mais grossas tendem a apresentar dobras do tipo $1 \mathrm{~B}$ e 2 , enquanto que as mais argilosas normalmente apresentam dobras do tipo $1 \mathrm{C}$ e 3 . Contudo, como as camadas arenosas estão próximas da interface granulométrica do silte, inclusive algumas são siltosas, prevalece a geometria de dobra do tipo 1B. Outras formas de dobras observadas nesta unidade foram dobras menores parasitas, dobras em caixa (box folds, Figura 6.1.9), e em cúspide, ou cuspidadas (cuspate folds), esta última preferencialmente como estilos secundários internos a dobras maiores ou próximas às falhas de acavalamento dúctil-rúptil.

Localmente, encontram-se sistemas de clivagens de fratura berm desenvolvidos, com fraturas espaçadas de milimetros a poucos centímetros, normalmente paralelas ou sutilmente inclinadas em relação aos planos de fraqueza (Figura 6.1.10). Segundo Aimeida (1953), estas clivagens teriam se originado posteriormente às deformações, sendo associadas a processos tectônicos de âmbito regional, que afetaram os sedimentos da Bacia do Paraná. Contudo, como estão restritas a determinadas dobras, podem representar apenas a resposta a tensão de cisalhamento exercida na gênese das deformações. No decorrer deste estudo notou-se que as clivagens estão intimamente associadas aos sistemas de dobras e falhas, formando ângulos agudos com os planos de fraqueza das dobras. Em termos interpretativos pode ser considerado que quando da aplicação dos esforços associados à movimentação, houve, inicialmente, o desenvolvimento de deformação dúctil, e, assim, estes dobramentos estariam, portanto, relacionados às diferenças de competências entre as camadas arenosas e silto-argilosas. Posteriormente, com o incremento dos esforços, estes passaram a superar a resistência dos corpos ao rompimento, formando as clivagens, que progrediram para planos de fraqueza $\mathrm{e}$, eventualmente, falhamentos, o que implica na presunção de que, por essa mesma razão, as camadas estivessem "consolidadas". Desta forma, acredita-se que, em termos reológicos, tenha ocorrido algo semelhante ao verificado em Capivari e Jumirim, onde se interpreta que os sedimentos se comportaram com se estivessem consolidados em virtude das condições hidráulicas então prevalentes. No caso de Boituva, a alternância de camadas rítmicas, permeáveis e impermeáveis, deve ter favorecido a expulsão de água intersticial dos sedimentos em questão, permitindo, desta forma, a formação de clivagem. 


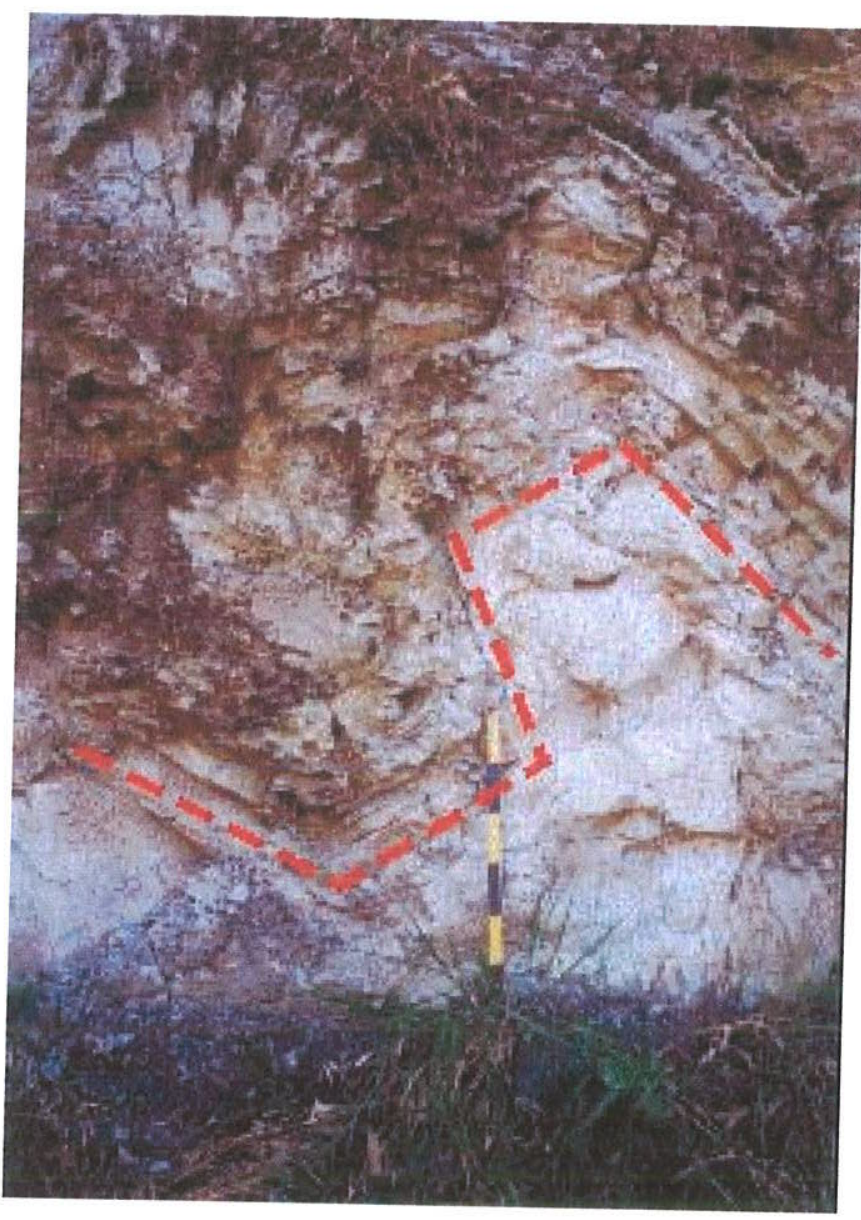

Figura 6.1.9 - Dobras em caixa (box folds) da Unidade Bd2. Escala: $60 \mathrm{~cm}$.

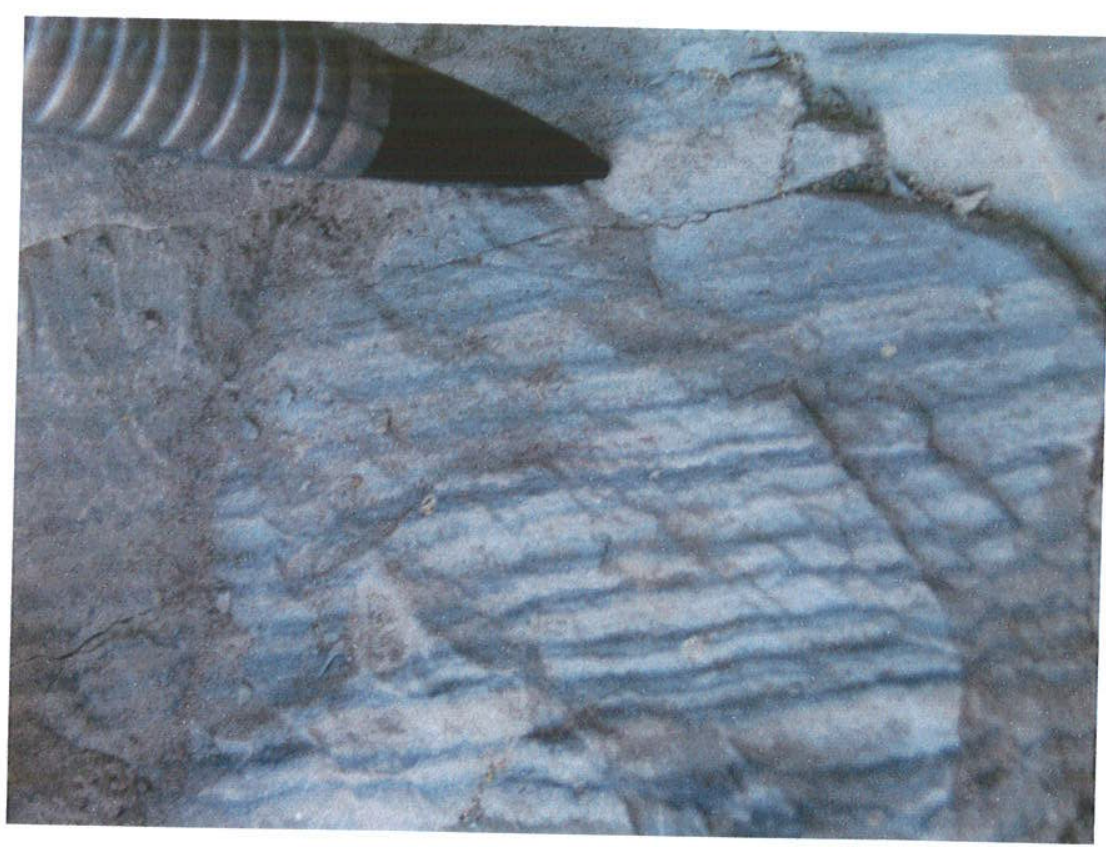

Figura 3.6.10 - Clivagens afetando ritmitos irregulares, em dobras flexurais assimétricas, Unidade Bd2 de Boituva. Escala: ponta de lapiseira. 
Utilizando o método estatístico $\mathrm{R} \%$ e centro $^{15}$ (Wallbrecher, 1986), calculado pelo software TectonicsFP, obteve-se a direção N333/01 para a média dos eixos das dobras, calculada através de 50 medidas de eixos, onde: o parâmetro de concentração ( $R$, Prozentueller Regelungsgrad) é 84\%; o parâmetro de precisão (k) é 12; o ângulo da amplitude da distribuição esférica do $R \%$ em torno do vetor principal é $23,9^{\circ}$; e a porcentagem de confiança é de 95\% (Figura 6.1.11). Outro cálculo efetuado foi a determinação dos autovetores, através dos eixos e dos planos axiais (Tabela 6.1.1). Os resultados dos autovetores pelos dois métodos apresentaram uma pequena diferença em virtude de eventuais erros nas leituras dos dados em campo, porém estão perfeitamente condizentes e configuram uma aparente direção de tensão mínima $\left(\sigma_{3}{ }^{\prime}\right)$ subhorizontal, e uma aparente direção da tensão máxima $\left(\sigma_{1}{ }^{\prime}\right)$ na para SW.

Tabela 6.1.1 - Tabela dos autovetores de acordo com os tipos de dados estruturais

\begin{tabular}{|llll|}
\hline Tipo de dados & Autovetor de $\sigma_{1}{ }^{\prime}$ & Autovetor de $\sigma_{2}{ }^{\prime}$ & Autovetor de $\sigma_{3}{ }^{\prime}$ \\
\hline Eixo & $\mathrm{N} 243 / 29$ & $\mathrm{~N} 065 / 61$ & $\mathrm{~N} 333 / 01$ \\
\hline Plano Axial & $\mathrm{N} 258 / 30$ & $\mathrm{~N} 062 / 59$ & $\mathrm{~N} 164 / 07$ \\
\hline
\end{tabular}

Obs.: $\sigma_{1}{ }^{\prime}, \sigma_{2}{ }^{\prime}$ e $\sigma_{3}{ }^{\prime}$ são as aparentes direções de tensão máxima, intermediária e mínima, respectivamente.

Os dados obtidos através da medição de eixos e planos axiais das dobras da Unidade Bd2 (Figura 6.1.11) são muito semelhantes aos apresentados por Martin (1964), único trabalho anterior a ilustrar esquematicamente em diagrama Schmidt-Lambert (figuras 2.2.1 e 2.2.2) suas interpretações a respeito das deformações deste afloramento. Tanto no presente trabalho como no de Martin (op cit.), o sentido da movimentação foi interpretado de NE para SW, mais precisamente ENE-WSW. Não obstante, a direção de tensão máxima, que indica a direção NE-SW, não seria um elemento suficiente para deduzir o sentido do esforço principal. Somando-se a estes dados estão as inferências obtidas através dos falhamentos, analisados a seguir, que indicaram que o esforço principal teria sido no sentido de WSW, ou seja, semelhante ao apresentado por Martin (op cit.).

\footnotetext{
${ }^{15}$ Não foi utilizado o método estatístico de Fisher, porque este método não pode ser empregado em dados subhorizontais com sentidos opostos (e.g.: para NNW e SSE). Nos casos das estrias glaciais, quando não ocorre tal situação, usou-se o método de Fisher, porque ambos os métodos resultavam no mesmo valor.
} 


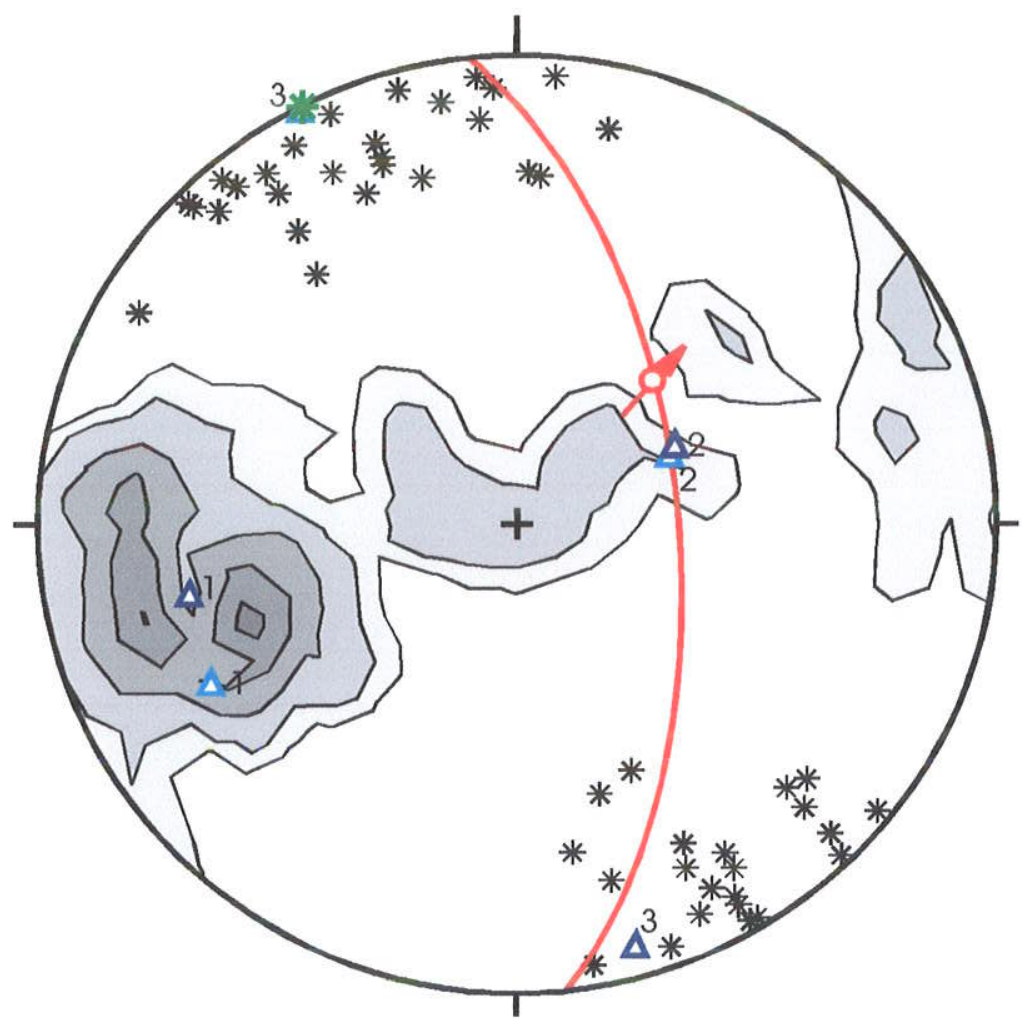

\section{Boituva}

* Direção principal dos

* eixos das dobras

* Eixos axiais das dobras

$\Delta$ Autovetores dos eixos

$\Delta \quad$ Autovetores dos planos axiais

Plano da falha e sua vergência

$\checkmark$ Contornos dos pólos dos planos axiais

50 medidas de eixos de dobras

50 medidas de planos axiais

Curvas de contorno em

$1,2,4,6$ e $8 \%$

Valor máximo: 9,19\% em N070/50

Figura 6.1.11 - Diagrama Schmidt-Lambert, hemisfério inferior, com curvas de contornos dos pólos axiais e medidas dos eixos das dobras, além dos autovetores deste sistema de dobras calculados através dos planos axiais (azul marinho) e eixos das dobras (azul claro), que foram comparados com um plano de falha (em vermelho), das deformações da Unidade Bd2.

$\mathrm{Na}$ Unidade $\mathrm{Bd} 2$ existe, também, uma sequência de falhas de empurrão, com planos de falha de alto ângulo mergulhando para ENE, com rejeitos da ordem de decímetros a poucos metros e de extensões limitadas, que evoluíram a partir de rochas já intensamente dobradas. Consequentemente, o sentido esforço máximo era aproximadamente para Oeste (Figura 6.1.11). Nota-se, também, que, no processo de deformação, as camadas apresentaram propriedades reológicas distintas, pois as camadas de arenito, mais incompetentes, foram dobradas e rompidas (Figura 6.1.12), enquanto que as camadas de ritmito, competentes, reagiram de forma dúctil, resultando em um sistema de falhas dúcteisrúpteis. A instabilidade das camadas de arenito durante a deformação por vezes formou boudins e, mais raramente, estruturas em constrições (pinch and swell, Figura 6.1.12), com variações de espessura muitas vezes descontínuas. 


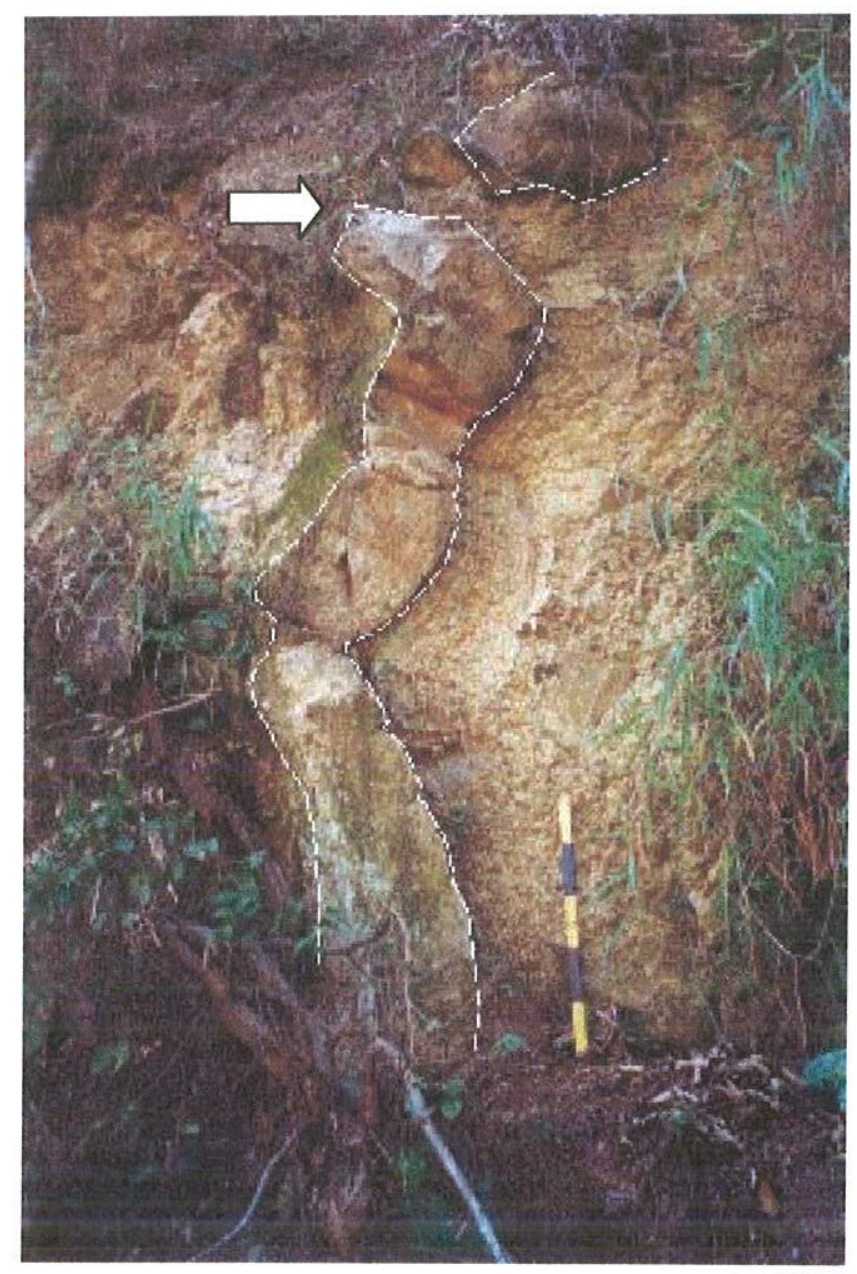

Figura 6.1.12 - Camada de arenito dobrado e rompido (Unidade Bd2). A seta indica o local do rompimento e as linhas tracejadas em branco o contorno da camada de arenito. Escala: $60 \mathrm{~cm}$.
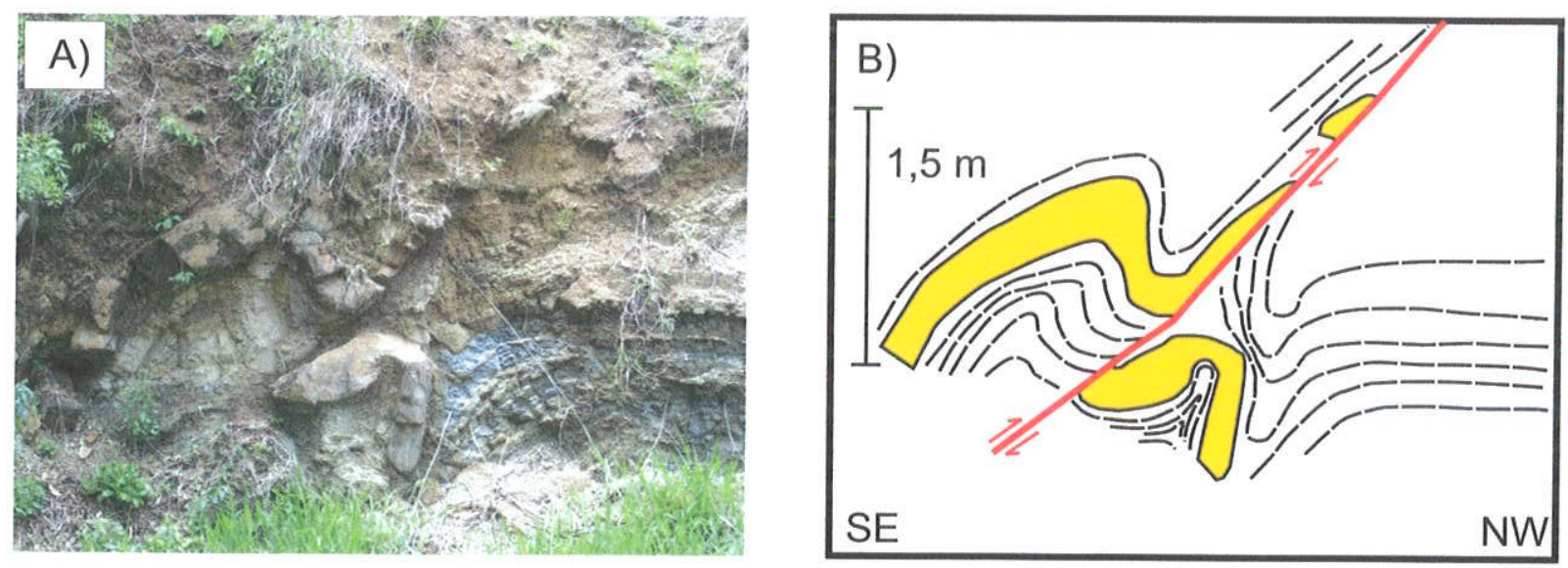

Figura 6.1.13 - Falha de empurrão dúctil-rúptil na Unidade Bd2. A) foto da falha B) Interpretação com o plano da falha em tracejado vermelho; camada de arenito dobrado e rompido em amarelo; e disposição aproximada das camadas de ritmito deformados, em linhas tracejadas. 
Utilizando uma falha de empurrão em particular como exemplo, cujo plano de falhamento é N084/63 (figuras 6.1.11 e 6.1.13), nota-se, inclusive, que o plano axial médio das dobras, representado pela guirlanda máxima que intercepta os vetores de tensão intermediária e mínima aparente (respectivamente, $\sigma_{2}{ }^{\prime}$ e $\sigma_{3}{ }^{\prime}$ ), apresenta valores muito semelhantes ao do plano de falha. Consequentemente, deduz-se que conforme os esforços compressivos foram aumentando progressivamente, planos de fraqueza eram gerados com - mesmo sentido que os dos planos axiais das dobras da Unidade Bd2 que, não suportando o aumento das tensões, romperam, gerando clivagens e falhas de empurrão, de acordo com a resistência das camadas.

No que se refere ao intervalo compreendido nos primeiros $3 \mathrm{~m}$ acima da superficie de descolamento (Unidade Bd1), as dobras ali desenvolvidas são formadas por camadas de ritmito silto-argiloso e arenito, cujos eixos encontram-se caoticamente dobrados (figuras 6.1 .1 e 6.1.14), demonstrando a superposição de duas direções de dobramentos. A maioria das dobras desta unidade é recumbente, com charneiras curvilineares contidas e não contidas em plano, além de eixos e planos axiais subhorizontais vergindo para norte e nordeste, e também de arrasto (drag folds) irregulares, que ocorrem entre as camadas mais competentes de arenito e incompetentes de ritmito e folhelho.

No entanto, de acordo com os tipos de padrões de interferência em dobras, apresentado por Ramsay \& Huber (1987, vol. 2), este redobramento se assemelha muito ao tipo 3 (padrão convergente-divergente, convergent-divergent pattem, Figura 6.1.15). Considerando este padrão de redobramento e, adicionalmente, que o sistema de dobras presente no topo das deformações da Unidade $\mathrm{Bd} 2\left(\mathrm{D}_{2}\right)$ redobrou uma deformação préexistente na sua base, o sistema de dobras mais antigo $\left(D_{1}\right)$ apresentara planos axiais perpendiculares aos planos axiais de $D_{2}$ e eixos com direção muito similar aos da segunda deformação. Estas premissas são, portanto, condizentes com as observações de campo, que constataram planos axiais horizontais e eixos variando entre N070-180 e N250-360, com mergulho de baixo valor, haja vista prevalecerem dobras recumbentes e de arrasto com vergência para norte e nordeste. 


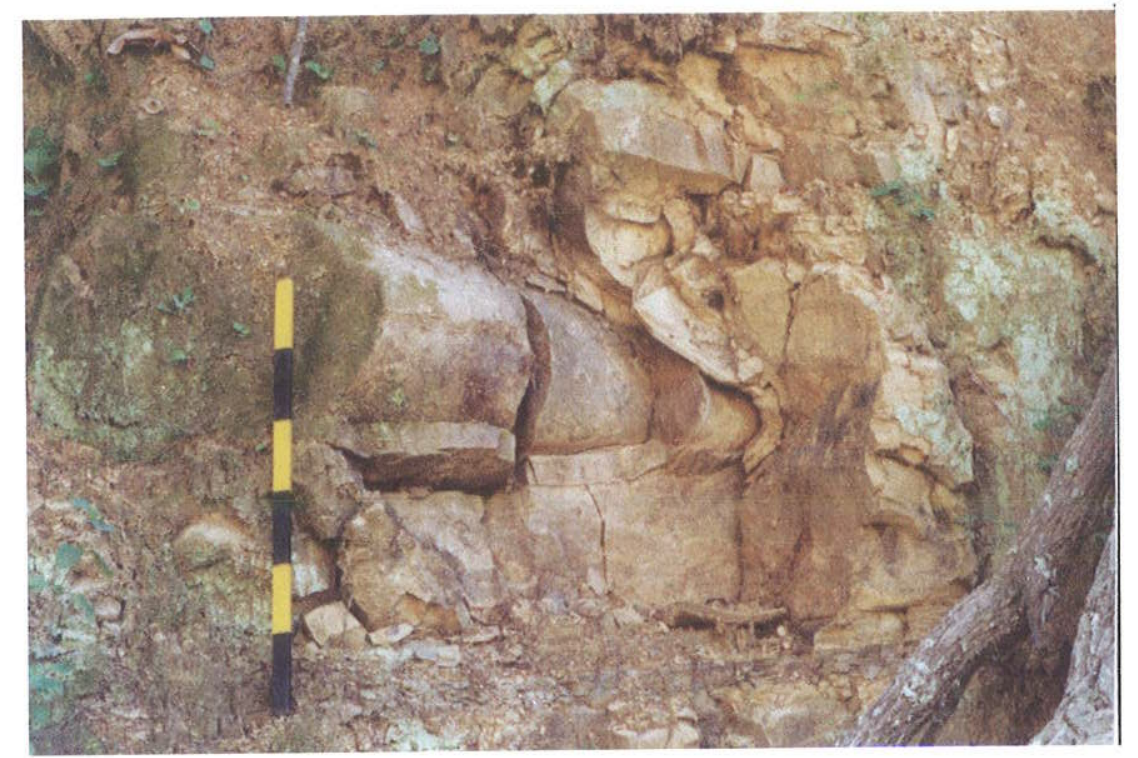

Figura 6.1.14 - Charneira de dobra recumbente redobrada na Unidade Bd1 de Boituva. A base da escala apóia-se na superfície de descolamento. Escala: $60 \mathrm{~cm}$.

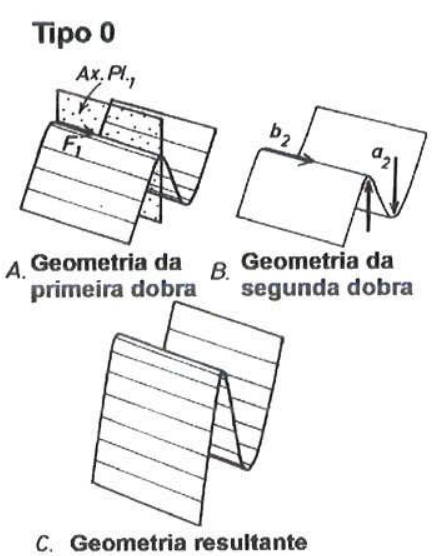

Tipo 2
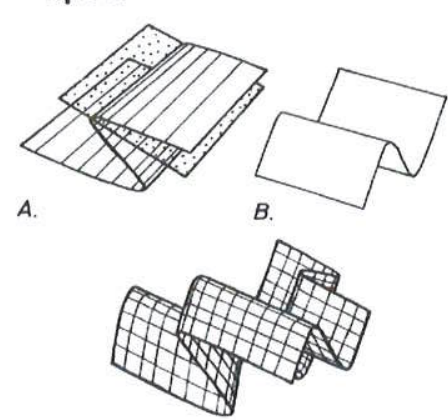

c.

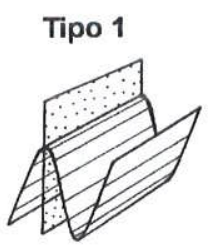

A.

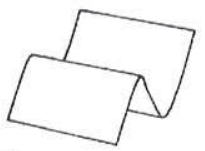

$B$.

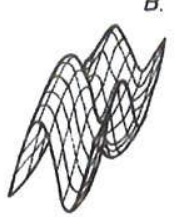

c.
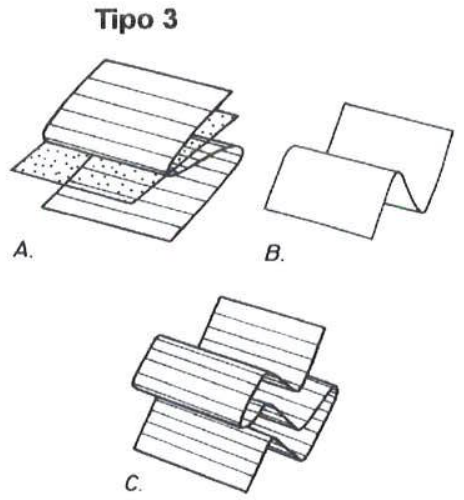

Figura 6.1.15 - Os quadros tipos principais de formas tridimensionais de dobras obtidas pela superposição de dobras de cisalhamento sobre formas de dobras pré-existentes (Ramsay \& Huber, 1987). 


\subsection{Considerações e interpretações sobre o afloramento de Boituva}

De acordo com suas características sedimentológicas e estratigráficas a associação faciológica reconhecida em Boituva é interpretada como resultante da deposição em condições relativamente distantes da área fonte dos sedimentos, em ambiente subaquático lacustre ou marinho. Devido à mudança das características sedimentológicas verificada ao longo da seção (unidades $A$ e $B$ ), considera-se que teria havido uma variação do nível relativo do corpo de água ou do aporte de sedimentos.

Intercalados à decantação dos sedimentos finos, tanto da Unidade A como da B, teriam se desenvolvido fluxos densos, arenosos (sandy debris flows), e/ou correntes de turbidez, possivelmente decorrentes de influxos de água de degelo com alta carga sedimentar, ou, alternativamente, como resultado da falência da resistência de atrito em sedimentos inconsolidados, através do gradativo empilhamento de sedimentos nas bordas da bacia, que, desestabilizados, fluiram talude abaixo, na forma de fluxos gravitacionais de massa do tipo fluxo de detritos arenosos. Estes sedimentos podem, ainda, ter sido transportados em suspensão por turbilhonamento, a partir de sedimentos inicialmente depositados na zona costeira, provavelmente como consequência da atuação de ondas, seguida de transporte por correntes para zonas de predomínio de deposição das argilas.

Nota-se, portanto, que a pilha sedimentar exposta no afloramento de Boituva configura um contexto de águas relativamente profundas, que, no âmbito do modelo sedimentar admitido para o Subgrupo ltararé (Santos et al., 1996), dificultariam a interpretação das estruturas de deformação presentes neste pacole sedimentar (unidades $A$ e B) como decorrentes de processos glaciotectônicas. Além do mais, a presença de horizontes com camadas deformadas intercaladas com horizontes sem deformação e, adicionalmente, a ausência de diamictitos capeando os horizontes deformados, reforçam esta interpretação.

Outro argumento a ser considerado no que se refere à gênese das deformações presentes nas unidades $\mathrm{Bd} 1$ e $\mathrm{Bd} 2$, diz respeito à espessura do pacote deformado (unidades $\mathrm{Bd} 1$ e $\mathrm{Bd} 2$, com mais de $10 \mathrm{~m}$ de espessura), muito superior à espessura média das estruturas subglaciotectônicas usualmente presentes em sedimentos pré-pleistocênicos, que são decimétricas. Restaria, desta forma, a alternativa de um processo proglaciotectônico para explicar a origem dessas estruturas, que poderia ser uma explicação razoável a ser considerada, mas que perde confiabilidade devido à própria estratigrafia do pacote sedimentar. Os turbiditos e/ou os fluxos de alta densidade, além da própria sedimentação contínua por decantação da bacia sedimentar, composta por folhelhos, siltitos e ritmitos, indicam regiões mais distais com águas relativamente profundas e condições ambientais relativamente calmas, contrastantes, portanto, tanto em localização como em processos sedimentares, com a região proglacial proximal. 
As deformações de Boituva podem, alternativamente, ser explicadas como resultantes de fluxos gravitacionais de massa do tipo deslizamento ou escorregamento. Realmente, em sedimentos afetados por deslizamentos (slides) dominam camadas internas sem perturbação, havendo, entretanto, deformações compressionais e/ou extensionais próximas às zonas limitrofes a jusante e a montante de pilha sedimentar movimentada. No entanto, zonas de tensão extensivas e compressivas internas podem fragmentar parte dos deslizamentos e ocasionar movimentos rotacionais ao longo de planos de falha côncavos (Figura 6.2.1). Estes blocos deslizados podem apresentar feições do tipo mélanges sedimentares, formadas por estruturas de fluxo e feiçöes de alivio (attenuation features), tais como boudins similares aos presentes em sedimentos com estruturas glaciotectônicas (Visser, 1983).

Os escorregamentos (slumps) ou colapsos, por sua vez, afetam sedimentos originalmente inconsolidados que, ao se deslocarem ao longo de um declive, desenvolvem complexas deformações internas, como dobras inversas e em caixa, imbricação de clastos e falhas de empurräo (Figura 6.2.2). A intensidade e o estilo das deformações variam de acordo com as suas localizações no interior do corpo deslocado e com a resistência e a heterogeneidade do material escorregado. Como os escorregamentos envolvem deformações plásticas, o movimento de massa do material se estabiliza quando o cisalhamento atinge um determinado valor crítico. Contudo, esta estagnação não ocorre no mesmo momento para toda a massa escorregada, fazendo com que aumente ainda mais a complexidade dos estilos de deformação, permitindo, inclusive, o desenvolvimento de estruturas rúpteis e dúcteis relativamente próximas em determinados casos (e.g.: Martinsen \& Bakken, 1990). Os escorregamentos diferenciam-se das deformações tectônicas pela presença, naqueles, de camadas não deformadas acima e abaixo da zona, ou zonas, afetada pelas deformações, truncamentos erosivos de dobras na superfície superior e capeamento rápido, eliminando qualquer alivio na superfície superior do escorregamento $e$ restaurando a horizontalidade da superficie (Reading, 1996).

Com base no que foi acima comentado, considerou-se que, entre as alternativas de fluxos gravitacionais de massa, a mais provável explicação para a gênese das estruturas de deformação das unidades $\mathrm{Bd} 1$ e $\mathrm{Bd} 2$ de Boituva seria aquela relacionada a um evento de deslizamento de massa. Com efeito, ali os sedimentos estão bem compactados, permitindo verificar que houve preservação das estruturas internas da massa sedimentar e até a formação de clivagens. Alguns pesquisadores, segundo Suguio (2003), não aconselham a diferenciação entre deslizamentos e escorregamentos de massa, haja vista a dificuldade de distinguí-los em afloramentos restritos. 


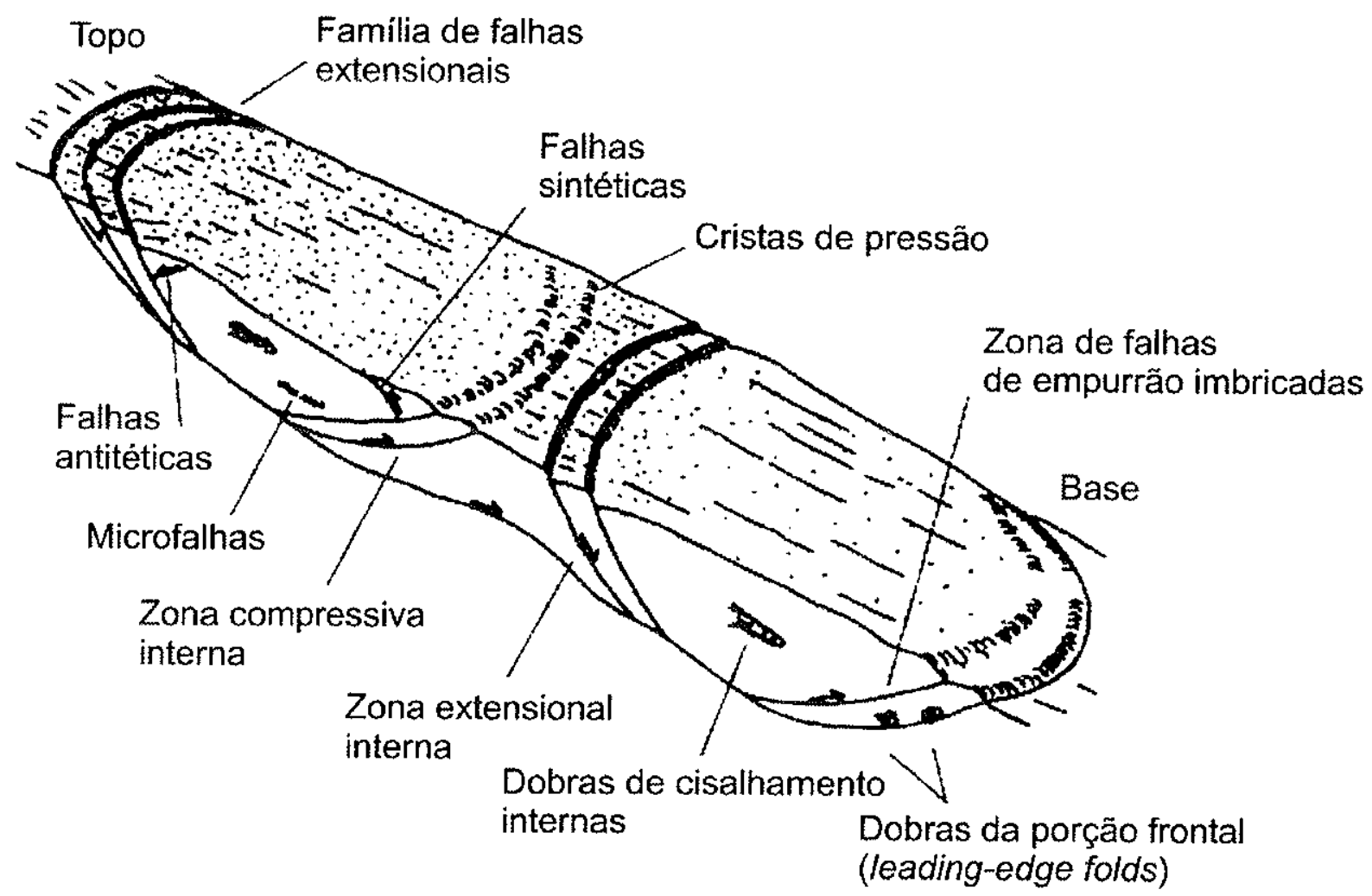

Figura 6.2.1 - Modelo esquemático sem escala da distribuição das deformações em deslizamento de material semiconsolidados. (Reading, 1996).

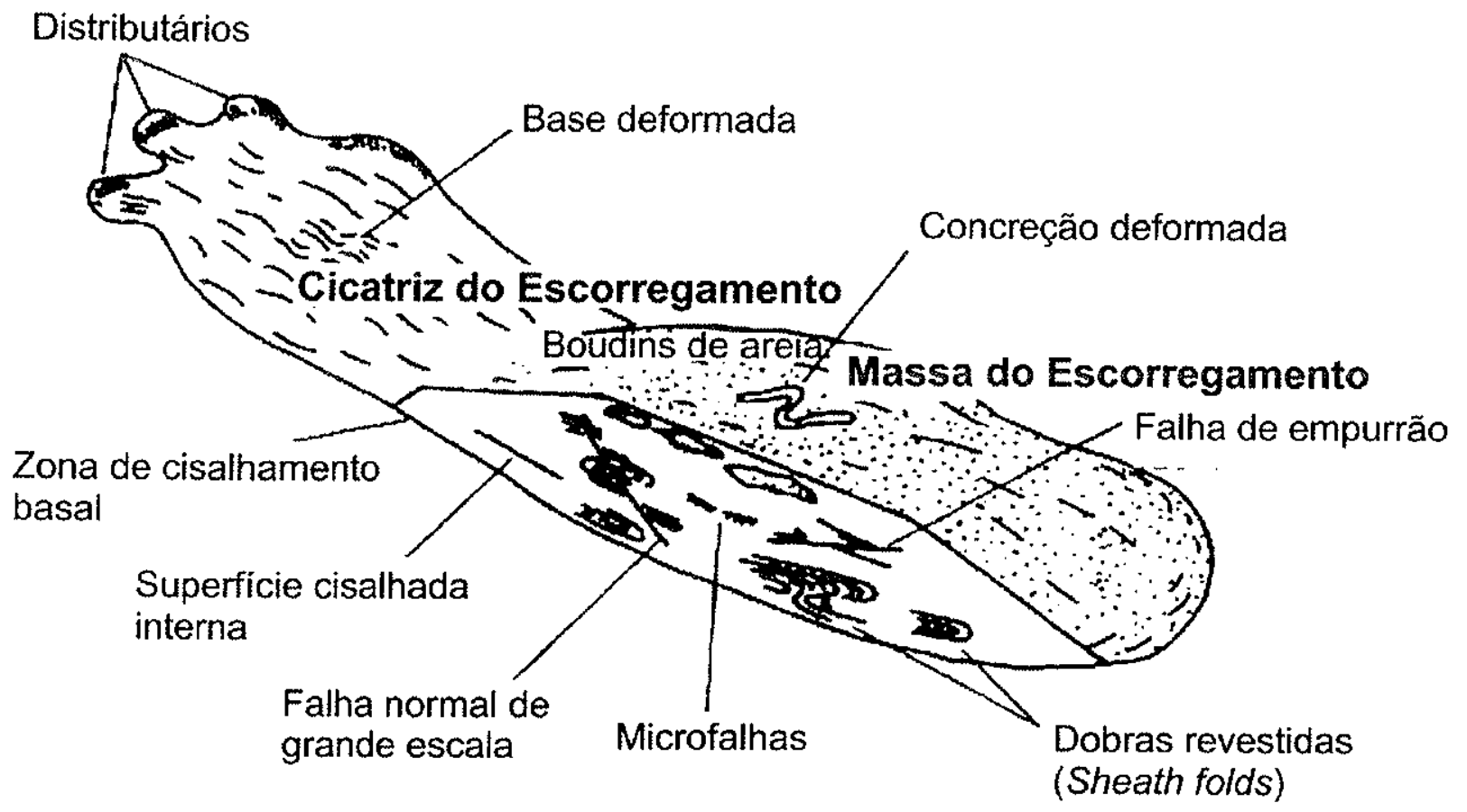

Figura 6.2.2 - Modelo esquemático sem escala do escorregamento de um material inconsolidado, mostrando a distribuição das deformações internas (Reading, 1996). 
Com base nessas considerações o afloramento de Boituva, as dobras e falhas de empurrão acima da superficie de descolamento (Figura 6.1.5) podem ser interpretadas, tentativamente, como um registro do deslizamento de uma pilha sedimentar em condições subaquáticas com o desenvolvimento de dobras da porção frontal (leading-edge folds) e zona de falhas de empurrão imbricadas, que representariam a porção frontal deste deslizamento, de forma semelhante ao apresentado na porção frontal da Figura 6.2.1. Este deslizamento teria ocorrido no sentido SW, mais precisamente WSW, e, por conseguinte, haveria uma região mais elevada a ENE, que teria possivelmente atuado como fonte dos fluxos gravitacionais de massa. Estas interpretações são condizentes com as de RochaCampos (1963), Gama Jr. et al. (1992) e Pires (2001), aduzindo-se que, através das medições estruturais da Unidade $\mathrm{Bd} 2$, foi possível deduzir que a direção regional de deslizamento do fluxo foi de ENE para WSW.

A vergência das deformações para oés-sudeoeste é, no geral, também coincidente com os dados direcionais relacionados ao deslocamento das geleiras (estrias glaciais, rochas moutonnées, etc.), presentes nas rochas do Subgrupo Itararé na sub-bacia do Médio Tietê. Apoiando-se apenas nos dados estruturais obtidos em Boituva, nota-se uma orientação bem definida das deformações, que é uma das características esperadas para as estruturas glaciotectônicas. Consequentemente, a presumida hipótese de se distinguir as estruturas decorrentes de fluxos gravitacionais de massa das glaciotectônicas através do grau de ordenamento das estruturas de deformação (e.g.: Hart \& Robert, 1994), torna-se comprometida.

Recentes estudos demonstram, de forma clara, a existência de grandes divergências entre os pesquisadores com relação à discriminação entre as deformações glaciotectônicas $e$ as relacionados à movimentação gravitacional de massa em ambientes subaquáticos, principalmente glaciomarinho (e.g.: as interpretações de Eyles et al., 1989 e Hart \& Boulton, 1991 para os sedimentos glaciais de North Sea Drifts ou Contorted Drifts, na costa de Norfolk, Inglaterra), além das estruturas decorrentes de processos tectônicos atuantes em um contexto de sedimentação glacial (e.g.: Owen, 1988, 1989). Com o intuito de contribuir para as tentativas de solução desta problemática, Hart \& Roberts (1994) definiram vários critérios discriminatórios entre sequências glaciotectônicas e glaciomarinhas deformadas. Entre os critérios relacionados às análises estruturais, sugerem eles que as estruturas glaciotectônicas apresentam um ordenamento maior das deformações, enquanto que, os fluxos gravitacionais de massa possuiriam direcionamentos mais dispersos.

No entanto, como foi demonstrado em Boituva, e baseando-se apenas nas análises estruturais (macro ou micro) das unidades Bd1 e Bd2, nem todo fluxo gravitacional de massa (deslizamento, no caso) apresenta estruturas com direcionamento dispersante. Uma 
provável explicação seria a de que este desizamento bem direcionado estivesse canalizado em algum paleo-vale subaquático, o que teria dificultado, assim, a dispersão de suas deformações. Consequentemente, somente os atributos estruturais de uma deformação não são suficiente para diferenciar as estruturas glaciotectônicas das decorrentes de fluxos gravitacionais de massa. Sugere-se, desta forma, como feito nesta tese, a complementação destes dados com análises sedimentológicas e estratigráficas, para diferenciar os processos deposicionais e verificar se os dados são coerentes, ou não, com o desenvolvimento destas estruturas, minimizando assim possiveis confusões. Além disso, verifica-se, também, que as análises não devem se limitar a apenas um afloramento, mas que se devem estender por áreas adjacentes, permitindo, desta forma, compreender o contexto estratigráfico, tanto acima como abaixo, em que as estruturas estão inseridas. 


\section{CONCLUSÕES}

As principais contribuições deste trabalho foram as seguintes:

1) As classificações para estruturas glaciotecônicas subglaciais baseiam-se, sobretudo, em características e expressões geomorfológicas, fato que inviabiliza a sua adoção para o estudo de rochas pré-pieistocênicas. Desta forma, propõe-se a discriminação das deformações glaciotectônicas pré-pleistocênicas através das suas características descritivas, condição esta que resulta nas seguintes possibilidade: estruturas glaciotectônicas rúpteis, dúcteis e rúpteis-dúcteis.

2) Caso seja possível identificar em qual ambiente foram geradas as estruturas glaciotectônicas, sugere-se o acréscimo do prefixo referente ao ambiente no termo "glaciotectônico". Consequentemente, o termo estruturas subglaciotectônicas seria utilizado para estruturas glaciotectônicas formadas em ambiente subglacial; estruturas proglaciotectónicas seriam estruturas glaciotectônicas geradas em ambiente proglaciais; e estruturas poliglaciotectónicas seria a designação mais apropriada para as estruturas glaciotectônicas geradas em mais de um ambiente glacial. Observa-se que não se trata da criação de uma nomenclatura nova, mas sim a readequação de termos já existentes, através de uma tradução mais correta gramaticalmente, sem a repetição desnecessária de radicais (e.g.: estruturas glaciotectônicas subglaciais, que apresenta a repetição do radical "glacio" e que seria a tradução literal de "subglacial glaciotectônic structures"), contudo sem perder o intuito original da designação. Cabe lembrar, também, que, a repetição de termos numa mesma frase é comum na língua inglesa, porém na língua portuguesa deve-se desestimular tal procedimento.

3) O método estatístico de autovetores nas análises de fábrica dos clastos é ineficiente, pois pode sofrer interferência quando existe mais de uma concentração de vetores, que, no caso, representam o sentido das inclinações dos clastos. A própria análise da fábrica dos clastos deve ser aplicada com muito critério em sedimentos prépleistocênicos. No caso de Capivari e Jumirim, por exemplo, a análise de fábrica de clastos não deve ser empregada para definir a direção do deslocamento dos corpos de gelo, pois os valores obtidos são muito dispersos, demonstrando que este deslocamento pode ter variado de direção com o decorrer do tempo.

4) É praticamente imprescindivel, nos estudos sobre estruturas glaciotectônicas ou sobre deformações decorrentes de fluxos gravitacionais de massa em ambientes glaciais (ou nas suas imediações), que se aplique análises estratigráficas e sedimentológicas, para 
definir a gênese mais provável das estruturas, além de análises estruturais, visando a obtenção de mais dados para compreender a reologia e a hidrologia destas estruturas. Estes estudos devem ser aplicados também nas regiões adjacentes, embora em estudos pré-pleistocênicos, nem sempre seja possivel.

5) As estruturas glaciotectônicas de Capivari e Jumirim são do tipo subglaciotectônicas, rúpteis (falhas e fraturas), enquanto que, as estudadas em Witmarsum e na Islândia são proglaciotectônicas dúcteis-rúpteis. Nas islandesas prevalecem as deformações rúpteis e nas de Witmarsum existe uma predominância de deformações dúcteis. Diferentemente das demais afloramentos, as deformações de Boituva foram interpretadas como decorrentes de deslizamentos de massa.

6) O modelo reológico do Ciclo Slip-Stick se aplica perfeitamente às estruturas subglaciotectônicas presentes em Capivari e Jumirim. Embora seja um modelo ainda em desenvolvimento, considera-se que seja o mais eficaz para explicar as deformações rúpteis nos arenitos e diamictitos destas localidades. Além disso, as estruturas analisadas contribuíram, significativamente, para a constatação da importância da pressão de água na gênese das estruturas subglaciotectônicas e para o progressivo aprimoramento deste modelo, visto que foi possivel verificar que o ciclo Slip-Stick não é um "caminho de mão única", podendo haver situações em que algumas etapas não tenham sido desenvolvidas ou que tenham apresentado, ocasionalmente, pouco registro geológico, conforme previsto por Bennett (2003). Por conseguinte, observa-se a importância dos registros pré-pleistocênicos na compreensão da dinâmica basal das geleiras.

7) As estruturas glaciotectónicas rüpteis podem ser geradas através de mudanças nas condições hidrológicas da base da geleira (e.g.: diamictitos deformados de Capivari e Jumirim) ou através do congelamento dos sedimentos subaéreos (e.g.: os sedimentos congelados de Hagafellsjökull-Eystri). No entanto, deformações rúpteis formadas pela variação das pressões de água, ou seja, devido às condições hidrológicas, não são exclusivas das estruturas glaciotectônicas podendo ser observadas em fluxos gravitacionais de massa, como é o caso das clivagens presentes nas deformações de Boituva.

8) Os pavimentos de clastos inferiores e superiores de Capivari e Jumirim são do tipo inter-tilitos, em virtude do perfeito alinhamento dos clastos e da presença clastos com estrias glaciais, nas porções facetadas voltadas para cima, cujas direções apresentam-se similares em cada pavimento de clasto. 
9) Com base nos dados obtidos pelas estruturas subglaciotectônicas e estrias glaciais, aparentemente, tanto em Capivari, como que em Jumirim, os avanços das frentes das geleiras mudaram gradativamente de direção, fato que pode ter ocasionado a grande dispersão das fábricas dos clastos nestas localidades. Além desta variação no deslocamento das geleiras, constatou-se que ocorreram 3 (três) avanços das frentes dos corpos de gelo sobre os sedimentos tanto em Capivari, quanto em Jumirim. O primeiro teria sido responsável pela geração das estruturas subglaciotectônicas rúpteis registradas nos arenito e diamictitos, além das estritas no contato destas litologias. $O$ segundo e o terceiro avanços das geleiras teriam sido responsáveis, respectivamente, pelas gêneses dos pavimentos de clastos inferiores e superiores. As estritas sobre os arenitos deformados de Capivari e Jumirim teriam sido produzidas durante avanços rápidos no deslocamento da geleira durante o primeiro avanço.

10) Os diamictitos deformados de Capivari e Jumirim seriam sedimentos subglaciais depositados em periodos em que houve condições propícias à acumulação de sedimentos na interface geleira/substrato, sendo posteriormente deformados em virtude da mudança das condições hidrológicas. Porém, não existem registros do recuo da frente da geleira entre o diamictito deformado (Dm2) e os pavimentos de clastos inferior (PCA) em Jumirim, possivelmente devido à erosão do till de degelo.

11) Durante a fase de aderência (stick), em Capivari e Jumirim, teoricamente não houve deformação, contudo a tensão efetiva sobre o substrato tomou-se tão intensa e concentrada, que atingiu o ponto crítico (a) para a formação de estruturas rúpteis. Neste sentido, vale lembrar que o valor crítico estabelecido pela equação $5\left(\mathrm{P}_{\theta}=(\tau-\right.$ C)/n), refere-se à pressão efetiva necessária para a formação de substratos rigidos e não ao citado ponto crítico a; e que a aderência é obtida por processos hidrológicos e não térmicos, e consequentemente, a geleira ainda era de base temperada.

12) Em Capivari e Jumirim, a formação das estruturas subglaciotectônicas rúpteis no estágio de aderência teria ocorrido pouco antes da passagem para a fase de deslizamento (slip), sendo, inclusive, um dos fatores responsáveis pelo seu início. Assim, à medida que surgiram as fraturas e falhas nos sedimentos enrijecidos, 0 aumento da pressão de água foi favorecido, o que resultou no início da fase de deslizamento.

13) Não é possivel correlacionar estratigraficamente os afloramentos de Capivari e Jumirim, em virtude das distâncias geográfica e estratigráfica entre elas e, principalmente, das grandes mudanças faciológicas verticais e laterais, que não permitem reconhecer uma camada-guia, e da presença de inúmeros falhamentos e 
intrusões de diques e sills de diabásio mesozóicos. Por conseguinte, apesar da grande coincidência entre os dados obtidos nestas localidades, não é possível afirmar que sejam contemporaneos, fato que remeteria o afloramento de Capivari ao topo do Subgrupo Itararé. Contudo, certamente demonstram que os avanços e recuos glaciais do Subgrupo Itararé ocorreram com padrões semelhantes nestas regiões do Estado de São Paulo e que, não sendo contemporâneos, estão a indicar que estes padrões se repetiram de forma análoga nos sucessivos ciclos glaciais já reconhecidos ao longo de toda a sucessão estratigráfica do Subgrupo Itararé (Santos, 1979; Santos et al., 1996).

14) A Falha Cancela constitui um falhamento do tipo trancorrente, pouco registrado na Bacia do Paraná, e afetou a região de Witmarsum após a litificação dos sedimentos do Subgrupo Itararé, sendo, portanto, posterior ao Neopaleozóico. Curiosamente, os pavimentos estriados e sulcados no contato com a Formação Furnas são excelentes camadas-guias, proporcionando estudos cinemáticos sobre esforços transpressivos e transtrativos.

15) O diamicitos deformados de Witmarsum (PR) seriam estruturas proglaciotectônicas, semelhantes às morainas de empurrão sazonais, que ter-se-iam formado na região de Witmarsum, durante curtos avanços da frente da geleira, e foram preservadas devido ao ambiente subaquoso, lacustre ou marinho, que se instalou posteriormente. A confirmação da ocorrência de morainas de empurrão em depósitos glaciais prépleistocênicos brasileiros, constitui um fato raro, singular e de grande repercussão no âmbito da Geologia Glacial. O paleo-relevo, subhorizontal, da região de Witmarsum influenciou na formação das Morainas de Empurrão Pequenas ou Sazonais ou Anuais.

16) Com base nas vergências das estruturas proglaciotectônicas de Witmarsum é possivel constatar que, num primeiro estágio, teria se formado um arco de morainas de empurrão, que, nesta localidade, apresentaria vergência para NW e, posteriormente, durante um segundo avanço, ter-se-iam gerado as deformações com vergència para norte, destruindo, em parte, o arco de morainas previamente depositadas.

17) De acordo com os dados obtidos na Islândia, permafrost pode, ocasionalmente, influenciar na formação de estruturas glaciotectônicas rúpteis, ao possibilitar o enrijecimento temporário do sedimento.

18) A correlação entre os estudos realizados no neopaleozóico brasileiro (em particular, Capivari e Jumirim) e as ocorrências recentes da Islândia indicam que o regime hidrológico, ou seja, a pressão de água, teria sido a responsável pelo avanço súbito da geleira (através da etapa de deslizamento, slip, do referido modelo). Todavia, também 
demonstra que, após um surge, a base da geleira pode voltar a ficar aderida ao substrato, provocando condições sub-congelantes. Estas interpretações verificadas na Islândia são semelhantes às apresentadas para as deformações subglaciotectônicas rúpteis de Capivari e Jumirim, de forma que verifica-se assim que o contexto apresentado para explicar as deformações neopaleozóicas brasileiras tem possiveis equivalentes atuais

19) Nem todo corpo arenoso intercalado na decantação dos sedimentos finos das unidades $A$ e $B$ de Boituva teriam se originado através de processos de correntes de turbidez. Alguns destes arenitos foram formados por fluxos densos, arenosos (sandy debris flows), possivelmente associados a influxos de água de degelo com alta carga sedimentar, ou, alternativamente, como resultado da falência da resistência de atrito em sedimentos inconsolidados, através do gradativo empilhamento de sedimentos nas bordas da bacia, que, desestabilizados, fluiram talude abaixo, na forma de fluxos gravitacionais de massa do tipo fluxo de detritos arenosos. Estes sedimentos podem, ainda, ter sido transportados em suspensão por turbilhonamento, a partir de sedimentos inicialmente depositados na zona costeira, provavelmente como consequência da atuação de ondas, seguida de transporte por correntes para zonas de predomínio de deposição das argilas. Nota-se, portanto, que a pilha sedimentar exposta no afloramento de Boituva configura um contexto de águas relativamente profundas, que, no âmbito do modelo sedimentar admitido para o Subgrupo ltararé (Santos et al., 1996), dificultariam a interpretação das estruturas de deformação presentes neste pacote sedimentar (unidades A e B) como decorrentes de processos glaciotectônicos. Além do mais, a presença de horizontes com camadas deformadas intercaladas com horizontes sem deformação $e$, adicionalmente, a ausência de diamictitos capeando os horizontes deformados, reforçam esta interpretação.

20) Considerou-se que a mais provável explicação para a gênese das estruturas de deformação das unidades $\mathrm{Bd} 1$ e $\mathrm{Bd} 2$ de Boituva seria aquela relacionada a um evento de deslizamento de massa. Com efeito, ali os sedimentos estão bem compactados, permitindo verificar que houve preservação das estruturas internas da massa sedimentar e até a formação de clivagens. Desta forma, as dobras e falhas de empurrão acima da superfície de descolamento (Figura 6.1.5) podem ser interpretadas, tentativamente, como um registro do deslizamento de uma pilha sedimentar em condições subaquáticas com o desenvolvimento de dobras da porção frontal (leading-edge folds) e zona de falhas de empurrão imbricadas, que representariam a porção frontal deste deslizamento, de forma semelhante ao apresentado na Figura 6.2.1. Este deslizamento teria ocorrido no sentido SW, mais 
precisamente WSW, e, por conseguinte, haveria uma regiäo mais elevada a ENE, que teria possivelmente atuado como fonte dos fluxos gravitacionais de massa. Estas interpretações são condizentes com as de Rocha-Campos (1963), Gama Jr. et al. (1992) e Pires (2001), aduzindo-se que, através das medições estruturais da Unidade $\mathrm{Bd} 2$, foi possivel deduzir que a direção regional de deslizamento do fluxo foi de ENE para WSW.

21) As estruturas de deslizamento analisadas no afloramento de Boituva, apesar de apresentar, em sua parte basal (Unidade Bd1), uma disposiçäo caótica, caracteriza-se, na porção superior (Unidade $\mathrm{Bd} 2$ ), por estruturas deformadas bem orientadas. Tal fato pode ser conducente à interpretação que as estruturas sin-sedimentares decorrentes de fluxos gravitacionais de massa nem sempre apresentam vergência difusa e que, portanto, estruturas bem orientadas não são necessariamente glaciotectônicas. $O$ fato das deformações estarem bem orientadas no deslizamento de massa de Boituva pode indicar um confinamento da massa deslocada. 


\section{REFERÊNCIAS BIBLIOGRÁFICAS}

ABER, J.S. (1979) The character of glaciotectonism. Geologie en Mijnbouw, 64: 389-395.

ABER, J.S. (1982) Model for glaciotectonism. Geological Society of Denmark Bulletin, 30: 79-90.

ABER, J.S. (1988) Spectrum of constructional glaciotectonic landforms, In: R.P. Goldthwait \& C.L. Matsch (eds.) Genetic classification of glacigenic deposits. Rotterdam: Balkema, pp. 281-292.

ABER, J.S. (1993) Glaciotectonics and mapping glacial deposits. Regina: Canadian Plains Research Center, University of Regina, $309 \mathrm{pp}$.

ABER, J.S. (2003) Bibliography of glaciotectonic references. Intemational Union for Quatemary Research (INQUA) Commission on Glacioation. (Feb/2003) [MUW document] URL http://www.geospectra.net/glatec_biblio/index.htm.

ABER, J.S.; CROOT, D.G. \& FENTON, M.M. (1989) Glaciotectonics landforms and structures. Dordrecht: Kluwer, $201 \mathrm{pp}$.

ALLEY, R.B. (1989a) Watermpressure coupling of sliding bed deformation: I. Water system. Joumal of Glaciology, 35: 108-118.

ALLEY, R.B. (1989b) Water-pressure coupling of sliding bed deformation: II. Velocity depth profiles. Joumal of Glaciology, 35: 11-129.

ALLEY, R.B. (1991) Deforming-bed origin for southern Laurentide till sheets? Joumal of Glaciology, 37 (125): $67-76$.

ALLEY, R.B. (2000) Continuity comes first: recent progress in understanding subglacial deformation. In: A.J. Maltmas, M.J. Hubbard \& M.J. Hambrey (Eds.) Deformation of glacial material. London: The Geological Society of London, Special Publication, 176: 171-180.

ALLEY, R.B.; BLANKENSHIP, D.D.; BENTLEY, C.R. \& ROONEY, S.T. (1986) Deformation of till beneath ice stream B, West Antarctica. Nature, 322: 57-58.

ALLEY, R.B.; BLANKENSHIP, D.D.; BENTLEY, C.R. \& ROONEY, S.T. (1987a) Till beneath ice stream B, 3, till deformation: evidence and implications. Journal of Geophysical Research, 92 (B2): 8921-8930.

ALLEY, R.B.; BLANKENSHIP, D.D.; ROONEY, S.T. \& BENTLEY, C.R. (1987b) Till beneath ice stream B, 4, a coupled ice-till flow model. Joumal of Geophysical Research, 92 (B2): 89318940.

ALLEY, R.B.; BLANKENSHIP, D.D.; ROONEY, S.T. \& BENTLEY, C.R. (1989) Water-pressure coupled of sliding and bed-deformation: III. Application to ice stream B, Antarctica. Joumal of Glaciology, 35 (119): 130-139.

ALMEIDA, F.F.M. de (1945) Episódio da última epoca inter-glacial permo-carbonífera no Paraná. Notas preliminares e estudos, Divisão de Geologia e Mineralogia, DNPM, 27: 1-18.

ALMEIDA, F.F.M. de (1948) A "roche mountonnée" de Salto, Estado de São Paulo.omações causadas pelos gelos na série Tubarão em São Paulo. Geologia e Metalurgia, Escola Politécnica, USP, Boletim 5: 112-118.

ALMEIDA, F.F.M. de (1953) Deformações causadas pelos gelos na série Tubarão em São Paulo. Notas Preliminares e Estudos, Divisão de Geologia e Mineração (DNPM), n. 64, p.: 1-4.

ALMEIDA, F.F.M. de; RE CARNEIRO, C.D. \& CREMONINI, O.A. (1980) Tectónica da Bacia do Paraná. Consórcio CESP/PT/PAULIPETRO, $187 \mathrm{pp}$. (Relatório $\mathrm{n}^{\circ}$ 14.091).

ÅMARK, M. (1986) Glaciotectonics and deposition of stratified drift during formation of tills beneath an active glacier - examples from Skåne, Southern Sweden. Boreas, 15: 155-171.

ANDERTON, R. (1985) Clastic facies models and facies analysis. In: P.J. Brenchley \& B.J.P. Williams (eds.) Sedimentology: recent developments and applied aspects. Oxford: Blackwell Scientific Publications, pp. 31-47. 
ANDRADE, S.M. \& SOARES, P.C. (1971) Geologia do centro-leste de São Paulo. Rio de Janeiro, PETROBRÁS / DESUL. (Relatório 407).

BADCOCK, E.A.; FENTON, M.M. \& ANDRIASHEK, L.D. (1978) Shear phenomena in ice-thrust gravels, central Alberta. Canadian Joumal Earth Sciences, 15: 277-283.

BANHAM, P.H. (1975) Glaciotectonic structures: a general discussion with particular reference to the Contorted Drift of Norfolk. In: A.E. Wright \& F. Moseley (eds.) Ice ages: ancient and modem. Geological Joumal Special Issue 6. Liverpool: Seal House Press, pp. 69-94.

BANHAM, P.H. (1977) Glaciotectonites in till stratigraphy. Boreas, 6: 101-106.

BANHAM, P.H. (1988) Thin-skinned glaciotectonic structures. In: D.G. Croot (ed.) Glaciotectonics froms and processes. Rotterdam: Balkema, pp. 21-25.

BARBOSA, O. (1940) Estrias produzidas por gelo permo-carbonifero. Revista de Mineraçăo e Metalurgia, 4 (24): 272-273.

BARBOSA, O. \& ALMEIDA, F.F.M. de (1949) A série Tubarão na bacia do rio Tietê, Estado de São Paulo. Notas Preliminares e Estudos, Divisão de Geologia e Mineração (DNPM), n. 48, p. 1-16.

BARBOSA, O. \& GOMES, F. A. (1958) Pesquisa de petróleo na Bacia do Rio Corumbataí, Estado de São Paulo. Boletim da Divisão de Geologia e Mineralogia, DNPM, 171: 1-40.

BATES, R.L. \& JACKSON, J.A. (1980) Glossary of geology. Falls Church, Va. : American Geological Institute, $749 \mathrm{pp}$.

BEDGET, J. (1986) Influence of till rheology on Pleistocene giacier flow in the southern Great Lakes area, USA. Journal of Glaciology, 32: 235-241.

BENN, D.I. \& EVANS. D.J.A. (1998) Glaciers \& glaciation. London: Amold, 734 pp..

BENNETT, M.R. (2001) The morphology, structural evolution and significance of push moraines. Earth-Science Reviews, 53: 197-236.

BENNETT, M.R. (2003) Ice streams as the arteries of an ice sheet: their mechanics, stability and significance. Earth-Science Reviews, 61: 309-339.

BENNETT, M.R. \& GLASSER, N.F. (1996) Glacial geology - ice sheets and landforms. West Sussex: John Wiley \& Sons, 364 pp.

BENNETT, M.R., WALLER, R.I., GLASSER, N.F., HAMBREY, M.J., HUDDART, D. (1999) Glacigenic clast fabric: genetic fingerprint or wishful thinking. Joumal of Quatemary Science, 14: 125-135.

BENNETT, M.R.; HUDDART, D. \& MCCORMICK (2000) An integrated approach to the study of glaciolacustrine landformsand sediments: a case study from Hagavatn, Iceland. Quatemary Science Reviews, 19: 633-665.

BENNETT, M.R.; WALLER, R.I.; MIDGLEY, N.G.; HUDDART, D.; GONZALEZ, S.; COOK, S.J. \& TOMIO, A. (2003) Subglacial deformation at sub-freezing temperatures? Evidence from Hagafellsjökull-Eystri, Iceland. Quatemary Science Reviews, 22: 915-923.

BENNETT, M.R.; HUDDART, D.; WALLER, R.I.; MIDGLEY, N.G.; GONZALEZ, S. \& TOMIO, A. (2004) Styles of ice-marginal deformation at Hagafellsjökull-Eystri during the 1998/1999 winterspring surge. Boreas, 33 (2): 97-107.

BENNETT, M.R.; HUDDART, D.; WALLER, R.I.; CASSIDY, N.; TOMIO, A.; ZUKOWSKYJ, P.; MIDGLEY, N.G.; COOK, S.; GONZALEZ, S. \& GLASSER, N. (no prelo) Neoglacial Ice-marginal deformation at Hagafelisjökuli-Eystri, Iceland as revealed by geological and geophysical investigation. Sedimentary Geology. Amsterdam, Elsevier.

BERTHELSEN, A. (1978) The methodology of kineto-stratigraphy as applied to giacial geology. Bulletin of the geological Society of Denmark, Special issue, 27: 25-38.

BERTHELSEN, A. (1979) Recumbent folds and boudinage structures formed by subgiacial shear: an example of gravity tectonics. Geologie en Mijnbouw, 58: 253-260.

BEURLEN, K. (1955) Formações gondwânicas no sul do Estado do Paraná. Boletim da Divisåo de Geologia e Mineralogia, DNPM, Boletim 153: 1-52. 
BIGARELLA, J.J. \& SALAMUNI, R. (1967) Some paleogeographic and paleotectonic features of the Paraná Basin. In: J.J. Bigarella et al. (eds.), Problems in Brazilian Gondwana Geology. Curitiba: Instituto de Geociências, UFPR. pp. 235-301.

BIGARELLA, J.J.; SALAMUNI, R. \& FUCK, R.A. (1967) Striated surfaces and related features developed by the Gondwana Ice Sheets (State of Paraná, Brazil). Palaeogeography, Palaeoclimatology, Palaeoecology, 3 (56): 265-276.

BOULTON, G.S. (1970) On the origin and transport of englacial debris in Svalbard glaciers. Joumal of Glaciology, 9 (56): 213-229.

BOULTON, G.S. (1971) Till genesis and fabric in Svalbard, Spitsbergen. In: R.P. Goldthwait (ed.) Till: a symposium. Columbus: Ohio State University Press, pp. 41-72.

BOULTON, G.S. (1974) Processes and patterns of glacial erosion. In.: D.R. Coates (ed.) Glacial Geomorphology, pp. 41-87.

BOULTON, G.S. (1975) Processes and patterns of subglacial sedimentation: a theoretical approach. in: A.E. Wright \& F. Moselevy (eds.) Ice Ages: ancient and modem. Liverpool: Seel House Press.

BOULTON, G.S. (1979) Processes of glacier erosion on different substrata. Joumal of Glaciology, 23 (89): 15-38.

BOULTON, G.S. (1982) Subglacial processes and the development of glacial bedforms. In: $R$. Davidson-Arnott; W. Nickling \& B.D. Fahey (eds.) Research in glacial, glaciofluvial and glaciolacustrine systems. Norwich: Geobooks. $6^{\text {th }}$ Guelph Symposium on Geomorphology. pp. $1-31$.

BOULTON, G.S. (1986) Push-moraines and glacier-contact fans in marine and terrestrial environments. Sedimentology, 33: 677-698.

BOULTON, G.S. (1987) A theory of drumlin formation by subglacial sediment deformation. $\mathrm{n}$ : J. Menzies \& J. Rose (eds.) Drumlin Symposium. Rotterdam: Balkema, pp. 25-80.

BOULTON, G.S. (1993) Glaciers and glaciation in: Duff (ed.) Holmes' principles of physical geology. Chapman \& Hall, pp. 401-438.

BOULTON, G.S. (1996) Theory of glacial erosion, transport and deposition as a consequence of subglacial sediment deformation. Joumal of Glaciology, 42: 43-62.

BOULTON, G.S. \& DENT, D.L. (1974) The nature and rates of post-depositional changes in recently deposited till from south-east Iceland. Geografiska Annaler, 56 (A): 121-134.

BOULTON, G.S. \& JONES, A.S. (1979) Stability of temperate ice sheets resting on beds of deformable sediment. Joumal of Glaciology, 24: 29-43.

BOULTON, G.S. \& SPRING, U. (1986) Isotopic fractionation at the base of polar and sub-polar glaciers. Joumal of Glaciology, 32: 475-485.

BOULTON, G.S. \& HINDMARSH, R.C.A. (1987) Sediment deformation beneath glaciers; interactions between sediment flow and drainage, and geological products. Journal of Geophysical Research, 92 (B2): 9059-9082.

BOULTON, G.S. \& CLARK, C.D. (1990a) A highly mobile Laurentide ice sheet revealed by satellite images of glacial lineations. Nature: $346,813-817$.

BOULTON, G.S. \& CLARK, C.D. (1990b) The Laurentide ice sheet through the last glacial cycle: the topology of drift lineations as a key to the dynamic behaviour of the former ice sheets. Transactions of the Royal Society of Edinburgh: Earth Sciences, 81: 327-347.

BOULTON, G.S. \& DOBBIE, K.E. (1993) Consolidation of sediments by glaciers: relations between sediment geotechnics, soft-bed glacier dynamics and subglacial ground-water flow. Joumal of Glaciology, 39: 26-44.

BOULTON, G.S.; DICKSON, J.H.; NICHOLS, H.; NICHOLS, M. \& SHORT, S.K. (1976) Late Holocene glacier flutuations and vegetation changes at Maktak Fjord, Baffin Isiand, N.W.T., Canadá. Arctic \& Alpine Research, 8: 343-356. 
BOULTON, G.S., VAN DER MEER, J.J.M., BEER, D.J., HART, J.K., RUEGG, G.H.J. (1999) The sedimentary and structural evolutionof a recent push moraine complex: Holmstrembreen, Spitsbergen. Quatemary Science Reviews: 18, 339-371.

BOULTON, G.S.; DOBBIE, K.E. \& ZATSEPIN, S. (2001) Sediments deformation beneath glaciers and its coupling to the subglacial hydraulic system. Quatemary intemational, 86: 3-28.

BOUMA, A.H. (1962) Sedimentology of some flysch deposits. Amsterdam: Elsevier, 168 pp.;

BOYCE, J.I. \& EYLES, N. (1991) Drumlins carved by deforming till streams below the Laurentide ice sheet. Geology, 19: 787-790.

BRODZIKOWSKI, K. \& VAN LOON, A.J. (1985) Inventory of deformational structures as a tool for unconsolidated Quaternary geology of glaciated areas. Boreas, 14: 175-188.

BRODZIKOWSKI, K. \& VAN LOON, A.J. (1991) Glacigenic sediments. Amsterdam: Elsevier Publishing Company, $674 \mathrm{pp}$.

BROWN, N.E.; HALLET, B. \& BOOTH, D.B. (1987) Rapid soft bed sliding of the Puget glacial lobe. Joumal of Geophysical Research, 92: 8985-8997.

BUDD, W.F. (1975) A first simple model of periodically self-surging glaciers. Joumal of Glaciology, 14: 13-21.

CALLEGARI, L.M. (2001) Palinologia da porçăo superior do Subgrupo ltararé na regiăo de Jumirim e Tiete, Estado de Săo Paulo. Monografia de Trabalho de Formatura, Instituto de Geociências, Universidade de São Paulo, São Paulo, 52 p. (inédito).

CANUTO, J.R. (1985) Origem dos diamictitos e de rochas associadas do Subgrupo Itarare. Dissertação de Mestrado, Instituto de Geociências, Universidade de São Paulo, São Paulo, 187 p. (inédito).

CANUTO, J.R. (2001) Estratigrafia de seqüencias da sucessão sedimentar glaciogenica neopaleozóica da Bacia do Paraná. Relatório Final FAPESP. (Processo $n^{\circ}$ 07/13.973).

CANUTO, J.R.; SANTOS, P.R. dos \& ROCHA-CAMPOS, A.C. (2001) Estratigrafia de seqüências do Subgrupo Itararé, Neopaleozóico, leste da Bacia do Paraná e norte de Santa Catarina, Brasil. Revista Brasileira de Geociencias, 31 (1): 107-116.

CAPUTO, R. (1995) Evolution of orthogonal sets of coeval extention joints. Terra Nova, 7: 479-490.

CHANG, M.R.C. (1984) Análise ambiental e estratigrafica do Subgrupo Itararé (PC) no sudoeste do Estado de São Paulo. Tese de doutoramento, Instituto de Geociências, Universidade de São Paulo, São Paulo, 234 p. (inédito).

CLARK, C.D. (1993) Mega-scale glacial lineation and cross-cutting ice-flow landforms. Earth Surface Processes and Landforms, 18: 1-29.

CLARK, C.D. (1994) Large scale ice-molded landforms and their glaciological significance. Sedimentary Geology, 91: 253-268.

CLARK, C.D. \& STOKE, C.R. (2001) Extent and basal lineation characteristics of the M'Clintock Channel ice Stream. Quatemary Intemational, 86: 81-101.

CLARK, P.U. (1991) Striated clast pavements, products of deforming subglacial sediment? Geology, 19: $530-533$.

CLARKE, G.K.C. (1987) Subglacial till: a physical framework for its properties and processes. Joumal of Geophysical Research, 92: 9023-9036.

COLLINSON, J.D. \& THOMPSON, D.B. (1989) Sedimentary Structures. London: Unwin Hyman Ltd., $1989,2^{\text {nd }}$ ed., 207 pp..

COTTAS, L.R.; FIORI, A.P. \& LANDIM, P.M.B. (1981) Divisão faciológica do Subgrupo Itararé e da Formação Aquidauana no nordeste do Estado de São Paulo. In: Simpósio Regional de Geologia, 3, Curitiba, 1981. Atas...São Paulo, SBG, p. 223-227.

COTTER, J.F.P.; ROCHA-CAMPOS, A.C.; SANTOS, P.R. dos \& CANUTO, J.R. (1992) The origin of striated boulder paviments: evidence from Capivari, São Paulo, Brazil (late Paleozoic) and the 
Minnesota River Valley, USA (Pleistocene). In: Congresso Brasileiro de Geologia, 37, São Paulo, 1992. Anais... São Paulo, SBG/SP, Boletim de resumos expandidos, p. 522-524.

CROOT, D.G. (1888) Glaciotectonics: Forms and processes. Rotterdam: Balkema, 212 pp..

DAEE/UNESP (1979) Mapeamento faciológico do Supergrupo Tubaråo. São Paulo: Departamento de Água e Energia Elétrica do Estado de São Paulo (DAEE) / Universidade Estadual Paulista (UNESP), mapas geológicos. (Escala 1:50.000).

DAEMON, R.F. \& QUADROS, L.P. (1970) Bioestratigrafia do Neopaleozóico da Bacia do Paraná. In: Congresso Brasileiro de Geologia, 24, Brasilia, 1970. Anais... São Paulo, SBG, Boletim de resumos expandidos, p. 359-412.

DANSGAARD, W.; JOHNSEN, S.J.; CLOSEN, H.B.; DAHL-JANSEN, D.; GUNDESTRUP, N.S.; HAMMER, C.U.; HVIDBERG, C.S.; STEFFENSEN, J.P.; SVEINDBJÖRNSDOTTIR, A.E.; JOUZEL, J. \& BOND, G. (1993) Evidence for general instability of palaeo-climate from a 250-kyr ice-core Record. Nature, 364: 218-220;

DARDENNE, M.A. \& CAMPOS, J.E.G. (2003) Glacigenic fácies stratigraphy of the Santa Fé Group in the Sanfrancisco Basin. In: Latinamerican Congress of Sedimentology, 3, Belém, 2003. Abstract Book... Belém, Museu Paraense Emílio Goeldi; UFPA, p. 148-149.

DARDIS, G.F. \& MCCABE, A.M. (1987) Subglacial sheetwash and debris flow deposits in late Pleistocene drumlins, Northern Ireland. In: J. Menzies \& J. Rose (eds.) Drumlins Symposium. Rotterdam: Balkema, pp. 225-240.

DE RAAF, J.F.M.; BOERSMA, J.R.; Van GELDER, A. (1977) Wave-generated strutuctures and sequences from a shallow marine sucesión, Lower Carboniferous, County Cork, Ireland. Sedimentology, 24: 451-483.

DELLA FÁVELA, J.C. (2000) Sedimentos de águas profundas. Uma revisão dos conceitos sobre turbiditos e contornitos. In: Curso Tópicos Fundamentais de Estratigrafia de Seqüências, Instituto de Geociências da Universidade de São Paulo, São Paulo, 2000. Apostila Digital do Curso... Rio de Janeiro, Universidade do Estado do Rio de Janeiro, Faculdade de Geologia, Laboratório de Análise de Bacias e Correlaçăo Geológica.

DOWDESWELL, J.A. \& SHARP, M. (1986) Characterization of pebble fabrics in modern terrestrial glacigenic sediments. Sedimentology, 33: 699-710.

DOWDESWELL, J.A.; HAMBREY, M.J. \& WU, R. (1985) A comparison of clast fabric shape in late Precambrian and Modern glacigenic sediments. Joumal of Sedimentary Petrology, 55 (5): 691 704.

DRAKE, L.D. (1974) Till fabric control by clast shape. Geological Society of America Bulletin, 85 (2): 247-250;

DREIMANIS, A. (1953) Two late Wisconsin interstadial deposits from Ontario, Canada. Geological Society of America Bulletin, 64 (12, Part 2): 1414.

DREIMANIS, A. (1989) Tills, their genetic terminology and classification. In: R.P. Goldthwait \& C.L. Matsch (ed.) Genetic classification of glacigenic deposits. Rotterdam: Balkerma, pp. 73-87.

DREIMANIS, A. \& RAPPOL M. (1997) Late Wisconsinan sub-glacial clastic intrusive sheets along Lake Erie bluffs, at Bradtville, Ontario, Canada. Sedimentary Geology, 111: 225-248.

DREWRY, D. (1986) Glacial geological processes. London: Edward Arnold, 271 pp..

DUNNE, W.M \& HANCOCK, P.L. (1994) Palaeo stress analysis of small-scale brittle structures. In: P.L. Hancock (ed.) Continental deformation. Oxford: Pergamon Press L.td., pp. 101-120.

ECHELMEYER, K.A.; HARRISON, W.D.; LARSEN, C. \& MITCHELL, J.E. (1994) The role of the margins in the dynamics of an active ice stream. Joumal of Glaciology, 40: 527-538.

EMBRAPA MONITORAMENTO POR SATÉLITE (2004) Brasil visto do espaço. Embrapa, Ministerio da Agricultura, Pecuária e Abastecimento. (08/Jun/2004) [JPG files] sp20_24.jpg, sp20_25.jpg, sp20_26.jpg, URL http://www.cdbrsil.cnpm.embrapa.br.

ENGELHARDT, H. \& KAMB, B. (1998) Basal sliding of Ice Stream B, West Antarctica. Joumal of Glaciology, 44: 223-230. 
ENGELHARDT, H.; HUMPHREY, N.; KAMB, B. \& FAHNESTOCK, M. (1990) Physical conditions at the base of a fast-moving Antarctic ice stream. Science, 248: 57-59.

EYLES, C.H. (1988) Intertidal boulder pavements in the northeastern Gulf of alaska and their geological significance. Sedimentary Geology, 88: 161-173.

EYLES, N. (1977) Wisconsinan glaciotectonic structures and evidence of post glacial permafrost in north-central Newfoundland. Canadian Joumal of Earth Science, 14: 2797-2806.

EYLES, N. \& BOYCE, J.I. (1998) Kinematic indicators in fault gouge: tectonic analog for soft-bedded ice sheets. Sedimentary Geology, 116: 1-12.

EYLES, N.; EYLES, C.H. \& MIALL, A.D. (1983) Lithofacies types and vertical profile models; an alternative approach to the description and environmental of glacial diamict and diamictite sequences. Sedimentology, 30: 393-410.

EYLES, N.; EYLES, C.H. \& MCCABE, A.M. (1989) Sedimentation in an ice-contact subaqueous setting: the mid-Pleistocene "North Sea Drifts" of Norfolk, UK. Quatemary Science Reviews, 8: 57-74.

FISCHER, U.H.; CLARKE, G.K.C. \& BLATTER, H. (1999) Evidence for temporally varying "sticky spots" at the base of Trapridge Giacier, Yukon Ternitory, Canada. Journal of Glaciology, 45: 352-360.

FISHER, R.A. (1953) Dispersion on a sphere. Proceedings of the Royal Society of London, Series A, 217: 295-305.

FLORENCE, G. (1907) Exploraçăo do rio Tiete. São Paulo: Commissão Geographica e Geologica do Estado de São Paulo. 21-34 p..

FRAKES, L.A. \& CROWELL, J.C. (1969) Late Paleozoic glaciation, I. South America. Geological Society of America Bulletin, 80:1007-1042.

FRAKES, L.A. \& CROWELL, J.C. (1972) Late Paleozoic glacial geography between the Paraná Basin and the Andean Geosyncline. Anais da Academia Brasileira de Ciencias, 44:139-145.

FRANÇA, A.B. (1987) Stratigraphy, deposicional environment, and reservoir analysis of the ltarare Group (Permo Carboniferous), Paraná Basin - Brazil. Tese de doutoramento. University of Cincinati, Cincinati, 188 p. (inédito).

FRANÇA, A.B. (1994) Itarare Group: Gondwanan Carboniferous-Permian of the Paraná Basin, Brazil. In: M. Deynoux, J.M.G. Miller, E.W. Domack, N. Eyles, I.J. Fairchild \& G.M.Young (Eds.) Earth's Glacial Record, Cambridge University Press, pp. 70-82.

FRANÇA, A.B. \& POTTER, P.R. (1988) Estratigrafia, ambiente deposicional e análise de reservatório do Grupo Itararé (Permocarbinífero), Bacia do Paraná (Parte 1). Boletim de Geociéncias da Petrobrás, 2 (2/4): 147-191.

FREEZE, R.A. \& CHERRY, J.A. (1979) Groundwater. Englewood Cliffs (USA): Prentice-Hall, 604 pp..

FRENCH, H.M. (1996) The periglacial environment. London: Longman, 309 pp..

FUCK, R.A. \& BIGARELLA, J.J. (1967) Glacial and perigiacial deposits of the Quero-Quero Geologic Quadrangle. In: International Symposium on the Gondwana Stratigraphy and Paleontology, 1 , Mar del Plata, 1967. Guide Book... Curitiba: Universidade Federal do Paraná, p. 17-37.

FUCK, R.A.; BIGARELLA, J.J.; SALAMUNI, R. \& ALESSI, A.H. (1965) Folha geologica de QueroQuero, PR. Curitiba: Contribuição da Comissão de Carta Geológica do Paraná. (Escala 1:50.000).

FÚLFARO, V.J.; GAMA JÚNIOR, E.G.; SOARES, P.C. (1980) Revisão estratigráfica da Bacia do Paraná. São Paulo: PAULIPETRO - Consórcio CESP/IPT, 125 p. (Relatório BP 008/80).

FÚLFARO, V.J.; SAAD, A.R.; SANTOS, M.V. \& VIANNA, R.B. (1982) Evolução e Compartimentação Tectônica da Bacia do Paraná.. Revista Brasileira de Geociéncias: 12 (4): 590-610.

FÚLFARO, V.J.; STEVAUX, J.C.; SOUSA FILHO, E.E. \& BARCELOS, J.H. (1984) A Formação Tatuí (P) no Estado de Såo Paulo. In: Congresso Brasileiro de Geologia, 33, Rio de Janeiro, 1984. Anais... Rio de Janeiro, SBG, v. 2, p. 771-724. 
FÚLFFARO, V.J.; PERINOTTO, J.A.J. \& BARCELOS, J.H. (1991) Formação Tietê: o pós-glacial no Estado de São Paulo. In: Simpósio de Geologia do Sudeste, 2, São Paulo, 1991. Atas... São Paulo, SBG/SP-RJ, p. 397-404.

GAMA JÚNIOR, E.G.; CAETANO, M.R.; WEYLER, G. (1980) Divisão faciológica do Grupo Itararé no centro-leste do Estado de São Paulo. In: Congresso Brasileiro de Geologia, 31, Camboriu, 1980, Boletim... Camboriú, SBG, 2 (resumos), p. 365.

GAMA JÚNIOR, E. G.; BANDEIRA JÚNIOR, A. N.; FRANÇA, A. B. (1982) Distribuição espacial e temporal das unidades litoestratigráficas paleoźbicas na parte central da Bacia do Paraná. Revista Brasileira de Geociencias, 12: 19-40.

GAMA JÚNIOR, E.G.; PERINOTTO, J.A.J.; RIBEIRO, H.J.P.S. \& PADULA, E.K. (1992) Contribuição ao estudo da ressedimentação no Subgrupo Itararé: um guia temático de campo. Revista Brasileira de Geociencias, 22 (2): 237-247.

GIJSSEL, K. van (1987) A lithostratigraphy and glaciotectonic reconstruction of the Lamstedt Moraine, Lower Saxony (FRG). In: J.J.M. van der Meer (ed.) Tills and glaciotectonics. Rotterdam: Balkema, pp. 145-156.

GLEN, J.W.; DONNER, J.J. \& WEST, R.G. (1957) On the mechanism by which stones in till become orientated. American Joumal of Science, 225: 194-205.

GOLDTHWAIT, R.P. (1989) Classification of glacial morphological features. In: R.P. Goldthwait \& C.L Matsch (eds.) Genetic Classication of Glacigenic Deposits. Rotterdam: Balkema, pp. 267-277.

GONZAGA, G.M. (2001) Glaciação Samburá (Neoproterozóico-Vendiano?) como possível agente transportador de diamantes no Estados de Minas Gerais. Revista Brasileira de Geociencias, 31 (4): 597-604.

GONZAGA, G.M. \& DARDENNE, M.A. (1991) The Jequitai Glaciation and the dispersion of diamonds during Upper Proterozoic. In: International Kimberlite Conference, 5, Araxá, 1991. Field Book... Araxá, CPRM, Special Publication, p. 83-93.

GORDON JÚNIOR, M. (1947) Classificação das formações gondwânicas do Paraná, Santa Catarina, e Rio Grande do Sul. Notas preliminares e estudos, Dívisão de Geologia e Mineralogia. DNPM, 38: 1-20.

GRAVENOR, C.P. \& ROCHA-CAMPOS, A.C. (1983) Patterns of Late Paleozoic glacial sedimentation on the southeast side of the Paraná Basin, Brazil. Palaeogeography, Palaeoclimatology, Palaeoecology, 43: 1-39.

HACHIRO, J. (1991) Litotipos, associaçðes faciologicas e sistemas deposicionais da Formaçæo Irati no Estado de Såo Paulo. Dissertação de Mestrado. Instituto de Geociências, Universidade de São Paulo, São Paulo, 175 p. (inédito).

HACHIRO, J. (1996) O Subgrupo Irati (Neopermiano) da Bacia do Paraná. Tese de doutoramento. Instituto de Geociências, Universidade de São Paulo, São Paulo,196 p. (inédito).

HANCOCK, P.L. (1985) Brittle microtectonics: principles and practice. Joumal of Structural Geology, 7 (3/4): 437-457.

HANCOCK, P.L. \& ENGELDER, T. (1989) Neotectonic joints. Geologist Society of America Bulletin, 1: 1197-1208.

HART, J.K (1995) An investigation of the deforming layer/debris-rich basal-ice continuum, illustrated from three Alaskan glaciers. Journal of Glaciology, 41 (139): 619-633.

HART, J.K. \& BOULTON, G.S. (1991) The interrelation of glaciotectonic and glaciodeposition processes within the glacial environment. Quatemary Science Review, 10: 335-350.

HART, J.K. \& ROBERTS, D.H. (1994) Criteria to distinguish between subglacial glaciotectonic and glaciomarine sedimentation, I. Deformation styles and sedimentology. Sedimentary Geology, 91: 191-213.

HART, J.K.; HINDMARSH, R.C.A. \& BOULTON, G.S. (1990) Styles of subglacial glaciotectonic deformation within the context of the Anglian ice-sheet. Earth Surface Processes and Landforms, 15: 227-241. 
HICOCK, S.R. (1991) On subglacial stone pavements in till. Joumal of Geology, 99: 607-619.

HOFFMANN, K. \& PIOTROWSKI, J.A. (2001) Till mélang eat Amsdorf, central Germany: sediment erosion, transport and deposition in a complex, soft-bedded subglacial system. Sedimentary

IVERSON, N.R., BAKER, R.W.; HOOYER, T. (1997) A ring-shear device for the study of till deformation: tests on tills with contrasting clay contents. Quatemary Science Reviews, 16:
1057-1066.

IVERSON, N.R., HOOYER, T.S., BAKER, R.W. (1998) Ring-shear studies of till deformation: Coulomb-plastic behaviour and distributed strain in glacier beds. Journal Glaciology, 44 (148):
$634-642$. JACKSON, M. \& KAMB, B. (1997) The marginal shear stress of ice Stream B. Journal of Glaciology,
43: $415-426$.

KAMB, B. (1991) Rheological nonlinearity and flow instability in the deforming bed mechanism of ice stream motion. Joumal of Geophysical Research, 96: 16585-16595.

KAMB, B. \& LA CHAPELLE, E. (1964) Direct observation of the mechanism of glacier sliding over bedrock. Joumal of Glaciology, 5: 159-172.

KARFUNKEL, J. \& CHAVES, M.L.S.C. (1995) Conglomerados cretácicos da Serra do Cabral, Mina Gerais: Um modelo para a distribuição coluvio-aluvionar dos diamantes do Médio São Francisco. Geociencias, 14: 59-72.

KARFUNKEL, J.; MARTINS, M. de S.; SCHOLZ, R. \& Mc CANDLESS, T. (2001) Diamonds from the Macaúbas river basin (MG, Brazil): characteristics and possible source. Revista Brasileira de Geociencias, 31 (4): 445-456.

KEIGWIN, L.D.; CURRY, W.B.; LEHMAN, S.J. \& JOHNSEN, S. (1994) The role of the deep ocean in North Atlantic climate change between 70 and 130 kyrs ago. Nature, 371: 323-325.

KLEMAN, J. \& BORGSTROM, L. (1996) Reconstruction of palaeo-ice sheets: the use of geomorphological data. Earth Surface Processes and Landforms, 21: 893-909.

KLEMAN, J.; HÄTTERSTRAND, C.; BORGSTRÖM, I. \& STROEVEN, A. (1997) Fennoscandian palaeoglaciology reconstructed using a glacial geological inversion model. Joumal of Glaciology, 43: 283-299.

KRÜGER, J. (1985) Formation of a push moraine at the margin of Höfdabrekkujökull, South Iceland. Geografiska Annaler, 67 A (3-4): 199-212.

KRÜGER, J. (1994) Glacial processes, sediments, landforms, and stratigraphy in the terminus region of Myrdalsjökull, Iceland. Folia Geograiphica Danica, Tom. XXI, 233 pp.

KUPSCH, W.O. (1955) Drumlins with jointed boulders near Dollard, Saakatchewan. Geological Society of America, Bulletin, 66:327-338.

LANDIM, P.M.B. (1973) Contribuição ao estudo dos mistitos do Grupo Tubarão no Estado de São Paulo. Boletim da Escola de Engenharia de São Carlos - USP, n. 175, Geologia 17, 98 pp..

LANDIM, P.M.B.; TEIXEIRA, J.A.; ODA, G.H. (1986) Estudo hidrogeológico do Grupo Tubarão na bacia hidrográfica do rio Capivari, in: Desenvolvimento de pesquisas hidrogeologicas no Estado de Såo Paulo. FAPESP/DAEE/UNESP-Rio Claro/USP-Ribeirão Preto/IG/SAA, 50 p. (relatório
interno).

LANGE, F.W. (1954) Estratigrafia do Estado do Paraná. In: Paleontologia do Paraná. Curitiba: Publicação da Comissão do Centenário do Paraná, pp. 27-29.

LAWSON, D.E. (1979) Sedimentological analysis of the western terminus region of Matanuska Glacier, Alaska. Cold Regions Research and Engineering Laboratory Report, 79-9, $122 \mathrm{pp}$.

LEINZ, V. (1937) Estudos sóbre a glaciação permocarbonífera do sul do Brasil. Boletim do Senviço de Fomento a Produçăo Mineral, DNPM, 21: 1-47.

LOCZY, L. de (1964) Problemas da estratigrafia e paleogeografia carbonífera da Bacia do Paraná. Boletim da Divisão de Geologia e Mineralogia, DNPM, 214: 1-113. 
LOWE, D.R. (1982) Sediment gravity flows: depositional models with special reference to the deposits of high-density turbidity currents. Journal of Sedimentary Petrology, 52 (1): 279-297.

LUCIO, M.P. (1999) Contribuiçăo a origem de pavimentos de clastos glaciais do Subgrupo ttararé (neopaleozoico), Bacia do Paraná. Monografia de Trabalho de Formatura. Instituto de Geociências, Universidade de São Paulo, São Paulo, 22 pp. (inédito).

MAACK, R. (1946) Geologia e geografia da região de Vila Velha, Estado do Paraná, e consideração sobre a glaciaçăo carbonifera no Brasil. Arquivos do Museu Paranaense, 5: 1-305.

MacCLINTOCK, P. \& DREMANIS, A. (1964) Reorientation of till fabric by overriding glacier in the St. Lawrence Valley. American Journal of Science, 262: 133-142.

MARK, D.M. (1973) Analysis of axial orientation data, including till fabrics. Geological Society of America Bulletin, 84:1369-1374.

MARTIN, H. (1961) The hypothesis of continental drift in the light of recent advances of geological knowledge in Brazil and in South West Africa. Alex. L. du Toit Memorial Lectures, n. 7 , Geological Society of South Africa, $47 \mathrm{pp}$.

MARTIN, H. (1964) The directions of flow of the Itararé Ice Sheets in the Parana Basin, Brazil. Boletim Paranaense de Geografia, n. 10-15, p. 25-76.

MARTINI, I.P. \& ROCHA-CAMPOS, A.C. (1991) Interglacial and early post-glacial, lower Gondwana coal sequence in the Paraná Basin, Brazil. In: H. Ulbrich \& A.C. Rocha-Campos (eds.), Gondwana Seven Proceedings. São Paulo: Instituto de Geociéncias, USP, pp. 317-336.

MARTINSEN, O.J. \& BAKKEN, B. (1990) Extensional and compressional zones in slump and slide in the Namurian of County Clare, Ireland. Jourmal of Geological Society of London, 147: 153-164.

MASSOLI, M. (1991) Relaçăo entre o embasamento cristalino e os sedimentos basais do Subgrupo Itararé na região de Sorocaba-Salto de Pirapora - SP. Dissertação de Mestrado. Instituto de Geociências, Universidade de São Paulo, São Paulo, 94 pp. (inédito).

MCCABE, A.M. \& HAYNES, J.R. (1996) A late Pleistocene intertidal boulder pavement from an isostatically emergent coast, Dundarlk Bay, eastern Ireland. Earth Surface Processes and Landforms, 21: $555-572$.

MENZIES, J. (1987) Towards a general hypothesis on the formation of drumlins. In: J. Menzies \& J. Rose (eds.) Drumlin symposium. Rotterdam: Balkema, pp. 9-24.

MENZIES, J. (1989) Subgiacial hydraulic conditions and their possible impact upon subglacial bed formation. Sedimentary Geology, 62: 125-150.

MENZIES, J. (1995) Modern glacial environments: processes, dynamics and sediments. Oxford: Butterworth-Heinemann Ltd.. Glacial Environments, Vol. 1, 598 pp..

MENZIES, J. \& ROSE, J. (1987) Drumlin symposium. Rotterdam: Balkema, 360 pp..

MENZIES, J. \& ROSE, J. (1989) Special issue: subglacial bedforms - drumlin, rogen moraine and associated subglacial bedforms. Sedimentary Geology, 62 (2/4): 117-430.

MIALL, A.D. (1978) Lithofacies types and vertical profile models in braided rivers: a summary. In: A.D. Miall (ed.), Fluvial Sedimentology. Memoir of Canadian Society of Petroleum Geologists, 5, pp. 597-604.

MIALL, A.D. (1985) Architectural-element analysis: a new method of facies analysis applied to fluvial deposits. Earth-Science Reviews, 22 (4): 261-308.

MIDDLETON, G.V. (1978) Facies. In: R.W. Fairbridge \& J. Bourgeois (eds.) Encyclopedia of Sedimentology. Stroudsburg (USA): Dowden, Hutchinson \& Ross, p. 323-325.

MORAN, S.R.; CLAYTON, L.; HOOKE, R.LeB.; FENTON, M.M. \& ANDRIASHEK, L.D. (1980) Glacierbed landforms of the prairie region of North America. Joumal of Glaciology, 25: 457-476.

MURATORI, A.; FUCK, R.A.; BIGARELLA, J.J.; SALAMURI, R.; PALKA, J.; LOPES, J.A. \& ALESSI, A.H. (1965) Folha geologica de Campo Largo. Curitiba: Contribuição da Comissão da Carta Geológica do Paraná. (Escala 1:50.000). 
NAGALI, J.T. \& CONSONI, J.O.C. (1984) Comportamento faciologico do intervalo que encerra as camadas de carvão, na região de Cerquilho. In: Congresso Brasileiro de Geologia, 33, Rio de Janeiro, 1984. Anais... Rio de Janeiro, SBG, 2: 974-982.

NORTHFLEET, A.A.; MEDEIROS, R.A. \& MUHLMANN, H. (1969) Reavaliação dos dados geológicos da Bacia do Paraná. Boletim Técnico da Petrobrás, 2 (3):291-346.

NOVICK, A.N.; BENTLEY, C.R. \& LORD, N. (1994) Ice thickness, bed topography and basal-reflection streghts from radar sounding, Upstream B, West Antarctica. Annals of Glaciology, 20: 128-152.

OLIVEIRA, A.I. de \& LEONARDOS, O.H. (1943) Geologia do Brasil. Rio de Janeiro: Serviço de Informação Agricola. Série Didática, n.2, 813 pp.

OLIVEIRA, E.P. de (1927) Geologia e recursos minerais do Estado do Paraná. Monografia Serviço Geologico e Mineralógico do Brasil, DNPM, 4: 1-172.

OWEN, L.A. (1988) West-sediment deformation in Quaternary and recent sediments in the Skardu Basin, Karakoram Mountains, Pakistan. In: $D$. Croot (ed.) Glaciotectonics. Rotterdam: Balkema, pp. 123-147.

OWEN, L.A. (1989) Neotectonics and giacial deformation in the Karakoram Mountains and Nanga Parbat Himalaya. Tectonophysics, 163: 227-265.

PACHECO, J. (1927) Exploraçăo da regiåo comprehendida pelas folhas topographicas Sorocaba, Itapetininga, Bury, Faxina, Itaporanga, Sete Barras, Capåo Bonito, Ribeirăo Branco e ltararé. São Paulo: Commissão Geographica e Geologica do Estado de São Paulo, 12 pp.

PALKA, J.; TREIN, E.; FUCK, R.A.; LOPES, J.A. \& MURATORI, A. (1966) Folha geologica de Porto Amazonas. Curitiba: Contribuição da Comissão da Carta Geológica do Paraná. (Escala 1:50.000).

PARK, R.G. (1989) Foundations of structural geology. Glasgow: Blackie, 148 pp.

PATERSON, W.S.B. (1981) The physics of glaciers. Oxford: Pergamon Press, $380 \mathrm{pp}$.

PEDERSEN, S.A.S. (1987) Comparative studies of gravity tectonics in Quaternary sediments and sedimentary rocks related to fold belts. In: M.E. Jones \& R.M.F. Preston (Eds.) Deformation of sediments and sedimentary rocks. London: The Geological Society of London, Special Publication, 29: 165-180.

PEDERSEN, S.A.S. (1993) Glaciodynamic event and glaciodynamic sequence. In: J. Aber (ed.) Glaciotectonics and mapping glacial deposits. Regina: Canadian Plains Research Center, University of Regina, pp. 67-85.

PEDERSEN, S.A.S. (1996) Progressive glaciotectonic deformation in Weichselian and Palaeogene deposits at Feggeklit, northern Denmark. Bulletin of the Geological Society of Denmark, 42: 153-174.

PEDERSEN, S.A.S.; PETERSON, K.S. \& RASMUSSEN, L.A. (1988) Observations on glaciodynamic structures at the Main Stationay Line in western Jutland, Denmark. In: D.G. Croot (ed.) Glaciotectonics: Forms and processes. Rotterdam: Balkema, pp. 177-183.

PENHA, U.C. \& ANGELI, N. (2001) Origem dos depósitos diamantiferos de Jequitaí, Minas Gerais, Brasil. Revista Brasileira de Geociências, 31 (4): 427-432.

PETRI, S. (1964) Grupo Tubarão. Boletim do Instituto Geográfico e Geologico, 41: 56-63.

PETRI, S.; VIEIRA, P.C.; ODA, G.H. \& BOTELHO, P.F. (1996) O Subgrupo Itararé, permocarbonífero da região do Médio Tietê, Estado de São Paulo: estudos em subsuperficie. Revista do Instituto Geológico, 17 (1/2): 63-78.

PIOTROWSKI, J.A.; GELETNEKY, J. \& VATER, R. (1999) Soft-bedded subglacial meltwater channel, from Weizow-Süd opencast lignite mine, Lower Lusatia, eastern Germany. Boreas, 28: 363374.

PIOTROWSKI, J.A.; MICKELSON, D.M.; TULACZYK, S.; KRYSZKOWSKI, D. \& JUNGE, F.W. (2001) Were deforming subglacial beds beneath past ice sheets really widespread? Quatemary Intemational, 86: 139-150. 
PIRES, F.A. (2001) Análise paleoambiental e estratigráfica do Subgrupo Itararé na regiáo do Médio Tiete, Estado de Såo Paulo. Tese de Doutoramento. Instituto de Geociências e Ciências Exatas, Universidade Estadual Paulista, Rio Claro, 113 pp. (inédito).

POLLARD, D.D. \& AYDIN, A. (1988) Progress in understanding jointing over the past century. Geologist Society of America Bulletin, 100: 1118-1204.

RAMSAY, J.G. (1967) Folding and fracturing of rocks. New York: McGraw-Hiil, $568 \mathrm{pp}$.

RAMSAY, J.G. \& HUBER, M.I. (1987) The tectonics of modern structural geology. Vol. 2: Folds and Fractures. London: Academic Press Limited, $700 \mathrm{pp}$.

RAPPOL, M. (1987) Saalian till in The Netherlands: a review. In: J.J.M. Van der Meer (ed.), Tills and glaciotectonics. Rotterdam: Balkema, pp. 3-21. RAPPOL, M. \& STOLTENBURG, H.M.P. (1985) Compositional variability of Saalian Till. Boreas, 14 :
33-50.

RAYMOUND, C. (1996) Shear margins in glaciers and ice sheets. Joumal of Glaciology, 42: 90-102.

READING, H.G. (1996) Sedimentary environments: processes, facies and stratigraphy. Oxford: Blackwell Science Ltd., $3^{\text {rd }}$ ed., $688 \mathrm{pp}$.

RICCOMINI, C. (1997) Arcabouço estrutural e aspectos do tectonismo gerador e deformador da Bacia Bauru no Estado de São Paulo, Brasil. Revista Brasileira de Geociencias, 27 (2): 153-162.

RIJSDIJK, K.J.; OWEN, G.; WARREN, W.P.; MCCARROLL, D. \& VAN DER MEER, J.J.M. (1999) Clastic dykes in over-consolidated tills: evidence for sunglacial hydrofracturing at Killiney Bay, eastern Ireland. Sedimentary Geology, 129: 111-126.

ROCHA-CAMPOS, A.C. (1963) Deformações penecontemporâneas em sedimentos glácio-lacustres do Grupo Tubarão. Boletim da Sociedade Brasileira de Geologia, 12 (1-2): 49-56.

ROCHA-CAMPOS, A.C. (1967) The Tubarão Group in the Brazilian portion of the Parana Basin. In: J.J. Bigarella et al. (eds.), Problems in Brazilian Gondwana Geology. Curitiba: Instituto de Geociências, UFPR. pp. 27-102.

ROCHA-CAMPOS, A.C. \& SANTOS, P.R. dos (2000) Ação geológica do gelo. In: W. Teixeira; M.C. Toledo; T. Fairchild \& F. Taioli (eds.), Decifrando a Terra. São Paulo: Oficina de Textos, pp.
215-246.

ROCHA-CAMPOS, A.C.; FARJALLAT, J.E.S. \& YOSHIDA, R. (1968) New giacial feactures of the upper Paleozoic Itararé Subgroup in the State Såo Paulo, Brazil. Boletim da Sociedade Brasileira de Geologia, 17 (1): 47-57.

ROCHA-CAMPOS, A.C.; FARJALLAT, J.E.S. \& YOSHIDA, R. (1969) Crescentic marks on a late Paleozoic glacial pavement in southeastern Brazil. Geological Society of America Bulletin, 80 :
1123-1126.

ROCHA-CAMPOS, A.C.; SANTOS, P.R. dos \& SAAD, A.R. (1972) São Paulo to Sorocaba, via Conchas. In: International Symposium on the Carboniferous and Permian systems in South America - Excursion Guide-book. São Paulo: Academia Brasileira de Ciências \& Instituto de Geociências, USP. pp. 20-29.

ROCHA-CAMPOS, A.C.; OLIVEIRA, M.E.C.B. de; SANTOS, P.R. dos \& SAAD, A.R. (19\%6) Boulder paviments and the sense of movement of late Paleozoic glaciers in central eastern São Paulo State, Paraná Basin, Brazil. Boletim do Instituto de Geociencias-USP, 7: 149-160.

ROCHA-CAMPOS, A.C.; OLIVEIRA, M.E.C.B. de; SANTOS, P.R. dos \& SAAD, A.R. (1977) in: International Gondwana Symposium, Calcuta, 1977. Papers... Calcuta, Hindustan Publishing
Corporation, v.1, p. 353-358.

ROCHA-CAMPOS, A.C.; SUGUIO, K.; SANTOS, P.R. dOS; CANUTO, J.R.; SOUZA, A.P. \& SUNDARAN, D. (1981) Mapa fotogeológico controlado da região de Cerquilho-Tietê 1:25.000, Secretaria da Ciência e Tecnologia, Estado de São Paulo. (Processo 1074/81).

ROCHA-CAMPOS, A.C.; SANTOS, P.R. dos \& CANUTO, J.R. (1986) Glaciotectonics strutures in the upper Itararé Subgroup (late Paleozoic) near Cerquilho, State of São Paulo, Brazil. In: 
Congresso Brasileiro de Geologia, 34, Goiånia, 1986. Boletim... Goiânia, SBG, Resumos e Breves Comunicações, v.1, p. 57-58.

ROCHA-CAMPOS, A.C.; COTTER, J.F.P.; SANTOS, P.R. dos \& CANUTO, J.R. (1992) Boulder paviments from the Itarare Subgroup (late Paleozoic) at Capivari, SP: new evidence on origin. In: Congresso Brasileiro de Geologia, 37, São Paulo, 1992. Anais... São Paulo, SBG/SP, Boletim de resumos expandidos, p. 521-522.

ROCHA-CAMPOS, A.C.; COTTER, J.F.P.; SANTOS, P.R. dos \& CANUTO, J.R. (1993) The boulder paviments of Capivari, São Paulo, Brazil: implications for the late Paleozoic glaciation. In: Carboniferous to Jurassic Pangea, a global view, environments and resources. Calgary (Canadá): 1993, Annual Convention of Canadian Society of Petroleum Geologists, pp. 261.

ROCHA-CAMPOS, A.C.; SANTOS, P.R. dos \& CANUTO, J.R. (1999) Multiple, glacially striated, soft sediment surfaces in the late Paleozoic and Proterozoic of Brazil. Anais da Academia Brasileira de Ciencias, 71 (4-1): 841.

ROCHA-CAMPOS, A.C.; CANUTO, J.R. \& SANTOS, P.R. dos (2000) Late Paleozoic glaciotectonic structures in northern Paraná Basin, Brazil. Sedimentary Geology, 130: 131-143.

ROCHA-CAMPOS, A.C.; SANTOS, P.R. doS; TOMIO, A. \& SALVETTI, R.A.P. (2003) Alternative paleogeography of late Paleozoic glacial rocks of NW State of Minas Gerais. In: Latinamerican Congress of Sedimentology, 3, Belém. Abstract Book... Belém, Museu Paraense Emílio Goeldi; UFPA, p. 144-146.

RUST, B.R. (1977) Mass flow deposits in a Quatemary sucession near Ottawa, Canadá: diagnostic criteria for subaqueous outwash. Canadian Joumal of Earth Sciences, 14: 175-184.

SÁ REGO, F.M. de; CAMPOS, J.E.G. \& DARDENNE, M.A. (2001) Fácies diamantiferas da Formação Chapadão na região de João Pinheiro (MG). Revista Brasileira de Geociências, 31 (4): 563568.

SAAD, A.R. (1977) Estratigrafia do Subgrupo ttararé no centro e sul do Estado de Săo Paulo. Dissertação de Mestrado. Instituto de Geociências, Universidade de São Paulo, São Paulo, 107 pp. (inédito).

SALES, A.M.F. (1999) Estudo morfotectonico do setor setentrional da alinhamento do Rio MojiGuaçu, Estado de Săo Paulo. Dissertação de Mestrado. Instituto de Geociências, Universidade de São Paulo, São Paulo, 106 pp. (inédito).

SALVADOR, E.D. \& RICCOMINI, C. (1995) Neotectônica da região do Alto Estrutural de Queluz (SPRJ, Brasil). Revista Brasileira de Geociencias, 23 (3): 151-164.

SALVETTI, R.A.P. (2000) Contribuiçðo à origem de pavimentos de clastos glaciais do Subgrupo Itararé (Neopaleozóico), em Capivani, SP. Projeto de Iniciação Científica-CNPq, 38 pp..

SALVETTI, R.A.P. (em preparaçăo) Evoluçăo paleogeográfica do Subgrupo Itararé junto à borda leste da Bacia do Paraná, na regiâo entre Salto e Indaiatuba, SP. Dissertação de Mestrado, Instituto de Geociências, Universidade de São Paulo. (em preparação).

SANTOS, P.R. dos (1979) Distribuiçăo estratigráfica, caracteristicas e facies de diamictitos e rochas associadas do Subgrupo Itararé no centro e sul do Estado de Săo Paulo. Dissertação de Mestrado. Instituto de Geociências, Universidade de São Paulo, São Paulo, 135 pp. (inédito).

SANTOS, P.R. dos (1987) Facies e evolução paleogeográfica do Subgrupo itararé / Grupo Aquidauana (Neopaleozoico) na Bacia do Paraná, Brasil. Tese de Doutoramento. Instituto de Geociências, Universidade de São Paulo, São Paulo, 128 pp. (inédito).

SANTOS, P.R. dos; ROCHA-CAMPOS, A.C. \& CANUTO, J.R. (1996) Patterns of Late Paleozoic deglaciation in the Parana Basin, Brazil. Palaeogeography, Palaeoclimatology, Palaeoecology, 125: $165-184$.

SCHERER, R.P.; ALDAHAN, A.; TULACZYK, S.M.; POSSNET, G.; ENGELHARDT, H. \& KAMB, B. (1998) Pleistocene collapse of the West Antarctic lce Sheet. Science, 281: 82-85.

SCHNEIDER, R. L.; MUHLMANN, H.; TOMASSI, E.; MEDEIROS, R. A.; DAEMON, R. F.; NOGUEIRA, A. A (1974) Revisão estratigráfica da Bacia do Paraná. In: Congresso Brasileiro de Geologia, 28, Porto Alegre. Anais... PortoAlegre, SBG, v. 1, p. 41-65. 
SETTI. G.C.X. (1998) Fácies e ambientes sedimentares no varvito e rochas associadas de Itu (Subgrupo Itarare, Neopaleozoico). Monografia de Trabalho de Formatura. Instituto de Geociéncias, Universidade de Såo Paulo, São Paulo, 29 pp. (inédito).

SHANMUGAM, G. (1996) High density turbidity currents: are they sandy debris flows? Journal of Sedimentary Research, 66 (1): 2-10.

SHARP, M. (1984) Anuual moraine ridges at Skálafellsjökull, South-east Iceland. Joumal of Glaciology, 30: 82-93.

SHAW, J. (1983) Drumlin formation related to inverted erosion marks. Joumal of Glaciology, 29: 461479.

SHAW, J.; KVILL, D. \& RAINS, B. (1989) Drumlins and catastrophic subglacial floods. Sedimentary Geology, 62 (2/4): 177-202.

SHIPP, S. \& ANDERSON, J.A. (1997a) Drumlin field of the Ross Sea continental shelf, Antarctica. In: Davis, T.A., et al. (eds.) Glaciated continental margins: an atlas of acoustic images. London: Chapman \& Hall, pp. 54-55.

SHIPP, S. \& ANDERSON, J.A. (1997b) Lineations on the Ross Sea continental shelf, Antarctica. In: Davis, T.A., et al. (eds.) Glaciated continental margins: an atlas of acoustic images. London: Chapman \& Hall, pp. 378-381.

SHIPP, S.; ANDERSON, J.A. \& DOMACK, E. (1999) Late Pleistocene-Holocene retreat of the West Antarctic ice-sheet system in the Ross Sea: Part 1 - geophysical results. Geological Society of America Bulletin, 111: 1486-1516.

SHOEMAKER, E.M. (1986) Subglacial hydrology for an ice sheet resting on a deformable aquifer. Joumal of Glaciology, 32: 20-30.

SMALLEY, I.J. \& UNWIN, D.J. (1968) The formation and shapes of drumlins and their distribution and orientation in drumlin fields. Joumal of Glaciology, 7: 377-390.

SOARES, P. C. (1972) O limite glacial - pós-glacial do Grupo Tubarão no Estado de São Paulo. Anais da Academia Brasileira de Ciencias, 44 (supl.): 333-341.

SOARES, P.C.; LANDIM, P.M.B.; SINELLL, O.; WERNICK, E.; WU, F.T.;FIORI, A.P. (1977) Associaçöes litologicas do Subgrupo Itararé e sua interpretação ambiental. Revista Brasileira de. Geociencias, 7(2): 131-149.

SOARES, P.C.; LANDIN, P.M.B.; FÚLFARO, V.J.; AMARAL, G.; SUGUIO, K.; COIMBRA, A .M.; SOBREIRO NETO, A . F.; GIANCURSI, F.D.; CORREA, W.A .G.; CASTRO, C.G.J. (1979) Geologia da região Sudeste do Estado da São Paulo. In: Simpósio Regional de Geologia, 6 , Rio Claro. Atas..., SBG, v.2, p. 307-319.

SOUZA, P.A. (2000) Palinoestratigrafia do Subgrupo Itararé, Carbonifero/Permiano, na porçăo nordeste da Bacia do Paraná, SP/PR, Brasil. Tese de Doutoramento. Instituto de Geociências, Universidade de São Paulo, São Paulo, 199 pp. (inédito).

SOUZA FILHO, E.E. de (1986) Mapeamento faciologico do Subgrupo Itararé na quadricula de Campinas ( $S P$ ). Dissertação de Mestrado. Instituto de Geociências, Universidade de São Paulo, São Paulo, $121 \mathrm{pp}$. (inédito).

STEVAUX, J.C.; SOUZA FILHO, E.E.; TEIXEIRA, J.A.; LANDIM, P.M.B. (1987) Sistemas deposicionais do Subgrupo Itararé (P-C) na bacia hidrográfica do baixo rio Capivari (SP):: um modelo de prospeç̧ão de água subterrânea. In: Simpósio Regional de Geologia, 6, Rio Claro, 1987, Atas..., SBG, v.1, p. 355-374.

SUGUIO, K. (1998) Dicionário de geologia sedimentar e áreas afins. Rio de Janeiro: Bertrand Brasil, $1217 \mathrm{pp}$.

SUGUIO, K. (2003) Geologia Sedimentar. São Paulo: Editora Edgard Blücher Ltda., 400 pp..

THOMAS, G.S.P. (1984) On the glacio-dynamic structure of the Bride Moraine, Isle of Man. Boreas, 13: $355-364$.

THORSON, R.M. (2000) Glacial tectonics: a deeper perspective. Quaternary Science Review, 19: 1391-1398. 
THORSTEINSSON, T. \& RAYMOND, C.F. (2000) Slinding versus till deformation in the fast motion of an ice stream over a viscous till. Joumal of Glaciology, 46 (155): 633-640.

TOMIO, A.; ROCHA-CAMPOS, A.C.; SANTOS, P.R. dos; \& CANUTO, J.R. (2000) Patterns of interaction between late Paleozoic glaciers and deformable beds, Paraná Basin, Brazil. in: International Geological Congress, 31, Rio de Janeiro, 2000. CD-ROM Abstracts Volume... Rio de Janeiro, IUGS.

TREIN, E.; FUCK, R.A.; LOPES, J.A.; MURATORI, A. \& PALKA, J. (1965) Folha geologica de Contenda. Curitiba, Contribuiçăo da Comissão da Carta Geológica do Paraná. (Escala 1:50.000).

TROSDTORF JUNIOR, I. (2002) Geologia Glacial permo-cambonifera (Subgrupo Itararé) no flanco sul do arco de Ponta Grossa, PR. Dissertaçåo de Mestrado. Instituto de Geociências, Universidade de São Paulo, São Paulo, 144 pp. (inédito).

TROSDTORF JUNIOR, I.; ROCHA-CAMPOS, A.C.; SANTOS, P.R. dOS; TOMIO, A. \& CANUTO, J.R. (2001) Origin and preservation of multiple, glacially surfaces in the Itarare Subgroup (late Paleozoic) in Palmeira, State of Paraná. Anais da Academia Brasileira de Ciências, 73 (3): 467 468.

TROSDTORF JUNIOR, I;; ASSINE, M.L.; VESELY, F.F.; ROCHA-CAMPOS, A.C.; SANTOS, P.R. dos; \& TOMIO, A. (no prelo) Glacially striated, soft sediment surfaces on late Paleozoic tillite at São Luiz do Purunã, PR.Origin and preservation of multiple, glacially surfaces in the ltararé Subgroup (late Paleozoic) in Palmeira, State of Paraná. Anais da Academia Brasileira de Ciencias. Rio de Janeiro, ABC.

TULACZYK, S.M. (1999) Ice sliding over weak, fine-grained tills: dependence of ice-till interactions on till granulometry. In: D.M. Micke/son \& J. Attig (eds.) Glacial Processes: Past and modem. Boulder (Colorado), Geological Society of America, Special Paper 337, pp. 159-177.

TULACZYK, S.M.; KAMB, B.; SCHERER, R.P. \& ENGELHARDT, H.F. (1998) Sedimentary processes at the base of a West antarctic ice stream: contraints from textural and compositional properties of subglacial debris. Joumal of Geophysical Research, 68: 487-496.

TULACZYK, S.M.; KAMB, B. \& ENGELHARDT, H.F. (2000a) Basal mechanics of Ice Stream B: I. Till mechanics. Joumal of Geophysical Research, 105: 463-481.

TULACZYK, S.M.; KAMB, B. \& ENGELHARDT, H.F. (2000b) Basal mechanics of Ice Stream B: II. Plastic-undrained-bed model. Joumal of Geophysical Research, 105: 463-481.

TULACZYK, S.M.; SCHERER, R.P. \& CLARK, C.D. (2001) A ploughing model for the origin of weak tills beneath ice streams: a qualitative treatment. Quatemary Intemational, 86: 59-70.

VAN DER MEER, J.J.M. (1987) Tills and glaciotectonics. Rotterdam: Balkema, 270pp..

VAN DER MEER, J.J.M. (1997) Particle and aggregate mobility in till: microscopic evidence of subglacial processes. Quaternary Science Review, 16: 827-831.

VAN DER MEER, J.J.M.; VERBERS, A.L.L.M. \& WARREN, W.P. (1994) The micromorphological character of the Ballycroneen Formation (Irish Sea Till): a first assessment. In: W.P. Warren \& $D$. Croot (eds.), Formation and deformation of glacial deposits. Rotterdam: Balkema, pp. 39-49.

VAN DER WATEREN, F.M. (1987) Structural geology and sedimentology of the Dammer Berge push moraines, FRG. In: J.J.M. van der Meer (ed.) Tills and glaciotectonics. Rotterdam: Balkema, pp. 157-182.

VAN DER WATEREN, F.M. (1995a) Structural geology and sedimentology of push moraines processes of soft-deformation in a glacial environment and the distribution of glaciotectonic styles. Mededelingen Rijks Geologische Dienst, 54: 1-168.

VAN DER WATEREN, F.M. (1995b) Processes of glaciotectonism. In: J. Menzies (ed.) Modem glacial environments: processes, dynamics and sediments. Oxford: Butterworth-Heinemann Ltd.. Glacial Environments, Vol. 1, pp. 309-335.

VAN LOON, A.J. (2002) Soft-sediment deformations in the Kleszczów Graben (central Poland). Sedimentary Geology, 147: 57-70. 
VESELY, F.F. \& ASSINE, M.L. (1998) Evidências de sedimentação subglacial na base do Grupo Itararé, Estado do Paraná. In: Congresso Brasileiro de Geologia, 40, Belo Horizonte, 1998. Boletim... Belo Horizonte, SBG-MG, Anais, pp. 523.

VISSER, J.N.J. (1983) The problems of recognising ancient subaqueous debris flow deposits in glacial sequences. Trans. Geological Society of South Africa, 86: 127-135.

VISSER, J.N.J. (1987) The influence of topography on the Permo-Carboniferous glaciation in the Karoo Basin and adjoining areas, southern Africa. In: G.D. McKenzie (ed.), Gondwana Six: Stratigraphy, Sedimentology and Paleontology. Washington, D.C.: American Geophysical Union, Geophysical Monograph, 41: 123-129.

VIVIAN, R. \& BOCQUET, G. (1973) Subglacial cavitation phenomena under the Glacier d'Argentiere, Mont Blanc, France. Journal of Glaciology, 12: 439-451.

WAAGEN, W. (1888) The Carboniferous glacial period. Records of the Geological Survey of India, 21: 89.

WAAGEN, W. (1889) Further notes on a letter from Mr. C. Derby, concerning traces of a Carboniferous glacial period in S. America. Records of the Geological Survey of India, 22: 6971.

WALDER, J.S. (1986) Hydraulics of subglacial cavities. Joumal of Glaciology, 32: 439-445.

WALKER, R.G. (1992) Facies, facies models and modern stratigraphic concepts. In: R.G. Walker \& N.P. James (eds.) Facies models: response to sea-level change. Saint John's: Geological Association of Canada, pp. 1-14.

WALLBRECHER, E. (1986) Tektonische und gefügeanalytische Arbeitsweisen. Stuttgart: EnkeVerlag, 244 pp..

WASHBURNE, C.W. (1930) Petroleum geology of the State of São Paulo - Brazil. São Paulo: Boletim da Commissão Geographica e Geologica do Estado de São Paulo, n. 22, 282 p.

WEERTMAN, J. (1986) Basal water and high-pressure basal ice. Joumal of Glaciology, 32: 439-463.

WHITE, I. C. (1908) Relatório final da Comissăo de Estudos das Minas de Carvăo de Pedra do Brasil apresentado a S. Ex. o Sr. Dr. Lauro Severino Muller, ministro da indústria, viação e obras públicas. Rio de Janeiro: Imprensa Nacional, 617 pp..

WILDENBORG, A.F.B. (2001) Research on radioactive waste disposal in the Nethertands with special reference to earth scientific studies. Rijks Geologische Dienst, Chapter 17, pp. 161-182 (n.d. 12/05/2001) [PostScript file - PDF] URL http://www-esd.lbl.gov/NW/wwr/wwr17.pdf.

WILDENBORG, A.F.B.; BOSCH, J.H.A.; MULDER, E.F.J. de; HILLEN, R.; SCHOKKING, F. \& GIJSSEL, K. van (1990) A review: effects of (peri-)glacial processes on the stability of rocks salt. In: D.G. Price (ed.) Proceedings Sixth Intemational Congress of the International Association of Engineering Geology. Rotterdam: Balkema, pp. 331-333.

WILLIAMS, P.J. \& SMITH, M.W. (1989) The frozen earth: fundamentals of geocryology. Cambridge: Cambridge University Press, 306 pp..

WOODWORTH, J.B. (1912) Geological Expedition to Brazil and Chile. Bulletin of the Museum of Comparative Zoslogy, Harvard College, 56 (1): 1-137.

WU, F.T.; SOARES, P.C.; MATTOS, J.T. (1980) Divisão faciológica do Grupo itararé no sudeste do Estado de São Paulo. In: Congresso Brasileiro de Geologia, 31, Camboriú, 1980. Resumos. Camboriú, SBG, bol. 2, p. 364.

ZALÁN, P.V.; WOLFF, S. CONCEIÇÃO, J.C. de J.; MARQUES, A.; ASTOLFI, M.A.M.; VIEIRA, I.S.; APPI, V.T. \& ZANOTTO, O.A. (1991) Bacia do Paraná. In: G.P. Hapa Gabaglia \& E.J. Milani (coords.) Origem e evoluçăo de bacias sedimentares. Rio de Janeiro: Petrobrás, pp. 135-168. 


\section{MAPA GEOLÓGICO E TECTÔNICO DA COLÔNIA MENONITA DE WITMARSUM}

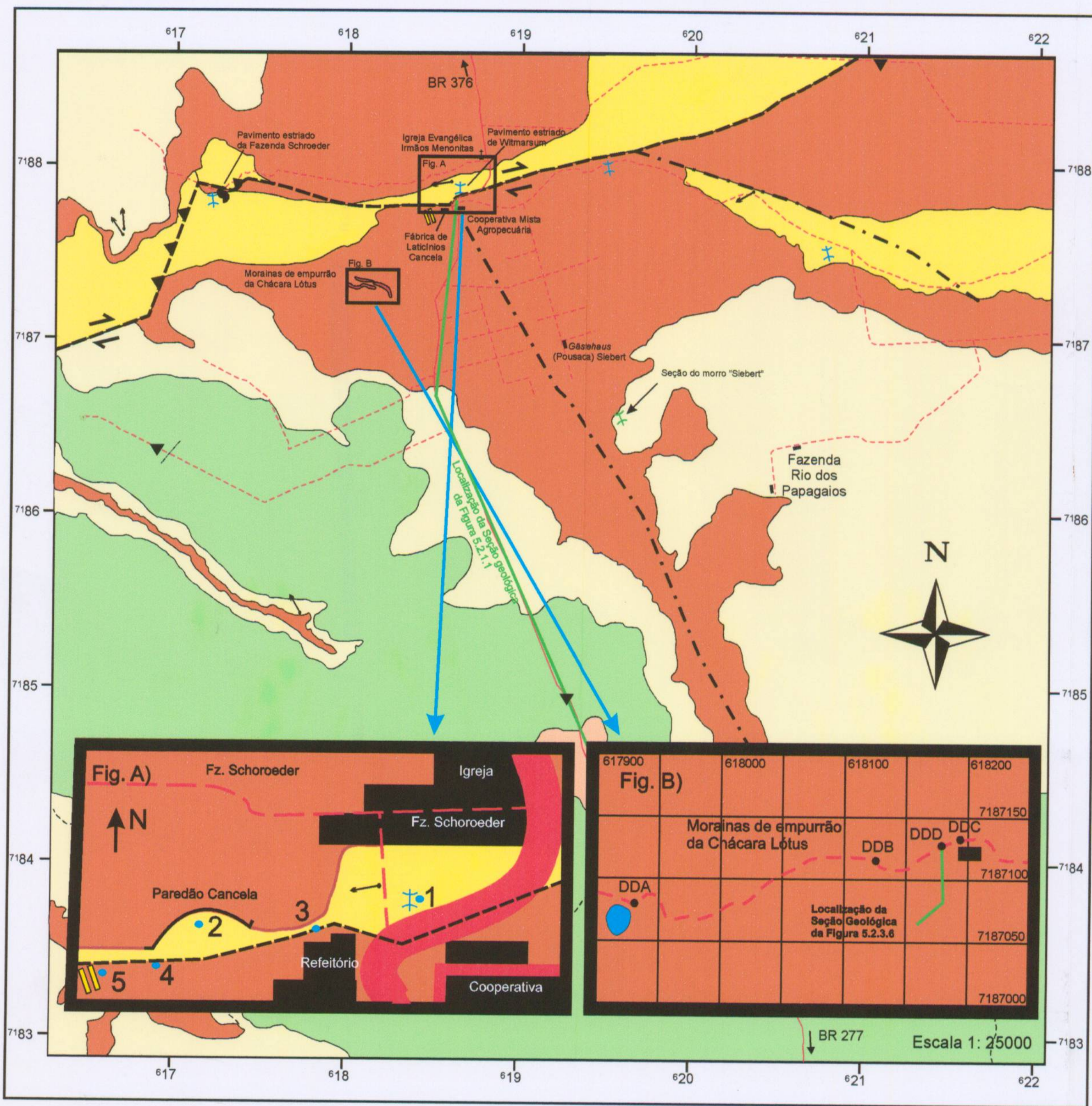

WSTITUTO OE GEOCI

- USP

- BiBLIOTECA -

\section{L e ge n d a.}

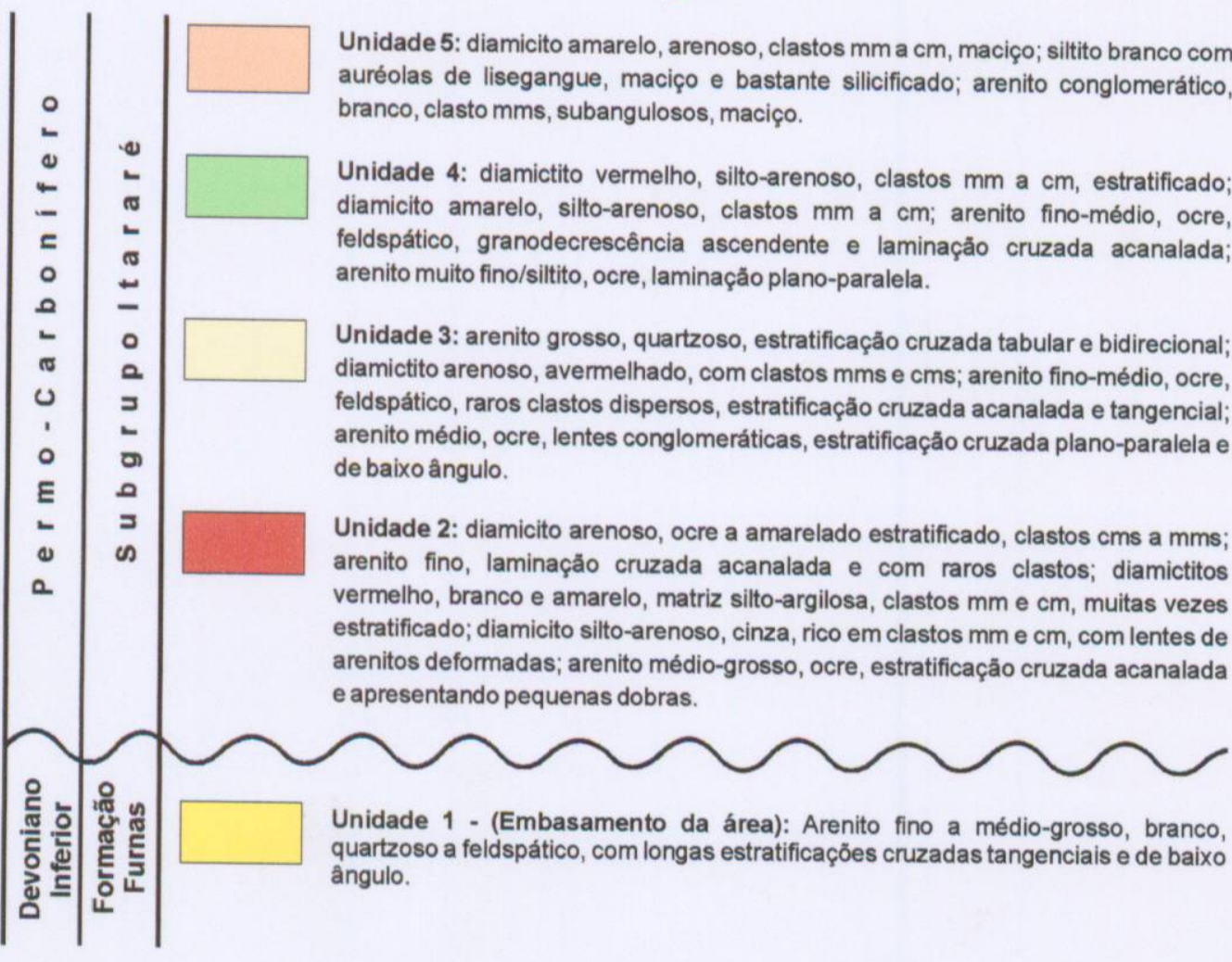

I Falha transcorrente destral, com componentes transpressivos e transtensivos, e

IV falha inferida ou sem dados cinemáticos

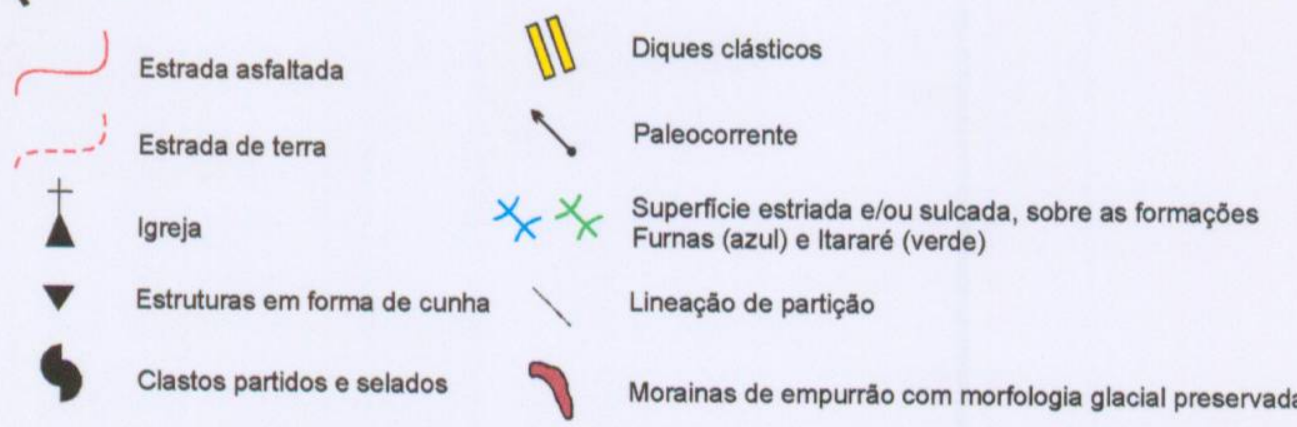

Legenda - Figura A

1. Pavimento estriado de Witmarsum

3. Plano de falha ao lado do refeitório

4 - Plano de falha em lente d'água

5 - Diques clásticos

Legenda - Figura B

DDA - Diamictito Deformado $A$

DDD - Diamictito Deformado D

ANEXO I

MPAGEOLOGICO DA COLONAA MENONITA DE WTMARSUM

Tese de Doutorado: Estilos de deformaçbes glacitectetonicas do Subgrupo Itararé, Neopaleozorico da Bacia do Parantá

Autor: Alexandre Tomio

Modificado de Trosctorf Jr. (2002) 